\title{
AMMESON'S fORY
}

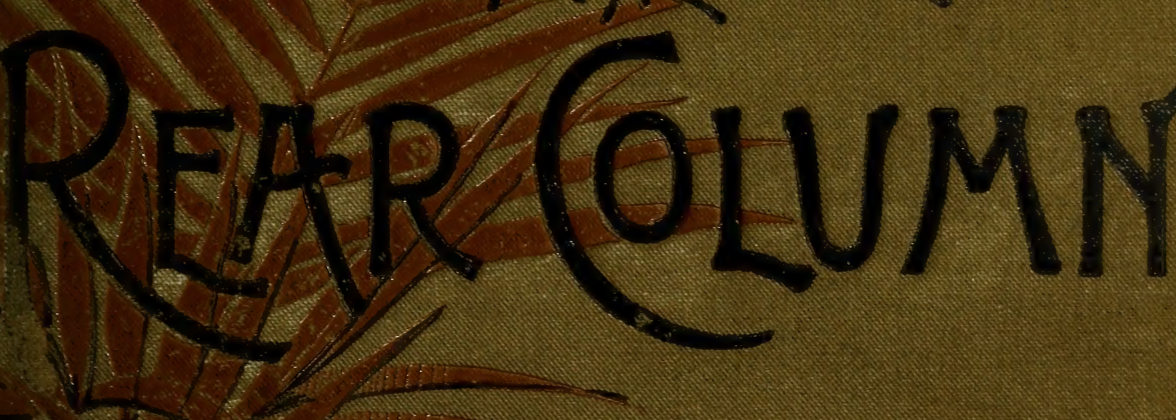

$-10 \times 2<2$
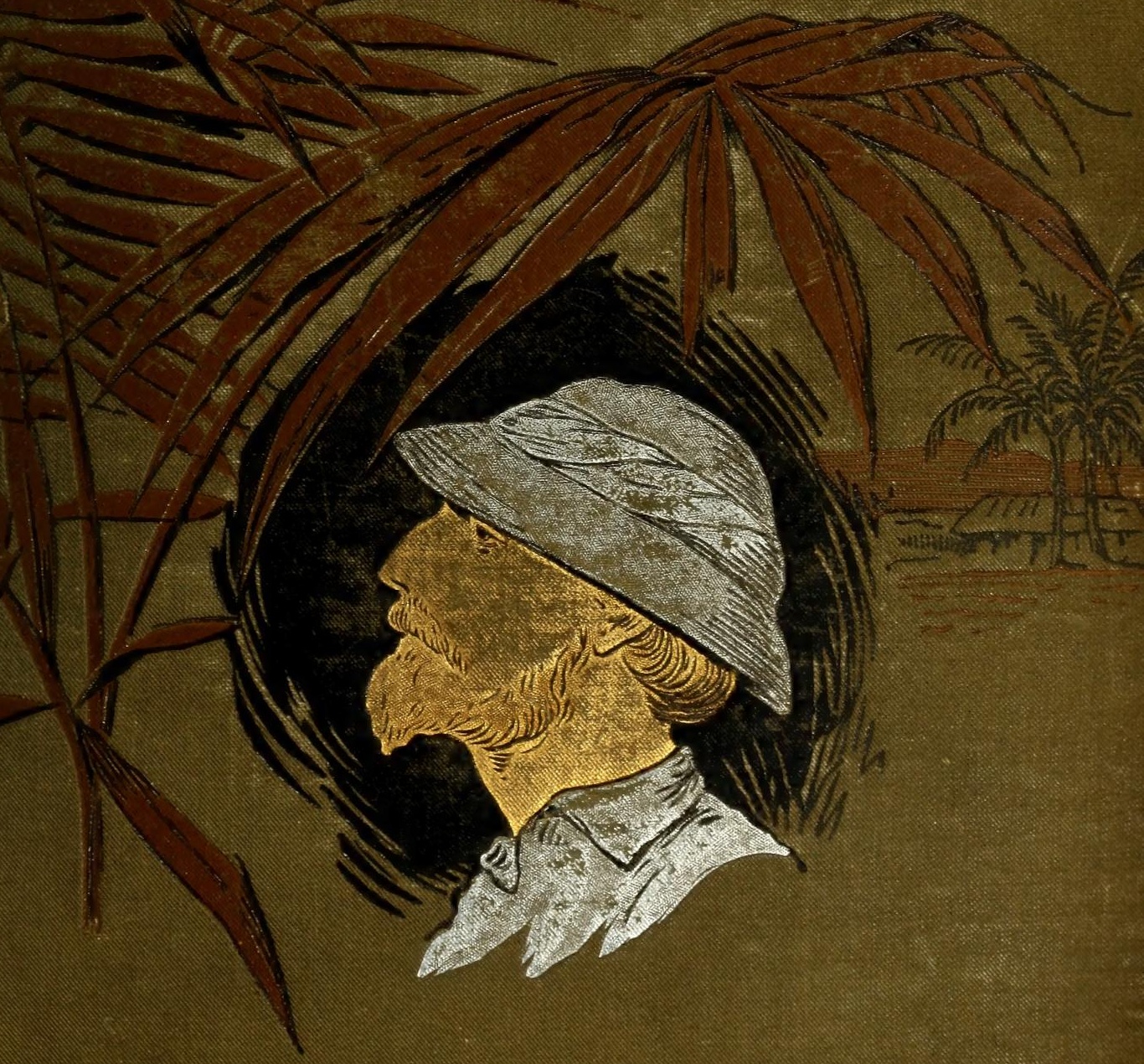



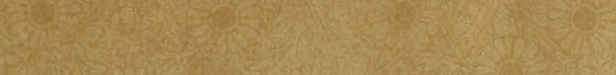

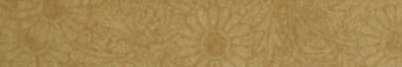

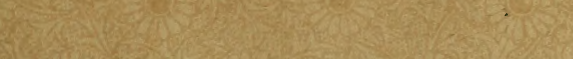

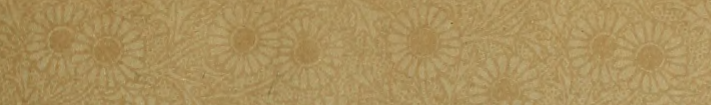

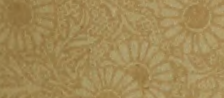

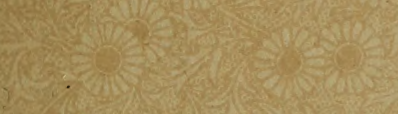

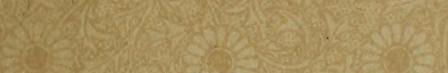

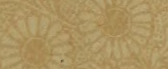

(2)

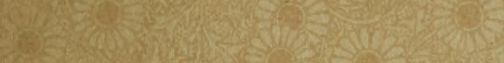

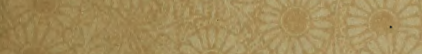

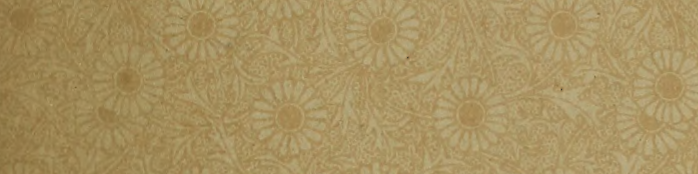

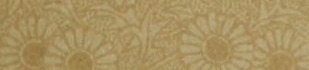

(in)

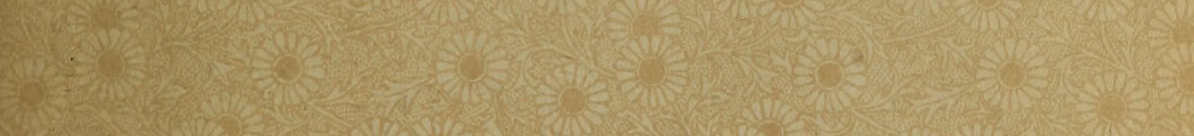

(3)

20.0

Sing

250

(1) $=5$

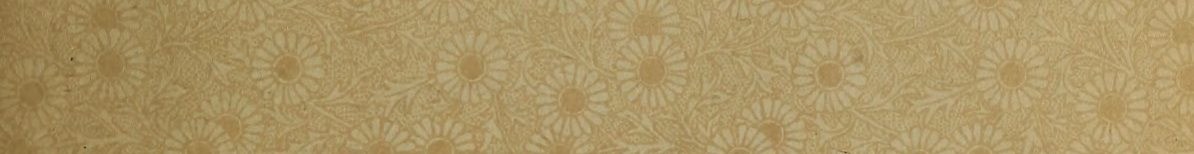

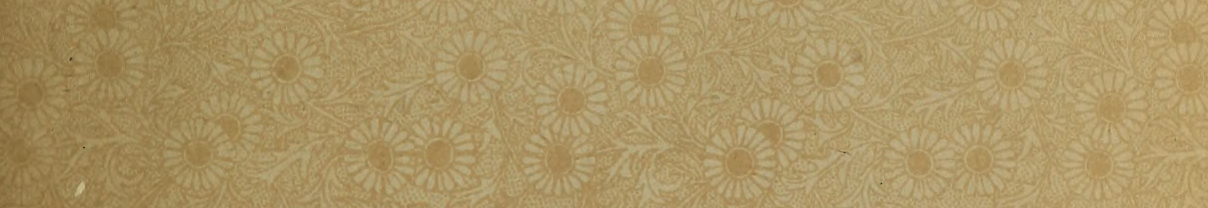

2050

sin

2. $9=$

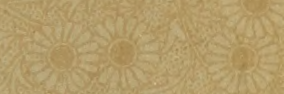

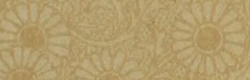

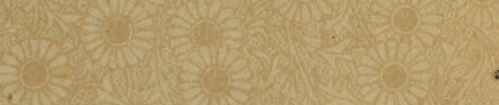

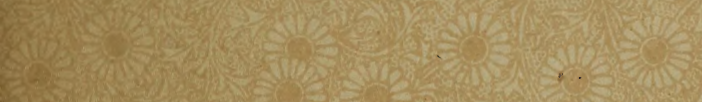

(30.52)

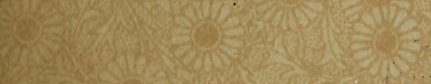

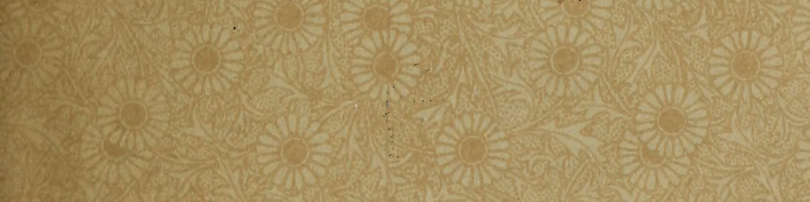

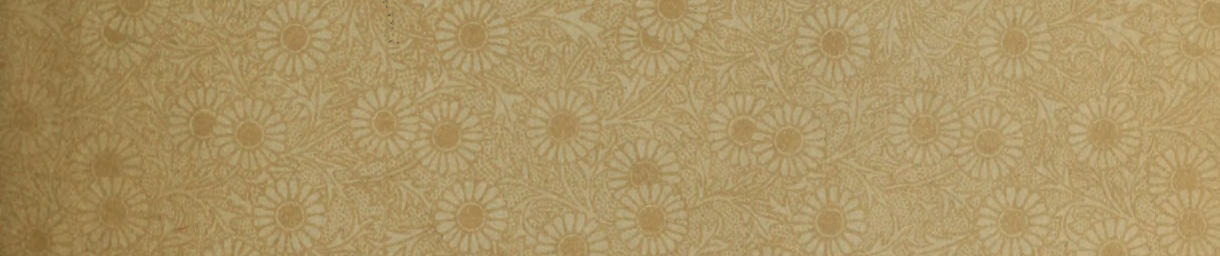

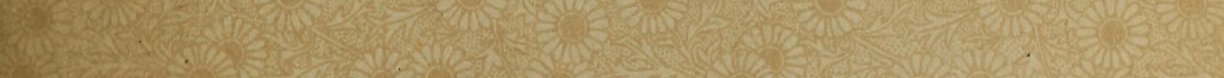

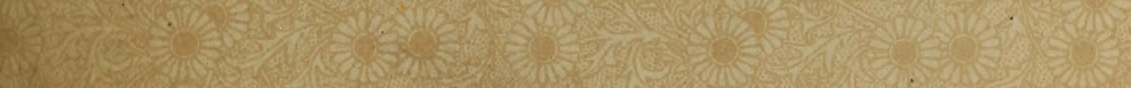

Q10.

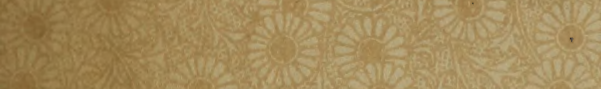

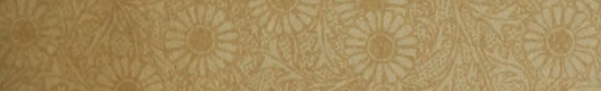

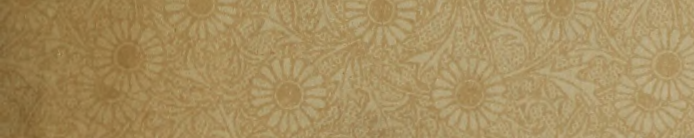

W.

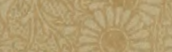

Q70.

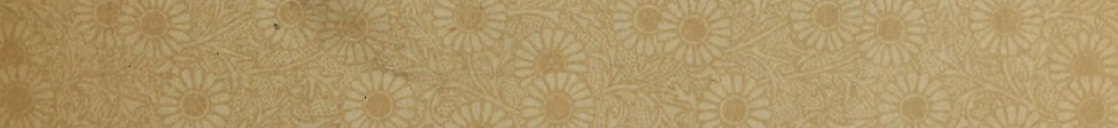

W.1.

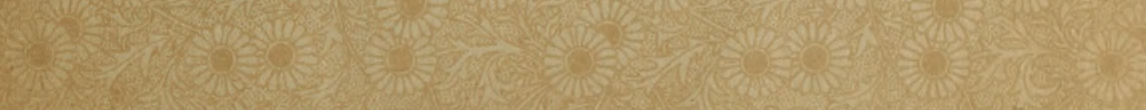

9.5 (2) Q 

4 in 




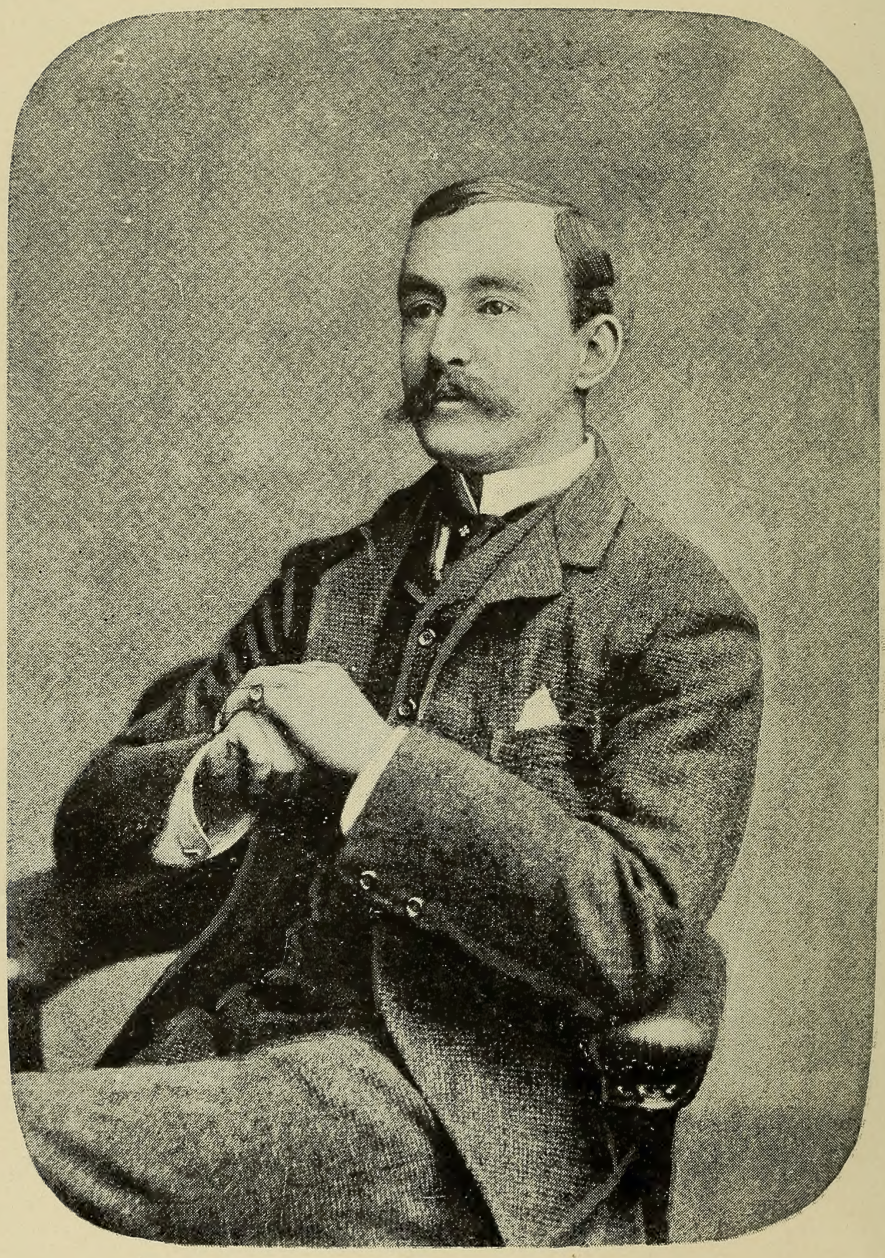

MR. J. S. JAMESON. 


\title{
THE SSTORY OF
}

\section{THE REAR COLUMN \\ OF THE}

\section{EMIN PASHA}

\section{RELIEF EXPEDITION}

\author{
BY THE LATE \\ JAMES S: $\int_{x=0}^{\operatorname{lig} A M E S O N}$ \\ NATURALIST TO THE EXPEDITION \\ EDITED BY \\ MRS. JAMES S. JAMESON
}

ILLUSTRATES BX C. WHYMPER FROM THE AUTHOR'S ORIGINAI. SKETCHES

WITH NEW MAP AND FAC SIMILE LETTER FROM TIPPU TIB

NATURAL HISTORY APPENDIX:

BIRDS, BY R. R. BOWDLER SHARPE, F.Z. S.

COLEOPTERA, BY H. W. BATES, F.R.S.

LEPIDOPTERA, RHOPALOCERA AND HETEROCERA BY OSBERT ȘALVIN, F. R.S., F. DU CANE GODMAN, F. R. S.,

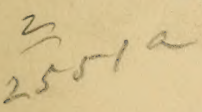

H. DRUCE, F. L. S.

Authorized Edition

\author{
NEW YORK \\ UNITED STATES BOOK COMPANY \\ SUCCESSORS TO \\ JOHN W. LOVELL COMPANY \\ I 50 WORTH ST., COR. MISSION PLACE
}


TROW'

TROW'S

NEW YORK.

$b^{3}$ 


\section{ONTENTS.}

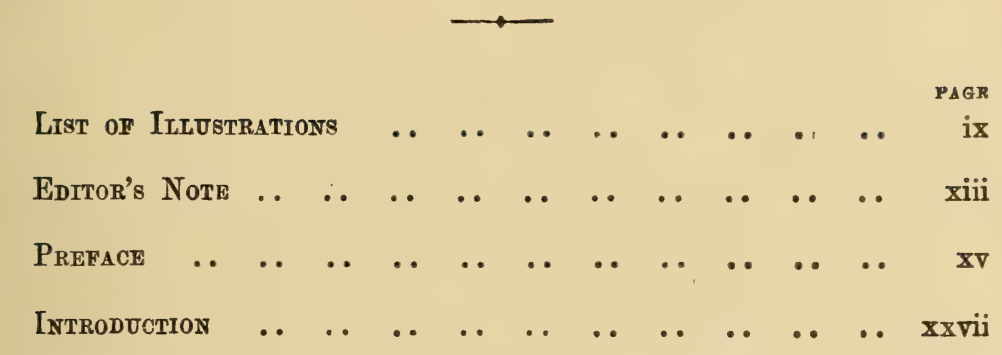

\section{CHAPTER I.}

\section{EXTRACTS FROM LETTERS.}

Joining Stanley and Orficers of the Expedition.-Zanzibar.Tippu-Tib. - War between Soudauese and Zanzibaris. Stories about Tippu-Tib.-Cape Town.-Buying dogs.Stanley refuses carrier for Jameson's collecting-things and big rifle.-Banana Point _.

CHAPTER II.

DIARY.-JOURNEY UP THE CONGO.

1887.-March 19th to April 30th.

Boma.-Ango-Ango.-Mpalaballa Mission Station.-March to Congo da Lemba.-Banza Manteka.-Day's march resembling slave-driving.-Kuilu River.-March to Vombo.-Stanley doing rear-guard.-Barttelot sent on with Soudanese.-Sick chief. - Lutété. - Kindness of the missionaries.-Stanley settling a row.-Inkissi River.-Thief.-Stanley's punishment of chiefs. - Off to shoot hippo. - Difficulty about steamers._Kinshassa.-Ward joins the Expedition .. .. 10 


\section{CHAPTER III.}

\section{THE UPPER CONGO.}

May 1 st to June 7 th.

Start up the Upper Congo.-Scenery on the Pool.-Spiders' webs.

-Mswata.-Bula Matadi._Man proposes, and God disposes.

-Bolobo.-Buffalo hunt.-Jameson is informed that he is to be left at Yambuya.-Looting.-Lukulela.-Scenes with Stanley.-Equator Station.-Dine with Mr. Glave.-Uranga. -Bangala.-Houssas eaten by natives.-Fever.-Upoto.-

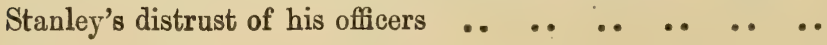

\section{CHAPTER IV.}

\section{OCCUPATION OF YAMBUYA.}

June 8th to July 31st.

Letter to Mrs. Jameson.-Pass burning villages.-Arrival at Aruwimi River.-Conical-shaped huts.-Occupation of Yambuya. -Arrival of the Henry Reed.-Stanley's letter of instructions.-Re-packing bales for Emin.-Barttelot made " bloodbrother" with native chief.-Rations for six months."Beggars must not be choosers."-Stanley's departure.Building boma.-Extraordinary flight of butterflies.-Palaver with natives._- "Collecting" captives.-Natives capture Omari. -Woman escapes._-Uselessness of chiefs.-Gum-copal .

\section{CHAPTER V.}

\section{YAMBUYA CAMP.}

July 27 th to December 31st.

Letter to Mrs. Jameson.-No news of Tippu-Tib.-Promise to protect natives.-Reported arrival of Tippu's men.-Return of deserter from Stanley's party.-His statement.-Arrival 
of the Stanley.-Raid on the natives by Tippu-Tib's people. -Final departure of the Stanley.-First visit of Tippu-Tib's Arabs to Yambuya Camp.-Bonny crosses river to native village.-Abdullah punished for stealing an axe.-Jameson and Ward start for Stanley Falls.-Natives offer to make them princes.-Yalisula.-Arrival at the Falls.-Received by Tippu-Tib.-He explains non-arrival of men.-Native wrestling-match.-Jameson makes Tippu present of big rifle. -Return to Yambuya.-Soudanese punished for theft.Selim bin Mahommed.-Arabs shoot down natives.-Disappointing news from Tippu-Tib.-Rumours of Stanley's return.-Barttelot and Troup start for Falls.-A man possessed by a devil.-Deserter's story.-Bonny's surgical skill. -The Major returns.-Omaha.-Report of a white man coming down river.-Fresh disappointment.-Jaundice.Arabs try to prevent trade with natives.-Burgari Mahommed steals meat from Ward's house.-Living skeletons.- . Three dreams.-Ungungu captured by Arabs.-Christmas Пay. - Fresh trouble between Arabs and natives ... ..

\section{CHAPTER VI.}

\section{YAMBUYA CAMP.}

1888.-January 1st to February 13th.

New Year's Day.-Natives return with captured Arab.-Barttelot and Jameson have palaver with natives.-Natives consult the oracles and inspect white men.-More reports from Stanley's deserters.-Assad Farran sees a whale.-Visit from Arab Venuses. - Sobarus Poggei beetle.-Dead bodies floating down river.-Wretched state of Zanzibaris in camp.-One fifth of entire force lost.-Goliath beetle.-Conversation with Selim Mahommed.-Probable dangers to Mr. Stanley's force from death and desertion.-Arabs attack natives.-Arabs fight among themselves.-Natives steal canoes from Arabs.Anniversary of Jameson's wedding.-More raids on the natives.-Burgari Mahommed at large.-Natives eat captured Arabs.-Burgari captured, and shot .. $\quad . . \quad \ldots \quad \ldots 177$ 


\section{CHAPTER VII.}

\section{KASSONGO.}

February 14th to April 26th.

Start with the Major for Stanley Falls.-Meet a number of men from Kassongo.- Singatini.--Interview with Nzige.-No news of Stanley.-Hunting for game in the jungle.-Letter from Yambuya Camp.-Shock of earthquake.-Anxious waiting.-Sketching regarded as sorcery by Mahommedans. -Fever.-Letter from Troup.-Barttelot arranges to send Jameson to Kassongo.-Letter to Mrs. Jameson.-Start for Kassongo. - Yankéwé. - Wild-looking natives. - Wamanga Rapids.-Meet men from Kassongo.-Kibongé.-Jameson writes to Stanley.-Kapruta.-Assad Farran hunts for onions. - Kasuku. - Kindness of Arab chief. - Poisoned arrows.-Riba-Riba.-Bhooting hippos.-Three great chiefs. Tippu-Tib's names.-Dangerous natives.-Head men fear a night attack.-Quanga.-Nyangwé.-Kindness of Arabs.Arrival at Kassongo.-Tippu-Tib.-Fertile country.-Salem Masudi. - Tippu agrees to provide men. - Sketching.Jameson writes to Mr. Mackinnon,-Letter to Mrs. Jameson. -Arab customs.-Conversation with Tippu-Tib.-Muni

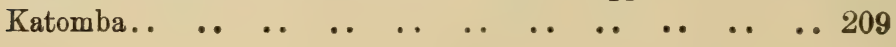

\section{CHAPTER VIII.}

\section{RETURN TO YAMBUYA.}

April 27th to June 10th.

Start back for Yambuya.-Delay at starting-point on the river.Thirty-four of Tippu's men run away.-Tippu and Cameron. -Chiefs arrive to bid farewell to Tippu-Tib.-Mirésa.Tippu's conversation in Swahili.-Two canoes sunk.-A narrow escape.-Assad Farran's uselessness.-Riba-Riba.Wacusu dance.-Cannibals.-Conversation with Tippu.- 
Muni Somai.-Kibongé.-Chimpanzees.-Tippu's account of a journey with Stanley.-Stanley Falls.-Barttelot's interview with 'Tippu-Tib._-Start for Yambuya.-Troup sends in application to be sent home.-Hard at work reducing loads. -Caps turn out to be bad.-Letter to Mrs. Jameson .. . .

\section{CHAPTER IX.}

\section{THE LAST MARCH.}

\section{June 11th to August 8th.}

Final start from Yambuya Camp.-Manyémas loot the Camp.Abdullah's village.-Muni Somai has trouble with Manyémas. Fourteen men desert.-Jameson returns to Yambuya in search of missing loads.- Selim Mahommed guarantees to recover loads and rifles.-More desertions.-Small-pox.Muni Somai goes in search of deserters, and is fired at.Theft of beads.-Trouble with the Muniaparas.-A long day of disaster.-Major Barttelot returns to Stanley Falls, leaving Jameson in command.-Fresh trouble with Manyémas.Jameson arrives at Ujéle.-Takes over command from Bonny. - Muni Somai utterly useless as a commander.-Mquangandy.-Letters from Barttelot ordering whole force to proceed to Unaria.-War amongst head men.-A night fusillade. - Bonny loses his way.-Muni Haméla hands over to Jameson 40,000 Enfield caps.-News of Major Barttelot's death.-Arrival at Unaria.-Interview with three head Manyémas.-Jameson offers reward for Sanga's arrest.Jameson proceeds to Stanley Falls.-Finds the Manyémas camped in forest.-Meets Muni Somai.-Nasoro Masudi warns Jameson that Manyémas have threatened to shoot him.-Arival at Stanley Falls.-Interview with Tippu.Muni Somai tried and convicted of desertion.- - Letter to Andrew Jameson.-Letter to Mrs. Jameson.-Rachid declines to accompany Jameson.-Tippu volunteers to do so for $£ 20,000$. - Trial and death of Sanga._Jameson determines to go to Bangala in order to obtain reply from Committee.Mr. Stanley's letter to Jameson 


\section{CHAPTER X.}

\section{LAST SCENES.}

August 9th to August 18th.

Last Journey.-Mr. Ward's diary.-Death $\ldots$. .

\section{APPENDICES I.-XI.}

Facsimile of Agreement written by Mr. Jameson forms Appendix IX.

Facsimile of Tippu-Tib's letter faces translation on page 391.

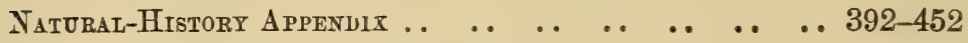

Explanation of MAP of Upper Congo $\ldots$. .

Map of River Congo, trom Stanley Falls to Kassongo (end of volume). 


\section{LIST OF ILLUSTRATIONS.}

Portrait of the late JAMes S. JAMESON

PAGR

White

$\begin{array}{lllllllllllll}\text { Slave Girl } & \ldots & \ldots & \ldots & \ldots & \ldots & \ldots & . & \ldots & \ldots & \ldots & \ldots & 9\end{array}$

$\begin{array}{lllllllllllll}\text { Peter's Fetish } & \ldots & \ldots & \ldots & \ldots & \ldots & \ldots & \ldots & \ldots & \ldots & \ldots & 10\end{array}$

$\begin{array}{llllllllllllll}\text { Boma } & . & \ldots & \ldots & \ldots & \ldots & \ldots & \ldots & \ldots & \ldots & \ldots & \ldots & \ldots & 11\end{array}$

$\begin{array}{lllllllllllll}\text { Ango-Ango } & \ldots & \ldots & \ldots & \ldots & \ldots & \ldots & \ldots & \ldots & \ldots & \ldots & \ldots & 12\end{array}$

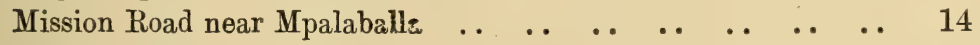

$\begin{array}{llllllllllll}\text { Native Justice } & \ldots & \ldots & \ldots & \ldots & \ldots & \ldots & \ldots & \ldots & \ldots & \ldots & 22\end{array}$

Native Method of Bird-catching $\ldots \begin{array}{llllllllllll} & \ldots & \ldots & \ldots & \ldots & \ldots & \ldots & 23\end{array}$

Irory War Horn . .

Diagram of Spiders' Webs $\ldots \begin{array}{llllllllll} & \ldots & \ldots & \ldots & \ldots & \ldots & \ldots & \ldots & 36\end{array}$

Head of Native of Mswata $\ldots \begin{array}{lllllllll}\text { He } & \ldots & \ldots & \ldots & \ldots & \ldots & \ldots & \ldots & 37\end{array}$

$\begin{array}{lllllllllllll}\text { Kwamouth } & \text {. } & \ldots & \ldots & \ldots & \ldots & \ldots & \ldots & \ldots & \ldots & \ldots & \ldots & 40\end{array}$

Fisherman's Hut ..

$\begin{array}{lllllllllllll}\text { Tattooing } & \ldots & \ldots & \ldots & \ldots & \ldots & \ldots & \ldots & \ldots & \ldots & \ldots & \ldots & 46 \\ \end{array}$

$\begin{array}{llllllllllllll}\text { Shields } & \ldots & \ldots & \ldots & \ldots & \ldots & \ldots & \ldots & \ldots & \ldots & . & \ldots & 58\end{array}$

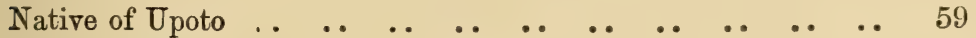

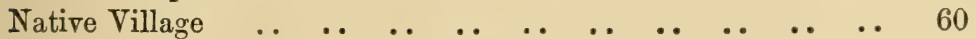

Native Chief in top hat $\quad \ldots \quad$. .

$\begin{array}{llllllllllll}\text { Spears and Shield } & \ldots & \ldots & \ldots & \ldots & \ldots & \ldots & \ldots & \ldots & \ldots & 66\end{array}$

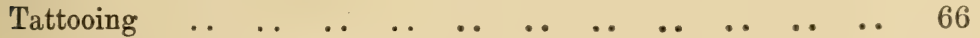

Entrenched Camp, Main Street $\ldots \begin{array}{llllllllll} & \ldots & \ldots & \ldots & \ldots & \ldots & \ldots & 69\end{array}$

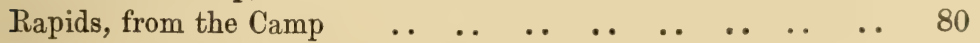

$\begin{array}{lllllllllllllll}\text { Idol } & \ldots & \ldots & \ldots & \ldots & \ldots & \ldots & \ldots & \ldots & \ldots & \ldots & \ldots & \ldots & 84\end{array}$

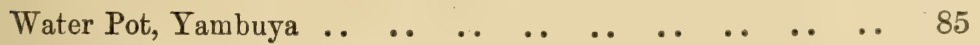

$\begin{array}{lllllllllllll}\text { Native Jar } & \text {. } & \ldots & \ldots & \ldots & \ldots & \ldots & \ldots & \ldots & \ldots & \ldots & \ldots & 92\end{array}$

Wataku Box ..

Yambuya.-View looking down river from Entrenched Camp 98

Plan of Entrenched Camp, Yambuya $\quad \ldots \quad \ldots \quad \ldots \quad$. . . . 101

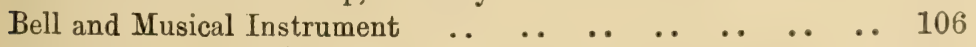

$\begin{array}{llllllllllllll}\text { Matajabu } & \ldots & \ldots & \ldots & \ldots & \ldots & \ldots & \ldots & \ldots & \ldots & \ldots & \ldots & 111\end{array}$

Native Drinking-bowls $\quad \ldots \quad$.

Chief's Grave, Yaweeko $\quad \ldots \quad$.

$\begin{array}{lllllllllllll}\text { Stanley Falls } & \ldots & \ldots & \ldots & \ldots & \ldots & \ldots & \ldots & \ldots & \ldots & \ldots & 121\end{array}$ 
A Champion ..

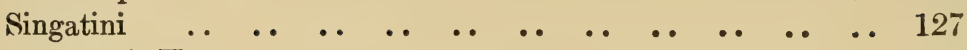

Elephant's Head .

$\begin{array}{lllllllllllll}\text { Yambau } & \ldots & \ldots & \ldots & \ldots & \ldots & \ldots & \ldots & \ldots & \ldots & \ldots & \ldots & 134\end{array}$

Selim bin Mahommed .

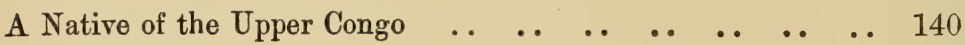

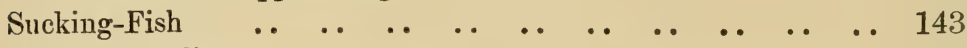

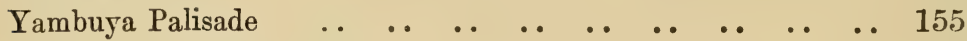

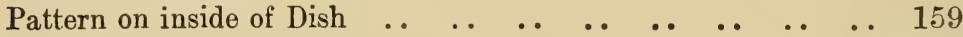

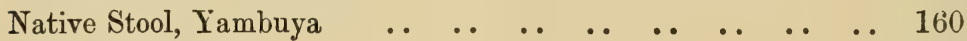

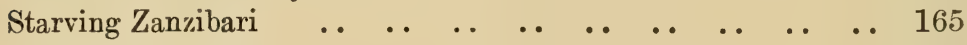

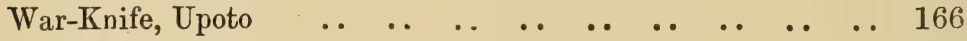

Native Method of Bird-catching . .

Mr. Jameson, drawn by H. Ward .

My Home $\quad$.

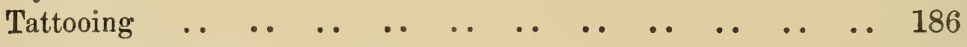

Cowrie Head-dress $\quad \ldots \quad$.

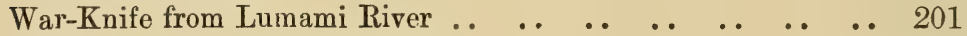

Wataku Pottery . .

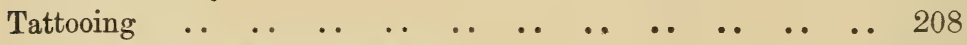

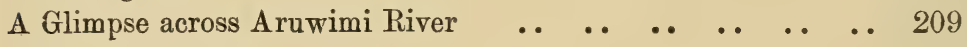

Small War-Knife .

Slave Girl .

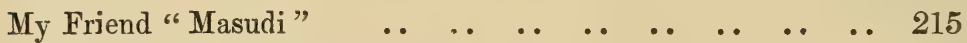

"Mashukulu"

"Curry-Eyes"

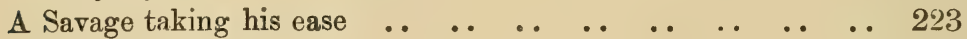

My Bow Paddle

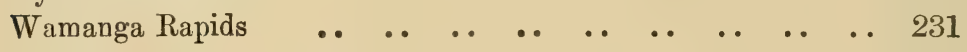

Kibongé $\quad \ldots \begin{array}{llllllllllll} & \ldots & \ldots & \ldots & \ldots & \ldots & \ldots & \ldots & \ldots & \ldots & \ldots & 233\end{array}$

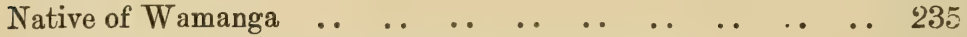

"A long shove, and a strong shove, and up she goes" .. .. 238

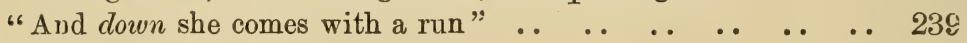

Knife from Kassongo . .

“Lukutula" . .

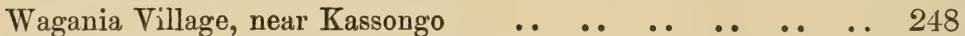

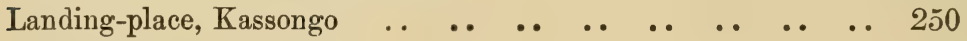

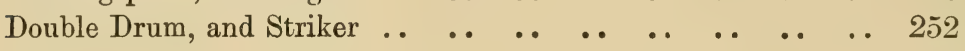

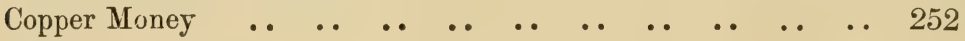

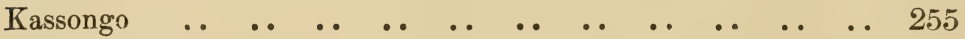

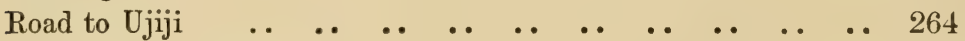

Native of Unyanembi . . 
PAGK

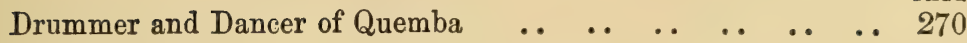

$\begin{array}{llllllllllll}\text { Lamba-Lamba } & \ldots & \ldots & \ldots & \ldots & \ldots & \ldots & \ldots & \ldots & \ldots & \ldots & 271\end{array}$

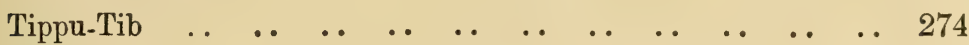

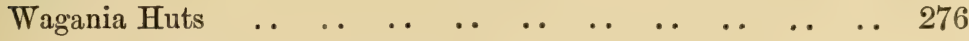

"Nothing like Independence"

Native Woman in Market . .

One of Tippu-Tib's Gun-bearers .

$\begin{array}{lllllllllllll}\text { Longa-Longa } & \ldots & \ldots & \ldots & \ldots & \ldots & \ldots & \ldots & \ldots & \ldots & \ldots & 283\end{array}$

$\begin{array}{llllllllllll}\text { Muni Somai . . } & \ldots & \ldots & \ldots & \ldots & \ldots & \ldots & \ldots & \ldots & \ldots & \ldots & 295\end{array}$

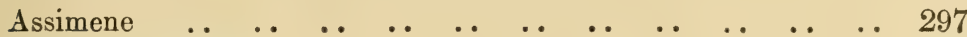

$\begin{array}{lllllllllll}\text { Bunch of Plantains } & \ldots & \ldots & \ldots & \ldots & \ldots & \ldots & \ldots & \ldots & \ldots & 299\end{array}$

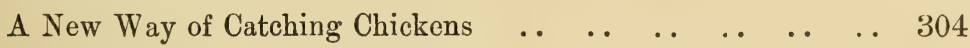

River Scene ..

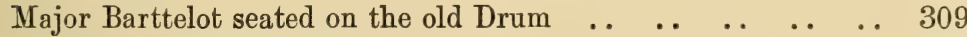

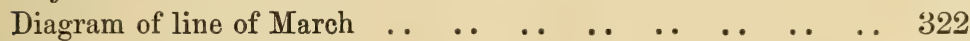

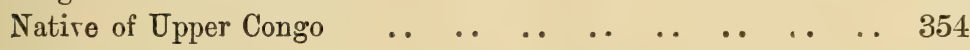

A Canoe Journey . .

The House in which Mr. Jameson died at Bangala $\quad \ldots \quad$. . . 370

$\begin{array}{lllllllllll}\text { The Last Journey } & \ldots & \ldots & \ldots & \ldots & \ldots & \ldots & \ldots & \ldots & \ldots & 372\end{array}$

Photograph of Grave $\quad \ldots \quad$. .

Native Vase .

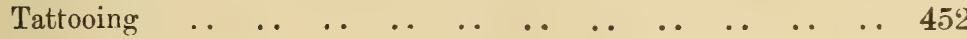

War-Knife . 


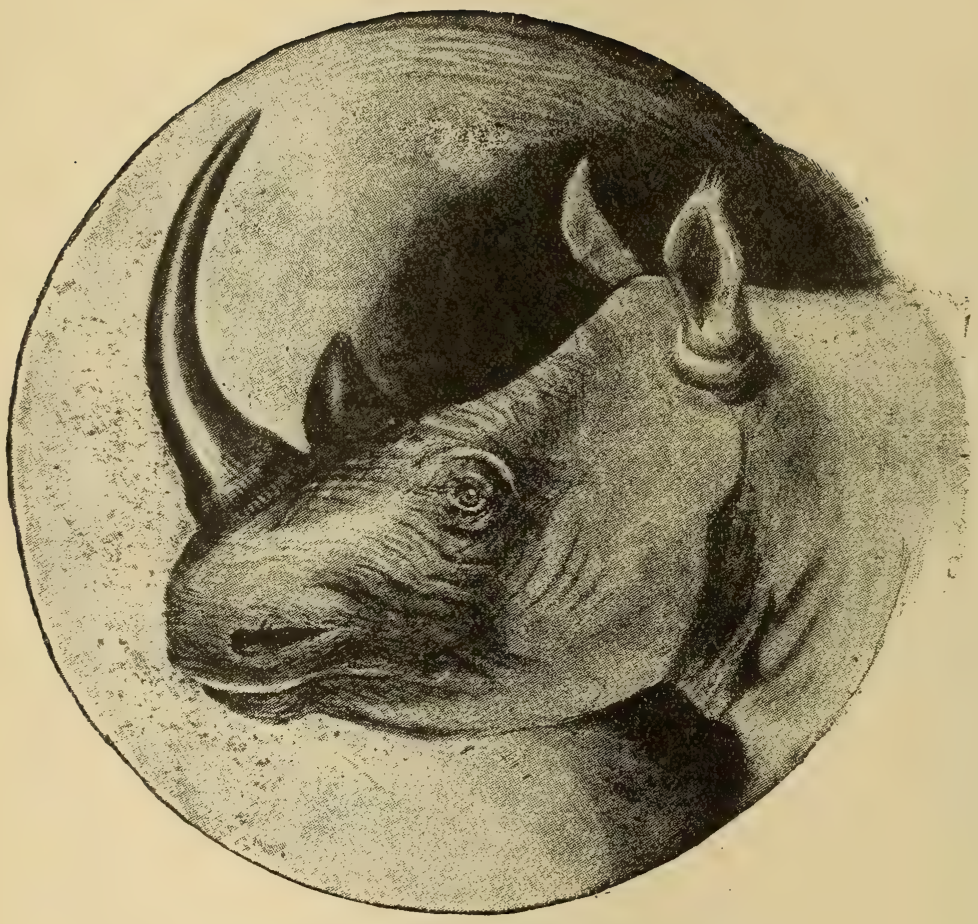

White or Square-Modthed RHInoceros.

[The above was mounted, together with the larger portion of the late Mr. J. S. Jameson's Collection, by Mr. Rowland Ward, F.Z.S.] 


\section{EDIT0R'S NOTE.}

These letters and diaries were not originally intended for pub. lication; but it has been thought that they may be read with interest by many, and that, having regard to the accusations recently made against the leaders of the Rear Column, it is desirable that they should be published in what is practically their original form, with only such alterations as their private nature required.

In the preparation of this work, I have throughout had the advantage of the constant advice and sympathetic help of my brother-in-law, Mr. ANdREW JAMEson.

I have received much kindness from Mr. Herbert W who sealed and sent home those of Mr. Jameson's diaries and papers which he brought with him to the coast, and gave me several interesting sketches of his own for insertion in this volume. A still deeper debt of gratitude is due to him for the tender solicitude with which he nursed my husband during those last hours at Bangala.

I wish further to express my hearty thanks to several of my husband's friends who have rendered me valuable assistance by preparing the scientific parts of this book, contained in the Appendices.

To Mr. R. Bownler Sharpe, F.Z.S., I am indebted both for a sketch of Mr. Jameson's career as a naturalist, and for his very valuable paper on the birds of the Aruwimi; and 
to Messrs. H. W. Bates, F.R.S., Osbert Salvin, F.R.S., F. DuCane Godman, F.R.S., and Herbert Druce, F.Z.S., my thanks are most deservedly due for the care they have bestowed upon the Entomological portion of the Appendices. It is a matter of deep regret that only a remnant of the collections made by Mr. Jameson on the Aruwimi ever reached my hands.

The Rev. J. M. Ropwelu has kindly rendered the translatiou of the Arabic letter from Tippu-Tib, and the Rev. Canon J. J. CARMichael, LL.D., has merited my warmest thanks for his valuable help.

Finally, I would acknowledge the artistic skill with which Mr. Charles Whymper has reproduced the spirit of my husband's sketches, and the attention and courtesy shown me throughout by Mr. R. H. Porter in the publication of this book.

December 12th, 1890 .

ETHEL JAMESON. 


\title{
PREFACE.
}

\author{
"LET THERE BE LIGHT." \\ (Mr. Stanley's motto for 'In Darkest Africa.')
}

\footnotetext{
"Cood name, in man and woman, dear my lord,

Is the immediate jewel of their souls :

Who steals my purse, steals trash: 'tis something, nothin

'Twas mine, 'tis his, and has been slave to thousands;

But he, that filches from me my good name,

Robs me of that which not enriches him,

And makes me poor indeed."
}

NeVer was the truth of these lines more vividly illustrated than in the case of the writer of this Diary. The dream of his early life was to add his name to the long roll of those who have striven for some good and useful object. At length the occasion offered itself, as he believed, in the Expedition in which he lost his life; to join it he sacrificed his wealth, his home, his family joys and comfort, to live "laborious days," and find some scope for the pent-up energies within him. He went to his work with a strong zeal and lofty sense of right, did his duty with unselfish heroism in the face of treacheries and overwhelming difficulties, and died a martyr to the cause for which he had so nobly laboured. What is his reward? He is sought to be made the scapegoat of his Commander's illjudgment and neglect! Charges of disobedience, disloyalty, forgetfulness of promises, desertion, cruelty, cowardice, and murder are brought against him, on the authority of discredited liars, by a man who is driven to his wits' end to sustain his 
reputation against serious imperative accusations. The charges are brought against Jameson when he is in his grave, when the common usage of humanity suggests silence, and when a man of a noble and honourable cast of nature would altogether prefer to lie under an unjust suspicion rather than asperse and defame the voiceless dead. This, however, is not the course which Mr. Stanley has followed. Lest any tinge of discredit should rest on his own fame, he has striven to destroy that of others who are powerless to reply. Upon his remarkable Expedition into Central Africa there rests one dark blot-the disastrous fate of his Rear-Guard, and Mr. Stanley is not a man to admit that he can make mistakes : no blame of any sort can be allowed to sully his record; if the Rear-Guard was wrecked, it was, of course, because his skilful plans and careful orders were neglected and disobeyed; no statement, however desperate and imaginary, will be kept back if only it serve to sustain his egotistical demands upon the credulous admiration of his readers; and so, apparently unconscious of the possibility of contradiction, and fully conscious of the fact that the men whom he defames are dead, he casts the whole weight of blame upon their helpless heads. The first answer to Mr. Stanley's charges comes from Captain Walter Barttelot; and it is a crushing one. His reply to this is a flood of malevolent gossip as wicked as it is unproven, in which good care is taken to make the least serious charges against the living, the gravest and most defamatory against the dead.

The amount of reliance that can be placed upon Mr. Stanley's accuracy is an easy question to determine. He suffers even abnormally from that shortness of memory which is, according to a well-known proverb, said to be characteristic of a certain class of people. Thus, on November 8th, 1890, he denies the truth of statements respecting the Rear-Guard made by himself in a book published in the month of June of that self-same year. In Volume I. of 'In Darkest Africa,' page 478, after giving a history of all the information he could get from Mr. Bonny, he says, "I have never' obtained further light from Mr. Bonny, though at erery leisure hour it was a constant theme" (and indeed, from all accounts, it appears that Stanley spared no pains to get from him all he 
knew). In the beginning of Vol. II. we find an account of the examination of witnesses from amongst the survivors of the Camp at Yambuya, and the conclusions arrived at are plainly stated-the deaths at Yambuya were due to the manner in which the men cooked their food, among the members of the garrison there were many thieves, and punishments were numerous, but were never inflicted except on those who deserved them. All this appears in the month of June 1890. Then Captain Walter Barttelot's book is published, and Mr. Stanley must needs mend his hand, and so on the 8th of November, 1890, he comes forth with fresh allegations against his officers, and tells a tale quite different from that which he had already published in 'In Darkest Africa.' His first statement about the November story casts the gravest doubt upon it, for he says he heard it all at Yambuya in August 1888 (Banalya, a place ninety miles from Yambuya, must be what is meant, as $\mathrm{Mr}$. Stanley never returned to Yambuya, but the mistake, whether intentional or not, is very convenient for him, and, curious to say, he has not yet corrected it). A considerable part of the November story comes from the lips of Mr. Bonny, but if Mr. Stanley heard it all in August 1888, how could he, although omitting all mention of it in 'In Darkest Africa,' write that he had inserted therein all he had heard from Mr. Bonny? Was, then, the statement published November 8th, 1890, that which was told him by Bonny in August 1888, or was it not? If it was, then the above statement by Mr. Stanley on the subject, published in 'In Darkest Africa,' was not true; if it was not the story told him in 1888, then Mr. Stanley's account of the real reasons which led him to condemn his officers, given in the most public and final manner, is absolutely false. On the second horn of this dilemma Mr. Stanley is inexorably fixed, for Mr. Bonny, in his statement to the 'Times,' declares that he told these things to Stanley for the first time on Sunday, October 26th, 1890, and not at Banalya, on the Congo, in August 1888. That is to say, the only justification which Mr. Stanley, when put on his defence, produces for the condemnation of his officers in 1888, is hearsay evidence procured by him in 1890 . 
It is worth while to expatiate a little upon this bold attempt of Mr. Stanley's to mislead people into believing that the evidence upon which he grounded his charge was obtained from a general inquiry into the matter made by him upon the Congo in 1888, and not upon the particular evidence of three witnesses obtained in 1890. For instance, he talks on this wise when introducing to public notice his charges of November 8th, 1890 :"The sentence of my report with which Mr. Barttelot finds fault, and in which I censure the commander of the Rear Column, was written in August 1888, two days after I had met Mr. Bonny and the emaciated remnant of the Rear Column. On learning then the details of what had trarspired during my absence, I wrote that the irresolution of the officers, the neglect of their promises, and their indifference to the written orders I gave them, had caused this woful collapse. You ask me to justify that censure. It will probably be the best way, in order to satisfy any legitimate interest in this question, to tell the story as I heard it at Yambuya, because in that way the public will better understand the shocking effect it had on me when, hastening to their relief, I was met by the following revelations*. And here comes the point. You will find in the log of my book 'In Darkest Africa,' even in its abridged form, that the men of the Rear Column came forward to present their complaints; and much of the following information I obtained from Mr. Bonny, the Zanzibaris, the Arabs, and the Manyéma." Then follow the statements which Stanley says were at that time made to him, the very first of them being the poisoning story, with which Mr. Bonny's most exciting statement has since made us familiar. But alas! for the accuracy of Mr. Stanley, Bonny informs us that he told Stanley that tale on Sunday, October 26th, 1890, two years and two months after the date which Mr. Stanley fixes for its first recital. The fact is that Stanley deliberately endeavours to lead the public to believe that the evidence upon which he bases his foulest charges against the officers of the Rear-Guard was obtained by him in August 1888, when, beyond yea or nay,

* The italics are my own.-A. J. 
he never got it till October 1890, so far as Bonny is concerned, and Assad Farran only made his statement to him in Cairo in March of the same year.

In respect of the cannibal story, a reader of Mr. Stanley's statement of November 8th, 1890, would conclude that at Yambuya in 1888, an eye-witness of the scene drew up a statement in his own handwriting in the presence of witnesses; that this statement was shown to Mr. Stanley there, and is the one he publishes; that the evidence taken on the subject by the Congo Free State authorities was also shown to him there, and that these facts were the principal reasons for the letter which he says he wrote to Jameson, but which has never since been seen, or even heard of, until now mentioned by Mr. Stanley himself. On the 10th November, 1890, however, he publishes another statement, in which he tells us that Bonny told him the story, that a Zanzibari who had been at Stanley Falls corroborated it, and that he was told the Congo Free State authorities intended arresting Jameson. Where has the eye-witness gone to, and the evidence taken by the authorities which he relied on before? The eye-witness in this second statement is revealed in Assad Farran, and the evidence taken before the authorities dwindles to the story told him about their intentions. But how do the two statements look when read together? Was not the first a plain attempt to make it appear that evidence obtained at a subsequent date was tendered to him at Yambuya, and does the second statement not show that Stanley's real "witnesses" were Bonny and Assad Farran? Does not Stanley publish the story Assad Farran tells him in 1890, and Bonny vouch for the truth of it, only placing it all in the mouth of Jameson himself?

It is absolutely necessary to nail Mr. Stanley to names and dates. He wants the public now to believe, contra his own already expressed statement, contra the inexorable logic of proven facts, that he was acquainted in August 1888 with all the charges of his outrageous indictment of November 8th, 1890, and that he then obtained the proofs of them from various witnesses among the survivors of the Rear-Guard, from Bonny, Arabs, Zanzibaris, and Manyéma, and that, on the information 
obtained in those two days of inquiry, he wrote his condemnation of his officers.

"I had a grandmother, she had a donkey,

And when that donkey looked her in the face,

His face was sad, and you are sad, my public."

In the enthusiasm of an evanescent hero-worship the British public sinks occasionally for a time below the level of its average sagacity It gazes with a sweet confiding affection upon the masculine idol of its temporary adoration; but woe to him who would presume upon the constancy of that love; it is too fickle and fastidious to have time or temper for lovers' quarrels and their proverbial results. By an inevitable reaction, it is certain soon to become as suspicious and exacting as it was once full of loud and intolerant confidence; the more so, if it comes to think that there is any attempt to trifle with its amiable credulity. This is what Mr. Stanley will soon begin to feel. The idea is already abroad that he is seeking to delude the public judgment, especially in the way of insinuating that he is embarrassed by the number of his witnesses, when, in point of fact, he has produced but three-Bonny, Assad Farran, and Saleh ben Osman, his own Zanzibari servant. That it is perfectly possible for Mr. Stanley to produce many more witnesses of the type of Saleh ben Osman no one can doubt who is acquainted with the real nature of native evidence of this description; and if the Congo Free State authorities had any wish to adopt his peculiar line of conduct, it is equally certain the application of the "questioning" system would be attended with satisfactory results.

But in what a light does all this place the author of 'In Darkest Africa'! Is it the pure light which shines round a man striving to make the truth known? or is it the baneful gleam of those darksome shades in which Mr. Stanley tells us a vast crop of lying is germinated?

He deals with his evidence like the Irish planners of an alibi. He changes the date to suit the necessities of his case; with an astounding unfairness, he condemns his officers first, and tries them afterwards. Having failed in his efforts at the time and on the spot to obtain from Bonny and the coloured witnesses 
sufficient condemnatory evidence against those whom he had deserted and misled, he strove to work up a case against them by straining the obvious sense and purport of his orders; by twisting and misrepresenting the writings of Barttelot and Jameson, so as to condemn them, if possible, out of their own mouths, then silenced for ever; and even by daring to break open the seals upon Jameson's private diary and papers.

Never, in the history of slander, were charges so injurious as those levelled against the officers dependent upon more worthless testimony. It is incomprehensible how any man, with the barest respect for his reputation, could make use of such instruments as two of Mr. Stanley's witnesses. Assad Farran, the prime concocter of these shameless inventions, is a man who (as he himself puts it) would, if he were only questioned enough, "give all the information his examiners wanted;" a man who, when he was asked by the Secretary of the Emin Pasha Relief Committee, Mr. MacDermott, why he had told stories about the officers which he admitted were exaggerated and incorrect, replied " that he thought Major Barttelot and Mr. Jameson had not treated him well, that he had been sent away without clothes or food, and his feeling was bad;" and then he added, "that when those to whom he made his statement on the Congo kept questioning, questioning, and would not let him alone, he had to say all they wanted him to say."

This is the man who, in March 1890, first told Mr. Stanley some of the stories which that gentleman stated he heard on the Congo in 1888. Nor is Saleh ben Osman, Mr. Stanley's Zanzibari servant, a more reliable witness than the pitifully discredited Assad Farran. The statement of this wortly, who does not pretend to be an eye-witness of anything, is transiated by Mr. Glave, and is a most extraordinary document, bearing its own refutation on its face. At the best it is a mere réchauffé of what he had heard concerning these events from Zanzibaris, Arabs, Manyémas, and Soudanese, and if the information derived at first hand from such witnesses is unreliable, what does it become when filtered through the head of a Zanzibari servant two years after he had heard the tales he tells? 
No one knows better than Mr. Stanley the utter untrustworthiness of these Zanzibaris, and the ease with which they may be made to say anything by "questioning, questioning." Even his own character is not safe in their hands, for he is accused by one of the tribe of ordering a live baby to be drowned in the Congo (vide page 111 in Diary), and the Zanzibari who made this statement had no apparent motive for telling a lie, which can hardly be asserted about Mr. Stanley's most useful witness.

Mr. Stanley is certainly unfortunate in being placed in a position where he must stake his credit on the veracity of such men as these. He has only produced three witnesses at the best : two of them have been proved unworthy of the slightest belief, and the third, his pièce de résistance, Mr. Bonny, is far from being as satisfactory as the cause of justice would require.

Bonny is an ex-sergeant of the Army Hospital Corps, and was a paid servant of Mr. Stanley's, who styles himself his employer. Our trust in his accuracy of recollection and intelligent appreciation of facts is somewhat enfeebled, when we remember that Mr. Stanley informs us how Bonny told him that Barttelot, in view of his possible death, had left to him (Bonny) the succession in command over Jameson, an absurd misapprehension, to say the least of it, complicated moreover by a most unpleasant controversy respecting the genuineness of certain orders produced by Bonny, and the alleged suppression of those he was bound to obey. There seems to be a certain amount of inaccuracy about Mr. Bonny. He is unable to adhere to one story, even in the case of such an important incident as that of Major Barttelot's murder, and varies his description of it, and the circumstances attending it, some three or four times in most vital particulars. But all the same, we are requested to believe that Mr. Bonny is a rare being, gifted with a sympathetic attractiveness that draws towards him the inmost confidences of all those with whom he comes in contact. According to Mr. Stanley's account, he must have been " fatherconfessor" to all in the Camp, for to him, without any sigillum confessionis, men appear to have confided the darkest records and intentions of their lives. 
The terrible Barttelot reveals to him his intention to poison Selim Mahommed; tells him that he is getting his brother so to take care of Troup that he will tell no tales at home ; imparts to him plots to start expeditions independent of Stanley, and at last even begs of him a medical certificate and leave to retire from the Expedition!

No conditions of existence such as those which apply to ordinary human beings seem able to make such things credible; and if reliance is to be placed on this part of Stanley's case, it can only be justified by a belief in some intense magnetic or hypnotic influence exercised by Bonny on those around him.

With all the elaboration, care, and publicity which Mr. Stanley has given to the evidence of these three witnesses, he has failed to produce a statement from their mouths which justifies his charge that "the Rear Column was wrecked by the irresolution, the neglect of promises, and the indifference to written orders of the officers he left in command of it," and he has not lightened in the slightest degree the load of blame under which he himself at present lies.

One turns, as in search of a great relief, from this story of self-seeking, unfairness, and deception, to the record of a noble and unselfish life. It must indeed be a strongly prejudiced mind that can read this Diary without being impressed by the sense of the immediate presence of a gentle, loving, and sympathetic nature, keen and true of observation, quick-willed and suggestive, with a pleasant humour and a gallant heart. A man's diary is a self-revelation. His true personality is as certain to present itself continually as the refrain in a theme of music. No man lies to himself, when night after night, as his work is done, he sits down to write out the story of his life from day to day; and the life which Jameson reveals to us in his Diary is one whose keynote is duty, kindliness, and hard work. " Little did I think," he writes to Mrs. Jameson a fortnight before his death, "when I spoke to you of my feelings of duty, that I should ever be placed in such a position as I now am, in which all that I feel for you and for our little ones cries out against 
what I must do as an officer of this Expedition. With one word or even a show of weakness on my part, I could stop the whole Expedition, which seems fated to meet with nothing but reverses, and return to you. But God knows such a thought never entered my heart, although I could easily defend such an action on my part. The first thing that flashed across my brain on finding myself so placed was your father's favourite text, 'Know, $\mathrm{O}$ man, that to know and love justice and do the thing that is right, that shall bring a man peace at the last;' and you will see what a help every word in that verse has been to me now."

On the same day he writes to his brother, "Whatever happens to me, old man, I tried to do my duty to this blessed Expedition; and many a time, when I have thought of Ethel and home, I would have liked to chuck the whole thing up when there were plenty of officers to take my place." A brave resolve to go through with what he had undertaken sustained him to the last in the face of dreadful odds. The neglect and unfairness of the Commander of the Expedition-who, as he says, "it is evident takes the word of the Zanzibaris before that of the white men," - the cruelty, dishonesty, treachery, and . falsehood of the Arabs with whom he had to deal, the miserable conditions of existence growing worse from day to day, the hope deferred, the bitter consciousness that the slanderer was at work to defame his honour,-however these irons cut into his soul, they dimmed not that gallant sense of duty, which most touchingly displayed itself as a ruling passion, strong in death, when, as he breathed his last, with husky voice he answered to the faintly-heard roll of the drums, "They are coming; they are coming. Let us stand together."

Numerous and suggestive also are the indications of his kindliness of heart in his anxieties about the sick people in the Camp-African and English, and the grief he so evidently feels at being utterly unable to give them the help they so sorely need. His pity for the natives, too, and the efforts that both he and Barttelot made to save them from the Arabs; the regret he expresses at the inevitable punishments and floggings, all indicate a kind, helpful, and unselfish nature. "Poor 
old Derrier Moussa, a Somali," he writes, "who has been our cook for the greater part of our journey, died to-day. $\mathrm{He}$ has been ill for a long time. It is horrible to watch these men slowly dying before your face, and not be able to do anything for them." "Poor Alexander, one of the Soudanese interpreters, died to-day; he has been ill for a long time." "It is a sad, sad sight to see men dying round you every day, and not be able to put out a hand to save them. Without a single fight we have lost close upon seventy men out of our small force, and there are many more who, I am sorry to say, will never leave that Camp. And now good night and good-bye. Kiss the little ones for me, and may God have you all in his safe keeping."

As to the flogging, he writes- "Two sentries, who deserted their post last night, were flogged this morning. It is sickening, this continual flogging, but there is no help for it;" and again- "Went the rounds last night. No sentries asleep, so no flogging this morning, thank goodness."

The Diary abounds with indications of a vigorous, capable, and unflinching personality. His determination and skill in working with and managing the Arabs, particularly displayed in his politic negotiations with Tippu-Tib, by which at last he obtained the carriers he required-his interview with Muni Katomba at Kassongo-his ungrudging labours at Yambuya before the last start from that home of misery-his unmurmuring endurance of toil and hunger in the march through the forest to Banalya-his fearless return march to Stanley Falls in the face of great dangers-his untiring efforts to secure another Arab commander to come with him-his splendid offer to pledge his fortune for the sake of the Expedition-his unflinching refusal to depart from the route which Stanley had ordered him to follow-his declaration that Barttelot, when he was murdered, was carrying out Stanley's orders, and that he meant to do the same-all of which acts show how he rose to the occasion of a great crisis : these are the doings of a competent and sagacious man, worthy of the part to which he had been appointed and of the praise of which his Commander has most selfishly and ungenerously sought to rob him. 
Amidst all the toils and changes of camp-life Jameson found time to gratify his love of natural history and to employ his valuable powers of observation. Unhappily, a large part of his valuable collection was lost when the camp he had just marched from was looted by the Arabs, in whose charge it was left.

There is no doubt that, if he had been possessed of more opportunity and had his life been spared, he would have contributed largely to the scientific results of the Expedition.

All noble lives are instinct with a purpose. They read the secret of their destiny, and find no rest until they work it out, wherever it may lead. Results they fear not, although it be their fate, as that of many gone before, to "perish in the wilderness."

ANDREW JAMESON.

D:ablin, Necember 10th, 1890. 


\section{INTRODUCTION.}

James Suigo Jameson was born on the 17th of August, 1856, at the Walk House, Alloa, Clackmannanshire. His father, Andrew Jameson, was a son of John Jameson, of Dublin. He held agencies for some estates in Scotland, and was a man of great cultivation and refinement, possessed of both literary and scientific tastes. His wife, Margaret, daughter of James Cochrane, of Glen Lodge, Sligo, died a few days after the birth of their third son, James.

At a very early age the tastes of the child foretokened those which were to form the ruling interest of his after-life, viz. those for travel and natural history in all its branches. When quite a small boy, between four and five years old, his grandmother once found him, at a late hour of the night, poring over a map, which, strangely enough, was the map of Africa. She asked him why he had not gone to bed, as it was some hours past his usual time. "Oh, grandmamma!" he said, "I want to learn all about these strange countries, for I mean to be a big traveller some day."

In 1867 Jameson was sent to Dreghorn, a boarding-school near Edinburgh, under Mr. Dalgleish, of which, in after-life, he always spoke as " an ideal school for boys."

Dreghorn lies at the foot of the Pentland hills, surrounded by woods. Through the beautiful park flows a stream which then held many a trout; and here it was that Jameson first developed those instinctive tastes for natural history, love for all animals, and keen interest in their habits, which formed such a marked trait in his character, even in childhood. Many are the treasures which even in those early days were 
ascumulated, and which formed the nucleus of his later valuable collection.

Speaking of his childhood, his aunt, Mrs. Burd, writes :" He knew every bird and live thing in the neighbourhood and their habits; and his joy and pride when he found a Roseate Tern is a thing not to be forgotten. I do not think he knew what the word fear meant."

He had long been anxious to procure some young Choughs which had built their nest high up on the cliffs at the back of Glen Lodge. At last he devised a plan by laying three ladders together, and, at the risk of his neck, succeeded in reaching the nest and bringing down four little ones. He took the greatest trouble in preparing their food, making it as like what he thought their mother would give them as possible, and even feeding them with a match which he shaped like her bill. $\mathrm{He}$ kept them in his own room, so that he might hear them the moment they cried for food, which was usually about five in the morning, and he refused to go on a shooting expedition to which he had long looked forward, until one of his cousins promised faithfully to take charge of and feed them at the same early hour. He kept them for about three weeks, putting them, in the daytime, in a pheasant-box on the lawn. But, alas! on the very night of his return from his shooting, a Bedlington named "Peachem" got at the box and killed them all! The boy was dreadfully grieved, and retired to his own room for some time. When asked by his uncle whether he had "given Peachem a good licking," he replied, "No; why should I hurt the poor brute and make him miserable as well as myself? It's only his nature, and he knew no better."

Small traits of this kind were an early indication of the kind and gentle nature which, in later life, so fascinated all who knew him.

Upon quitting Dreghorn, he went to the International College at Isleworth, until, in 1873, he began reading for the army. This, however, he abandoned in 1877, when he started on the first of his travels to Ceylon, Calcutta, Singapore, and Borneo. From Borneo he returned with a fine collection of birds, butterflies, and beetles. 
At the close of 1878 he went out again,- - this time to South Africa,-in search of big game.

After a few weeks' hunting on the borders of the Kalahari Desert, where he obtained excellent sport in the veldt belonging to the chief Montsioa, he returned to Potchefstroom, to commence preparations for a more extensive trip into the Zambesi District. The town was at this time in a general state of excitement, owing to the presence of some 700 disaffected Boers, who, fully armed, were camped just outside the town, blocking the road to Pretoria, and stopping all the mails. Their latest act of audacity had been to seize and detain a special despatch sent by Colonel Tucker, of the 80th Regt., then quartered in the town, to Sir Garnet Wolseley. Upon hearing of this, Jameson at once offered to ride to Pretoria with a second despatch. His offer was accepted, and he started that night bearing the important document, with power to shoot anyone who might attempt to detain him. The next morning he encountered a party of about sixty Boers, who stopped and closely questioned him. Having allayed their suspicions, Jameson rode on, making no pause and taking no rest until he reached Pretoria, and safely delivered the despatch to Sir Garnet Wolseley.

Having completed his outfit, he now started for the interior, leaving Zeerust as the last civilized town on his route. From here he trekked along the Great Marico River, where he had excellent fishing, up to the Crocodile or Limpopo River, meeting with large game in great abundance. At Shoshong he was joined by Mr. H. Collison, who had been hunting in Africa for four years; and at this place he also heard from Mr. F. C. Selous, the well-known African hunter, who promised to join the party at Gubuluwayo. Pushing on, therefore, through the "Great Thirst-Land," Jameson arrived at Umganin, where he made acquaintance with Lo Bengula, King of the Matabeles, who received the travellers with great cordiality, granting them willing permission to hunt in his country. His friendly behaviour towards Jameson was on this, as on all subsequent occasions, unvarying.

$\mathrm{Mr}$. Selous having joined them, they now took leave of the 
King, who sent with them an induna to guard their waggons and property; and the party proceeded into Mashona Land, where they obtained splendid shooting.

In July, Selous and Jameson started for six weeks' hunting in the Fly Country, and were able to demonstrate the junction of the two rivers, the Umvuli and the Umnyati*.

In connexion with this shooting-expedition of 1879, the following letter from J. M. Sadleir, Esq., will not be without interest to the reader :-

My deAR Jameson,

Easton Neston, Towcester,

November 29, 1890.

.... I must say I can never forget your brother's kindness to me in Africa. I send you the particulars.

In the month of April, 1879, I was travelling from Durban, Natal, up country. I was taken ill with dysentery at Colenzo. When I had been bad for a fortnight, and was lying in a shed attached to the hotel, your brother, who was trekking to the Zambesi, found me. He at once went back to his camp and brought Dr. Sketchly, one of his party, who attended to me for some days, till I could be moved. Jameson then had a hammock slung for me in one of his waggons, and took me up country with him, till I was strong enough to go back to Durban. To his treatment and care alone I believe I owe my life.

Very sincerely yours, J. M. SADLeir.

Andrew Jameson, Esq.

In the spring of 1881, Jameson returned to England, bringing with him a fine collection of large heads, as well as birds, butterflies, beetles, flowers, and grasses.

In the following year he went out to the Rocky Mountains with his brother, Mr. John A. Jameson. In the Crazy Mountains, and near the upper waters of the Musselshell in Eastern Montana, they shot several hear, wapiti, buffalo, deer, and antelope.

* See 'Proceedings of the Royal Geographical Society,' June 1881 F. C. Selous. 
In 1883 they went through the Crow Reservation, Montana Territory, on to the North Fork of the Stinking Water, in search of sheep, of which they obtained thirty-six, besides several buffalo, bears, wapiti, \&c.

In 1884 Jameson travelled through Spain and Algeria; and upon his return in $\mathbf{1 8 8 5}$ he married Ethel, daughter of the late Major-General Sir Henry Marion Durand, R.E., K.C.S.I., C.B.

Two years later, in January 1887, the attention and sympathy of all England were attracted to the Expedition for the relief of Emin Pasha-Gordon's worthy lieutenant and friendwhich was on the eve of departure for Africa, under the command of Mr. H. M. Stanley. The scheme was one which could not fail to appeal most strongly to Jameson's chivalrous nature; moreover, it promised almost boundless scope for the exercise of his special talent for natural history research. $\mathrm{He}$ at once volunteered his services to Mr. Stanley, who readily accepted them.

The following words are taken from a letter written on January 22, 1887, by him to Lady Durand :-

“.... Why all the ambitions of my lifetime should have been concentrated at this time, with a seemingly prosperous issue, I know not; but I assure you that I did not accept the position without weighing well all there was for and against it. Ever since my childhood I have dreamt of doing some good in this world, and making a name which was more than an idle one. My life has been a more or less selfisb one, and now springs up the opportunity of wiping off a little of the long score standing against me. Do not blame me too much. . . . I must thank you for your generous kind-hearted wishes. . . ."

A sadder tale than that contained in these diaries has seldom been told; for, strive as he would to lighten its hopeless misery, even Jameson's bright and dauntless spirit was weighed down by the wretchedness of the position in which he was placed; and, had it not been for the sincere friendship which arose between Edmund Musgrave Barttelot and himself, the tale would have bi en sadder still. 
The letters and diaries graphically describe his share in the Expedition, speaking more powerfully than any panegyric could do for the single-hearted, loyal, and courageous spirit in which he met all difficulties and bore every hardship and bitter disappointment, as he saw his dearest hopes, one after the other, shattered by the exigencies of a position in which the revolting duties of a slave-driver were forced upon him; whilst every opportunity for scientific work was ruthlessly withdrawn.

* $* * * * * * * * * * * * * * *$

We only add a few words, written by one who knew and appreciated him :-

" His character was one which it was impossible to know without loving-unselfish and generous, pure-hearted and brave; a rare combination of manly strength and courage with the most tender sweetness and gentleness of spirit. Seldom, if ever, has such an instance been known to me of utter forgetfulness of self and thoughtfulness for others, at all times and under all circumstances." 


\section{CHAPTER $\mathbf{I}$.}

\section{EXTRACTS FROM LETTERS.}

Joining Stanley and Officers of the Expedition.-Zanzibar.-Tippu-Til.War between Soudanese and Zanzibaris.-Stories about Tippu-Tib.Cape Town.-Buying dogs.-Stanley refuses carrier for Jameson 8 collecting-things and big rifle.-Banana Point.

UnTIL the start up the Congo, on March 19th, 1887, Jamesun kept no regular diary. The following extracts are taken from letters to his wife:-

\section{S.S. Peshawur. Red Sea.}

Fehruary 1887.- . . I met Stanley at Suez, with the black troops, awaiting the Navarino, which had not yet come through the Canal. He advised me to go on to Aden, where I should meet Major Barttelot, who is one of the staff. We have got Dr. Parke as doctor to the Expedition, who went through the Soudanese War and behaved splendidly....

S.S. Oriental. Aden.

February 10th.-. . . I have met Barttelot, and like him very much indeed. $\mathrm{He}$ is to have command of the black troops, as he speaks their language and has seen a good deal of them in Egypt. We are going to have a charming night of it. Another BritishIndia boat has just arrived, and they will be all night transhipping their cargo on to our steamer. 'To-morrow

1887.

February.

Red Sea. 
1887. we go into the outer harbour to await the arrival Aden. of the Navarino. . . I I have just tried to spear an enormous cockroach with my pen, but he escaped me!

February 12th.-The Navarino has turned up at last, and we start some time to-day. Stanley and the whole party are here.

February 17th.-Jephson is in my cabin; he is a volunteer, having joined the Expedition on the same terms as myself. Stairs has been teaching us mapping, and we all get on, so far, capitally together, and I think we are likely to go on well, as each man will have his own particular duties to attend to. ... The trying part of this Expedition will be the want of news from home. However, I am sure to get letters from you on our arrival at the Congo.

\section{S.S. Madura. Zanzibar.}

February 23rd.-... At last we are on board the steamer which is to take us to the Congo. At Lamu I landed with Dr. Parke at daybreak, and we spent a few hours in quest of game, succeeding, after long walking under a hot sun, in shooting three birds-a species of partridge. We saw a good many gazelle, but did not get any I made a sketch of the village. Next day we stopped at Mombasa, but I had no time to go on shore. Yesterday we arrived here; and I must say I was agreeably surprised with the whole place-town, harbour, and people. The streets are only about five feet wide; but the windows and doors are all carved in different designs, and the effect of the black carved wood against the pure white building is very picturesque. I wish I had time to etch some of them, or even to make rough sketches. 'This morning we got up at 5 A.M. and went on shore to the powder-magazine, where we remained at work until 6.30 P.M. I don't think I ever put in a harder twelve hours' work; but it does one good. We packed 4,500 lbs. of powder in 
special cases which came out from home, besides a lot of work with caps. To-morrow evening we are all dining at the British Consulate, and next morning (thank goodness!) we sail for the Congo. We have sixty-one donkeys on board, and the braying that they keep up at night is dreadful. One starts it, and the others prolong the chorus in different keys ad infinitum. To-morrow morning 600 Zanzibaris are coming on board; then we get at least 600 more at the Congo, which, with the Soudanese troops, will make a good lot of men. Goodness knows how we are going to feed them all, for they seem a hungry set!...

February 25th.-I am not going to keep a diary until I start up the Congo, that all the time that I can give to writing may be given to you. So I shall write every day, and send it all from the Cape when we call there. .... At Lamu, of which I spoke in my last letter, there are the remains of a great battle, the whole shore being covered with bones and skulls. Some of our party gathered very good specimens. I believe the fight was one between the Arabs and the natives. Mombasa-a quaint old town, full of old Portuguese ruins-possesses a pretty and almost landlocked harbour. Off the Island of Pemba we fished with land-lines over the stern of the steamer, and caught a number of fish, small, but of the most beautiful colours - some bright red, others barred with blue, silver, and brown-a kind of bream or sea-perch, I think. ... The Sultan's Palace at Zanzibar is a wonderful structure, quite square, with an enormous corrugated iron roof, about four stories high-quite the ugliest building I have ever seen, looking very like an immense doll's house. Imagine my surprise when I heard that the famous Tippu-Tib was coming with us round to the Congo and on to Emin Bey. Six hundred of his fighting men are to meet us at Stanley Falls. After dinner, at the Consulate, we were all introduced to Tippu-Tib, who is a fine old Arab, very lively, and a thorough old gentleman.

1887.

Feb. 23.

Zanzibar. 
1887. We started to-day at daybreak. Tippu-Tib has about Feb. 25. 20 wives on board, and, including wives, 90 followers altogether. They have all been more or less sea-sick, with the exception of his interpreter. It was most amusing to see old Tippu led off by the interpreter and taken below, trying to walk straight, and make jokes-his man in fits of laughter. War broke out this morning between the Soudanese and the Zanzibaris. It was not until some damage had been done to both sides that order was restored. I was standing by the main hatch with Mr. Stanley, when his servant ran up to him, and said the niggers in the forehold were killing one another. Mr. Stanley, Nelson, Jephson and I ran forward, and the sight that met our eyes was exactly like an "Inferno" by Gustave Doré. They all had great clubs, and were fighting like demons. We went down and drove the Zanzibaris into one place and the Soudanese into another; but it took some time to disarm them and get them to cool down. I took an iron bar from a man who had broken one man's arm, and the finger of another. These, and a large number of broken heads, constituted the results of the fight. All has been quiet since.

February 26th.-Busy all day, making vocabulary of Swahili language, which the Zanzibaris and Somalis all speak. The Somalis are twelve picked men, procured at Aden; they are to be armed with Winchester rifles, for Stanley's special guard-splendid fellows, and they all speak English. In the afternoon I had to find out, and write down, the names of the 117 men who have been placed under my charge. I have one splendid boy amongst them, who is my interpreter, and whom I am going to teach to skin birds; he is one of the most intelligent little chaps I have ever seen. To-day some of those troublesome Soudanese soldiers attempted to take liberties with some of 'Tippu-Tib's wives; in consequence there has been a row, and a special sentry placed over their apartments. 
After dinner Mr. Stanley told us a few stories about Tippu-Tib. It seems that at one time he borrowed about $£ 4,000$ from the Rothschild of Zanzibar, and started into the interior with a good many followers to trade for ivory. After some time he came to a very large native town, enclosed within double palisades. The town was so large that, if a gun was fired off at any point in the outer circle, it could not be heard at an opposite point in the same circle. The king kept all his ivory and wives within the inner palisade, and there were 10,000 warriors guarding him in the outer circle. After keeping Tippu for a long time in his town, the king gave an order that, should any of his men catch Tippu alone outside, they should kill him. One day he left the town by himself, and on his way back he met two of the king's men, who began to shoot at him with bows and arrows. He ran for the gate of the town, but just as he reached it an arrow struck him in the leg and brought him down; he got up again and running towards his own camp, he shouted out to his people to bring him his gun. He was again struck and knocked down, but his wife managed to give him his gun, with which he shot both of the king's men. The shots roused the king's warriors, and brought all Tippu's men running into his camp. They first shot down a number of the natives, and when about one hundred of them had mustered, Tippu ordered them to rush for the gate of the big town, and to fire all together as the warriors came on. This they did, and burned the houses nearest to them. The fight lasted three days, by which time they had burned all the outer circle of the town. They then proceeded to fire through the inner palisade, until they had decimated the people gathered inside; then they made a rush, seized and beheaded the king, and captured all the ivory and women. Tippu next went to all the smaller towns in the kingdom and collected enormous quantities of ivory, which he afterwards sold at the coast for $£ 40,000$. He became king of a whole country, entirely through his own cunning. He once came to

1887.

Feh. 26 At sea. 
1887.

Fəb. 26.

At sea.

a strange country, where he was told that the king had been taken away years before, with his little son, and that the natives had long expected his return. Having asked numerous questions of every native he met, without saying who he was, Tippu-Tib at length said to one man, "Had your king not such and such coloured eyes?" The man said, "Yes." Tippu then exactly described the king, until the native said, "Why, that is the very man!"-when Tippu told him he was the son who had gone away with the old king, and that he was to go and tell all the people. This he at once did, when they came to him with presents of all kinds : and to make a long story short, he is king of that country at the present time. The following is a specimen of his cruelty:-He was once attacked by a tribe, of whom he succeeded in making some prisoners. He knew he would be attacked by them again, so he killed all the captives, and having cut them up small, he put them in large pots to boil, mixing up bananas and all sorts of things, until a rich savoury aroma arose from the pots. When he was attacked by the natives, he pretended to retreat, and watched his enemies - who had found the pots on the fire-set to and ravenously eat up their own people.

March 2 nd.-... This morning Mr. Stanley read to me Tennyson's 'Ulysses.' . . . All the spare time I had to-day I was reading the 'Light of Asia.' . . . Stanley savs he has got a copy with him, too. He gave us all the most lovely little medicine-chests to-day.

March 3rd.-Out of the tropics at last, and the weather is decidedly cooler. ... Not an item of interest, again! The only things which seem to change at all on board are the horrible smells from the crowd of natives; and they only change in so far that they are at times much worse than at others. ...

March $7 t h .-.$. I have heard the real story from Stanley as to how he got Tippu-Tib to come with us. Before leaving England, he heard that 'Tippu was in 
Zanzibar. He at once telegraphed that he particularly wished to see him, and to keep him at any price until his arrival. When Stanley saw him at Zanzibar, Tippu first said he would stop our going in at all; so Stanley assured him that we were quite willing and prepared to fight him, but that he had better take care what he was about. He then gave him the choice of fighting us and taking the consequences, or of helping us and being made Governor of Stanley Falls, under the King of the Belgians. Next day Tippu-Tib said he would accept the latter; and Stanley telegraphed the same to Belgium, and received a reply confirming the appointment. The night we dined at the British Consulate, Tippu-Tib signed an agreement to help us in every way, and was made Governor. $\mathrm{He}$ is not going with us further than Stanley Falls himself, but is sending his head men with us, and 600 fighting-men. We expect to reach Emin Bey in July; so that, if we come back down the Congo, we ought to be home in no time. A more definite time than this I cannot give you: I wish to God I could! . . .

\section{March 8th.-Arrived in Simon's Bay. . . .}

March 9th.-Lady Hunt-Grubbe and her daughters came with the Governor and inspected the ship, and showed great interest in Tippu-Tib and especially in his wives. Reached Cape 'Town about 7 o'clock.

March 10th.-Went on shore with Jephson and Nelson to buy a lot of things and to get dogs.... Had a delicious breakfast on shore, ... and searched all the morning for dogs. We collected a very curious lot, consisting of bull-dogs, bull-terriers, fox-terriers, a Bedlington, and several unknown species. Mr. Stanley bought the two fox-terriers-one for himself, and one as a present for Tippu-Tib. Jephson and I secured the two large bull-terriers, and tossed up for them. The large brindled one fell to me, and a horribly low white one to Jephson. They are about the two most ruffianlylooking dogs I have ever seen. 
1887. Mar. 11.

Cape Town.

March 11th.-... The deck is quite lively with all the dogs; but the increase of insects of the carnivorous species is much to be deplored. . . .

March 13th.-A donkey died: the first death on board, with the exception of a few goats. ...

March 14th--A Zanzibari died to-day, and was consigned to the deep. It is horrible the way the natives neglect their sick, or any one of them who is hurt. Busy most of the day in packing musket-caps into new boxes for Emin Pasha....

March 15th.-Jephson, disgusted with the low habits and appearance of his dog, flung him overboard in the dead of the night, with a furnace-bar attached to him. Alas! poor Bill, his life on board was a short and anything but a merry one.

March 16th.-Another Zanzibari died to-day, of inflammation of the lungs.

March 17th.-You cannot tell what real joy your letter and telegram brought me at the Cape. I could hardly believe my eyes when they brought them to me! ... One thing that makes one sad is knowing that, after a time, it will be hard to send you any letters or news.... To add to my cheerfulness, Mr. Stanley informed me yesterday that he would not give me a man either to carry my collecting-things, or my big rifle and its ammunition. This is a bright look-out for me, who came to collect, and shoot meat for the Expedition. Mr. Stanley was present when I was speaking to De Winton about my big rifle, and advised me to take shells for it. I have, however, reduced my wearing-apparel and my bedding to so little that I can take most of my collecting-things; and some of the other fellows have been good enough to offer to carry some of them for me. I have reduced myself to one spare coat besides the one on my back, one pair of boots on and one pair packed, one blanket, and all the rest on the same scale. Thus, at the expense of all my own 
personal comfort, I can take my collecting-things-or at least some of them. All this certainly takes a good deal of the gilt off the trip to me; but though I

1887.

Mar. 17.

Cape

Town. must say I was rather mad at first, I am now making the best of a bad business. I have had to give or throw away every ounce of my tobacco ; but the empty tins will come in beautifully for "bugs" and small birdskins. ... I shall take the big rifle on shore, and hire men myself to carry it, whenever we have to go overland, until we reach Stanley Falls, where I hope to get a couple of men from 'Tippu-Tib to carry it on to Wadelai. . . .

March 18th [Banana Point].-... We start up the river to-morrow; and as we begin to put everything on board at daybreak, I shall have no time to write to you in the morning, and must make up my mind to say "Good-bye;" for this is at last the great start of the Expedition: God knows, I can hardly pluck up courage to say it!

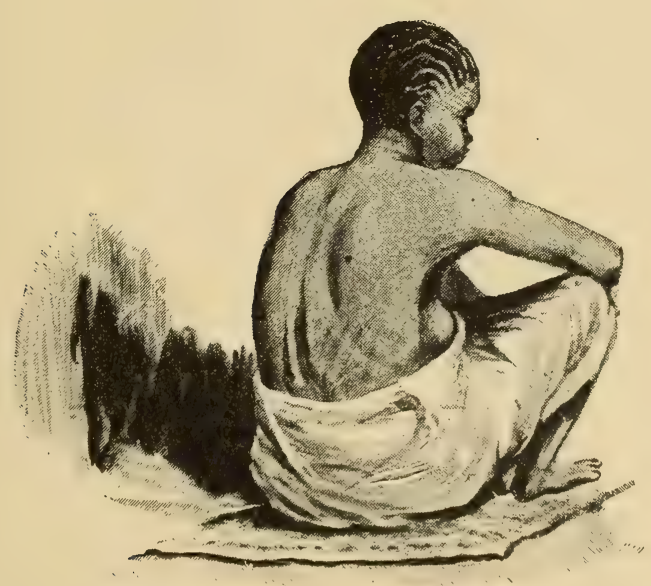

Slate Girl. 


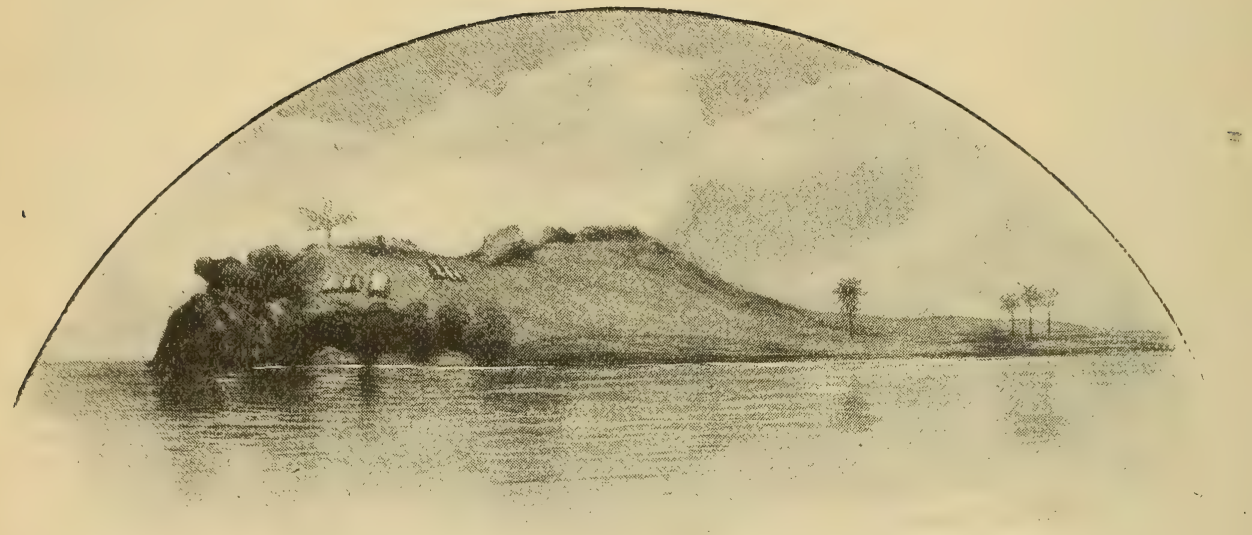

Peter's Ferish.

\section{CHAP'TER II.}

\section{DIARY.}

March 19тh to April 30th.

Boma.-Ango-Ango.--Mpalaballa Mission Station.-March to Congo da Lemba-- Banza Manteka. -Day's march resembling slave-driving.Kuilu River.-March to Vombo.--Stanley doing rear-guard.-Barttelot sent on with Soudanese.-Sick chief.-Lutété.-Kindness of the missionaries.- Stanley settling a row.-Inkissi River.--Thief.-Stanley's punishment of chief s.-Off to shoot hippo.-Difficulty abont steamers. -Kinshassa.-Ward joins the Expedition.

1887. March 19th, 1887.- Started up the Congo at last in the Mar. 19. Dutch Co.'s steamer Nieman, Nelson, myself, and 232 Congo. men. We were the first to start. Next came the British Congo Co.'s steamer Albuquerque with cargo, and Dr. Parke and his company. Mr. Stanley follows in the Portuguese steamer Serpa Pinto, with about 300 men and the donkeys, and Major Barttelot and Jephson bring up the rear in another steamer with the remainder of the men. 'The view as far as Kishanga is very limited, as the banks are covered with dense tropical 
vegetation, and the high land at the back is only now and again visible. After Kishanga the river opens out, with beautiful undulating country on either side, and we pass numerous large grass-covered islands. The English Mission Station appears on the sky-line of the uplands on the right, immediately after entering the river. A good fresh breeze blowing from the sea all day prevented one feeling the heat. At Mataba, the river opens out grandly. Here the banks are low, discovering beautiful undulating grassy country at the back. Anchored at Alligator River at one o'clock. From the top deck of the steamer we could see nearly twenty miles of country on every side. We lay opposite Peter's Fetish, a beautiful rock, partially covered with trees.

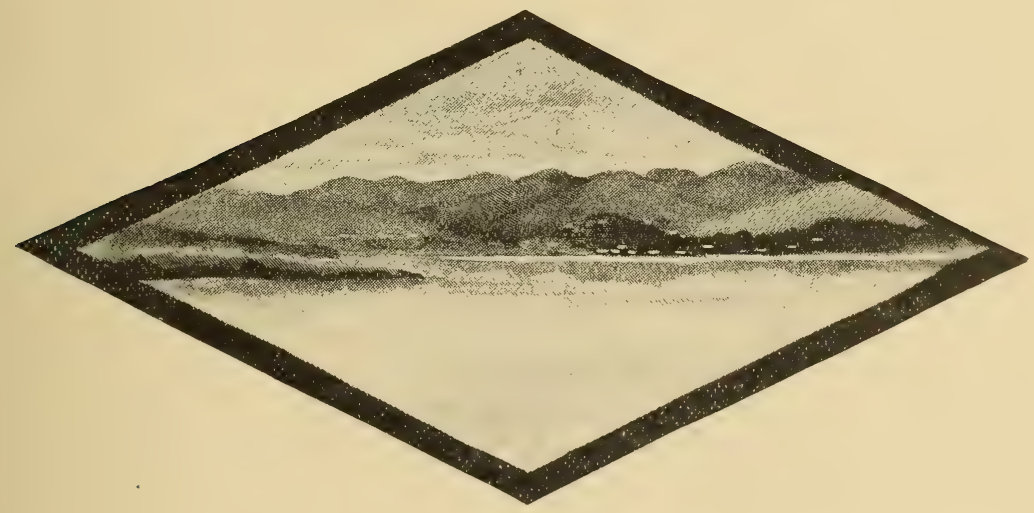

Boma.

March 20th.-Passed Boma, the principal town (?) of the Congo Free State. It consists of a few factories or trading-houses, Dutch, French, Belgian, and Portuguese, also a French and English Mission. It is very prettily situated, and in a more flourishing condition of things may, I suppose, become a big place. There is a large, beautiful pool above Boma, after which the river runs between high barren hills on both sides, for although they appear brilliantly verdant, the hard. 
1887. red rock betrays itself on every square yard. Arrived Ango- at Ango-Ango at 2.40. Mr. Stanley passed at 5 o'clock Ango. in the Serpa Pinto for Matadi, and shouted out a message which I could not understand. Sent a messenger overland to him. The answer arrived at 10 P.M. to have everything ready to ship on board the Serpa Pinto at 7 o'clock next morning, and Parke and Nelson to walk with their men overland.

March 21st.-Stayed at the Dutch House with Mr. Cramer, who gave Nelson and myself beds, and the best of everything. Parke and Nelson started for Matadi. The Serpa Pinto steamed past about 10 o'clock without stopping, leaving Mr. Walker and myself with the cargo on shore looking after her! A little later the Portuguese gunboat came up with Barttelot on board, and took off most of the cargo. 'Then Jephson came down from Matadi in the Ileron, and took off the remainder with my men. Arrived at Matadi about 5 o'clock, having had nothing to eat all day, and then had to tow

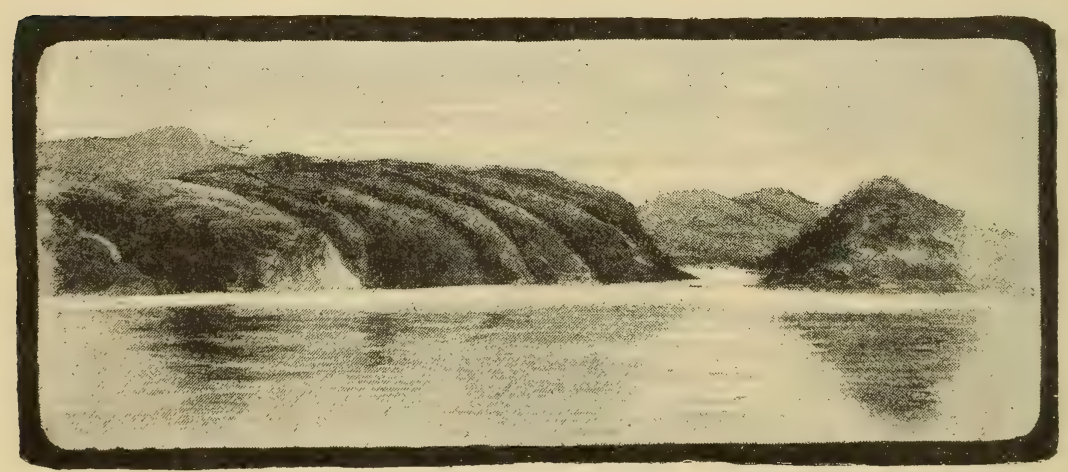

Ango-Ango.

up the cargo in a lighter to Stanley, who was at the Portuguese Factory. I tramped back in the dark, thoroughly disgusted with everyone and everything, to get my first square meal that day. Visions of sketching \&c. are rapidly fading. 


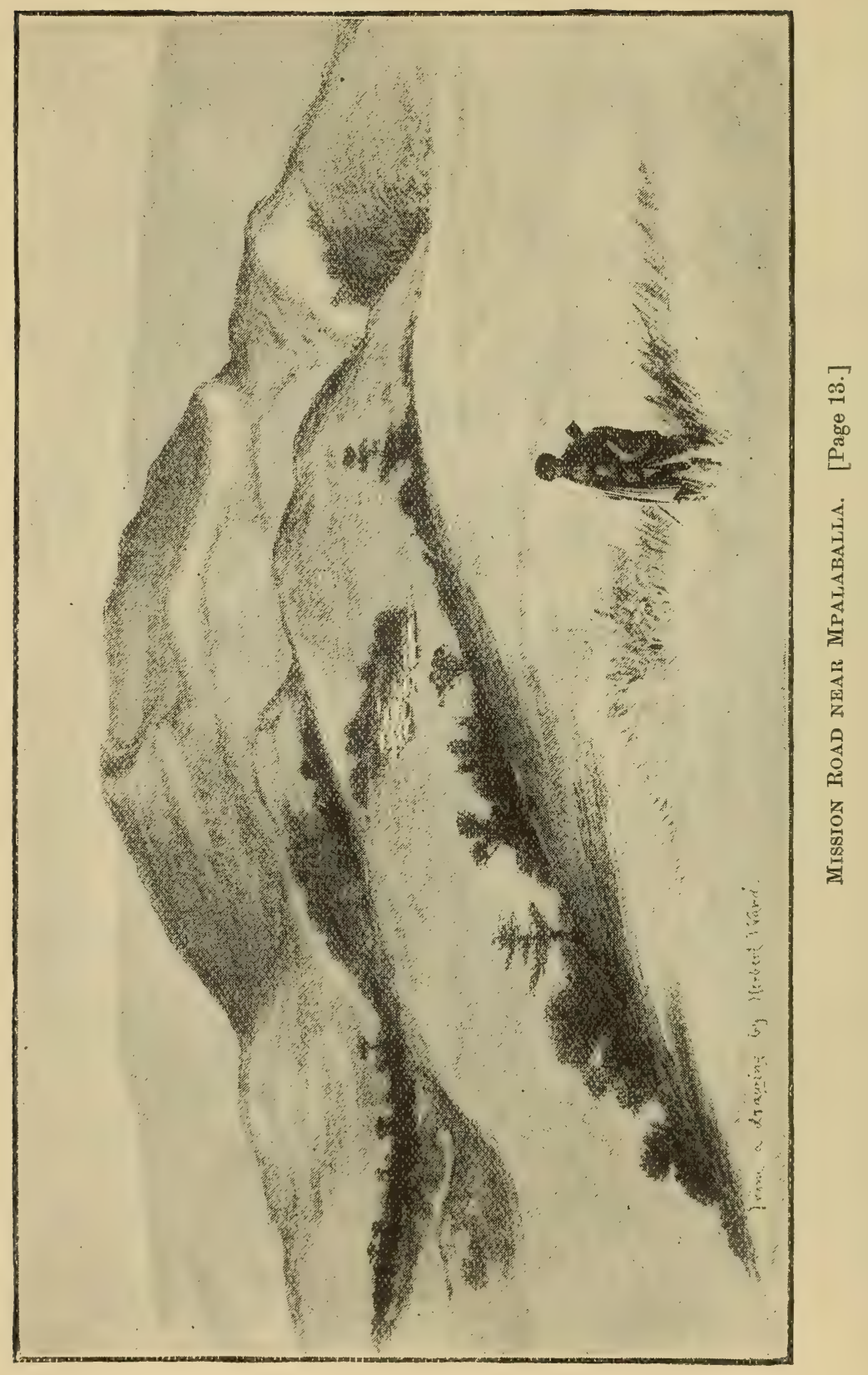


March 22nd.-Hard at work all day breaking open cases and making up loads. Slept in the Portuguese House. They are very kind to us, and feed and "drink" us right royally.

March 23rd.-The cry is still we break open cases and make up loads. Had a grand parade of men and distributed Remington rifles, with which I hope they won't shoot us, and spears, which from their rottenness are comparatively harmless, half of them being already without heads.

March 24th.-Marched about three quarters of a mile over to the Congo State Station. They gave us breakfast, but after that left us entirely to ourselves. Had some practice with the Maxim gun, which worked wonderfully well. Mr. Walker left for the Mposo River, with the iron boat, in order to put it together.

March 25th.-Marched to the Mposo River, over one of the worst roads I have ever seen, up and down masses of cinder-like rock and broken quartz: my donkey fell three times, and it was lucky I did not attempt to ride him; I very nearly shot him in simple disgust. Found the boat not put together, and when we did get it in the river, it took us hours to cross, pulling it backwards and forwards on a rope. This miserable little river is scarcely more than thirty yards wide.

March 26th.-Marched to Mpalaballa Mission Station. Went ahead of most of my men, and had a delightful walk. The road much better than yesterday, and the country very pretty indeed. Shot a Whydah finch, black, with yellow shoulders. Mr. Clarke, the head of the Mission, and the ladies treated us with the greatest hospitality.

March 27th.-Remained all day at Mpalaballa, waiting for men with loads from Matadi. Met Mr. Ingham, who is one of our staff, and came out here straight from England, coming down with native carriers to carry our loads up country, which are far in excess of the number 
1887. of the Zanzibaris. He gave us a very bad account of Mar. 27. the condition of the steamers on the Upper Congo balla. The country round here is very beautiful, but without any game, although bird and insect life seem to be on the increase. I was very busy all day sorting loads, and parading men.

March 28th.-Marched to Massam Mankengi. The path seems to be made to cut the soles off one's boots, and the donkeys do nothing but tumble up the hills, or tumble down them. The order was given this morning that we were to march in the rear of the men, and assist them with their loads, so good-bye to all chances of collecting.

March 29th.-Marched to the deserted native village of Congo da Lemba, which, until burnt by the Congo Free State, was a flourishing native town. 'The Congo Free State people have burnt the huts and driven away the natives from nearly every village on the road, consequently there is not a scrap of food to be obtained for love or money. They say that the natives interfered with their carriers on the road. The work we are doing is not fit for any white man, but ought to be given to slave-drivers. It is all very nice for Mr. Stanley, who rides ahead straight on to the next camp, where we arrive hours afterwards, having done nothing all day but kick lazy carriers, and put the loads on to the heads of those who choose to fling them down. On arriving in camp one has to go over all the loads to see that they are correct, then stack them and interview the men about the loads that have gone wrong; so that it is dark before one has even time to wash. I have given up all hopes of collecting, although I have seen many birds, and especially butterflies, that I should dearly like to have obtained.

March 30th.-Rained nearly all morning, so did not start until late for the Lufu River. The Bembezi River was in flood, and having got all the men and loads over, we found Mr. Stanley had gone on miles 
ahead. We eventually pulled up in the dark, in the middle of a tropical forest, the men throwing down their loads, and going to sleep in every direction. Dr. Parke was in the front of the column, Stairs and myself in the centre, next came Jephson and Barttelot, Nelson bringing up the rear-guard. The column being over a mile long, when it became dark some of the most advanced had reached camp. Stairs and Parke soon gave it up as hopeless, and bolted for camp. I, finding myself deserted, lit my lantern and only piece of candle, and struck out for camp also, leaving the men hopelessly lost in the bush to make the best of the night. Shortly after arriving in camp (where Mr. Stanley regaled us with rice, biscuit, tea and brandy, and the latter was very acceptable, as I had waded the river and been soaking wet for hours), Barttelot and Jephson turned up, but Nelson slept in the wood, in the camp belonging to a man who was bringing up things for the Sanford Expedition. In consequence of this night, some of the loads were lost, and several of the men bolted. I slept on the ground in Mr. Stanley's tent, on my waterproof-about as hard a bed as I ever had. From this you will observe what a splendid expedition it is for a naturalist. It is sometimes very hard to think of all the glory of relieving Emin Bey.

March 31st.-Having got the men and the loads out of the wood, we started amidst much grumbling from the men, who had had nothing to eat, and marched to the Lufu River. Here there is a ford, and also a curious old swinging bridge of native construction, with large gaps in it every few yards, and a deep drop into the river if one fell. A couple of miles further on we camped.

Mr. Stanley here behaved to me in a way which was utterly undeserved, and which I did not expect from him. On passing the Lufu River he was attacked with acute dysentery, and although he was apparently all right again in the evening, he was weak, and had to be 
1887. carried from the river to the camp. When there I went Mar. 31. to him to report that one of my men had deserted with Lufu R. his gun on the march, and at the same time said I was very sorry to hear that he had been so ill. He turned round very sharply and said, "No wonder. I have only you to thank for it. I have had nothing but tea for two days, whilst you have had meat for your breakfast yesterday, and I consider you are entirely to blame for my illness." I may here state that I had volunteered to take over the cooking and ration arrangements for a week, as no one else seemed inclined to look after them, and before we really could often get nothing to eat. The facts about his having had no meat for two days are the following:-The evening before leaving Congo da Lemba I sent a messenger to ask him if I should kill a goat or the four fowls which were in camp, as there was no meat. The message sent back by his own servant, William, was, "Save the goat and kill the four fowls, if they will be enough for to-night." I killed the fowls, and they were quite enough, for some of the other officers had some in the morning. Jephson, Stairs, and I breakfasted next morning in my tent on a tin of sardines, the last but one that I had, so that Mr. Stanley's taunt that I had meat when he had none falls to the ground. That morning it rained for hours, and he would not say whether we were to march or remain, so that it was utterly impossible to kill any meat. He then arranged his march, so that in the middle of the night the goats were left in the wood, and he marched again next morning before they were out of it. He then turns round and says that it is entirely my fault that he is ill. Altogether I think the whole business is a very thankless job, and the moment this week is over the cooking arrangements may go to the devil for all I care.

April 1st. - Marched to the American Mission Station, Banza Manteka, a beautifully situated spot, standing high and surrounded by wooded valleys, brilliant with tropical verdure. The water here is worse than any I have seen, too dirty to wash in. 
I obtained a number of good butterflies out of the Mission garden. After dinner a fearful thunderstorm came on, and blew in the end of the officers' tent. From the door of mine, which was snug and dry, I had a beautiful view of all the fun, in the middle of which a whole pile of ammunition-boxes fell down, to add to the confusion.

April 2nd.-In the morning we had a general parade of all the men, and Mr. Stanley addressed each company in turn, and I noticed that all the lazy blackguards, who had given us the most trouble, were foremost in shouting out all sorts of fine things about going on to the end of the world with him! After this came a drenching storm of rain, and then we marched six or seven miles across the valley and camped.

April 3rd.-Had an awful day's work. Had to go with Barttelot as rear-guard. Started at 6 A.M., and did not get into camp near the Kuilu River until nearly 6 P.M. I had nothing to eat the whole day but the fifth part of a tin of sardines, and did not sit down for more than a quarter of an hour. The work was truly sickening, as every twenty yards one had to stop to put a load on a man's head who had flung it down, and very likely give him a good dose of stick before he would go on. There was no rest upon getting into camp either, for I had to go over all my loads, stack them, and send out men to find those who had not come in. The work must greatly resemble slavedriving. I succeeded in shooting a swallow, which is the same as the small South-African one, and a bee-eater which is new to me. Both were skinned by the light of a small piece of candle, and the skins are worthless, as two days elapsed before I had a chance of drying them.

April 4th.-Marched on to the Kuilu River, a muddy rapid stream, which we had to cross, ten men at a time, in an old dug-out canoe. Such is the great road of the Congo Free State! This morning, in trying for the

1887. April 1.

Banza Manteka. ("The town of mud.") 
1887. first time to ride my donkey across a muddy marsh, he April 4. fell and was nearly drowned, precipitating me into the River. mud (the blackest I ever have seen), which filled my saddle-bags containing my collecting-things! Early in the march we crossed a lovely clear trout-suggestive stream, running over and between ridges of pure limestone, which, says Mr. Stanley, is about the only limestone we shall see in the whole country.

April 5th.-Still at the Kuilu River-from 6 A.M. to early in the afternoon still getting men, loads, and donkeys across.

April 6th.-Marched to Mwembi. On reaching the top of a hill, I found all the baggage and tents lying on the side of the road, the men being about a quarter of a mile off in a native garden, pulling up manioc, and seizing whatever they could. No shouts on my part or from the chiefs could bring them back, so, taking up a good stick, I ran down the hill towards them, and having waded through a swamp for about 150 yards, I met the first man trying to sneak back. I applied my stick, and he made such a row that all the others decamped, and when I regained the top of the hill, I found all the tents and baggage gone on. On arrival at Mwembi, the news was brought to us that one of our chiefs had been shot dead, and one of Tippu-Tib's men shot in the hand by some of the natives of a village which they had been looting. Went to bed dead beat.

April 7th.-Marched to Vombo, quite the quickest march we have done, owing to a good level road, and Mr. Stanley doing rear-guard with some of his Somalis himself. How he did lay his stick about the lazy ones, and the Somalis whacked away too. It was a sight for sore eyes to see the lame, the sick, the halt, and the blind running with their loads, as if they were feathers; and I was delighted to see some of my men catch it hot, after I had been told by Mr. Stanley himself not to strike them. The march was otherwise uninteresting, 
over a high plateau, covered with long rank grass, which cut off any view of the land. Camped in an old native village amongst palms, and collected a small number of butterflies.

April 8th.-Marched from Vombo to Lukungu Station. The road lay through beautiful country, affording glimpses on both sides of valleys filled with tropical vegetation. Shortly after leaving camp a severe thunderstorm came on. Barttelot and I were doing rear-guard, with Stanley a little ahead of us. We both saw one of the lightning flashes strike the side of a hill, about 150 yards off, and a small cloud of dust and smoke immediately floated away from the spot. It was a severe march, as some of the hills were bad, and the wet made them worse. Stairs had to shoot his donkey, as his boy led it badly down a steep place, and it broke its leg. I was getting intensely annoyed with the carriers, who, since Mr. Stanley went ahead, had done nothing but sit down, and was generally down on my luck towards the end of the march, when I saw Parke seated under a tree. He gave me a drink of my own whiskey, thirteen years old, and then everything changed to a brighter hue; but it also lent strength to my arm, when, within a mile from camp, I found all the men had flung down their loads, and gone off looting in the native gardens. I seized a large stick and went for them. It was more than I could bear to be stopped within sight of camp, at the end of a long march. I laid about me, and soon had them all in camp.

April 9th.-Barttelot was sent on in the afternoon with the Soudanese, and all the worst men in camp, all by himself, to be always one day ahead on the road to the Pool. It looks strange on Mr. Stanley's part to send him by himself with the very worst and most rebellious lot in camp, who will not move a yard so long as they know that all the food is behind them. Barttelot has done a lot of work which he need not have done, as it was beyond his actual duties, and it seems a poor return for it all. 
1887.

April 10

Kimbam.

wanga.

April 10th.-After sending Jephson's men to Manyanga to meet him and bring the boat on to Lutété, we marched to Kimbamwanga, where our advanced guard ran into Barttelot's rear-guard, already proving that it was wrong to send him ahead. This morning Mr. Stanley placed me in a very false position with my men. Just as we were starting, I told him that one of my chiefs was very ill indeed, and that I did not think he could go on. He told me not to bring him any reports of the kind, that he would not listen to them, and that his orders were for all the sick to go on, and that I was to see that they did so. I only said, "Very well, sir." I behaved very cruelly in making the man get up, amidst the murmurs of all the chiefs, and then driving him on. In a few yards he fell down, and could not get up. Mr. Stanley, on passing, recognized him, and went up to see how he was. He called to Dr. Parke to come to him, and told him that, as he was a good man, we must not lose him; gave him medicine then, and left more with him, at the same time telling one of the officers of the State to look after him, get him into a hut, and do everything he could for him. Of course all the men now look upon me as a brute, and Mr. Stanley as a sort of guardian-angel, although I was only carrying out his own orders. My dog Bull ran away back to the Station at Lukungu, and, poor beast, I am not sorry, for there he will be well looked after, and in camp I could not get him enough to eat.

April 11th.-Marched to the Mpwka River; a short march, brought to a close by the river itself being in full flood, with only an old rickety wicker-bridge, a few feet wide, over which to cross. We felled two trees; but of course they both fell in the wrong direction, as everything does in this beastly country! By the time the donkeys were swum over it was nearly dark. The wood was too thick to put up the big tent, which is the worst and most useless of its kind I have ever seen in my life. Stairs and Nelson slept in part of it which they put up. As it promised to be a fine night, Parke and I slept in 
our Ashantee hammocks. Before retiring, we killed a magnificent specimen of a centipede in Stairs' tent. I was sleeping soundly when, towards morning, down came a fearful thunder-plump, and before I could get my waterproof sheet over me it wetted all my bedding and myself; the rest of the night was not pleasant. Saw two splendid kingfishers, and many beautiful butterflies on the river; but it made me quite sick not to have a moment to collect anything. Got a beautiful shellbacked spider with horns on the back, the same that I have seen in Borneo; but I lost it in the confusion of the next camp.

April 12th.-Did a good long march over beautiful country to Lutété, where we found Jephson, who had got in before us from Manyanga. He gave me the most glowing account of the birds and insects on the river, which made my mouth water. Barttelot stayed with us, as half his men had gone on to Lutété, and the other half were so far behind that they were too late to go on. The whole idea of his going ahead with these men is a perfect farce. The march lay over beautiful country gradually rising all the way, the highest hill we climbed being 500 feet, measured by Stairs from the creek at its foot. From this point there was a lovely view down to the Congo on one side, to Lutété on another, and behind us to the Mpwka River. One of the Somalis died this morning, and several others are very bad indeed.

April 13th.-Had a very easy day. Marched to Lutété, the English Baptist Mission Station, beautifully situated, standing very high, and I should say quite healthy. The missionaries received us with kindness, but did not ask us to feast with them; I suppose we were rather a rough-looking lot. Personally, I must say I am not so "genteel "looking as when I left town, being of a kind of brick-colour, with an untrimmed beard of no great length, of a colour to match. One of the men was to-day placed in chains for stealing potatoes. Poor Barttelot has a terribly rough time of it

1887.

April 11.

Mpwka

River. 
1887. with the Soudanese, as he cannot get them alıng at any Lutéte. price. It is a splendid sight to see Mr. Stanley settle a row. To-day some of the Soudanese and Zanzibaris began fighting about a cooking-pot, and awoke Mr. Stanley, who was asleep. He seized a stick, ran in, and whacked away right and left, giving one fellow a regular facer with his fist, and, in less time than it takes to write this, there was perfect quiet!

April 14th.-Had a long march; but the men did it splendidly. Made an early start, and camped at Nzungi. Bonny lost two of the pack-donkeys at Lutété, but turned up about 5 o'clock in the evening with them, Mr. Stanley's orders to him being that he need not turn up at all unless he found them! Bonny suspects the missionaries of having hidden them ; for, when he was left behind, they asked him to breakfast, and inquired how long he would wait for the

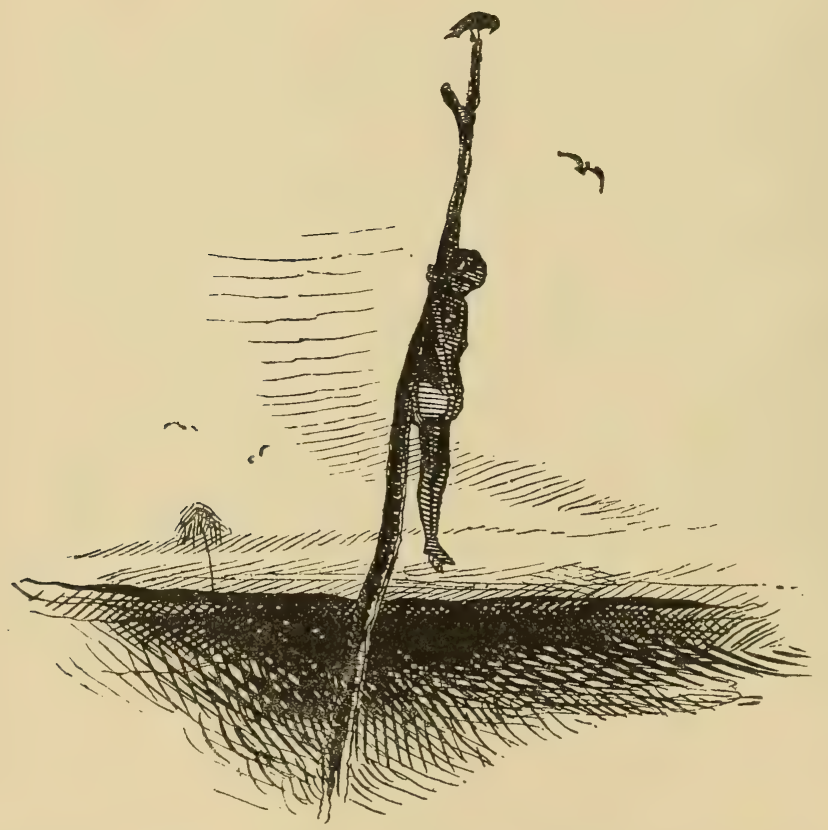

donkeys. He replied, probably three or four days, that all his boys would be with him, and that the 
missionaries would have to find them in everything, as Mr. Stanley had left them nothing. Two of the missionaries then went out, and returned in about an hour 1887. April 14. Nzungi. with the two donkeys, saying that as they were taking a stroll they heard one of them bray in response to one belonging to the station. Bonny, however, thinks that the prospect of keeping him and his boys for three or four days produced the donkeys.

April 15th.-Marched to the Inkissi River. It is now quite a pleasure to see the men walk along cheerily with their loads. Our road lay for a long distance close to the banks of the Congo. Some of the glimpses of the river were very beautiful. I would give anything to have time to make a sketch, no matter how rough, of some of them. The foliage is gorgeous in colouring. Some of the palms bear a bright scarlet flower, growing in great clusters down the centre of each branch. About half-an-hour from here we passed a dead native tied upright to a pole, by the side of the path. Mr. Stanley says it is the body of a thief, put up thus as a warning to others, and that he was executed by the natives themselves. The body was there when $\mathrm{Mr}$. Stanley camped in the same place three or four years ago, and is mentioned in his book on the Congo Free

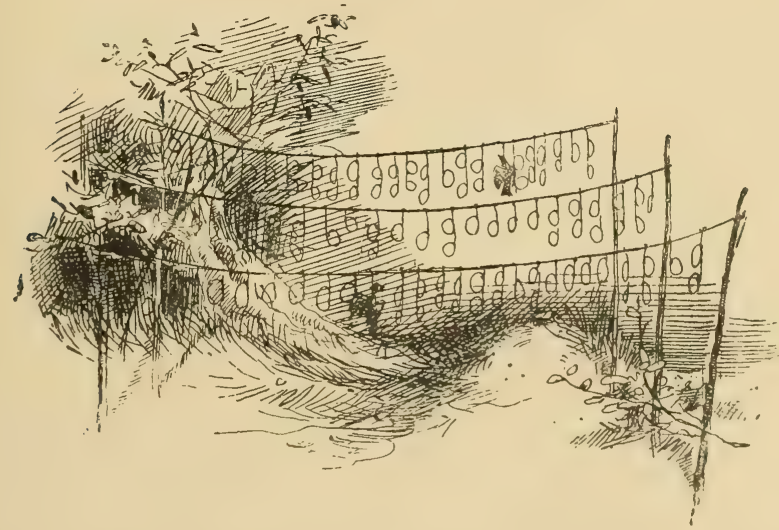

State. The natives here have a curious method of catching birds by hanging long ropes, formed of 

1887. creepers, from the trees on the edge of the forest to

Inkissi

River.

poles stuck up in the ground about 15 or 20 yards off. Hanging from these ropes are numbers of snares, made from finer creepers, in which the birds are caught as they fly past.

April 16th.-All day long crossing the Inkissi River. I luckily got across early with all my men, and had a glorious time amongst the butterflies, getting some magnificent ones, though I daresay the more insignificant, which I did not fail to catch also, will turn out to be the rarest, as is usually the case. Last night was a horrible one. We slept in a deserted native hut which looked waterproof, and retired with fond hopes of a good night; but about four hours before daylight it began to pour, and poured on until 7 o'clock. The water came in through the roof just above my head and shoulders in torrents; and although I had an umbrella up, and two coats over me, I was drenched and all my bedding, which, by the bye, consists of one blanket and a waterproof sheet with some grass under it.

April 17th.-Had a long march. I had to do rearguard, but now that the Zanzibaris go so well, it is not nearly so tedious or heart-breaking a business as it used to be. The birds all seem to be in bad plumage for skinning, as most of the feathers are still in the quill, and they make the most horribly bare-looking skins.

April 18th.-Marched to Nkalama. There is a most beautiful waterfall just below camp, where the Mpwka falls into the Congo. The Congo itself is remarkable for the masses of bare, black, horribly forbidding rocks which abound on either shore, and crop up here and there in reefs all over the river. Shot a warbler, the skin of which I saved. I found out that one of the ammunition-boxes carried by my company had been 
lost to-day, so I reported the matter to Mr. Stanley after sending back two chiefs all along the road to look for it. Mr. Stanley ordered the whole company to fall in, and then made each man take a load from the heap of loads brought in. He asked the chief who had received the loads in camp to recognize those of the men who had brought in theirs. He did not remember seeing one unfortunate man, so Mr. Stanley fixed upon him as the man who had lost the box, although he is really one of my best carriers, and swore he brought in his box, and showed Mr. Stanley the tree he cut down to keep the boxes off the ground. Mr. Stanley then called the Somalis, and gave all my chiefs, with the exception of the one who had received the loads in camp, fifty cuts each with a stick, whilst they were held down on the ground. He then gave to the man, whom he accused of having lost the box, a hundred lashes, asking him several times during the beating where the box was, - the man each time still swearing that his box was in camp. He then chained and padlocked the chiefs all together, and accused me of losing three boxes of ammunition (which I flatly denied), and told me that in '77 it would have been death*, and if it happened again we must part. If this sort of thing is to go on, and he speaks to me again as he did to-day before the men, I should not be sorry if we did part, for I certainly will not keep my temper again. Afterwards I went to his tent, and asked him to explain his statement that I had lost three boxes of ammunition; and this he utterly failed to do. He said, "You have three times reported to me boxes lost." I then told him that the last time was only two days ago, when Dr. Parke and I had explained the matter to him, and Parke had handed over to me the box missing from my loads; and the only other time I had reported a load lost, I had also reported to him its recovery. If he goes on much more like this, I shall get sick of the whole thing. He has failed to

* 1877 was the date of Mr. Stanley's return journey 'Through the Dark Continent.'-Ẽ. 
1887. find out the man who lost the box, and has degraded April 18. three of my chiefs, who were simply the best men I have River. ever seen. They are to carry loads to-morrow, and I don't know how to fill their places. I heard from Stairs to-day that at present the Stanley is the only steamer ready to take us up the Congo from the Pool. The English Mission has refused the use of its steamer, and the American Mission is awaiting instructions. This is the magnificent fleet of steamers placed at Mr. Stanley's disposal for ninety days by the King of the Belgians!!

April 19th.-This morning Mr. Stanley succeeded in breaking up my company, I think for good. He made my chiefs, all chained together as they were, carry loads of ammunition, and made new chiefs, picking out two of the worst men amongst them. We marched on to the Luila River, and having crossed it, camped just above it.

April 20th.-Marched to Makoko's village. Here, thank Heaven, Tippu-'Tib interceded on behalf of my chiefs with Mr. Stanley, and he ordered them to be unchained. I at once gave them back their rifles, and made chiefs of them again. Old Makoko, the chief here, is an extraordinary-looking object, possessing what the Americans call a chin-whisker, which he has divided into two, making each division into a ringlet. His old visage is wrinkled and of a perfect chocolate hue. Parke is very seedy with dysentery.

April 21st.-Arrived at Leopoldville, which is a pretty spot, looking right up the Pool, the views of which are rather too peaceful from this end to please me, and not what I had expected.

April 22nd.-Very busy until midday making out returns of men, rifles, hoes, axes, spades, billhooks, loads, \&c. for Mr. Stanley. 'Then Major Barttelot came and told me I could start off at once and try and kill some hippos, for there were no more rations in 
camp for the men. I got my things together as quickly as possible, and of course, in my excitement and eagerness, forgot the two most important things-food and a mosquito curtain! Such small details as these were quite secondary as compared to hippopotami. I trusted to getting some biscuits and tinned stuff at the Dutch trading-house, higher up the Pool, where I had to call for my big rifle; but, on arriving there, found neither rifle nor edibles, but a most acceptable drink of very excellent cognac. I was in a fine big canoe with ten Bangalas to paddle me, and camped some distance above Kinshassa on the river-bank. Never did I spend a more miserable night. My boy had forgotten my waterproof; the rain came down in torrents; and I was wet through before retiring to bed in my tent, and passed the whole night in this soaking condition. Sleep I could not, for the mosquitoes were in thousands; and next morning I was a perfect wreck.

April 23rd.-I started at daybreak; and although I shot two hippos, I only succeeded in getting one of them, as the Bangala, whom I left to watch the first one rise, went sound asleep, and let it float down the Congo. I returned in triumph, however, with the meat to camp. The Bangalas are the greatest savages I ever came across, and about the most difficult to manage. They simply do nothing except when it suits their fancy, although they are splendid men when they do work. On returning to Leopoldville, I heard of great rows going on about the steamers. It appears that, after all, the missionaries had refused to lend the Henry Reed, as one of them (the engineer) was going down to the coast to be married. (This steamer, with the Peace and the Stanley, are the only three available to rake us up the river.) They had taken away some parts of the machinery to render her useless, so Mr. Stanley sent down a guard of Soudanese under Major Barttelot to the Mission House, with orders that if the pieces were not given up, the house was to be searched, and a second guard under Jephson to take 
1887. charge of the steamer. Then the chief of the station, April 23. Mr. Liebrichts, said that Mr. Stanley was wrong in Pool. acting as he had, but that he could make it all right, as the State has the power of taking the Mission steamers whenever they are required; so he removed the Soudanese, replacing them by his own guards. The missionary who was going to be married, said he had considered the whole matter over with God, as Mr. Stanley says, "even to the third watch," and that he could not lend her.

April 24th.-This morning I hear the matter about the steamer is satisfactorily arranged; and Mr. Walker goes as engineer, the steamer being lent under protest, although very well paid for. Meat is so badly wanted that I am off again up the Pool to shoot more hippos. This time, however, I am not going without food or a mosquito curtain. Mr. Liebrichts is sending one of the officers of the State also, as he wants meat for the men of the station. Mr. Stanley has the mails intercepted before reaching Leopoldville, so that the missionaries cannot receive unfavourable advice about lending their steamers.

April 25th.-The Free State officer started this morning in the large canoe, leaving me the small one, out of which it was simply impossible to shoot. His proposition was that, when we saw hippos, one of us should go to the other side of them, that they might be driven from one canoe to the other. I did not quite see this, as the river is narrow between the islands, and I thought of the bullets that would be flying about when one rose between us; so shortly after starting I took a line of my own, and soon shot one, more by good luck than good guidance, as the moment I raised the rifle to fire, over went the canoe on one side. I unfortunately lost this hippo, as $I$ shot it in a rapid current between two islands, and it was carried down before rising. I had a tiresome wait on a sandbank in a scorching sun for four hours ; but no hippo came up. I shot another later, and it did not rise before dark; so we lost it also. 
April 26th.-Got up with a distinct touch of fever, and very shaky; but as I saw some hippos not far off, and succeeded in making some natives lend me a big canoe for the promise of meat, I started off after them, and with the very first shot killed a large cow stone dead-she just opened her jaws and sank. I then struck another, which came up, but I had shot it too far forward, and so it could not keep under water. This one gave me a lot of trouble, charging the canoe over and over again; and although I stopped it each time with a bullet in the head, it was not until the fifth time that I killed it. The way that the Bangalas shouted, and darted round and round him in the canoe, was great fun. Went on shore to wait for the hippos to rise; and while the natives were cutting them up I began a letter home.

Extract from a letter to Mrs. Jameson, dated April 26th:- "On a sandbank in the middle of Stanley Pool, cutting up a hippopotamus just killed. . . . . This is the first chance of writing to you I have had since leaving Banana. It is a cloudy day and cool, so I am writing whilst waiting for a canoe from Leopoldville to take away the meat. I had rather a sharp touch of fever this morning at daybreak, the first I have had, although everyone else has been ill. Stanley has had a bad attack of dysentery, Parke is very ill with it, and Jephson, Stairs, and Nelson have all had fever, while Barttelot has had nothing but bad headaches, and your husband has been in splendid health! There was little or no food for our 700 or 800 men at Leopoldville, so they have sent me to kill meat for them. I have shot a lot of hippos, and would have shot a number more if I had had my big rifle. I got it forwarded from AngoAngo by the Dutch House, as Stanley would not give me carriers for it. I am shooting with an express of Barttelot's, which, although a good gun, is no weapon for hippopotami. The march from Matadi was one of the most disgusting pieces of work I have ever had to do, until the latter part, when the men marched 
1887. better. A lot of slave-drivers of the old days would April 26. have done it much better, for that-slave-driving-is

what it often resolved itself into. (There is a big hippo in the middle of the river looking at me, but I will not try to shoot him as I have not canoes enough to carry the meat.) I have no letters from you later than the one dated February 3rd; the Portuguese mail having broken down, we are without any news, and it is awfully disheartening. The sport and natural-history part of this Expedition is a regular farce, and I can see very little hope of its being any better later on. This is very tiring work to be at so long, sleeping in a swamp at night, and, after shooting a hippo, remaining for three or four hours on a sandbank in a blazing sun, until he rises to the surface, and two hours more, while the superbly lazy, though savage, natives cut it up. I have never been in a country where I believe there is more to be collected. The birds and insects are lovely, but with the work one has to do it is impossible to get anything. All my lovely dreams have been very roughly knocked on the head. I will give you a specimen of a day's work on the march. Barttelot and I started one day as rear-guard a little after 6 A.M., and did not reach camp until after 6 P.M., with not a quarter of an hour's rest all day. Nothing but beating niggers with a stick, and lifting their loads on to their heads, and day after day the same disgusting work. It must take a great deal of glory to make up for it all. I am keeping a diary for you .... .

"Wednesday, 27th.-Still on this sandbank; the canoes have not arrived. When I finished writing yesterday, I went and lay for over an hour in the sun to try and get that big hippo that I told you was looking at me. At last he got up on a bank, and I shot him through the heart, although it was a very long shot. It brought on the fever twice as bad, and I had a very bad time of it all yesterday and last night. . . . It seems years since I left home, and the want of all news from you makes it seem much longer. I am very shaky this morning, so I will lie down for a little. . . . 
" 8 P.M. The Camp, Leopoldville.-I arrived here safely a few hours ago; the canoes turned up at noon. The fever has quite left me. . . A moment ago a perfect tornado of thunder, lightning, rain, and wind came on, and I had to jump up and make the tent right. Thank Heaven, I am not on that sandbank! The natives here seem very much like those of the Mashona country. They have the same kind of 'pianos'*, and there is a great similarity of language, but they are not nearly so far advanced in agriculture. The Bangalas who were with me in the canoe came from higher up the river, and are the people whom Stanley fought. They have never forgiven him for killing the brother of their chief. They are cannibals, and file all their teeth into points. They told me that one of their chiefs, who was very rich, is now quite poor from buying nice, fat, young women to eat; this I know to be a fact. The price of one is from three to four hundred kantakas (short brass rods, which are the money of the country). They eat all those whom they kill in battle. They remove the inside, stuff them with bananas, and roast them whole over a big fire. I can believe anything of them from the little I have had to do with them. The Pool is full of lovely birds, many of which I know to be very rare. We have all had one or two rather disagreeable moments with Mr. Stanley, but I think they are over for the present. I cannot help admiring him immensely for his great strength of will and power of overcoming difficulties ; but there are some points in his character which I cannot admire. I will give you an instance. One day, whilst talking to Dr. Parke, he told him that he had heard that two of the boxes of provisions had been opened by the white men-meaning the officers. Dr. Parke asked him who told him. He replied, some of his Zanzibaris. Parke then told him that the only two cases opened were opened to get out arrowroot and milk for himself (Stanley), when he had dysentery, and that he could not understand his listening to tales about the officers from

* See sketch on page 106.-ED.

1887. April 27. Leopold. ville. 
1887. April 27. the niggers. He had a row with Stairs in exactly the Leopold- same way. Stairs' donkey broke its leg* ${ }^{*}$, and he had ville. to shoot it. I saw the broken leg myself. When he reported the matter, Mr. Stanley informed him that he had been told that the leg was not broken, and that he shot it in a rage; and when asked who had told him, said, "Some of Tippu-Tib's people." Stairs then gave him a real good piece of his mind on the subject. It is impossible for any one calling himself a gentleman, and an officer, to stand this sort of thing. The fact is, this is the first time Stanley has ever had gentlemen to deal with on an expedition of this sort."

\section{DIARY (continued).}

April 27th.-Arrived at camp about 5 o'clock. The meat had nearly all gone bad, and the voyage down the Pool, in a hot sun, with the stinking meat, was anything but pleasant in the condition I was in. I was greatly amused with the Bangalas' method of buying fish from the natives. I landed one day on a sandbank to wait for a hippo to rise, and I noticed all the Bangalas going off to the shore, where there were three native canoes full of fish. I asked my boy where they were going. He replied, "To buy fish." The Bangalas suddenly made a rush at the canoes, upset the natives from out of them, beat them with their paddles, and returned loaded with cooking-pots, young crocodile ready cut up, fish, native bread, and water-bottles made of gourds. I saw some very fine darters, larger than any I saw in South Africa. Shot a spur-winged plover, with beautiful bright orange wattles and pale lemongreen coloured legs.

April 28th.-Marched to Kinshassa. Dined with Mr. Greshoff, who gave us the best of everything.

April 29th.-I saw the natives bringing in a number of fish exactly like our barbel-scales, beard,

* See Diary, April 8th. 
mouth, tail, and everything. After dinner Mr. Greshoff showed us a beautiful chart of the Kwanga River, which led to Mr. Stanley producing Dr. Junker's map

1887. April 29 Kinshassa (his original one), which he has kindly lent him, also a skeleton map of the country between Stanley Falls and Wadelai, ready to fill in all the unknown country. We had a long conversation about natives, geography, \&c., and I spent quite one of the pleasantest evenings since I started. Mr. Stanley, when he throws off his reserve, is one of the most agreeable of men and full of information.

April 30th.-Two hundred men went off under Nelson and Stairs to try and get the Florida into the water, as the slips, on which she was, had broken down when they tried to launch her. Mr. Greshoff very kindly filled my large silver flask with spirits of wine for beetles*. This will be invaluable to me for collecting on the march. In about three hours' time the men returned, having successfully launched the Florida. About 3 o'clock the Stanley and Henry Reed came round from Kinshassa, followed by the Peace from Leopoldville, and by our iron boat, which has been christened the Advance. Before dark we had them all loaded, and ready for the men and donkeys to be put on board in the morning. Just as we were finishing, Ward and Troup turned up in a canoe from Leopoldville. Mr. Stanley has decided to take Ward with him; he was originally in the employ of the State, later on in the Sanford Expedition, and has now joined Mr. Stanley. Mr. Troup was formerly in the Free State service.

* This flask (containing beetles), with the bulk of Jameson's colleotion, never reached England.-ED. 


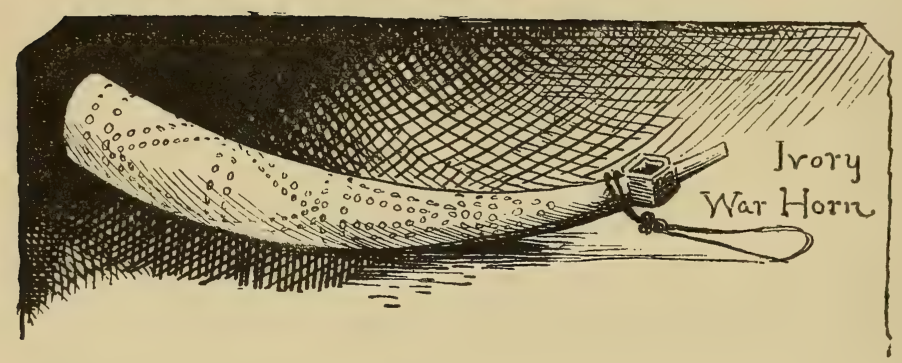

\section{CHAPTER III.}

Mat 1st to June 7 TH.

Start up the Upper Congo.-Scenery on the Pool.-Spiders' webs.-Mswata. -Bula Matadi.-Man proposes, and God disposes.-Bolobo.-Buffalo hunt.-Jameson is informed that he is to be left at Yambuya.-Looting. -Lukulela.-Scenes with Stanley.-Equator Station.-Dine with Mr. Glave. - Uranga. - Bangala.-Houssas eaten by natives.-Fever.Upoto.-Stanley's distrust of his officers.

1887. May 1.

Upper Oongo.

Sunday, May 1st.-At last we have made our final start up the Upper Congo, and on a lucky day. The Henry Reed went first with Tippu-Tib, all his people, and Bonny and Walker on board, towing two whale-boats full of men. We came next in the Stanley, towing the Florida. Towing is not the right word, as both the Henry Reed and the Stanley are stern paddle-wheel steamers; they have to make both boats fast alongside. Stairs, Nelson, Jephson and myself, the Captain, engineer, and 168 men, with three donkeys, made up our number. Next came the Peace with Mr. Stanley, his servant William, and Ward on board. We steamed on to Kimpoko, where the American Mission is (Bishop Taylor's). We landed all the men to cut wood for the 
steamer, and finished by moonlight. My head has been very bad ever since that dose of fever, and, although desperately hungry, I cannot enjoy food. I saw two beautiful large black-backed terns on the Pool, the only ones I have ever seen; but I did not get a shot at them. The scenery on the Pool is completely spoilt by the numbers of low sandy islands, covered with long rank grass, upon which the hippos feast, and where I found large colonies of pigeons and numbers of small herons.

May 2nd.-Mr. Walker and Bonny turned up while we were at dinner, and complained bitterly of the manners and customs of Tippu-Tib and his people on the Henry Reed, their ways not being European ways.

The upper end of the Pool is much finer than the lower; the hills are higher, and the vegetation more luxuriant. Perhaps for the first time you realize what a splendid river the Congo is, as you see it in one grand unbroken stream, not inclosed by rocks as below, but flowing between beautifully wooded hills, their sides covered with tropical forests right down to the water's edge, and their tops with bright green grass, and small clumps of trees dotted here and there. At the end of the Pool are some sandstone cliffs, which, with the morning sun upon them, look exactly like the cliffs of Dover, and are named after them.

May 3rd.-Passed a very large crocodile, numbers of large geese, and several white eagles with brown wings and tail. Saw a nightjar, apparently larger than the Mosambicus, but same colouring, and plenty of elephant-tracks for the first time. We stayed just below the Black River for the night. We could see large and small fish rising at insects all day; I feel sure they would take the fly. It is very disappointing for a sportsman to pass through a country that looks as if it ought to abound with game, and then see nothing but a few old elephant-tracks and crocodiles.

May 4tk. -At some places to-day I should say the D 2 
1887. river was quite a mile and a half wide. The hills are Congo River. much lower, and on the right-hand bank the forest grows only along the water's edge. The landscape is altogether much tamer. Saw a beautiful pure white heron (about the size of our common English one), many spur-winged plover, hornbills, and geese. There

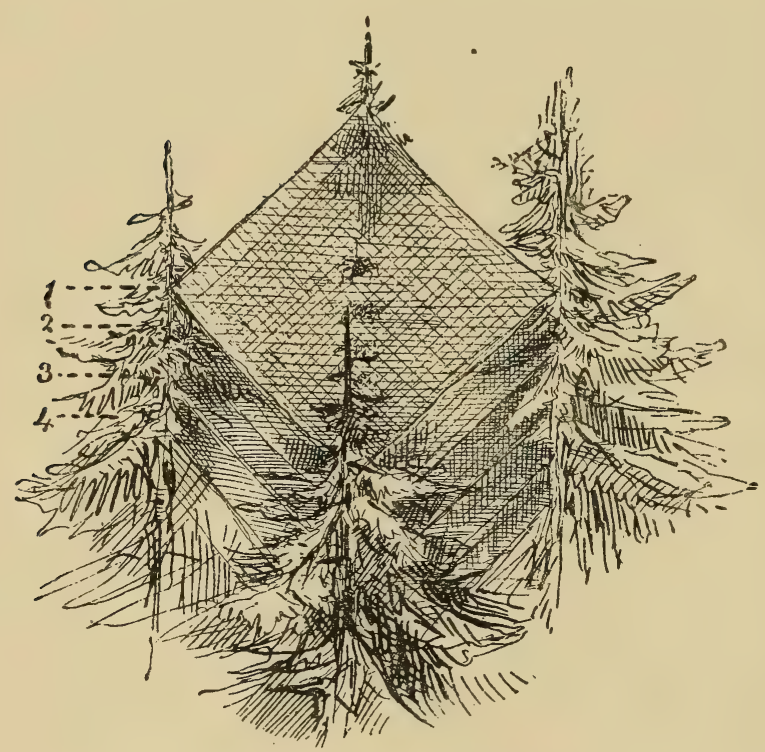

Diagram of Spiders' Webs.

is almost a total absence of swifts and swallows, which is curious, as the Lower Congo abounded with different kinds. Saw a few guinea-fowl, of the common species, and not the crested variety I expected to see. Elephant-tracks again abounded in the forest, which is full of giant creepers. In it I noticed a curious colony of spiders. There were four trees at equal distances, forming a square, and near to the top of each a spider had attached one corner of his web, so that it hung from the four corners just like a blanket. About a foot below this one was another exactly similar, and again a third below it, and so on to within a few feet of the 
ground. There were at least six or eight webs. Each spider took up his station at the centre point of his web, which was a thicker part than the rest, and cupshaped. Between these suspended webs were others upright, connecting them, so as to catch anything flying between. Enormous quantities of ants, of every size and description, swarmed in the forest, and made it anything but a pleasure to walk therein. In the night the men started off to some manioc plantations a long way from the steamer, and returned loaded with roots; and the noise with which the others in camp greeted them was enough to waken the dead. For nearly the whole of the night they did nothing but shout, cook, and eat.

May 5th.-Reached Mswata at 9.30 A.M., where we found Barttelot and Parke flourishing. Their tent was pitched right in the centre of the main street of the town, if it may so be called, and amidst quantities of bananas. The old chief was most friendly and anxious to see "Bula Matadi," as all the natives call Mr. Stanley. The meaning of the name is "Stone-breaker," and it was given him whilst at Vivi. One of the Zanzibaris was trying to break a large rock, and striking it in the wrong direction. Stanley noticed the lay of the cleavage and took the hammer, sending the stone flying in pieces with one blow. This so astonished the

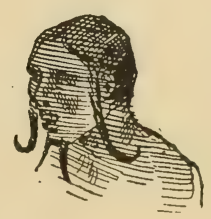

natives that they at once called him Bula Matadi, and he is universally known all over the country by this name and no other. Mswata in Stanley's time was one of the Congo State stations, but, like many others, has been abandoned. The chief has the same mark of 
1887. distinction as old Makoko, namely a chin-whisker, May 5. divided into two curls. They divide their hair into two long tails, one on each side of the forehead, bending outwards, exactly in the shape of buffalo horns, and sometimes have one in the middle also. The number of these horns is evidently a sign of the degree of rank of the wearer, the greatest swells having the largest number. I went for a stroll through a lovely forest, full of small streams, at the back of the town, and got a glorious lot of new butterflies. This is the first place where I have noticed a decided change in the butterflies from those of the Lower Congo, some of them being very beautiful. Barttelot and Parke are to march to Kwamouth. They dined with us, and we spent a very pleasant evening. Mr. Stanley sent for Stairs after dinner, and told him we were to go on straight to Bolobo with as little delay as possible, and there to ask the chief's leave to land our men for a few days, as the last time Stanley was there he was fired upon, and they had to burn down the town. Whilst it was a Free State station and Mr. Liebrichts was in command, they had no palavers, and burnt the town both times; so no wonder the natives don't like the white man. Mr. Stanley says, if they refuse to let us land, we must occupy one of the islands opposite to the town, and await his arrival. He thinks it is about even chances that we have a row.

May 6th.-Never came a saying more true than did the old one to-day, "Man proposes, and God disposes." We were hours ahead of both the other steamers, boasting by how far we should beat the Peace up to the Falls, if we were allowed to go ahead, all sitting in the top deck-house with the Captain, when there came a violent bump, then another, and another, and we were stuck fast on the top of a rock, with the water pouring into three compartments, through about five holes in our bottom, and we three or four hundred yards well out in the river! Luckily the Zanzibaris behaved splendidly, sitting perfectly still and doing as 
they were told. With the aid of buckets we could just keep the water from gaining, but could not get it down. Upon sounding, we found ourselves on the top of a large flat rock, with not more than three feet of water on any part of it. Luckily the Florida, which was fastened alongside with 168 men on board, numerous loads and donkeys, was drawing so little water that she did not touch. The holes were all in the afterpart of the forward compartments; and, as she is built in nine water-tight compartments, as long as we could keep the water from gaining and the steamer from bumping, we were safe. We shifted the whole of the cargo into the stern, and dropped two anchors. Just then a thunderstorm came up, with a strong breeze; she at once swung round, and we started the engine full speed astern; with one more bump we swung clear right into the deep water, breaking one anchor, and leaving the other with a lump of chain on the rock. Then we went full speed ahead up-stream, and baled away with the buckets, as our lives depended upon it. We ran both boats on to a sandy beach on the mainland, half a mile above the scene of our disaster. That puff of wind just came in time, and saved us. Had we sunk, probably the Florida would have been wrecked too. In any case most of the ammunition, and all the European provisions and stuff to buy food, would have been lost in the Stanley. I thanked God, not once but a good many times, that we got out of it as well as we did. The view passing Kwamouth is very pretty. The Kwa, which is really only the mouth of the Kassai River (which runs into it), is the largest tributary of the Congo, being navigable for over 400 miles.

May 7th.-Up at daylight, but very sleepy. The Henry Reed appeared in the mirage, down river, about 8.30 A.M., so we sent our pilot off in a canoe, to warn them about the rock, as they were steering straight for it. Much later we saw the Peace going along close in to the opposite shore; we signalled, and the Henry Reed whistled, and they came across to us. Mr. Stanley,

1887.

May 6

Congo

River. 
1887. of course, was rather annoyed at our disaster, and told Congo the Captain he had no business to come over to this side River. of the river, but he replied that this side was the course marked on his chart, and explained to him by Captain Anderson, the late commander of the Stanley, and that the missionaries also used the same course. Mr. Stanley then took in hand the directions for patching up the steamer, and the Captain and the three engineers carried them out. We first of all removed all the cargo, and swung her round side on to the beach, then dug a trench with hoes right under her to the largest of the holes. A plate was passed through the water on to the outside and screwed on by bolts. Little hopes of starting to-morrow. Mr. Stanley said to-day that every day of delay cost the Expedition $£ 25$ in wages to the men alone.

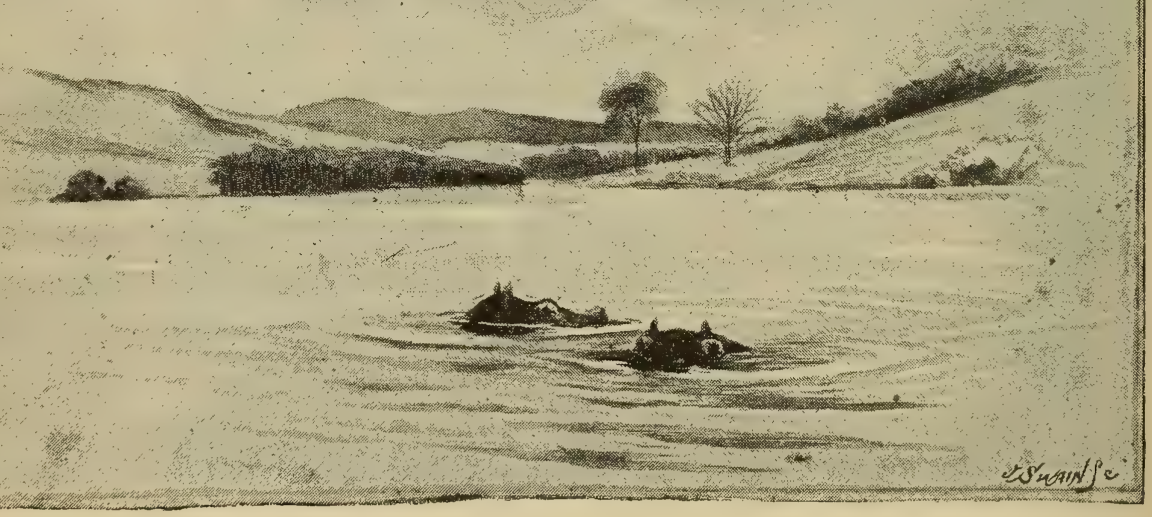

KWAMOUTH.

May 8th.-Mr. Stanley, the Captain, and engineers worked away until about 8 o'clock at the leaks with a good deal of success.

May 9th.-Loading up the Stanley ready for a start in the morning. Mr. Stanley and the engineers finished 
putting the plates on by 11 o'clock; the former left for Bolobo at 12.30 .

May 10th--To-day the scenery became very beautiful. The river widened to about four miles, and was dotted all over with small islands covered with tropical foliage. At the back of every sandbank or island, in the still water, the heads of the hippopotami could be seen moving up and down, or their long backs just above the water resting on the banks. Numbers of geese were wading on the shores, while large black and white eagles soared from island to island, and ever and again gorgeous bee-eaters and kingfishers darted out of the forest, the bee-eaters hawking away, then tumbling over and floating away to another tree, their colours glittering in the sun. The kingfishers would dart out, hover for a moment over the water, then apparently dive into it, to return to their perch, and sit pensively gazing down at the river below them. Large cranes stood solemnly on the banks, absorbed in the contemplation of some deep and momentous subject. Then a heavy thunderstorm passed over us, in the midst of which the far shore stood out in bright sunlight, with a background of exquisite mountains and valleys, and one longed for the skill of an artist to give to the people at home an idea of this magnificent river. The villages of brown huts, embedded in the gorgeous green of the plantains, with giant trees towering all around them, the canoes lying on the sandy beach, with the fishing-nets hung out to dry, here and there a native with spear in hand-all these scenes furnished splendid subjects for the artist-who is not with us!

May 11th.-Arrived at Bolobo, which is prettily situated, looking over one of the broadest parts of the river. Found fresh buffalo-tracks to-day, and for the first time saw the crested guinea-fowl which I expected to meet. The natives here paint themselves in an extraordinary fashion, some having a black band across the forehead with white lines drawn over and under the eyes. Others have long white lines running down 
1887. the shoulders and arms, and the same down the forehead May 11. and nose. Some of the lines are blue and yellow for a variety. The knives and axes are very fine, but they will not part with them. Their spears resemble the Mashona spears. Their guns are old flint-muskets.

May 12th.-The Henry Reed arrived with the Peace in tow. Mr. Stanley came to the officers' tent in the afternoon, and had a long chat with us. He is going to reorganize all the companies, and only take on the best men, leaving the bad ones here with Major Barttelot to come on when the Stanley returns down the river. Had to go off very early to cut wood for the Stanley.

May 13th.-We are are all going to be put on short rations now; $\frac{1}{5}$ ounce of tea a day for each man, and everything else in proportion. Major Barttelot is to come on to the entrenched camp after all, and Ward is to be left here. I feel very sorry for him, as up to the very last moment he thought he was going on. Mr. Bonny is also being left here. Good news! Mr. Stanley has given me leave to start at daybreak to-morrow for a buffalo hunt, and get meat for the men.

May 14th.-After about three and a half hours' walking, I came upon one of the most lovely valleys for game I think I have ever seen or dreamt of, and in any other country but this it would simply swarm. A few clumps of trees grew here and there close to some pools of water, the rest of the valley being covered with luxuriant grass, amongst which shone out patches of tender green, where it had once been burnt. After walking about a mile up along the pools, I came across the tracks of a bull buffalo, two cows and a calf, which had evidently passed just before I arrived on the scene. I tracked them until after 1 o'clock into the middle of a dense forest, so thick that I had to leave my helmet and go down on my hands and knees, and crawl nearly every yard of the road. I heard them break once quite close to me, but could not see them. Finally I gave it up, 
and tried the rest of the valley without finding a single fresh track. I broke one of my big-toe nails, right across the very centre, against a stump in the beastly 1887. May 14 Bolobo. wood, and had to walk the six or seven miles back to camp in anything but a nice frame of mind. I was greatly surprised to find the Stanley had just arrived with Barttelot and Parke, for we did not expect them until to-morrow. Mr. Stanley has rearranged all the companies, and mine is entirely broken up; he has taken a lot of the best men from nearly every company to make up his own to its full strength. Mine was used to fill up the others, so at present I am without one. We all start to-morrow.

May 15th.-Alas for all my bright dreams about the march from the Falls to Wadelai. To-day Mr. Stanley informed me that I was to be left with Major Barttelot in command of the entrenched camp on the Aruwimi. Of course he tried to soften the matter as much as he possibly could, by telling me that as most of the ammunition and stores were being left here, he required two of the best men to remain and guard them, for if anything happened to them the whole Expedition would be at an end. He also told me that the men who went on must not think that they would have the larger share of honour; but whatever he may say about it, it makes me mad to think of it. When he told me, I merely replied "Very well, Sir," as I knew that somebody must be left. I am quite sure that Major Barttelot had already asked him to leave me with him as his lieutenant, his chief reason being that he was afraid he would not pull so well with some of the other officers. It is frightfully hard luck on me. Mr. Stanley told me to get a canoe, and find out as much as I possibly could about the river. The natives are a bad lot, and I believe we will have to fight for food for the men by looting villages. The bright side of the whole thing is the splendid opportunity it gives me of collecting in a country never collected in before, and altogether, as far as I can make out, we shall have rather an exciting time of it. 
1887. May 15. Bolobo.

[Extract from letter to his wife, June 8th, 1887 :"He (Stanley) also told me that those, who went on first "to the Albert Nyanza Lake, must not think that they " had one atom more honour attached to what they did, " as he himself would be the only one to meet Emin "Pasha in his steamers on the Lake; the others would " be left in a camp on its shores."]

The Peace started first this morning, then the Henry Reed, and lastly ourselves in the Stanley. We made fast to the shore at a village about twelve miles above Bolobo, and when Stairs and Nelson landed with the axe-men, it seems the natives did not want to let them go through the village. Some of the men ran back yelling out that the natives were coming, and to bring all the guns. Barttelot thought they were being attacked, so he landed all the Soudanese and a box of ammunition, but on getting up into the village not a native was to be seen; they had all run away. When the Soudanese returned to the shore, they made a rush across a small stream to the village on the opposite side, followed by the Zanzibaris, when an awful scene of loot commenced. They seized goats, fowls, bananas, manioc, spears, and everything that they could lay their hands on. I saw one man with an enormous wooden stool which he could not possibly have taken with him on the steamer, and I caught a Somali redhanded with an immense bundle of manioc and a spear; I smote him rather hard and he dropped the lot. The spear I attached to my person. The river to-day widened out very much, being dotted over with small and large islands. I am trying hard to look at the bright side of my being left at the entrenched campthe collecting, sketching and fighting-but I cannot get over a thorough feeling of disappointment.

May 16th.-Just as we were leaving the natives began to return, and were in a fearful rage when they missed their things, though some of them were willing to trade, and we got a few fish and bananas from them. 


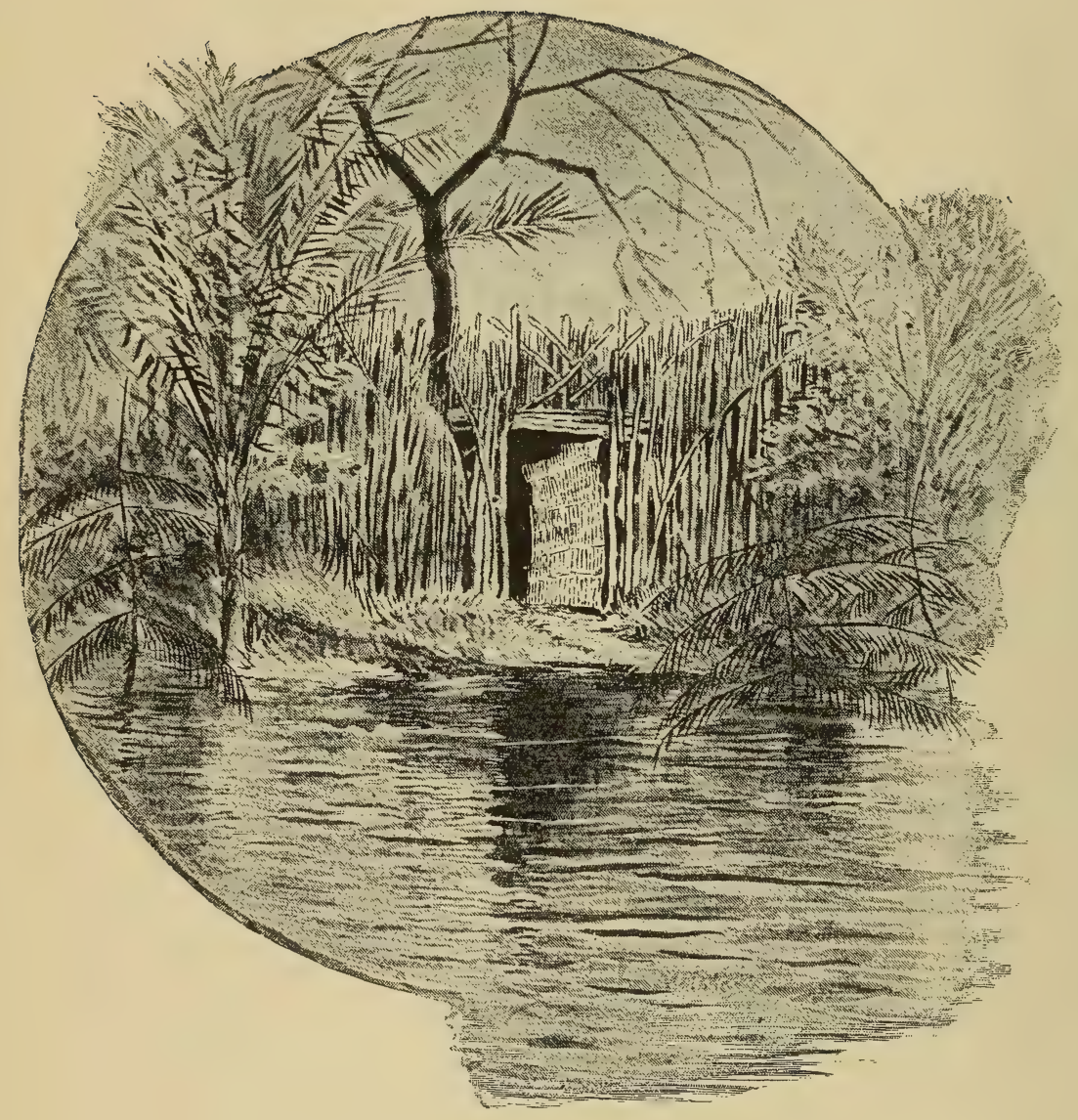

Fisherman's HUt. [Page 47.] 
May 17th.-Very seedy. Last night I had to stand over half an hour in water above my ankles waiting for the wood-carriers, who could not find us in the dark, the consequence of which is a bad internal chill.

May 18th.-Too seedy to do anything. This evening we made fast to the shore at a little fisherman's hut, which had a regular palisade and gateway between it and the river. Our only hope of wıod was a large dead tree which stood inside the palisade.

May 19th.-Still seedy. Reached Lukulela, after steaming for twelve hours. We saw two small elephants within 150 yards of the steamer in the long grass. Stairs and Barttelot landed and tried to get a shot, but the noise from the steamer had sent them away at a quick march. They saw any quantity of fresh tracks of both elephant and buffalo. It is great fun to see the Stanley start in the morning; before they can get her head well up-stream, she waltzes round and round two or three times, sticking her stern and bows alternately into the bushes, exactly like a toy boat in a stream. The Doctor came on board to-night and saw me. Thank goodness, I am much better.

May 20th. - This morning, I am sorry to say that the most disgraceful row I have ever heard of happened between Mr. Stanley and Jephson and Stairs. It appears that early this morning a number of the men and chiefs went to Mr. Stanley, and complained that the officers had flung away their rations for one day. Mr. Stanley sent for Stairs. The men swore they had bought the food from the natives last Sunday at the village they looted (for description of how they bought it, see diary of that day, May 15th). Stairs told Mir. Stanley this, assuring him that only stolen stuff was taken away from them, and sent for Jephson, who gave the same testimony. It is still quite evident that Mr. Stanley takes the word of the Zanzibaris on every occasion before that of the white men, and when he saw that he had hold of rather the wrong end of this stick, he attacked them about their

1887.

May 17 .

Congo

River. 
1887. tyranny to the men. He attacked them in a frantic May 20. state, stamping up and down the deck of the Yeace. He called Jephson all sorts of names, a "G-d d-n son "of a sea-cook," "You d-_ d ass, you're tired of me, of " the Expedition, and of my men. Go into the bush, get, "I've done with you. And you too, Lieutenant Stairs, "you and I will part to-day; you're tired of me, Sir, I can "see. Get; away into the bush." Then he turned round to the men (about 150) sitting down, and spoke Swahili to the effect that the men were to obey us no more, and that if Lieutenant Stairs or Jephson issued any orders to them, or dared to lift a hand, they were to tie them up to trees. He had already told Stairs that he had only to lift his hand for the men to throw him into the sea. He lastly offered to fight Jephson, "If you want to fight, " $\mathrm{G}-\mathrm{d} \mathrm{d}-\mathrm{n}$ you, I'll give you a bellyful. If I were " only where you are, I'd go for you. It's lucky for you "I'm where I am." Mr. Stanley was on the deck of the Peace, Jephson on shore. All this was said before the missionaries, Tippu-Tib, and every one. As for Stairs or Jephson being tired of the Expedition, no men could work harder or have their hearts more in it. I should think a repetition of this kind of thing would make them both pretty sick of Mr. Stanley and the Expedition $\mathrm{He}$ also called Jephson, " $\mathrm{G}-\mathrm{d}$ d-d impudent puppy." Barttelot next interviewed him, and he told him that he was very sorry for Stairs, but had made up his mind they should stay where they were-that there was evidently a compact among us against him. Barttelot assured him that there was nothing of the kind. Stairs next went to him, and after a long interview it ended in Mr. Stanley taking him back, and telling him that he had given orders to the chiefs to obey him as before. Imagine this being necessary, simply from what he had himself said to them! Jephson went last, and the interview ended by Mr. Stanley apologizing for the language he had used, and taking him back also. I had no idea until to-day what an extremely dangerous man Stanley was. Could there be anything more inciting to mutiny than what he had told the Zanzibaris? He for- 
gets one thing, however, that if they dared to lift a hand to one of us there would be a terrible lot of them shot, which would rather weaken his Expedition. It is a curious fact, when one thinks over it, that the very men who complained to Mr. Stanley ought, by his own orders, issued when we left the Pool, to have been severely flogged. Such is life! Thank goodness, I am beginning to feel myself again. On his way back from Mr. Stanley, Jephson brought me an enormous spider, quite the biggest I have ever seen, although rather mutilated. One of the men brought me a splendid crested lory; I skinned it, but am puzzled how to carry it because of its size, which is about that of a hornbill. The village here stands amidst beautiful timber, and the huts shine out like gold in the sunset against the dark shadows of the forest, making a beautiful picture.

May 21st.-We did not start for a good hour after the Peace and Henry Reed, the engineer said because the wood was too wet, and they could not get up steam. Mr. Stanley's orders were that all the steamers were to keep within sight of each other in case of anything going wrong. We came in sight of them early in the forenoon; a little later they stopped because of a storm which came on, and we stopped to cut wood, having run short. They have now both gone on out of sight; it is 4 P.M., and I should think there must be miles between us. The Henry Reed and the Peace took different routes, and we are staying here for the night. This is keeping within sight of one another with a vengeance!

May 22nd. - Until about 12 o'clock to-day we were passing through the most lovely tropical forest scenery. Our passage lay through long lanes of water, that scemed to be cut like canals through the centre of the forest, the right bank being the mainland. Every now and again we could catch a glimpse of the great river covered with islands. 'The rainy season has set in now, and every afternoon, as regularly as clockwork, at 
1887. three or four o'clock, up comes a storm which lasts Conga until nightfall.

River.

May 23rd.- Started at 5.30 well ahead of the Henry Reed and Peace, which we had caught up yesterday evening, but ours was a short-lived glory, for we very soon ran short of wood, and at 11 o'clock had to stop and cut some. Started again at 2 o'clock, and steamed until 5 o'clock. More woodcutting, dinner, and to bed. It is beginning to be decidedly monotonous.

May 24th.-We all reached Equator Station shortly after 5 o'clock. This is one of the nicest looking stations we have yet seen. We have been passing numerous native villages very prettily situated on the edge of the forest, and of which the huts are now changing in shape altogether, and a good many of them are stockaded. Some are very long, with angular-shaped roofs, and many doors to them. The spears, too, have changed in shape; they are very light in shaft and blade, being used for throwing only, whereas those lower down the river are heavy-bladed and are used for stabbing. 'The palm-trees here are curiously ragged in appearance, owing to the attacks of the weaver-birds, who have stripped them of almost all their leaves, with which they build their nests on other trees. The natives are a finer-looking people, resembling the Bangalas I saw at the Pool. I was delighted to hear that the Peace had to stop and cut wood as well as ourselves, for Mr. Stanley had been blaming us for loitering on the road.

May 25th.-Went on shore early with the axemen to cut wood. In the afternoon, Mr. Glave, who now belongs to the Sanford Expedition*, came on board, and asked us all to dine. He was formerly in the service of the Free State, but has left it like many more, as rats leave a sinking ship. I notice that one of the chief occupations of the Belgian officers at the different stations is to civilize the country by adding to the population

* The Sanford Expedition was an Ivory Trading Company, called the Sanford Exploring Company; vide 'Darkest Africa,' vol.i. p. 93.-En. 
specimens of half-breeds, as they are all more or less married to native women. This mode of civilization seems to be adopted by all the white men here, whether officers of the State or not. I saw some beautiful perch, almost exactly like our own. We dined with $\mathrm{Mr}$. Glave, and during dinner Captain Van Gèle related a story about some wonderful river, a tributary of the Congo, which he had been exploring, and from which he had brought some ivory mallets, used for crushing corn or manioc. He produced them, and was greatly annoyed when both Dr. Parke and I declared them to be bone, and not ivory at all! This, I am sorry to say, damped the conversation. The ivory here is very large indeed. Amongst a lot bought by Glave for the Sanford Expedition were tusks of 118, 111, 97, 95, and 90 lbs. Much of it is greatly discoloured through having been buried. He only paid $2 s$. $2 d$. a lb. for the $118 \mathrm{lb}$. tusk, which is a fairly white one.

May 26th.-Steamed all day through the usual number of wooded islands. Close to where we made fast for the night was a small bare sandbank, inhabited by a small colony of the most beautiful terns I have ever seen. The top of the head, neck, and back are all black ; throat, breast, and belly are pure white; bill and legs red. They are, I think, similar to two which I observed at Stanley Pool. As I had no small boat, I could not get a shot. We had the usual woodcutting business in the jungle, became covered as usual with the ants, and later on up came the usual thunderstorm. Mr. Stanley's orders are that we are not to go ahead of the Peace, and the Henry Reed has to obey the same orders. Mr. Stanley has ordered Parke to come on with us in the Stanley, and Jephson to take his place in the Henry Reed, because he says there are so many sick on the Stanley and Florida. However that may be, it seems a mistake putting Jephson on the same steamer with Tippu-Tib and his men, as he has already had one rather nasty row with Salem, 'Tippu's brother-in-law.

May 27th.-After a very short piece of steaming and E 2 
1887. going frightfully slowly to keep behind the Peace, we Mranga. 27 reached Uranga at 10.30 A.M. Mr. Stanley is a "bloodbrother" of the chief of this place. I try every conceivable plan to protect my specimens from the ants, but though I may succeed for a short time they are sure to defeat me at last. I noticed many of the spears here resemble the Mashona ones, having a long piece of iron between the blade and the ordinary wooden shaft, which latter is bound round by rings of iron; they also have the leaf-shaped blade. I unintentionally swindled an old chief out of a goat, but it served him right, as he swindled me about a spear which I bought from him with cloth, knowing that I was giving too much; but as I wanted it badly I did not wrangle over the price. He then said he would make me a present of a goat, which in this country means that I had to give him a present in return. I told him I did not want it; but when I came back, late in the evening, it had been sent on board. After dinner he came and made a great fuss, saying he must have the goat or a present. Nelson, who was on deck, turned him off. We started just after daybreak, and he tried to board us with his canoe, instead of coming for his present before we got under way. We left him in the middle of the river, evidently using anything but nice language. He will be rather chary of giving presents again, and we will eat the goat, which seems fat.

May 28th.-A most monotonous day's steaming. I am sorry to say I have read nearly all our small store of books.

May 29th.-Islands, river, scenery, natives, canoes, \&c., just the same as yesterday. The only excitement was caused by a troop of large brown monkeys who appeared on some trees on the banks, and who seemed not to be the least bit frightened at the steamer, but went on scratching and hunting as though nothing out of the common was near them. Stopped for the night on an island opposite Bolombo.

May 30th.-Numbers of natives in canoes came round the steamers, trying to persuade us to stop at Bolombo 
and trade for food; but as Iboko, or Bangala, was only a few hours ahead there was not much chance of that. Bolombo is on the south bank, and Iboko on the north bank of the river. We arrived at the latter place at 12.30. Mr. Stanley was saluted from the Station by shots from one of the Krupp guns, of which they have two. The Houssas and Zanzibaris were drawn up in a line, and the excitement on shore was intense to know what on earth so many steamers and people had come for. They thought it was an Expedition to retake the Falls, as they had not heard any news for four months. The Station, which is the last, and one of the largest on the Congo, consists of three white buildings, constructed of mud, plaster, and stick walls, with a thatched roof, beneath which is built, I believe, a solid ceiling of mud to prevent it falling-in in case of fire. A Frenchman here, by trade a brickmaker, has utilized all the different kinds of clay to be found on the shore, witli which he has constructed regular brick sheds, yards, and kilns; when I saw them there were 300,000 bricks, principally on the floors, but one very large kiln was already made and burning. The women here dress in quite a different way to any I have yet seen, their costume being composed of a light band of palm-fibres, made from the bark, and dyed-some orange, some lemon and orange, others black or deep lake-red; they look for all the world like a ballet-dancer's skirts. Both men and women are a very fine-looking race. The new Station is defended by three palisades and a ditch; at the corners are raised platforms for the Krupp guns. There is the making of a good garden, which is the result of Mr. Bailey's teaching, who seems to have taught them more than half of what they know on the Congo, especially in matters connected with sport, gardening, and planting. Mons. Baert give us dinner in the evening, after which Mr. Stanley rose, and in a speech proposed the health of the King of the Belgians. He began by telling us of the state Bangala and the other places on the river were in when he passed down ten years ago, and had the great fight with the natives here. He continued:- "Now here I find an hotel 
1887. (doubtful compliment to the Belgians, who call it a Free May 30. State station!), where one can have a good bed, good dinner, and everything that one wants." He then traced how this was all owing to the King of the Belgians, and went on to say that we were here at the very last point of civilization between us and Zanzibar. The speech ended by his proposing the health of the King of the Belgians, which was duly drunk.

Major Barttelot, with forty of the best of the Soudanese, goes on to Stanley Falls in the Henry Reed, where he leaves 'Tippu-Tib, and comes up the Aruwimi to where we are to make the entrenched camp, about 120 miles up the river. The reason that Stanley is sending the Soudanese instead of the Zanzibaris, is that he fears that if they saw Tippu's place and people, the discontented ones would come back to the camp, and persuade the others to desert us; as, should they once get to Tippu-Tib's camp, it would be a simple matter for them to get out to Zanzibar with one of his caravans, or find employment in some of his towns. The tribes on the Aruwimi are very fierce and warlike, and are real cannibals, so they will be rather interesting to study. Mr. Stanley is the only white man who has been any distance up the river, and I believe he has not been so far as where we intend to make our camp.

Captain Hausen, in the Free State service, left three of his Houssas at one of the towns near the mouth of the Aruwimi, and the natives tied them to trees, and crammed them with food until they considered them sufficiently fat, when they ate two of them, but the third, being a thin old fellow, was reserved. However, he escaped, and was caught and tied up again; this happened twice, but the third time he got away to the river, and was picked up by one of the steamers. The same curious appearance is given to the palm-trees here as at Equator Station, by the weaver-birds stripping off all the leaves for their nests, which they have built on a large tree without any leaves in the centre of the Station. The hippopotami are becoming very scarce; we have hardly seen one since leaving Equator Station. 
May 31st.-The Henry Reed left for the Falls, with Major Barttelot and Tippu-Tib, at 6 A.M. Mr. Stanley left in the Peace at noon. Our men strolled on board evidently just as they pleased, and we did not get away for a good hour and a half after him. Since that speech of his to them at Lukulela they have lost what little sense of discipline they ever had. We all lunched with Mons. Baert, and a capital lunch he gave us.

Major Barttelot left nineteen of the Soudanese and Alexander (one of the interpreters) in my charge until he arrives at the Aruwimi camp. Alexander and four others are in a very bad state, and one of the men especially I do not expect to live more than a few days. They are the most helpless and desponding lot of men when they are at all sick that I ever came across. I tried to buy a very curious knife from one of the Bangalas this morning, but he asked such an absurd price for it that I told him he ought to keep it at home for fear of losing it. The Captain told us to-day that at Manyanga, on the lower Congo, a hippo that was on shore was fired at, and, charging through the village, ran clean through the middle of the walls of a house on to the roof of which a lot of people had retreated.

June 1st.-Kept steaming away all day behind the Peace until nearly sunset. Went to bed with a distinct touch of fever.

June 2nd.-Had to lie up all day.

Tune 3rd.-Bad night; had to lie up again all day, but got better towards evening, thanks to old Parke, who has given me the right medicine to begin with, and topped it up with arrowroot, milk, and brandy. There are enormous quantities of orchilla-weed all along the south bank, and for the last three days we have passed through one continuous stream of the common white butterfly of the Congo, all migrating from the south bank to the north. A day or two before I saw them crossing the river I noticed them flying 
1887. through the trees on the south bank in enormous numbers, and all going eastward in the same direction as ourselves; then suddenly they began to cross in thousands, and have been crossing ever since.

June 4th.-Thank goodness, feel myself again. Steamed away all day through the same monotonous scenery, although I must say some of the gorgeous colouring can never seem anything but fresh and pleasing to the eye. A few monkeys looked at us, and helped to relieve the monotony of the scene. We never managed to catch up the Peace. The first hippos we have seen for a long time came up close to the steamer after we had made fast for the night, and Parke had a shot at one of them, but put the bullet just over his head. After he fired I noticed a very large flight of birds, all flying due south, and from their form and flight, seen in the dusky light, they appeared to be medium-sized owls. The flight continued for quite twenty minutes. One of the Somalis died to-day; he had only been ill about twenty-four hours.

Sunday, June 5th.-Started very early-almost in the dark-in hopes of catching up the Peace; this we failed to do. One of the Soudanese died to-day, the second death amongst them since leaving Bangala. When they once get sick they neither eat, drink, nor move ; in fact, like the Somalis, they simply make up their minds to die. I saw many very fine orchids in the jungle to-day, but none of them in flower, and one beautiful fern growing high up in the palm-trees. The leaves of it grow outwards for only a few inches, and then hang straight down in perfect masses round the trunk of the palm. This would be a most effective plant in a European hothouse.

June 6th.-Quite an exciting day. Made an early start, and after going through the most difficult passages between islands and sandbanks, we at last came within sight of Upoto, which stands at the foot of the first high ground we have seen for some time. No signs of either 
the Peace or the Henry Reed! 'There were three separate villages some distance apart, so we steamed up to the one highest up river, to see if the steamers could be there. Not finding them, we made for the middle village, and upon our approach to land, all the natives rushed down to the shore with their spears, shields, and guns, yelling and shouting at us to keep back. They certainly meant an attack, so we started for the lowest village, the natives following us and running along the shore, where they were joined by all the men of the third village. As wood was very short, and we must get food for the men, we ran the steamer straight for shore, and they all stood about forty yards off, making a terrific noise. They at length listened to our spokesman, and agreed to allow us to land if one of the white men would come on shore and be made blood-brother to their chief. Stairs and the Captain of the steamer landed, and the ceremony was performed with much pomp. Stairs' arm was slightly cut until blood came, and the chief's also, then the bleeding parts were rubbed together, each man swearing to be a "true brother" to the other. All this time a wild song was kept up by the natives, beer was drunk, and the chief sent us a present of a goat. The fierce natives of half an hour ago were in one moment transformed into the sharpest and most eager traders, ready to sell everything they possessed. What little modesty one has left, after seeing daily so many naked forms, here received rather a shock, for the women are as Eve was before she went to Madame Figuier for her costumes. There were a few exceptions among the elder women, but their attempts at dress are so much of a failure that they had far better remain as their sisters. The people here are the genuine savage, without a vestige of civilization. I bought three very curious knives, two handsome spears, and a shield, which, if they ever reach home, will be great curiosities. In the afternoon up steamed the Peace. Mr. Stanley was in a fearful rage. It appears that after missing us yesterday he steamed back down river to look for us, thereby losing a whole day. He told us that had he 
1887. not found the steamer here, he would have treated us Upoto. all as deserters. Now this is hardly fair, as from what the Captain and Engineer of the Peace both say it is evident that he missed us owing to a fault of his own. He mistook a channel of the main river for a small river which he thought ran into the Congo at this place. He therefore steamed away outside an island when we went up the passage along the mainland. He used some very

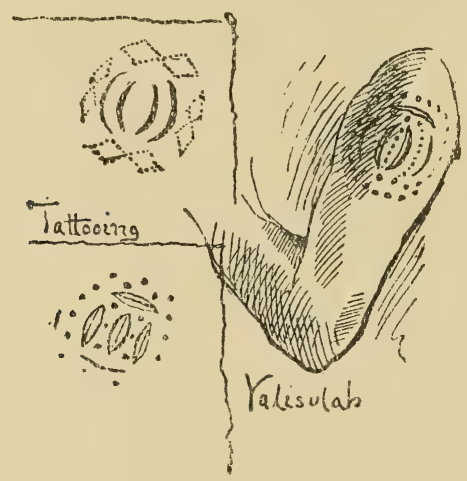

hard words whilst talking to us, and it seems as if he did not trust us when one yard away from him. As for myself, I know I have done nothing, but then I have been so seedy until yesterday; but the other officers

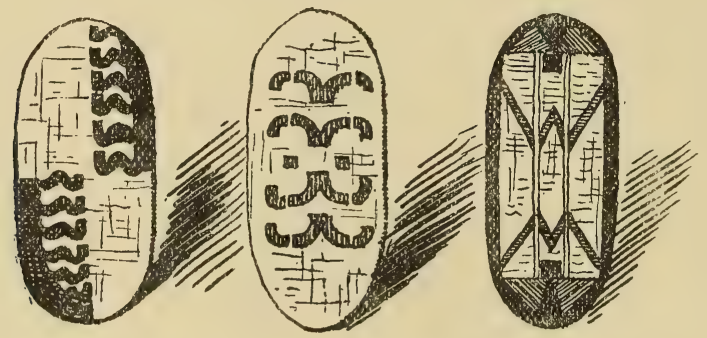

have worked away as hard as any white man can, standing for hours in the most horrible swamps till long after dark to get enough wood. What sickens one of the whole thing is the utter distrust which Mr. Stanley plainly tells us he has of us all; and how long this state of things is going to last I cannot tell, but it is frightfully 
disheartening. The necklaces in fashion here are mostly of human or crocodile teeth, which are bored and hung in large numbers on a piece of string; the earrings worn by men, instead of the women, are of cowrie-shells. They had a lot of ivory to sell at absurdly low prices, but all very small and discoloured. Their huts, which are miserable, are built in small streets at right angles to the river-bank. Had an interesting chat with Mr. Charters of the Peace, who confirmed in every particular the story of the Houssas being eaten at Basoko.

June 7 th.-The war-like natives of yesterday are peaceful traders now, coming up with a shield and spear in one hand, and two eggs or a fowl in the other, and begging one to buy. Mr. Stanley told them that had they attacked us yesterday, there would not have been a vestige of their village left this morning. We started at 12 o'clock, and steamed away into the usual maze of islands, quickly losing sight of the high mainland, which had been so refreshing to our eyes. We started this time with every intention of its not being our fault if we lose the Peace again. Both steamers stopped at 5 o'clock, and the usual cutting of wood in swamps was gone through. This time I was fit and went out too.

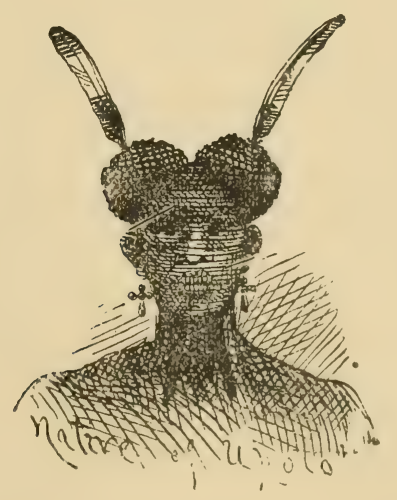

Native of U'OTO, 


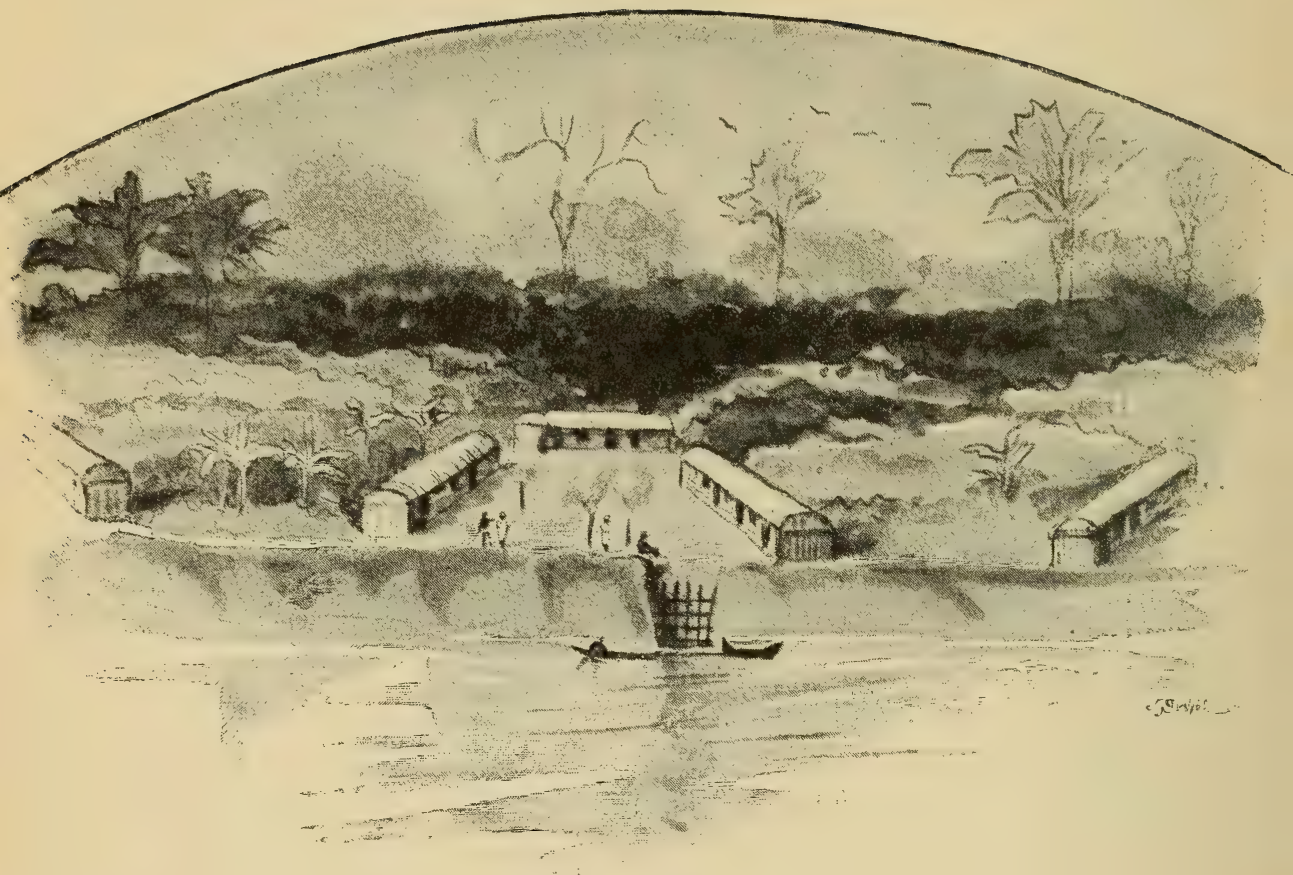

Native Village.

\section{CHAP'TER IV.}

June 8TH to JuLY $31 \mathrm{st.}$

Letter to Mrs. Jameson.-Pass burning villages.-Arrival at Aruwimi River. -Conical-shaped huts.-Occupation of Yambuya.-Arrival of Henry Reed.-Stanley's letter of instructions.-Re-packing. bales for Emin. -Barttelot made "blood-brother" with native chief--Rations for six months._-"Beggars must not be choosers."--Stanley's departure.Building boma.-Extraordinary flight of butterflies.-Palaver with natixes.-_ "Collecting" captives.-Natives capture Omari-_Woman escapes.-Uselessness of chiefs.-Gum-copal.

\section{FROM A LETTER TO MRS. JAMESON.}

1887. June 8th.-I will now give you a general idea of the June 8. plan of campaign. At present we have left behind us 
a force of 124 men at Bolobo under Ward and Bonny, At Leopoldville is an enormous quantity of stores and ammunition which we could not bring. When the steamers leave us at the entrenched camp, they return down the Congo, and the Stanley will bring up all the stores and ammunition with the 124 men from Bolobo. In the meanwhile Stanley will have gone on with 350 men (leaving 100 men with us in camp), carrying light loads, to make a forced march through the unknown country to Lake Albert Nyanza, where he expects Emin Bey to come down from Wadelai to meet him. On the return of the Stanley to the Aruwimi camp with the stores and the 124 men, our force will consist of a little over 200 men. Tippu-Tib will then send us about 400 men from Stanley Falls. When they arrive we shall take all the stores and ammunition and march after Stanley; he will have marked the trees on his route. And now I think I have told you as much as any of us, except Stanley, know about our plans for the future.

June 10th.-I must give you the menu of our midday meal, which we have just finished:-

Soup.

Weevil-eaten beans, flavoured with goat.

Entrée.

Stewed goat and rice.

Roast.

Roast leg of goat and rice.

Vegetable.

Rice and fried manioc-flour.

Swret.

Fried bananas.

So you see we are not so badly off! We have no spirits of any kind, but drink boiled Congo water.

I enclose a little sketch I made of a native chief who came to make a present of a goat to Mr. Stanley at a 
1887. place called Nzungi, on the march from Matadi to Congo Stanley Pool.

River.

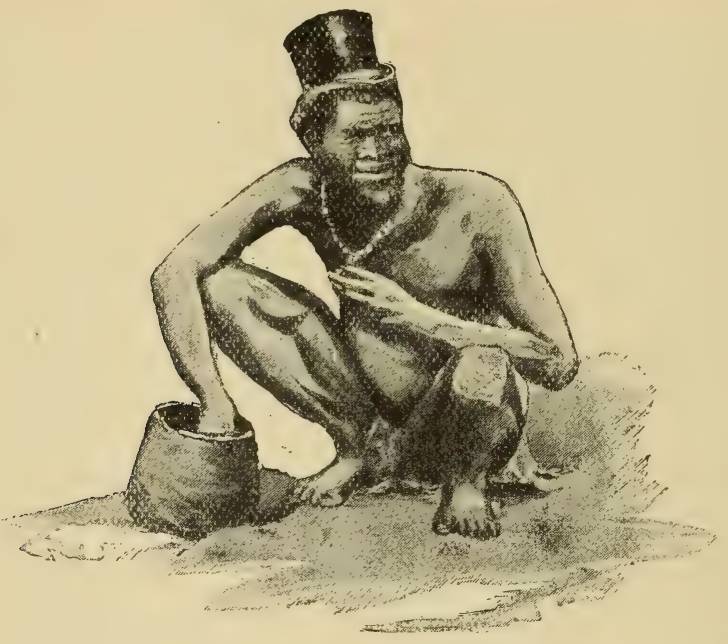

I have never been on any trip where there is so little enjoyment of any kind; it is all so serious, and a sort of gloom hangs over it all. If one does say anything which raises a laugh, it is the most ghastly imitation of one, and dies a sudden death, not to be raised again, perhaps, that day.

\section{DIARY (continued).}

June 8th.-Just after starting this morning we disturbed an old hippo at his breakfast in the long grass, and he walked quietly into the water, giving us a splendid view of his person. In the afternoon we passed one very large native village, which is the first I have seen really constructed on a definite plan. It was all built in small squares, the river forming the fourth side, with a regular landing-place for canoes to each little square, and roughly-made ladders up the bank. The people were very eager to trade, and followed us a long way in their canoes. The women, with few exceptions, still 
continue to wear nothing whatever. I must say that at one village, however, most of the women had tied round their waists large green banana-leaves, cut into fine long shreds, and just pulled off the trees, as if they knew we were coming. 'The bright green against their dusky skins was very effective. I noticed one very large black monkey to-day, with an immensely long tail.

June 9th.-Cup-day at Ascot. What crowds of recollections suddenly spring up when one thinks of this, and how I wonder if, amongst the number of one's friends there, any of them will give a thought to those who are absent like myself. We passed great numbers of native villages, the inhabitants of which are a really savage-looking people, of whom it is very easy to believe all the stories of cannibalism; they all, however, wanted us to land and trade, holding up goats and fowls, and following us for long distances in their canoes. 'The whole of the deck-cabin nearly came down to-day, owing to the great pressure of the top deck, which is crowded with men. We had to move half the men off it on to the lower one, where they are now packed like sardines. If the top deck comes down, it will burst all the steam-pipes, scald a lot of us, and throw most of the men into the river.

June 10th.-Some of the villages we passed on the banks of the mainland are very large. The natives were collected in groups at every landing place opposite to the huts, some of them with their bodies entirely covered with bright red clay, and their black faces yet more blackened and shining, presented a very curious appearance. It is very funny to see them in some places, peering out of holes in the dense undergrowth of the furest, just like frightened animals. At one village their principal occupation seemed to be in making canoes; they use a tool very like our adze. I noticed a great number of elephant tracks all through the forest. It was my turn to sit up and see the wood split for the steamer. Did not get to bed until 2.30 P.M. 
1887. June 11.

Congo

River.

June 11th.-Passed some very large villages, one of them extending over two miles; they seem to be very thickly populated. They are all built on the same plan as that one described above Upoto, in small squares, the river-bank forming the fourth side of the square, with a bare courtyard in the centre, where they make their pottery, \&c. The native shields are nearly all made of hide of some kind, I think goat, but I saw one which looked very like bush buckskin; they have a raised basin-shaped dome in the centre in some cases, made of metal. Between the small squares of the villages are either patches of plantains and bananas or jungle, while at the rear there is generally a strip of Indian corn or manioc, and then comes the forest. 'There are evidently great manufactures of pottery, for I saw great heaps of pottery in all stages. In all the squares is a great drum formed of a hollow log, covered at the end with skin. Many of the natives dye their bodies bright red with cam-wood, others are blackened all over with the forehead painted pure white, and a small patch under each eye. This gives them the most ghastly appearance. One of the largest villages, Mbunan, had just been burned the night before we passed, and some of the huts were still burning. A few of the inhabitants were wandering about in their war-paint, and looking at the ruins, but they all fled at our approach. They are anything but friendly, as at nearly every village they yelled and shouted at us, shaking their spears and shields, and making signs of cutting our throats, heaping all sorts of insults upon us. It is a bad look-out for our chances of trading for food at the entrenched camp.

June 12th.-Arrived at the Aruwimi at last. Did not pass as many villages as yesterday. One large one on the north bank is called Yalumbo. The natives seem to be of a much lighter colour than those we have seen on the south bank; they are shorter and better built. Their paddles are very long in the blade, and beautifully shaped. We came in sight of the mouth of the Aruwimi about 4 P.M., and entered by the channel 
on the north bank; the other channel is hidden by a large island which stands in the centre of the mouth of the river. Mr. Stanley steamed across to Basoko, a large town on the opposite bank, and told the people River. he wished them to bring us food. He then returned to an old camping-place of his, and we put in a little lower down. At our approach immense numbers of canoes left the town for the opposite banks and islands. The view at the mouth of the river is very pretty, as there is a grand stretch of the Congo without islands, and the forest is very fine. Baruti, Stanley's native servant, originally came from Basoko, and I believe there was a most interesting scene when the Peace went over there, between him and his relations. Much weeping and kissing! Basoko stands in lat. $1^{\circ} 15^{\prime \prime}$ and long. $24^{\circ} 12^{\prime \prime}$. The river here is just 900 yards wide. The natives all have their ears stretched in several places by pieces of stick placed in the holes.

June 13th.-Orders came from the Peace that we were not to start until 12 o'clock, in the hope that the people would bring us food, but no canoes came near us. The Stanley was the steamer which carried the men belonging to the Free State, who burnt the town about fourteen months ago, and they are still afraid to come near her. Not five minutes after we had started, a number of natives who must have been hidden quite close to us in the bush, ran down to our landing-place. We all went into fits of laughter at a few men on the bank (further up) who gave us a regular war dance, the principal features of which were insulting gestures. 'The banks of the river are far more thickly populated than the Congo. If they chose to attack us when we are scattered in small parties through the dense forest, woodcutting, where one could not use a rifle until they were close to one, they could easily finish us all. I was to-night in the dark, on one of the native paths, without a light of any kind for over an hour, not a dozen men with me, and I have not the least doubt that the natives were close to us in the bush. I 
1887.
June 13. see that the curious appearance of their ears is due to June 13. tufts of dry coloured grasses, bunches of teeth, and all River. sorts of things stuck into the holes bored all along

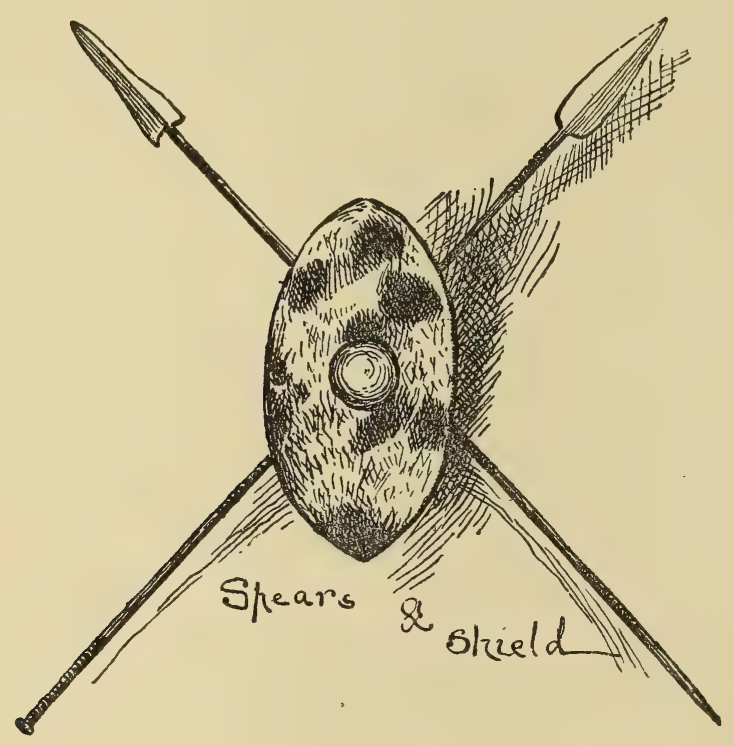

their edges. I saw one man to-day, with a long piece of stick, put right through both nostrils at right angles

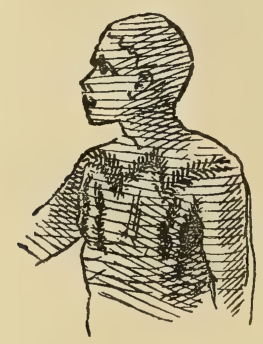

to his nose. They have small oval shields, sharp-pointed at both ends, with a raised dome in the centre, different from any others down river. 
June 14th.-Just before we started some of Mr. Stanley's company set fire to the huts, a most uncalledfor piece of devilment, and a thing to be regretted, as 1887. June 14 Aruwimi River.

it is more likely to set the natives against us than anything. Saw the first of the conical-shaped huts mentioned in Stanley's book; they are made of the leaves of palms cut off near the trunk, and overlapping one another layer upon layer, like a shingle roof. The door is small and low, the huts being generally very high. Some of the natives came across and wished to trade. Most of their paddles have a knob of ivory on the end, and are of the most graceful shapes.

June 15th.-Last night ten rounds of ammunition per man were served out, and now we go about in fear of our lives that they will be trying the cartridges in their rifles, and letting them off by accident. The river is now very much narrower, not over 500 yards wide, and the north bank is much higher than the south. A little after 5 o'clock we came within sight of the rapids, and the town of Yambuya, where the entrenched camp is to be, and which is to be our home for so long. I was greatly disappointed with the rapids, which are nothing in appearance but a few lines of broken water, although a great volume of water must pass over them. We made fast to the bank opposite the town, and Stairs went over to see Mr. Stanley, and returned with the following orders. We were to have steam up at 6 A.M. The Peace was to start first, go over to the village, and if possible have a palaver with the natives. We were to steam out into the middle of the river, and just keep headway against the stream. No whistle would be blown except by the Peace, and that would be a signal that negotiations had failed. We were then to cross over to her, when Jephson would land his company, Stanley having already landed his; they were to ascend the bank, and spread in skirmishing order through the village. Whilst the others were landing, Stairs, if necessary, was to work the Maxim gun from the top deck of the Stanley. As I had no company, I was 
1887. prepared to do any general fighting. No shots were to Jambuya be fired, and no damage done to the village unless the natives showed active resistance.

June 16th.-At 6 A.M. the Peace steamed over to the village, and Mr. Stanley had a very long palaver with the natives, who would not hear of our landing there. So the whistle was at last blown, and we at once cast off and joined the Peace, which had dropped down below the landing-place. The orders were carried out exactly, and it was a ludicrous sight to see Jephson's chief going up the bank first, which was fearfully steep, and about $40 \mathrm{ft}$. high, holding his rifle as far out in front of him as possible, and peering on every side for a lurking foe. Not a native was to be seen when they did get up, and the whole village was occupied in perfect peace. We put up our tents, and destroyed the huts which were not required for our men. After dinner Mr. Stanley called us all to his tent, and had a long talk with us. He explained the plan of the fort, which was to be a triangle, with its base the river-bank, stockaded, and with an outside ditch of $6 \mathrm{ft}$. wide and $4 \mathrm{ft}$. deep, $10 \mathrm{ft}$. from the boma (stockade). He told us that Tippu-Tib was coming with as many men as he could get together, seven days after our landing, and going on with him to the Lake. He would also send enough men to enable us to follow after him with all the stores left here, and those brought up by the Stanley on her return journey. He also said that where there was enough food for so many natives, there must be far more than enough for us. He dwelt a long time on the great importance of Barttelot's and my position, being left in charge of the fort to guard all the stores, as, if anything should happen to them, the Expedition would be at an end. Mr. Stanley said he would finish the stockade, and as much of the defences as possible, and that he would not in any case leave us until we were in what he considered a position of perfect safety. He also told us of his intention of returning from Lake Albert Nyanza on the route which he will take from here, in 


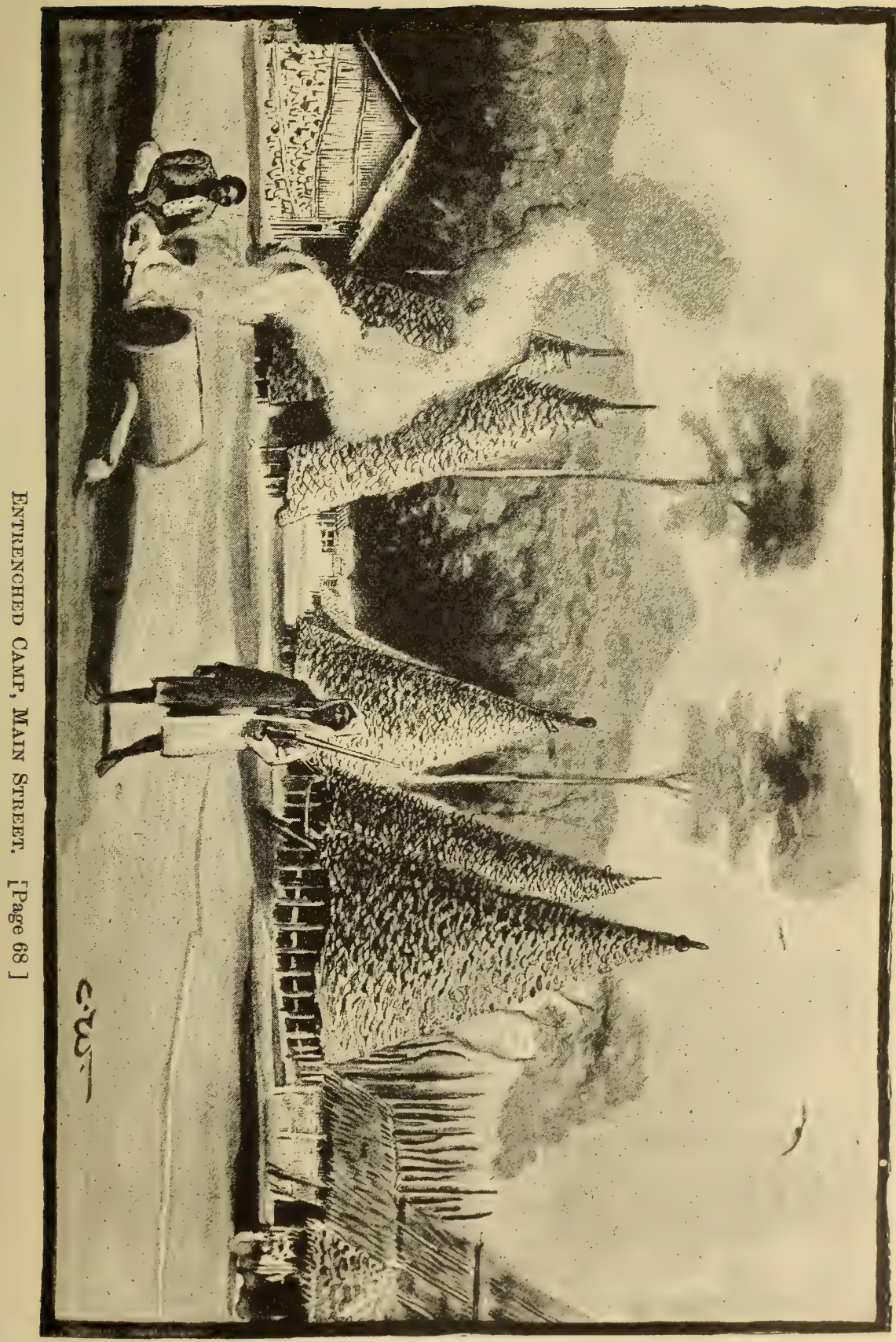



case we had not enough men to come on with the ammunition and stores; in any case we would meet on the road. The natives have removed every vestige of food. In the centre of this village are three poles between which are built up the most extraordinary collection of native skulls, baskets, and all sorts of implements.

June 17th.-My orders for the day were to unload the Stanley and Florida, and stack all the stores and ammunition. 'This took the whole day to finish. Nelson and his company were all day making a road up the river through the villages in that direction, so as to give Mr. Stanley and his party a fair start on their long journey. All the villages were deserted. Stairs finished the clearing round the camp, and began the stockade, Jephson and his men cut wood for the steamers, and Parke explored in search of manioc plantations. A few natives came in and told Mr. Stanley that the country further up the river becomes very hilly, the travelling stony and rough, but that there are plenty of villages. News gradually spread through camp that Baruti, Mr. Stanley's native boy, whom he has had for years, had run away, taking with him Mr. Stanley's belt with cartridges, revolver, and compass, and also a rifle belonging to William Hoffman, his servant. Feruzi and Bulla, boys belonging to the Captain of the Stanley, and one of the Engineers had bolted too. This proves how the savage in a man will out, no matter how you train him. 'The natives have crossed the river, and formed a large camp on the opposite shore.

In a letter to his wife, dated the 14th June, Jameson writes:-

"I cannot get over the feeling of disappointment at being left alone here with only Major Barttelot, when all the others are marching on to the Lakes. We shall have to do afterwards by ourselves, with Troup, Ward, and Bonny, the same march through the same unknown country as the others are doing with Stanley as their 
1887. leader, and all the picked Zanzibaris in the Expedition.

June 18. I suppose we shall be here about two months before the
Yambuya. steamer returns up river, and we can start. I am a giant of health just now, and once we are settled in the camp I shall have time to draw, paint, and write all sorts of things for you. I like to linger over my letters to you for hours, for then the Expedition and all its surroundings seem to fade far away, but I am rudely awakened, as usual, to the dry hard facts of our progress up this river ...."

And later on, from Yambuya, he says :-(June 18th)

"This is an unfortunate place for me to be confined to, as there is not a single track of game of any kind . . June 19th. . . To-morrow morning we shall eat our last piece of the old milk-goat, and I expect it will be a good two months before Barttelot and I get any more, for the natives have brought in nothing. Stanley and his party, however, should get plenty, as they will come upon villages before the people have time to carry away anything...."

\section{DIARY (continued).}

June 18th.-Nelson, Parke, and Jephson were all out cutting wood. Stairs was finishing poles for stockade, whilst I was collecting wood, and seeing it stacked. No natives came in; not a bit of meat in Camp.

\section{June 19th.-Nothing of interest.}

June 20th.-Every one out woodcutting. I again superintended splitting and stacking. The Stanley left at last for Leopoldville, carrying all our mails. There were many happy hearts when she started, we had had to cut ten days' wood for her, which was an enormous pile. The Peace is to remain and go back with the Henry Reed. The Stanley is to make all haste en route, and return as soon as possible with all the stores and 
ammunition from Leopoldville, and the men from Bolobo. Mr. Stanley has promised the Captain and Engineer $£ 50$ each, if they return in August, or at the latest in September, and handed to me the orders on the bank to give them if they do so.

June 21st.-Have been very seedy for the last week, and felt worse to-day. Inspecting stacking and splitting wood again. Mr. Stanley began to build the store, which is also to be my house, and blamed me for not having done so before, although he must have known that for the last three days I could not have got a man or an axe to help me, and he himself told me to look after the splitting and stacking of wood. The Henry Reed, with Barttelot, never turned up, although overdue. Some natives came into camp to have a palaver with Mr. Stanley; they proposed that we should send five Zanzibaris over with them to the other side of the river to show confidence, and make palaver. Stanley said no, but that they must send two goats and ten fowls to us, and then palaver. Still no meat in camp. Living on rice, manioc cakes, and beans with biscuit; no sugar or salt-a fact! The natives get manioc by crossing the river below camp at night, and going up into the plantations.

June $22 n d$.-Mr. Stanley was getting very anxious to-day about the Henry Reed, and ordered the Peace to start down the river with Stairs and 30 men on board to-morrow, and proceed to the Falls. He thought that perhaps Tippu-Tib might have seized the steamer -rather a curious fact, since he stated to us that he considered Tippu's word as good as any white man's. However, when we had given up all hope, late in the evening she appeared round the bend of the river, and Barttelot brought two magnificent, big, fat goats and some bananas and plantains. There was also a splendid fat cow on board, a present from Tippu-Tib to the native chief at Leopoldville, which I wish Mr. Stanley would have allowed us to seize, as I do not see a chance

1887.

June 20.

Yambuya 
1887. of our getting any meat after he is gone. The large June 22.
Yambuya. people on the Henry Reed after all, as Tippu-Tib's people had been looting and were attacked, and some of them were badly wounded, after which they burnt the whole place. Tippu-'Tib is not coming after all, but is going to send a chief and some men instead. It appears that in Mr. Stanley's contract with him, Mr. Stanley promised to supply all his men with ammunition; Tippu-Tib found out that he could not do this, as all the powder and caps are still at Leopoldville, so he is very much annoyed, and at first was not going to send anyone; but Major Barttelot persuaded him, telling him that all the ammunition would be here on the return of the Stanley. Mr. Charters, the missionary engineer of the Peace, made me exceedingly anxious this morning by informing me that there is a great chance that my letters sent by the Stanley will never reach home, as they would almost certainly be opened, read, and destroyed at Boma; he told me that letters are constantly stopped there*. 'This is a most disgraceful thing, for if there is one thing ever respected in any country by the governing body, it is the mails.

June 23rd.-All day stacking stores and ammunition. In the afternoon four or five Soudanese came in, carrying one of their party, who had been speared by a native; they had been looting a village, when the natives attacked them. Two Zanzibaris, who were with them, fired and killed a native, when the others all ran away. Dr. Parke says it is a dangerous wound (in the groin), although he ought to live. 'There was great beating of drums after this, but no further attack. Poor Alexander, one of the Soudanese interpreters, died to-day. He has been ill for a long time, and ought never to have been taken on the Expedition.

* In justice to the Congo authorities on this occasion, it must be stated that all the letters sent by Jameson arrived safe and unopened. -Ev. 
June 24th.-The Henry Reed and Peace left early this morning. All men out cutting poles for palisade, which was partly finished by evening.

June 25th.-Jephson and I had to write a report upon the state of the bales of clothes \&c. for Emin. In consequenc of the way in which they were packed, nearly the whole of them were rotten; but there were a good many which, with patching, might still be made wearable, so we decided to repack these, and use the rest for medical bandages. Stairs is really very bad with fever; in fact, so bad that Mr. Stanley warned me to be ready to go instead of him at a moment's notice. To-day Mr. Stanley gave Major Barttelot a long letter of instructions and advice, of which I had to make two copies *. I was very glad indeed to get the letter, as it cleared up many things, of which I had only a very hazy idea. It is clear upon every point, but as regards our relations with Tippu-Tib's people, I think more might have been told us on this subject.

June 26th.-Engaged all morning in re-packing the bales for Emin Pasha, which are now reduced from five to three. I had to use the cover of my tent to pack a good many of the things in, which is a great loss to me, but it is in a good cause. The chief of the natives came over to-day, with whom Major Barttelot was made "blood-brother," in order to increase our friendly relations with them after Mr. Stanley's departure. A chicken (needless to say supplied by the natives) had its head cut off, the blood being scattered over the lookers on, then a cut was made both on the Major's arm and that of the chief; the bleeding parts were rubbed together, and then rubbed on the back of each other's necks. They then kissed one another, and are now supposed to be fast friends. Let us hope that it will induce them to bring us something to eat. The European provisions were opened to-day, and Nelson

1887.

June 24 .

Yambuya 
1887. June 26.

was busy all day in sorting them out in rations for each man for six months. Each man's allowance is the following :-

Coffee $2 \frac{1}{2} \mathrm{lbs}$.

Tea $1 \frac{1}{2} \mathrm{lb}$.

3 tins of jam.

$1 \frac{1}{2}$ tin sardines.

$\frac{1}{2}$ tin red herrings.

$\frac{1}{2}$ tin tapioca.

1 small tin of salt.

3 small tins of butter.

$\frac{1}{2}$ tin chocolate.
$1 \frac{1}{2}$ tin sausages.

1 tin flour.

$\frac{1}{2}$ tin sago.

4 tins condensed milk

$\frac{1}{2}$ lb. sugar.

$1 \frac{1}{2}$ tin cocoa.

2 tins biscuit.

2 pots Liebig.

When one reflects that the above have to be eked out over 180 days, one would really rather be without a great many of them than only have enough to make one wish for more! The tins are the ordinary small ones in general use in very small households. Here are Major Barttelot and myself left absolutely without one atom of meat, tinned or fresh, for several months, and no visible means of obtaining any, for the natives have brought in nothing, and have removed everything from all the villages within reach of this camp. There is not a pound of game-meat, either bird or animal, in the whole country round. Had Mr. Stanley only used three of his many men to carry tinned meat, the Major and I might have had $\frac{1}{2} \mathrm{lb}$. a day each of good meat for the whole six months, far more than we should ever have used. When complaining of food some one might say, "Oh, you had such luxuries as chocolate, sausages, red herrings, and sardines! What have you got to complain of?" One could only answer that $\frac{1}{2}$ a small tin of chocolate, $1 \frac{1}{2}$ ditto of sausages, $\frac{1}{2}$ ditto red herrings, and $1 \frac{1}{2}$ ditto of sardines was not tasting much luxury for 180 days. This evening Mr. Stanley sent round, to all the officers he is taking with him, his orders for the conduct of the march. Always first will be a company, commanded by him in person, of fifty men, who will clear the road; then the main bodv, consisting of all 
carriers and supernumeraries to help the tired or sick; lastly the rear-guard, of thirty armed men, with no loads, and others to help those who fall out from the main body. There were numerous other directions about communications between parts of the column, \&c. Lastly he stated his intentions of forming a camp on the S.W. corner of Lake Albert Nyanza. From there he will cross in the boat to — - in Unyoro, where he will meet Signor —_, from whom he will find out the whereabouts of Emin Pasha. If in the neighbourhood of the Lake, he will meet him, and, after discovering his intentions, will start back for this Camp to bring on the rest of the stores and ammunition, should we not be already on the road to the Lake. If not, he would reach here some time in November most probably. The above is all in Mr. Stanley's letter of instructions to Major Barttelot.

June 27 th.-All morning and forenoon were taken up in arranging the men who are going on, into companies, and sorting out those who are to be left behind. Seventy-six of the very worst were left, and only one chief called Munichandi, a man who is utterly worthless, as the men do not care one rush for what he says. Had Mr. Stanley tried, he could not have left a worse man as chief over the class of men left behind. It was the greatest mistake not to leave us at least one good man whom the men would respect and obey, but I suppose beggars must not be choosers. He has taken ten of the best of the Soudanese, and the bugler who would have been a great help in camp. To-day the Major and I made our last good square meal of meat, I expect, for a long time. Stairs is still very ill, but is going to be carried.

June 28th.-At 10 minutes past 8 A.M. Mr. Stanley started, after bidding us a very kind good-bye, with an exchange of wishes for the best of luck on both sides. A good-bye and God-speed was exchanged with all the other officers, Nelson being the last to leave, as he had charge of the rear-guard. Then Major Barttelot and 
1887. I began the real work of the camp, collected all the June 28 . wood from the deserted huts, and cleaned up the whole camp. I got ten men together and arranged the things left behind. Barttelot went out to cut poles for the boma. Having finished the work in the store, I brought up my things from my tent, bed and all, and made the place habitable. It is frightfully damp, and Mr. Stanley could not have chosen a worse place for it. Before dinner we set the following sentries:-2 Zanzibaris at bastion behind the store, 2 Zanzibaris at covered way to the water, 2 Soudanese on platform, 1 Soudanese at west end of boma, 2 Zanzibaris between western limit and path to landing-place, 1 Soudanese on path to landing-place, 4 Zanzibaris on open space of unfinished boma, 1 Soudanese at the main gate east. I went round of sentries at $8.30,10$, and 4 o'clock.

June 29th.-Off at 6 o'clock with 20 men to cut poles to finish boma. We have only been left five axes which can by any possibility be used, and of these only two can be called fairly good. We cut ninety poles, and returned to camp at 11.30. The chiefs are worse than useless, and the Major and I have to inspect every little thing that is done. 'There were one or two very small scraps of meat left last night in the stew, the last we are likely to see for a long time, so we ordered them to be kept for our mid-day meal to-day, although we should have turned up our noses at them a few days ago. When the pot arrived, Major Barttelot plunged his fork into it, and drew forth-not meat-but a filthy piece of old rag! Heavens! were'nt we in a rage!-our last piece of meat, and we could not eat it! Went out and cut more poles. Dined off three pigeons, which I shot, manioc and bananas. The manioc nearly finished me. Went round of sentries 7.30, 11, and 2.30 A.M.

June $30 t h$.-At 6.30 A.M. I started off to cut poles for boma. When the natives on the opposite side of the river saw us, they evidently thought that the camp was deserted, and at least fifty canoes crossed over between us and camp. I at once ordered the men to turn, as I 
thought we might be cut off. Upon seeing us return to the camp, the natives all bolted and re-crossed the river, so we quietly proceeded to cut poles. Seedy all day and night. Pounded boiled rice, fried in cakes, quite a success.

July 1st.-6 A.M., off again cutting poles for that infernal boma, but, thank heavens, finished it at last. I shall hate the sight of any kind of wooden paling after this. 'The Major began the big ditch round the boma to-day, 10 feet from boma, 6 feet wide, and $4 \frac{1}{2}$ feet deep. He shot a pigeon, and as there were three very, very small chickens which I was trying to rear, and as "two are company and three are none," I killed one of them, and we had a stew for dinner, which was a great success. Major Barttelot took night of sentries, as I am still seedy. We have begun from to-day to take night about in going the rounds.

July 2nd.-Three sentries were caught asleep last night. There is no excuse for them, as they have been warned two or three times they will be flogged if found asleep, and they go on duty two together, so that one may sleep while the other watches. They got 25 strokes each. My boy Matajabu succeeded in buying one small pot of honey and three ripe plaintains from some natives to-day. I would knight him, had I the power! Went round sentries; caught two asleep.

July 3rd, Sunday.-Began by flogging the sentries caught asleep. This sort of thing must be stopped, as we are a very small force, liable to be attacked at any moment. Nearly all hands at ditch again. Gave the men a half-holiday. Served out one mataka and six cowries to each man as their weekly allowance; they at first refused to take the cowries, saying the natives would not take them, but I told them those were Mr. Stanley's orders. 'The rain came through my roof in streams, and wet my bed and everything.

July $4 t h$.-No sentries asleep last night. Nearly 
1887. all hands digging ditch again. Munichandi very mutiJuly 4. nous, but afterwards repentant. Finished plantains.
Yambuya. Dinner simpler than ever. Went round sentries.

July 5th.-Rahani Wadi Seruru, a Zanzibari, died last night; he had been ill for a long time. All morning at ditch. An extraordinary flight of butterflies passed over the camp all the afternoon, the same common white ones that I noticed in large flights on the Congo. This lot flew from north to south as straight as the compass could point. The damp in my house is very

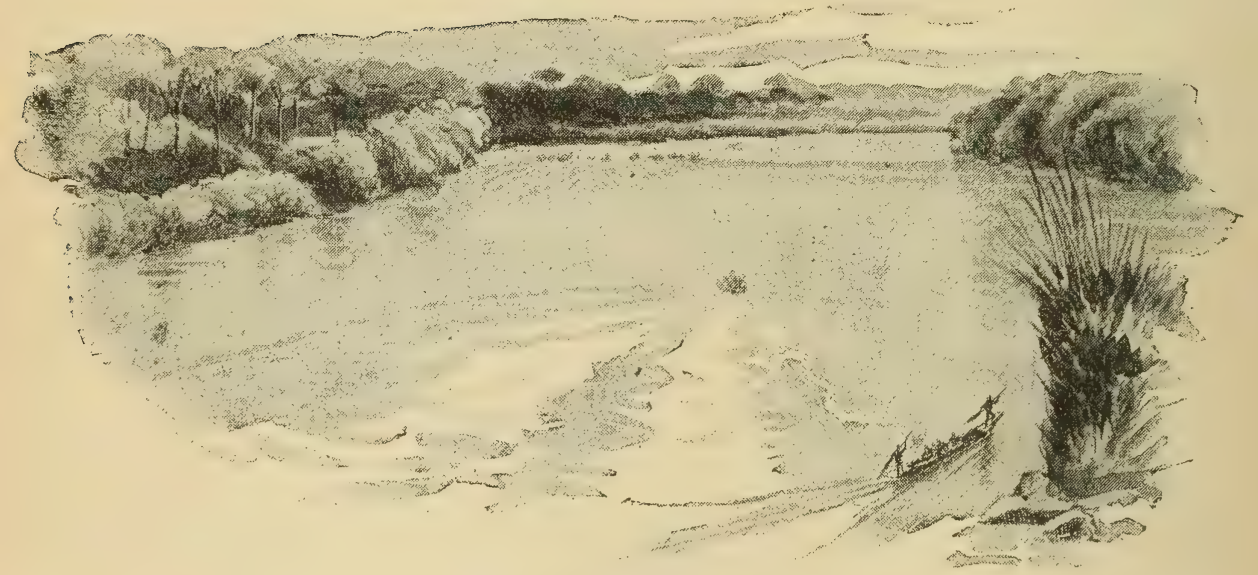

RAPIDS, FROM the CAMP.

bad, and I fear some of the things will come to grief, although I have done all I could think of to remedy it. How I will bless the day when I get a little time for collecting and drawing! But it seems far off still.

July 6th.-Two sentries who deserted their post last night were flogged this morning. It is sickening, this continual flogging, but there is no help for it. Nearly all 
hands at ditch again. If the men would only show a little more spirit, and work less reluctantly, it would make it much easier for Barttelot and myself. The same curious flight of white butterflies is still going on. Had a new cook-house built this afternoon; of course there is nothing to cook in it. I succeeded in buying a small fish cut in half from one of the boys to-day for two matakas, and gave him one for himself. Famine prices. It turned out to be the same fish exactly as those we used to catch in the rivers running into the Zambesi, with teeth outside the jaws, of which I have one stuffed at home I heard Matajabu holding an animated conversation with some of the men to-day, and asked him what it was about. He told me that the men said they knew why the place was being made so strong: Mr. Stanley was going to sell it to the Belgians for two or three hundred pounds, for a new station, as it could not be for us only, for our guns were quite enough without the boma and trench to keep off the natives. It gave me a real good laugh, the first I have had for some time.

July 7 th.-Went the rounds last night. No sentries asleep, so no flogging this morning, thank goodness. At the trench a!] morning. I succeeded in shooting a pigeon, which was unlucky enough to come near where we were digging, and Matajabu bought three small fish, so we had quite a day of it in the eating-line-fish for lunch, pigeon for dinner-though of course that ass of a cook kept the best fish for dinner, and it smelt so, having been left all day in the sun, that we nearly left the house when it came in. Edi, one of the little donkey-boys, died this afternoon; he had been ill for some time, and I had given him medicine, but he had been on parade every morning. We let the men off work an hour earlier than usual to go and get manioc. No signs yet of Tippu-Tib's people. No chance of collecting yet, for one cannot leave the men for a moment; the chiefs are perfectly useless.

July 8th.-Another morning without any flogging,

1887.

July 6.

Yambuya. 
1887. and another day at the ditch! A native came who told

July 8. us that they wanted to buy the canoes which we had seized when occupying the village, and that they were ready to pay for them in chickens, goats, and plantains. We told him we would let them have one, but that they must first produce the payment. This he said he was willing to do. He then told us he had a lot of plantains with him in his canoe, and if Matajabu would go with him, he might bring them back to camp. But unfortunately a number of Zanzibaris ran out with matakas, and, although Matajabu told them that the plantains were for us, they made the natives sell them to them. I was very angry at this, and when the men paraded at 1.15 I told them that when my boy was sent by the Mainr and myself to buy-especially in a case like this, when the natives had already promised the plantains to us-he should have the first chance of buying, and if prevented, I would shut the gates in future whenever a canoe came, and not let a man out until we had got what we wanted. Great beating of drums to-night in all the villages round. Ten canoes passed up the other side to-day, to the natives camped there.

July 9th.-The sentries, I am glad to say, are now keeping awake. Finished the ditch to-day. Major Barttelot still seedy. No sign of the native who was to buy the canoe with goats and chickens; but in the morning a native-evidently a man of position-came into camp, and had a palaver with Barttelot and myself. He wished to know whether he could take any quantity of manioc, and re-occupy the village next this one. He said that, if allowed, he would bring us plenty of chickens, the price of each being five matakas. This is the price they ask for a chicken hardly fledged. After a lot of palaver, we told him that our terms were thesethat he should bring us two goats, and we would give him a present, that he could then take the manioc in peace, and we would talk about the occupation of the village, and further that we should certainly not give 
five matakas for any fowl. If he did not do this, we told him we should take steps to stop their getting any manioc at all. As things are now, they come across to the villages above us at all times in the day, and carry away enormous quantities to the other side. He finally said he would return in the evening with the two goats. He has, however, not turned up, so I am going to show them that we are in earnest to-morrow morning, by taking twenty-five of the Soudanese with me, and stopping all the river-paths to the manioc fields. I will try and capture a woman, and then they will come to terms I think. For the last two or three days there have been a number of large canoes coming up river to join them, and I think it looks like mischief, but we are now prepared for them. The wind was from the north again to-day, and the flight of those white butterflies in the afternoon was so dense as to resemble drifting snow.

July 10th.-I had a most delightful day, for instead of digging the ditch I was out all day. I had determined to begin collecting to-day in the natural-history line, and succeeded in a much larger way than I intended, by collecting two native women, one baby, and a boy. After an inspection of rifles at 6 A.M., I started off with twenty-three Soudanese to stop the natives taking manioc, and to try and catch women. However no natives ventured near, so we returned to camp. After lunch the Soudanese reported that two canoes were made fast to the bank at some distance above camp, and that the natives had gone for manioc. Major Barttelot asked me to take ten of his men, and to go and try to catch them. I went off, but found only one canoe. I went up about ten yards from it to place my men in the paths leading to the fields, when a woman and two men jumped out of the grass where we had been standing a moment before, and, bolting down the bank into the canoe, they got clean off. We must have been standing almost on the top of them! We looked dreadfully foolish, for we had been thoroughly sold, and I was disgusted at the idea of going back to

1887.

July 9.

Yambuya. 
1887. camp and telling this to Barttelot. Meanwhile I had Jumbuya 10 noticed a great number of very large canoes crossing to Yambuya. our side, far up the river, just beneath the upper rapids. Knowing there must be a large gathering of natives there, and having so few men with me, I at first hesitated about going up; but remembering what a sudden dash might do, when not expected, I started up the path. We pretty soon came to large manioc plantations, and the noise of the rapids told us we were close to them. The path took a sudden turn down to the water's edge, and there lay a very large canoe with only

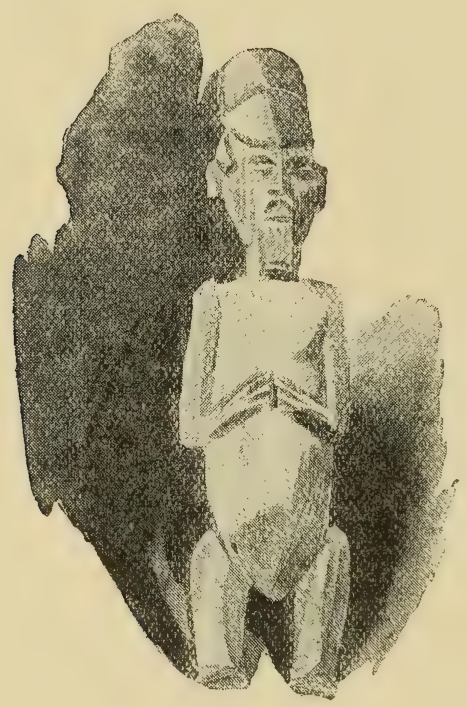

one man in it; he tried to push off, but we made a dash at it, seized the end, and he jumped overboard. He made a great noise, and I hid my men on the path close to the canoe. Presently down came a woman with a load of manioc, looking about her on every side, as she had evidently heard the noise. We let her come quite close, then made a dash, and caught her. We tied her up and waited, when along came another woman with a baby. We caught her too, but she 
screamed fearfully, and I thought she would bring a perfect hornets' nest about us; but the noise of the rapids drowned her voice. In the meantime there were 1887. July 10. now five men and two boys standing up to their necks in the water, as we had got between them and the canoe. The Soudanese officer advanced to the edge of the water, and, pointing his gun at one of the boys, he swore he would shoot him if he did not come out. He came out, and we promptly collared him, tied the two women together, and went off at the double for

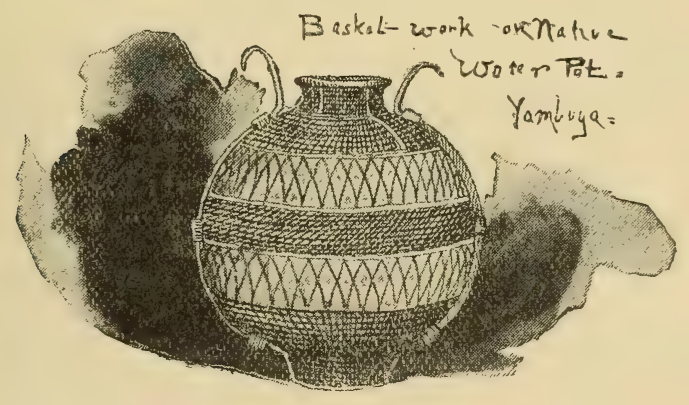

camp. We passed a great number of canoes full of natives, close to the bank, who, when they saw our prisoners, started off at once for their villages across river. Major Barttelot was delighted when I returned with the captives. He sent the boy away to his village to tell the chief that he would only give up the women for goats and fowls, and that he must come and have a palaver himself, as his people had not fulfilled their promises to us, for which reason we had taken the women. We gave the little chap four matakas for himself. He had hardly gone, when we observed a canoe coming down river straight for camp, and the enraged husband of the woman with the picaninny arrived. Luckily he turned out to be the same man who was here yesterday, and who had broken his promise of bringing us fowls and goats. He now assured us he would bring us five goats and ten fowls for his wife and baby, if he might take them away. We told him that 
1887. had he kept his former promises the women would not

Fambuya. have been taken, that the moment ten goats, twenty chickens, and some honey for the baby were brought over, the two women and the child would be given back at once. He promised to come to-morrow morning without fail, and left camp quite gaily, shaking hands with everyone all round. This will bring things to a definite issue, either peace and trade, or war. The two surviving cheeping chickens were slaughtered for our Sunday dinner, and an excellent little stew they made-the first bit of meat we have had for a good many days, and oh such a small bit!

July 11th.-After breakfast the native arrived to palaver about his wife. He brought one fowl and some fish to show that he was in earnest. We allowed him to see the women and the baby. He said the chief was up the river somewhere. I then went off to look after the men cutting poles, taking my small gun and butterfly-net with me; so the collecting has begun at last! The butterflies are rather disappointing, as there are not many different from those on the Congo, nor as large a variety. Returned at 11.45, and found Barttelot had been palavering nearly all morning with the native about his wife, and was very sick of it. He arrived again after lunch, but refused to come into camp. I went out with the men again, and heard tremendous shouting amongst them; and found that the natives had seized Omari, one of the donkey-boys, and taken him across the river. He had strict orders not to go out of sight of the camp; but he left the donkeys, and went to the next village where the natives sell fish, and there they seized him; so he has only himself to blame for it. If the gentleman comes about his wife to-morrow, he will find himself tied up, and told he will be shot if Omari is not given up. I am sure they had not meant to capture any of our men, as they had a dozen fowls and a goat in the canoe, which they were bringing as part ransom for the woman. On seeing Omari, the sudden idea must have entered their heads 
to take him prisoner. Barttelot is suffering from a kind of low fever. At present our situation with the natives is this :-we have two fowls and some fish, two 1887. July 11. Yambuya women and a baby; the natives have got Omari. I hope things will be straightened out a little to-morrow. Visited sentries last night as usual.

July 12th.-Gave orders this morning that no man is to leave camp without an order from Barttelot or myself, nor without a rifle. One of the Somalis died to-day; he has been ill for a long time, and had almost entirely lost the use of his legs. Barttelot still seedy; he eats simply nothing. Certainly plain boiled rice and musty beans do not encourage a weak appetite.

July 13th.-After parade sent the men to continue clearing the river-bank, and to deepen the ditch at both ends where it joins the boma. At the end next the spring the bottom of the ditch is stone, and the men have regularly to quarry it. They have built a wall across the end, which would be quite a respectable one, even in Ireland. The natives have made no signs of coming to terms. I shot a small bird, black, with white spots on the wings, which is quite new to me. After lunch had a tremendous time amongst my collections, drying them in the sun. Killed one of the chickens. and ate it stewed in rice for dinner. A little bit of meat like this is a great godsend, but I manage to thrive wonderfully on rice and beans. I proposed to-day that one of us ought to take Matajabu and some of the Soudanese to-morrow to the place where the natives land for manioc, and, hiding the men, see if Matajabu cannot get them to have a palaver.

July 14th.-Had to begin the day by flogging a sentry, whom I caught so sound asleep that I had to strike him three times with a stick before he awoke. To this class of men we have to trust ourselves at night! Major Barttelot took Matajabu and some of the Soudanese to palaver with the natives. They proposed to give back Omari and six fowls for the women; but 
1887. Barttelot told them if they did not bring Omari, five July 14. goats, and twenty fowls, the women would cease to Yambuya. exist. They came in the afternoon, and asked to see the women, thinking we had already killed them. We allowed the women to go just outside the gate. The husband stood about 150 yards off; and the conversation was kept up by screaming and shouting, the women telling the men they were fools, and calling them bad names for not bringing the fowls and goats, and freeing them. The husband then brought six fowls and a kid as an instalment of the ransom. Omari, who was in the canoe, says the kid is the only one in the village; he tells us they treat him very well.

July 15th.-Began to-day to cut wood for the Stanley. We have only five axes, three of which are almost useless; so it promises to be a long business, for we have to cut wood for ten days. The natives came again with a few more fowls, and a promise to get five goats from a village lower down the river. They asked first for the baby, then for the mother; but were told that when they brought the ransom they would get them. Just before returning to camp this afternoon I heard the natives making a fearful noise, and then two shots were fired. I was certain it must be 'Tippu-Tib's people arriving; but on getting into camp I found a very different state of affairs. It appears that the two Soudanese guarding the women had taken them down to the river to wash. When their backs were turned, the women jumped into the river. The one without the baby was caught, and Omaha, one of the Soudanese officers, and another man jumped in and swam after the other; they caught her, but were surrounded by canoes with armed natives in them, and were obliged to let her go. A number of the Soudanese had run down the bank after them, and fired two shots at the canoes, but without any effect. All our chances of goats and fowls are gone, I fear, as the natives do not seem to care a bit about the other woman,-and they have got Omari. The position now is:-we have got eight fowls, a kid, 
some fish, and one woman; the natives have got back a woman and the baby, and still have Omari: so I should say the balance is in their favour. Major Barttelot is a 1887. July 15. little better to-day, as I have persuaded him to take some Liebig and sago, for he cannot eat the rice and beans.

July 16th.-Whilst out with the men this morning I shot a woodpecker and a very pretty bird, which I believe to be a redstart or some species of warbler. Matajabu has succeeded in making a very good skin of it. On return to camp, I found Omari had effected his escape from the natives, and reached camp. It appears that last night they forgot to tie him up as usual, and he got into a canoe and came down river. He was followed, and did not reach this side until far below the camp at the big native village. His pursuers shouted out to the men on shore to catch him; but he got into the water amongst the bushes at the side of the river, and managed to elude them, getting back to camp all safe. It was a very plucky thing for a small boy like himself to do. He says the natives treated him well, and that when the woman and the child got back, the chief told his men to seize any of our men they could. The husband of the woman whom we still have eame to-day, and offered to ransom her. He says that they wish to re-occupy the villages up river. Major Barttelot says he will certainly not allow them to do so, as they are much safer on the other side. He believes the man who came over to-day had leprosy, and he got rid of him as quickly as possible. The position is now altered with regard to ourselves and the natives. They have got one woman and the baby back. We have got Omari back, still have one woman, one kid, eight or nine fowls, and some fish; so I think the balance is now in our favour. A tremendous thunderstorm came on to-night, and my house is flooded and my bed wet. I had no time to-day to put the tarpaulin on the roof. The smell from the wet rotten grass on it is frightful, and I should say anything but healthy. 
1887. July 17th, Sunday.-Awoke at 5 o'clock, to find it July 17. raining away steadily. It cleared up, however, before 7 , and we sent the men off to clear the rest of the village. Shortly after 10 o'clock down came the rain again; and we knocked the men off work for the day, as it was pay-day, and a half-holiday in any case. Just as we were finishing our usual repast of rice and beans at mid-day, the leprous native arrived with two others, and brought a fair-sized goat, which we took, giving him back the woman. Great rejoicings took place amongst the natives; and I do hope they will come and trade after this. Spent most of my day in etching, and writing out a new store-book, lists of men, rations issued, \&c. Our position with the natives now is:we have got two goats, nine fowls, and some fish, with a promise that they will trade; and they have got back both their women and the baby.

July 18th.-Had to flog a sentry this morning. Caught him sound asleep at 4 A.M. Major Barttelot and $i$ still take turns in going the rounds. My hours for going the rounds are-a little after 8 P.M. with Barttelot, then alone at 11, 2, and 4 . It is wonderful how one wakes every night within a quarter of an hour of the hours without being called. The big drum is sounded at 5 o'clock, the men fall in at 5.30, and are all started off to work before 6 o'clock. Went off woodcutting again, also cutting poles for Barttelot's new house. The dews are so heavy here at night that in going through the bush and manioc plantations one gets soaked, and has to dry gradually as the sun gets up. Shot a black and white finch, and a very handsome pair of birds, with beaks like barbets. I also got a lovely warbler that I have never seen before, olivegreen in colour, with grey breast and yellow spots on the wings, and a yellow line over the eyes. I took out :ny birds' skins to give them a drying in the sun, when, to my horror, I found a number of small black-beetles (grey underneath), hard at work eating them. How they got into my tin box is a mystery to me. They 
have damaged several skins, "bad luck to them," and are the same kind that used to eat our antelope skins in South Africa. I shall now only use the arsenical

1887. July 18. Yambuya soap I bought at Zanzibar. One soldier managed to buy a little fish to-day.

July 19th.-It is hopeless to send the men out with any of the muniaparas (chiefs), as they sit down and let the men do just as they like; the consequence is that from 6 A.M. until after 11 in the forenoon, and from 1.30 until after 5 P.M., I have to do nothing but stand over them and make them work. It is a wretched way to spend one's time. It is only by sitting up at night, and on the Sunday half-holiday, that I get any time to do anything. I have now 25 birds' skins, and this morning added some lovely specimens to my butterfly collection. Spread two tarpaulins over the roof of my house, hoping to prevent the rain from flooding it as the last did. The Major s house is now in an advanced state, as nearly all the framework is up. Fared sumptuously to-day, lunching off a stewed pigeon and dining off a stewed chicken. There has been no trading with the natives. The rats are getting very numerous in my house, and I must begin to shoot them, or, if I get the time, make a trap. They fight and scamper about across the floor and over the boxes without taking the slightest notice of anyone.

July 20th.-Spent the whole day with the men cutting and carrying wood. I took my painting things out with me in the hopes that I might be able to get a few sketches of some of the principal trees; but what with looking after the men, and my drawing being visited (whilst wet) by every known species of insect, I found it a very hopeless task. The moment that you move a few yards from the men they stop cutting, and when you shout at them to show that you are quite close, they cut a few strokes, stop, and wait until you shout again; then at last you fling down everything in a rage, rush at them, swear, threaten and "cuss" the chief as well as the men, then go back to find 
1887.
uuly 20. all your things one mass of ants, and that the men have Yambuya. stopped cutting again, when you give it up, and go and sit down on a log beside them. Of course, if one only had a decent chief, things would be very different. Just after lunch I heard two shots fired, and found that two of the Soudanese stated that they had been surrounded by the natives, and had fired. I wish they would shoot some one when they do fire, as ever since that woman escaped and the Soudanese fired two shots and hit nothing-not even a canoe-the natives now swear that the guns are harmless. One miserable canoe, with some stale fish for sale, was the only sign of trade to-day.

July 21st.-The chief of my men being ill, I could not leave them for five minutes all day, so I had a really nice time of it. The weather has been lovely

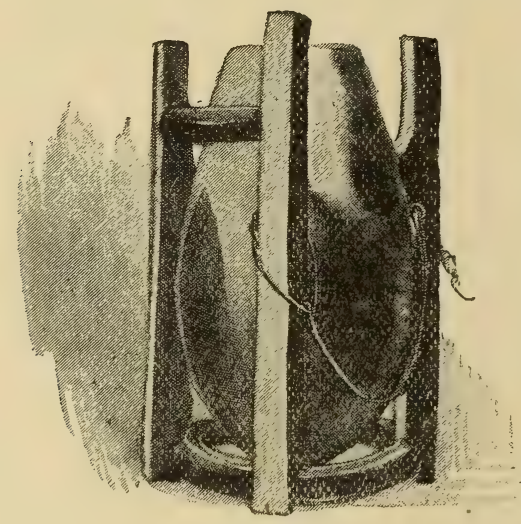

ever since Mr. Stanley left, broken only by a few thunderstorms. The prevailing winds are from the westward. We finished our last plantain to-day, and have only two more fowls left, a kid and a goat; I see no chance of getting any more, for the natives do not trade, or offer to, in the least. As a last resource we must catch some more of their women.

July 22nd.-Woodcutting without a chief over the men is pretty bad when you are well, but when you 
have a racking headache, and are full of rheumatism, it is simply-detestable. So I found it to-day. Major Barttelot is himself again, I am happy to say. Trade 1887. July 22. Yambuya still stagnant.

July 23rd.-Some men, I believe they were Zanzibaris, tried to steal our two goats last night, but were surprised, and did not succeed, although they managed to get away without being identified. The men, both Soudanese and Zanzibaris, are in a very discontented, mutinous state, and I shall be very glad when either Tippu-Tib's people or the steamer arrive.

July 24th, Sunday.-Began the day by flogging one of the sentries, whom I caught sound asleep last night, as early as 8 o'clock. So fast asleep was he that I took away his gun from him without awakening him. Halfholiday to-day, so the men only worked till 11.30 . The Major went down river on an exploring trip. He brought back some delicious ripe bananas. We killed the small goat this morning, and the consequence is, we have simply feasted like kings. In a conversation after dinner, Barttelot and I came to the conclusion that, in all the countries we have been to, we have never seen any place so utterly devoid of all sport as this. There is not a game-bird of any kind, and I have only once seen the tracks of a wild pig. He came back to-day quite delighted because he had found a lot of salt for his men in the village they visited; but when one of the men-having, I suppose, tried itbrought some of it up to my house, I told the Major what il really was-gum-copal.

July 25th.-Barttelot caught one of my men asleep last night, and took his rifle away, without awakening him, to his tent. This morning I asked him where his rifle was, when Barttelot was standing beside me on parade. The man coolly said some Zanzibari had stolen it, and described his dress, and was greatly astonished when the Major told him it was in his tent. As the man was only a poor half-demented sort of creature, 
1887. who, as I told my chief, ought never to have been on July 25 . guard, I only gave him six light strokes with a cane for form's sake. I think the Zanzibaris are quite the most barefaced liars I ever met in my life. One night I took a rifle from one of the sentries who was asleep, and brought it to my house, leaving it against a palm at the door. I went back and woke up the sentry, asking him where his gun was. He at once took hold of the other man's gun, and said that was his. I told him to come with me, and that I would show him where it was, which I did, and he then calmly told me, oh yes, he had left it there, and making a sign with his finger across his throat, said I might cut it if he had been asleep. He found out, however, who had taken it when he got his 25 strokes in the morning. It is really a great shame the state our biscuits are in; we opened a fresh box to-day, one of the tin-lined ones, and the water had got in so that the biscuits were a mass of blue mould, weevils, and small maggots. The only way we can eat them is by roasting them in the hot embers or in the frying-pan, which kills the "bastes." I have no doubt that they are more nourishing with the quantity of animal matter in them, but we prefer them without.

July 26th.-Shot a sandpiper with ruffs on the neck. The country was frightfully wet, so Major Barttelot did not go on his usual exploring expedition. After lunch, I made a sketch of him seated on the old drum opposite my door, with all its surroundings. I cannot believe this to be so large a river as is supposed, for last night's rain, though apparently local, was sufficient to raise the river at the very least two feet, and from the highest rapids down as far as we could see was a smooth unbroken sheet of water. Yesterday there were three distinct bars of broken water across the river, in some of which the rocks were showing. This rapid rise takes place whenever we have any heavy rain, and the river falls with equal rapidity. A terrible calamity happened to-day. The uncooked piece of the goat which was 
hung up last night, being affected by the thunderstorm, I suppose, took it into its head to go bad, and so we have only one small scrap left for to-morrow, and meat is very, very precious.

July 27th.-Shot one pigeon, two woodpeckers, and a swallow. The men were greatly astonished at my shooting the swallow. He was flying very high and fast, and coming straight at me; he fell yards behind my back, amidst all sorts of exclamations! We are down again on rice and beans, very wholesome, but not appetizing!

July 28th.-The men still splitting wood, and I make them work in relays, so that none of them are idle all day. One of the Zanzibaris died to-day, a poor miserable little man, whom I always thought half-witted. We bought some honey to-day, and opened a tin of butter, half a teaspoonful of which, added to the rice and beans, makes them slip down in a way they never did before. Did a little etching, wrote a lot of pages for home consumption, and had out all the birds. I have a busy time of it, but life is very much pleasanter than it was.

July 29th.-Poor old Derrier Moussa, a Somali, who has been our cook for the greater part of our journey, died to-day. He has been ill for a long time. It is horrible to watch these men slowly dying before your face, and not be able to do anything for them. The moment a man falls really ill with dysentery, or any other affection of the stomach, he slowly wastes away, becoming a living skeleton, sometimes lingering for weeks before he finally goes out. Shot a woodpecker and a weaver-bird; the latter of the bright rich golden kind, with black neck and throat.

July $30 t h$.-Had a bad night to go round the sentries, for shortly after 11 P.M. it commenced to thunder, blow, and rain in torrents, continuing until 5 A.M. Barttelot started with 20 Soudanese for a big village down river, but he found the natives had bolted, taking everything

1887.

July 26.

Yambuya 
1887. with them, so our visions of goats and fowls are disJuly 30 . pelled. I shot a swift with a curious spined tail, each Yambuya. feather of which ends in a short bare point like a needle. I also got a large, handsome, black-and-orange weaverbird, and the hen of the spur-winged plover.

July 31st, Sunday.-Shot a nightjar, with which I was quite elated, as it is. the first I have seen here, and was a very difficult snap-shot, flying very fast through a lot of high manioc.

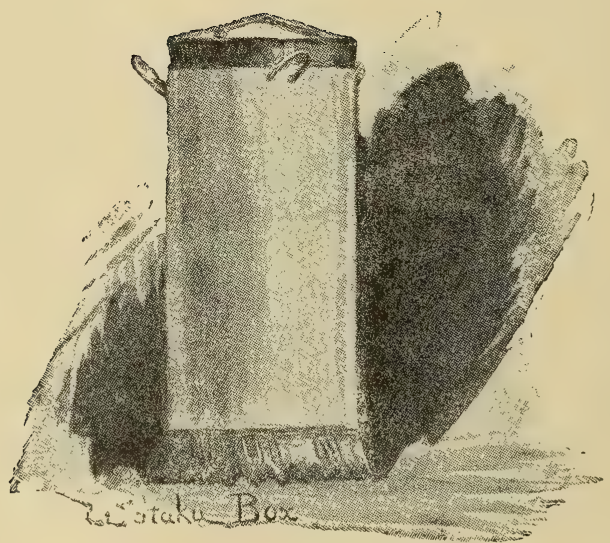




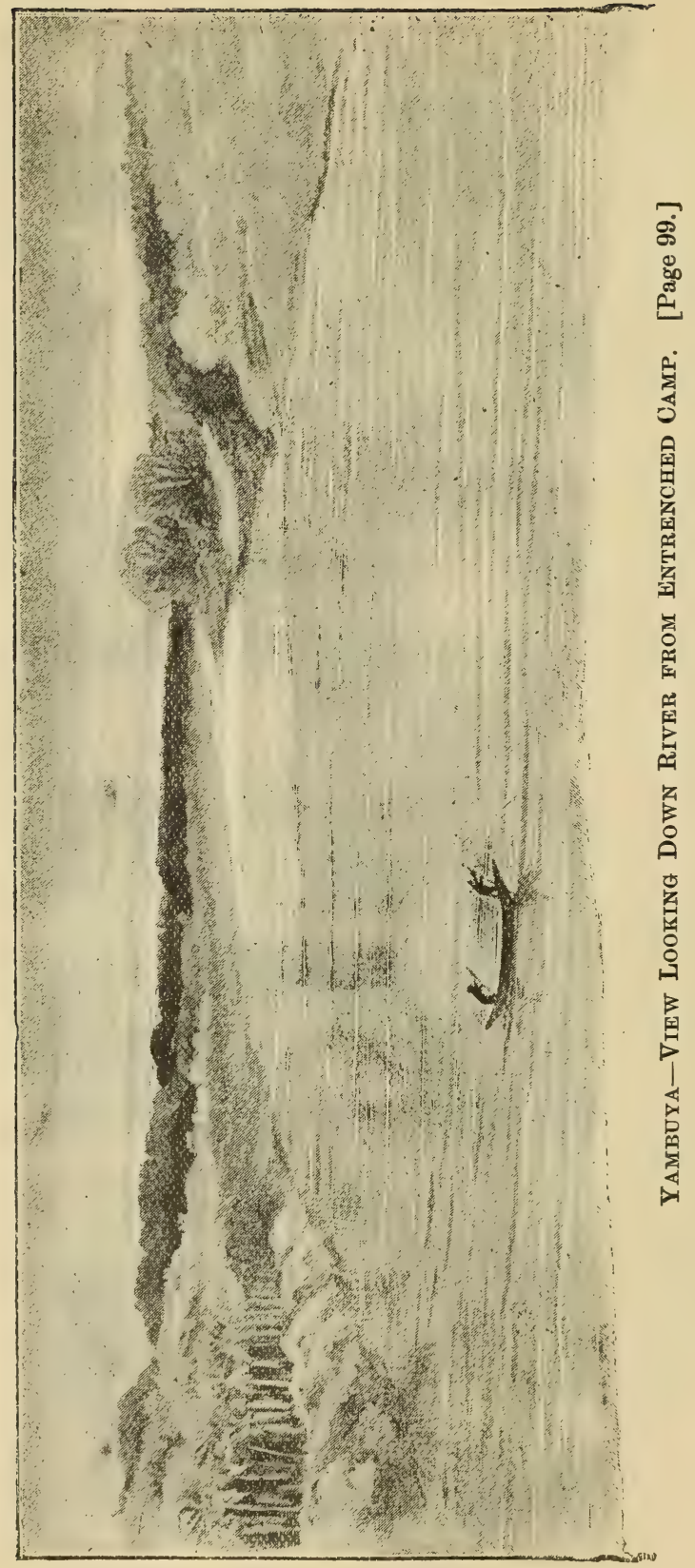




\section{CHAPTER V.}

\section{JULy 27th to December 31s r.}

Letter to Mrs. Jameson.--No news of Tippu-Tib.-Promise to protect natives. - Reported arrival of Tippu's men.-Return of deserter from Stanley's party.-His statement.-Arrival of the Stanley. - Raid on the natives by Tippu-Tib's people.-Final departure of the Stanley.-First visit of TippuTib's A rabs to Yambuya Camp.-Bonny crosses river to native village.Abdullah punished for stealing an axe.-Jameson and Ward start for Stanley Falls.-Natives offer to make them princes,-Yalisula.-Arrival at the Falls.-Received by Tippu-Tib.-He explains non-arrival of men. -Native wrestling-match.-Jameson makes Tippu present of big rifle. - Return to Yambuya.-Soudanese punished for theft.-Selim bin Mahommed.-Arabs shoot down natives.-Disappointing news from Tippu-Tib.-Rumours of Stanley's return.-Barttelot and Troup start for Falls.-A man possessed by ఓ devil.-Deserter's story.-Bonny's surgical skill.-The Major returns.-Omaha.-Report of a white man coming down river.-Fresh disappointment.-Jaundice.-Arabs try to prevent trade with natives.-Burgari Mahommed steals meat from Ward's house.-Living skeletons.-Three dreams.-Ungungu captured by Arabs.-Christmas Day.-Fresh trouble between Arabs and natives.

\section{EXTRACTS FROM A LETTER TO MRS. JAMESON.}

July 27th, 1887. - . . . It is just a month since Mr. Stanley left us here. Tippu-Tib's men have not yet arrived, and we are both very anxious about them, for should they not turn up we shall have to wait here until Mr. Stanley comes back from Lake Albert Nyanza, and goodness knows when that may be, perhaps not until November. The men are mutinous enough already, and I do not like to think of what they will be like before then. I must make a little sketch-map of the Camp for you.

August 1st.-I am so thankful that I have a taste for collecting, etching, and things of that kind, for had I not I don't know how I could possibly exist here. Now that the whole of the fortifications are finished, 

1887.
August 1. there is nothing to be done but cut wood for the steamer. I manage to enliven that work by taking my collecting-gun and butterfly-net with me, and generally manage to pick up something. All my spare time in camp is taken up with skinning, attending to collections, drawing and writing, so that it is very seldom I have a single idle moment. Barttelot does none of these things, so I am afraid he often finds me a poor companion, and the time falls rather heavily on his hands, although he is a most active man, and always wants to be busy at something. I don't think Stanley could have left a better man here in command. The natives have deserted all the villages for miles round, and gone over to the other side of the river, unfortunately taking all their goats and chickens with them. So there is no loot of any kind, although we continually make long excursions, seeking what we may devour. We sometimes come suddenly upon a large village and find not a living thing in it, although the fires are still smoking, and it has evidently been full of life only a few minutes before. How they know we are coming often puzzles me. I have got about half a dozen nice spears, two fine shields, and four very fine battle-knives, which will make a nice addition to our collection.

August 3rd.-I will now tell you something about our entrenched camp and its surroundings. As you will see in the plan, it is shaped in a sort of triangle, the river forming one side, a natural ravine and part of a ditch another, and the rest of the ditch the third. Our chief defence is a strong palisade surrounding the whole camp, composed of strong poles placed close together, about 3 feet deep in the ground, and 10 feet high, with long horizontal bars fastened along it. There are only two gates. The main gate, $\mathrm{D}$, looks up the river over a large flat clearing where the rest of the village originally stood. The other gate, $\mathrm{E}$, is at the top of the steep path down to the river, the bank of which can only be ascended at this one point; there is another opening in the palisade down to the spring $\mathrm{C}$. The ditch is 10 feet from the palisade, 7 feet wide, anc $4 \frac{1}{2}$ deep; so that the place is pretty strongly fortified 


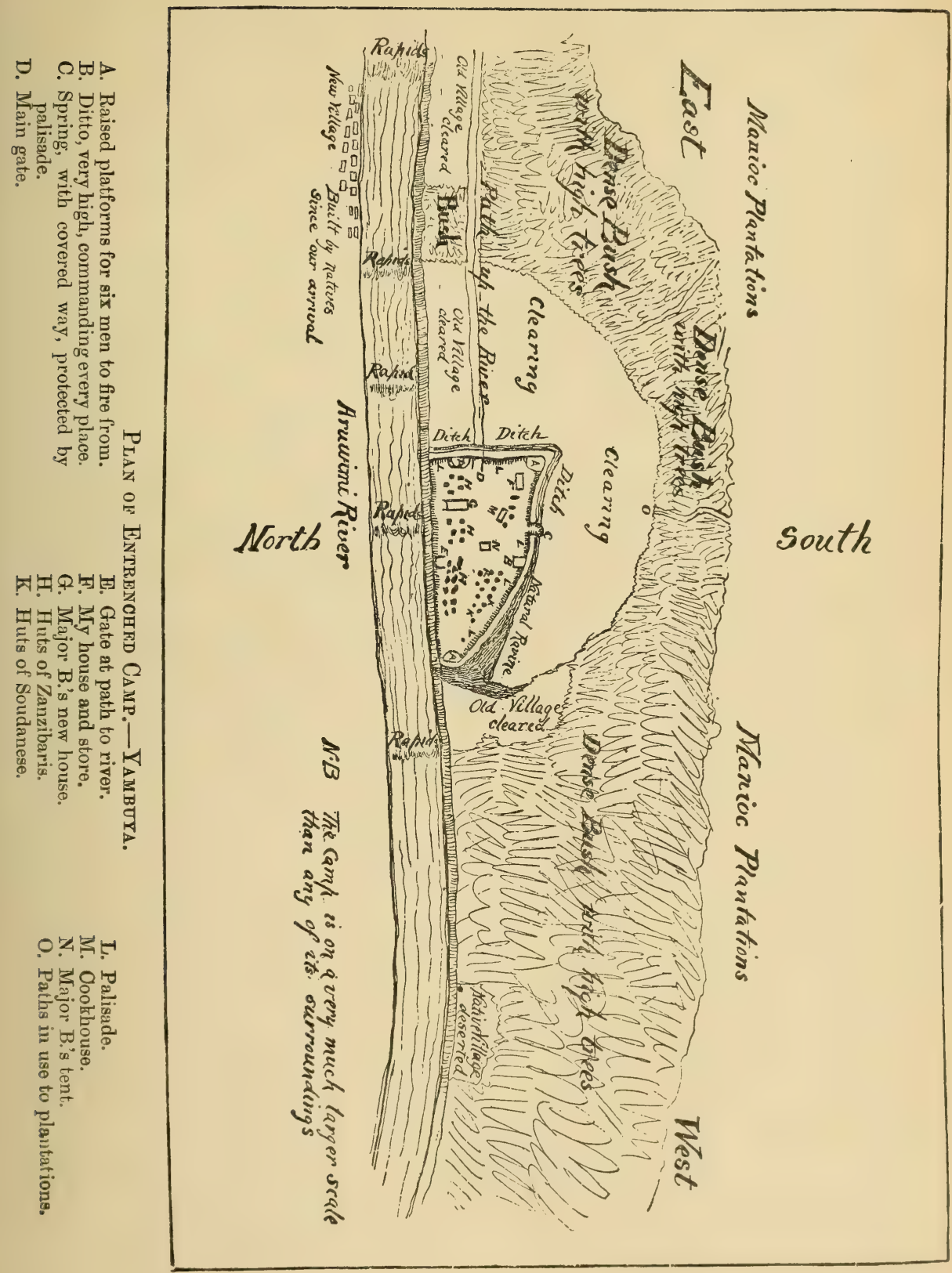



against natives without guns. The places you see marked "Clearing" were all originally dense bush, which we cut down and carried away, so as to see anyone attacking from that side. Inside the camp are four raised platforms, to hold six men, each of which commands a long range on every side, and can sweep the ditch and ravine up and down. The camp is not over 50 yards wide at its broadest part, and about 150 to 200 yards long. The river here is from 600 to 700 yards wide. In my plan you will see that the camp is drawn on a much larger scale than any of its surroundings; this I did to give you a better idea of what it is like. All the natives who inhabited the places you see marked "Old village cleared" have gone over to the other side of the river, and formed one immense village, where you will see it marked just under the upper rapids. The road Stanley has taken to the Lake, and the one we hope soon to be travelling, is an old native path going from village to village up the river, and leading nearly due east.

August 5th.-Barttelot and I sat on after dinner to-night talking of home and old times. These chats cheer us both up immensely. I am so glad that he and I pull so well together, for if we did not, life here would be unbearable. I wonder how he guessed we should do so well together; for he asked Stanley especially to leave me with him. I cannot help still feeling terribly disappointed at not having gone on; but I try to think of it as little as possible, and make myself as useful as I can here. After leaving for the Lake, I do not care if I never have time to collect a single thing, as every step will be one nearer home.... It will be wonderfully interesting marching through that new country.

\section{DIARY (continued).}

August 1st.-Bank holiday in England, but not recognized on the Aruwimi river. Barttelot went out with the men woodcutting, so that I had a great time amongst my birds and butterflies, and also found time to etch one of the giants of the forest here. The natives 
1887. have heard that Tippu-Tib's people are on their way August 1. Yambuya. here, which is joyful news for us, but as these natives are the same as those who killed a lot of his people some time ago, they believe that the men are not coming to us, but to revenge themselves upon them, so they say that they will remain on the other side of the river, and bring us no more fish or honey. If this news be true, it is a splendid thing for us, as we shall be able to start for the Lake almost immediately after the arrival of the Stanley. We are beginning to have a little too much of rice and beans, and each time we pass the goat, still in camp, our glances have a terrible look of hunger in them, and I don't think he will survive another day or two.

August 2nd.-No more news of Tippu-Tib, but the natives will not trade. A lot of black weaver-birds have made a colony in the palms over my house, and have stripped all the other palms, far and near, of their leaves, for the nests. It is very interesting to watch them building their nests. They tear a long thin slip off a palm leaf, hold it tight to the side of the nest with one foot, take hold of the loose end in the beak, push it through a small hole in the side, pull it out through another, and make it fast, using the unemployed foot as well as the beak the whole time, regularly weaving the strip of leaf in and out in a wonderful manner.

August 3rd.-Last night I caught two of the men asleep on sentry duty. This morning, on parade, I told one of them that, as I had never caught him before and he had had a hard day's woodcutting, I would let him off with a caution; but he at once proceeded to say that he had not been asleep at all, and had been sitting up awake. When I caught him, he was lying on the ground at full length, and I gave him two kicks before he even stirred. However, he persisted in the lie, and I ordered him twenty-five, at the same time explaining it was for the lie he was flogged. Taking thirty men with me I went to the big village down river, where Barttelot had been abou! a week ago, and on our way we passed a strongly 
stockaded village, the gate of which had been newly blocked up. We had to climb over and cut it away from inside. Some of the huts here were most beautiful, quite works of art. I have not seen any like them; they are very low, their walls about $4 \mathrm{ft}$. high, perfectly circular, ending in a dome-shaped roof. I am going back to make sketches of them. The large village we found to be deserted. The natives here place a number of small sharp spikes of very hard wood round their huts, and in the paths ; the points stick up, and are calculated to give very nasty wounds to bare feet. We found that all the people were encamped on the opposite side of the river, and when they saw us they set up the most hideous noise, yelling, beating drums, and blowing large horns. As they did not attempt to attack us, we proceeded to gather quantities of corn, bananas, plantains, and tobacco, all the men returning to camp well loaded. On my arrival in camp, in the absence of Major Barttelot, I interviewed a native, who informed me that a number of Zanzibaris were coming down the river in canoes, and had fought the natives, and burnt the village above the rapids, where their chief was, in spite of their having told them that they were "blood-brothers" of Bula Matadi; and he asked if he might move all the people across to the deserted village above camp, that we might protect them. I told him I would allow him to occupy the deserted village below camp, and that then we should be between them and their enemies. He fairly shouted with joy. I gave him a small piece of cloth, and sent him off to tell his people that we would not hurt them, and would try and keep others from doing so. I cannot understand Tippu-Tib's people coming down the river, unless they struck it far above us. They ought to be here to-morrow.

August 4th.-The natives came and had a palaver with Barttelot, telling him that Tippu-Tib's people will be here in two days, and again asking for protection. They have begun to occupy the villages on this side, and are evidently in an awful fright, though they seem to have great confidence in us. 


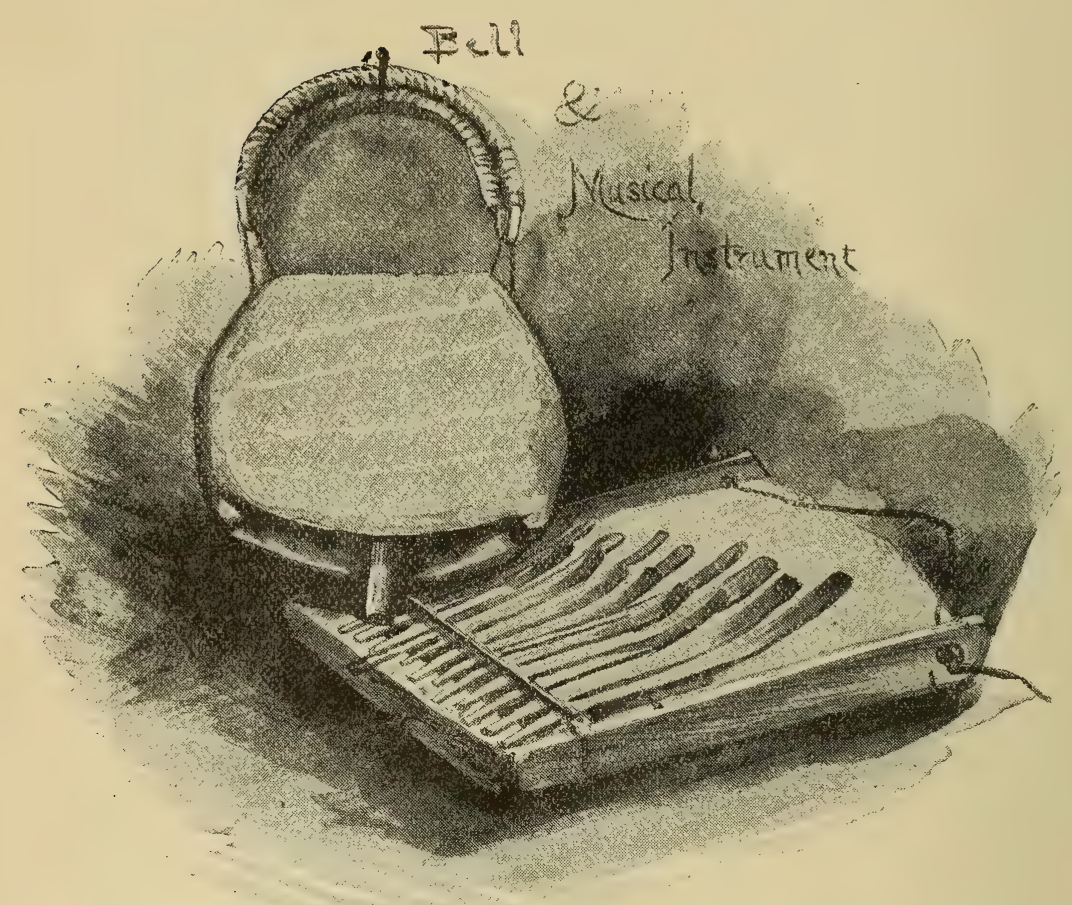

1887. 5ugust 5. August 5th.-We at last summoned up sufficient Yambuya. courage to kill the goat, in spite of the great uncertainty as to when we shall get another, but one really cannot live altogether on rice and beans, and see a live goat walking about, and eating the grass in camp. As there was too much meat to use whilst fresh, I cut off all from the hind legs into strips, salted it, and hung it in the sun to dry. No more news of Tippu-Tib's people. One of the Soudanese officers told me that there were four Zanzibaris about a mile from camp, right at the end of the furthest village, buying stuff from the natives. I put on my hat and started off to catch them, and found them at the very spot where the officer said they were. They were awfully astonished when I came upon them; they had broken every one of our rules, they were far from camp without rifles, had 
not asked leave to go, and had deliberately left their work. The officer told me the same four were there every day; each man had five or six matakas with him, and this made me nearly certain the chiefs had sent them, although of course they denied it. Some one must have given them matakas to go with, for they only get one each a week. I was going to have them flogged as an example, but Major Barttelot advised me to fine them each the amount of matakas they had. This will punish whoever gave them the matakas, so I told them that I would let them off the flogging, and for the next five or six weeks would pay them out of their own matakas.

August 6th.-The Major went out in the morning with the woodcutters, whilst I looked after camp, and the men were employed stacking wood. I dried and packed ready for home all my Aruwimi collection of butterflies, consisting of just 100 specimens, did a little etching, dried the beltong, and went through my birds before packing. I have had the old flag of my company tied to the highest post in the boma, that 'Tippu-Tib's people can make no mistake and pass us*.

August 7th.-After breakfast Barttelot went off with some Zanzibaris and Soudanese to a village some distance away from the river, and returned with a splendid lot of plantains. The natives are evidently still in a great fright, as they send all their women every. night down to the village below camp, and the men themselves sleep on this side of the river, above it. No news of Tippu's people! Hoisted another flag at the river-gate, so that no one can very well miss us passing down

* From letter to Mrs. Jameson, August 6th._- I do hope Tippu-Tib's people will come soon, and then we shall be able to start for the Lakes at once, and save some months. Had the wonderful fleet of steamers of the King of the Belgians, which Stanley spoke about before leaving England, really existed, we could all have gone on to the Lake at one tine, and saved six weary months, which have been added on to this trip." 
1887. the river. Still feasting away like kings on the old Yambuya. goat. We'll miss him when he's gone!

August 8th.-Started the men at building a hospital.

August 9th.-Major Barttelot and I are both decidedly seedy. Very bad news to-day, according to which the supposed Tippu's men up-river are a body of wandering Arabs, who are looting and destroying every village they come across. This is a dreadful damper to us, as we were sure they were Tippu-Tib's men, although from the beginning I was puzzled to understand why they were coming down the river in canoes. The native who came over and told us this returned this afternoon with a small pot of palm-oil. He seems to bear us no ill-will for having taken his wife and child, but was as merry as possible.

August 10th.-Heard heavy firing up the river in the direction of the Arab camp. One of the men lost one of the axes to-day. He was going out with the rest of the men woodcutting, and stopped just outside the boma to sharpen the axe on a large flat stone, after which he left it on the side of the road, and ran back into camp for a moment to get something. On returning he found the axe gone. He says that Munichandi and Songoro were close behind him when he left it, but they both deny having seen it. I have told him that unless it is found he will be fined 25 dollars. Some of our own men, either Zanzibaris or Soudanese, must have stolen it to sell to the natives, as they have asked for one several times, and no one else but our own men could have stolen it. The Major says the best plan will be to stop all the men's matakas until it is produced. Saw a couple of rollers hawking away from the top of the highest tree near camp. I shot them both, and they are different from any I have shot in S. Africa.

August 11th.-Told the men this morning on parade that not a single mataka would be issued until the axe was found and the man who stole it. If this does not get it back, nothing will, but there were no signs of it 
this evening. Shot four beautiful bee-eaters and two shrikes, one black, the other black and white. Found a very curious small rat or mouse in the ditch with a August 11 long proboscis like an elephant's trunk. No sign of Tippu-Tib's men or the steamer.

August 12th.-News of Stanley arrived unexpectedly to-day. Barttelot and I were standing at the gate, when we saw a Zanzibari coming along the up-river road, leaning on a stick, very lame. We recognized in him one of Stanley's party. Barttelot and I took him to my house, and interviewed him. From what he says it appears he left Mr. Stanley after they had been marching for a month, when they reached a large river running into the Aruwimi, on this bank, from the south. This they had to cross in the boat; and this man and another, being too done up to go on, were left behind, Mr. Stanley advising them not to remain in the camp, but to go some distance into the bush and wait there until they were stronger. The natives speared one of them, but this man made his escape, and got back here frightfully done up and with very sore feet. The officers were all well, but there was great scarcity of food. The men had sometimes been four days without food, and were so weak that as many as twenty had often to be used to carry one section of the boat. It appears that one day they succeeded in capturing a large canoe, four men, a goat, and some women with babies. They had first of all shot one man in the canoe. The women ran away, and left the babies in the camp, so they were drowned in the river. Stairs had to be carried twelve days from this camp, so he must have been ill for some time. The road is level and all through dense bush. They passed many villages, but the majority of the manioc was very small, with no roots, so they had to eat the green tops. Mr. Stanley put the four natives captured in chains, also one of the Soudanese who lost his rifle, after giving him 170 strokes with a rod. We are going to have a regular examination of the man tomorrow, writing down the questions and answers, as this news of Stanley is important. 
1887. August 13th.-Yesterday being the first day of grouseYambust 13. shooting, Barttelot and I had serious thoughts of taking a whole holiday, but, as the steamer is due, we thought it better not to do so. Our friend the native came over and offered to take me to where there are buffalo, not a day from here. $\mathrm{He}$ is very anxious we should lend him ten men with rifles to go and take a village lower down, where there are goats and chickens, and the men of which captured two of his wives some time ago. The result of our cross-questioning of the man from Stanley's party is this:-It took Mr. Stanley eighteen days to reach the river, which they had to cross in a boat. The road lies close to the river for two days after leaving this camp. All bomas were still standing on the road when the man returned. Mr. Stanley made a zariba in each village he camped in. Eight men were left sick on the road; one was killed, six were left in the bush, the last returned here. No men died on the road. Only one skirmish with natives the day they ieft here, at the village where they slept. One man was wounded in the forehead with an arrow. In the night four natives threw spears behind Mr. Stanley's tent. There are six villages in the first two days' march; none between that and the river they had to cross. They walked for five days, when the road left the river through a swamp. This river was smaller than the Aruwimi. Great want of food after the first two days. After crossing, Mr. Stanley still appeared to continue along the main river. Mr. Stanley still had two bags of rice, the other officers none; but they still had biscuit. They only got one goat, and no chickens, on the march. They saw no game but elephants, and never used the Maxim gun. The men were very weak. They started each day at daybreak, marched till noon, cooked and ate food, then marched until 5 o'clock. The man who returned, belonged to Nelson's company, and was named Moussa bin Dhama. When they reached the river running into this one they saw a canoe with eight men in it, and a woman and baby, also a goat. I suppose they would not stop, but in any case they were fired 
upon, and three of the eight men shot. Mr. Stanley then took the canoe, men, woman, goat, and some pots of palm-oil which were in it. The men were taken 1887. August 13. Yambuya. away by Mr. Stanley as guides, and the woman escaped in the night, leaving the baby in the camp. The man says that Mr. Stanley ordered it to be thrown in the water next morning*. About two days up the river, whilst he was lying down, two elephants passed close to him. This is the man's account, translated by my boy Matajabu.

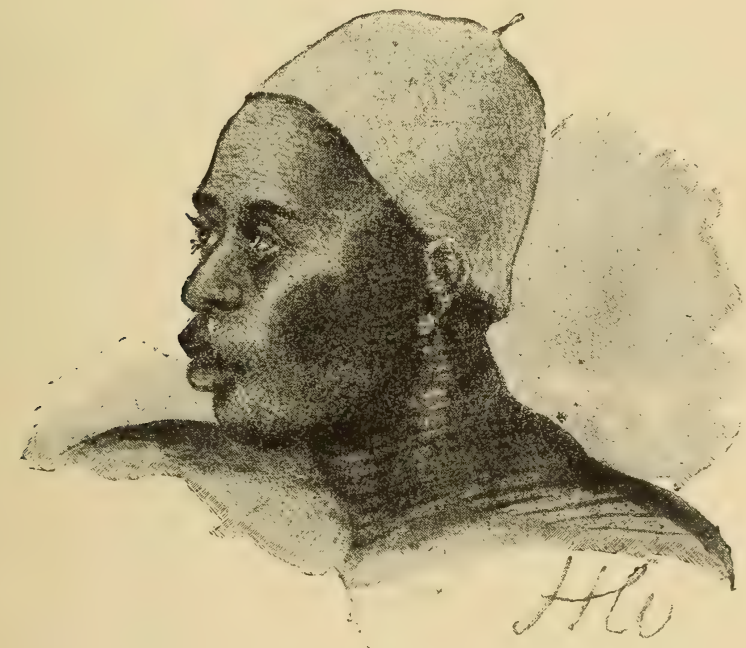

Matajabu.

August 14th.-The Stanley arrived to-day. About 11.30 she was sighted coming round the bend, and 1 don't think anything ever gave me such a thrill of pleasure as this news did, for I have looked forward most anxiously for her arrival, as she brought us the last letters we shall get until we reach Zanzibar. It appears that a second time the Expedition was nearly wrecked. My letters from home revived all my fading spirits, and I went to bed happier than I have been

* Mr. Stanley published in 'The Times' of Nov. 17th, 1890, the statement of Saleh ben Osnan, another Zanzibari follower, as reliable evidence of atrocities committed by Jameson and Barttelot.-Ev. 
1887. for a long time, after sitting up till three in the morning Yambuya. finishing my letter home.

Auqust 15th.-After lunch the natives on the opposite shore made a fearful noise, and began going down stream as fast as they could. Then we heard shots, and on running out with my glasses I saw the smoke still hanging in the bushes behind the village, and a number of natives swimming in the water. Presently our native friend, with a few more, turned up, and said they had been attacked by Tippu-Tib's people, and some of their women taken. They begged for a white man to be sent out to ask the Arabs not to fight them. Lots being drawn as to who should go, it fell to Bonny and Ward; and they went over, but could see nothing of the Arabs, who had decamped. They had killed two men and taken some women.

August 16th.-Hard at work all day packing curios. The Captain and Mr. Walker gave us a little help towards our stores in the way of some pepper and a few

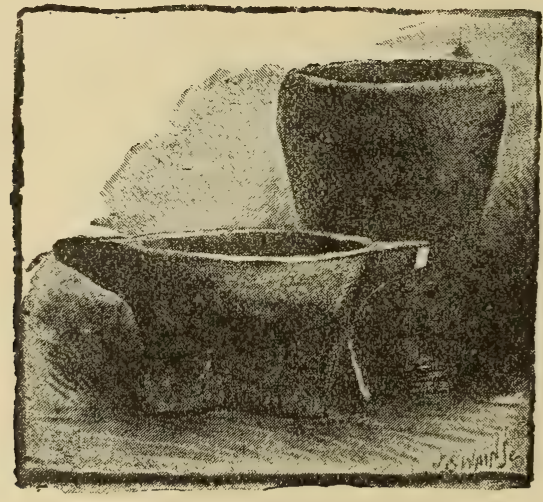

Native Drinking-Bowis.

matches, of which we were sadly in want. Ward had very bad news to-day, as he saw in one of the papers that the steamer in which he had sent home a large collection of curios, and all his notes for the last two or three years, had been run into and sunk in the Mersey, 
with all her cargo. It was awfully cold, and rained nearly all day.

The Stanley starts at 6 o'clock to-morrow morning. She only brought us one goat and some plantains. Hard lines, as the Major and I had been dreaming of her decks crowded with goats and chickens! I am sending my boy Matajabu back to Leopoldville, as he would only die on the road, not being strong enough to keep up with us, and then the natives would get him. $\mathrm{He}$ is a great loss to me, as not only was he a capital servant, but he could speak the language of the natives, and was our interpreter with them and the Zanzibaris, and he did all my bird-skinning.

August 17th.-Settled down to our old work again. Started men to cut poles for a mess-house. Opened European provisions in order to give out three months' rations to Troup, Ward, and Bonny. Barttelot has sent three Zanzibaris in a canoe up to the Arab camp to find out who they are. We are now fairly cut off from the world. We have almost given up hope of TippuTib's men, and are already talking about how we shall employ our time until November. The Stanley left at 6 A.M. for Leopoldville.

August 18th.-The Zanzibaris returned with ten of the Arabs, who really are Tippu-Tib's men. Their head chief and two others came into the house, shook hands, and had a long palaver with Major Barttelot and myself. It appears that they were sent from the Falls by TippuTib to collect men, but, as far as we know of their proceedings, it looks far more like collecting slaves and ivory. They said that 700 men had started under Sheik Rachid to come to us, but that upon arriving at a camp on Mr. Stanley's road, where he had left some mark, they had concluded that the whole Expedition had gone on, and had returned, now being encamped on some river between this and the Falls. 'This Sheik's name is Abdullah Coroni, and he offered either to send a letter to Tippu-Tib for us, or to escort one of us to the Falls, four days from here. After thinking it 
1887. well over, and speaking to all of us about it, Major August 18. Barttelot has decided to send two of us, and got the Yambuya. Sheik's promise to return in two days with twenty men to escort us. This, of course, will be our only chance of getting the men now, for, if we did not go for the men, the chances are that they would be scattered all over the country, and we should never see them. I am more than glad that Barttelot has decided upon sending me, and Ward to accompany me as a witness of the interview with Tippu-Tib. The tramp will be through a piece of unknown country, and full of interest.

While the Arabs were talking with us, I could not make out where I had seen one of them before, as I seemed to know his face, when it suddenly dawned upon me that he bore a wonderful resemblance to Florence St. John, the actress. I never saw a more remarkable likeness, and Ward, to whom I mentioned it, saw it at once.

Before leaving, Sheik Abdullah promised not to molest any of the natives near us.

August 19th.-The men worked at the mess-house, and brought in fire-wood, and cleaned up the camp, a daily duty which we look upon as the most important one of all. In the afternoon Bonny went over, with the chief, to the village on the other side. He says that on his arrival the people were tremendously excited and pleased at a white man coming over. The men in his canoe made a circle with the poles they use for poling up the rapids, to keep the crowd back, for the natives were even up in all the trees. They made such a noise that he could not hear the chiefs speak, but when he rose and put up his hand, they were all silent at once. He then waved his hand, and they all sat down. He first asked them if they were not glad that the white men had prevented their being killed by the Arabs, to which they all shouted an assent. They then brought a lot of leaves from the roof of one of the huts, closely rolled together, and made Bonny hold one end, while an old chief held the other; they next gave him a knife and 
told him to cut the leaves in two, after which the chief 1887. cut them, when they were dipped in water, with which the bystanders were sprinkled. All the people then August 19 Yambuya. shouted, "We are at peace! We are at peace!" Bonny told them that we wanted goats and fowls, not as presents, but that we would pay for them. They said that 'Tippu-Tib's people had taken all their goats, but that they had a village inland where they kept all their fowls, and they would bring them. The natives made him a present of six fowls, one man actually bringing a little chicken with no feathers on, saying it was all he had. Bonny gave the chief a piece of handkerchief.

I received my letter of instructions from Major Barttelot, and to-morrow I hope to start for the Falls.

August 20th.-The Arabs never turned up all day, much to our disgust. Just as I came out of my bath to-night, a large centipede nearly walked right over my foot; this is only one of the many insects of every abominable species that infest my house.

August 21st.-My birthday*, which reminds me that I have spent two others in South Africa, and two in America, all under canvas, for although this is a wooden hut with a grass roof, a tarpaulin covers the whole. Some of the Arabs have arrived, the rest come tomorrow, under the chief Abdullah, and on the following day we begin our march, thank goodness! They say it will take at least six days, and at an ordinary pace nine. They brought with them two little dots of children, the eldest, I should say, not more than five years old, and a small dog, all proceeds, I suppose, of their late raid on the natives.

On the strength of its being my birthday, we opened a tin of sardines, and feasted off them with some rice.

There was great grumbling among the men because their matakas are still stopped, as they have not given

* This is a mistake; his birthday was on the 17th August, the very aate upon which he died at Bangala, in the following year, 1888.-ED. 
1887. up the man who stole the axe. Deputations both from Yambuya. the Soudanese and Zanzibaris waited on us, and at last the Major told them that as they could not find out the man who stole it, and as Abdullah was really the cause of its being stolen, if by to-morrow morning they had all come to the conclusion that he ought to be punished, we would give him fifty lashes, and give them their matakas.

August 22nd.-It was decided by all the men that Abdullah should be flogged, and so he was. From the quiet way in which he received it, I begin to think that he stole the axe himself, or lost it. After lunch, Sheik Abdullah arrived with the rest of the Arabs, about thirty men in all, including those in camp, and a number of native slaves (armed with splendid spears), who are their carriers. Sheik Abdullah brought his wife with him, and a very fine fowl, which he gave to Major Barttelot. They say there is not the least doubt that we shall get the men from Tippu-Tib. The natives with them are the most horrible-looking lot I have ever seen, beautifully tattooed with cuts from a knife, and with their upper and lower lips cut into fringes, and their teeth filed into points.

Auqust 23rd.-Started for the Falls at 7 o'clock. For the first two hours our road lay parallel to the river, then struck off through the forest. The general direction was S.S.W., sometimes due S. A struggle took place on the way between some of Tippu-Tib's men and the natives from near Yalisula, which was rather exciting while it lasted. At one time we heard a tremendous noise ahead, and found all hands hunting like hounds in a swamp, and they at length returned with an old man, a woman, and a child, whom they made captives, but Sheik Abdullah made them release them. Had we not been there, little chance would they have had of escape, as the Arabs would have kept the woman and child until they were ransomed with ivory by the husband. It was pitiable to see the old man following his wife ind child, although the Arabs did 
not want him. It is wonderful what they will pay to get back their women. Tippu-Tib's men's faces of disgust showed plainly that this was not their ordinary treatment. The natives buy ivory with large pieces of iron shaped like a spear-head, and about six feet long, of which ten will buy a good tusk, and should they have no ivory they pay the Arabs for their women in these iron pieces. For the first part of our road we had to walk like tight-rope dancers along immense fallen trees, wade numerous swamps and small rivers, after which the path lay through splendid open forest, witr very fine timber in it.

August 24th.-Started at 6 o'clock. The road was hilly, and led through the same forest. At one village the natives said we were the first white men they

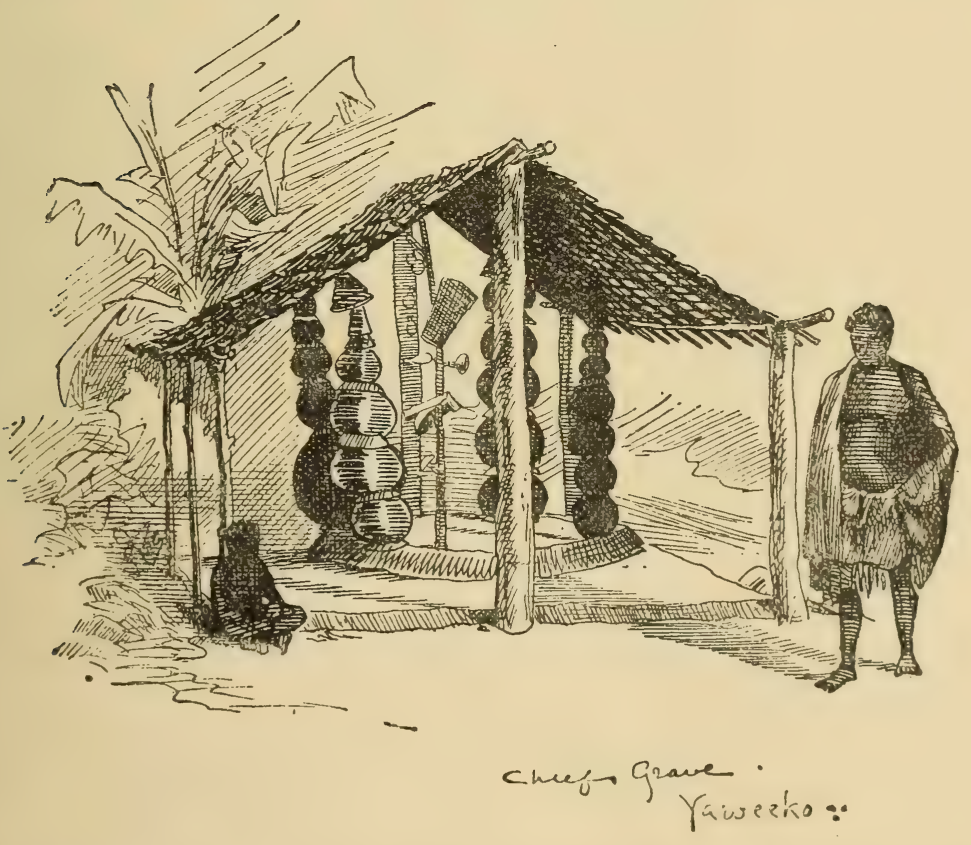

had ever seen, and that they must make us princes, bu' they did not do more than produce a pot of malafu. 
1887. The ceremony is therefore much simpler than in our August 24. country. Fancy the big potentates at home sitting March to Stanley Falls. down round a pot of beer to make two new princes! Eight or nine Arabs then arrived, some of them great men, in the most spotless turbans, of whom Bartholomew told us that they had hidden all their slaves in the bush, being afraid we would come to their village, which I quite believe, for when I asked them where it was they said "Very far, too far to go to," yet they had just left it!

August 25th.- The guides turned up about 6 A.M., and we began one of the worst marches I have had for a long time. At first the road lay through groves of plantains and small villages, until about one o'clock, when we entered a large cane-brake intermixed with prickly palms and creepers, and of all the roads I ever travelled this was the worst. At one moment you were caught by the throat and your helmet knocked off ; then, having struggled out of that fix, you were next tripped up by a creeper, and fell on your nose. We met some of Tippu-Tib's people coming from Singatini, who told us that Tippu-Tib was going off to see Sheik Rachid at the Lumami River in two or three days, so we pushed on, doing, I should think, very little short of twenty miles. The natives of the last village we passed said that as we were the first white men they had ever seen they must make us a present, and they started off to get us a small dog to eat, which they consider a great delicacy, but we had not time to wait for it. About a hundred yards from our camping-ground we had to wade waistdeep through a river, and as the man with my bag did not turn up until long after dark, I had rather a bad time of it. Our road lay S.E. nearly all day. We had nothing to eat since morning but some mouldy biscuits, and dined off the remnants of the cold rice and fowl of yesterday.

August 26th.-Started at 6 A.M., and our road lay for some hours through a beautiful open forest, then down a steep hill, and along the bed of a river for nearly a 
mile. As our caravan slowly wound its way up the silvery bed of the stream, gleams of light fell here and there, piercing the shadows of the tropical forest.

1887.

August 26

Congo

River.

At last, after many steep hills, and having crossed one very broad river in a canoe, we suddenly came upon a full view of the Congo, and descended into a large village called Yalisula, where we changed our wet clothes, got into canoes, and went on to Yawami, a village higher up the river on the left bank. Here we slept in a whitewashed mud house belonging to the Arabs. At both villages we were objects of the greatest curiosity, especially while changing our things, when there was perfect quiet amongst the two or three hundred onlookers. The Arabs treated us very kindly, making us presents of rice and fish. We marched fifteen miles, and came about two miles in the canoes, our road again lying S.E.

August 27th.-Started at 6 o'clock in canoes, and after two hours reached Yadzembi, where we changed canoes; in each village the Arabs sent us on with their own natives to the next. Those who accompanied us from this place were great swells, wearing brass and iron wire right up to their elbows; and their hair was dyed bright red with cam-wood. At two o'clock we reached a large village on the right-hand bank named Yatuka, at which there was a market going on. Sheik Abdullah's village is about an hour from here, up a small river, and he very much wished us to stay at Yatuka for the night, but I insisted on going on at once. Opposite this place lies Yarracombi, another of 'Tippu-Tib's villages. After we had started, a terrific thunderstorm came on, half filling the canoe with water. We went on after dark for a couple of hours, finally reaching Tatiacusu, where we stayed for the night. The Arabs gave us a fowl, two eggs, and a lot of rice. Unfortunately I had had nothing to eat all day but some raw chiquanga, with a drink of malafu, and I was so sick that I could eat nothing when we did get food. I must here say a word for our waterproof bags. Mine had 
1887. been lying all the evening in a good half-foot of water, August 27.
Tatia-

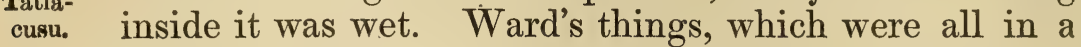
waterproof sheet, were soaked through. We slept in the verandah of the Arabs' house, surrounded by the usual crowd of inquisitive natives.

August 28th.-Left Tatiacusu at 5.30, and, after about three hours in the canoes, reached Atiacusu, where we saw no Arabs, but an immense number of natives. Here we had to change canoes. There was rather a row about poles and men for our canoe, which at one time threatened to be serious, but it ended in a slogging match with sticks and logs of wood. I was greatly amused with Abdullah, who rushed back to our canoe, and seized my big revolver, and was going to shoot a native with it, with the leather cover on.

About two hours before coming to the Falls, we passed the mouth of the river Wamanga, and further on that of the Chopo River, both on the left bank. We arrived at the Falls about 5 o'clock. Tippu-Tib himself came down to meet us, and conducted us to his reception house, where his brother and all his officers were assembled. He gave us some delicious fried plantains, tea, and coffee, and made Sheik Abdullah tell him all about our journey, camp, \&c. I then told him I had a letter for him from Major Barttelot, which I would present after we had changed our wet clothes. We went to the house he had placed at our disposal, where a man presently brought us some excellently cooked fowl and rice. We then went down, with Bartholomew as interpreter, to present the letter, and I told Tippu-Tib that anything in it that he could not understand I would explain, as I held a translation in English. I used Bartholomew as interpreter, but Tippu replied to me each time through Salem, making him ask me any questions he had to put. I then gave him the revolver from Barttelot, and a knife from myself. He thanked me for them, and explained the reason for the men promised to us not having 


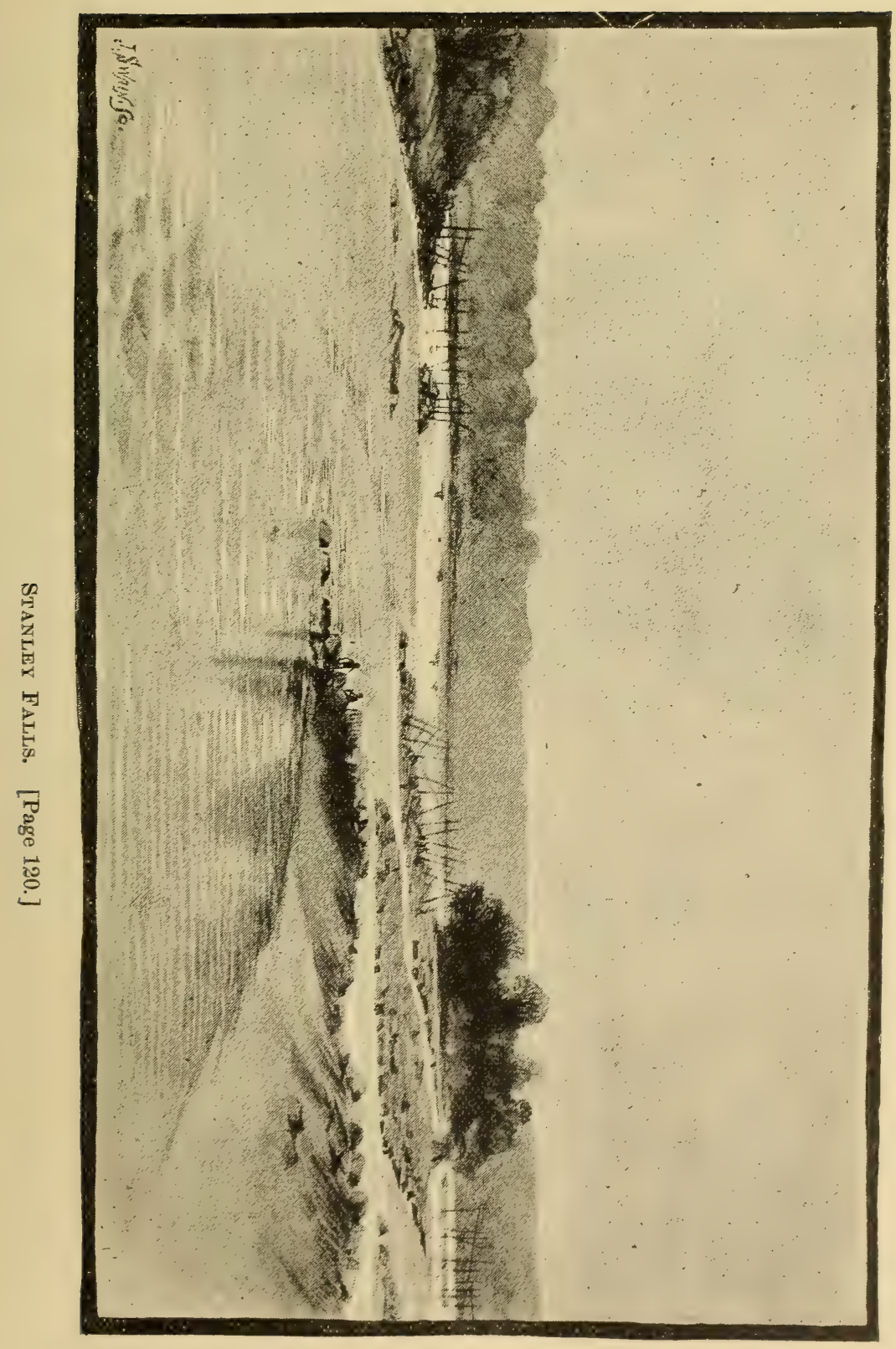



reached our camp. They started from the Falls with 'Tippu-Tib himself, 500 men for Mr. Stanley, and with the men paddling the canoes (of which there were fifty), 1,500 in all. Arriving at a small village, which must be within half a day of our camp, they sent over some men to a large village which lay on the opposite bank of the river, to get food. The natives all ran away at their approach; but they had no sooner taken fowls and plantains, and were returning to their canoes, than the natives, who had been hidden in the bush, rushed down and killed four of them, cutting them up and dividing the meat on the spot. Tippu-Tib attacked the village that evening, and burned it next morning.

By this time all the paddlers in the canoes were either sick with fever, or their hands were sore, so they had to return. He says Mr. Stanley had told him the camp would be at Basoko, or near it, at least not so far up the Aruwimi. He then sent 200 men to try and find the camp overland, but they returned, saying they could not find it. He again sent 200 men under Abdullah, with orders not to return until they had found it, or Mr. Stanley's road. This is the Abdullah who brought us to the Falls, but he must have known about our camp long before we sent up to him. Tippu then promised to send out to-morrow morning to collect as many men as he could, and that after three days, it now being their Christmas, he would start himself with them for our camp, leaving his brother to send on the rest. He asked me if we should start after Mr. Stanley with the men he brought with him, leaving some of the white officers to bring on the remainder when they arrived. I told him I had no authority to say what we should do, but that I thought the Major would not start at all until he knew definitely how many men there would be, or until they were all there. He again promised to start in three days, but said he was not sure if he should be able to give 100 men, as they were now scattered all over the country. This ended the conference. 
August 29th.-Was awakened by a boy bringing in a most delicious breakfast of vermicelli and plantains fried in ghee, followed by a chicken and rice. After breakfast Tippu-Tib sent to say he would like to show his brother my Winchester and revolver, so I took them down to the reception house. After everyone had examined them, I told Tippu-Tib that, upon reflection, I thought it might be better for him to stay here a few days longer than the three days he proposed, in order that he might collect more men, and gain a definite idea of how many men he would be able to give us. He seemed rather annoyed at this, and explained that his reason for wishing to start in three days is that the majority of the men are in villages below the Falls, and that by thus going down himself he will have far less difficulty in collecting them. This sounded reasonable, so I let well alone, and said nothing more. I shall now start with him, and when we leave the canoes shall send Ward ahead as fast as possible with a letter to the Major. After this there was a regular reception of about twenty Arab Sheiks, who had come to breakfast, and then Tippu asked us if we would like to go round the station. We all crossed the river to the old Free State Station beiow the Falls, and examined the Krupp guns, and found they still have the breech blocks, which were not destroyed as stated by Mr. Deane. Then large canoes were summoned to take us to the island above the Falls. Here we witnessed a great wrestling match between two picked men, one from the village we had left, the other from the island village, which was a very grand affair. In the centre of the main street a space had been cleared, and at one end were all the chiefs, athletes, and girls of one village, with their champion, and opposite them stood the rival party. The two champions were splendid-looking men, covered over with different coloured clays, these being their distinguishing colours. 'The girls all wore a small piece of cloth in front, and a long tail of black palm-fibre, which waved about as they danced. Those belonging to the one 

village began the ceremony by dancing, clapping their hands, and singing a wild chant, taunting the opposite party with being afraid of their champion, upon which the

1887.

August 29 .

Stanley

Falls.

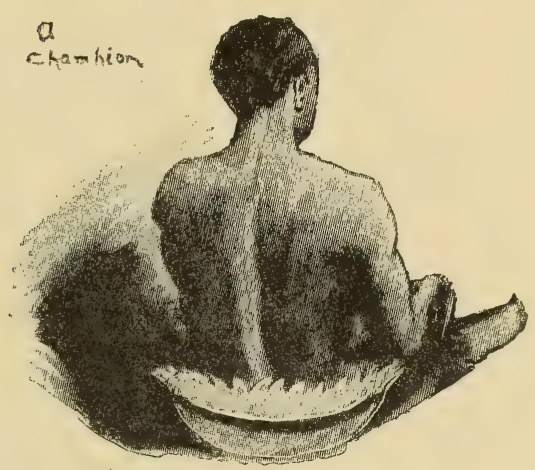

others went through the same performance. Finally the champions came forward, and after many attempts at getting fair grips they closed, and after a short wrestle, in which neither got a fall, they parted amidst tremendous uproar. All the girls of both parties then danced up and down the centre. Before the men began to wrestle, old women came and spat on them and jeered at them, evidently for the purpose of arousing their courage. There was also great running up and down of magnificently attired chiefs, with small brooms in their hands, to clear the arena. The wrestlers came out again, but this time there were so many disputes about the grips that finally the party from the mainland led off their man altogether. These disputes often end in blows, and sometimes in bloodshed. We then rejoined Tippu-Tib, and crossed to the other island above the Falls, to see a tree which was considered a great marvel. It had lain on the ground for a long time, and quantities of fire-wood had been chopped off it, notwithstanding which it had suddenly sprung upright again. This was easily explained, for the roots had never been cut, and after some of the stem and many of the branches had been 
1887. removed, they were sufficiently strong to raise it up

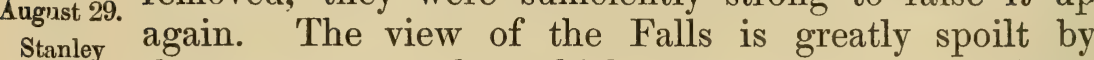
Falls. the enormous poles which are placed across them, holding large baskets swinging in the water to catch fish. The Arabs are wonderful civilizers; they grow quantities of rice, sweet potatoes, onions, guava trees, mangoes, paw-paws, and pomegranates. A blacksmith's shop is one of the sights here. One very good law made by them to encourage trade is, that no natives living near the water are allowed to cut fire-wood, and no natives from inland are allowed to catch fish, thus the dwellers by the river buy their fire-wood with fish. Two of the big chiefs here speak Swahili.

August 30th.-After breakfast we took our sketching things and went down to see Tippu-Tib. He gave us a boy and Salem to take us all about the place. We crossed to the old Station below the Falls, where we were met by Sheik Selim Mahommed, Tippu-Tib's nephew, one of the nicest of all the Arabs, a gentleman every inch, down to the soles of his feet. We went on to lunch with old Sheik Nasoro, a very courtly old gentleman. From his house we could see the natives coming down to the edge of the Falls, some holding on to the poles, whilst others mounted them, and dragged up the large baskets of fish. After saying good evening to Tippu-Tib, we sat on the rocks by the river, and, smoking our pipes, watched the setting sun. I can easily understand anyone getting quite fond of this place. There is a mixture of wildness and quiet about it which is really charming. Whilst resting at Sheik Mahommed bin Said's house, an Arab brought in seven or eight small tins of Crosse and Blackwell's Liebig, a large tin of lard, and a ripe paw-paw, an excellent fruit, which I had not eaten before. $\mathrm{He}$ asked what was in the tins, and, to our great amusement, told us they had been in the habit of using it for sores on the legs. He gave us all the Liebig, but took away the lard in disgust upon hearing it was hogs' fat. History does not relate from whom he had got all this, and 


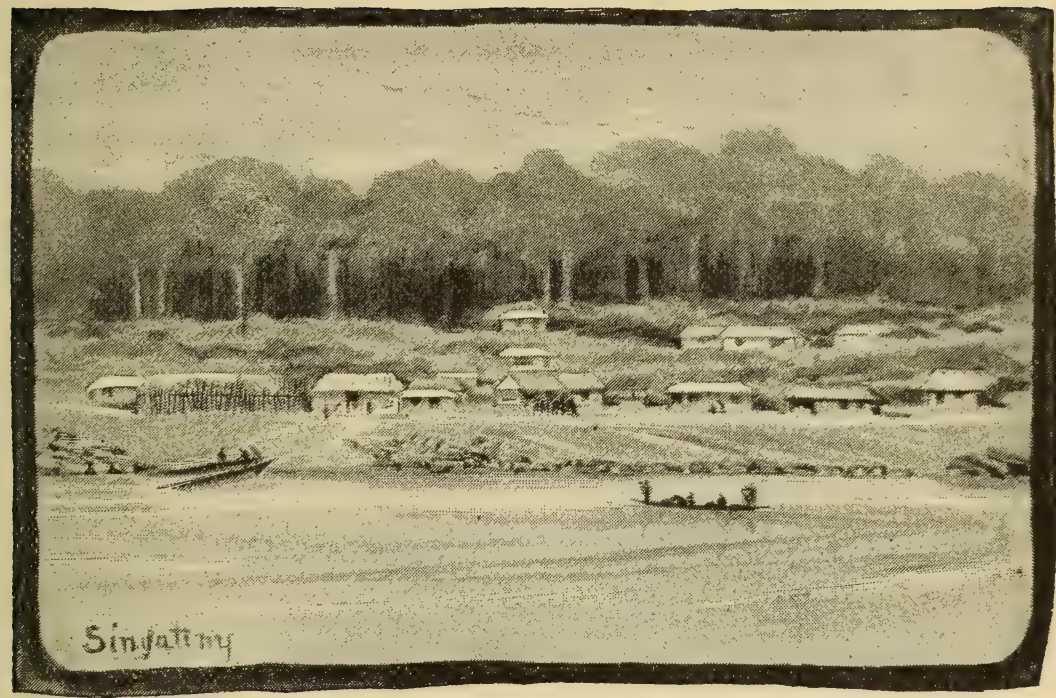

the small packet of lettuce seed which he also showed us; I feel sure they were stores taken when the old Station was captured from Deane. I am trying to get 1887. August 30. Stanley Falle. one man to buy all the fowls we want, and settle with him.

August 31st.-The laziest day I have spent since joining the Expedition! It was the Mahommedan Christmas, and we did nothing but eat all day. All the Arabs were in Sunday best, and looked very handsome in their long black embroidered cloaks over snowy white linen. One Sheik had on a buff-coloured robe, embroidered with gold and silver. Tippu-Tib's nephew, a handsome little Arab, paid me a visit, and he was delighted by my giving him my Egyptian tobacco-box. His father is Tippu's philanthropist brother, a tall, light-coloured Arab with a long beard. the most benevolent and pious-looking old gentleman. We were informed that he is very religious, and might be rich, but that he gives away nearly all his ivory to 
1887. very poor Arabs. This is very different from the opinion

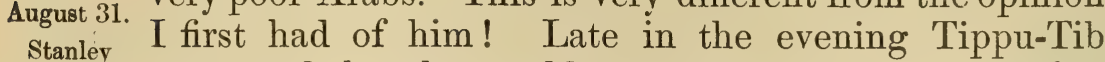
Falls. sent word that he could not start until the day after to-morrow, as the natives have refused to lend their canoes, or to paddle others, saying they believed we were going up the Aruwimi again. This makes me believe the story of their refusing to go higher up ivith Tippu-Tib before. We were honoured by a visit from four or five of 'Tippu-Tib's Lights of the Harem, who are not his real wives, as those are never seen by any one. The Arabs and natives here appear to live in the most perfect harmony. You will meet an Arab strolling along hand in hand with one of the native chiefs, and if a canoe is wanted, it is ready in a moment, the chiefs themselves paddling it. All day long we were visited by people who either wanted presents, as it was Christmas, or had something to sell, until it got so bad that we had to close our doors. With the exception of a few guns being fired off, and a great quantity of food being eaten, there did not appear to be much rejoicing, and they all wished they were at Zanzibar, where Christmas could be kept in a proper fashion.

September 1st.-Had a most enjoyable day, and, I am sorry to say, the last here. After breakfast Salem came to say that the natives of the island village were going to have another day's wrestling, so we started at once, and whilst waiting for a canoe at Sheik Nasoro's house, saw the old gentleman cupped on the legs for rheumatism. The Arabs put up an awning for us to see the sports; the wrestling was much better than the last, and I saw one really good fall. Both Ward and I got some sketches. Salem informed me that it is almost impossible to get any fowls, as the people will not sell them on trust. I am going to try to make them bring some anyhow. We had enough matakas to buy a dozen, but they were all stolen. This morning I wanted one or two to make a present to a girl who brought back one of my tortoises which had strayed. Upon asking Bartholomew for them, he at first pre- 
tended not to understand, and then could not answer at all. He confessed to having received seventy, and upon adding up all that had been spent, I found that it was only thirteen, so that he must have stolen fiftyseven. When I accused him, he did not even deny it. This is one of those beautiful boys brought up at a Mission, and I must say that I have always found them beat any savage at lying and thieving! This man had been most energetic in reviling Msa for stealing Munichandi's knife and Koran.

September 2nd.-Went down before lunch to thank Tippu-Tib for his kindness to us. I told him I was going to make him a present of my big rifle, which pleased him greatly. He gave us two sheep, three fowls, two large baskets of sweet potatoes, and a bag of rice. He also wrote a letter which he gave me, telling everyone that $\mathbf{I}$ had been his guest, and that they were to look after me. He intends to start to-morrow, and if the canoes arrive from Kassongo, he will bring goats and rice. He gave us some of the most delicious coffee I have ever tasted, which grows wild at Kassongo. After lunch we started, Tippu-Tib and all his followers coming to see us off. Five canoes in all. Selim Mahommed and Salem went with us. We found upon examination that a piece of cloth had been stolen, so I asked Tippu-Tib to put Bartholomew and Msa in chains, as I felt sure they would attempt to escape. They had, I afterwards discovered, told Tippu-Tib they meant to run away, but he declined to connive at their escape, so the two gentlemen are now in irons. Salem told us that Taboro, the chief of the Manyéma, had refused to allow his men to carry 'Tippu-Tib's goods, either to the Falls or to Zanzibar, so that he now has to señ his ow men all the way, which makes it doubly difficult for him to give us men. Salem also told us that he now owns thirty men with guns, but he means soon to have 150. We asked him if he had the money to pay for them, upon which he said, "Oh! that is simple enough. I have a razor and some white cloth. I go down to either Kassongo or Manyéma, take hold 

1887. of a man and shave his head, put a gun into his hands,

and give him enough cloth to make him decent, and he becomes my follower." He says they never start on any journey without consulting the Koran to see if the day and hour are lucky. If they did not do this, he says, they would certainly all go to Jehannum. According to him, no one owns anything but Tippu-Tib, and they all covet whatever he has. They all wanted the knife I gave him, and would steal it if they dared. TippuTib's brother will succeed him as chief, and afterwards Sefo, his son. We suggested that his brother was too peaceful a man to be chief of the Arabs, but he replied, "Oh! Sefo and Rachid will do quite enough fighting." He also told us that Tippu-Tib had made an agreement to settle up the whole country as far as Bangala, and to establish stations; this means that he will fight every tribe in succession, and then put his Arabs in.

September 3rd. - Left Tatiacusu at six, and only went as far as Yatuka. Here we stopped all day to buy food for the men, and pick up Abdullah and his men. I to-day saw the most horrible sight, a woman was nursing a child not bigger than a three or four-year old boy, but whose head might have belonged to a grown-up person, while its body was an absolute skeleton, every bone (even the very smallest) being visible, and covered only by loose skin. Tippu-Tib shows what a gentleman he really is, in his thoughtfulness for others. He noticed that Ward had no umbrella, and at once insisted on giving him one of his own; and, as our two men were in chains, he sent his wife's boy, Farani, who speaks a little English, to look after us on the road.

September 4th.-Bartholomew and Msa broke their irons and escaped during the night. Selim bin Mahommed assured me that they would be caught, and that we had better go on, as they would have to come into the villages for food, and would not do so until we were gone. I found out, on arriving at the next camp, that Bartholomew had stolen altogether 57 matakas, one piece of cloth, one axe, one knife, one plate, a pair 
of scissors, and a table-napkin. Selim and Farani informed me that they knew him well. He had been servant to a German on the coast near Zanzibar; he there stole two bales of cloth, a lot of clothes, and whatever he could lay hands on, and then set fire to the place. He enlisted with Mr. Stanley because he was running away from the people who were after him at Zanzibar. The German had offered Selim and Tippu-Tib £3 for his recovery. Reached Yalisula at midday, frightfully hungry, as we had no time for breakfast before starting, and no amount of "cussing" would make the Arabs paddle a bit quicker; they simply floated with the current, or we should have arrived a good three hours sooner. I was so hungry that on arrival I devoured mouldy, weevily, maggoty biscuits, rancid butter, and Liebig, with avidity. It was one of the most curious luncheons I have ever eaten. I made arrangements with Selim Mahommed for Ward to start back to camp to-morrow, and determined to wait here myself another day to see if the two culprits would turn up. I had some difficulty in getting men for Ward, as, although we had hired Abdullah's men at our camp to go to the Falls and back for a certain price, Selim said they were not Abdullah's men, but Tippu-'Tib's, and 'Tippu-Tib had given orders that we were to be sent back to our camp without any expense. I at last succeeded in making Selim understand that we had entered into a contract with the men, and that, according to our views, payment was due to them.

September 5th.-The market in the evening was interesting. About 4 o'clock a drum is beaten to collect the natives from the villages near, when each party of villagers takes up a separate position on the ground, bringing with them all they have to sell. 'Those from inland supply plantains and manioc, both roots and tops, the green leaves of which are tied up in plantain leaves as neatly as though they were to go to Covent Garden market. The salt which they sell they 
1887. obtain by burning grass and plantain husks and stems;

Sept. 5. they also bring fire-wood and fishing-nets. The natives from the shores bring fish and pottery. Once all are assembled at the sound of the drum, a tremendous trade begins, accompanied by an uproar very much akin to that proceeding from the betting-ring at the Derby. No form of money is used; the articles are exchanged for one another. I bought two ivory pestles for pounding manioc. Neither of our escaped thieves has turned up to-day, so we are obliged to stay another day, although this is a horrible spot; I can only get rice and plantains to eat, but endeavour to discover a new flavour in each at every meal.

September 6th.-No signs of Bartholomew, so we start for camp to-morrow. At the Falls, and wherever the Arabs trade on the river, the only form of money used, except the large pieces of iron for buying ivory, is small iron axe-heads. Kassongo must be a wonderfully rich place, for according to the Arabs everything, iron, copper, rice, goats, salt, coffee, chickens, \&c., comes from there.

September 7th.-Started at 8 A.M., and marched steadily, with one small break, until 5 P.M. I find that Selim Mahommed's band accompanies him on land as well as water. It consists of three Kassongo drums, played by men, and three hand-rattles, played by women; and they all sing, or rather wail and grunt. We took a different road to the Falls from that which we had followed before. I told the Arabs it was far too much to the east, but they maintained that it was shorter. It lay nearly due north of Yalisula. The small rivers were so high that we had to wade them up to our arm-pits, which made the walking very unpleasant.

September 8th.-Got under way at 6 o'clock, and reached a very large village held by 'Tippu-Tib's people, called Sugurru, at about 4 P.M. This village was about twenty miles out of our course. I told the Arabs that 
the road was all wrong, as I could see by my compass, but they persisted in believing the natives. We were at one time completely lost, but luckily caught two women, who brought us to Sugurru. Passed an immense number of monkeys, and I shot one for the natives, who use the skin for helmets, and consider the flesh a great delicacy. There were numerous fresh elephant-tracks; the whole bush was in some places trodden down by them. It was positively dangerous work walking fast in the forest, for the natives have

1887.

Sept. 8.

Sugurru.

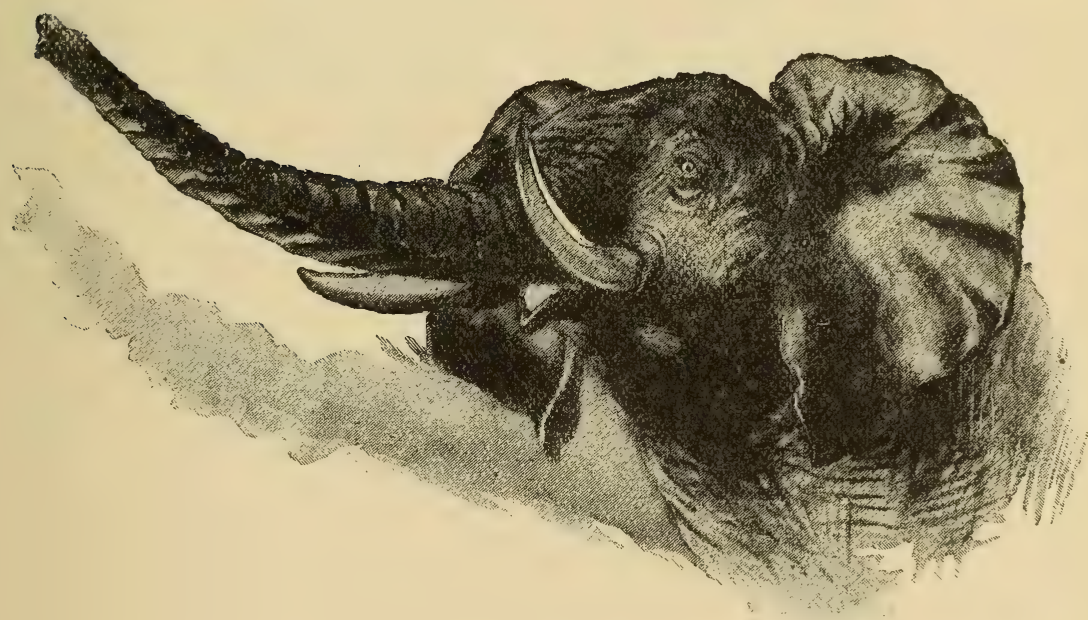

large poisoned spears tied to immense logs of timber, suspended between trees over the elephant-path, and across which they place a light rope attached to a trigger, so that the moment the rope is touched by an elephant, down comes the spear into his back. Two or three times I very nearly walked under one. We escaped this danger to run into a worse, for the Arabs at the next village all but fired at us, thinking we were enemies. Crossed a great number of rivers and swamps. Was wet through all day.

September 9 th.-One of the most disagreeable days I 
1887. have ever spent. Started at 6 A.M., and could get no Sugurru natives to carry the sheep. Our road lay through the to Yambau. most horrible country, for more than an hour down the bed of a small river, which was dammed up in places, and through them one had to flounder up to one's waist and sometimes higher. Then followed another river, cane-brake, and swamp. I walked ahead with the natives, and we went for a good ten hours with only one short break. We pulled up at 4.30, a long way from Yambau (which should have been our camp), in a village where not a drop of water was to be had for love or money. I had nothing to eat all day but a few plantains before starting, and a little cold rice cooked yesterlay, before I turned in for the night; so that, after ten hours' hard work, I went to bed more hungry and thirsty than I think I ever have been before. "Had Selim Mahommed not been so far behind, I should have walked on, as I am sure we should have reached Yambau, or at least water, before dark; but as it was the Arabs were evidently annoyed with me for having come so far.

September 10th.-Owing to heavy rain we did not start till 6.30. Went nearly due north until we struck our old road to the Falls, which I recognized at once. The native guides were so troublesome, stopping frequently, that at last I went ahead with my boy, and soon struck the village, where Ward and I had slept before, and there I got an Arab to take us into Yambau. One of the Arabs brought me a magnificent ivory horn, which, when standing on the ground, came up to my chin; but he would take nothing but a revolver for it, so I could not buy it. I wronged the Arabs when I was last near here, by saying that I thought they lied when they declared their town to be a long way from where Ward and I slept. The road is a bad one, with two nasty rivers to wade, and it takes about an hour. I succeeded in getting a very small fowl here, which I deroured (body and bones), for I had nothing for breakfast but a cup of malafu and a few plantains. 


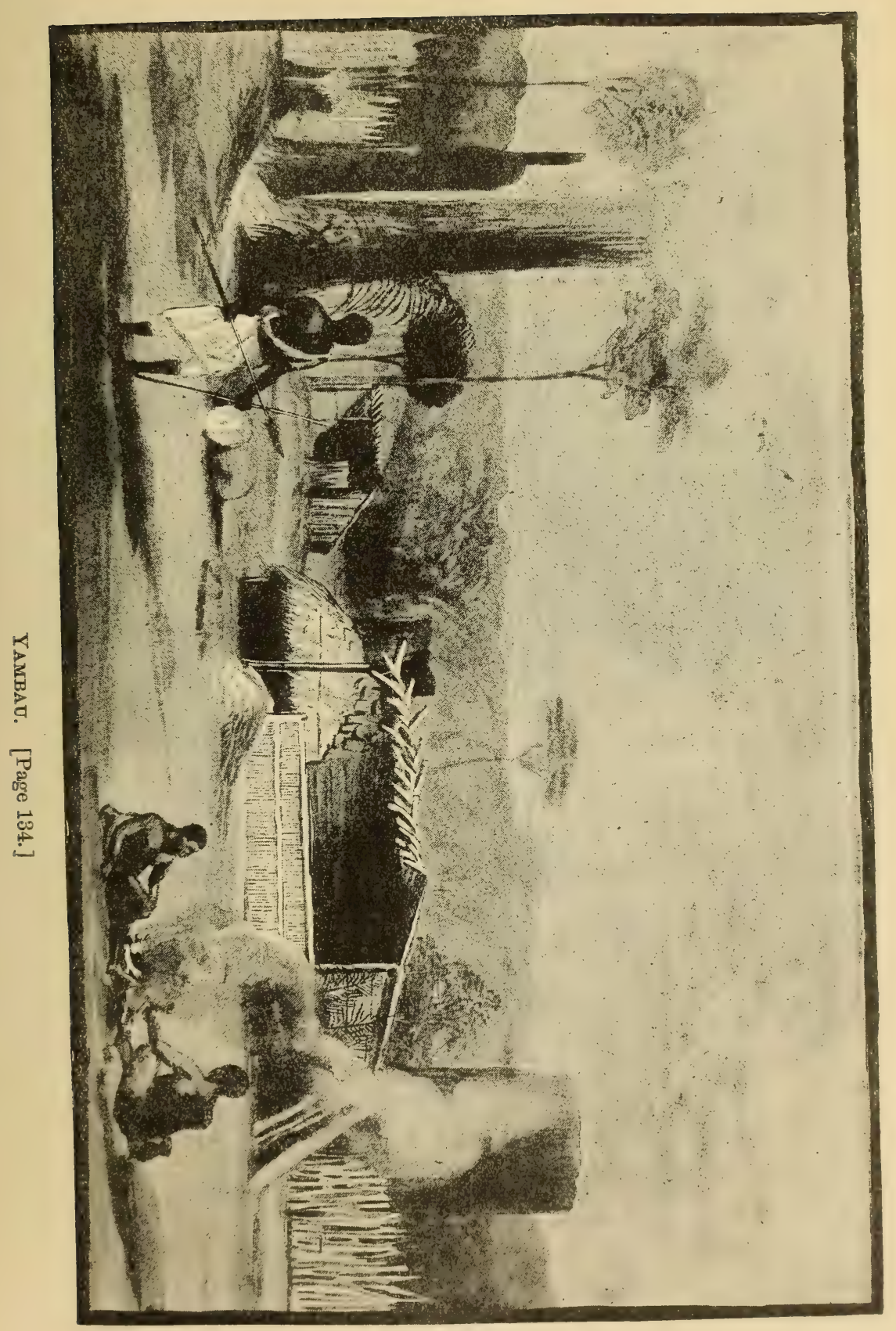



September 11th.-Got away before 6 o'clock, and went steadily on until 1 o'clock, when we reached the river, on the further side of which Ward and I had slept our first night out. News came that the two men who escaped had not been captured, but a letter had been received from Tippu-Tib telling the Arabs they must be careful, and a number of men had been sent out after them.

September 12th.-Reached Yambuya at 12 o'clock. About three hours from camp came across fresh elephant and buffalo-tracks. Found poor Ward very seedy. The others all in good health, and eager to get on the march again.

September 13th.-During my absence the natives have been giving trouble, and brought nothing to sell, so the Major sent Bonny to catch some of their women. He caught eight women and a baby. Two have been ransomed for a gun which they had stolen, 13 fowls, and a lot of fish. Selim Mahommed has formed a camp on the rising ground behind our camp.

It is a very true saying that when thieves fall out some crime is sure to come to light. To-day, through some row among the Soudanese, the whole story of the stolen axe came out. It appears that, between the stealing and selling of it, there were five of the Soudanese implicated in it! They were the very men who had made most fuss about their matakas being stopped for a theft which they said they had not committed.

September 14th.-This morning, after breakfast, we had a second parade for the punishment of the Soudanese who stole the axe. The Zanzibaris having always been blamed for the theft, Major Barttelot wished them to witness the punishment of the real thieves. The two companies of Zanzibaris fell in outside the boma, and the Soudanese fell in between them. The prisoners were then led out, and the two who stole the axe received 100 lashes each, and those who had connived at the theft received 75 each. The men

1887.

Sept. 11

Yambau to Yambuya 


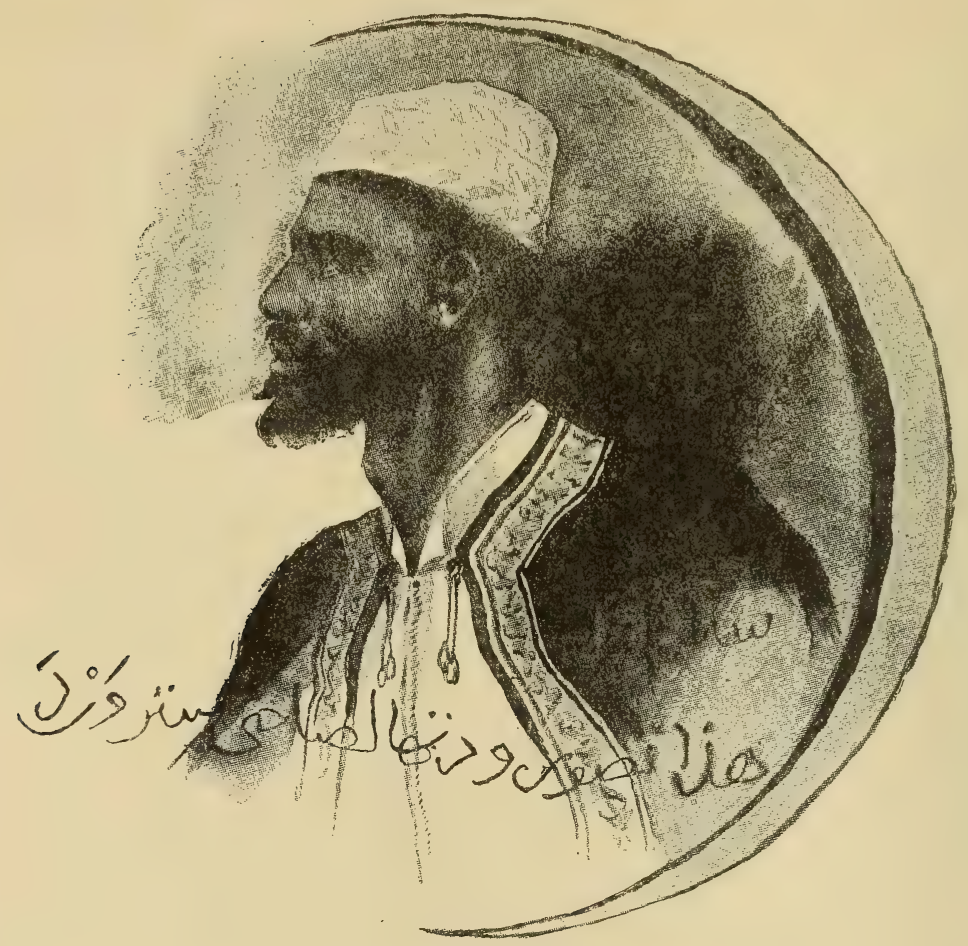

Selim bin MaHommed.

1887. were then warned that any one of them losing an axe Sept. 14. or a gun would receive the same punishment. Ward Yambuya. still very seedy, but decidedly improving, I think. The natives brought us a splendid fish to-day, exactly like an English chub, and weighing about $12 \mathrm{lbs}$; the best fish I have tasted on the Congo. Our evenings are very pleasant; we all dine together and yarn about old times and future prospects.

September 15th.-Our men put up a railing round the graveyard, in which there are now fifteen graves, and I fear, if we are much longer here, there will be a good many more. Rather an unpleasant business with the Arabs to-day. One of our men brought a large fish into camp, when Salem came down and claimed it, 
saying he had given Munichandi two axe-heads and some matakas to buy it with. The Major was naturally much annoyed about this, and he told Salem that he did not wish them to have anything to do with our men, but to keep to their own camp; if they wanted fish they could perfectly well buy it for themselves. Down came Selim Mahommed with Salem, very much annoyed at the order to keep his men to their camp, wishing to know if it was only on account of the fuss about the fish. Barttelot explained that it was not only because of that, but because we are very crowded, and that if they used our camp, on Tippu's arrival his men would think they could do the same, and as a good many of our men wished to run away, they could then plot with his people how to do so. Selim Mahommed then gave back the revolver Major Barttelot had sent to Tippu-Tib, and said he had sent it back owing to there being so few cartridges for it, and his inability to get any more; it would therefore be quite useless to him, but at the same time he thanked the Major for it very much. A second interview with Selim Mahommed in the afternoon ended in a perfect understanding and agreement.

The natives on the opposite side of the river were again attacked to-day by some Arabs, who must be Abdullah's men. This is very unfair, as he promised us to leave them in peace. The natives were fired upon several times, and the whole village cleared out. Ward still very seedy.

September 16th.-One of my men died to-day, and two died during my absence, making eight deaths in my company. In the evening the Major, Troup, Bonny, and I had a game of bowls, the bowls being a large kind of fruit we found lying on the ground. Made some sketches in my diary. I find I never have an idle quarter of an hour from one week's end to another. No sign of Tippu-Tib yet. The natives are coming back to their village.

September 17th.-Just before lunch to-day we heard 
1887. a succession of shots across the river, and, running out with my glasses, I saw a most pitiable sight. A number of natives were swimming in the water, others in canoes trying to pick them up, whilst the Arabs, who had surprised them in the village, were firing into them from the bank. A good many who had not time to escape in the canoes had jumped into the water, and hidden under the overhanging scrub. I saw the Arabs peering down into it, and noticed one man fire, upon which a poor native could be seen splashing about, but a second shot finished him and he sank. Three were deliberately shot in this manner. The Arabs were Abdullah's men, and he had given his word not to molest these natives, and this is the third time he has attacked them. The Major went to Selim Mahommed and told him of this, and Selim promised to stop it, and sent a canoe over to the other side, but all the Arabs had gone. Ungungu came into camp afterwards, and told us that nine of them had been killed; this destroys all our chances of getting food and trading with them for anything. We told Ungungu that he could sleep in our camp to-night, and advised him to come over to this side close to our camp, and bring his people with him. He said that nothing would make him stay on the other side again.

I had some sticks cut to-day, and Troup and I had a great game of "Aunt Sally" in the evening.

September 18th.-Selim Mahommed sent men to Abdullah's camp up-river, and they returned with a letter from him to the Major apologizing for having attacked the natives. They were, he said, retaliating upon them for having killed one of his men, and wounded another who is dying.

September 19th.-The only thing that cheers us up now is the hope that Tippu-Tib may bring enough men to enable us to start after Stanley. This weary waiting, month after month, is perfectly sickening, and takes all the spirit and interest in the Expedition clean out of it. 
September 20th.-When on my way to Barttelot's tent this morning, Chama, the cook, informed me that the two tortoises which I had brought from the Falls had been stolen during the night. Both the cords which fastened them to the cook-house were cut. We at once suspected the Soudanese soldiers, as the Zanzibaris will not touch them. Barttelot sent for their chief, Omra, and the interpreter, Assad Farran, and said I would give a reward for them, dead or alive. They presently returned with the charred remains, and said that the same men who had stolen the axe were concerned in this robbery also. It appears they have regular messes of three or four who share everything in the way of food. Last night Turgamus Mahommed woke up and found Murjad Redwan eating something by himself, and asked him, in a rage, what it was. He replied, "A rat," which it was. Turgamus said he must also eat something, and thought of the tortoises, and he woke up a third man to take them, and a fourth to share them! The whole lot will be flogged if they do not confess who actually stole them. The tortoises had very handsome shells; and I was going to take them home, after removing the bodies-one to be made into a box for my wife's dressing-table (as all her brushes \&c. are of tortoiseshell), the other to be made into a cigar-case on rollers, to pass round the table after dinner: so it is a great disappointment to me. Ward mending, but very slowly. The sunsets are very beautiful now, when looking straight up the centre of the river. I am beginning to long for an active life again. I would rather a thousand times go through all sorts of hardships than lead this miserable existencedoing nothing and living upon what we can get in ransom for the few native women we can catch!

September 21st.-Turgamus Mahommed, who stole my tortoises, was flogged this morning before all the men. No sign of Tippu-Tib or of his men. Another of the captive women was ransomed to-day for eight fowls and a lot of fish. 


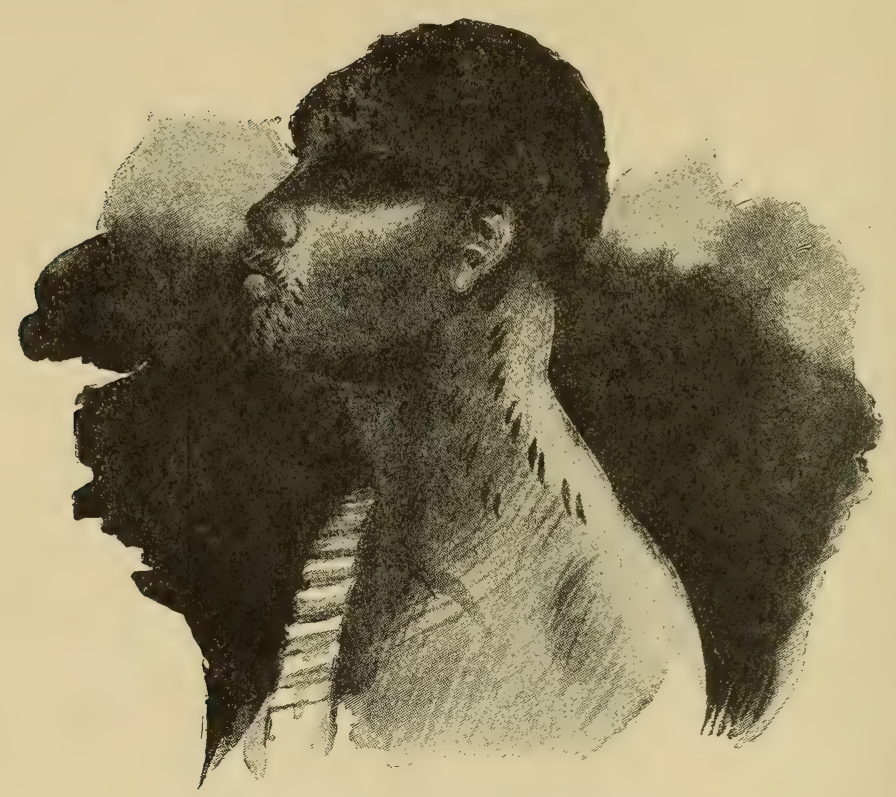

A Native of the Upper Congo.

1887. September 22nd.-Selim Mahommed, who has re-

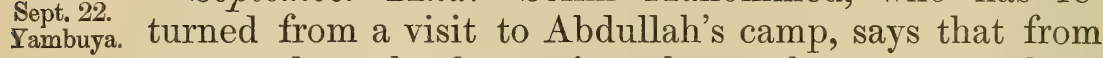
reports brought by natives here, the country about fifteen days from here changes from forest to grass, where there are cattle and sheep. They say that Mr. Stanley had one fight with some natives who are governed by a queen, or female chief. One of my men died to-day. 'This makes seventeen graves, and the ninth death in my company.

September 23rd.-Finished all the sketches I made during our trip to Stanley Falls, and to-morrow I mean to begin collecting again. I spoke to Selim about the information he gave Troup yesterday. He told me that $\mathrm{Mr}$. Stanley had a fight with the natives six days from here; only three natives were killed, the chief's brother and two women. It must have been a white man who shot him, for he was described as a man with a large hat on his head. Fifteen days from here, he says, you come into a lovely grass country full of sheep, but no 
cattle. This information was obtained from Manyéma natives, who ran away when Mr. Stanley entered the country.

September 24th.-I feel more and more every day what a waste of life it is being left for months in this miserable camp. If Mr. Stanley has all the confidence in Tippu-Tib which he says he has, he could easily have left all his stores at the Falls, and taken us ors with him.

September 25th.-Bartholomew and Msa were brought in chains by Tippu-Tib's men to-day. Although very fat, they were evidently very much down on their luck at being caught and brought back to camp. Barttelot had them removed in chains to the guard-house. It is a capital thing, their being caught and brought back, as it shows the other men the uselessness of running away. One of the men from Bolobo died to-day, making the eighteenth death in camp. Heard that Tippu-Tib is at the Lumami River.

September 26th.-All our hopes of being able to go on after Stanley have been destroyed to-day. Selim Mahommed came down and had an interview with us. He informed us that news had arrived from Tippu-Tib to the effect that he would have come himself, but was ashamed to do so, as he was not able to bring the promised men with him. His men had heard from those who came up with us from Matadi of the weight and size of many of our loads, and this seems to be one of the chief causes of their not coming, also the failure of their first attempt. They are all scattered over the country, fighting natives and following their own vocations. Tippu-Tib sent forty men, whom he gave us to use as carriers, without any pay, in case we should think fit to send them with a number of our own after Stanley (with some of the loads), under white officers. He has written to his son Sefo, at Kassongo, to send him the necessary number of men for us, but it takes thirty days to get there from the Falls and fourteen to return, so that Mr. Stanley

1887.

Sept. 23. Yambuya 
1887. will, according to his calculations, have returned here Sept. 26. before they arrive. We shall simply have to sit down for another two or three months, and exist. Barttelot has determined to go to the Falls and see Tippu-Tib. I have very grave doubts as to whether we shall ever see Lake Albert Nyanza, and it is a pretty ending to our share in the relief of Emin Pasha.

September 27th.-This morning justice was meted out to Bartholomew and Msa, the deserters and thieves. They were flogged in front of all the men, Bartholomew receiving 150 lashes and Msa 100. The former kept calling out "I die to-day, I die to-day," in a sort of prolonged howl. Omaha, the Soudanese officer, announced that the native chief Ungungu had heard from natives up river that Mr. Stanley was returning with a large force. He had had a big fight, in which the natives had used bows and arrows; twenty of the Zanzibaris were killed, and one donkey. Mr. Stanley then defeated the natives. This happened twenty days' journey from here. In consequence of this rumour Major Barttelot has postponed his departure for the Falls until he can find out what truth there is in it. Troup and I went up the river after lunch to see Ungungu, but he did not turn up, and so we returned to the camp. How are the mighty fallen! It is really sad to see the shelter, for it cannot be called a hut, that this chief now lives in, or rather sleeps in, since the Arabs attacked his village and killed a lot of his men. It is built just below the rapids, in the forest at the edge of the water, and consists of a few leaves placed across a couple of horizontal poles. He lives all the daytime in his canoe, the few wives left to him accompanying him. Ward is mending, but still frightfully weak, and Bonny has had a bad bilious attack, with severe rheumatic pains. The men are all busy getting grass and poles for the new houses we are having built for them in the fort.

September 28th.-For some reason or other Selim Mahommed is very anxious to find out why Major 
Barttelot is going to the Falls, and he evidently does not believe what the Major has told him, that it is principally to buy food and for a change.

September 29th.-I have found out a capital plan to make the men work; any of them I catch idle I bring into camp, and make them carry a case of ammunition up and down inside the fort: they prefer to cut grass and poles after this.

September 30th.-Troup and I went up and saw Ungungu, the native chief. $\mathrm{He}$ told us that $\mathrm{Mr}$. Stanley was within four day's' march of the camp.

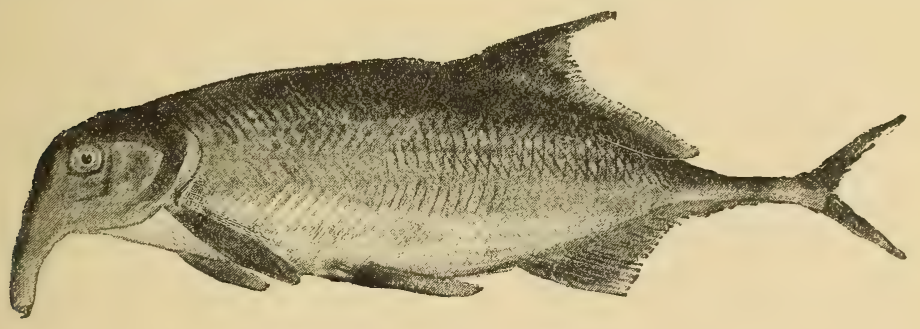

We bought from him a tne fish and a small sucking-fish, of which I have made a sketch. Major Barttelot has postponed his departure for the Falls for five days, in case there is any truth in the rumour of Mr. Stanley's approach.

October 1st.-Usual monotonous day, uninterrupted by one single incident worth mentioning.

October 2nd.-A number of natives passing in canoes shouted out that Mr. Stanley was only two days' journey off. Later on Ungungu came to the fort, and said that twenty Zanzibaris of Mr. Stanley's force were coming down in canoes, and would reach us to-morrow or the day after. Stanley and the rest of the force were at Upi, seven days from here, where he was having very heavy fighting, the natives using bows and arrows. Ungungu showed us a knife which the Zanzibaris had given him for fish, as a proof that he was speaking the truth. 
1887. 'Thank Heaven! we shall know something for certain at

Oct. 2. last. Selim Mahommed sent the Major and myself a very fine goat as a present, and the sheep I had to leave at Sugurru arrived to-day, so that it never rains but it pours. We have been saving the remainder of the fowls for Ward, and have had nothing but rice and beans for the last two or three days. Selim Mahommed's band came into the fort, and gave us a great serenade during dinner. Made a sketch of my house, in which I have passed the dullest four months I have ever spent anywhere.

October 3rd.-Anxiously awaiting the arrival of the men from Mr. Stanley. The Major and I are going up to-night, with twenty Soudanese, to Abdullah's camp, to set the matter at rest, once for all. Ward picking up rapidly; he went over to Troup's house, and sat there several hours.

October 4th.-The Major and I started at 2.30 A.M. for Abdullah's camp, with a guard of twenty Soudanese soldiers. The path is bad, and the jungle so thick that, although the moon was a good one, we did not reach the first village from here, where Mr. Stanley camped, until 6.40, and Abdullah's camp at a quarter to 9. We could find no traces nor obtain any news about the twenty men supposed to be on their way to us from Stanley. The Arabs are making a regular station of this village, and have burnt and razed to the ground all the other villages passed on the road. They told us that the natives are constantly coming to them from below river, saying that Tippu-Tib is coming, and only about a day or two off; and with us they say the same about Stanley coming down from the opposite direction. I am sure they think they will get a little peace and quiet as long as either is expected to make his appearance. There are a good many rapids and islands on the higher stretch of the river, and these and the large patches of tall rushes scattered along the banks make a far prettier scene than the monotonous tameness of the views lower down. We saw tracks of a good 
many hippos, but all remarkably small. Tippu-Tib has a very hard job before him, if he means to put a stop to slavery in his territories. Ivory is really the wealth of the country, and captured native men, and especially women, mean ivory, those of them not ransomed by their friends remaining slaves. In Abdullah's village we saw one gang of women working with ropes round their necks, and all fastened together, who bore on their bodies the unmistakable marks of pretty severe floggings. As the Arabs do not shoot elephants themselves, and hunt nothing but men and women, it is their only means of becoming rich and obtaining ivory. Once put a stop to this trade, and their only reason for remaining in the country ceases. I cannot believe that any effectual change will take place for a very long time, no matter how much Tippu-Tib himself may desire it.

October 5th.-The Major and Troup leave to-morrow for the Falls, and expect to be back about the 1st of November. I fear the spring under my house has not ceased to flow, for it is as damp as ever, and the lovely fresh green of the palms surrounding it shows that their roots are well watered. All the men are now employed in building the new houses inside the fort.

October 6th.-Barttelot and Troup left at 9 o'clock. Sheik Bin Nasoro passed through to-day, with a large retinue, on his way up river. The Arabs seem to be making stations right along the route Mr. Stanley went to the Lake; they will soon have a very large force up there. It looks as if Tippu-Tib were largely increasing his territory, so that, in case of any disagreement with the Congo Free State, he will be more powerful than ever. Selim swears that he has entered into an arrangement with the Free State to settle the Congo right down to Bangala, making stations at all the principal native towns. If he once does this, the State will find him a very nasty customer to dislodge, should they ever wish to do so. This morning one of the men out 
1887. cutting grass returned to camp with his arm and Yambuya. stomach slashed right across with a knife-a quarter of an inch deeper would have finished him. I sent out at once for the man who had stabbed him, who coolly informed me that they had had some dispute about manioc, and that the devil had entered into him, and made him do it. He was evidently the aggressor all through; so I told him I should take measures to drive the devil out of him, and had him placed in chains in the guard-room. I mean to have him flogged before a full parade to-morrow. It is evident that TippuTib can find plenty of men able and willing to go slave and ivory hunting, although he cannot find men for us.

October 7 th.-Justice was administered upon the man who stabbed the other, this morning before a full parade. He will think twice before he lets the devil master him a second time. A donkey-boy brought me in a small rail this evening which is quite new to me; although I have seen some like it in South Africa, yet I know none where the colouring of the neck and breast so abruptly terminates, differing entirely from that of the rest of the body. Ward is now quite well, though weak, but Bonny is seedy to-night with a severe dose of fever, leaving me the only fit white man in camp.

October 8th.-Bonny still very seedy. No more fever, but constant sickness and pains in the head. Ward had a bad night, and is not so well as yesterday. Painted and skinned the small rail, as well as a young one, brought me by the same boy. The Arabs have spoilt our fish-market by trading with the natives in axes and cloth; they will sell nothing but the smallest fish for matakas now, and we have to go a long way from camp to get even those.

October 9th.-Mahommed Dowd, one of the Soudanese officers, died to-day. This makes our twentyfirst death since we have been here-a large number out of so small a force. 
October 10th.-A fearful storm of thunder and rain last night, during which the four native women prisoners made their escape through a hole in the boma. I cannot help thinking the Soudanese had a hand in it, for they could not have passed the sentries without being seen, and they were certainly all awake each time I went my rounds.

October 11th.-Rained nearly all day; the camp is now in a horrible state. The enormous quantities of fresh grass put on the roofs of the houses are now rotten from the continuous wet, and at night there is a most unpleasant smell from them. Last night I went to sit for a bit with Ward, who was in bed; our conversation was disturbed by a noise from under the head of the bed, and a rat ran out into the middle of the floor. Ward said he thought there was a snake after it, and sat up; he had hardly done so, when a large snake glided up beside his pillow. He sprang out of bed, and got on to the top of a box in the middle of the room, whilst I procured a stick. The snake fell on to the ground before I could hit it, and came out from under the bed straight at my legs. A well-directed blow broke its head, however, just as it raised it to strike. It proved to be a long black snake about five feet in length, and a really poisonous one, very much resembling the common black cobra. Its belly was pale yellow, with beautiful tints of opal on it. Immediately afterwards I killed a large bat with immense ears, which came in to see what was going on.

October 12th.-Heavy rain again last night. Caught six rats last night in my house; but it does not seem to have diminished the stock to any degree. Painted some heads of natives from pencil sketches of Ward's. No one, who has not been situated as I am, can tell how thankful one is for even small resources to occupy one's time. Were it not for the occupation which drawing and collecting give me, I feel sure I could not have kept free from illness during the four months I have spent in this camp. Thank goodness, Bonny is 
1887. well enough to take a turn round the sentries at night;

Oct. 12. six nights' running of it is rather wearing !
Yambuya.

October 13th.-This afternoon Selim Mahommed brought me a letter from the Major, which contained serious news. He had reached Yalisula on the 8th, and Tippu-Tib had come to the same place next day, and told the Major that ten Zanzibaris had deserted Stanley and come to him, bringing ivory, and claiming his protection. He is going to send them here. Abdullah did capture them, and Ungungu's story was true, for some of them were in the camp when the Major and I went over there. The letter went on to tell me to put the deserters under a guard of Soudanese on their arrival here, to allow them to hold no communication with any one, and to disarm all the Zanzibaris in camp except the Muniaparas, stacking their rifles in our houses. This I shall do to-morrow. When I had finished reading the letter, Selim Mahommed told me that he had received a letter from Tippu-Tib, telling him that there were still several deserters at Abdullah's camp, and that he was to ask me to send a few men with some of his, with a letter, ordering Abdullah to hand them over, with their rifles and any ivory or loads they might have with them. I at first thought of going myself, but decided not to do so, as the Major left me here, in sole charge of the camp, and should there be any row here about disarming the Zanzibaris, Ward being ill, Bonny would be the only white man left; so to-morrow morning I shall send five Soudanese, under Omaha as their chief officer, with Selim's men. The deserters told Tippu-Tib's people that they left Mr. Stanley because nearly every day they were fighting natives who used poisoned arrows, and there was some kind of fly where they were, whose bites nearly killed them. When they deserted, Mr. Stanley was still forcing his way on to the Lake. I cannot think, however, that the country can be such a very dangerous one to go through, or these ten men could never have got back here. The Major left Yalisula for the Falls on the 
11th. It was a perfectly lovely day, so I was able to take out all Nelson's and Stairs' things and give them a good airing. The deserters have not yet arrived.

October 14 th. - The rainy season really seems to have set in, for not a single night passes without a severe thunderstorm. Sent off Omaha and five of the Soudanese, with three of Tippu-Tib's people, to bring in the prisoners from Abdullah's camp. They did not start until after breakfast, as Selim Mahommed was busy sending off his men, with Ungungu as guide, to attack a large native village some distance down the river. After lunch, we made the men fall in with their ritles and stack them outside our houses, inside which they were placed after being well oiled.

October 15th.-The Soudanese returned with only one prisoner, six rifles, 67 cartridges, one belt, and a bundle of clothes done up in a blanket. The prisoner's story is as follows:-After being with Stanley for a long time (he could not say how long, but it might have been 100 days), his foot got very bad, and he asked Mr. Stanley to allow him to go in the boat with the sick, which Mr. Stanley refused, but took his load from him. He went on for three days, when he again requested to go in the boat, but was not allowed. $\mathrm{He}$ could go no further, and so was left. The natives tried to take away his gun from him, but he frightened them. They then offered to show him the road, but left him on an island alone, where he remained for three days. On the fourth day he noticed a canoe coming down river with eight men in it. He shouted to them, and they took him on with them. They had deserted from Stanley, taking a quantity of clothes and ivory with them. 'The ivory had been taken in a village which Stanley had sent his men to capture. On their way down river, whilst sleeping in a village from which they had frightened the natives by firing off their guns, one of them was stabbed through the leg by a native who had stolen in amongst them. On reaching Abdullah's camp, six of them went off to Tippu-Tib at 
1887. Singatini. This man and the one who had been

Yct. 15. man went with Abdullah to show him a place where he could find any amount of ivory. Of the front column, no men had been killed in fighting, but two had been killed when gathering manioc, and a good many had died on the road. Nelson had been wounded in the side by an arrow, and had gone one day in the boat, but was marching again the next. When he was left, Stanley was still keeping along the river Aruwimi, using his boat for the sick and some loads. They had stolen a quantity of cloth and clothes from Stanley, but had sold most of it to the Arabs. The prisoner said he had really told me the truth, for he was afraid of being punished severely if he told any lies. The bundle that reached me contained 1 blanket, 5 fezes, 2 black cloaks, 2 red cloaks (one gold embroidered), 3 pairs of red pants, 1 striped tablecloth, 1 short white shirt, 1 long ditto, 2 waistcoats, 1 long coarse white shirt, 2 checked sashes, 1 piece of coloured handkerchief, 1 piece of blue cloth, 1 bundle of ties. Selim Mahommed informed me that the other six prisoners are at Yalisula. There he has 28 women captives in his camp, who will all have to be ransomed with ivory or remain slaves. After the reports about the hardships of the road spread by the deserters amongst Tippu-Tib 's men, I fear there is but little chance of our ever being able to get any men as carriers from him.

October 16th.-Nothing occurred to break the deadly monotony of our existence. I am glad to see a much brighter tone amongst the men. They have made a couple of drums, and had a regular dance this afternoon, and a free fight with sticks, in which one man received a crack on the eye, which completely closed it up.

October 17 th.-Had a long conversation with Selim Mahommed to-day, in which he gave me a good deal of interesting information about the people in these 
parts. Upon my inquiry as to why the natives here did not exchange their ivory for guns, he told me that there is no trade whatever between these natives and those lorver down at the mouth of the river. If they attempt to go down river, they are caught and eaten, which fate equally awaits those who come up from below. Upon certain days markets are held, similar to the one described by me at Yalisula, but to these no arms of any kind are allowed to be brought. The same people who sell and buy from one another to-day will eat one another to-morrow. All the natives from Bangala up to the Falls, both on the Congo and on all its tributaries, are cannibals. They certainly are such at the Falls, and further up the Congo to within a few days of Nyangwé. Curious to say, a river marks the boundaries of cannibalism in that direction, as on this side of the river they are cannibals and on the opposite side there are none. I asked him if they preferred black or white people to eat. He at once said, "White." They say that our white colour arises from our being "all fat," and have asked Salem what we eat to make us so "fat." He asked me whether, at Sugurru, I had observed how the natives had stared at me, adding that he had heard them remark, as I strolled amongst them, not "Here is a white man," but "This is fat." They cannot believe that our colour is natural. He assures me that even the bravest of the Arabs, he himself amongst the number, are bad hunters, as they are all afraid of big game. One day he was out after elephants with a Swedish officer from the Falls, and when they came across one the white man fired and struck it in the head, upon which it shook it violently, and Selim ran away! When he returned he found the elephant dead. Tippu-Tib, he tells me, is on the Lumami River with Rachid. He also says the Arabs have taken nearly all the villages on the lower Aruwimi, and that most of the native chiefs have gone to the Lumami to make peace with Tippu-Tib.

October 18th.-Our camp was visited to-day by a 
1887. number of native chiefs and their followers, who had come up from villages lower down the river, to make peace with Selim Mahommed. They have promised to trade with us. Shot a small dotterel, or ringed plover, and sketched it; it appears to be exactly the same as the English one. The other, which I shot and sent home in August, was slightly different in plumage, and without the white ring round the neck. Another Zanzibari died yesterday, making the 23rd death.

October 19th.-Selim Mahommed told me to-day that one of the chiefs who visited him yesterday, who comes from Abdullah's camp, says it is perfectly true that eight men escaped from Stanley and carne down river in canoes, picking up the ninth man on an island. He says they were with Stanley for two months, or moons, before they deserted, and that they were fifteen days in the canoes, paddling all day. If they only paddled ten hours a-day, or rather floated at the rate of two miles an hour, they must have come three hundred miles down river! Salem tells me that they arrived at Abdullah's camp with an enormous number of spears and knives, which they had taken from the natives. Upon approaching a village they fired a few shots into it, when all the natives ran away; they then entered, and took all they could find. This afternoon Msa, Bartholomew, and another thief, who went out in chains under the guard of one sergeant and a private, to gather firewood, all escaped. I sent off all the available men after them, as did Salem Mahommed, and went out myself and scoured the bush in every available direction, but to no purpose.

October 20th.-Torrents of rain all night and no moon, so the escaped prisoners had no chance of getting far away. After breakfast Selim Mahommed sent down their chains, which had been found in the water between his two camps. They have evidently smashed open the rings with a stone. At four o'clock one of the sick men reported having seen all three men in the maniocfields, a few moments before. I then sent off Omaha 
and six of the Soudanese soldiers in the opposite direction, to prevent any of the Zanzibaris in camp from giving warning to the thieves, with orders to turn back from the manioc-fields and return to camp. I ran up and told Selim Mahommed where the prisoners were, and he at once sent off men for them. They were beautifully caught, for they found my Soudanese men outside them, and Selim's men coming at them from the camp. The little old man and Bartholomew were captured, and men are now after Msa. I have placed the sergeant, who allowed the prisoners to escape, under arrest until the Major's return. Sketched a tortoise Omaha brought me.

October 21st.-Sent off a letter to Barttelot, telling him that Msa is still at large. The Zanzibaris are the laziest and most heartless lot of men I have ever come across. I found them to-day taking the wooden headstones out of the graveyard for fire-wood, rather than go a few yards further on to where there was plenty. Selim tells me that Tippu-Tib's men have taken Basoko, getting a good deal of ivory and some guns.

October 22nd.-Sent out the Soudanese after Msa again to-day, but they returned without having seen him.

Sunday, Oct. 23rd.-Shot a beautiful specimen of the chanting falcon this morning, and made a sketch of it. Selim Mahommed has a most excellent plan of trading with the natives. He first of all captures a number of men, and then every day they are sent out to gather two loads of manioc, the one for food, the other to buy fish from the natives. Of course all the manioc really belongs to the natives, but he does not let them take it, so they have to buy it from him with fish, or whatever else they have that he requires. It really amounts to the same as going into a man's shop, turning him out into the street, and then selling him his own goods. Assad Farran tells me that Selim Mahommed has sold to one of the Soudanese sergeants a young slave. 


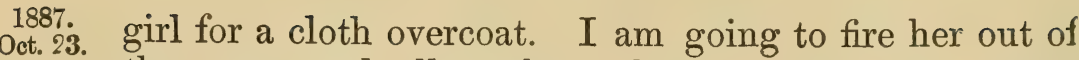
Yambuya, the camp, and allow them then to settle the matte: themselves. The men had their usual half-holiday.

Octoher 24th.-All the men at work repairing the main boma, and getting grass for houses.

October 25th.-The camp is now almost completely finished, and there is little or nothing for the men to do. One of the Soudanese soldiers died yesterday.

October 26th.-Tippu-Tib, according to Selim Mahommed, has been back at the Falls some time. Whole armies of ants attacked some of the houses of the Zanzibaris to-day, rendering them quite uninhabitable, but they left them again this evening.

October 27th.-We had just finished lunch when a Zanzibari, whom I did not recognize, came into the camp, walking frightfully lame, and dragging himself by the aid of a pole; he sat down outside my house. It turned out he was the wounded deserter from $\mathrm{Mr}$. Stanley. He has been badly stabbed through both legs. I have made two examinations of him. He says they were two months and a half with Stanley before they deserted, and twenty days in the canoe coming down river. Only seven deserted according to him, and picked up the eighth man on the island. They escaped by going ahead of the column when on the march, and, purposely taking the wrong road, lay down in the grass to hide. They had seven rifles with them, but lost one. They also brought an enormous number of spears and knives, which they took from the native villages. At one village which Mr. Stanley entered, the natives ran away when the guns were fired, but returned again and attacked them. Nelson shot two, but was hit by an arrow in the chest, and was ill for some time, having to go in the boat, but all were well when they deserted. A long distance from here this river turns to the southeast, where another river, equally large, runs into it from due east. Mr. Stanley had on one occasion told them that it did not matter if they all ran away, he 


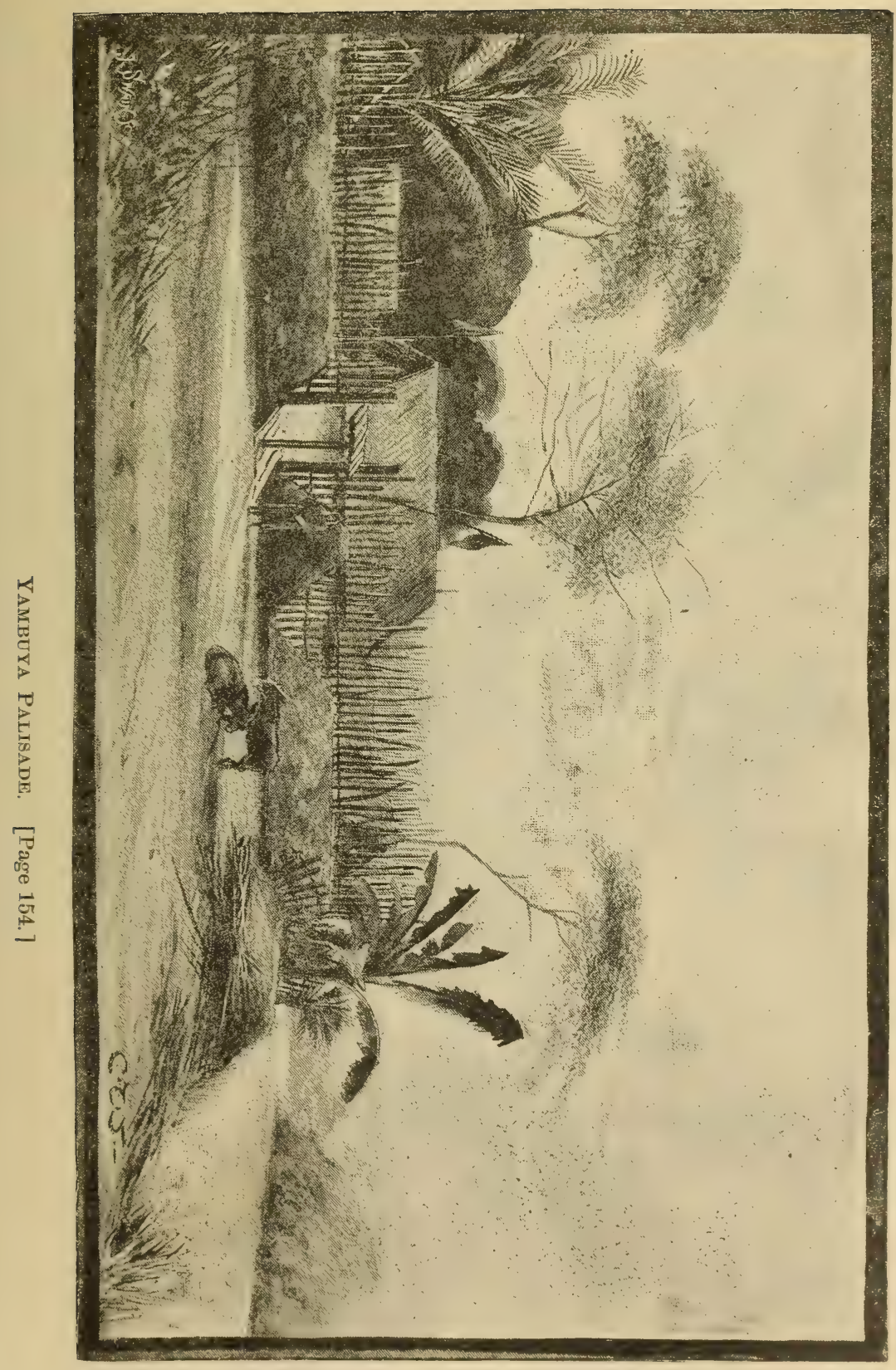



would reach the Lake. The natives brought this deserter in a canoe as far as the rapids yesterday, from which point he dragged himself here. The names of the two deserters now here are Dahoma and Mufta. Selim Mahommed came down to tell me that two of his men had been badly stabbed by natives not far from camp, and he wished to know if we could do anything for them. They met two natives, one of whom sat down with them in quite a friendly manner, but after talking for a bit he suddenly jumped up, pulled out his knife, and stabbed the two Arabs, one in the chest, the other in the stomach. They say that they killed him, but I do not believe it, for their wounds are too bad. Bonny and I went up to see them. The man stabbed in the stomach was very bad, a large portion of the entrails protruding from the wound, and he has not a shadow of chance, for the entrails themselves are badly cut; however, after much difficulty, Bonny succeeded in pushing them back again, and sewed up the wound. The other man had a large wound in the left breast. Were other natives as plucky as the man who assaulted these two Arabs, the slaves would not be so easily captured!

October 28th.- Strange to say, the man who was stabbed in the stomach was much better this morning. I shot a yellow wagtail and two spine-tailed swifts. The wagtail I have been after for some time, and the swifts were really sporting shots, flying very fast at a great height. One of the Soudanese was bitten by a snake; the bite is a nasty one on the ankle, with the marks of the fangs very wide apart. We put a tourniquet on above the wound, cut it open, and burned it with a red-hot ramrod. We had no ammonia. The leg was very little swollen, but the man complained of pains in the stomach and left side, especially over the heart. As far as I could see, he was suffering more from fright than anything else. The snake was described as a small, thin, red one; the marks of the fangs were about an inch and a half apart. I have never in my life spent such an 
1887. utterly useless four months, and I hope I may never Yambuya. have to do so again.

October 29th.-The man who was stabbed in the stomach is to-day walking about, fetching wood and water. I have heard of miracles before, but never seen one until now! I found my boy Mufta, whom I was really beginning to trust, had been stealing my salt, so I had to recur to the only method to make a nigger honest, and gave him fifty well-applied strokes. It is only through fear that one can make them speak the truth.

October 30th.-Another axe is missing to-day, and a spade, so I stopped all the men's payment until they are produced. At 3.30 this afternoon Barttelot came into camp, all by himself, having come ahead of his men. Troup he had left at Yalisula, with Salem Masudi the interpreter, to come on with the goats and fowls. They had 16 goats and 52 fowls when the Major left. There is no hope of getting men from Kassongo, as Sefo has some war going on there. The Major says Tippu-Tib was greatly pleased with the rifle I gave him, and had sent me a present of two goats. They seem to have had a very pleasant time at the Falls, and enjoyed their trip very much. The five deserters from Stanley are coming on here with Troup. They give the most contradictory reports about Stanley, and about the amount of food they found on the road. Tippu-Tib does not seem to be playing a straight game, and the Major thinks that he is probably hanging back on the chance of Stanley having eventually to place the whole thing in his hands for so much powder and a lump sum.

October 31st.-Four of our men went up to the village where Selim Mahommed's Arabs had been stabbed in search of plantains, when the natives seized one of them, and were going to kill and eat him, as they thought he belonged to the Arabs. They have been driven out of their village on the mainland and are now living on an island. As soon as our man succeeded in 
making them understand that he was one of Mr. Stanley's men, and not Tippu-Tib's, they let him go. It is a good point in favour of the natives, that they will not willingly molest any of our men. The Major to-day released the two deserters from Stanley, and the thief, but Bartholomew is still in chains. One of the Soudanese was reported dead, and a burying party was told off, when he suddenly came to life again, and is still alive. Selim Mahommed sent to the natives on the island, who stabbed his two men, to tell them that he will spare them if they will send him two large tusks of ivory, but if not he will annihilate them.

November 1st.-Ungungu, the native chief, paid Selim Mahommed in ivory to-day for some of his captured

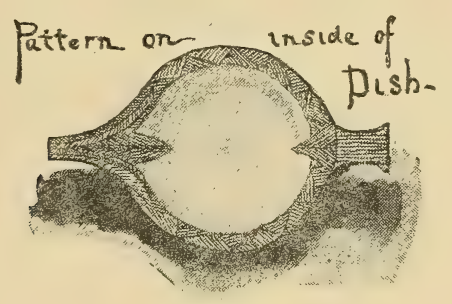

women. When Selim Mahommed first came here, he talked a great deal about making our camp into a permanent station after we leave it, as they wished to settle all the natives and live amongst them. However, the other day he showed his true colours, when, in reply to some remarks of the Major's about what a good camp it would be for them, and a sudden inquiry as to whether he really was going to occupy it, he exclaimed, "Oh, no ! there is very little ivory about here!" Directly they find ivory scarce amongst the natives, and that they cannot ransom their captured women, the Arabs at once move on to pastures new.

November 2nd.-This morning Major B. had a long interview with the deserter who is stabbed through the legs. He told us that a very long way from here they had 
1887. come to a native village in which some of Tippu-Tib's

Ysmbuya. Arabs are living. They made friends all round, and Stanley bought fowls and goats. Next morning, when they started, he found that fifty men had deserted, and not a trace of the Arabs was to be found. He also said that a great many men had died on the road, and a great many loads had been lost through the upsetting

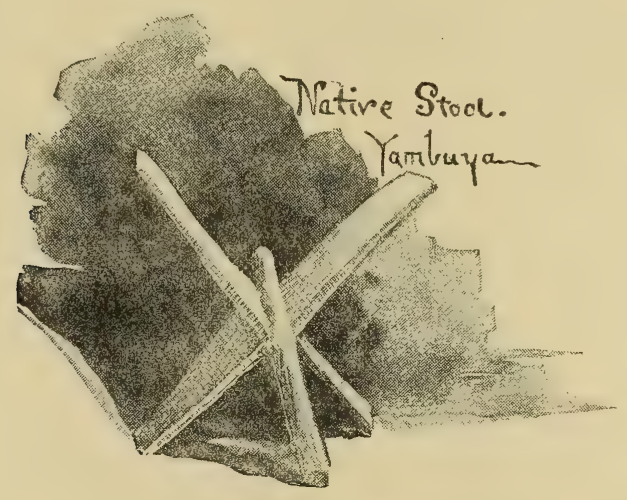

of the boat in the rapids, which naa occurred several times. All the donkeys were dead except two. Mr. Stanley would not allow the men to loot the native gardens and villages, and therefore they were very short of food. Salem, the interpreter, arrived shortly after lunch, and Major B.'s luggage some time afterwards; the men carrying it said that Troup was some distance behind, but would be in to-day. However, he did not make his appearance by daylight. We had just finished our pipes after dinner, when we heard five shots fired in rapid succession, either from a revolver or a Winchester, not far from camp. Then came several dropping shots, which we answered. I started off with Omaha, thinking that Troup was either in trouble with the natives or lost in the bush, and found him about half an hour from camp, stuck in a cane-swamp (having lost his way), with fifteen goats and about forty fowls in baskets. The air was blue all about the swamp with the bad language that had been used in many tongues. Great 
were the curses hurled against Salem, the interpreter, for leaving them without a proper guide; however, we Yambuya. got them all into the path, and safe into camp.

November 3rd.-Barttelot told Selim Mahommed today that it would be much better if Salem, the interpreter, did not come inside our camp at all, in consequence of the many unpleasantnesses that have occurred since leaving here for the Falls. Selim Mahommed told us that Tippu-Tib had written to him, telling him that as soon as Sheik Mahommed Ali arrived here, he was to leave for the Falls, in order to go up to Kassongo, and bring down the six hundred carriers Tippu-Tib is trying to get from there. He afterwards brought down the boy Farani, whom Tippu has sent me as a present to keep as long as I like, either to take to England or to send to Zanzibar, whichever I chose. It appears that the Major and Troup have been fearfully taken in about the payment for the goats. They paid three pieces of handkerchief for each, quite double their value, all being small, and a number of them kids.

November 4th.-Msa turned up in the charge of some of Tippu-Tib's Arabs. Ali Mahommed, Tippu-Tib's chief sheik at the Falls, arrived, also the chief of Yambau. Selim Mahommed is going away the day after to-morrow, and all his men cross to the other side of the river, so we shall be left alone again. Ali Mahommed brought the Major a young antelope, which I think must be a bush buck. It is alive, but too young to live without milk, so I am going to kill it and preserve the skin. Salem Masudi, the interpreter, left for the Falls to-day, evidently in high dudgeon. Both the Major and Troup had to use very plain language to him on their trip to the Falls. He is one of those men who, sooner than remain silent, lie, simply to make conversation. Captured a lovely goliath beetle this morning, the first I have seen here, and another rare beetle figured in Herr Pogge's work.

November 5th.-The Major left it to Troup, Bonny, 
1887. Ward, and myself to try, and pass sentence on, Msa and Nov. 5. Bartholomew. I proposed working them hard every day in chains, as I am sick of flogging, but the other three proposed 150 lashes each, and as they are in the majority, that sentence will be administered to-morrow morning. Selim Mahommed leaves to-morrow for the Falls, and is to start immediately from thence to Kassongo to collect carriers for us. We had sat down to dinner, when Bonny noticed a light in the other store, and upon going over, discovered his boy and Troup's filling a large basket with manioc flour out of one of our bags. They were placed in the guard-room for the night, and there will be more flogging to-morrow.

November 6th.-Major Barttelot postponed the prisoners' punishment till to-morrow morning, but the two boys received thirty lashes each.

November 7th.-Msa took his 150 lashes, Bartholomew only 75 , as he is still tender from his last flogging. Shot a beautiful paradise flycatcher, and a small barbet with lovely turquoise wattles round its eyes. Troup and the Major very seedy.

November 8 th. - There is the beginning of what might be a very serious disagreement between the Arabs and ourselves. They are beginning to prevent the natives trading with us. Both yesterday and to-day, when Omaha was sent to buy honey and fish, the Arabs interfered and prevented the natives selling him anything. The Major spoke to the Arab left in charge of Selim Mahommed's men, and told him that if it occurred again he should send at once to Tippu-Tib, and make a formal complaint.

November 9 th.-Omaha crossed to the native village, accompanied by the Arab left in charge by Selim Mahommed, but returned with only a small pot of palm-oil. It now appears that a few days ago he had some dispute with the natives in a canoe, and threw stones at them, and now they will sell him nothing. The natives say if we send another man, not Omaha, 
they will sell to him. This, it seems, is the real reason why he got nothing yesterday.

Glorious news, if it only turns out to be true! A white man (or men) is coming down the river with a large party, some in canoes, some on land, and they will be here in three days' time. This must be Stanley or messengers from him. Thank God, there are now hopes of doing something at last. The day I hear we have to go up to the Lake, I shall certainly do a dance round my old helmet and jump upon it! The Major has a bad touch of fever.

November 10 th. - Natives still tell the same tale about the white man and many followers coming down the river. We are all in great spirits at the prospect of making a move at last! Had the fence round our graveyard repaired to-day, and new headstones, or rather sticks, placed to all the graves, which now number twenty-five.

November 11th.-To-day all our hopes were scattered to the winds. The chief Arab informed us that the news of Stanley's approach is false. A large party of Arabs, the chief of whom is almost white, passed through here some time ago, and went up the river on an ivory and slave-hunting expedition, and it is their return to which the natives refer. Sketched a couple of barbets. The Major is better. A Zanzibari died to-day, making the 26 th mound in our graveyard.

November 12th.-Shot a small squirrel, of which I made a sketch life-size. Began building a large new house to-day, half of it for a mess-room, the other half as the Major's dwelling-house.

November 13th.-Had to lie up all day. Full of rheumatism.

$\left.\begin{array}{c}\begin{array}{l}\text { November } 14 t h \\ \text { to } \\ \text { November } 30 t h .\end{array}\end{array}\right\}$ Laid up with jaundice. 
1887.

Dec. 1.

Yambuya.

December 1st.-Yesterday for the first time I was able to take a short walk up and down the road, and join the others at meals. The Arabs left behind by Selim Mahommed have been giving a great deal of trouble for some time, by preventing the natives from selling us food. They tried to make us buy things through themselves, of course at treble value. At last Major Barttelot determined to send a letter to Tippu-Tib, and ask him to set matters straight. Ward accordingly started on the 19th November, and got back here yesterday evening. Tippu-Tib had started for Kassongo five days before his arrival at the Falls. The Arabs assured Ward he had gone to collect men for Mr. Stanley. Selim Mahommed said he would return here himself in a few days. After all Ward need never have left, as a few days after his departure for the Falls all the Arabs went down river to "make war," as they call it, with some village near Basoko. Troup has been very ill; at one time it was quite serious, but yesterday, thank goodness, he began to mend. Ward brought about forty eggs with him from the Falls, so he ought to pull himself together with them. Last night the men killed a poisonous snake, which I have made sketches of. It measured $5 \mathrm{ft} .9$ in. Whilst writing this I heard a great uproar, and on going out found they had killed another snake, similar to the one I killed in Ward's house. There is one in my house, and I hear him chasing the rats all round the place at night, but have not yet seen him. No news of Mr. Stanley.

December 2nd.-A whole half and a separate leg of a goat were stolen from Ward's house last night. Some of the picked bones were discovered in the camp close to the Soudanese quarters. This is the most daring robbery they have yet attempted.

December 3rd.-The greater part of the meat was discovered in the thatch of the hut of Burgari Mahommed, the suspected Soudanese sentry. He was at once put under arrest, when he accused Mulédi, the Major's boy, of having actually stolen it, a most improbable 
tale. Last night the snakes made a regular attack on the camp, and I heard this morning of five having been killed. The natives on the other side of the river had quite a gala afternoon, canoe-racing, manœuvering, dancing, singing, and tomtoming to any extent. One of my men died to-day. Several of the men in camp are only walking skeletons, and the marvel is how they

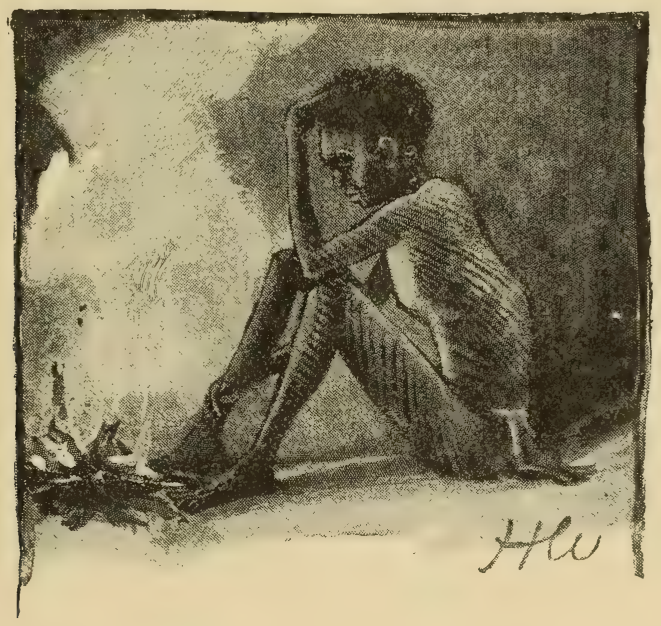

exist or move at all. One man, who walks with rather an active upright motion, is a horrible sight, having nothing but loose folds of skin over his bones.

December 4th.-Burgari Mahommed was flogged today, before all the men. The Soudanese are wonderfully plucky in bearing pain, for although he received 150 strokes, which cut him up very much, he never uttered a sound. One of the Zanzibaris from Bolobo died, making thirty deaths. Had my first good night's sleep for a long time, and woke up quite a new man.

December 5th.-I was perfectly right in thinking that Barttelot's boy, Mulédi, had not stolen the meat, for to-day Burgari Mahommed confessed that he had lied, and that the boy had not taken it.

1887.

Dec. 3.

Yambuya 
1887.

Dec. 6

December 6th.-Every day that passes without news of Stanley makes me think that he has persuaded Emin Bey to come out with him by this route, and then across to Zanzibar by Tippu-Tib's route. It is perfectly sickening to think of it all. Here am I within nine days of having been six months in this camp! Had I ever dreamt of such a thing, I would certainly never have joined the Expedition. There is not a new variety of bird, beast, fish, or insect to give a moment's excitement to the naturalist's side of my nature; and the deadly monotony of an existence, for it cannot be called living, may be imagined, in which the only incident to be noted is the occasional flogging of a man.

December 7th.-A Soudanese soldier died to-day, the 31st death in this camp. When one of them gets really sick here, his comrades will not do one single thing to help him, unless positively ordered to do so; and yet these are the very men who, on the march, from Matadi to the Pool, swore that they would rather remain behind than desert a sick comrade, and if a man fell out, two or three more fell out with him at once, according to their oath, making Major Barttelot mad with the constant delays. Dinner to-night consisted of plain boiled rice and fried plantains, ditto for breakfast.

December 8th.-Heavy rain. Spent great part of the day in drawing Christmas cards to give to the other

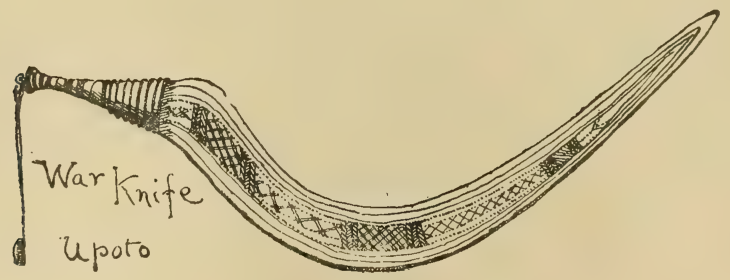

officers on Christmas Day. To-night, thanks to Ward who is mess-president, we had the best dinner I have eaten since we left the coast. Since he has taken over 
the mess, there is great improvement in the cooking in every way.

1887.

Dec. 8.

Yambuyan

December 9th.-Two more deaths. Shot two very handsome plovers, chocolate-coloured breasts, and bright lemon-coloured wattles over the eyes. The Major told me that he had heard to-day that Tippu-Tib sent messengers after Stanley, who had followed his route nearly to the Lake, as far as he could gather, but that they could hear nothing of him. He seems to think this bad news, but I consider it good, for it proves that Stanley must have got on at a good pace; had he heen stopped anywhere, they would have heard of it.

December 10th.-Another Zanzibari from Bolobo died. Ward has been sketching some of our living skeletons. A great many of them have a most horrible disease. They break out all over in pimples, which gradually grow together and form great sores. Others have their legs covered with large ulcers, and out of all the men in camp there are not more than 130 who could carry loads.

December 11th.-Some of Selim Mahommed's men have arrived, with orders to build him a house, so he really is coming. It is a great nuisance, as we get on so much better without him and his men. The first birth we have had in camp took place to-day. One of the goats had a kid, and both mother and child are doing well.

December 12th.-Another of the Zanzibaris from Bolobo died to-day. In the morning Bonny had told one of his men to cook some food for the sick in his company, and also told him to bring the food, so that he might see it given to the sick. When the man brought it, he went up to the huts where the sick are, and, after seeing some of them, he turned to one of the huts and said, "Who is in here?", at the same time pushing the door open, and was astonished to find a man inside dead and quite cold. When asked, they said it was not long since they had attended to him; 
1887. but I expect the truth is they had not seen him since Dec. 12. yesterday. Unless made to do it, they would not move Yambuya. a hand to help a sick man, but just leave him to die, even if he were their own brother.

December 13th.-As Troup was ill on his birthday, we had the great dinner to-day which we intended to have had on that festival, as Barttelot said the 13th of this month is a great day with him. Dined off soup, roast shoulder of goat, and a rolly-poly pudding. Troup supplied a pot of jam, and the Major and I gave the flour, which constituted the whole of one of our tins, or one man's allowance for six months. No news whatever of Stanley. If he is bringing out Emin Bey and his ivory, that would certainly delay him a good deal.

December 14th.-Spent part of the day in making a sketch from one of Ward's drawings of a Soudanese soldier. Both in the morning and evening I took a stroll with my gun, but did not get a shot or see a bird to shoot at, that I have not already got. Not a single thing of interest to make a note of. The monotony of this camp life, without one atom of sport or excitement of any kind to relieve it, is becoming perfectly sickening.

December 15th.-I find the average temperature here to be from $72^{\circ}$ to $85^{\circ}$ in the shade, up to $110^{\circ}$ in the sun; very seldom lower than $72^{\circ}$ or higher than $85^{\circ}$ in the shade. Lowest temperature at night $69^{\circ}$. Barttelot brought me a lovely beetle to-day, a longicorn. It is quite new to me, and I believe I put the female into spirits this morning without taking much note of it. This day six months ago we arrived at Yambuya!

December 16th.-The natives across the river killed an elephant yesterday; they have done nothing but feast ever since. Killed a tortoise to-day; it has a beautiful shell, which I shall take home. Made a sketch of his head, which looks like that of some antediluvian monster. 
December 17th.-Troup, the Major, and I all dreamt of Stanley's return the night before last. Troup dreamt that he came back by himself, without any of the other white officers, and when asked where they were he quite calmly remarked that he did not know, and evidently did not care, merely saying that they had each chosen their own road, and he knew nothing about them. The Major dreamt that he arrived at camp looking jolly and well; that William, his servant, came inside our boma, when the Major at once ordered him out, and proceeded himself to Mr. Stanley's tent, and found him with a lawyer, upon which he at once remarked, "Oh, you are for the Crown, I won't say anything;" and the dream ended. I dreamt that we saw a number of canoes coming down the river in a long line, and in one of them a large white umbrella, and I at once saw that it was Mr. Stanley, at which moment I awoke.

December 18th.-Shot the handsomest sunbirds I have yet seen, much resembling some I got in the Mashona country.

December 19th.-Two deaths in camp to-day. Cut open the throat of a goat which was dying. It appeared healthy, with the exception of the lungs, where there was a black spot, which when opened proved to be a regular cell; inside this again was an egg-shaped semi-transparent body, with a white worm inside, and two black marks on it, caused by some body of that colour, inside, near the outer shell. There were no signs of inflammation about the black spots on the lungs, and the cells were completely buried in the lung itself. The two sunbirds I shot yesterday were evidently breeding, for the hen had fully developed eggs inside her, and yet the cock was quite a young bird in immature plumage, which makes me think that they must rear more than one brood in the year. I notice the chanting falcon is still going about single, and has not paired again since I shot its mate about two months ago. I tried to kill a splendid

1887. Dec. 17. Yambaya 


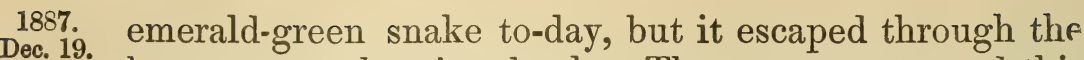
Yambuya. boma on to the river-bank. The men commenced this afternoon to put up the frames of the house for Stanley's men when they come back.

December 20th.-Succeeded in getting three beetles to-day, quite new to me, one of them a very beautifully marked longicorn. Our days are divided by breakfast, lunch, and dinner, which, in their turn, are regulated by the sun, as there is only one watch that goes -Troup's - and that only goes by fits and starts. It is very like life at sea, the same deadly monotony, only broken by intervals of eating.

December 21st.- Shot a beautiful golden cuckoo, larger than any I have seen before, a large blue and white kinghunter, and found two longicorns quite new to me. The men are cutting poles for the new houses, and the beetles are all to be found on the piles of freshly cut poles. According to Selim Mahommed's orders, the Arabs this morning captured Ungungu, the native chief, and put him in chains as hostage, until his people begin to build their village on this side, and commence a regular market, which they promised to do long ago. The natives, to retaliate, seized one of our men, who was gathering manioc, thinking he was an Arab. Daodi, hearing him scream, ran to his assistance; but the natives seized him then, letting the first man go, as they recognized him to be one of ours; but Daodi they said was an Arab, and took him across to the other side of the river. We at once sent for the chief of the Arabs, and told him to take Ungungu down to the side of the river, and make him shout across to his people to let Daodi go. This they did, and he was at once brought back across the river and released. The natives will not willingly interfere with any of our men; but they distinguish them with difficulty from the Arabs, whom they hate, and justly.

December 22nd.- Shot a pair of swallows I have been after a long, long time. I have never seen more than 
the pair here, and they arrived about a month after we came; they are a much brighter blue than any swallows I have ever seen before.

December $23 r d$.-One of my men brought me a very curious mole. Its fur is a beautiful light grey, which, in the sun, has many opal tints. The hair is stiff, and shines exactly like unplucked otter or beaver. We are making preparations for our Christmas dinner. Barttelot and I are contributing a tin of flour (our last) and a tin of jam; Ward gives a tin of flour, and Troup a ham, a bottle of prunes, a tin of marmalade, a bottle of pickles, and some English mustard, a thing I have not tasted since we left the steamer.

December 24th.-Our Christmas goat was killed at daybreak, and he is the largest and finest I have ever seen, and just as good to eat as he looks. Ward and I both made sketches of his head. We gave the men a half-holiday, and shall give them a whole one to-morrow.

December 25th.-Christmas Day has come and gone, and I must say it was a much pleasanter one than I ever anticipated. Great were our efforts in the cooking line, and singing after dinner, and I noticed that songs of a more sober nature than usual, and those which reminded one of home, were by far the most popular. Troup gave us a beautiful ham, which, with cold mutton in the morning, made a capital breakfast. For lunch we had a meat pudding, consisting of five eggs, parrots (species unknown, but good), two small doves, and a chicken (same size), ham finely chopped up, suet and mutton (Christmas name for goat), onions, pickles, and a little Worcester sauce; the whole enveloped in a blanket of dough and boiled. This pudding was certainly one of the best I have ever eaten anywhere. We all took violent walking exercise when the sun sank low enough to admit of it. Our dinner consisted of soup, mutton steaks done on the gridiron, a roast leg of mutton which no one tried to eat. reserving themselves 
1887. for the pudding, which was a superb rolly-poly made Yambuys. with raspberry jam. The whole dinner was an immense success, and we gave a hearty vote of thanks to Ward, who superintended everything, and made both puddings himself. There were still about two glasses of brandy left in the two bottles Mr. Stanley left the Major and me when he went away, so there was just enough to give each of us a taste after dinner, and I don't think a drink was ever more appreciated. We tried to make the day a happy one for the men too, giving them a whole holiday and a present of two matakas and twelve cowries to each man, and three matakas and eighteen cowries to all the muniaparas; to Assad Farran we gave a lot of meat and a cupful of salt, and I gave him and each of the Soudanese officers a piece of tobacco. My Christmas cards to the other officers were a great success, and Ward gave me a bar of soap, which is simply invaluable. My only pipe was just burnt through, and what was my delight when Troup made me a present of a new one! We all regretted $\mathrm{Mr}$. Stanley's party not being with us, and many were our speculations as to how and where they were spending their Christmas.

December 26th.-Feasting again to-day, but after that we shall have to go down to our old rations of rice and plantains, with an occasional bit of fish. There are only four boxes of biscuits left to do until we get to Zanzibar, so we have determined not to touch them until Mr. Stanley's return. Those four boxes represent the whole of our bread-stuff for the rest of the Expedition, and yet there were over twenty boxes left lying at Leopoldville. Gave the men another holiday to-day. The chief of Selim Mahommed's men here informed me that the natives had refused to come over and build a village, or start a market. I wish they would leave the natives alone, as we get on perfectly well without any Arab interference.

December 27th.-Shot a beautiful sparrow or finch which I have never seen anywhere except here. Head, 
neck, breast, and some way down the back and sides are bright, dark, crimson; all the rest of the bird is a beautiful velvety-black. I have seen several of them here, and shot two, but lost them in the long grass. It has suddenly dawned upon me since that it is a cardinal grosbeak, only a young bird. Hard at work all day writing out my bird-notes.

December 28th.-This morning, about two or three o'clock, I was wakened out of a sound sleep by a great yelling amongst the Arabs outside the camp. On going out I heard loud singing proceeding from a large canoe which was going down the river, on the opposite side, and it was at this canoe that the yells of the Arabs were evidently directed. After a time a gun was fired below our camp, and then all was still. This morning we heard the following story:-Yesterday the Arabs captured a large canoe from a village down river, and took it up to a small camp they have formed just above us. This morning at about three o'clock, when the moon was shining brightly, some natives came up from the village in a canoe and surprised the Arabs who were asleep in the captured canoe, and who were supposed to be guarding it. According to one version of the tale, there were five men in the canoe, of whom three escaped without wounds, one escaped badly stabbed, and the fifth was killed or taken captive by the natives. The other account said there were three men in the canoe, of whom one was taken prisoner, the second stabbed, and the third killed. Both stories agree on one point, that the natives captured four guns. The Arab chief came and asked if we could do anything for the wounded man, so Bonny went up after breakfast, and found him lying with a very severe cut in the stomach, through which about four yards of the intestines were protruding. He had received two other bad stabs on the left side. Bonny succeeded in sewing up the cuts, but as the man was bleeding internally $\mathbf{I}$ don't think there is a chance of his living. How he ever succeeded in escaping by swimming after receiving 
1887. such wounds, and still to be alive, is a perfect marvel Pec. 28. to me, but I can believe anything respecting the recovery of these men, after seeing the recovery of the last man that Bonny sewed up. Khamis, Jephson's boy, who was left behind sick, when Stanley went away, died to-day. He has been nothing but a living skeleton for the last four months, and it is a wonder that he has lived so long. This makes the thirty-ninth death in camp.

December 29th.-Another of the little boys, Abadi, died to-day. He and Khamis lived in a house we had built specially for them, and they have both been ill ever since last June. Curiously enough, I said to the Major last night, "You will see that Abadi will die almost immediately, for I have always noticed that where there are two people together, who have both been ill for a long time, when one dies the other is almost sure to follow." I hear that the natives from down river have captured four more Arabs, and the chief came to-day to know if we would help them to attack the natives, but if they choose to slave-hunt, I do not see that we have anything to do with it. The man that Bonny sewed up yesterday died to-day; the marvel is that he lived so long In the evening I took a walk through the manioc plantations, and succeeded in obtaining one of the large swifts which I may say I have been after for months. I have fired at them several times, but they fly at such a height that I have to use very large shot, and this, combined with their very swift flight, makes it difficult to shoot them.

December 30th.-This morning we heard three shots fired in quick succession, just above the camp, and saw a canoe rapidly paddling across to the other side with a few natives in it. When half-way across a number of canoes came to meet them from the opposite bank, and we saw a man lifted out of the first canoe and placed in one of the others, when they all returned to the village. Presently some of the Arabs from up river arrived and told us what had happened. It seems 
that the Arabs asked some natives in a canoe if they knew anything about the four missing men. They replied, in a jeering tone, " $\mathrm{Oh}$, we have made soup of 1887.

Dec. 30 . them," upon which the Arabs at once fired into the canoe, killing one man and wounding another. The Arabs then all went to the village down river. The Major started off after lunch with two of the Soudanese to see what had happened, but he had not gone far before he met the Arabs returning with one native prisoner. They said they had found the village deserted, but had captured this man, who told them that Ungungu (after having been released by the Arabs) had gone down there and captured three of their men, and wounded the fourth. The Major told the Arabs that if they would leave Ungungu alone, he would try and get him over here, and recover the men, if they were not already eaten. This morning a dead body was discovered in the river close in to the bank of our camp; it was that of one of Tippu-Tib's men who was with Sheik Abdullah a long way up this river. He was tied to a stick and was horribly wounded.

December 31st.-1887 passes away to-night, and here we are still in Yambuya Camp. The last six months have been the most miserable and useless I have ever spent anywhere, and goodness knows when it is going to end. Barttelot means to go to Stanley Falls at the end of the second week in January (if he hears that Tippu-Tib has returned from Kassongo), and ask him finally if he has got all the men for us, and if not, how many he can let us have. If he can give us a hundred men, the Major will then start with them and the fittest men in camp, leaving two white officers in charge here, and go on Stanley's route to find out what he is doing; so that, whether Mr. Stanley returns or not, there is a chance of our making some kind of move at last. Had it not been for odd little bits of collecting and drawing, which filled up a lot of my time, I think I certainly should have become an idiot here. None of us can summon up interest enough to sit up and see the old 
1887. year out, and the new year in, and I must say there Yambuya is very little inducement to do so. We had a great number of ripe plantains, so we determined to make some plantain beer or malafu. The only vessel large enough for the purpose was my bath, which is a large zinc-lined biscuit-box, so we made it in that, but no one has had the courage to drink it yet. This finishes this book, and my diary for the old year, 1887.

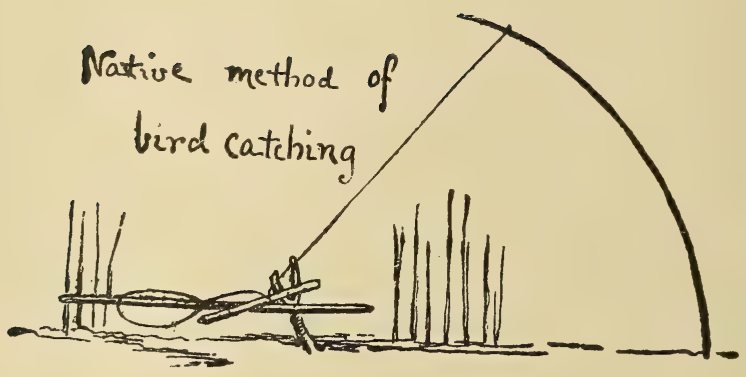




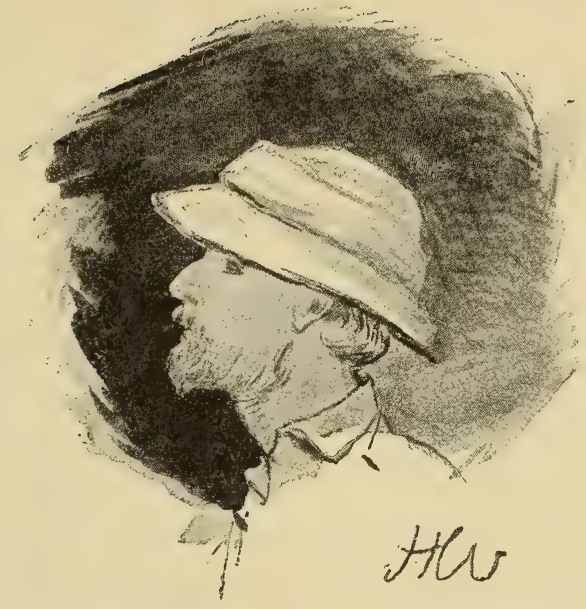

Mr. JAMESON, DRAWN BY H. WARD。

\section{CHAPTER VI.}

\section{8.-January 1st to February 13th.}

New Year's Day.-Natives return with captured Arab.-Barttelot and Jameson have palaver with natives.-Natives consult the oracles and inspect white men.-More reports from Stanley's deserters.-Assad Farran sees a whale.-Visit from Arab Venuses.-Sobarus Poggei beetle. - Dead bodies floating down river.-Wretched state of Zanzibaris in camp.-One fifth of entire force lost.-Goliath beetle.-Conversation with Selim Mahommed.-Probable dangers to Mr. Stanley's force from death and desertion.-Arabs attack natives.-Arabs fight among themselves.-Natives steal canoes from Arabs.-Anniversary of Jameson's wedding.-More raids on the natives.-Burgari Mahommed at large.Natives eat captured Arabs.-Burgari captured, and shot.

January 1st, 1888, Sunday.-We have begun the New Year with one of the finest days I think I have ever seen. We made a mild attempt at feasting, having meat at

1888 .

Jan. 1. Yambuva every meal, prunes at luncheon, and a rolly-poly at dinner. Troup presented the mess with a tin of flour, one of jam, and one of prunes. I am sorry to say the rolly-poly was not quite such a success as the last, for 
1888. the flour was a trifle musty, but I noticed that we ate Jan. 1. quite as much of it, none the less. I had just sat down to skin some birds this morning, when the natives arrived opposite to the camp in a canoe, with one of Tippu-Tib's captured people in it. They said that if one of us white men would come over to their village, and hold a palaver with them, they would hand over the three men and the guns to us. Major Barttelot then sent for the Arab head-man and told him that, if he would allow the natives to fish in jeace, and promise not to molest them in any way, he would get the men back. He agreed to this. The natives then asked for a white man to go to a landing-place higher up the river, without any of the Arabs, as they wanted to speak to us. Major Barttelot and I went up the river, and after waiting some time, a canoe arrived with some natives in it, and one of the captives with his arms bound. At first they were in a great fright about coming near the shore, but eventually did so, and told us that all their chiefs were up the river, but that if we would come to the same place to-morrow morning early, they would bring a large canoe to take us over to the other side, as the chiefs would then have arrived. We told them we would be there, and left, after buying some fish from them. I am sure that although we may obtain for the natives a short time of peace, the Arabs will have a terrible day of reckoning with them when we leave.

January 2nd.-Spent a most interesting forenoon. The Major and I started after breakfast up the river to wait for the canoe to take us across to the native village for the big palaver about their Arab prisoners. After waiting quite half-an-hour, two natives came across in an old canoe with one end broken, and in a shocking condition, so we told them they must get another. 'This one arrived in an equally broken-down state; the nose being smashed off, the smallest waves came in, and a hole was in the side, over which one native had to hold his hand in order to prevent the canoe from 


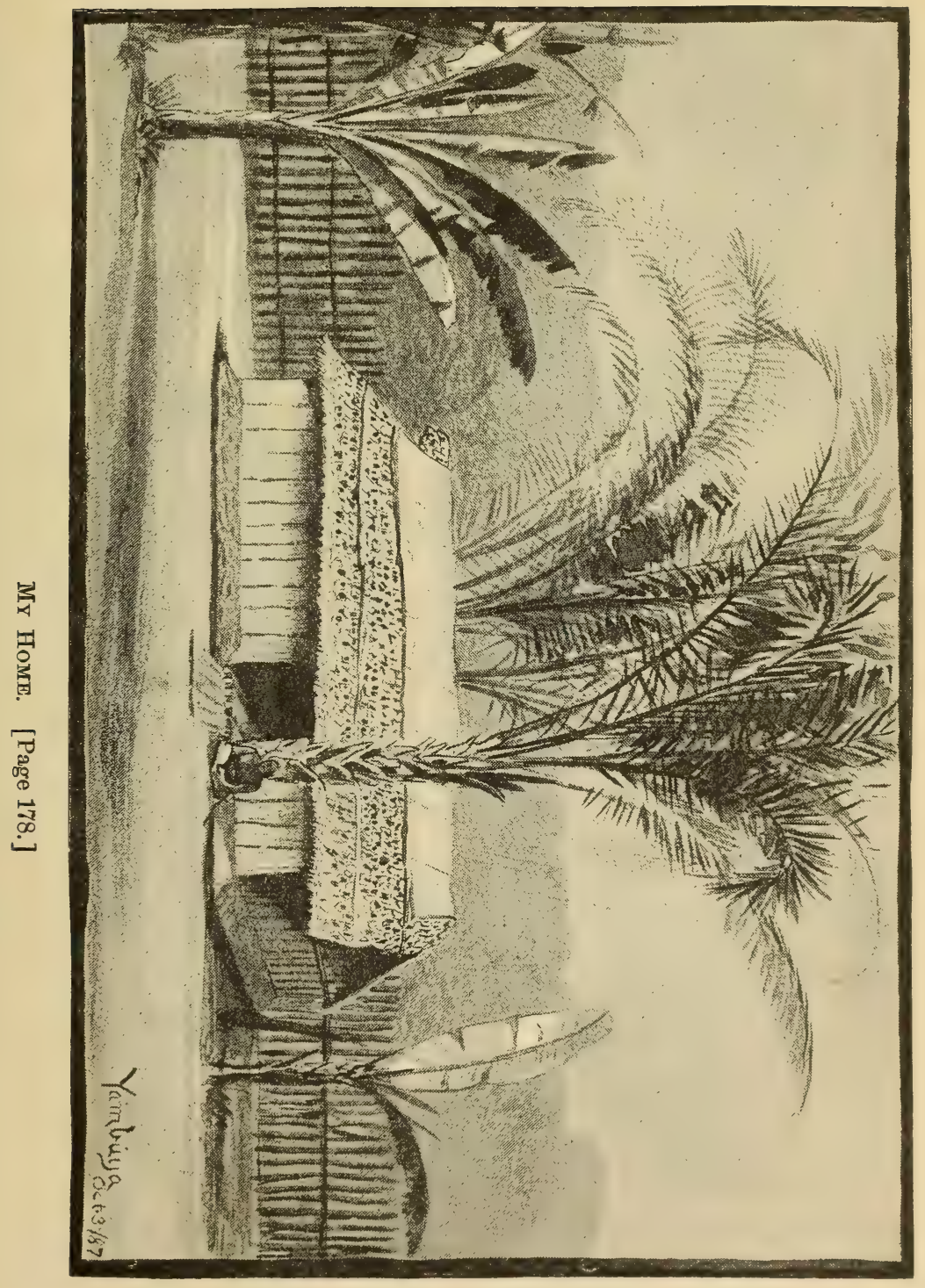



filling. Into this one we got, and crossed over. We tound a small piece of ground, under some trees, swept clean, and they brought us stools to sit on. Presently a great crowd collected, men, women, and children. The men nearly all had their knives, and a good many, spears. After waiting some time amidst a perfect babel of voices, a chief arrived with his face all blackened; the two prisoners (one of the three having escaped, or been eaten) being also present. He opened the ball with a long speech about friendliness to the white men, or "Tuku-Tukus" as they call us. This name is animitation of the puffing of the steamer in which we arrived. When he had finished, and silence was again restored, Major Barttelot told them that, if they gave up the two remaining prisoners and the three guns to us, he would guarantee that they would be left in peace as long as he remained here. This having been translated to them, there was more noise, and the chief finally retired to consult the oracles. After some time a man, evidently of authority, arrived with two sticks, one with what looked exactly like a bunch of small carrots tied on to the end, the other a short thick one tied up in dried palm leaves, having one end bare. These he solemnly placed on the ground, and informed us that any man, white, black, native, or Arab, who looked upon them, and had witchcraft in him, would die. They did not like the presence of my boy Farani, whom Tippu-Tib gave me, recognizing him as an Arab at once, so they gave him first of all the short thick stick, which he had to hold in his hand close to his face, and look at the bare end, whilst he swore friendship towards them, and finally he had to blow upon it, which was the great test. Next he had to take up the stick with the "carrots" (which I noticed were the dried seed-pods of some plant like a poppy), and whilst he chipped it with his knife, looking at it all the time, repeat the same oath. The chief then took the short stick, and holding it in turn to his eyes, ears, and mouth, blew across it on to him; then, taking one of the "carrots," passed it in a circle round his chest and back. As Farani did not die during the process, they 
1888. considered it all right. The chief then informed us that

Jan. 2. the guns were away at another place up the river, that Yambuya. to-day they would hand over to us one of the prisoners, and to-morrow the other man and three guns. We said we would agree to this, and the palaver ended, the chief walking off solemnly with his medicine sticks. We had to undergo a general inspection before getting into the canoes, and two natives, much lighter coloured than the rest, and who, as they informed us, came from a country far away to the north, where all the people were being killed, and who had never seen white men before, had a very close inspection of us. They wanted the Major to open his collar, and let them see if he was the same as other people inside it. During the long pause, whilst they were consulting the oracle, they asked Farani what was inside my tobacco-box, and when told, expressed a wish to see me smoke, so to oblige them I filled my pipe, and lit it with a flint and steel. There was breathless silence during the performance, but when I lit my fuse with the flint and steel, they could contain themselves no longer, and burst out into loud expressions of astonishment. My umbrella and its uses were next explained to them, and immensely admired. My rings were also a source of. interest, but I am sorry to say were considered to be brass, like their own bracelets. One native noticed the point of Farani's revolver sticking out from under his coat, and remonstrated with him on the subject. Taking Farani's hand in his, he closed it, then opening it, he swept his hand across the open palm, saying, "Why do you come with your hands closed-not open as they ought to be?" meaning why had he concealed weapons about him. I too had a very good revolver with me, but as it was inside the large breast-pocket of my coat, they did not see it. We finally got back to camp, with the released prisoner, after 12 o'clock, quite tired out by the noise, smell, and heat, for these natives are anything but savoury. A heavy thunderstorm came on after lunch, and it rained nearly all the afternoon, so I made a sketch of a goat's head, which died this morning, 
and we distributed the meat amongst the muniaparas and the Soudanese officers, the cook and our boys also getting a bit. This is the first real rain we have had for over a month, and the river has never been so low since we have been here. I am afraid, with the return of the wet and cold, some more of the men will die.

January 3rd.-Went for a stroll with Ward this morning up the river, he doing a little sketching, and I a little collecting. I shot a hornbill, which turned out to be too young to be of any use, and amongst other birds a very handsome one, of which I do not know the name, and which I have often tried to shoot before, but they have always been too high. I also got the most peculiar caterpillar I have ever seen. I made a couple of drawings of it, which fail to do it justice, and then deposited it, with all the other curious beetles, spiders, bees, bugs, \&c., in my silver flask full of spirits of wine. The natives did not fulfil their promise to-day of bringing over the other prisoner and the three guns, so Major Barttelot told the Arab head-man that he ought to send them a message to-morrow, and, if they did not give them up, he was to take his own way of getting them.

Not a word of news of any kind about Mr. Stanley. If we do not hear of him soon now, it will look serious.

January 4th.-The three men who were sent up to Abdullah's camp to try and buy fowls returned with four. Some of the reports we receive about Mr. Stanley are certainly very curious. These men say that, when they reached Abdullah's camp, some natives had just arrived there, who said that they had seen Mr. Stanley four days' march from there, still on his way to the Lake. Bonny has been cross-examining some of the deserters from Stanley with the following result:-They were two months and a half with him before they deserted. They do not know of any other deserters besides themselves, except Msa and three others who left with them, but who have never been heard of since. The reason they gave for leaving was that they were 
1888. badly treated about food. Although there was plenty Jan.4. of manioc (and plantains) on the road, Mr. Stanley would not allow them to take it, and in fact often took manioc from them. The country became very hilly, with quantities of water. The boat was always kept upon the main river, the party going by land; when they came to an unfordable stream they had frequently to go a long distance up it before they reached a village where they could procure canoes to cross in. At one of these villages they were fighting for three days. This is where Nelson was wounded, and two men killed, besides some wounded. Just before leaving Stanley, they had passed through a place where there were fifty of TippuTib's people. The natives used bows and arrows with iron heads. There was plenty of food all along the road, but the natives, on their approach, removed all their fowls and goats into the bush. They were 25 days coming down the river from where they left Mr. Stanley, to Abdullah's camp.-Went for a stroll down the river with Ward this morning, but shot nothing. We both got a sketch of the rapids, and a general view of the river, looking up it. Took out my gun in the evening, but unfortunately lost two very good birds in the thick bush, after shooting them. Painted some birds in the afternoon.

January 5th.-Yesterday the natives sent over the remaining prisoner, but no guns were given up. The men who came back from Abdullah's camp said that Ungungu, the native chief, had passed up the river with several canoes, and seven guns which he had taken from the Arabs. They were looking for a new place in which to make a village. The Arabs were going to let them settle, then surround them, and take Ungungu, and as many of them as they could. It is now evident that it was Ungungu who stabbed the Arabs in the canoe, and took their guns, and not the natives from down river. The Major had just dictated a letter wu Assad Farran, to be put into Arabic, and sent to Selim Mahommed, asking him to get us goats and fowls, and 
to let us know the exact date of 'Tippu-Tib's return from Kassongo, when two of his men arrived, and told us that he was on his way to our camp, and would be here in three days, bringing with him fowls, goats, potatoes, and rice. They brought us six beautiful pineapples, and two fowls. The pine-apples were simply delicious. I spent most of the day in making a sketch in black and white of the view I took of the river yesterday. Last night I was wakened out of my sleep by a gun being fired off in the Arab camp, and then I heard them all give chase to something. Their cries and shouts to one another were exactly like a pack of hounds giving tongue. I believe one of their native prisoners escaped, although of course they denied it this morning.

January 6th.-Just after lunch to-day, the Arabs returned from a slave-raiding expedition beyond Abdullah's camp, up river, bringing with them three women with babies and two children, whom they had captured. We had one of the first rain-storms unaccompanied by thunder that I have seen in this country. It was very cold and cloudy all forenoon, and after midday heavy clouds drifted up with a westerly breeze, ending in a storm of wind and rain. Barttelot has been very seedy for the last three or four days, and had to lie in bed most of to-day. I had a great day, cleaning up all my weapons, and finishing sketches of scenery, birds, beetles, \&c. Saw four large ducks pass the camp to-day; they looked to me like wild muscovy, and are the first I have seen on this river. I fear our fish supply is over for the present, for the natives are afraid to come over to this side, as they have not yet returned the guns to the Arabs.

January 7th.-Whis morning Nasibu, the Arab chief of Yambau, Yalisula, and all the surrounding districts, arrived, bringing us a present of a goat, and nearly a sackful of beautiful fresh rice. We bought two goats from the Arabs who came with him. He told us that news of Mr. Stanley had been brought by 


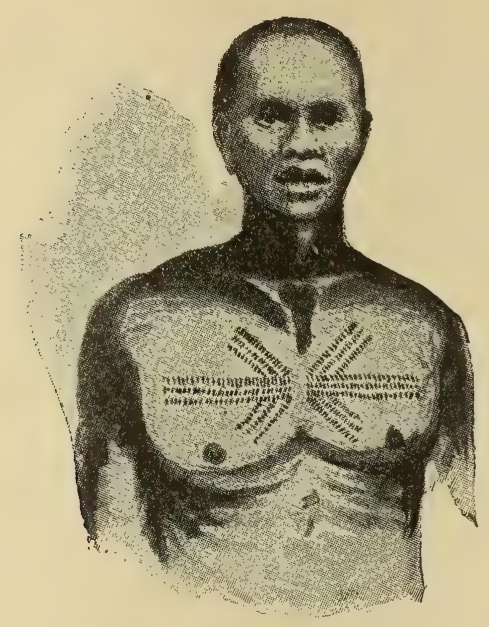

TatToong.

1888. natives to Abdullah's camp up the river, according to Jan. 7. which Abdullah had gone with his men after Stanley, rambuya. and had caught him up, assisting him in his fights with the natives. Abdullah had remained at Upi to form a large camp and raid for ivory. This place is only sixteen days' march from Stanley Falls, so that Stanley must have been travelling very slowly. Nasibu is going up to Abdullah's camp to-morrow, when he says he will be able to give us more definite information. Tippu-Tib is still at Kassongo, but will return next month. They say he is bringing a great many people for us, and is arranging for canoes in which to convey them. Selim Mahommed is at Yambau, one day's march from here. I had a very busy day, beginning by shooting a small finch which I wished to draw, but on my way back to camp with it I passed a tree covered with lovely blossoms which I had often longed to paint, but was afraid to try, as I am no good at flower-painting; in fact, I never tried it before I came here. However, I got some cut down, and set to work, and I think the result is a success. I was just finishing the leaves when 
Bonny brought me in a beautiful lizard, which $I$ at once painted, as I am certain its colours will fade unless put into spirits. Assad Farran came to me this morning, 1888.

Jan. 7. and told me that a curious beast, which he was sure was a whale, habitually came out of the water near our two canoes, and fed on the grass on the bank, but disappeared back into the water on the approach of any one. He said the sentry over the canoes constantly saw it, and on my inquiring if he was certain that it was. a whale, said, "Oh yes! it is something like the shape of a crocodile; I am sure it is a whale." I imagine the animal to be an iguana; however, he is to let me know the next time it is visible, for me to shoot it. Just after Nasibu arrived, the Arabs who are at this camp fired on a canoe full of natives, and killed several of them, so there is little hope of our getting any more fish.

January 8th, Sunday.-Nasibu came down to-day, but could give us no more information than yesterday. He spoke of a curious tribe of natives who live near Upi, the women of which, instead of wearing the usual small apron of a few square inches, and a dressimprover not much larger, wear two pairs of living fowls, one pair as an apron, the other as the dressimprover. When the fowls die, they are thrown away, and fresh ones substituted; they are only used for this purpose, and not for food. He told us that some of the Lights of his Harem had never seen white men, and had expressed the wish to come down and visit us, especially a woman who came from Upi. We told him we were quite willing to be inspected, and shortly after his departure a man came down in charge of four black Venuses, evidently in their Sunday best. Two of their names were translated as "Sugar-stick" and "Finish Everything." When asked to be seated, they all sat down in a body on my poor camp-bed ; but luckily, just as it was going smash, they got up and dispersed. The lady from Upi was certainly the best-looking of the lot, but the gilt of civilization sat very lightly upon her. 
1888. We presented each with a few matakas, and they went Jan. 8. away evidently much pleased with their visit. Nasibu Yambuya. says that the natives here have no religion of any sort, and consequently no worship, even of fetishes, but they have a firm belief that, when they die, they will come to life again. They affirm, however, that we must come from heaven, for all people are white there. Another of the men who came up from Bolobo died to-day, making forty-one deaths in camp since we arrived, and I hear another of the Soudanese is dying.

January 9th.-Selim Mahommed arrived to-day, and brought no end of presents with him, giving me a very good ivory-handled knife, manufactured at the Falls; to the Major and myself jointly a small bag of candied sugar, which is a great luxury, as I have not tasted sugar now for over seven months, a box of vermicelli, and a small sack of coffee-beans; and a fowl to Ward. He brought me, as a present from Tippu-Tib, a splendid big goat. My boy Farani also gave me a very good spear, so the day seemed like a birthday. Selim told us that they had not heard from Tippu-Tib since he went to Kassongo, but that he was expected back at the Falls by the 12th February. He said that the men coming from Kassongo could only arrive slowly in. small detachments, as the Congo is now very low, and they have to travel in very small canoes. He has had no news of Stanley later than that brought by the deserters, and he does not believe in the statement that Abdullah had caught him up, and fought the natives with him. Selim's intention is to make treaties of peace, and trade with all the natives round here, and not punish Ungungu, as it was wrong in the first place for his head-man to have tied him up. One of the head Arabs at Stanley Falls, called Nasoro, fired off the big rifle I gave to Tippu-Tib, but came to grief in doing so. He knelt down, imagining it to be the safest plan, but it kicked him right over on to his back. Tippu told Selim Mahommed, when he left for Kassongo, to fire the rifle, but he said that, after hearing of Nasoro's 
mishap, he thought it wiser to leave it alone! This afternoon I took a long walk, and shot a beautiful warbler, that I have never seen before, and one of the black shrikes, which, although only about the size of blackbirds, look as big as crows, owing to the effect of the masses of black, fluffy feathers with which they are covered. I stood and listened to the warbler singing for a long time before I noticed that he was a new one to me, and then, alas! he also had to die!

January 10th.-Major Barttelot sent for Selim Mahommed this morning, and asked him to tell the plain truth as to whether we were likely to receive the men promised by Tippu-Tib or not. Selim answered that he could not read Tippu's heart, but he believed we should get the men, and that Tippu himself would return to Stanley Falls on the fifteenth of next month, when he expected to have 200 men there from Kassongo. It was very difficult, he added, to get the men to carry loads, so they were told that they were required here to fight the natives. The Major asked him why, in the first place, we did not get the men who were on the Lumami River. He said (as Farran translated it) there were murmurs amongst them, which I suppose simply meant that they flatly refused to carry loads. The Major then asked if there was any personal feeling of dislike to himself in the matter, and Selim said there was none. I am afraid that if we do get the men from Tippu-Tib, once they discover that they have been taken in, we shall be unable to do anything with them. Selim told the Major that there were two more deserters from Mr. Stanley at Abdullah's camp, besides the man who led him to the place where the ivory was.

January 11th.-A most unpleasant accident happened to me last night. I was in the midst of pleasant dreams, when, with a crash, my bed broke down, and I fell with my head and shoulders on to the ground, and my feet in the air. I put my hands out to see what on earth had happened, when they met with the mosquito curtain, which I found all round me, and at once commenced to 
1888. struggle with. Luckily I realized what had happened

Jan.11. before I had torn the curtain too badly, and I fixed the whole thing up somehow, but for the rest of the night had to sleep with my heels in the air, and my head almost on the ground. It is a curious thing what an amount of thought goes through one's brain in a second of time when one is asleep. I remember perfectly well that my last dreaming thoughts were of being in a chair which kept tilting over backwards, and yet, from the manner in which the bed was broken, it must have happened instantaneously. One thing is certain, however: the next time we receive the Lights of any one's Harem, they will not sit on my bed! Spent most of the day in skinning birds and painting. A boy came in the evening from Nasibu's camp, which is about an hour from here, and told me that Nasibu had a fullgrown antelope, with horns, for me, and wanted two men sent out to bring it in. When it arrived we untied its legs, and put it in my house on some grass ; it then appeared to be all right, but on coming out from dinner we found it dead, which is a great pity, as I wished to sketch it before killing it. Unfortunately it has only one horn, having evidently lost the other in the wars. Just as I was going for a stroll with my gun, I met one of my sick men, who presented me with a Doo-Doo, as they call every species of fly, beetle, bug, or any other insect. This one was wrapped up in a leaf, and turned out to be a beautiful longicorn beetle, which figures in Herr Pogge's book, and I have only seen one other specimen of it here. This was Ward's birthday, so we had quite a feast at dinner, soup and grilled meat, topped up with the best rolly-poly we have had yet, made with some flour we had over from Christmas Day, and a pot of gooseberry jam. Unfortunately Bonny was feeling very seedy, and had to go to bed before dinner.

January 12th.-It was so hot that $I$ had to skin the antelope, fearing the meat would go, and I had not time to get much of a sketch, even of the head. Nasibu told me he thought this one was about eight or 
nine months old, that a full-grown one was not much larger, and had straight horns about eight or nine inches long. He has promised to get me a full-grown one, as I have never seen any like it. It is certainly different from any of the South-African antelopes that I know of. We cut up and grilled one of the hind legs, and made soup of some of the meat for dinner, and it was excellent. To-day was one of the hottest days we have had yet. The thermometer went up to $130^{\circ}$ in the sun, and then I took it in, as it only measures $145^{\circ}$, and I feared it would burst. It stood at $89^{\circ}$ in the shade. All the degrees of heat in the shade are taken in my house, which is the coolest spot in camp, as it is open at both ends, so that every breeze blows right through it. An Arab who came in on his way to Stanley Falls says that Abdullah has gone back to his camp beyond Upi, and that the two last deserters from Stanley are there, sick, eight men having deserted at the same time, when six died, or were killed. I am thankful to say that I have not had a single day in this camp with nothing to do, except when I have been ill.

January 13th.-Stretched the antelope skin this morning, and finished the drawing of its head. In the afternoon made a sketch of the Sobarus Poggei beetle, which I find is far from correctly drawn in the plates in his book. Another of the men who came up from Bolobo died to-day, making the 42 nd death in camp. Some of the Soudanese are in a wretched condition, and will, I fear, die very soon. Nasibu paid us another visit to-day. He is certainly one of the nicest of all the Arabs, and quite the most straightforward. As a rule, when they have not much to say their conversation is a tissue of lies, made up of information which they think will please you. Salem Masudi was one of these men, who, rather than say nothing, told a lie.

January 14th.-Spent most of the day in making coloured drawings of some of the native pottery. The designs are occasionally very beautiful, and would be still better, if they were left without the small cross

1889.

Jan. 12. Yambuya 
1888. strokes with which they are covered. The pots are jetYambuya. black when new, and the designs are coloured by rubbing cam-wood into all the sunken lines. The forms of some of their vase-shaped pottery, used for carrying water or palm-oil, are very fine. Dead bodies of natives and Manyéma men are constantly caught by the trees which have fallen into the river from the bank below our camp. Yesterday there was one, and again to-day, a most loathsome object to be seen-a woman with her throat cut in such a way that the head was almost severed from the body. A rope was tied round her wrist, and the sight was rendered more horrible from portions of the skin having come off the face, breasts, and other parts of the body in large patches. I believe the Arabs living at Abdullah's old camp up the river had a fight to-day with the natives on some islands above the rapids, killing eight or nine of them, and capturing over twenty women. When Ward was at Stanley Falls the last time, Rachid, the Arab chief on the Lumami River, promised to send him some knives and spears from there, and to-day they arrived. They are quite the finest I have ever seen. He was kind enough to make me a present of one of the spears and a knife, which were very acceptable, as I have nothing whatever to buy anything with.

January 15th, Sunday.-Dhuma Bisalum, one of my men, died to-day, making the 43rd death in camp. He has been in a sort of decline ever since arriving here, and for the last two or three months has been merely an animated skeleton. In the morning I shot a couple of swifts, and a very beautiful swallow. Made a sketch of the large native knife sent by Rachid to Ward. A hippo passed down the river to-day in front of the camp. It was the first I had seen, although there are a good many tracks of them between this and Abdullah's camp. Gave the men a whole holiday.

January 16th.-We had a hot sun, and I got all my skins dried. Took a long walk in the evening with my gun, but only succeeded in shooting one big pigeon. 
January 17th.-Had a great slice of luck in the way of collecting to-day. After breakfast, Ward and I started on a botanizing expedition, and I took my gun. Just opposite the graveyard, I noticed a small bird dart into a tree. I said to Ward, "I must get a shot at that bird; it's a new one." We lost sight of it for some time, but luckily I stood still, and presently I saw it through the branches and fired, when to my surprise I saw two birds fall, and found I had shot a pair, both cock and hen. They turned out to be the most beautiful sunbirds I have ever seen, and quite different from any I know of. There is a hummingbird in Gould's collection, as far as I remember, exactly like them. We got a number of botanical specimens, but unfortunately did not press them sufficiently, and had to throw the whole lot away.

January 18th.-Saw the natives catch two very large fish to-day, in nets just below the camp; one of them must have weighed from 40 to 50 lbs. Just as I got into my bath this afternoon, I saw a snake climbing up the end of the house, and presently he proceeded to come inside through the sticks. I jumped out, seized Barttelot's stick, and gave him what I thought was a nasty jar, but he wriggled over the top of the boxes, and disappeared. I had just got into my tub again, when I saw him going along where the roof joins the wall. Went at him and gave him a knock, upon which he fell at the back of the boxes, and I saw him no more, although I hunted everywhere for him. This life is becoming tedious and monotonous beyond measure, and God knows when and how it will end!

January 19th.-Made a sketch of five spears used by the natives on this river. Some of them are very handsome, the blades ornamented by cam-wood being rubbed into the deep lines graved on them. One of them, belonging to Bonny, has a blade $23 \frac{1}{8}$ inches long, and is quite the finest $I$ have seen anywhere. One of my men brought me a most extraordinary caterpillar. It has two long horns of lovely silky hair, black and 
1888. white, and a tail of pure white spun silk. Its back is Jan. 19. a rich velvety dark olive-brown, barred with yellowishcreamy white, like satin, and the sides are pure snowy white, shining like the richest silk. The head is ochre and perfectly bare like a skull, with jet-black eves. Another man brought me a very fine specimen cf the leaf-insect. One of the Soudanese is dead. $\mathrm{He}$ has long been ill with dysentery, and was reported dead a fortnight ago. This is the 44 th death in camp.

Jinuary 20th.-Another of the Zanzibaris from Bolobo died to-day. A cold wet day or night is almost sure to be followed by the death of one or more of these wretched men, who are simply living skeletons. They are nearly all without blankets or clothing of any kind whatever except a ragged piece of cotton, or native cloth, round the loins, and having no flesh on their bones, the cold kills them at once. We have now lost a fifth of the entire force in camp. I find it almost impossible to paint the leaf-insect, on account of the marbled veining and the thousand shades of colour which render it so beautiful. This evening I shot another new sunbird, if possible more brilliantly coloured than the last. Throat rich grey, fading into bright metallic green on the breast, succeeded by a bar of orange, merging into grey on the belly, which in its turn changes into lemon-yellow on the vent. It has a tuft of bright lemon-yellow feathers on each side of the breast, which project over the shoulder of the wings. The head and back are a metallic green, and the wings are a beautiful mixture of dark olive and lighter greens. It is a remarkably small sunbird, and the first that $I$ have seen of the kind. Unfortunately the hen flew away when I shot this one, and although I waited a long time did not return.

January 21st.-A splendid addition to my collection arrived to-day! One of the Zanzibaris brought me a magnificent Goliath beetle, the largest I have ever seen, but not so brightly coloured as those I got in the Transvaal and Mashona country. I saw one some time 


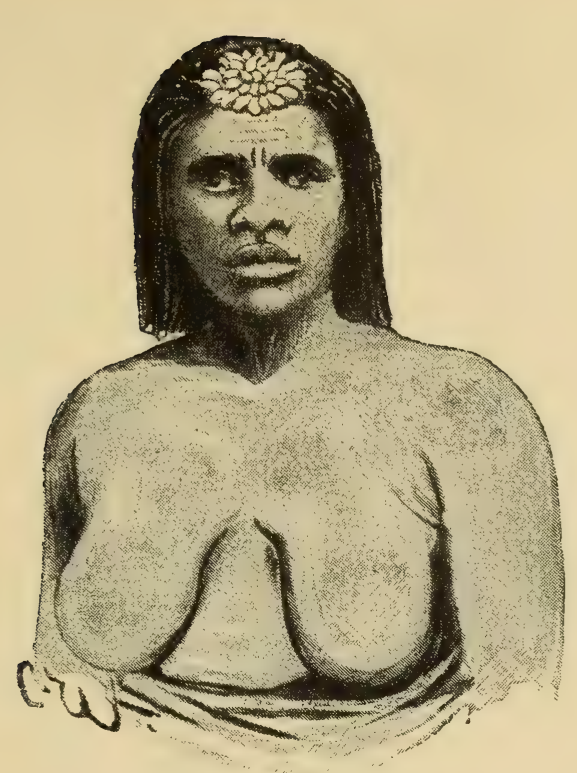

Cowrie Head-dress.

ago, flying very high, and could not get a shot at it; and to-night, just before dinner, I had sent my gun in with one of the men, when one flew right over my head, but 1888. Jan. 21. Yambuya. did not settle anywhere within sight. These are the only three I have seen during this trip. There seem to be very few beetles here, but the few there are, I think, are most of them rare specimens. Saw a very large hippo going down the river to-day.

January 22nd, Sunday.-Took a walk with Ward up the river. It is now evidently the flowering season for almost every tree and shrub; and some of them are very beautiful. I did not shoot anything then; but in the evening I had a grand time with my gun and the birds, getting three which are new to me. I first saw a sunbird dart over the path and fly into a tree some distance in the jungle. As far as I could see in the moment's time, it was a cock bird, with a bright red breast, belly, and vent, and the rest of it dark blue or green. It flew away before I could get a shot, when the hen made her appearance, and was shot instearl. 
1888. Shortly afterwards I got a very handsome bird, of Jan. 22. what species I do not know. It is a little larger than a thrush, and has a powerful and crow-shaped beak. The breast is very flat, and the colouring resembles that of the barbets. It has large bright orange wattles and beak; head, neck, and throat being of very deep claret. The feathers are glossy and hard like short hackles; the breast and belly are bright lemon-yellow, spotted here and there with black; vent black; shoulders white; wings, back, and tail black; eyes very dark red. I also got a beautiful Paradise flycatcher; and on the road home a large black shrike, which Bonny wanted. Having left the birds in my house, I went out again, and shot a very handsome warbler, almost as large as a thrush, which I have never seen before, so that to-morrow I shall have a really busy day. It was great luck getting the large bird and the warbler, as I should never have seen them had I not gone into the thickest part of the jungle in search of birds I thought I had wounded.

January $23 r d$.- Got a few good new beetles. A heavy thunderstorm came on about an hour ago, after dinner, and has wetted nearly everything in my house, as the wind drove the rain clean through the sides, so I expect to pass a pretty damp night! I am afraid the long spell of fine weather we have had is drawing to a close.

January 24th.-Selim Mahommed came down to my house this morning, and we had a long talk with him. It appears that he has with him a man who left Emin Bey's territory some time after Dr. Junker, and came down through Uganda and on to Kassongo, reaching Stanley Falls a few days before Ward's last visit there. Emin Bey has been known to the Arabs for a long time, but always as Abdul Emin; and they heard him named Emin Bey for the first time by Dr. Junker. He states that, when he left, Emin Bey was at his station, which, from his description, appears to be at the northern end of Lake Albert Nyanza, on an island, with the river on one side and the lake on the other, close to a very large mountain. The 
people of whom he stands in danger are the kings of the three surrounding native kingdoms, all three very powerful. From what this man says he is not on friendly terms with any one of them, and appears to be more or less hemmed in on this island. He has two steamers in which he goes backwards and forwards between his stations. Selim Mahommed says that he heard of Emin Bey going down to Uganda a long time ago to try and make terms with the king about getting out that way; but he has not heard of his being there a second time. The Arabs know all his movements, the Sultan of Zanzibar having sent orders to all the Arab stations to the effect that, should Emin Bey come to any of them and be in need of anything, they were to supply it, the Sultan himself repaying them for it. This man says that when Dr. Junker left he took with him a lot of Emin Bey's ivory to Uyoro (Ugogo ?), where he bought cloth and other necessaries with it, and sent them back to Emin; also that Emin has a quantity of ivory, but that it is scattered among his different stations. He says the natives at this end of Lake Albert Nyanza are a very savage and warlike people. They have no guns or spears, but fight with a large knife and shield. They are not like the natives here, who are afraid of guns, and run away when a few of them are shot, but they come right on in great numbers. Thus the great danger to which it appears Mr. Stanley is open is being attacked on the march when his men are tired and straggling, and the Maxim gun can only be used at one point. Another danger is the weakness of his force, owing to the great number of desertions and deaths; for although we only know definitely of 23 or 24 desertions, these men and the Arabs all say that many others have left him, principally owing to his treatment of them on the road. We have not seen or heard of those other deserters, because they have gone down by another route,-probably viâ Kibongé to Kassongo; but very likely 'Tippu-Tib on his return will have heard something of them. For these reasons Selim Mahommed inclines to the belief that Stanley is in some way hampered, and unable to get on or 
1888. send men back; he thinks that only his oldest and Jan. 24. most faithful followers have stuck to him. We have Yambuya. talked the matter over amongst ourselves, and can only await Tippu-Tib's return from Kassongo, and see how many men he will give us. If we only get two or three hundred, we shall start with them and the pick of the men here, with light loads (principally ammunition), and force our way through to see what has become of Stanley, leaving two white officers here, with the rest of the men and loads. I told Selim, in chaff, that if I remained out here much longer they would think at home that I was dead, and that I should find, on my return, my wife had married some one else. He laughed very much, and told me about one of the Arabs at the Falls called Nasoro Masudi. Some time ago there were two men of this name, one at Manyangwé and this one at the Falls. The man at Manyangwé was killed in a fight; and when the news reached Zanzibar, the relations of Nasoro Masudi (of Stanley Falls) thought it was he. His wife, mother, and some relatives then divided his property amongst themselves, and his wife married another man; but before long she received a letter from her husband at the Falls, saying he had made some money and was returning to Zanzibar. This rather took them aback; but the men relatives bolted with their share of the property, and poor Nasoro returned to this painful state of affairs. Selim Mahommed told me that justice does not exist at Zanzibar; everything is done by bribery, and the case is always gained by the richest man. If a rich man beats or ill-treats a poor one, and he complains, he is at once accused of having cursed the rich man, or some other crime of that description, and is put into prison, the rich man having bribed the judge.

January 25th.-One of my Zanzibaris died yesterday, and one of the men from Bolobo to-day. This makes 47 deaths in camp. My man has been ill ever since August, when he was so bad that I took his rifle from him, as he could scarcely carry it. The man who died to-day was well except for a sore leg. He was found 
dead this morning, with a quantity of blood which had flowed from the leg right outside the hut. The sore had evidently eaten into a vein, which had burst in his sleep, and he had bled to death. He was one of our camp policemen, and quite one of the best men we had. Selim Mahommed spoke very cheerfully about the certainty of the men arriving from Tippu-Tib, saying that he himself much wished to see the country that we should go through, and that we could go by a much straighter road than Stanley's, for where he had made a détour from the river and returned to it again, we could go straight on. Had a great day painting beetles and drying specimens. In the evening I shot a sparrow almost identical with our English one.

January 26th.-The forenoon was so dark that I could hardly see to do anything. It was just like a day at home-cold and cloudy. No news of any kind, either from the Falls or of Stanley. It is now a very serious question as to what has befallen him, and what we are to do should Tippu-Tib not bring enough men with him from Kassongo. Make a move of some kind we must; but it is useless to do so unless we are in a position to be of real help to Stanley.

January 27th.-Had a most successful day's collecting. In the morning I shot two cock sunbirds, quite new to me, one of them the most beautiful I think I have ever seen. The throat and upper half of breast are bright metallic golden green, and below this. on the breast, is a line of prussian blue, edged with carmine. The lower part of the breast, belly, and vent are a rich, dark velvety brown. There is a small patch on the crown of dark green and purple, and on the cheeks a line of dark green. The rest of the bird is a rich golden olive-brown in dark and light shades. The other is much smaller, and not nearly so beautiful. Painted and skinned them. In the evening I shot a very handsome pair of weaver-birds. Selim Mahommed's men attacked Ungungu's brother's village this morning. It lies lower down the river, on the opposite bank. We heard the firing quite distinctly.

1888.

Jan. 25.

Yambuya 
1888. They killed the chief, and brought back his right hand Jambuya. with them. They captured twenty-seven women and children, and killed four men besides the chief. Ungungu will be a great fool if he does not give up the guns now, as this will certainly happen to him also. Selim Mahommed's band from Kassongo came down, and played and sang to us whilst we were at dinner.

January 28th. - Ahmed Abdullah, a Soudanese soldier, died to-day. Spent most of the day in painting birds and flowers. In the evening I took a stroll through the manioc plantations and shot a beautiful paradise flycatcher, the cock bird of the hen which I got a few days ago. It appears that the native chief whom Selim Mahommed's men killed was under the protection of an Arab, called Ali Mahommed, and so trouble has arisen amongst themselves, and I heard that Selim Mahommed had sent off a lot of his men to fight the others. It must be rather a curious and pleasing sight for the poor natives to see them fighting among themselves.

January 29th, Sunday.-This was one of the hottest days we have had. The thermometer stood at $88^{\circ}$ nearly all day in my house, and $136^{\circ}$ in the sun. Skinned some birds, dried specimens, and finished painting some flowers. In the evening shot a small warbler, which is new to me. The natives of the village on the other side evidently had a fright to-day. I heard a great row, and on going out with the glasses, saw them all tumbling into their canoes as fast as they could, and pushing out into the stream. Some of those who were left behind were jumping into the water and swimming. It was only a scare, for they all soon returned. Theirs must be a miserable existence, liable to be attacked at any moment by the Arabs, their women and children taken, and the men shot; yet they always appear light-hearted and jolly in spite of all. The chief who was killed the other day is the head chief of the whole district. 
January 30th.-Bought a very curious native war- 1888 knife to-day. The man wanted cloth for it, but as I Jan. 30 had none, I offered him gunpowder, which he declined.

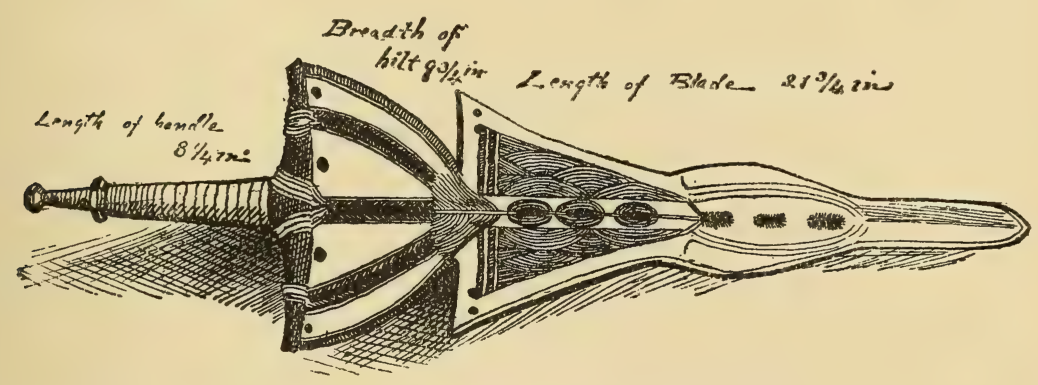

WaR-Knife from Lumami River.

The Major then tried to buy it for me with the canvas off his old bed, but he would not have that either, when I remembered that I had an old Pigou and Wilks powder-flask painted black, with a bright yellow paperlabel on it. I showed him this, and extolled its value; he jumped at it and asked for some powder in it, so I put a little in and obtained the knife. The curious shape of the top of the blade is evidently taken from the bill of a hornbill.

January 31st.-This morning I shot a pair of finches, of which I have only seen one specimen before, and that was one I shot on our arrival here, the skin of which was destroyed by beetles. This evening I shot a beautiful small warbler. I find that every minute of the day I have something to do. First thing in the morning parade men and tell them off to their work, then breakfast, followed by a stroll with the gun as long as it is cool. Most likely a new bird is shot, when he has to be drawn, painted, and skinned; then perhaps a boy will come in with a new beetle or a curious insect, which is subject to the same fate; then, before the sun goes down, another ramble with the gun. Through it all, one cannot help feeling how utterly one 

1888. is left out of all the real work we came to do, and the Tambuya. sense of keen disappointment crops up at all times.

February 1st.-The men came back from Yalisula today, with palm-oil and fowls, and a present of a goat from Saidi Chongo * to the Major. They had been lost in the forest for three days, having mistaken a large elephanttrack for the right road. They brought a great many reports, but no definite news. Tippu-Tib, they say, will soon be back from Kassongo. Already nine or ten canoes have arrived from there with men, but they have been sent off to a river called the Lumami (not the one we know of), to settle some dispute, after which they will come here. Another report says that the white men (Stanley and his party) are on an island fighting an angry king. Selim Mahommed places no faith in this rumour. He is expecting a letter from TippuTib. Had a good evening's shooting, viz. one warbler, a sunbird, and a finch. A curious thing happened on my way back. I had shot a sunbird close to where I shot the warbler last night, and pointing out the shotholes through the top of the small bush where he had been, I said to Barttelot, "I wonder if there are any feathers from the tail of that bird. I looked yesterday but could find none." On stooping down, what was my surprise to find a dead bird exactly resembling that which I shot yesterday, lying in the same spot, but in this one the tail was perfect. I must have shot both birds, but I certainly only saw the one when I fired, and I fail to understand how I missed seeing this one.

February 2nd.-Last night the natives stole two large canoes belonging to Selim Mahommed, which he had placed below our camp for safety. A man must have swum down and cut them loose with a knife, for the sentry says that although he heard a slight noise, he could see no one to fire at, and immediately afterwards he saw the canoes floating away down the stream. The natives, however, were only taking what belonged

* Chief of Yalisula.-Ev. 
to them, for the canoes had been taken from them about a week ago. Made a sketch of a very handsome Goliath beetle which Bonny got to-day.

February 3rd.-One of my men died to-day who has been ill for the last two months. He seemed to be getting better, but the last two or three nights have been very cold, and have evidently finished him. Shot three finches, a sunbird, and a warbler. I have only one specimen of the sunbird and warbler. Selim Mahommed has sent over twenty-eight men to the other side of the river, there to lie in wait during the night, and attack and burn Ungungu's village at daybreak to-morrow. He has not given up the guns, and has broken faith in every way with Selim Mahommed. A brother of the chief whom the Arabs killed the other day paid us a visit to-day, and was shown round the camp. The Major and I have talked matters over together, and have decided, in case we hear of Mr. Stanley having either met with disaster or being hemmed in, that we will personally sign a guarantee for $£ 5,000$, which we will give to Tippu-Tib upon his signing an agreement to give us sufficient men to go up to the Lake, and see what has really happened; that is, if he will not do it for less, or if he will not give us enough men to move the loads now. If we have to do this, we shall only take food and ammunition, and go simply to fight our way through if necessary. The man who died to-day makes the 49 th death in camp.

February 4th.-To-day was the third anniversary of my wedding, so we killed the big goat, Tippu-Tib's present to me, and feasted. Bonny contributed a tin of flour, and the Major a tin of jam, and the result was a splendid culinary surprise to me, for they had purposely not told me about it. We had, unfortunately, nothing stronger than tea to drink my wife's health in. 'This morning, shortly after daybreak, I was awakened by the guns of the Arabs who were attacking Ungungu's village, almost opposite our camp. I ran out with the glasses, but there was a thick mist,

1888.

Feb. 2.

Yamhuya 
1888. and nothing to be seen but the flashes of the guns as Feb. 4. they shot the unfortunate natives swimming in the water, and the shadowy furms of the canoes going up stream. Nearly all the canoes made for the rushes in the centre of the rapids, where they had built a lot of huts, but they were soon driven out of that refuge, and went in a body away up the river. Selim Mahommed himself, with some men, was stationed on this side to guard against their landing. I saw two poor fellows, in a canoe which came rather close in, have a very narrow escape, as Selim began shooting at them with his Martini, but they jumped out and put the canoe between them and the shore. A number of natives were shot, but I cannot tell how many, as most of them sank in the water; however, they captured one man, and brought back one head with them, which Ward and I sketched. Afterwards I skinned and preserved it, and shall try to get it home with me*. The Arabs captured five canoes, some very fine ones, and I fear the natives have little chance of escape, as Abdullah's people hold the islands up river, and have canoes. The Arabs had burnt the whole of the village, which now made a beautiful picture, with the smoke and flames rising up from under the dark foliage of the forest, and reflected as in a mirror across the sunlit waters, while higher up the river the canoes were disappearing into the mist which still hung over the rapids. When one thinks that Selim Mahommed is one of Tippu-Tib's head men, Tippu now being an officer of the Congo Free State, whose charter binds him to put down all forms of slavery, and that these head men of his send out parties in all directions to hunt ivory and slaves every day, it seems a curious medley. To-night Burgari Mahommed, the man who stole the meat out of Ward's house (and who has been in chains ever since, doing walking-punishment every day), escaped from the guard-house, taking with him the sergeant's rifle and twelve cartridges.

* This head reached home safely, and was the one which gave rise to the atrocious attacks in the Press on the late Mr. Jameson.-Ep. 

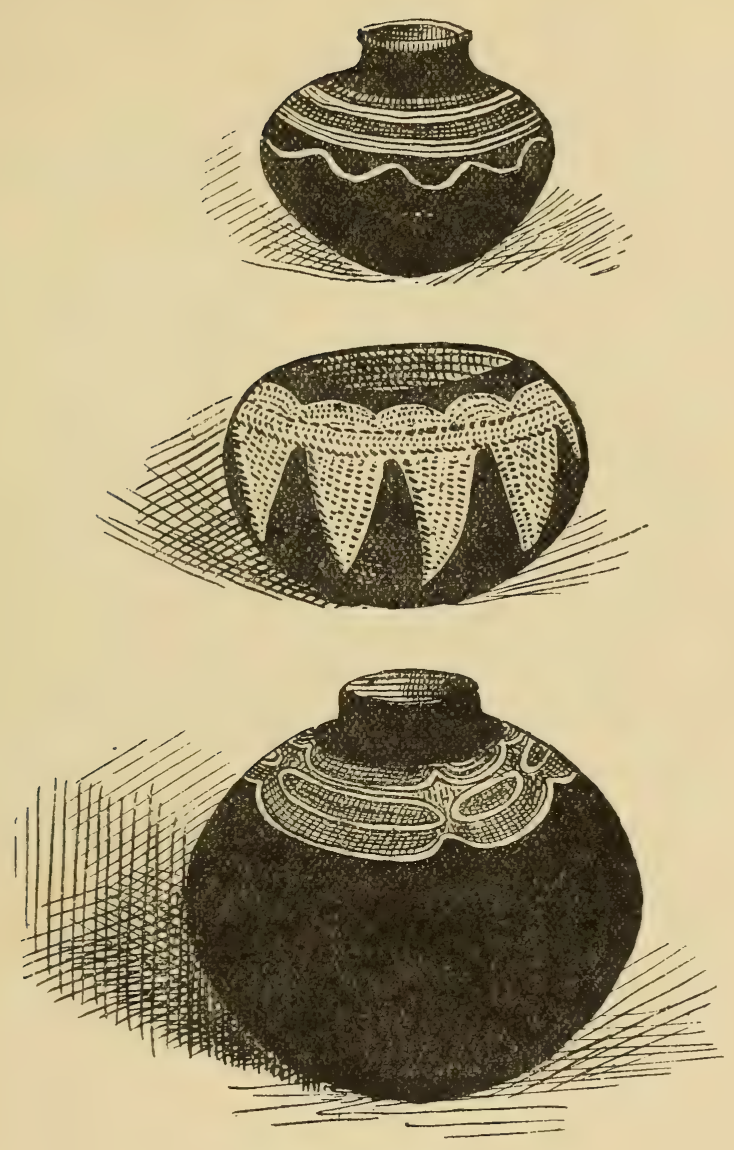

Watako Pottery.

February 5th, Sunday.-Another of the Soudanese soldiers died to-day. The Arabs, who tried to intercept the natives going up river yesterday, met with decided 1888. Feb. 5. Yambuya. reverses. Ten of them, in a canoe which stuck on a rock, were killed by the natives, who took all their guns. Last night all the natives passed the camp and went away down the river; thus of course Selim Mahommed, who went up river to-day to hunt for them, did not succeed in his quest. Selim, however, shot two unfortunates, who were fools enough to show themselves. It is not 
1888. pleasant to reflect that Burgari Mahommed is still loose Feb. 5. round about the camp with a rifle and 12 cartridges !

February 6 th.-I painted a lovely snake which a man brought in, and a fish, which I had in a large earthenware jar. Selim Mahommed says that when they reached the place, yesterday, where the ten Arabs had been killed by the natives, they found the native fires still burning, and a lot of the dead men's flesh left in the pots. The natives had eaten nearly all the bodies, and had nailed their fingers to the surrounding trees. I believe it is quite a common practice amongst the Arabs, when they have made friendly terms with one village, to capture the natives of another place, men or boys, and give them over to be eaten, as a present, to the natives of the friendly village. When the Arabs brought back the hand of the chief whom they killed the other day, some natives, who were in his camp, said to Selim Mahommed, "You say you are a friend to us, and yet you give us no one to eat! Give us the hand!" This is the hottest day we have had, $90^{\circ}$ in the shade, $137^{\circ}$ in the sun.

February 7 th.-Thunderstorm and torrents of rain all forenoon. Wrote up my bird notes. Some Arabs arrived from the Lumami River, and we succeeded in buying seven goats and some fowls from them. Not a word of news of any kind about Stanley! The Major and I start on Saturday for Stanley Falls to meet Tippu-Tib, and force him, if possible, to show his hand to us. If he will only give us a few men, we will go up and see what has happened. This waiting here in utter darkness is sickening, and the men are dying off like rotten sheep.

February 8th.-Another man from Bolobo died today (51 deaths). It is almost certain that a death will be reported after any of the cold storms which visit us. Did a little painting to-day, but it was so cold and dark inside my house that I did not feel much inclined to do anything. When it is fearfully hot we all pray for cold weather, and when it comes it upsets our livers, and then we prav for the heat again. This is the worst 
place I have ever collected in; it is almost impossible to get anything I do not already possess, and yet I have only a few specimens.

February 9th.-Burgari Mahommed was captured and brought into camp this morning. One of my men who was out a long way from camp yesterday, getting manioc, saw him sitting down, and told the Arabs in a village close by. They went out this morning, and Burgari fired at one of the natives; but when the Arabs came up, and said "Do not fire at us, we are friends, come into our village," he did so, and was then surprised, disarmed, tied up and brought into camp. He is to be shot to-morrow morning. Troup and I were the only ones who thought the extreme penalty might be mitigated. No one can deny that, according to military law on active service, he ought to be shot, and there is no doubt that it ought to have a very good effect upon the others; but when one thinks what a miserable poor wretch he is, and from what a miserable existence he tried to escape, one cannot help pitying him. It is a long time now since he stole the meat out of Ward's house, which was the offence for which he was punished originally. I think, all things taken into consideration, a little leniency to such a poor wretch would not be flung away. We have arranged to start for the Falls on Sunday, and the idea of the change from this horrible existence is delicious.

February 10th.-Took everything out of the store and gave it all a sunning. After lunch had all my birds' skins out in the sun, and got them thoroughly dried. They are all in capital condition, and no sign of beetle amongst them. Burgari was shot this morning, and all the men in camp were paraded to witness it. He was tied up to the flogging post on the road outside the camp, and eight Soudanese formed the firing party. Death was instantaneous, one bullet going right through the backbone, and another through the heart. He took the whole thing quite coolly, without the sign of a tremble, or an utterance of any kind, and waited 
1888. quietly with his head slightly bent for the signal to fire. Feb. 10. The Major has decided to start for the Falls on Sunday. Selim Mahommed says Tippu-Tib is not there, and he does not know when he will return. We may have to wait there a month or more before he arrives, knowing all the time that we are unwelcome guests. Goodness knows I shall be glad of the change, but I don't think it a good move until we hear of Tippu-Tib having left Kassongo.

February 11th.-Another Bolobo man dead (53 deaths). Our departure is put off to Tuesday.

February 12th, Sunday.-The men had a whole holiday, as usual on Sunday. Bonny bought a very good specimen of the white-nosed monkey yesterday. The river is so low now that in some places I think one could wade across.

February 13th.-Busy all day arranging my store and packing.

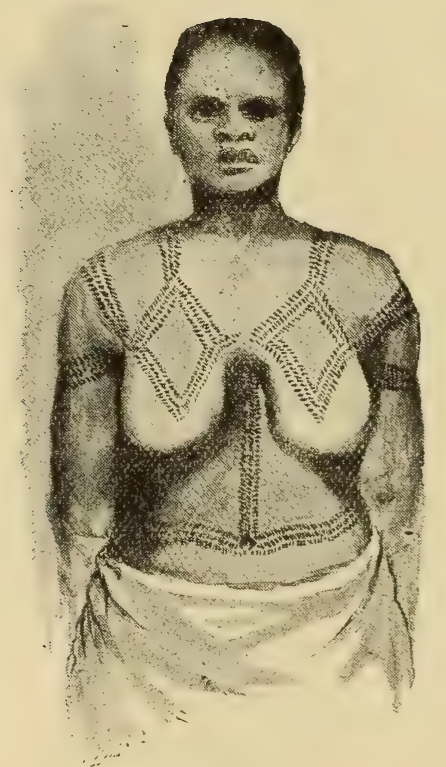

Tattooing. 


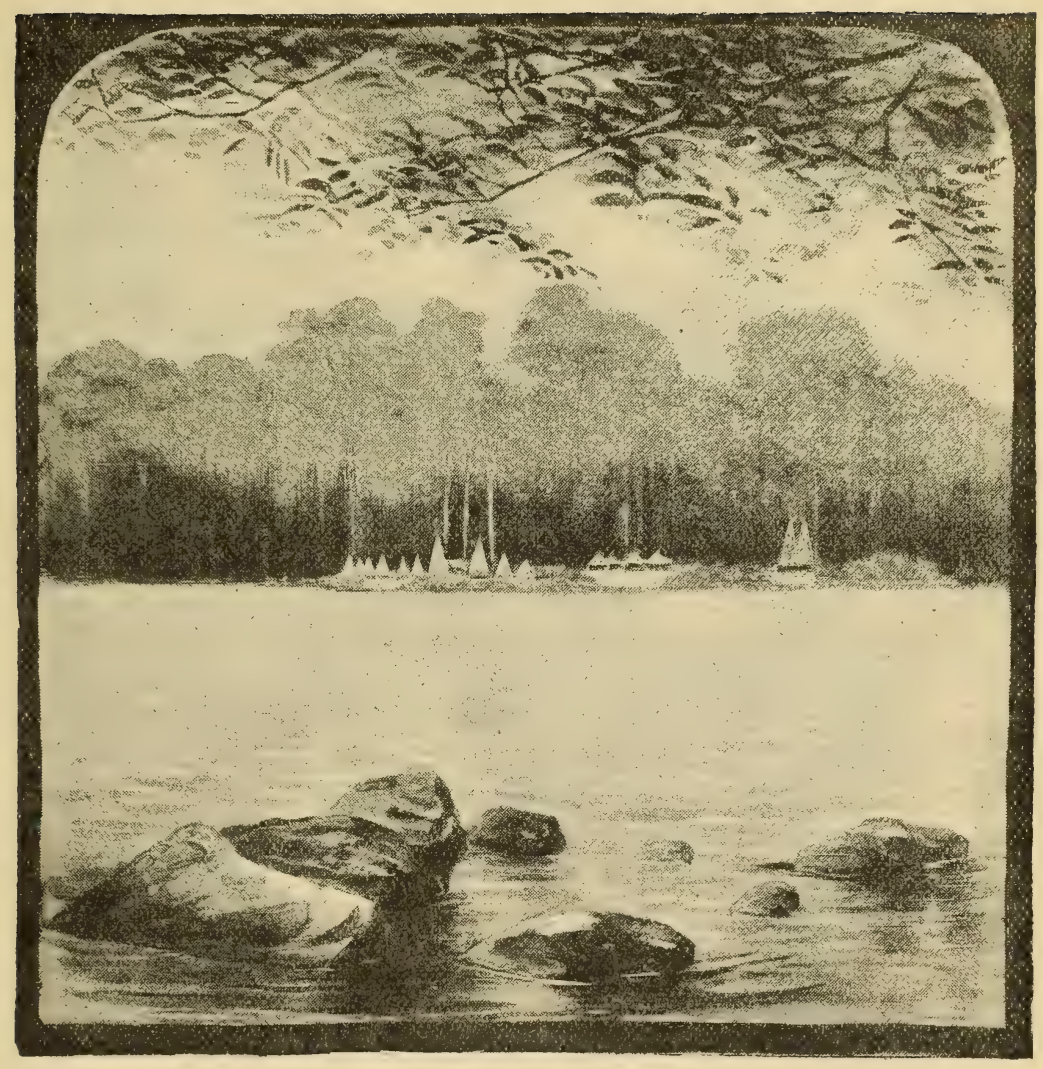

A Glimpse across Aruwimi River.

\section{CHAPTER VII.}

\section{February 14th to ApriL 26th.}

Start with the Major for Stanley Falls.-Meet a number of men from Kassongo.--Singatini.-Interview with Nzige.-No news of Stanley.Hunting for gane in the jungle.-Letter from Yambuya Camp.-Shock of earthquake.-Anxious waiting.-Sketching regarded as sorcery by Mahommedans.-Fever.-Letter from Troup.-Barttelot arranges to send Jameson to Kassongo. - Letter to Mrs. Jameson.-Start for Kassongo. - Tankeerwee. - Wild-looking natives. - Wamanga Rapids.Meet men from Kassongo.-Kibongé.-Jameson writes to Stanley.Kapruta.-Assad Farran hunts for onions.-Kosuku.-Kindness of Arab chief.-Poisoned arrows.-Kiba-Riba.-Shooting hippos.-Three great 
chiefs.-Tippu-Tib's names.-Dangerous natives.-Head men fear a night attack.-Quanga.-Nyangweé.-Kindness of Arabs.-Arrival at Kassongo. - Tippu-Tib.-Fertile country. — Salem Masudi. - Tippu agrees to provide men.-Sketching.--Tameson writes to Mr. Mackinnon.-Letter to Mrs. Jameson,-Arab customs.-Conversation with Tippu-Tib.-Muni Katomba.

1888. February 14th.-Left Yambuya Camp for Singatini. Yaweeko. Did a long march to Yaweeko. Crossed nineteen streams. Found a very beautiful small white tree-frog in the forest. Belly bright lemon-orange. Toes dark orange. Rest of body pure milky white. Eyes, black centre, surrounded by ring of bright gold, rest of eye reddish gold. Same size as small green tree-frog commonly sold at home. When put into a box, it faded into pale reddish white. It was found close to shrubs, some with pure white leaves, and others with light red leaves. Assad Farran was behind, took the wrong path, and did not get into camp until next morning.

February 15th.-Passed a very bad night. My clothes were wet, and as my bag did not arrive until this morning, I had to sleep in my shirt and waterproof. Mosquitoes and a host of detestable insects fed on my legs all night. Started late, and marched through the cane-brake beyond Yarina, when we missed our road and camped for the night. Assad Farran was again lost; he declared in the morning that whilst going up the bed of the stream yesterday he heard a fearful noise above the bank, and thinking it was some very large beast trying to climb a tree, he hurried on. In the village of Yarina there was a small patch of millet growing. When Assad Farran heard us discuss what sort of corn it was, he remarked that he thought it must be macaroni. The cane-brake was so trodden down by elephants that it was almost impossible to follow the track.

February 16th.-Some of the men went out at daybreak to look for Assad Farran, and Selim Mahommed went to find the right road. The men returned without Assad, so the Major and I started off to look for him. After going some distance, we heard shots in camp, and found that he had returned. Selim soon came in, 
and we made a start about midday, camping near the long water just as it got dark. Assad was again left behind, and men had to be sent out for bim.

February 17th-Marched into Yalisula about 3 o'clock, just in time to miss a heavy thunderstorm. One scene on the march formed a very beautiful picture. As the carriers wound their way in a long line over the white sand, now thickly strewn with brown dead leaves,

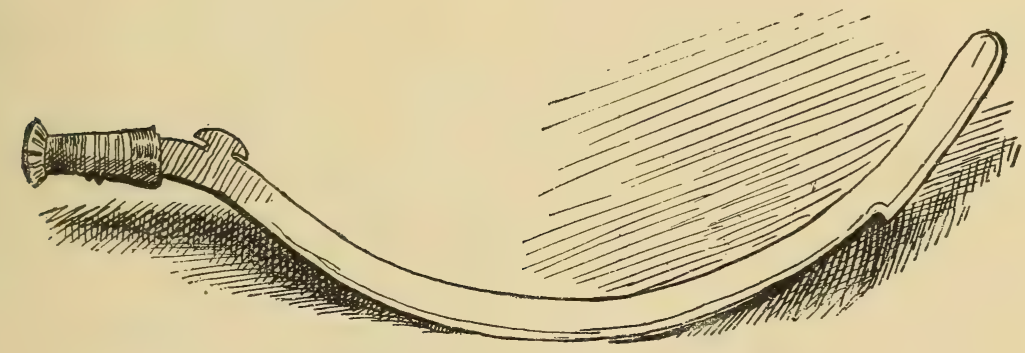

Small War-KNife.

and up the high wooded banks, gleams of sunshine fell upon them through the dark tropical foliage. In the foreground lay an old log across the stream, over which had crept mosses and large ferns, and far away through the depths of the forest, every now and again gleamed patches of sunlight on water and figures, while from bough to bough, hanging in graceful festoons, clung giant creepers. Saidi Chongo, the Arab in charge of Yalisula, made us a present of a splendid fish, carpshaped, weighing close on $20 \mathrm{lbs}$., and a goat, so we were in clover. Spent most of the evening in endeavouring to avoid the streams of water which came through the roof of our house.

February 18th.-After paying carriers, \&c., we got into canoes, and started up river about midday, and reached Yatuka, where we stopped for the night, at 9 P.м. Shortly after leaving Yalisula, we passed a number of canoes, filled with men from Kassongo, who we found were on their way to Selim Mahommed, at 
1888. our camp. He told the Arab in charge of them to Feb. 18. wait near Yalisula a few days, until his return. We left Yalisula in great style, with chiefs paddling us, and a band of drums in each canoe. The group of men paddling, and musicians in the stern, made a fine picture, full of life and action, and the singing and drumming added to the wildness of the scene. The Major, in the foreground, lying on a bale of cloth, surrounded by guns, bags, and cooking-pots; two boys seated behind him, one a little in front of the other; then two men paddling, standing on the bottom of the canoe, between whom stood a man singing, his right hand raised, using a switch as a batton; beside him, seated on the edge of the canoe, a boy, beating a drum between his knees. Behind these again stood two men on the high end of the canoe, paddling, and then another seatec, beating a drum. The red dye of the cam-wood, which adorned their hair and clothes alike, the monkey skins and feather hats, the knives hanging from the band over the shoulders, the brass and copper bracelets and anklets, all added to the bright and picturesque effect of the scene, to which one element lent a strong characteristic, viz. the tattooing on all the figures. I shot a very fine black monkey, with remarkably long hair. It is jet-black all over with the exception of a tuft of long white hair on each shoulder, and the lower half of the tail, which is white. It measures five feet two inches, from nose to tip of tail, the tail being very long. Skinned him in the canoe, by the light of a small palm-oil lamp, giving the meat to the natives, who sang with delight.

February 19th, Sunday.-Left Yatuka early and reached upper Tatiacusu about 5 P.M. Shot two large white-nosed monkeys for the natives. Found black and large orange weaver-birds breeding on the same tree. Slept in a native hut. The natives kept up singing and dancing nearly all night. We thought it was in honour of us, but discovered it was in that of a small boy who had been circumcised. 


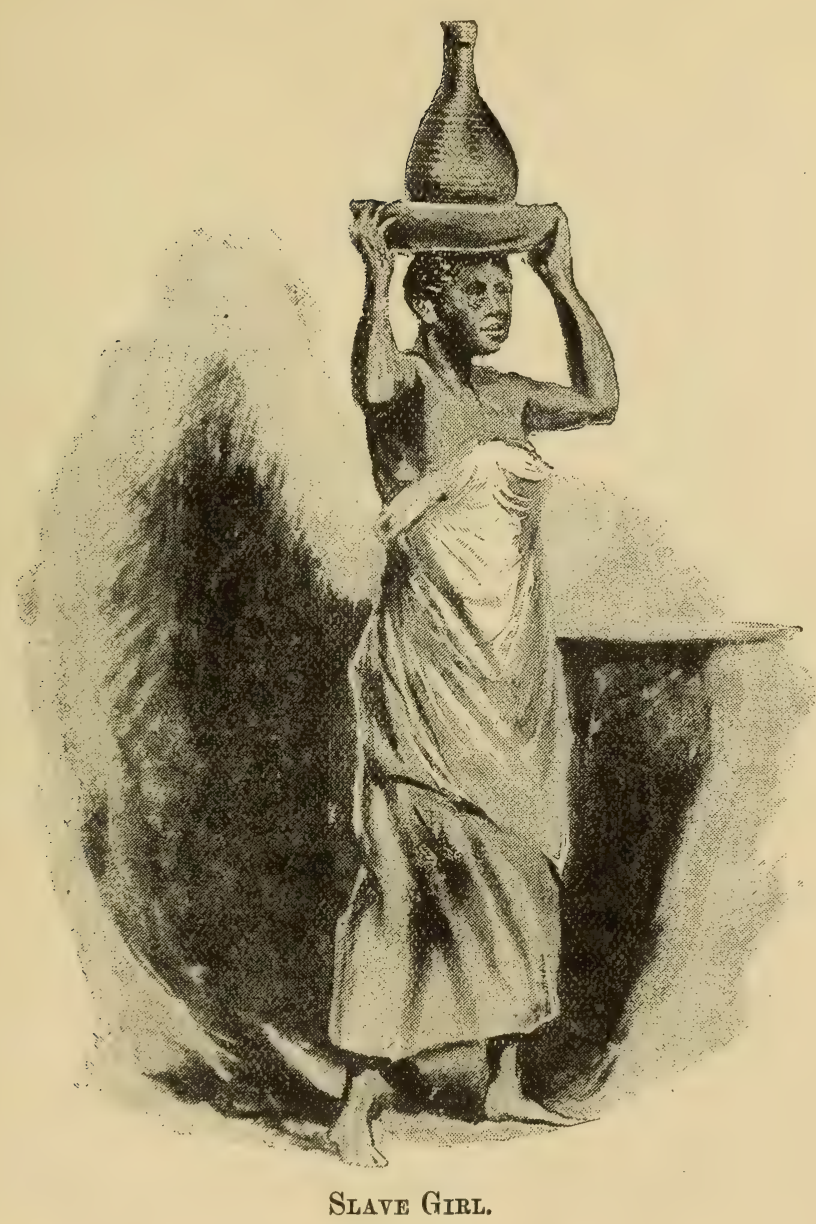

February 20th.-Left Tatiacusu, 8 A.м., and reached Singatini at 3 P.M. On our arrival we had an interview with Nzige, Tippu's brother, who told us that the 150 1888. men we had passed in the canoes near Yalisula had come from Kassongo, besides 50 more, who were somewhere else. Tippu-Tib would not be back until next month. No news whatever of Stanley. Tippu-Tib would bring more men with him, but how many he could not say. Altogether the interview was most unsatisfactory. He gave us the same house that Ward 
1888. and I had before. Heavy thunderstorm and rain nearly Singatini. all night.

February 21st.-Had an interview with Nzige, when Barttelot presented him with a very handsome knife. He again told us that two hundred men had come with orders to wait under Selim Mahommed at our camp until Tippu-Tib's arrival. The canoes have gone back to Kassongo to bring more men with Tippu next month. He was as anxious as we were about Mr. Stanley, and was very glad to see us here. Selim Mahommed came up to our house afterwards and gave us the same news, and he said that the people most likely to stop Stanley were those of the country at the southern end of Lake Albert Nyanza, who had been feared by Dr. Lenz, and who were governed by a very powerful king. He said he should like to go with us himself. Arranged to go after chimpanzees and buffalo to-morrow. 'The river is very full, and it is a fine sight to watch the natives lifting the fish baskets under the falls. Called on old Nasoro Masudi, who told us that Mahommed bin Said had gone to Kassongo, where he had married the girl intended for his grandson.

February 22nd.-Selim's men never came, so I sent down to Nzige for some, and as soon as they turned up, went for a long round through the forest, at the back of Singatini. Saw no fresh track of elephant or buffalo, but a good many fresh ones of antelope, although I did not get a shot. 'The Major had a bad bilious headache, so he did not come out. No news of any kind. The natives cannot understand where 'Tippu-Tib comes from; they declare his mother is either here or at Kassongo, and they are puzzled about his having come up the Congo with Stanley.

February 23rd.-Had a long day in the jungle on the other side of the river, looking for chimpanzees. Lately I have heard nothing but tales of the wonderful numbers of elephants, buffaloes, and chimpanzees which 


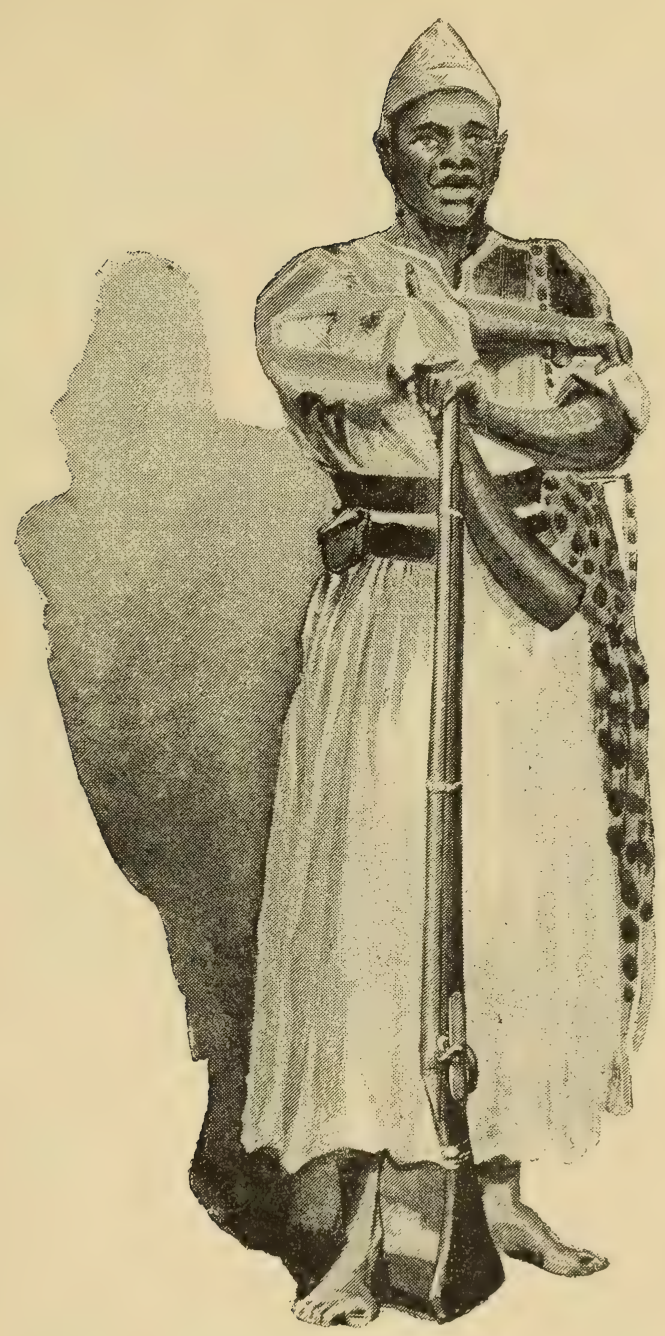

Mr Friend "Masudi," one or the Tamba-Tambas.

haunt this neighbourhood, but to-day I did not see a fresh track of one of them! A heavy thunderstorm came on at 2 o'clock, with torrents of rain and a gale of wind. Altogether I had a bad time of it. It is great fun crossing the river now, as it is in full flood,

1888. Feb. 23. Singatini. 
1888. and the canoes get twisted and turned about in the
Feb. 23. Singatini. most extraordinary way.

February 24th.-Another long day in the jungle on the other side of the river. Not a sign of any game; shot three small monkeys to pay the natives. Spent the whole day, with my chin nearly between my knees, going through cane-brakes, swamps, and thick jungle; luckily there was no rain. Selim Mahommed left for Yambuya. The white-nosed monkey (not the lesser) seems to be the commonest here. Saw the natives get a splendid fish out of one of the baskets to-day, which must have weighed at least 60 or $70 \mathrm{lbs}$. It was a large carp-like fish, and two men were carrying it.

February 25th.-A lazy day. Nzige and a number of Arabs paid us a visit and had a great inspection of our guns, and Nzige said he would give us a canoe and men to go up the Chopo River for two or three days' shooting. Some men arrived from Kassongo or Nyangwé this morning, but they were all for Sheik Habib on the Lumami River. The only news they brought was that Tippu was still collecting men at Kassongo. The Major and I took a long walk through the forest, and I shot a very fine nightjar and a large squirrel.

February 26th, Sunday.-Very dull day. Skinned the nightjar and the squirrel, and found inside the former a fully developed egg, pure white, and as large as a pigeon's. Bought some fowls and onions to take with us to-morrow. As Nzige's men did not turn up, he is sending us to a village of his, about three hours' walk on the other side of the river. Put a new sight into the Major's Winchester. Had a very vivid dream last night of Mr. Stanley's return.

February 27th.-Nzige asked us to start to-morrow, so we put off going till then. He has written to TippuTib, telling him that we are both here anxiously awaiting his arrival. From all accounts there seems to be plenty of game where we are going, and poor old Nzige seems quite pleased at the chance of our shooting him 
some ivory. Was rather seedy, so simply did nothing 1888. all day.

Feb. 27 .

February 28th.-Left soon after breakfast, and having crossed the river and marched for three hours in a N.E. direction, reached this village, called Batiumbēle. The head Arab, called Nunikatoto, had prepared a house for us, the only drawback to which was that the mud-walls were still dripping wet, it being only just finished. Arranged with Mabruki, a native chief of the nearest village, to start at daybreak to hunt for elephants.

February 29th.-Mabruki did not arrive till late. Saw fresh elephant-tracks, and having followed them some distance found another native was after them a long way ahead, so gave it up. Looked about through jungle all day, but did no gond.

March 1st.-Natives never came until 10 o'clock, and the consequence was that although we found fresh elephant-tracks and followed them until evening, we never caught them up. Got a shot at a chimpanzee, but the cane-brake was too thick, so I did not get him. The natives swear they will come to-morrow morning at daybreak.

March 2nd.-Natives did not turn up until late, so we packed up and returned to Singatini. The Major told Nzige that he wished to see him privately on business, so he came alone to our house. Barttelot then informed him that in consequence of receiving no news of Stanley, or from Tippu-Tib, and having important proposals to make to the latter, he meant to send me to Kassongo, to meet Tippu there, on his way to Singatini. The Major explained to him that the case was very urgent, and that he was going to convert our loads into half loads, as he knew that their weight was one of the reasons why we could not obtain carriers. He wished Tippu to supply him with 400 fighting men, as well as the 600 carriers. Therefore it was necessary to place before Tippu his proposals for men and their payment as soon as possible. Nzige 
1888. replied that the natives here refuse to go up river, that Singatini. his men were not able to paddle, but if I would wait ten or twelve days he expected canoes with letters and men (from Tippu), with whom I could return. He promised to send me by the first canoe that came, which possibly might be in a few days' time. He was most courteous, and assured us he would do all in his power to help us. 'Two of the cocks at the back of the house began to fight, a scene which appeared to be fraught with interest to this philanthropically-minded old gentleman!

March 3rd.-The Major presented Nzige with a box of matakas. He seems greatly annoyed at our getting no elephants. Late last night, as we were going to bed, two Zanzibaris from the camp arrived with a note from Troup to the Major. We both thought that it would either announce news from Stanley or a mutiny in the camp, but it contained no news beyond the general condition of the camp, and the fact that fifty men from Kassongo had arrived for us.

March 4th, Sunday.-Another lazy day. The Major and I meant to take a long round through the jungle, but it rained steadily most of the day. Nzige sent for us in the afternoon to see some canoe races, which were a failure. There were two canoes, one containing about fifty or sixty men, the other about half that number, and all they did was to paddle across to the other side! After this we had a long talk with Nzige, and told him a lot about England, and he expressed a wish to accompany us thither on our return, but inquired anxiously if he would receive many presents there, as, if he returned here without any, Tippu would request to know why he ever went!

March 5th.-We sent back Troup's messengers and one of our own men to the camp to-day. Sketched some of the people here. About 10 o'clock this morning we felt a distinct shock of earthquake. 'There was a hollow rumbling sound like distant thunder, and the whole earth trembled, giving our house and everything 


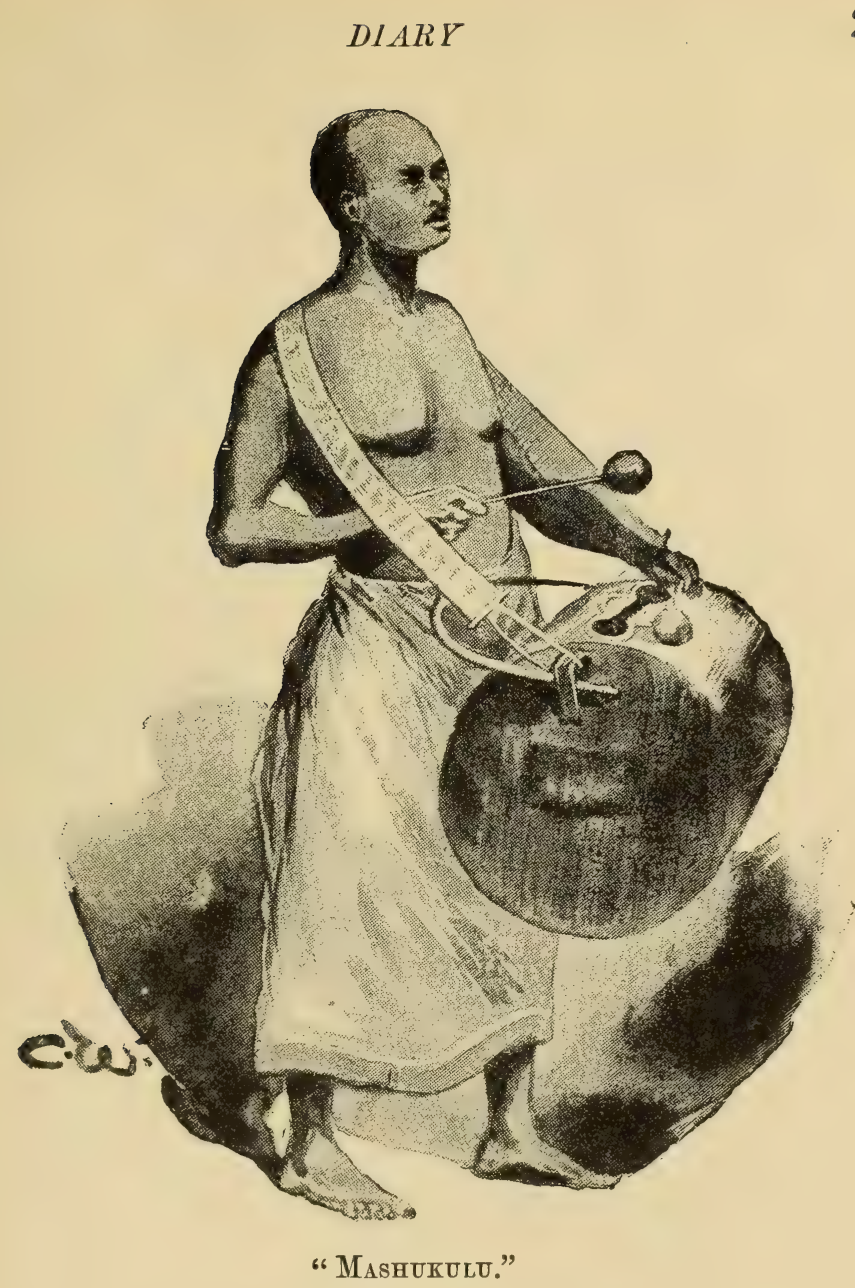

in it a decided shake. Barttelot and I took a long ramble through the forest, where I shot a very handsome weaver-bird, a parrot, and a squirrel.

March 6th.-Another lazy day. Sketched a small drummer-boy from Kassongo. The Major made two trips into the jungle, whilst I was sketching, in search of birds wounded yesterday. The first time he returned with a parrot, and the next with a large crested lory. I skinned the weaver-bird and took plumes from both the parrots. In the evening I made a great stew of

1888.

March 5. Singatini. 
1888. parrots, lory, \&c., which was voted a decided success. Singatini. The monotony of this existence is awful, and the harder to bear with the consciousness that the fate of $\mathrm{Mr}$. Stanley and his party may hang upon our course of action; and yet here we are, unable to move hand or foot, and praying daily for a canoe from Kassongo, that I, at least, may be able to get hold of Tippu-Tib. About one third of our force at Yambuya have died, and I fear many more will die before we leave it.

March 7th.-Sketched one of the chief Arabs here, and two women of his harem. No news. A man died here yesterday, and a good many are sick. It looks to me like small-pox.

March 8th.-Finished the sketch of Yahid bin Hamis. Never has life seemed so weary and utterly useless, and yet one can do nothing to alter it.

March 9th.-I find that most of the unenlightened Mahommedans look upon picture-drawing as a species of sorcery, and will not allow me to sketch them at any price. They say, if you wish to kill the person you have drawn, you have only to tear off the head in the picture, when the subject of the sketch will certainly lose his or her head. Even the more enlightened look askance at it. When I asked Nzige to let me make a sketch of him, he replied that he had not quite made up his mind, but would let me know when he did!

March 10th.

March 11th. $\}$ Fever.

March 12th.

March 13th.-Up all day, but still seedy. Have lost a stone in weight. I was to start to-morrow in a canoe, but in a letter received by old Nasoro it is stated that canoes and letters from Tippu-Tib will be here tomorrow, so I shall most likely get away the day after. Nzige urges that it is better for me to go in one of Tippu-Tib's canoes, as the men in the others do not belong to him. 


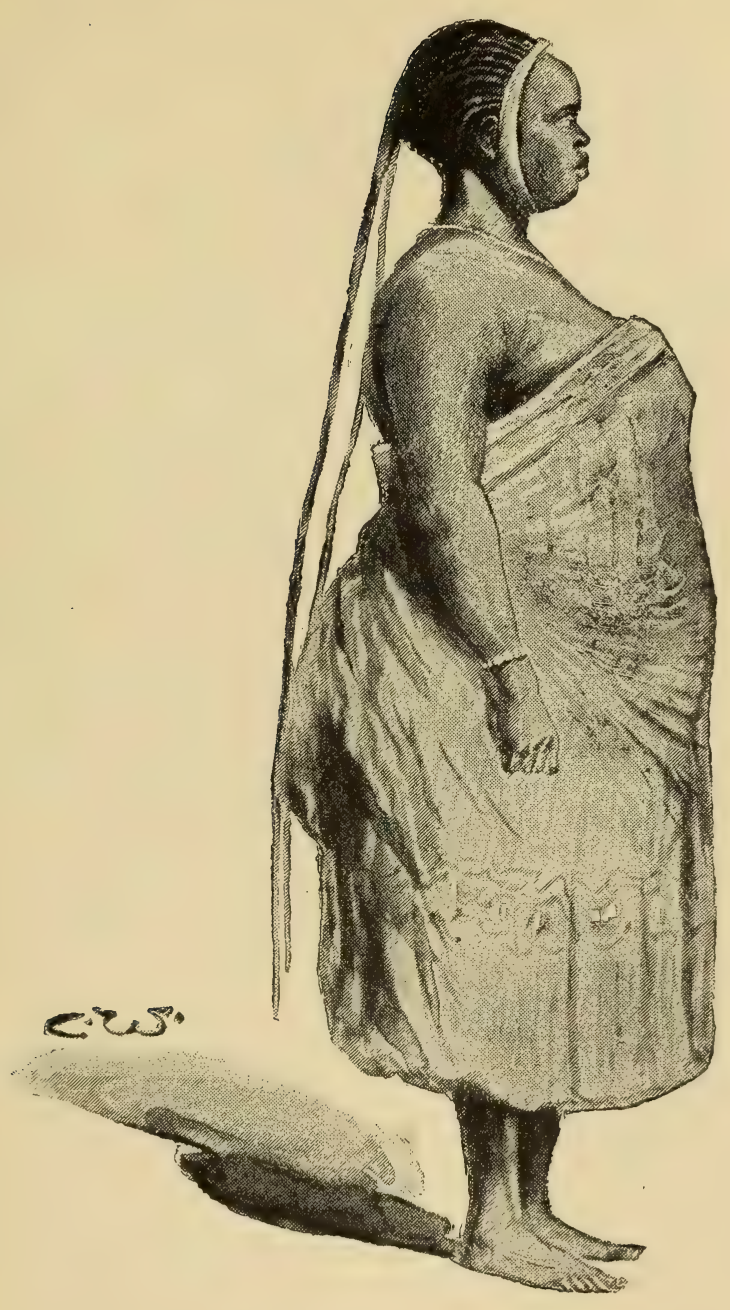

"Currt-Eyes," the Iight of the Hareu of Yahid bin Hamis.

March 14th.-Men arrived from Kassongo at last. March 14. Sixty were sent for us, but only fifty-two arrived, eight singatini. having died on the road, of small-pox. Tippu-Tib will not leave Kassongo until after the return of these canoes, so I start with them on Sunday. It takes thirty days 
1888.

March 14.

Singatini.

to get there, weary work when one is not fit. The Major is going back to Yambuya, and will make arrangements to send a white officer down the Congo in a canoe to despatch a telegram and letters to the Committee, stating our present situation, and asking their advice.

March 15th.-Took a stroll for the first time during the last six days. The Major is arranging with Nzige about a canoe. One of the head Arabs who live here, Nasoro bin Saef, arrived to-day, returning from a big slave and ivory hunt. There was the usual amount of shouting and shooting. It almost always rains here now at daybreak or in the evening.

March 16th.-Nasoro bin Saef brought letters to the Major from Troup. All is right at Yambuya, except that three of the men from Kassongo have got smallpox. Nasoro bin Saef had seen two deserters from Stanley's force, who are now at Abdullah Karongo's camp at Unaria. They had been there over two months, and asserted that Stanley had taken five months to reach the point at which they deserted. Seven of them left together, and it took them a month in a canoe, coming down stream, to reach Abdullah's camp. The canoe had been upset, and five of them were drowned or eaten by the cannibals. The native villages they had come to before they deserted were very large, but on the approach of the force the natives crossed to the other side of the river, so there was little fighting. All the white men were well. Stanley had been wounded near the ankle by an arrow, but was all right again. At a village above Unaria, Abdullah found a rifle and pieces of cloth.

March 17th.-Spent most of the day looking at canoes, as the Major wants to buy two for Ward to go down river in. He succeeded in getting one after a weary hunt among rotten ones. 


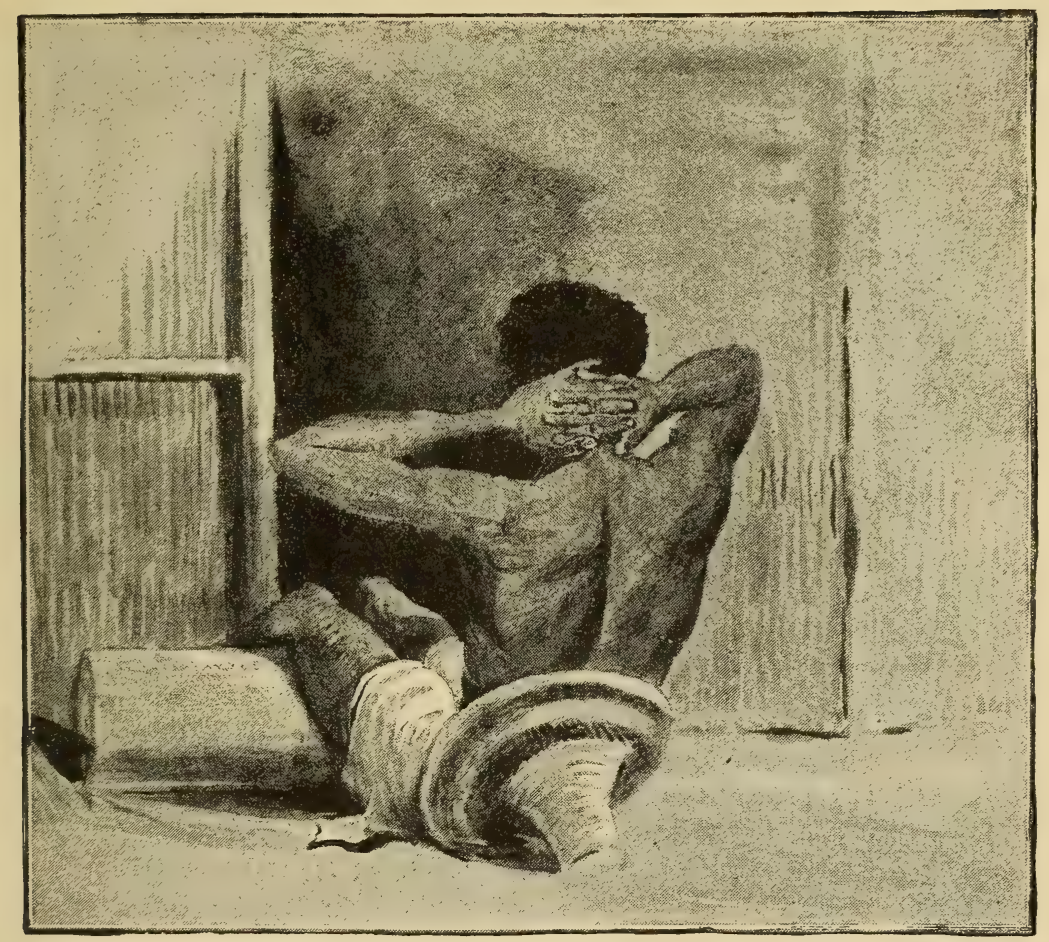

A Savage taking his ease.-Stanley Falis.

FROM A LETTER TO MRS. JAMESON.

Stanley Falls, Upper Congo, March 17th, 1888.

.... At last, after all these long weary months, I think there is a chance of a letter reaching you. Not one word have I heard from you since that letter written from Italy, dated April 28th, 1887, now all but a year ago, and you can imagine how anxious I often feel. In my last letter to you in August, I told you that by some bad luck we might be left in the camp at Yambuya until Mr. Stanley's return in November. But, alas! he has never come back, and we are there still. I only left it the other day, with Barttelot, to come here

1888. March 17. Stanley Falle. 
1888.

March 17.

Stanley

Falls. and see Tippu-Tib, but he is at Kassongo, about 300 miles from here, higher up the Congo, and not far from Lake Tanganyika, and I have to start off in a canoe to-morrow, and do thirty weary days' journey to see the great Tippu-Tib, and force him to come to definite terms once and for all. The Major goes back to Yambuya, and will send two canoes down the Congo with letters and a white officer to send a telegram to the Committee in London, telling them of the serious situation, and asking their advice. The last report of Stanley's party that is at all authentic was brought here yesterday by an Arab who has been at an Arab camp a long way higher up the Aruwimi River than Yambuya. . . A According to him, it must have taken Stanley the whole time, in which he meant to go to the Lake and return to our camp, to get to the point on the Aruwimi River at which the deserters left him! We have not heard a single word of really authentic information about him, and not one atom of news sent personally by him, so we take it for granted that he is in a very bad scrape of some sort, and evidently in such a position that he is unable to get any news out to us. I will now tell you our part of the history. On August 23rd, the men from Tippu-Tib never having arrived, Barttelot sent me off to Stanley Falls to interview Tippu'Tib personally on the subject, and I did not return until September 12th. My interview with him was most satisfactory; he made the most plausible excuses for the non-arrival of his men, and gave the most gushing promises of instant aid. The result of all these promises was that after many weeks sixty-four men arrived, which small number was of not the slightest use to us. Barttelot then went in October to Stanley Falls, and there saw Tippu-Tib, who informed him that he could not get the men there, and must go to Kassongo to obtain them. He left for that purpose early in November, but up to the present date he has only sent us two hundred men altogether. You can imagine how utterly helpless we are, and how utterly dependent upon Tippu-Tib, when I tell you that we have already lost fully one 
third of our entire force at Yambuya Camp from sickness, and that I do not believe we could produce eighty really sound carriers to-morrow, and yet we have between six and seven hundred loads there. This hope deferred, and weary waiting, month after month, with no brighter outlook, is horrible work, far, far worse than any amount of hardship and fighting. No steamer has been up the Congo since the one that came to us in August, so that we are completely shut off from all the world. ... When I look ahead and see nothing but darkness, and no signs of its brightening, it drives me nearly mad at times. If my interview with Tippu-Tib is satisfactory, I may expect to be back at Yambuya at the end of the second or third week in May, and then if we have the whole 600 carriers and 400 fighting men we want from Tippu-Tib, or as many under that number as he can give us, we shall start at once up the Lake to relieve Stanley, or at least find out what has happened to him, and see if Emin Pasha is still there. If we do not meet Stanley before we get to the Lake, and are detained there for some time, I do not see that we can get home much before the New Year; but, on the other hand, Stanley may turn up any day, in which case we could be home as soon as the end of September, or beginning of October. If Stanley is really in a bad fix, and we succeed in relieving him, I am afraid that by that time there will be little hope of our being able to relieve Emin Pasha; but still we shall have done all that lies in our power. . . . . My pleasures in this existence ( $I$ cannot call it anything else) are few, but the most enjoyable of them was on the anniversary of our wedding-day, when we had quite a feast in camp. We killed an enormous goat which Tippu-Tib had sent me as a present, and feasted right royally in your honour. We ate to your long life and happiness, for we had nothing to drink it in. I have done a great deal of drawing and painting in my diary, and am looking longingly forward to the day when you and I shall go through it all. Ever since Mr. Stanley's non-arrival in November there has been a sort of gloom 
1888. over all of us in Yambuya Camp, sometimes brightened March 17.

up by the news of approaching help from Tippu-Tib, only to be made darker by the help being put off for indefinite months. It is a sad, sad sight, to see men dying round you every day and not to be able to put out a hand to save them. Without a single fight we have lost close upon seventy men out of our small force, and there are many more who, I am sorry to say, will never leave that camp, or, if we leave it, must be left there to die. I have had my turn of health and sickness, but I must thank God that I have been in better health than almost any other officer. . . . I have learned nearly the whole of the 'Light of Asia' by heart, and there is something of real comfort in the many beautiful truths contained in it. I am sending you a small telegram, just to tell you I am well, as I know you will value one small one from me more than the long one that goes to the Committee! I am afraid I shall arrive at Zanzibar with literally nothing but a few rags upon my back. As Stanley would not give me another carrier, I had to send a lot of really necessary clothing, \&c., to England, in order to be able to carry my ammunition and collecting-things. I will write you another long letter from Kassongo which I will send to Zanzibar. I am going alone, with only an interpreter and two boys. It seems so sad to have to go all the way to Kassongo (so far on my way to Zanzibar), and to have to turn back again. And now good night and good-bye; kiss the little ones for me, and may God keep you all in His safe keeping. ...

\section{DIARY (continued).}

March 18th, Sunday.-Started for Kassongo at last. I am sorry to say I left the Major very seedy indeed, and I attribute both our illnesses principally to the want of proper food. We have had nothing to eat but fish, seldom fresh, boiled to rags in a little water, plantains and sweet potatoes soaked in palm-oil of the coarsest description, and scarcely cooked. I had to 
wait two hours while Nzige finished his letters, and to while away the time Nasoro gave me about the best curried fowl I have ever eaten, and I did not waste either my time or the fowl! We got away at 2 o'clock and camped at a village called Atkaléla* at dark. I slept in the canoe, as there were only about four square yards of open ground, upon which all the natives lay around the fires. The smoke was so dense that the mosquitoes had no chance of living, and human beings but a poor one.

March 19th.-Started at daybreak and kept steadily on all day until 5 o'clock. The banks continue the same as lower down, thickly covered with dense tropical vegetation.

March 20th.-We sent the canoes up over the rapids empty, and carried all the ivory and loads round by land. The path was a good one, and we did it in little over an hour, after which we journeyed on in the canoes till sunset. I again slept in the canoe. Had a bad night; there was a lot of water in the canoe, and the Kassongo natives are perfect devils at arguing all night at the top of their voices. You stop them, but in about ten minutes, just as you are dropping off to sleep, you will hear a whisper, which soon swells into a louder dispute than ever. The village we stopped at, in common with the whole group on this bank, is called Yankéwé. I find all the villages are built in groups, each group bearing a sepatate name. From the rapids (where we had to portage) to Yankéwé it is navigable for $\varepsilon_{0}$ steamer, but the numerous rocks make it very dangerous. One very bad passage cannot be avoided. When we camped, the natives came down in great numbers. They are a very wild-looking set of fellows, many having guns. Their spears are quite different from those used below Stanley Falls and on the Aruwimi River, being very long in the shaft, and having a short broad blade, sometimes not longer than three inches. They brought a

- See Map. 


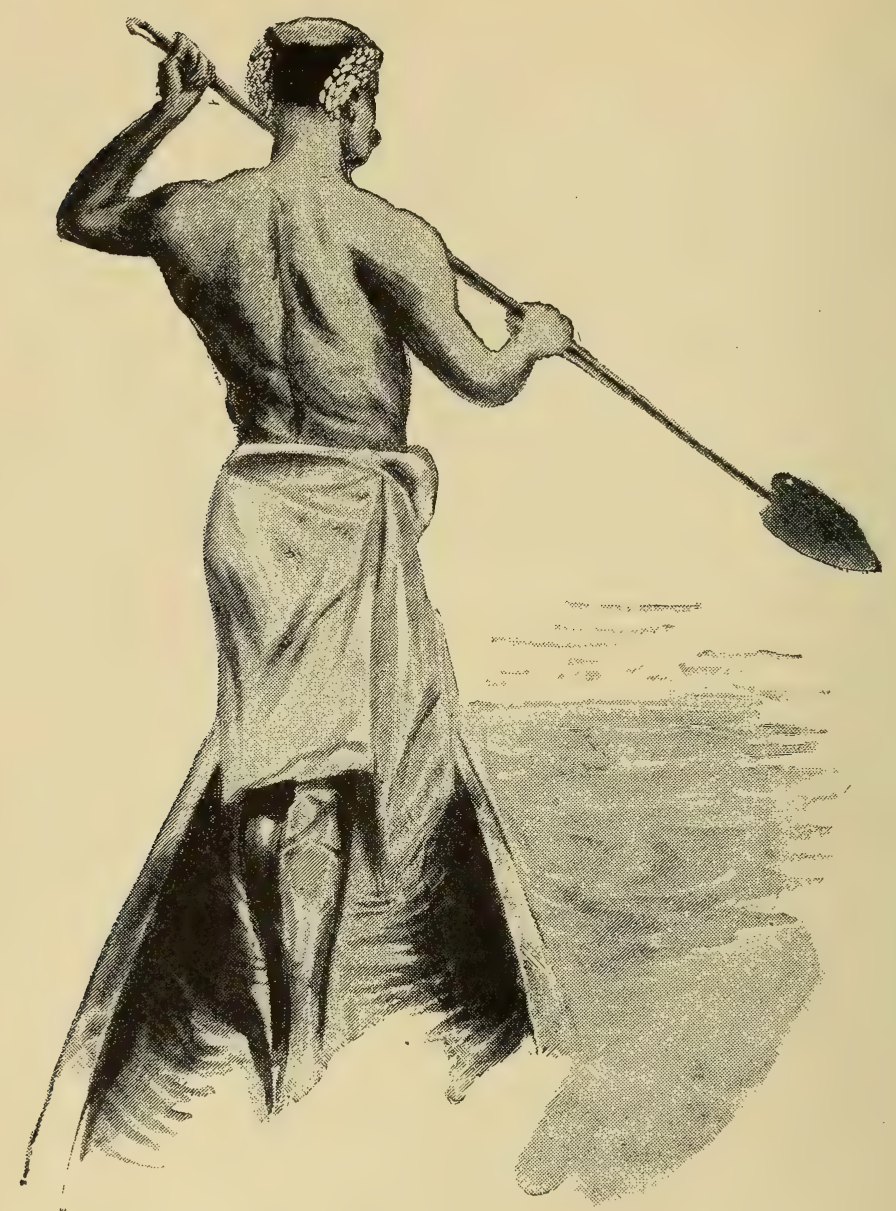

Mr Bow PADdLe.

1888. small chimpanzee to sell, but wanted a gun for it, so I March 20. could not buy it. It was a comical beast, and the very Yankéwé. image of the one at the Zoo, though not so large. I saw the first limestone to-day since passing a small river near Banza Mantéka, below Stanley Pool. The banks of the river opposite Yankéwé are limestone, with some very pretty caves in them. 
March 21st.-Terribly slow day's work, only going for some time at the rate of one mile an hour. We started before daybreak, and soon passed ten canoes full of men from Kassongo, in charge of an Arab, Rachid ben Serur. He stopped and came into our canoe, and told me he did not know if any of the men in them were for us, but that five of the canoes were for Nzige. He did not know the number of men, and I could not count them, as they were all mixed up with boys and women. He said that Tippu had sent an Arab to Ujiji for men, and that he thought Tippu-Tib would not leave Kassongo until after Ramadan, which is in May. The bank on our left is composed of sandstone rock, and very steep. We passed numerous villages, the natives of which wanted to exchange canoes for guns, the price of a canoe being one gun. Some of the canoe landing-places would make pretty sketches. They are clefts in the sandstone rock, with steps worn or cut in them, rising from a small open space at the water's edge, from which spring giant-stemmed trees, with festoons of enormous creepers hanging from them. The whole picture should lie in deep shadow, with a streak of bright sunlight falling through the trees, from high up in the cleft, on the dark forms of the natives as they sit or stand round the bases of the giant stems. We camped at Wonyakimbi, a village in charge of some of 'Tippu's Arabs, where I secured a hut, and passed a much better night than the last, although the mosquitoes were bad. Opposite the village lies a low, long, grass-covered island, with a number of hippopotami on it.

March 22nd.-Started at daybreak and reached Wamanga Rapids about 12 o'clock. Here we passed three canoes full of men from Kassongo, belonging to TippuTib, but I don't think they were for us, as they were most of them the white-shirted Tamba-Tambas. Pitched my tent and made a sketch of the rapids. The natives here wear large ear-rings of semicircular teeth.

March 23rd.-It was almost a quarter of a mile to 
1888. where the real rapids began. Here the whole river Warch 23. rushes through a passage not more than one hundred yards wide, and at very low water not more than sixty. Everything was taken out of the canoes and carried up to the head of the rapids by the Kassongo natives, or Wagania, as they are called, to a distance of about two miles. The natives of Wamanga hauled the canoes up the rapids, and in many places over the bare rocks. They are paid at the rate of an axe for every canoe. The canoes and all the loads reached the head of the rapids at mid-day, but not a foot further than this point would the men go, although I used strong language, and swore that Tippu-Tib would have vengeance on them. Eventually I had nothing to do but to pitch my tent and make the best of it. Got another sketch of the rapids. The view is not at all unlike Millais's landscape "The sound of many waters," strange as it may seem.

March 24th.-Started at daybreak. After some hours came to rapids, and passed the mouth of the Waundwy River, which looks about the size of the Chopo and Wamanga rivers, but from the little current in it I should not think it is large. The colour of the water is rich dark brown, quite different from the muddy waters of the Congo. We stopped for the night at Bangingélé, which is under 'Tippu-Tib's Arabs. I slept in the canoe, as we were to make an early start. At the rapids we met two canoes full of men from Kibongé. They told me there was a man named Mirabu at Kibongé, who had seen Mr. Stanley a long time ago, far up country, still on his road to the Lake; there Stanley had given him two guns, and had spoken of boxes which he wished to get to our camp. This was all I could elicit from Farani, whose English is very imperfect.

March 25th, Sunday.-Started before daybreak and reached Kibongé, about 5.30 P.M. It is a large place, more than twice the size of Singatini. 'There are a great number of Arabs, evidently from all parts, here. 


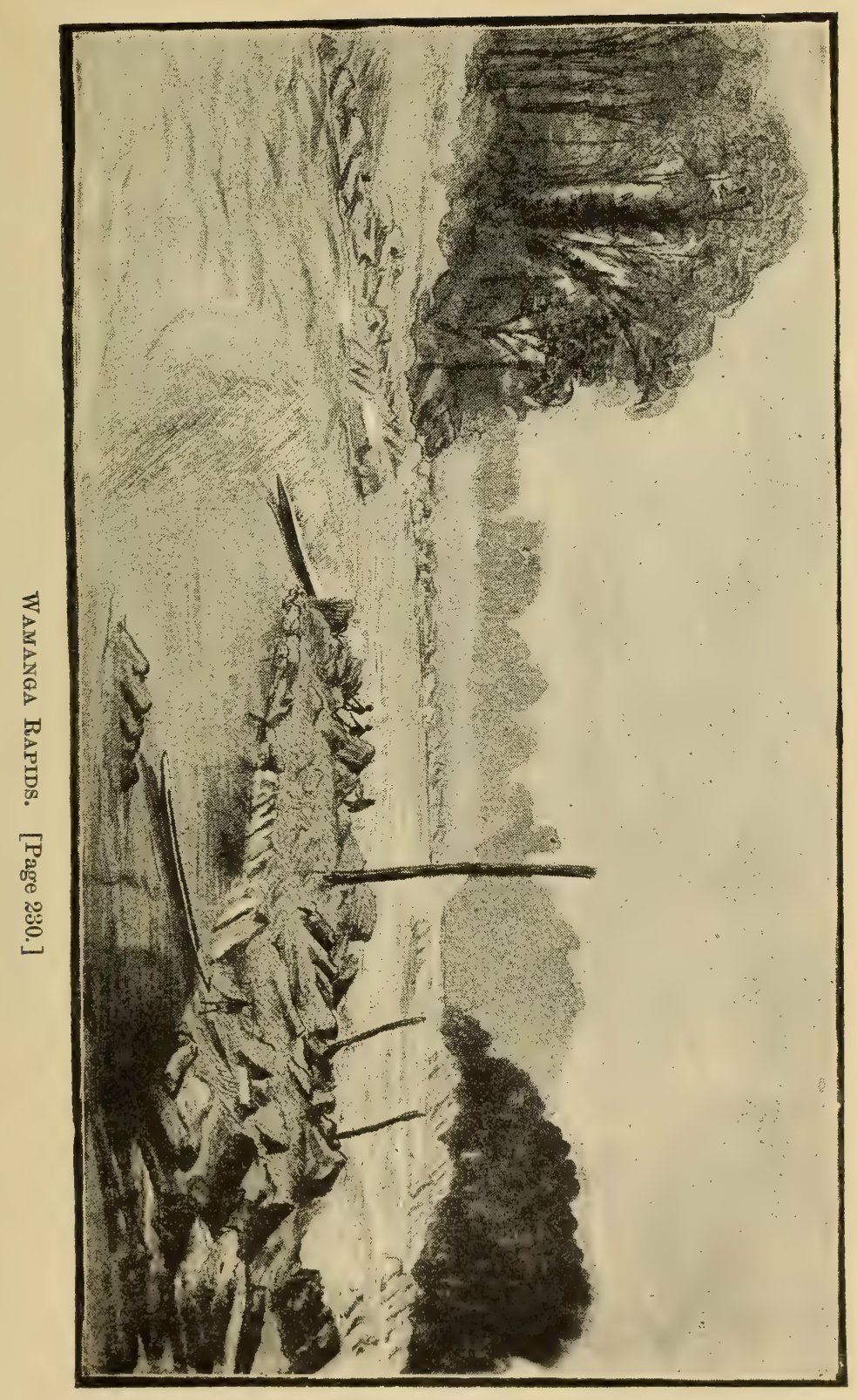





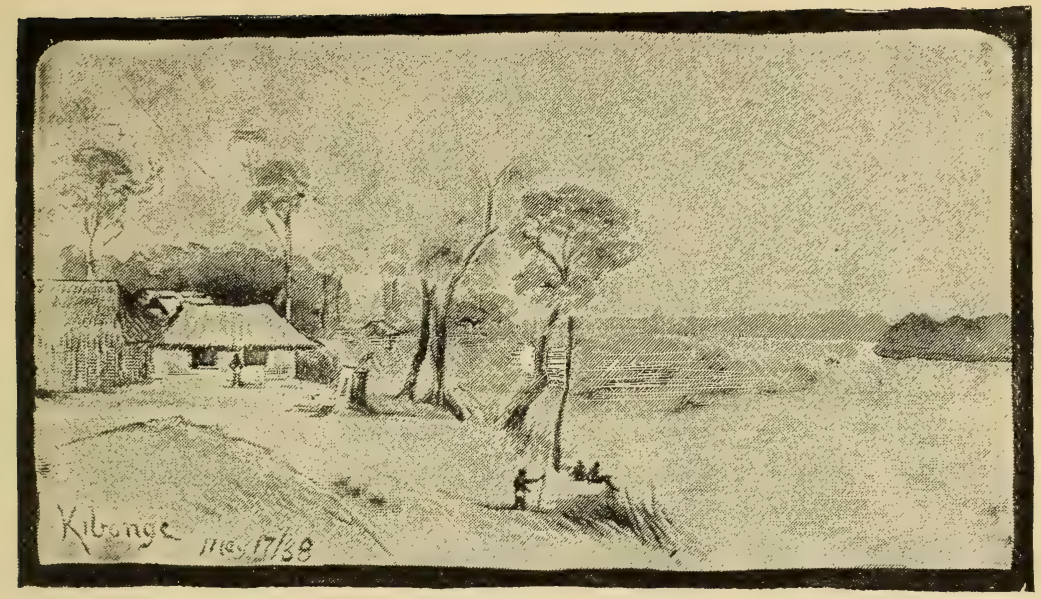

Kibongé.

They gave me my choice of two houses, telling me to March 25 . ask for whatever I needed, and brought me one bowl of Kibongé. the most delicious thick milk and another of fresh milk. I am in luck, as I have every symptom of a dose of dysentery, and the milk is the very thing I wanted. They have four cows here ; there were six, but two died from the fly and eating bad grass. They also gave me lovely ripe bananas and guavas, but, alas! I could not eat them. The chief Arab, Kibongé, is away, but his representative, Sala bin Ali, did all he could for me; he assured me that men from this place had met Stanley very far up the Aruwimi River, when he had left forty sick men with them, and given their guns into the Arabs' charge. There is one Arab here from Madagascar who speaks a little French, but it is very difficult to understand the little he does speak. 'The whole place is under the chieftainship of Kibongé, an Arab who came from Madagascar, and who has given his name to the town. He is himself subservient to Said bin Abéde, whose headquarters are at Nyangwé. His people hunt for ivory and slaves, principally to the $\mathrm{N}$. East; in this way they avoid interfering with the 
1888. followers of other Arabs. Although I was given a Karch 25. house, I could in no way call it my own. Every Arab here appeared to have sent his women to see me, and they were regularly ushered in, about ten at a time. Every Arab who knew any language but his own attempted to interview me in it; I was tried in English, French, and Hindustani. Added to this my host started a band of drums and women singing, so altogether I had rather a bad time of it.

March 26th.-Ali bin Hanis says there are no deserters from Stanley's force here. The report arose from the fact of the forty sick men having been left with the Arabs, to whom also Stanley gave their guns, with orders to keep them until his return along that road. Spent most of the day and half the night in writing letters to Mr. Stanley and the Major; the one* to the former I am sending to Eturi, the place where the Kibongé men met him, as it may find him on his return, or before we meet. I find that Kibongé is an independent chief, only slightly subservient to Said bin Abéde. Kibongé, Said bin Abéde, Said bin Habib, Muni Mahara, and Hamed bin Hamis, chief of RibaRiba, are among the important Arab chiefs, who owe no allegiance to Tippu-Tib, and only act with him in any common cause, each owning a separate district for slave and ivory hunting. In a very few years, I should say, these Arabs will have overrun the whole of Central Africa. There is no road between this and Stanley Falls. The general opinion here is that Stanley has met with no mishap. I was badgered the whole day by interviews with all the Arabs, and finally refused to see or to be seen by any one who was not of great importance, the female element being entirely kept out. The Kibongé people presented me with a large sack of rice and a sheep. My host, whilst striving to impress upon me the importance of such a present, told me he was one of the chief men at Kibongé, and had given me his house, and suggested that I should therefore give

* See 'Life of Edmund Musgrave Barttelot,' Appendix III. 


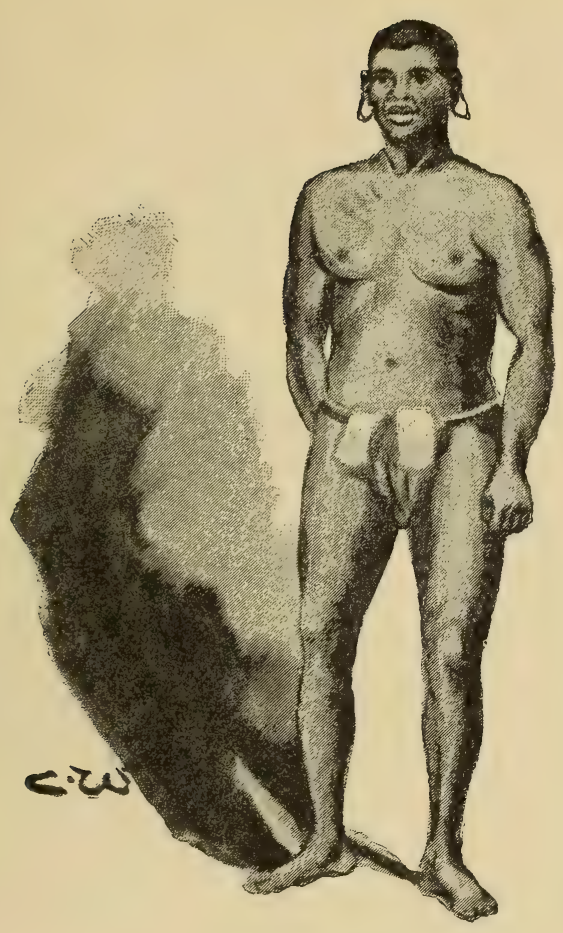

Native of Wamata.

him a whole piece of handkerchief, and ten matakas for each of his women, of whom he has fifty! Kibongé's representative, Sala bin Ali, also presented me with a 1888 . March 26. Kibongé. sack of rice and a quantity of delicious limes and guavas. My host, I am sorry to say, has been more or less intoxicated with palm-wine during the whole of my stay here.

March 27th.-My host, one Kapruta by name, told me a long story last night of how he had met Stanley on his road across Africa at Nyangwé. I started from here with a fat-tailed sheep (only so in name!), two sacks of rice, a lot of guavas and limes, and a large bundle of sugar-cane-all presents from the Kibongé folk. They have a donkey here as well as the cows. 
1888. The town is larger than I at first supposed, quite four Karch 27. times as big as Singatini, and the gardens extend to a great distance. They say it is very unhealthy, fever being prevalent, owing to the cold and damp. It seems to be a great centre for ivory trading, which is of course accompanied by slave-dealing. We did not get away until 11 o'clock, principally owing to Assad Farran, who was loafing about on his own account, hunting for onions, and I had men out searching for him for over an hour. The head Arabs appear to lead a very idle life, leaving all the slave and ivory hunting to their followers. My host, a decidedly lowcaste Arab (if one at all), spent his evenings in the midst of his fifty women, with a band of Kassongo drums and rattles playing incessantly, whilst the women grunted and squeaked a most unmelodious chant. This was generally kept up till midnight, though I think the time of duration greatly depended upon the amount of palm-wine he had drunk. We did a good day's work, camping about 5.30 amidst splendid timber on the river-bank. I had to kill the sheep, which, having been tied to the bottom of the canoe, was nearly dead from the heat of the sun. I find that a present of a few matakas to the men in the canoe has a wonderful effect; they worked splendidly, to-day. Five canoes have joined us from Kibongé, so our fleet consists of seventeen canoes, and a pretty picture they make, winding up the river with their white awnings and red and white flags, beneath the shadows of the tall dark forest trees.

March 28th.-So far the birds and butterflies are the same as on the Aruwimi River. Last night the mosquitoes were terrible; they simply dragged the handkerchief off my face!! Some of our camping places are the most swampy, feverish spots I have ever seen, notably the one we camped in this evening. As caravan after caravan camp in the same place, without paying any attention to cleanliness, the condition of these resting-places can be better imagined than de- 
scribed. Assad Farran says he has had a bad fever, but I think he has overeaten himself on onions. The March 28 river the Kibongé river-banks here are low, but the timber is very to Kasuku. fine.

March 29th.-Did the best day's work since we started. We kept in close to the bank on our right, and although there were many villages on the other side, we did not go near them. The men say that the natives living between our last resting-place and the mouth of the Roba River are a very bad lot. The Arabs can do little or nothing with them. Almost all the villages have asked at different times to have a man from the Arabs stationed with them, but as it always ended in their being eaten, they have given up sending them. These villages and the Roba River belong to the Kibongé hunting-grounds. The Roba River flows due East, but, as far as one can see up it, comes from the N.E., and is very densely populated; the natives are said to be very dangerous. Nearly all the villages here have a number of guns, thus being on a more equal footing with the Arab settlements. We had some splendid canoe racing in the evening. I shall thank Heaven when this monotonous journey is over. The scenery never varies: nothing to be seen but timber, water, and low islands, and one's only possible attitude is sitting cramped up like a trussed fowl the whole time.

March 30th.-Reached Kasuku, an Arab village at the mouth of the river of that name. During the last two or three days I have noticed a great increase in the number of palm-trees, which makes the vegetation look more tropical. At mid-day we passed the mouth of the Linde, a large river flowing into the Congo on the left-hand bank, from the East. The Kasuku is not more than twenty yards wide at its mouth, although the Arabs tell me that it comes from a great distance. The town is built on both sides of it. On my arrival I was taken to a small reception shed, and inspected by 


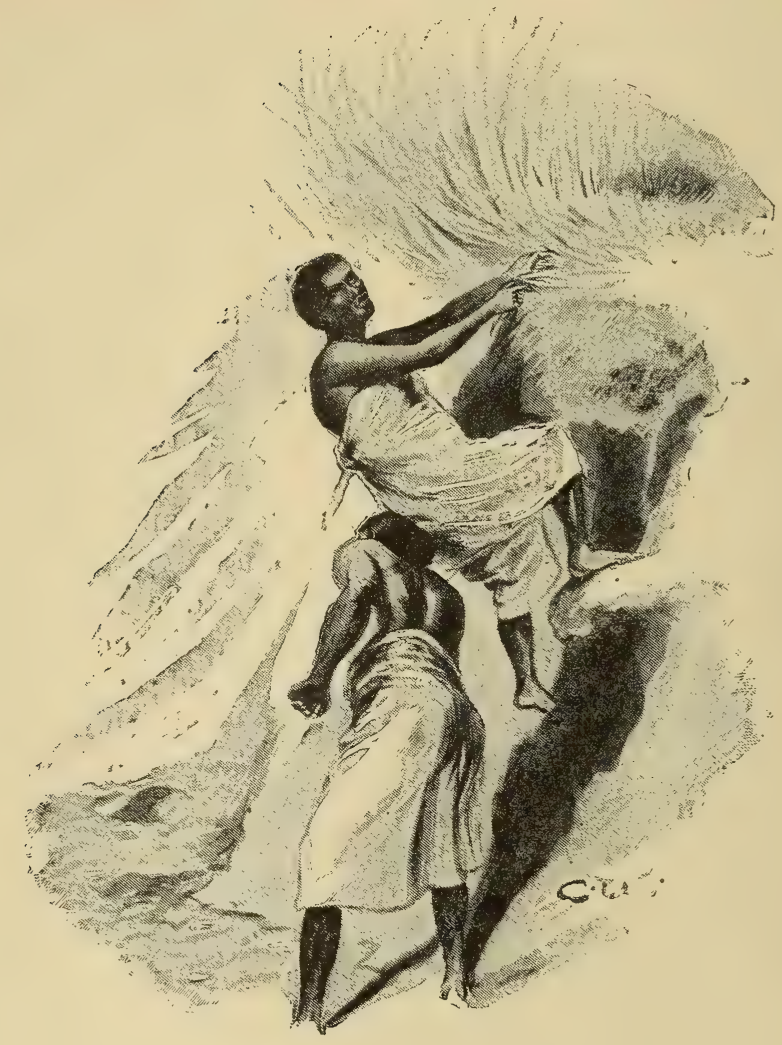

"A LONG SHOVE, AND A STRONG SHOVE, AND up SHE GOES!"

1888. all the inhabitants, both Arab and native. Presently March 30. they brought me two enormous baskets of rice, which Kasuku. filled three sacks, four fowls, and thirteen fresh eggs, all of which I was told were presents from the chief Arab, who was sick and could not see me. I asked one of the head Arabs whether the natives used spears or bows and arrows, and he replied the latter. He 


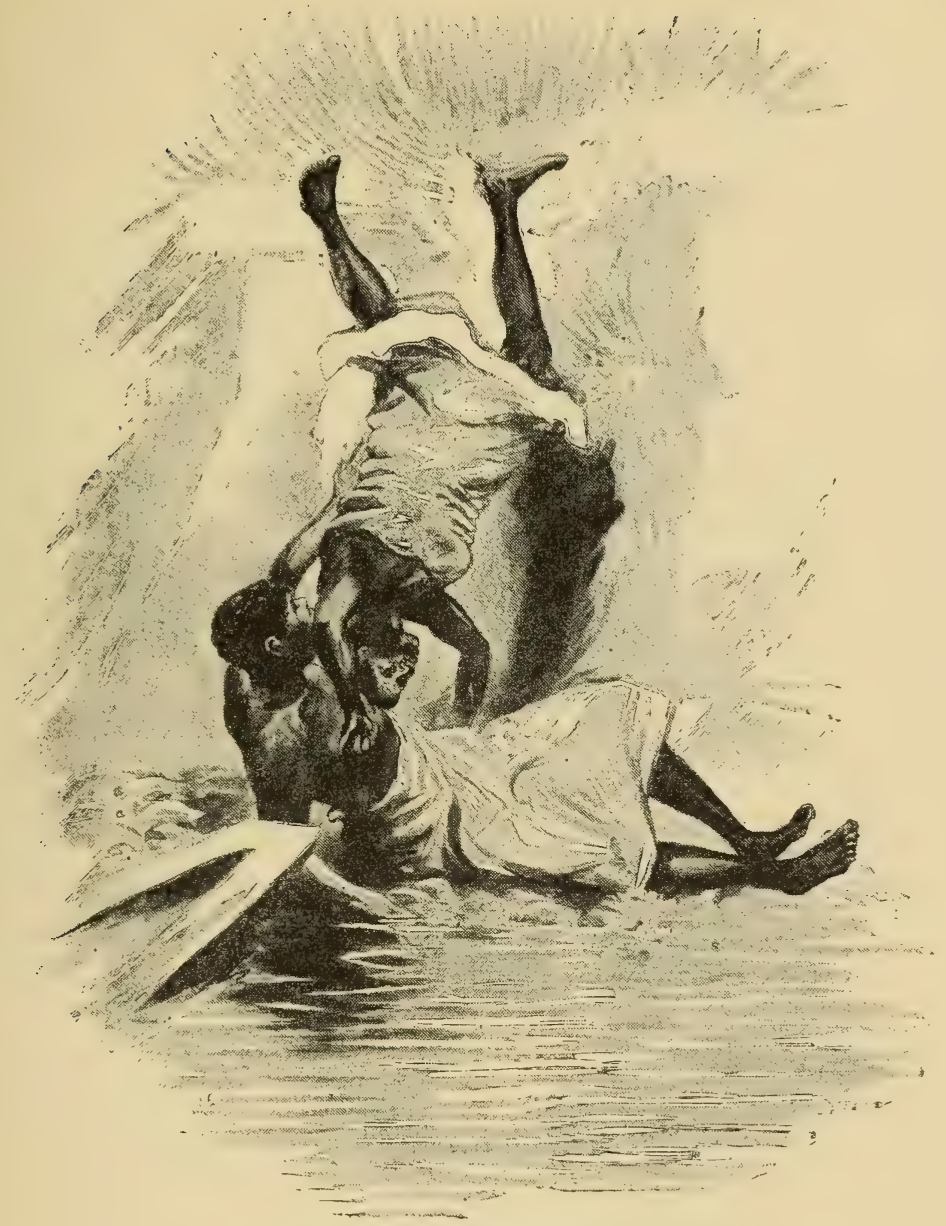

"AND down SHE COMES WITH A RUNe"

ordered one of the natives to bring some. The arrows are long thin slips of hard wood, not much thicker than a match. Some of them are poisoned and very deadly. 1888. March 30. On inquiring of the natives what the poison was and where they got it from, they replied that they obtained part of it from a tree, and mixed it with snake poison, as well as with portions of the body of a child which 
1888. had been dead a long time, heating it all up together March 30. in a pot, thus composing a veritable hell-broth! I was given a house to sleep in. The women's dress here consists of a thin string round the waist, with a very small piece of cloth hanging down behind, and a yet smaller strip of plantain leaf hanging in front, which I think was only put on for the occasion. The men, I am happy to say, are more decent, which seems to be the case with all the natives of the Upper Congo. The hippos are distinctly on the increase. I would much prefer to sleep in my tent, but one cannot well refuse the chiefs' hospitality, when they turn out themselves, bag and baggage, leaving behind them, unfortunately, legions of smaller inhabitants who are not so easily evicted. I regret to say that the canne is densely inhabited by more than one species.

March 31st.-We started at 9 o'clock, and did not stop until 9 P.M. Just before dark, the natives ran the canoe under a tree, and all but upset us. An Arab ran forward, and administered to one of them a licking with a stick; the other at once jumped overboard. When he got in, the belaboured man jumped over, but after a great deal of talk and many threats we made a fresh start. Finally, long after dark, we stopped at a place where I was informed there was no fire-wood, and therefore I could have no food, and the men refused to go on. I sent for the head man and told him in very forcible language that fire-wood must be produced, or I would go on. The fire-wood was produced. It is no use being complaisant to these head men; the only plan is to let them know what you want, and that you mean to be obeyed. The banks, and in some parts the country inland, are now frequently covered with long grass, and palm trees instead of forest, and I noticed numerous buffalo-tracks in these places. My host of last night evidently distrusted the white man. There were two hens sitting on eggs in the room I slept in, and this morning, before we left, he asked leave to come 
in and see if they were all there. Although I took none of the hens' eggs, I am afraid I took with me a number of the inhabitants of the small species mentioned above.

April 1st, Sunday.-Started at the first streak of light, and went on until 3 o'clock, when we reached our camping-place. I had pitched my tent and made everything ready for the night, when they informed me that they would start again as soon as the moon was up, so I took down the tent, and slept in the canoe.

April 2nd.-We started directly the moon was up, but after a couple of hours had to put in for shelter to escape a heavy thunderstorm. When it cleared a little we made a fresh start, but before reaching Riba-Riba the rain came down in torrents again and lasted until 10 o'clock. We have to sleep here to-night. The chief, Mahommed bin Hamis, is a little old Arab with very Jewish features, except about the lips, which are very thin. He placed a house at my disposal, and sent me an excellent breakfast of curried mutton cutlets and coffee. After breakfast I got some of the Kassongo natives and a canoe, and went off to shoot a hippo for the men. Just opposite the town and at the back of an island there were two, one of which I shot, and left a man watching for it to rise. I then went after an old bull, and fired four shots at him, missing him every time. He was very mad, snorting and rearing his head and neck clean out of the water. I was still more mad! The rifle was a Remington, with, I shoulu say, a 40-lb. pull, and each time I had to pull so hard it threw the muzzle up. The men in the canoe were fearfully disgusted; so was I, so much so that I went straight back to the town, where I found that the man whom I had left watching the hippo had been taken away by the natives, so we never got one after all. I took a fairly good sketch of the chief. It is a curious fact that the Arabs, and I may say all the natives, hold a 


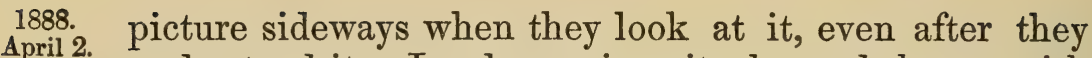
April 2. understand it. Landscape is quite beyond them; with any amount of explanation they do not understand a picture as a whole, although they will recognize trees or figures in it.

Mahommed bin Hamis is an independent chief. The three great chiefs of this country are Tippu-Tib, Said bin Abéde, and Said bin Habib. Then come such others as Kibongé, Mahommed bin Hamis, and Muni Mahara. Tippu-Tib's two chief towns are Kassongo and Singatini, at Stanley Falls. Said bin Abéde's headquarters are at Nyangwé, as are also Said bin Habib's and Muni Mahara's. Tippu-Tib owns the whole of Manyéma. At first there was much quarrelling and fighting amongst them, but now they are settled, and each chief owns large districts, in which they hunt for ivory and slaves. "Hamed bin Mahommed bin Dhuma," better known as Tippu-Tib, possesses three names-Tippu-Tib or Tippu-Tippu, a name given to him from the sound of his guns, when he first fought the natives; Mkangwa Nzala, "afraid of hunger," in reference to an old saying of his that he does not mind a road where there is plenty of fighting, for there there is food, but a road without fighting means hunger; and lastly, Mtipoora, "footsteps" or "foot-marks." When natives come to a village which he has attacked, they look at the foot-marks, and say, "Tippu-Tib has been here, it is a bad place, we will leave it!" This latter name, Mtipoora, is the one by which he is generally spoken of all over the country. The people of Manyéma are cannibals, and the natives between this and Nyangwé are a dangerous lot, and possess many guns. They have lately looted two canoes of ivory, taking twenty tusks at a time, and in one village they received sixty guns in exchange for ivory. There is not much regular slave-dealing in this country; the Arab practice is to capture the native women, keeping them until they are ransomed with ivory. The real slaves of the country are the Manyéma and Wacusu, the natives, or Washenzies as they are called, being considered too much disfigured by tattooing, slit ears and 
lips, \&c., to possess much value. The Manyéma and Wacusu are bought and sold as slaves for household work, agricultural purposes, and for fighting men

1888. April 2. Riba-Ribs

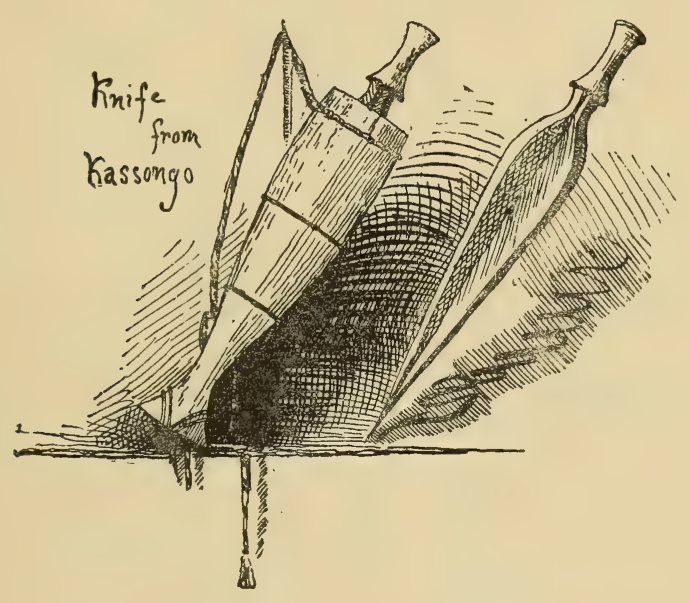

April 3rd.-I tried to get a sketch of some of the natives in the market, but they would not hear of it, all declaring they would die if I were to draw them. Fowls, fish, plantains, manioc, palm-nuts, ground-nuts, and Indian corn appeared to be the principal articles for sale. The chief sent me a breakfast of curried fish and coffee, and, before I started, two fat Muscovy ducks, and asked me to wait until the arrival of a goat ordered by him for me, but I represented to him that I was very anxious to advance, and could not delay. He was so kind and civil, without asking for a singl thing in return, that he quite won my heart. He tried to discover, through Assad Farran, what I stood in need of, and what I should like to have. I gave him my large pocket-knife, which has been my companion for years, and is the only one I had, for I had nothing else of my own, and I did not care about giving Expedition cloth when I could avoid doing so. He was greatly pleased. We passed a number of canoes bound for Kibongé, and with them were two belonging to TippuR 2 
1888. April 3. Tib, on their way to Singatini, to one of which I entrusted my letter to the Major. The head man informed me

River. that ten men had already run away, the usual occurrence on these occasions. We camped at sunset, when I roasted one of the ducks with some onions, and feasted like a king. Scarcely got a wink of sleep; the rats were in swarms, and ran all over one-every species of vermin was largely represented. The house was far filthier than any Irish mud-cabin that I have ever seen.

April 4th.- Started at daybreak, and camped at sunset. Did not sleep any better again last night, owing to the mosquitoes. The natives we passed seem a wild set; nearly all speak Swahili, and some wear white cloth garments, like the Tamba-Tambas. Their hair is dressed in a knot at the top of the head, from which a long fringe hangs down behind. The Arabs appear to be very much afraid of them, which seems a curious reversion of their relations, compared with the state of affairs on the Aruwimi, where the natives only ask to be let alone. One would certainly have thought that men like Tippu-Tib and Said bin Abéde would have given them such a lesson that they would not so soon have recovered it.

April 5th.-I said last night that it was a curious thing to meet dangerous natives so near Nyangwé and Kassongo, but they are having their lesson now. At 2 o'clock we passed one of the largest and worst of all the villages, called Numbi, situated on an island, close to the eastern bank. When we came within sight of it, we noticed smoke rising in every direction, and over forty Arab canoes lining the bank, the owners of which were camped in the lowest village. It appears that until a short time ago all the villages near here were peaceful; but they lately took to looting canoes, killing and eating the Arabs in charge of them, and taking the ivory. These villages are in Said bin Abéde's district, and most of the canoes looted were not his, so complaints were carried to him, and he was told that if he did not punish the natives other men would, and so 
Kibongé, his head chief, undertook to do so. It appears that the rebel villages, the natives of which the Arabs have never been able to tame, commence about a day above this, and he came down from Nyangwé, destroying them all as far as Numbi, which he attacked this morning. $\mathrm{He}$ is going to wait here for two weeks, then go up to Kibongé for more men, and return to settle them once for all. He warned us that we should find the natives in a very dangerous mood, as by this time they will have returned to their villages, and be ready to take any opportunity of revenge. We found his men stationed at different points for some distance up the river, and we camped just before sunset opposite a deep bend in the river, surrounded by native villages. The drums began to sound in every direction, and their canoes came up very close, evidently not a bit afraid. The men could not go to attack them, as they are not allowed to leave the ivory in the canoes. The head men told me that they very much feared a night attack, and that we must keep on the alert all night. I then asked a head Arab from Kibongé, and Nzige's head men, if I should fire a shot at them with my Remington, to show them that they were not safe, although out of reach of the Arab guns. They at once asked me to do so, as it would frighten them off, and very likely prevent them from coming at night. I got the rifle and sat down. I fired several shots at the most conspicuous canoe, some three or four hundred yards away, and so far as I could see hit two or three of the men in it. There was a tremendous getting away in every direction, and after putting some bullets right beside two or three more, there was not a man to be seen. I think it gave them a lesson, which will be useful to us to-morrow, for we have to go up the rapids right through the middle of them. After my shots a number of Kibongés men came up with their guns and flags ready for a fight, and they were quite disappointed. Below us, on the opposite bank, are two high wooded hills, the sight of which did one's eyes good, for I have seen none since leaving the Lower Congo. The only sleep I get now is in the

1888. April 5 Numbi. 
1888. early morning in the canoe, as it is impossible to sleep April 5, at night on account of the mosquitoes. We passed River. some very beautiful high cliffs to-day, of a sort of limestone shale, thickly wooded on their summits.

April 6th.-Passed up the rapids and through the enemy without any mishap. All we saw of them was an occasional canoe scurrying across the river in the distance. There was no venturing near us to-day, nor beating of drums in canoes going up and down before us, like yesterday. The whole character of the river has changed; it is now studded with long low islands, destitute of any trees, save an occasional palm, and the banks are covered, in some places for a long way inland, with high grass.

April 7th.-After a heavy day's work reached Quanga, a large native village under Said bin Abéde. The chief made a capital subject for a sketch, and although the old gentleman was very drunk with palm-wine, and would not sit still, I got a fairly good likeness. $\mathrm{He}$ had the usual band of drums with him, and every now and then would get up and dance, going through the most extraordinary contortions with his body. 'These natives are the Wagania, and inhabit the banks between this and Kassongo; they are not such a savage-looking lot of men as those lower down the river, and trade only for white cloth and blue beads, declining matakas.

April 8th, Sunday.-Left at 8 o'clock, reaching the Gulungumwézé rapids at 11 o'clock, at the foot of which we left the canoes and walked overland to the top, the loads going in the canoes. It took us about an hour and a half to reach the head of the rapids. Here we stopped for two or three hours, whilst all hands cooked food, as we are going on all night, in order to reach Nyangwé early to-morrow.

It is a very remarkable thing, the sudden change above the rapids, in the whole appearance of both the country and the river. The banks are high and finely timbered, but beyond them the country opens out into 


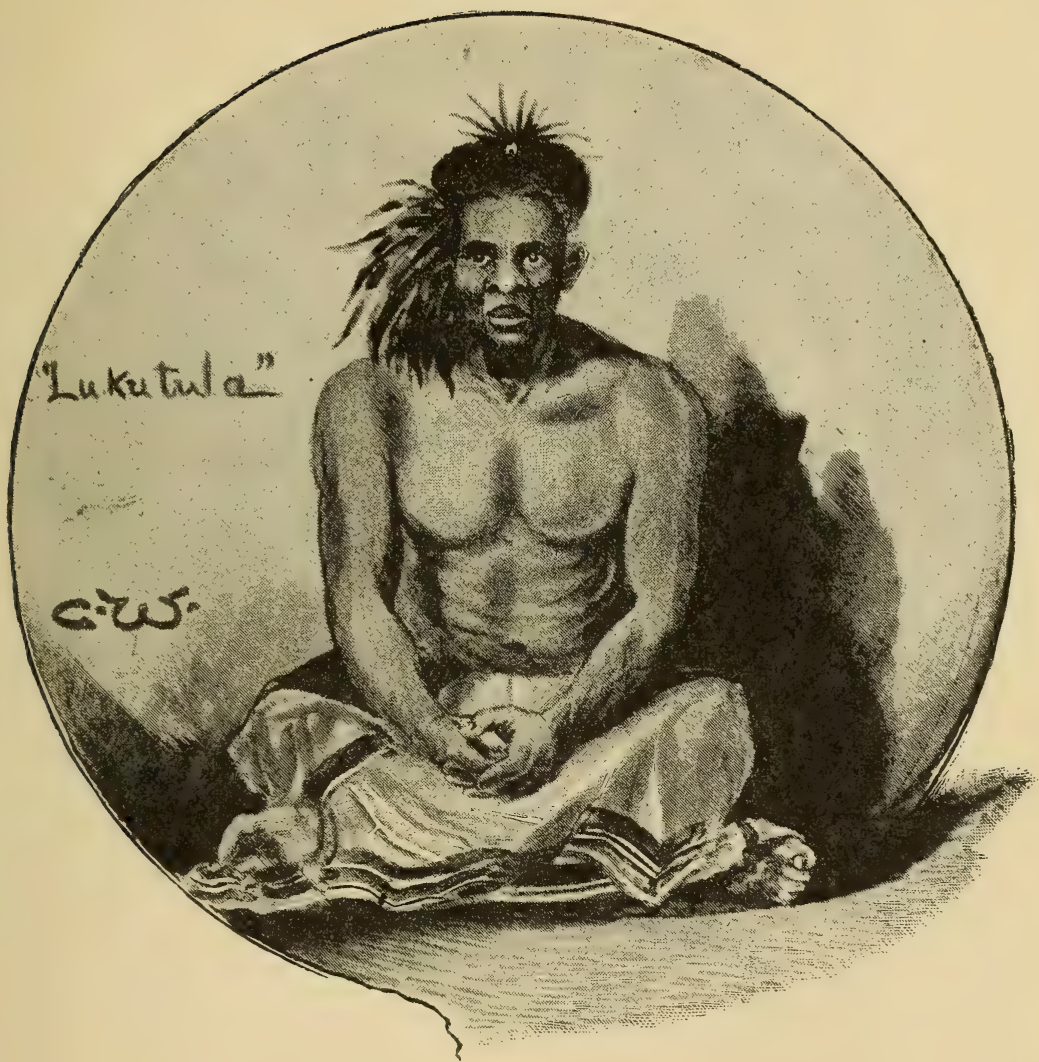

a great rolling grass-covered prairie, with little patches of bush here and there, and a few palmatrees, while there is scarcely an island to be seen. When I went to sleep we were still steadily paddling ahead. I noticed 1888. A pril 8. Gulungumwézé Rapids. no remarkable change, during our walk, in either the birds or butterflies, from those of the Aruwimi River.

April 9th.-The men had a short rest of two hours in the night. After sunrise we passed the mouth of the Lefubu River, flowing in from the West; reached Nyangwé between 9 and 10 o'clock, and I was taken to the house of a chief, Muni Mahara by name, with whom Tippu-Tib always stays. He is the representative 


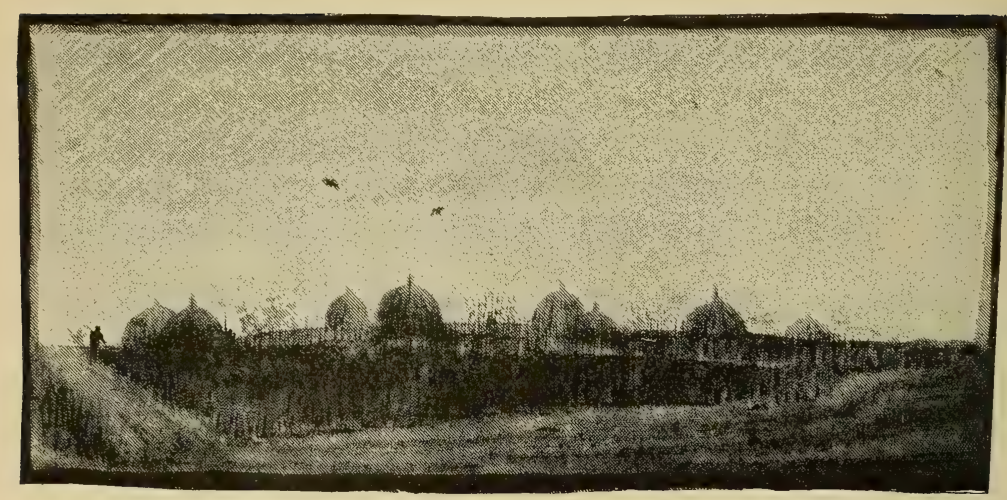

Wagania Village, near Kassongo.

1888. of Mahara, a big chief in Bagamoya. Nyangwé is comApril 9. posed of three villages, the one on the north being Nyangwé. subject to Muni Mahara, and peopled chiefly by settlers from Bagamoya ; the central village is owned by Said bin Abéde, and principally inhabited by Arabs of Zanzibar, as is also the one on the south, belonging to Said bin Habib. Muni Mahara's house forms one side of the large square in which the market is held. On my arrival the natives picked up all the articles they had for sale, and fled in the wildest disorder, shouting and yelling at the pitch of their voices. I was shown into the large reception-room, where a great number of Arabs soon arrived, amongst them an old silvery-haired Arab, almost blind. 'The chief asked me if I would stay until the following day. I sent for Nzige's head man, who promised to try and get the natives to push on about sunset. I was then conducted to a house, and a man soon arrived with a large pot full of fresh milk, ripe pineapples and bananas, a goat, a large basket of rice, about fifty fresh limes, and some fire-wood-all presents from Muni Mahara. While I was waiting for my food, I was inspected by all the inhabitants of the town. After dinner, the canoes being ready, I went and said good-bye to the chief, and thanked him for his kindness. 
At the landing-place I met the brother of the chief of Riba-Riba, who was greatly astonished at my speedy departure, and who told me he had sent a man a whole day's journey to a village to bring me a pig. $\mathrm{He}$ is the very image of his brother, and seems just as nice. We went on until 11 P.M., when we lost our way, and finally camped in the middle of an immense swamp. The smell of the water and mud was awful, and the mosquitoes were in thousands ; but we killed the goat, and I gave all the men a big feed, dining myself off fried liver and kidneys, followed by thick milk and rice, then a pipe-and I slept like a top !

April 10th.- Started before daylight, and reached the point of debarkation for Kassongo long after dark. The river is very picturesque during the last four hours, the banks being hilly and wooded, resembling many parts of England. I heard on arrival that Tippu-Tib had been ill, but was all right again. It would be fatal to our hopes were he to become seriously ill now. Curiously enough, with one or two exceptions, we have escaped all storms during our twenty-four days' journey in the canoe; and though they have passed on every side of us, we have had but little rain. The Arabs on the road have made me presents of five sacks of rice, one sheep, one goat, four fowls, two ducks and thirteen eggs, besides a quantity of limes, guavas, bananas, papaw, and pineapples. We passed Kabanga, a large native village, between 9 and 10 A.M. This village marks the boundary of Tippu-Tib's territory on the river, all above it being his.

April 11th.-After a good sharp walk of two hours we arrived at Kassongo. I went straight to Tippu-Tib's house, followed by an immense crowd, and after a little while he came in and greeted me. I had no one to interpret, as Assad Farran did not arrive for over two hours. However, Salem Masudi soon came in, and I told Tippu-Tib I was sorry to hear he had been ill, but glad to see him all right again, and that I had been sent here by Major Barttelot to speak with him about 


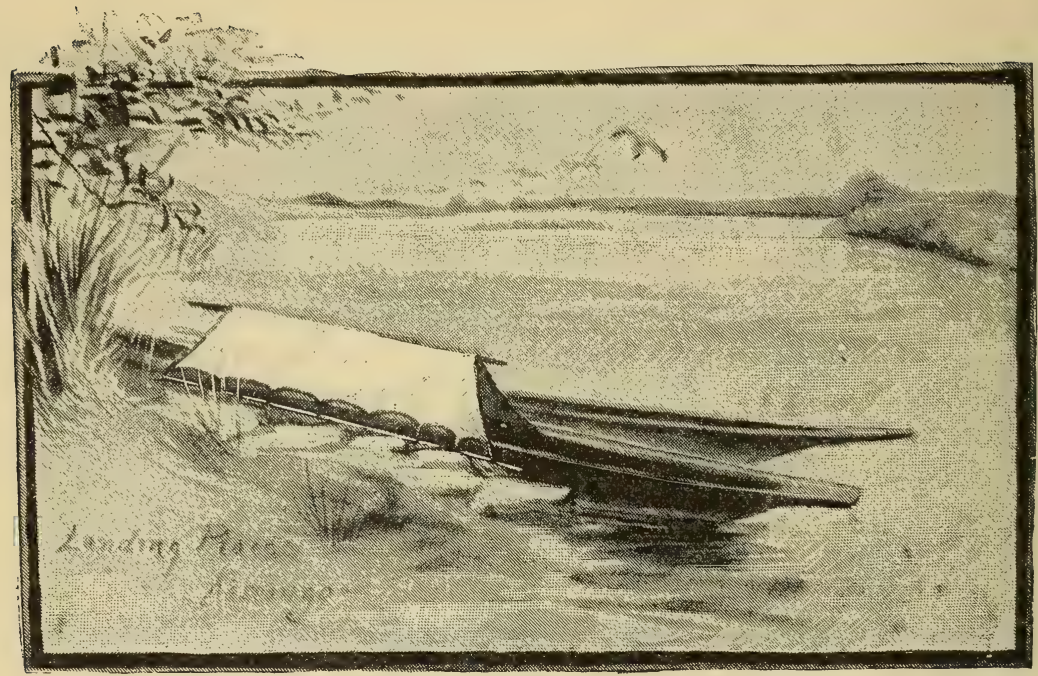

Landing-Place, Kassongo.

1888. certain matters, and that as soon as Assad Farran arKassongo. rived, and I had changed my wet clothes, I should like to see him about them. He said that a house was being prepared for me, and that he would come there to talk with me. He had not then read his letters from Nzige. I told him of the kind treatment I had received from every one on the road, and, after partaking of coffee and pineapple, I was conducted to my house. Salem Masudi came up to see me after Assad Farran had arrived, and I told him, in Assad's presence, that I was quite ready to see Tippu-Tib at any time, that I should use Assad as interpreter, according to my definite orders, and asked him to tell Tippu-Tib, so that he might bring with him a man who spoke Arabic. I waited in all the afternoon, but he did not come; he is going to see me to-morrow.

There is no European news, except that there is no great war. At Nyassa the English and the Arabs have had a fight, in which the Arabs have been driven out. They have come to Tippu-Tib to ask for men and powder, which he refused them, telling them that he 
wanted all his powder and men in case of having to fight Said bin Abéde, whose father had some dispute with Tippu-Tib about some villages which they both claimed. 'The matter was settled by the Sultan in Zanzibar, but on 'Tippu-Tib's arrival here Said bin Abéde came and stayed for two or three days, and at once reopened the quarrel (his father had died on his way to Muscat); but Tippu-Tib told him that it had all been settled in Zanzibar, and that he would not talk to him on the subject, as he was only a boy, but that his son Sefo, who was young, might do so. Said bin Abéde then said " he had strength enough now to settle the matter." 'Tippu-Tib told him to use it, but warned him that if there was a row he would not leave him a station, and would drive him clean out of the country. Tippu-Tib then went and burned the three villages in dispute, and took from them a number of men, one hundred of whom he sent to us, and these were the canoes full of men I met near Riba-Riba. He has sent away 700 men in all; a number of them ran away on the road, but a great many have been recaptured, and fifty of them are here now in chains; Assad Farran saw them as he came in. Tippu-Tib, it appears, has collected men by going round personally, and asking the different native chiefs for them. On his return from this trip, he got a very bad attack of fever, and for two days was not expected to live.

Salem Masudi let out one thing which rather corroborated the fact of Tippu-Tib's having started in June for our camp. I asked him if Sefo was married; he replied, "Yes, to Rachid's sister." I mentioned that I had never seen Rachid. Salem said, "Well, he was coming to Yambuya when we went up the Aruwimi, but Tippu-Tib told him to wait until his return."

Tippu-Tib, I believe, is ready to start for Singatini on the 10th day of next moon, which will be April 24th. Sefo, his son, is here. The only other news is that the Germans have hired two ports from the Sultan of Zanzibar for the export of gum-copal, and are not likely to give them up again. In the evening I received visits

1888. April 11. Kassongo. 
1888. from Sefo, Ali bin Mahommed, and other Arabs. They April 11. are evidently very much puzzled at the non-arrival of Kassongo. any steamer at Stanley Falls up to the time I left, and I do not wonder at it.

The country between the landing-place and this is fine, open, and hilly, covered with very long grass. Quantities of metammeh, Indian corn, manioc, groundnuts, and sweet potatoes are grown. The gardens of the town extend for a great distance all round it. The town is built on both sides of the valley, and is very large. My house is nice and clean, the best Arab

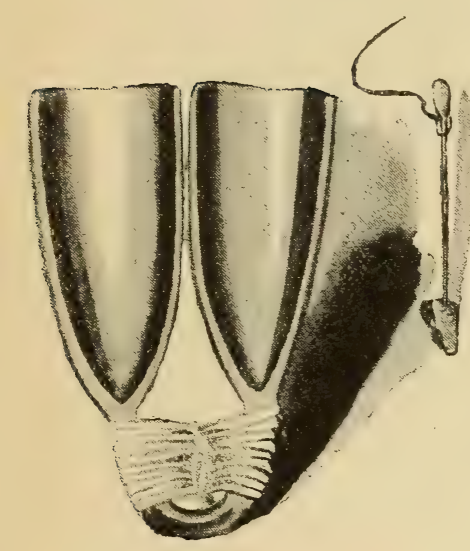

Double Drum, and Striker.

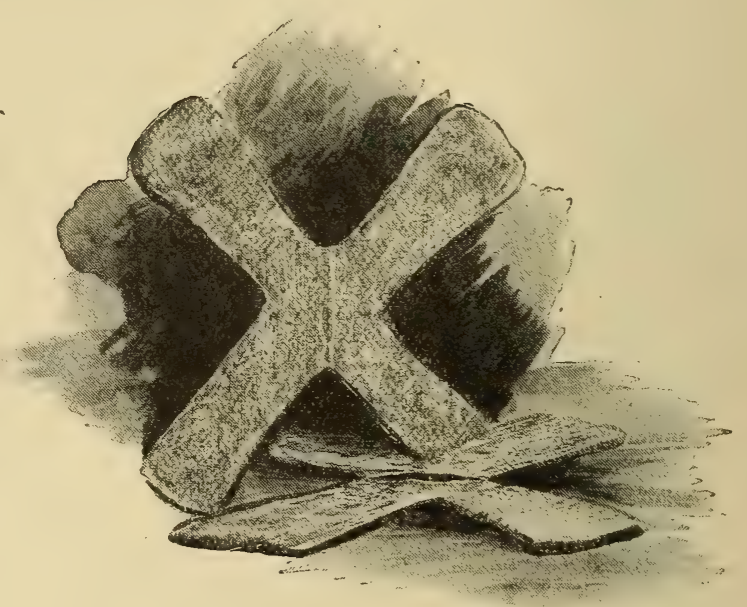

Copper Moner.

house I have yet been in. The money chiefly used here is ribas, small pieces of native grass-cloth. Fifty of these native cloths can be bought for six handkerchiefs ; for one cloth you may buy twenty-five pieces of dried manioc, or fourteen plantains ; for twelve pieces, one fowl; for one hundred, a goat. A man can live here for two days on one "cloth," or less than half a mataka. With one cloth he buys twenty-five pieces of manioc; with two of these he purchases the green leaves ; with three, salt; with one, oil ; and with another fire-wood, so that he still has eighteen pieces left for other food. An eshoka, or trade iron axe, can be bought 
for five cloths, or less than two matakas. One cloth will procure a measure of rice just under $2 \mathrm{lbs}$.

1888. April 11.

Kassongo,

April 12th.-Tippu was busy writing letters when I went down to him this morning, but he gave me a guide to show me the town. It is really a very large place; we walked for about an hour and a half through acres of rice, Indian corn, metammeh, \&c., and did not go round a quarter of it. Judging from the crops, the soil must be splendid. Returned for breakfast, after which Salem Masudi came in, and gave me the details of the Nyassa row, in which he declares the Arabs were entirely to blame, so much so that Tippu-Tib thought of sending men to take them as prisoners to Zanzibar. It apppears that the Arabs borrowed some money from a merchant there, and promised to pay it back in six months, in ivory. They never paid it, and he sent a clerk to them, whom they insulted and abused. This happened several times, and at last the merchant went to the British Consul, Mr. Goodrich (?), who sent for the Arabs to come in, but they refused to do so. He sent three times altogether, and the last messenger they killed, so he went out with his men, and there was a fight, in which the Arabs were driven out.

I asked Salem if he had any idea of how many people there are here; he told me no one had. He said it was impossible to know, for they had no system like ours, which I explained to him. Supposing one man, he said, bought twenty slaves of the first class, these in a short time would each have slaves of their own, and those others-ad infinitum. No one took any note of the death of a slave; when one died they generally waited till nightfall, and then dragged him along the ground and threw him into the river, or left him opposite some one else's house. For one load of cloth you could buy at least twenty slaves. He presently said, "There is no one here now-it will be a good time for Tippu-Tib to come," and went out, but soon returned, saying thit Tippu-Tib had sent him to tell me that, from Nzige's letters from Stanley Falls, he knew all that I 
1888. had come for, and he would give us all the men we April 12 wanted, and be ready to start on the 10th of next moon, by which date his brother will have arrived from Ujiji. I told Salem that Nzige did not know all I had to say to Tippu-Tib, and that I must see him, so I went straight to him, taking Assad Farran, and told him that my principal reason for coming was to get him to enter into a contract for the supply of men (especially four hundred extra fighting men), and to settle about payment for them. He told me that he would undoubtedly give us the men, if not 400 , then 300 ; that as regarded the payment of the 600 , he would see Mr. Stanley, and settle it with him, and arrange with us for the 400 extra men, upon our return. I told him that, as the men had been so long coming, Mr. Stanley might refuse to pay the money, and that a contract with Major Barttelot was really a safeguard for himself, Barttelot and I guaranteeing him the money. He then said he would settle everything with Stanley, and would evidently have nothing to do with the contract with Major Barttelot. He assured me three or four times that I need not be anxious, and promised to leave here on the 10th of next moon, if I would wait quietly here and go with him. He stated that he had received letters from Zanzibar, where it was reported that Mr. Stanley was dead, asking him why there was no news of Mr. Stanley, and what he (Tippu-Tib) was doing, to which he had replied that Mr. Stanley was not dead, and that, Inshallah, he would get news of him. I strove to impress on him the necessity of speed and the value of a contract to himself, when he reiterated what he had said, and seemed annoyed at my pressing the point. Two or three times he tried to speak to me through Farani and Aramense, but I told him that they did not understand me, nor I them, so he had to use Assad Farran as interpreter; he understood nearly every word that Assad said, without the help of the third man, although he used him in answering, as he evidently understands more than he speaks of Arabic. I decided to accept his promise and leave him alone for the day, deferring 


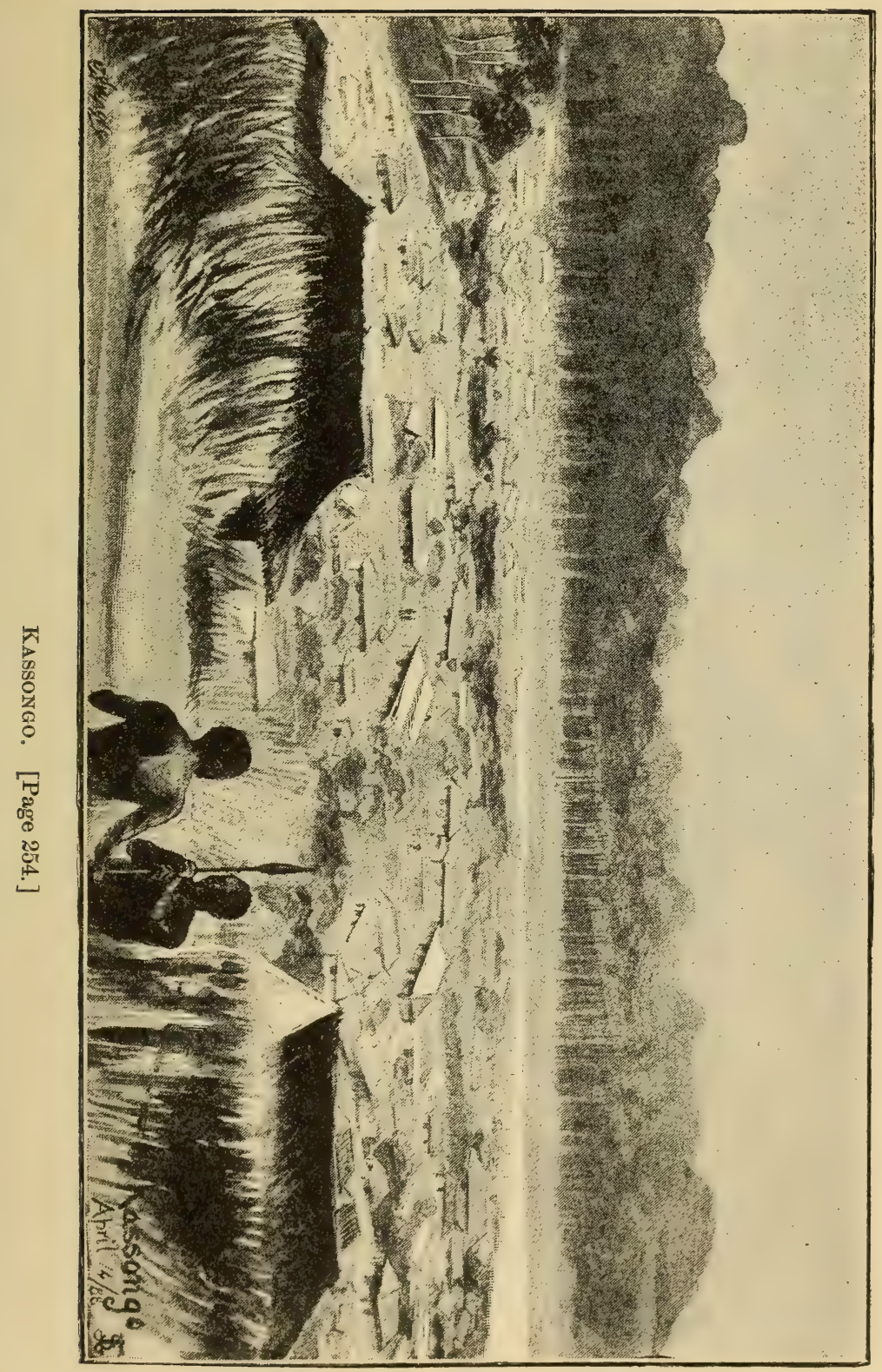



my other questions till to-morrow, as he was evidently not in good humour, and I can see that he is now as anxious to see us start as we are to go ; I think he has been hurried up from Zanzibar. He says he has received news, although he cannot vouch for its truth, that the king of Unyoro had been collecting men to carry out Emin Pasha's ivory, and escort him to the coast. He thinks, if this news is true, that Mr. Stanley has gone down the other road by Unyoro and Uganda, either with Emin Pasha or behind him. I told him that had Mr. Stanley done so he would undoubtedly have sent messengers back to us; it was the want of news that made us so anxious.

Several of the Arabs called upon me in the afternoon. Tippu-Tib supplies me with the best of food, and is going to send me a bowl of milk every morning.

April 13th.-Again interviewed Tippu-Tib. I took down my sketch-book with me, and I am glad I did so, for I got him into a splendid humour. The sketch of Yahid made him roar with laughter, but when he came to that of the chief of Riba-Riba he snatched it up, and went off with it to Sefo, Ali Mahommed, and some other Arabs, when I heard them all laughing. He came back presently in an excellent humour, and gave me a good deal of news. He told me that all the Indian merchants in Zanzibar, and all English subjects, had celebrated the Queen's Jubilee for three days, scattering presents broadcast to everyone. The Germans have got Dar el Salem, and several other ports. Tippu-Tib says there are a great many discontented people in Zanzibar, who are only waiting for an opportunity to ask Germany to annex it, and pension the Sultan, and he asked me what England would do. I told him that if they took it against the Sultan's wish he could appeal to the Powers of Europe ; that they would call a congress and settle the matter; and I added that I thought two strong voices against its being taken by Germany would be those of England and France. It would be a deathblow to Tippu-Tib's aspirations were Germany to take 

1882. Zanzibar, and I find his aspirations are enormous, far Kassongo. greater than most people think. An Arab arrived here to-day from Zanzibar, and I hear that, upon his return from Stanley Falls, Tippu-Tib is going to give him 1,000 men, with guns; his destination is a gold country south of Lake Banguela, as far as I can make out. Tippu-Tib constantly questions me very closely about all the parts of Africa where gold is found. I warned him that if he crossed the Zambesi he would have to fight either the Matabele or Khama, either of whom would be far too strong for any thousand men of his. I told him that north of the Zambesi I thought the Barutzi were the strongest. He evidently means to have the whole country up to Lake Albert Nyanza, and God knows how much of the Congo. His son Sefo is not going to be chief, and the great fighting man I thought he was, for he is going to Mecca, which prohibits him ever afterwards from doing anything but praying. (I have since heard that he has given up this idea.) He has two other sons, however, and Rachid, Nzige's son, will, I believe, be a very great man.

I asked Tippu-Tib who would command the men he sent with us, and he told me he was going to ask Selim Mahommed. I told him he was the very man Major Barttelot wanted; that of course, as he would command, and give all orders with regard to marching and fighting, it would be a splendid thing to have a man whom we all knew and liked. He said that if Selim would not go, he would give us the very best man he could. I next asked him for a definite date, at which all the men would be delivered, and we could leave Yambuya Camp. He said he thought the 1st of June would be the very latest, and he certainly thought it would be before then, for he would only wait one day at Singatini, and come on straight to the camp himself. He is evidently now in a desperate hurry to get us off. There are two causes for this,-1st, he has been hurried up from Zanzibar; 2ndly, he has other big games on hand, which he cannot attend to until we go. I can see perfectly that he leaves very little for others to do. I asked him when 
I could send a letter to Major Barttelot, and he said there were men just starting, and that if I wrote it quickly it could go to-day. So I went straight home, wrote my letter and sent it off; then went out and made a sketch of the town from the eastern side of the valley.

I heard an example to-day of how Tippu-Tib gives slaves to poor Arabs. When he left his place to collect men for us, two Arabs went with him to Nyangwé, and in each village they stopped at Tippu-Tib called out a lot of the people, women and children, and asked the Arabs to take their pick. When they reached Nyangwé, one man had fifteen slaves, the other over twenty.

April 14th.-There are three classes of people in this country-Arab gentlemen, slaves, and natives or Washenzies. An Arab gentleman in this land may have been of a very inferior class in his own. One of these gentlemen, - a great swell with lots of ivory and slaves,-on his road to Zanzibar, came here with us from Kibongé, and told Assad Farran that he had left Teheran when a child, and had been a servant to some Europeans in Muscat, from which place he had come to Zanzibar, and is now quite a great man in his way.

April 15th, Sunday.-Spent the whole forenoon in writing to Mr. Mackinnon; Tippu-Tib will send my letters by special messengers to-morrow morning. Before dinner I went for a walk round the town, and the more I see of it the more I perceive what a quantity of wealth there is in the soil. After dinner I walked up over the hills to the south, and got a beautiful view across the valley to the hills on the road to Ujiji (eastward). I met two natives of Unyanembi, wild-looking devils, with great feather hats, and bells on their legs, under the knee. They promised to come and be sketched to-morrow. The great success of the day, however, is a promise from Tippu-Tib to let me make a sketch of him. How I wish I could do him justice!

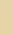


1888. April 15.

Kassongo.
LETTER TO MRS. JAMESON.

Kassongo, April 15th, 1888.

From the departure of Mr. Stanley in June, until the arrival of the S.S. Stanley in August, we had heard nothing whatever of the promised men from Tippu-Tib, without whom we could make no move after Stanley. On his departure in June, he had told us that, should we not be able to come after him, he would be back at the camp in November; but November, December, January, and February came, and still no news from Mr. Stanley, and no men from Tippu-Tib. .... I I left Stanley Falls on March 18th, and reached Kassongo on April 11th, having been twenty-four days in the canoe. It generally takes thirty days, but twice we pushed on all night as well as day. What a weary journey that was, sitting all day in the canoe, doubled up like a trussed fowl, and at night often sleeping there too, devoured by mosquitoes, or, if on land, lying in the middle of a swamp, and how terribly hot it was! I had little or no medicine with me, and scarcely any clothes, as when I left Yambuya I had not the remotest idea that I should have to go upon this journey. However, the Arabs were very kind to me all along the river, and made me presents of all sorts of food, so that I arrived here quite fit, in spite of having been very seedy for the first week, from a bad touch of fever at the Falls. Tippu-Tib has given me his word that he will give us all the men we want; he will leave this on the 24th inst. for Stanley Falls, and has asked me to go with him. He will make no agreement about the money or anything except with Mr. Stanley, but that does not matter to us provided he gives us all the men we want. 'Tippu told me that he had received letters from Zanzibar, where it was reported that Stanley was dead, asking him why there was no news of him, and what he, Tippu-Tib, was doing. He had replied that Stanley was not dead, and that he would get news of him. ... I was up nearly all last night writing to Mr. Mackinnon. . . . 
April 16th.-Night again, and time to write to you. You have no idea what a lot of sketching I have done. My diary at Yambuya Camp is very nearly one page of writing and then one of drawing all through. I used at first to copy figures, and faces drawn by Ward, but when I left for Stanley Falls this last time I took to drawing human figures, with and without clothes, myself. I am awfully anxious to make a sketch of TippuTib, but my heart fails me every time I think of it, for he is a difficult subject, and I am anything else you may like to call me but a portrait painter. I sent home a lot of drawing-paper which I could not carry, and now I would willingly give a guinea a sheet for it. . . . . The Major and I have been thrown more together than any of the others, having been left alone at the camp for a long time, and we have kept up the same sort of intimacy ever since the others arrived. $\mathrm{He}$ is a real honest gentleman, and I cannot say more. We both come to one another for advice at any moment, and he has been placed in a hard and difficult position with Mr. Stanley, who, no matter what you do, is sure to say it is wrong. We shall both be blamed, I know, for the long delay in Yambuya Camp, but God knows we have done everything in our power to prevent it. Out of the whole force in our camp, we could only muster eighty sound men, and of what use would it be to go after Mr. Stanley with this force, when he, with 400 men, sixty of whom (besides officers) were armed with Winchester rifles, a Maxim gun, and all the rest armed with Remingtons, has evidently met with opposition which prevents him from either returning to us, or from sending us any message? Twice Barttelot and I have been going to start with the few men we could scrape together, and go after him, but wiser counsels have prevailed, and we at last decided not to go until we had a force sufficient to be of real aid to him. I cannot believe that Mr. Stanley would have gone out by any other route, either with or without Emin Pasha, and not have ensured a message getting back to us. If he has done such a thing, he will be wasting a large sum

1888.

April 16. Kassongo. 
1888. of money, and risking the lives of all the men, for no Kassongo. earthly purpose. . . A And now my little palm-oil lamp is almost at its flicker, so I must bid you good-night. How I wish that I could kiss little Gladys, and the small baby that I have never seen! I pray for you all so earnestly every night.

April 17th.-Some canoes returned to-day from Stanley Falls, but there is no news of Mr. Stanley. It is horrible to sit still here, and know that he may want help, and be unable to stir hand or foot to help him. We are entirely in the hands of Tippu-Tib, and dare not have a row with him. Since I came here I have twice succeeded in getting him into anything but a nice temper, and he showed it, but I smoothed him down again. $\mathrm{He}$ is now just as anxious as we are to get us started, the letters from Zanzibar having evidently hurried him up tremendously, and should we have a row with him now, he would send up his men after Stanley, and leave us in Yambuya Camp. He treats me in the most princely manner. He sent for my boy Farani this evening, and told him to tell me I was to buy nothing at all, that I was his guest, and that he would give me everything I wanted. Farani belongs to me now entirely. He originally belonged to TippuTib, and when I went to Stanley Falls the first time with Ward, he used to bring us our food. He speaks a very little English, and I took a great fancy to him. When the Major went to the Falls, I sent a message to Tippu-Tib, asking him to lend me the boy for the trip. He sent him to me, with the reply that he was mine, and that I could do what I liked with him. $\mathrm{He}$ is simply invaluable-cooks, pitches the tent, mends my clothes, roasts the coffee, \&c., and carries my gun. $\mathrm{He}$ is a wild sort of savage, but honest and plucky. My interpreter, whom I brought with me, Assad Farran by name, is a Syrian from Jerusalem, and about as good-for-nothing a specimen of a Jerusalemite as I ever saw. He has succeeded in making himself properly 
ill here, through over-eating, and taking no exercise. He would come to me at least four times a day, and say he was going out to "try his chance," which is 1888. April 17. a great expression of his. He would then go to the Arabs and eat with them, and return very much swollen out, and tell me of all the things he had eaten. It has, however, done for him, as I warned him, and to-day he has done nothing but lie on his back and groan horribly. I had no medicine for him, having scarcely an atom for myself, but I procured a large half breakfastcup of native castor-oil from an Arab; it is fearfully strong, and I made him swallow the whole. It has done him a world of good, and I tell him he will be a new man to-morrow. 'This is certainly the cheapest place I have ever been in. You can buy any quantity of slaves here-good ones-for $£ 1$ per head. I bought over $90 \mathrm{lbs}$. of rice to-day for less than half-a-crown. A fine large goat costs $2 s .6 d$, and a great big fowl $10 d$. A common man can live here on less than one farthing a day. The money used is small pieces of grass-cloth, worth less than one half-penny each. A large market goes on here for three or four hours every day. When the metammeh harvest (a sort of corn) comes on, things are cheaper still, so no wonder that a man can keep a number of slaves, for these very slaves make the grasscloths which buy their food, and all he has to provide is the grass of which they are made, which grows at some distance from here. When we are both quite "broken," this will be the place to come to, but I think that I have seen enough, and more than enough, of this country, to last me a lifetime. . . One day, as I passed through a native village from which the people had just run away, I picked up a thigh-bone freshly cooked and picked. The natives who live inland eat any of the natives from the river whom they can catch, and vice versâ....

April 18th.- ... I took a long walk this morning along the road to Ujiji, which is the road to Zanzibar. 


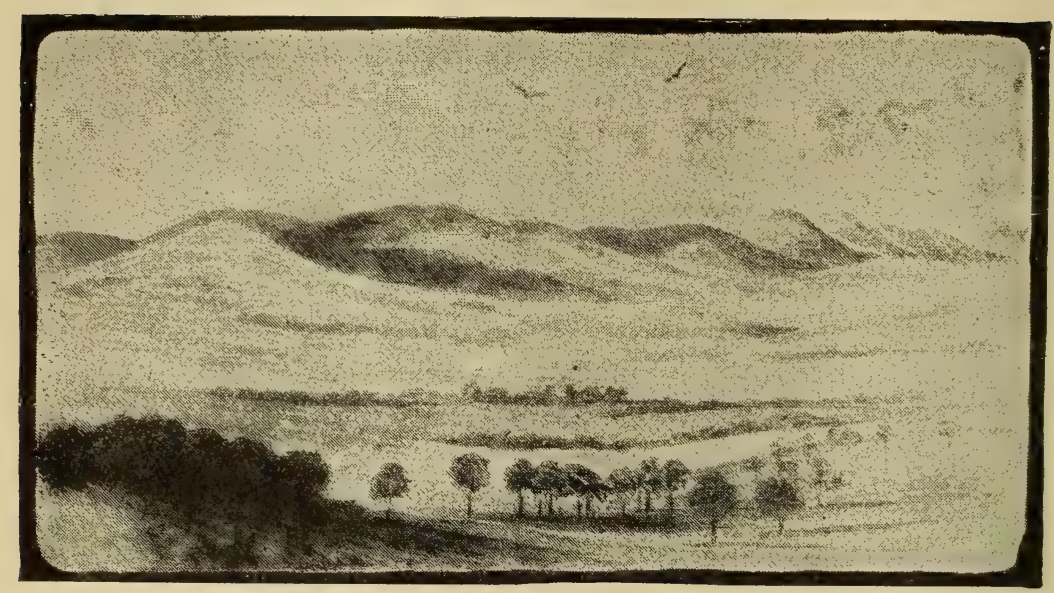

ROAD tо UJIJI.

1888. Before turning back I took a long lingering look in April 18. that direction, and my thoughts wandered over that Kassongo. road homewards. . . . Another Arab came to me today to have his portrait painted, but I have no paper to spare, and prefer to sketch the natives. ...... The only book I have with me is the 'Light of Asia.' I have read it so often. . . . .

April 19th.-Tippu-Tib came up to my house after breakfast to let me take a sketch of him. About a dozen of the head Arabs came with him and pressed round me, making remarks all the time, which so annoyed me that I could not make a really good picture; it is like him, everyone says, and he has promised to come again for me to alter the face a little.... Curious how one's fate turns upon a hair sometimes! Had I not gone to _-'s rooms that Sunday morning, and read that paper whilst he was dressing, I should probably never have been here now, for most likely I should not have heard of the Expedition until it was just starting. It does seem as if one were guided by 
an unseen hand or power, of which Edwin Arnold writes:-

1888. April 19.

Kassongo.

"A power divine wbich moves to good, Only its laws endure. ... .

This is its work upon the things ye see,

The unseen things are more; men's hearts and minds,

The thoughts of peoples, and their ways and wills,

Those, too, the great law binds. ...."

I shall surely have wrought out my mission in the way of travel after this long journey is over. My ambition to do something good in this world before I died was right, but there were a thousand other things which I might have done which would never have called me away so far. . . .

April 20th.-Tippu-'Tib has had some letters from Ujiji to-day, but I cannot get any news out of him. .. I went for a long walk this morning; it is delightful to be able to see far over the country again, after being shut up in that camp for months. . . . Almost all the Arabs' slaves come from this country, Manyéma, where they are very cheap. (They do not take many slaves from the natives of the Aruwimi, as they are of little value, being so disfigured by tattooing, and having their ears and lips full of slits and holes.) My boy Farani has two slaves of his own. I saw one offered to him this morning for three pieces of cotton cloth, worth $7 s .6 d$, but he said it was too dear. Notwithstanding the slavery, I don't think I have ever seen a country where there is so much general happiness, and so little misery; one sees far more of the latter at home. There is no starvation here, and no one without work. When they do wrong, instead of being imprisoned or dismissed, they get a good sound beating with a stick, and I am not sure that it is not the best plan. The long grass-cloths that are worn here are really very beautiful, and I am going to try and buy one to-morrow for you. The head chief of all the Wagania (the tribe living round Kassongo) came to be sketched this morning; to show 
1888. me how much greater a chief he considered me than April 20. himself, he picked up dust off the floor as he was going away and threw it on to his shoulder.... Major Barttelot has told me that when we start for the Lake I am to go on in front, and give all directions about the road, as we shall have to steer by compass, having no instruments with us. It will be much pleasanter work than the slave-driving I had to do between Matadi and Stanley Pool. Troup is to be left behind at Stanley Falls, in charge of all the loads we leave there, as the men are only to carry half loads in order to accelerate our movements. . . I am nearly in rags now, and am positively ashamed to go about amongst these beautifully dressed, clean Arabs with my elbows sticking out, and holes in the knees of my trousers. But 'Tippu-Tib says that on some of his trips he has had nothing to wear but a piece of native grass-cloth!...

April 21st.-The time has come when I must say good-bye. In two days' time I shall be returning to that abominable camp . . . but it is pleasant to think that the only news you will hear of me after this will be of my return journey. . . . I cannot possibly think why Stanley has never been able to send us any news, unless he is in a very bad fix indeed. If he is and we relieve him, of course it will be something done, but what a fiasco after all we were going to do!

\section{DIARY (continued).}

April 16th.-I got a splendid sketch of a native of Unyanembi, and of 'Tippu-Tib's two gun-bearers. A great raid was made upon my cloth to-day. I bought 100 native cloths from an Arab for one piece of handkerchiefs, and Tippu-Tib happened to see the piece, which had a good deal of white about it. He sent to ask me if I had any more of the same, as he would like to have some. I had none exactly the same, but a few double pieces very like it, so I sent them down to him. He wanted more, and said he would give me other cloth for all of them, but I told him they 


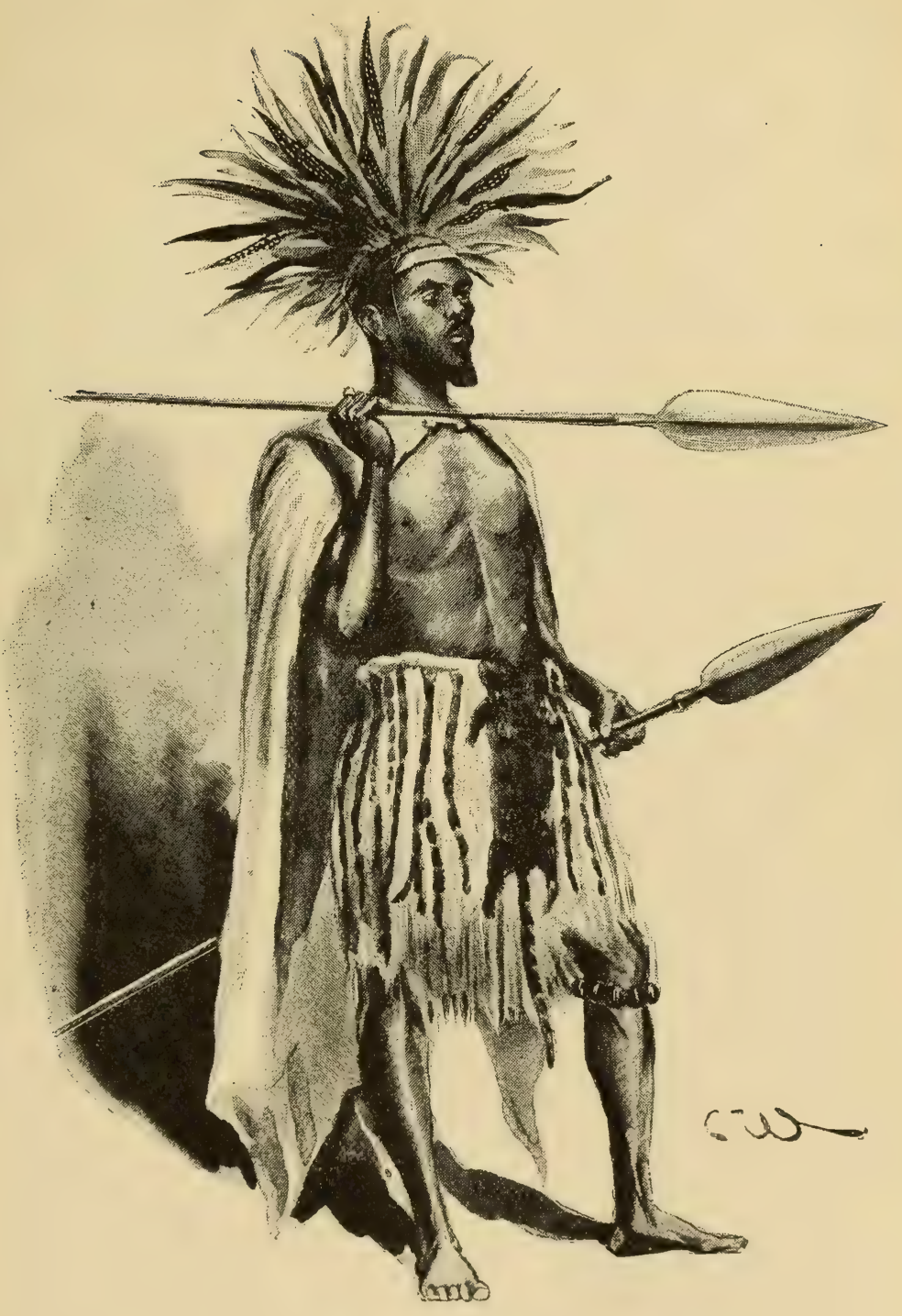

NAtive of Unyanembi. [Page 266.] 

were a present, and that I was glad to find I had something to give him that he wanted. I had also to give Sefo, his son, a double piece. All the other 1888. April 16. Kassonga Arabs then begged me to sell cloth to them, but I put my foot down, and refused to part with another handkerchief. 'They were exactly like vultures round a dead body. Fifty more men, for us, came in to-day. Tippu-Tib sent me up some coffee-beans and sugar.

April 17th.-I bought three sacks full of rice, in all I should think over $90 \mathrm{lbs}$., for 42 native cloths, or ribas, or about ten matakas, or $2 s .1 d$. An Arab sent up two large baskets of rice, for which he wanted cloth in exchange, and I was just asking how much they wanted for it, when Tippu-Tib sent up one of my boys to tell me not to buy it, or any more rice at all, as he would give me all I required. The Arab was annoyed, to say the very least of it. Tippu-Tib then sent Salem Masudi up with the same message and another lot of coffee-beans.

April 18th.-This morning I took a long walk along the road to Ujiji; I passed through nothing but gardens for about an hour and a half, and they extend on all sides of the town. After breakfast Farani brought me a splendid specimen of a savage to sketch. He belongs to some tribe far away to the south, and has come, I believe, from Quemba; he is a drummer and dancer. After I had sketched him he treated me to a dance, which is exactly like the Highland fling. It is a curious thing that some of the steps were the very same. This sketch is the best I have attempted, both as a likeness and a drawing. It has just struck me as possible that Mr. Stanley may be in Uganda, and have told the king that we are coming on with plenty of stuff to pay him with, and he may be kept there waiting for us. Last night I was awakened by the most dreadful noise, all the people in the town seemed to be yelling; this morning it was still going on, and I found out that an Arab woman had died, and nearly everyone in the town was at the house 


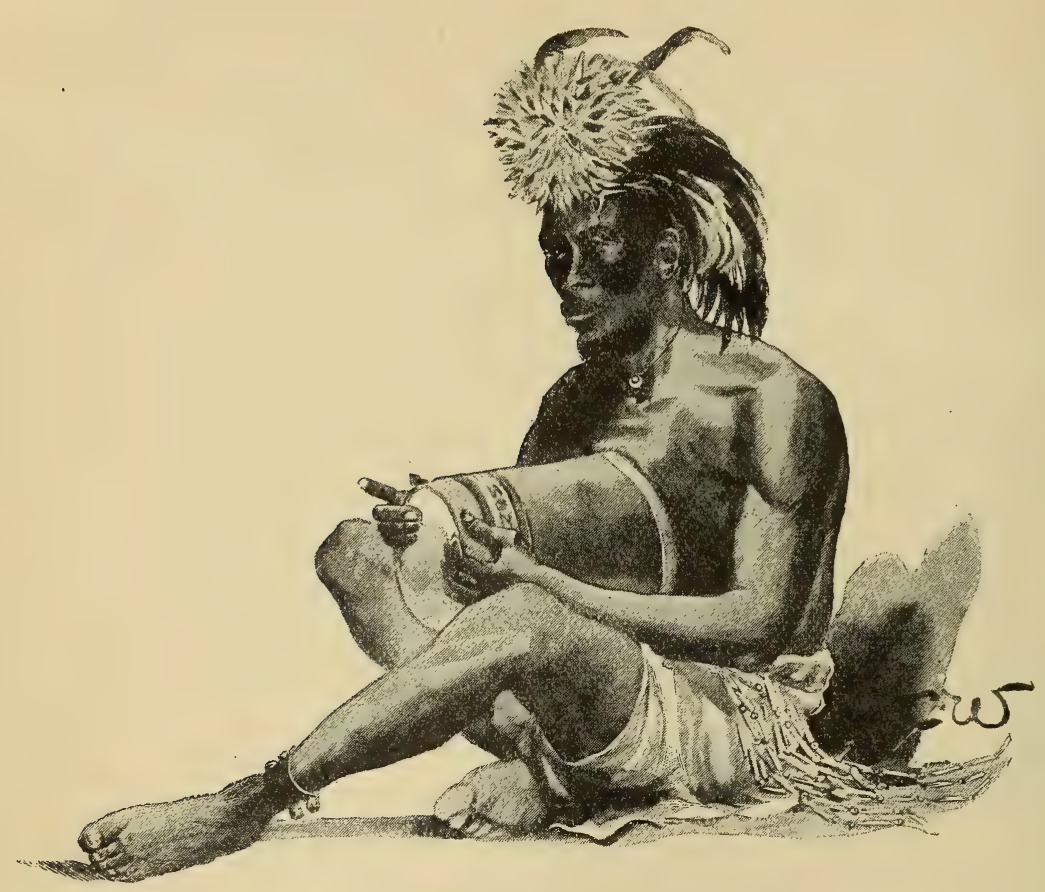

Drummer and Dancer of Quemba.

1888. Tippu-Tib amongst the rest. When, as in this case, April 18. it is a woman who is dead, the men all sit inside Kassongo. the house and in the road, while the women assemble in the small enclosure at the back of the house where they bury the body. The moment she is buried, the men go home, and the women go and wash themselves in the river. In the case of a man's death, the men all stay in the house for three days, at the end of which time there is an enormous quantity of rice cooked, and all comers have a great feed.

April 19th.-In the afternoon I got a good sketch of Lamba Lamba, one of the native chiefs of this place. Salem Masudi let out to-day that Tippu-Tib had received the news about the king of Unyoro collecting men for Emin Pasha, in a letter. I asked Tippu-Tib if I could send a letter to Major Barttelot, but he told me that no one would go to Stanley Falls before we did. 


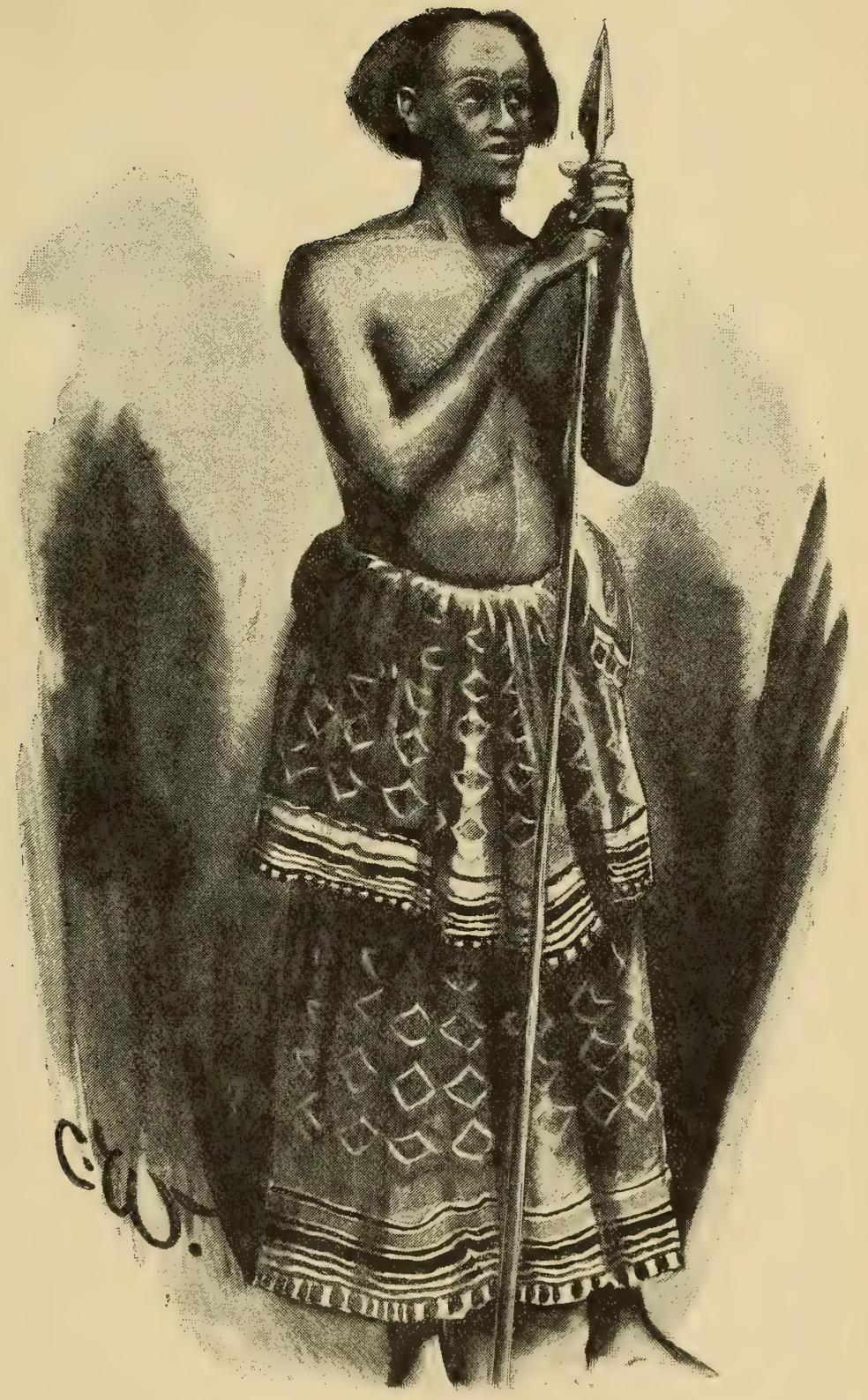

Lamba-Lamba, a Wagauta Chief. [Page 270.] 

April 20th.-Sketched Mwana Halumba, the head native chief of Kassongo, then took a portrait of an Arab gentleman of this place at his request, and presented him with it. Tippu received letters from Ujiji.

April 21st.-I believe Tippu-Tib will really start on the 24th, as all his things go down to the canoes to-morrow. I made a drawing of a curious native stool from Walua, shaped like an idol. Another Arab bothered me to take his portrait. Tippu-Tib gave me six sacks of rice. Had a row with Assad about not washing himself. He confessed to not having washed since we have been here.

April 22nd, Sunday.-Tippu-Tib informed me this morning that the canoes had not yet returned from Kibongé, but were expected here either to-day or tomorrow, and that he would start without fail in four days' time for the river, sleep there that night, and go on next morning. When coming here on the river, I was told that he could not start until these canoes returned. Had to do another portrait of an Arab, and there are many more applicants, but I have shut up shop. Went for a long walk in the evening, to get some axes made for the camp.

April 23rd.-Tippu-Tib is really going; he is paying the paddlers. Finished letters home.

April 24th.-Had a long talk to-day with Tippu-'Tib, whom I found in a particularly good humour. I took down my letters, and asked him to send them for me. He said they would not take long on the road; he is sending some himself, and they go with the regular monthly Mission post. He told me that he could give us any number of canoes, carriers, \&c., in the event of our return by this route. I asked him, in case of our return by Uganda, what we should do with his men, and he told me that he would give all necessary orders to Selim Mahommed, or whoever went in command of them. I then asked him what were the best trading things to take. He said that beads, cowries, and brass wire would do as far as Uganda and Unyoro, and that the particular kind of beads did not signify, as no one had been up the road 


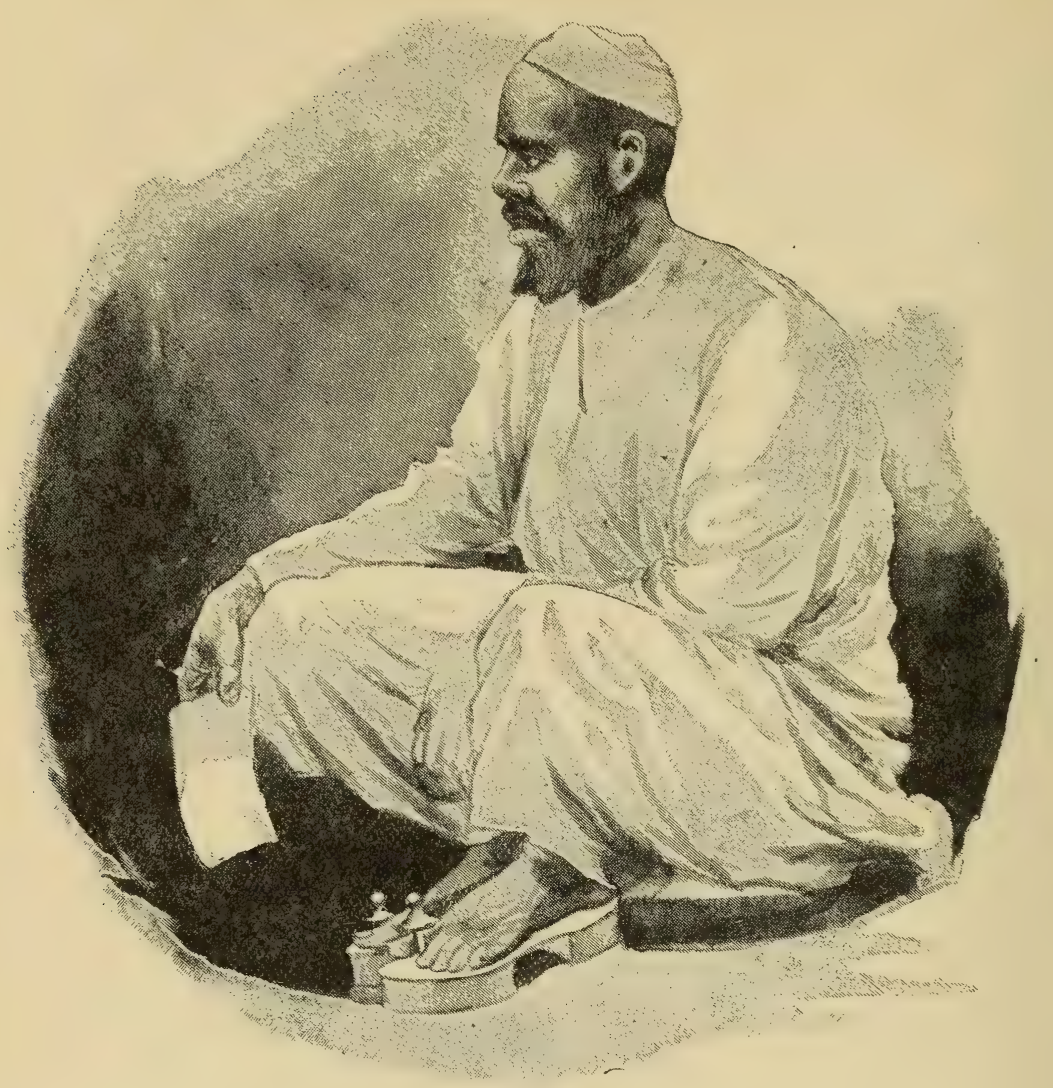

TIPpU-Tiв.

1888. before to spoil the market. He then brought me some April 24. cloth which is good in Uganda and Unyoro, much smaller Kassongo. and thinner than ours, and said, "Where this is good, how much more valuable must yours be." I had a long talk with him on various subjects, Germany and France, Germany and Zanzibar, gold, silver, and diamond countries, \&c. He showed me some copper money, and said that, when he first came to this country, for one or two pieces of copper money, worth about 1s. $3 d$. each, you could buy five 60 - or 70-lb. tusks of ivory, but that day is all over. There are two places from which the copper comes; one south, the other north of Kassongo. He seemed anxious that France 
should go to war with Germany, evidently thinking that it would check the progress of the Germans in this country for a little. He also asked me a great deal 1888. April 24. about the Congo Free State. He sent me up word later in the day that he would start in three days. Tippu does not allow the natives here to be ill-treated by his own men. An Arab was flogged by his command to-day for having unjustly struck a native. There was a regular sale of slaves to-day, about fifteen being sold by auction, of whom Tippu bought eight.

April 25th.-I generally take a walk every evening up the hill, at the top of which lives a rich Arab, called Muni Katomba, from Bagamoya. Two evenings ago, on my way home, he came out and said to me, "You pass my house every day; why do you not come in and see me?" I promised to do so the next time I passed, and called on him this evening. He was delighted to see me, and we had a long talk. These Arabs cannot believe that there are many poor white men (I opened his eyes on that subject), nor can they understand that there are people in England richer than the Queen and the Prince of Wales. He asked me why I had bought the native axes, and when I told him, he brought me out four large native knives, and asked me if they would be of any use, and I gladly accepted them. He took me into his house, and into the large courtyard at the back, in which he showed me all his women slaves, of whom there must have been two hundred of all manner of tribes. The women brought me a mat to sit on, and they crowded round to see me, most of them never having seen a white man before. On my departure he presented me with a goat, a quantity of fruit, and a beautiful Tanzibar mat, and then walked half-way down the hill to bid me good-bye. How different his treatment of me from that of the Arabs who live near 'Tippu-Tib's house, whose only object is to try and get everything they can out of one! He is a perfect gentleman in manner, and he is the only Arab who has taken me inside his house and shown me his women. The scene inside the courtyard would have made a 
1888. splendid picture. Women of all tribes, in every sort of Kassongo. dress (and many with scarcely any), stood in groups all round the enclosure, engaged in different kinds of work. My interview with Muni Katomba certainly did much to raise my opinion of the Arabs, not by his presents, but by his manner of giving them, and his whole treatment of me. I believe he is very rich, and owns many villages and slaves. He cannot at all understand why white men, with plenty of money, should leave their own country (and risk their lives) to see others. I bade him farewell in true Oriental fashion, placing my hand upon my heart, telling him that his kindness to me, a stranger and a passer-by, had made a mark upon it, which would never be obliterated.

April 26th.-Gave a copy of my sketch of the chief of Riba-Riba to him, according to my promise. TippuTib really means starting to-morrow. Thank God! there is a chance of our making a start in the right direction at last. Tippu-Tib gave me a piece of the copper money.

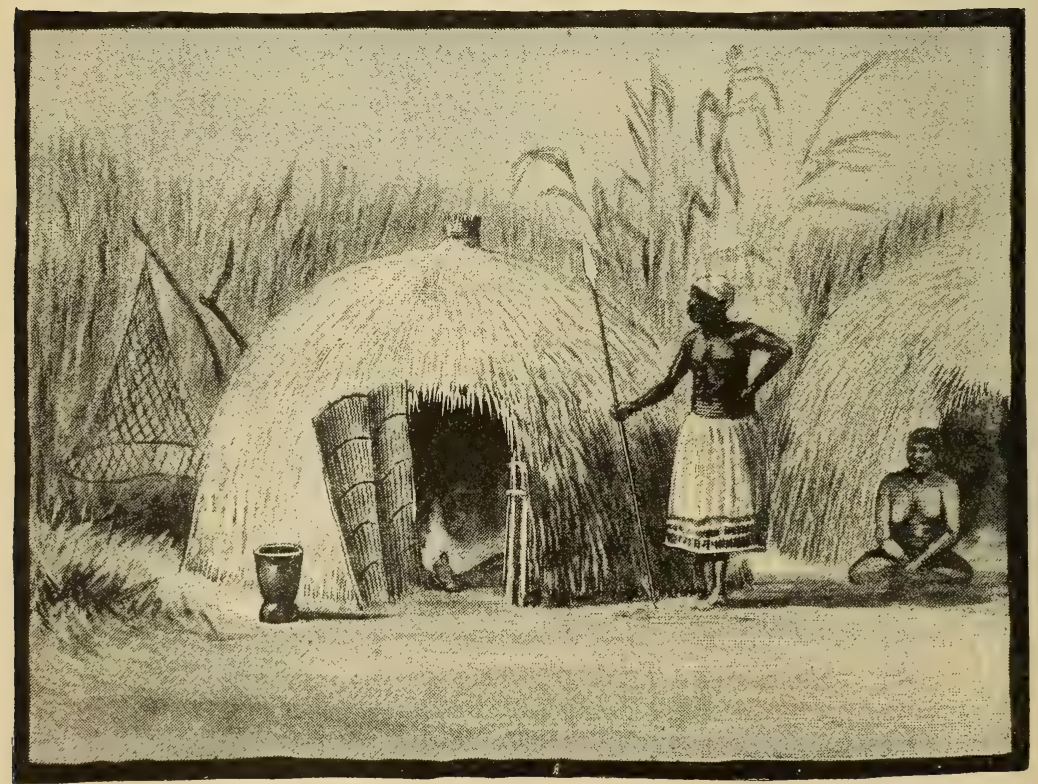

WaGANIA HUTS. 


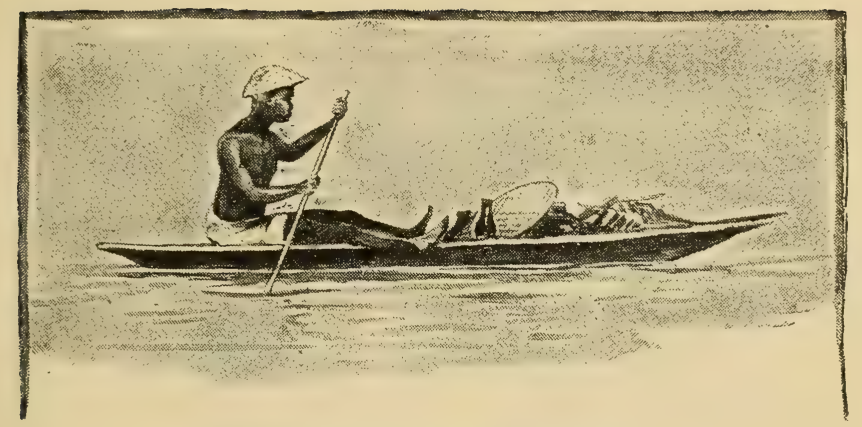

"Nothing LIKE IndePendence"”

\section{CHAPTER VIII.}

AprIL 27 Th to June 10TH.

Start back for Yambuya.-Delay at starting-point on the river.-Thirty-four of Tippu's men run away.-Tippu and Cameron.-Chiefs arrive to bid farewell to Tippu-Tib._Mirésa.-Tippu's conversation in Swahili._Two canoes sunk.-A narrow escape.-Assad Farran's uselessness.Riba-Riba.-Wacusu dance.-Cannibals.-Conversation with Tippu.Muni Somai.-Kibongé.-Chimpanzees.-Tippu's account of a journey with Stanley.-Stanley Falls.-Barttelot's interview with Tippu-Tib.Start for Yambuya.-Troup sends in application to be sent home.Hard at work reducing loads.-Caps turn out to be bad.--Letter to Mrs. Jameson.

April 27th.-Off at last, thank Heaven! On my way down to the river, I stopped to ask my friend Muni Katomba for his proper name, as I want to send him something from England. I now understand why his heart went out to me, for he must be a Scotchman, or at least of Scottish descent, his name being Abéde bin Mackya, or Abéde the son of Macky. It is curious that he was the only Arab who was generous to me besides Tippu-Tib. The walk to the starting-place on the river took about two hours' good going. It was a lovely day, with a fresh breeze blowing. Strings of

1888. April 27. Return Journey. 
1888. slaves, chained together, carried our loads. Most of April 27. them came from Maléla and the other side of the Journey. Congo, a great many from the head of the Lumami River. They, in most cases, carried their spears, bows, and arrows, just as they had left their villages. They are all for us, I believe. About a quarter of a mile before reaching the landing-place, I had to wade a river up to my waist. I thought it would be all right, knowing that my clothes had left hours before I did, but out of all the loads they were the only ones that did not arrive. I am now sitting, long after dark, cold and nearly naked, as there is scarcely any fire-wood here. On passing Tippu's house, about half a mile from here (the landingplace for Kassongo), I met Said bin Habib, a venerable white-bearded old Arab, with whom Tippu-Tib was having a conference. He was on his way to Zanzibar; he is very rich, and is one of the Arabs who questioned Tippu-Tib's authority as an officer of the Free State, as he had no visible signs of authority. Assad Farran did not arrive until long after dark, having started at least two hours before we did. No signs of clothes to-night.

April 28th.-I am afraid there is little chance of our getting away from Yambuya by the 24th May. There is another delay here which I had not bargained for, and a serious one; there are not nearly sufficient canoes to take us all at one time. This morning, when I went to see Tippu-Tib, he made me a present of a very handsome leopard skin upon which he was seated, and I went down with him to the canoes, as he was seriding away about one hundred of the men to an island opposite Nyangwé, where they could not run away. Unless 'TippuTib has more canoes further down river, this delay will occur again and again. The place has been really lively all day long, men arriving with drums beating and flags flying. They are always saying that all the canoes on the river belong to Tippu-Tib, but this is merely an empty boast. I was told the other day that he owned one hundred canoes and meant to buy more, but it looks to me as if he only owned about twenty! 


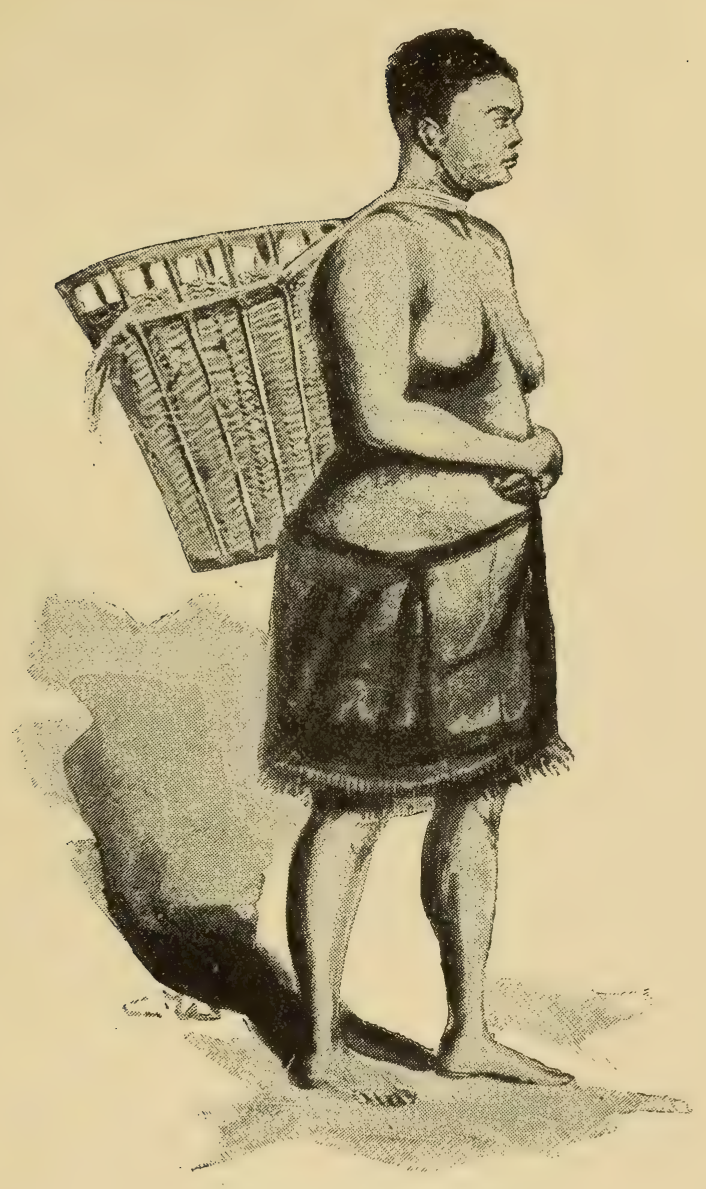

Native Woman in Market.

Passed a sleepless night from the cold and mosquitoes, for my clothes never came till this morning. They were carried by the men of one of 'Tippu's muniaparas, who is himself bringing a lot of men for us, and, I believe, is going with us from Yambuya. Thirty-four of his men ran away yesterday, hence the delay. Patience is a virtue you need to acquire in this country, if you have it not. Tippu-Tib gave Assad Farran a small boy to-day, belonging to the tribe Banga-Banga. The boy can speak no language but his own, and Assad is afraid

1888. April 28.

Congo River. 
1888. to send him on any errand, lest he should run away. April 28. A dirtier, more helpless and useless specimen than River. Assad Farran I have never met in my life.

April 29th, Sunday.-Was awakened by the drums of fresh arrivals. Tippu-'Tib personally superintends the shipping of all the men, whom he sends off to Nyangwé as fast as they arrive, for he is afraid of their deserting us here.

Mirésa, the Arab chief of Ujiji and Tanganyika, was to arrive at Kassongo to-day, and comes here to-morrow. Tippu-Tib told me this morning that the road from Kibonge is the one we ought to have gone by, as it is a much shorter and better one than Stanley's road. He says that most likely there will not be much water on our road, as after Ramadan, which is next month, there is less rain. He told me how he had met Cameron. He was at that time south of the Congo, in a large tract of country he had conquered below Maléla. Tippu did not then know that there were any Arabs at Kassongo and Nyangwé, nor did they know he was there. At the same time that he was fighting the natives to the north of him, the Arabs from Nyangwe crossed the Congo and went south, and as the natives about there had no guns, the Nyangwé people were astonished to hear shots fired near them, and they found Tippu-Tib's men fighting the natives. Tippu then came to Nyangwé, where he found Cameron, who wished to go on down the Congo, but the Arabs of Nyangwé refused to help him in any way; so he asked Tippu-Tib to take him back to his country south of the Congo, but Tippu-Tib told him he wished to go to Kassongo, to his brother Nzige. Cameron, however, asked him so often that at last he took him back to his country, where they met some Portuguese, with whom Cameron eventually travelled towards Loanda. TippuTib told me that Stanley had tried to strike across country to the north of this place, but found the bush so thick and the road so bad that he turned back, and begged Tippu-Tib to assist him to go down the Congo. 


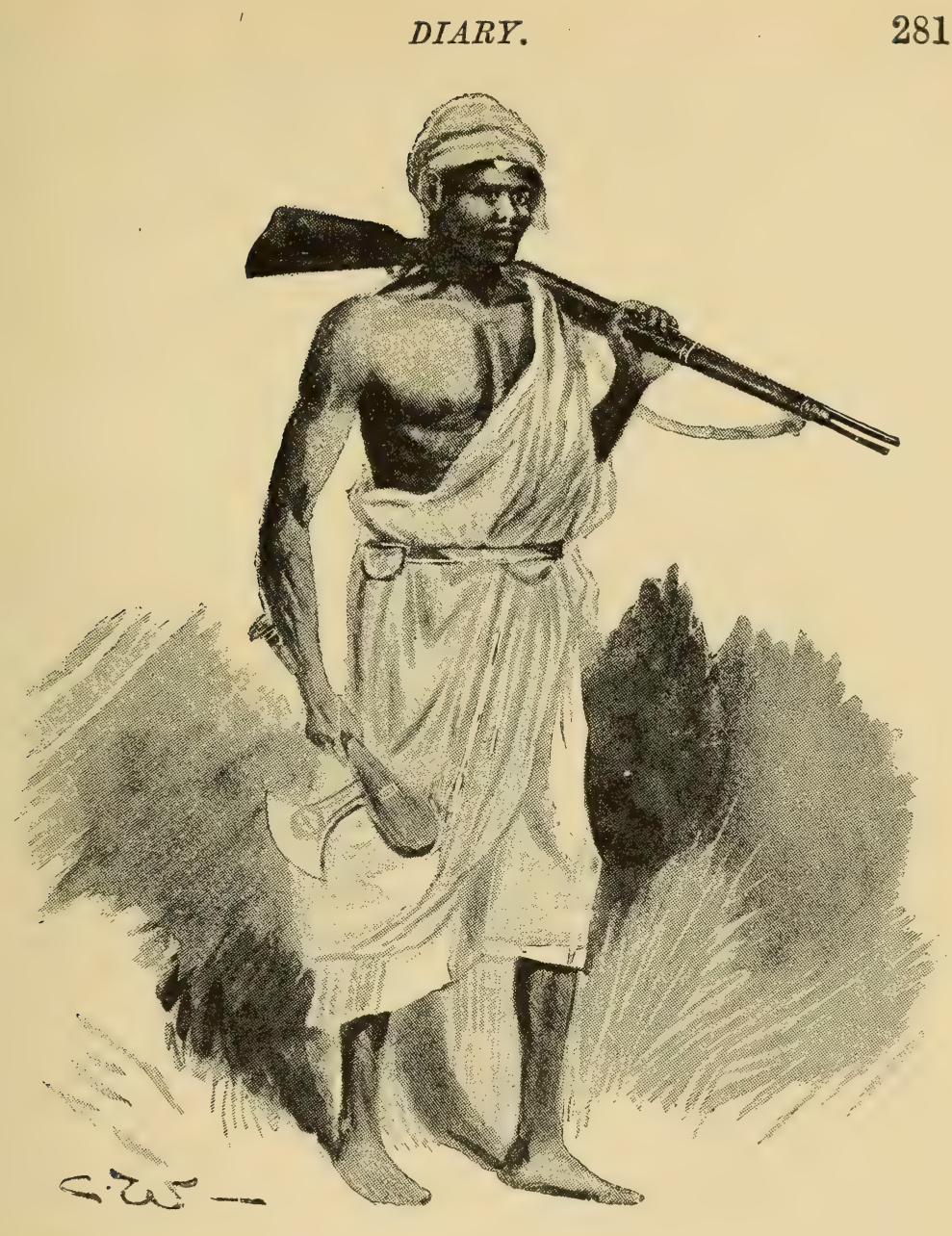

One of Tippu-Tib's Gun-bearers.

They struck the river at the rapids a day below Nyangwé, and there fought the natives, capturing canoes from them, in which Mr. Stanley descended the river.

I was rather amused to-day, when the canoes were starting, to see a lot of women crowding into one, leaving a number of men on the bank. Tippu-Tib handed all the women out, and put the men in, turning round to me and saying, "I don't want to see women going; I want to see men." The Manyéma men will

1888. April 29.

Congo River. 
1888.

April 29.

Congo

not go without some of their women, and, as far as 1 can see, there are nearly as many women as men.

River.

On the way to the river from Kassongo a man tried to run away, but he was caught by Sefo and made to carry a load for me. On our arrival here, Farani handed him over to Tippu, who put him in chains with a lot of others, and sent him off to Nyangwé next morning. Today his owner caught us up here, and asked Farani for him, Sefo having told him that the man was with me. Farani referred him to Tippu-Tib, to whom he then went, and who said to him, "Oh, yes, he was brought here, but he must have run away in the night, as I have not seen him since." This is the way in which one of our men was obtained! They have only a little over three months' rainfall here and the rest of the year is dry, so the river gets terribly low.

April 30th.-Tippu-Tib told me yesterday that he had received a letter from Selim Mahommed, who said that the men he had sent across the Aruwimi River to the north of our camp had crossed four rivers, and reached an open country with high grass, where the natives grew metammeh and Indian corn, not manioc. Here they had met a number of natives who had run away from some big chief to the north, who was fighting, and had been beaten by, some white men. Tippu-Tib asked me if I knew who the white men could be, but I told him I did not know of any one travelling in that direction. (Found out afterwards that this was M. Van Géle, of the Free State, on the Mobangwé or Wellé.) Only one canoe has arrived so far from Nyangwé. More men were sent away, but none arrived; there are many men here still in chains. God knows how long the delay here is going to be. When I speak to Tippu'Tib about it, he only loses his temper. One of his guncarriers was drowned to-day whilst bathing; he got into the current, which looks quite slow, but an eddy seemed simply to suck him down, although he was a good swimmer. Assad gets dirtier and more lazy than ever.

May 1st.-There is a hope of our getting off the day 


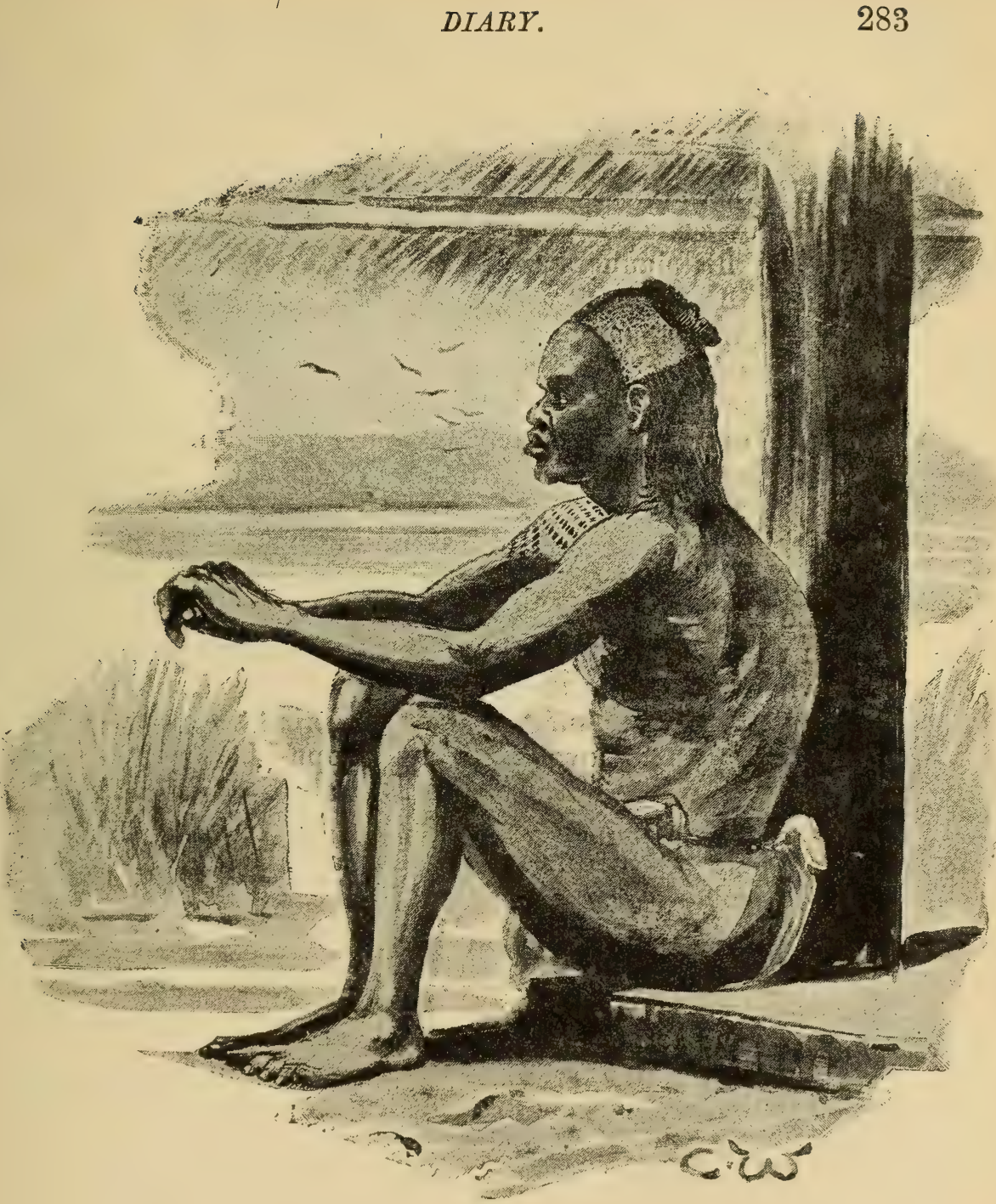

Lovga-Longa, Chief of the Mculusi.-Riba-Riba.

after to-morrow. All the grandees of the place arrive 1888 . to-morrow, to bid farewell to Tippu-Tib. Spent most of May 1 . the day with Tippu-Tib, sending off the loads in the Congo canoes.

May 2nd.-My heart is lighter to-night than it has 
1888. been for a long time. Mahommed bin Alfan, better May 2. known as Mirésa, arrived to-day, and I believe we shall

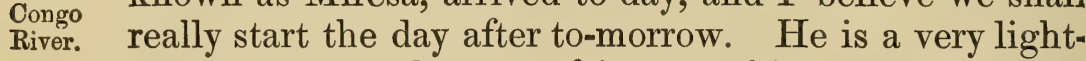
coloured Arab, almost as fair as a white man, and, were it not for the scars of small-pox, would be a good-looking fellow; his manners are those of an English gentleman. His head-quarters are close to the missionary, Mr. Hoare, at Tanganyika. I am beginning to understand a good deal of Swahili now, especially if the person gesticulates and acts. Whilst I was sitting with Tippu-Tib and Mirésa to-day, 'Tippu.Tib told him all about Stanley and the Expedition. From what I understood, 'Tippu-Tib knows nothing of Mr. Stanley's whereabouts, and he went on to tell Mirésa that Mr. Holmwood had been making a row about the men; he also made the old excuses about the powder not having come up with us at first, and the Soudanese not being allowed to fire when his men were wounded, and finally said that Mr. Stanley had gone off with a lift of his helmet, and nothing more was known of him. Tippu-Tib does not think that I understand a word of Swahili. Mirésa is a quiet-looking man, but from all I hear is a very devil at fighting the natives, and feared accordingly. Muni Katomba, my friend of Scottish descent, came to say good-bye.

May 3rd.-Sefo and Ali Mahommed came to bid us farewell. 'The former has a splendid band. Two girls go in front, singing and keeping time with bead rattles. Then come three men with side drums played by the hand, and last of all one man with a large drum, or chondo as it is called, slung before him, and played with drum-sticks. All the drums are slung on broad bands of leopard skin over the shoulders, and on the big drum are small bells, which tinkle when it is struck. 'The men sing as well as the women. Early in the afternoon a terrible storm came on, and, in spite of every effort, two canoes sank, and three others were only just saved. This was the result of loading the canoes several days before the start. When I was sitting with Tippu-Tib in 
the evening, about ten more men arrived from Maldla. There is no canoe for them. He remarked, "'The more the better," and I agree with him. They will go overland to Nyangwé. Tippu gave me the choice of one of four enormous goats to-day. I chose a beauty, the first long-haired one I have seen in this country, and it is as fat as butter; he gave me a very large one the other day, and this evening sent me two tins of sugar, and some Arab biscuits. I really do think that he is anxious to give us all the men, and to see us start. He will have to wait till midday to-morrow to dry his bales, which were nearly drowned to-day.

May 4th.-Tippu-Tib's things certainly did want drying; his cloth was all wet, and most of the gunpowder. The river-bank looked exactly like a bleaching-green, with the long strips of white cloth spread all over the grass. Sefo asked me to take a sketch of him, which I was only too happy to do, and Mahommed bin Kassim expressed the hope that "God would take me safely to my home, where I should find all well." Surely nothing will occur to delay us now ; but the old song of "What will to-morrow bring? Who can tell ?" is most applicable to this country and these people.

May 5th-OOff at last, thank Heaven! but-we had not gone far when we were nearly stopped for good and all. I have thought several times that the canoe was too small, and when everything was in it to-day it nearly sank. Everyone declared it was all right, but I put my foot down when Farani's women arrived, and insisted on their going in another canoe. Had I not done so, this diary would never have been written tonight. In the canoe were nine men, two boys, three goats (two very large), ten fowls, fourteen sacks of rice, one sack of peanuts, one large heavy tin box, two wooden boxes, three enormous loads of manioc, one tent, one lot of bedding, one bed, bags, baskets, plantains, cooking-pots, guns, mats, \&c. \&c. If a goat or a man moved one inch, in came the water! We went on, however, like a water-logged ship, until after midday, 
1888. May 5. Wagania village.

when a sudden heavy thunderstorm came up behind us. The men lost all control over the canoe, and she turned sideways to the squall; as it caught the large awning, there was no way of letting it go. I flung myself on to the board of the awning outside the canoe, and made my boy Farani do so too. For about a minute we were rushing through the water on our side, out into the middle of the river, luckily at such a pace that although the water was three or four inches over the side of the canoe, not very much came in. At last the men got her before the wind, when in came the waves, and we reached a bed of rushes near the bank only just in time. I have not had such a squeak for many a day, and I thanked God when it was well over. Had Farani and I not flung ourselves as far out of the canoe as possible, she certainly must have gone over. The two women of his, whom we did not take, would have done it, and the awning would have drowned us like rats in a hole. We camped at sunset in a small Wagania village in a swamp. Tippu-Tib's canoe came past some time afterwards, but I was not going on in the dark, when a single knock against a stump would have sent us to the bottom!

May 6th, Sunday.-Passed a terrible night between the mosquitoes and feeling very seedy. Hired a canoe from the Waganias, and put into it the three goats, six sacks of rice, and two boys. Reached Nyangwé early. Told Tippu that if I did not get another canoe I should have to leave the goats and rice behind. After some trouble, he promised I should have another canoe in the morning. Had to lie down all day, but luckily got some fresh milk; violent sickness all day. Said bin Abéde came in to see Tippu-Tib. He is nineteen, but looks younger. Had a great show of guns with him-silver-plated Winchesters, \&c. Mirésa had a Colt's repeating-rifle, about the same as a Winchester. Tippu-Tib is certainly wonderfully kind to me; he sent all sorts of food to try and make me eat, and after dark came up himself to the house, and brought me a large 
bowl of milk with his own hands, asking me if I was all right for the night.

May 7th.-Did not get away till about 1 o'clock. Passed a very bad night and morning. Brandy-andmilk is the only thing I can take. Seedy as I was, I had to stand out in the sun by the canoes, and superintend everything myself. I often wish Assad could be removed to another sphere of labour, as he is worse than useless in this one, only taking up the place of a better man. As I went down to the canoes for the last time, Mahommed bin Alfan and Salem Masudi ran after me, to bid me a last good-bye and a safe journey and return to England, and to ask if I had any messages to send to Ujiji. I begged them tell Mr. Hoare that all the officers were well, and that we were just about to start after Mr. Stanley. Tippu-Tib presented me with a puppy, bred in this country from English parents, one of which belonged to Mr. Deane at Stanley Falls. Assad is even more useless than I thought he was. Reached the rapids after dark.

May 8th.-Passed another very bad night. My boys let the canoe go over to the island, from whence it did not return until morning, with my coffee, milk, fruit, salt, and everything I required, in it. Assad sat on the bank and looked on. Consequently I had only some rice to eat and water to drink. The mosquitoes were frightful. Made an early start, and walked to the foot of the rapids, the canoes taking the loads. To mend matters, Assad, although he knew that to lighten the canoes everyone, even the men in chains, had to come out of them, walked quietly down to one of them, got into it, and went off. When I asked for him, he had gone. Last night he ate the rice which I was keeping for my breakfast this morning, so I started on nothing. I told him, when we met, that had anything happened to the loads in the canoe in which he went, I would have shot him, and so I should, for he is a positive danger to any boat. It took a good sharp hour and a half's walk to get to the foot of the rapids. The 
1888. picture was a bright one along the road to the foot of the Rapids. rapids, with the strings of Arab women in gay-coloured dresses, interspersed among the lines of chained men, and here and there the Arab chiefs in their robes of spotless white. Tippu met me at the foot of the rapids, and sent me a breakfast of pineapple, cakes, and thick milk. He considers yesterday a capital day's work. We camped at 4 o'clock, sending all our men on to an island. I am going to follow Tippu-Tib's example and sleep in the canoe. My little dog follows me about everywhere, as though he knew his parents were English, and recognizes me as his lawful master.

May 9th.-Got away, before sumrise, and did a good day's work, camping near Numbi, which was the place where we found the natives fighting with Kibongé. They are all quiet now, as he gave them a tremendous hammering, and took all their guns away. Tippu offered to take me down the rapids in a long canoe, but I told him the walk was what I wanted. Assad, as usual, kept everyone waiting. The start this morning was a fine sight, - the white awnings, red flags, and dark figures of the natives under a bright sun were very picturesque. I counted forty-five canoes, but there were many more which I could not see, and the men singing, drums beating, and the shouts of the paddlers made it very lively. A journey of this sort is an experience worth having, but $\mathrm{I}$ am afraid it is too late to be of any use.

May 10th.-Started long before sunrise, and reached Riba-Riba at sunset, making a long, hot day's work. I am so cramped up in this canoe that I am twice as tired as I should be after a hard day's walking, and for the same reason get no sleep at night. The chief here came down to meet and conduct me to the same house I occupied before. It is being re-mudded, and is more filthy and damp than ever, nor is there any diminution in the number of rats. I found out my dog's age today. She is between five and six months old. I don't think I have ever seen so young a dog with the same 
amount of sense. We have to stay here all to-morrow to buy food for the men, which is a pity, as we were getting on so well. However, it is no light matter to arrive in a place like this suddenly, and find food for four hundred men.

May 11th.-Took a long walk round the outskirts of: the town, and found some parts very pretty, standing in small clearings in the forest on little hills, with streams running between them. Opposite many of the houses I noticed small huts, not over two or three feet in height, made of grass mats, which, I was told, were graves, and in one I found a circular mound with a hole in the centre, resembling the one in the chief's grave at Yaweeko. Salem told me that they had heard from the Falls that Major Barttelot had sent Ward down to Banana, and that he was asking for a steamer. As 'Tippu-Tib was very busy, I went over to the old chief's house to have a talk with him, when presently a band, consisting of four drummers, arrived with three pedestal-shaped side-drums, and one wedge-shaped chondo. The players, whose heads were covered with thick white clay, and ornamented with a coronet of white feathers, knelt in front of the house, one a little in front of the others. The upper part of their bodies was streaked with the same white clay, and their dress consisted of strips of fresh palm-leaves hanging from a green branch fastened round their waists. Presently there danced into the reception house two men and a woman; the first man was dressed like the drummers, but the other man and the woman were clad in the ordinary Tamba-Tamba cloths. The first man held a large bunch of small branches and leaves in each hand, which he struck together over the head of each of us, dancing all the time, and all three singing a wild sort of chant. 'The woman had a knife in one hand, and a bunch of leaves in the other, with a circle of saffroncolour surrounding each eye. The other man held a spear and a bunch of leaves. These were followed by six men and the same number of women, with heads 
1888. whitened, and dressed the same as the drummers. Riba-Riba. They danced in, and, each in turn, clapped their branches of leaves together over our heads, and danced out again. The man and woman with the spear and knife, as well as a small boy holding two chickens with their throats cut, and two youths, all dressed the same as the others, went and stood behind the drummers. The other men and women then danced forward in a line, the men first, then the women, the drums striking up a lively measure. They now moved round the band in a circle, their bodies bent forward in a half-sitting posture, going through the most extraordinary contortions. 'This was kept up for some time by the men and women alternately, but at last they all stood still in a half-circle round the band, and sang a wild chant. Next came a handsome, tall young nigger, in the long white Arab dress, with a head-dress of red parrot feathers, and a woman dressed in gaudy-coloured clothes, and this couple, having become the centre figures of the group, went through a sort of benediction pantomime, raising their hands as the others all bowed their heads. The chief then presented them with a gun, and explained to me all about them. They are slaves from the Wacusu, and a good many of them have been dying lately, so these men and women went away into the bush for two months, during which time they have not been seen by anyone. 'They only returned to-day, having finished their medicine-making. Tippu-Tib, who came in before it was over, told me that they usually kill several people, and have a grand feast, for the Wacusu are terrible cannibals. He then told me, amongst other stories, that long ago, when fighting near Maléla, they killed a great many of the enemy. The natives who were with him were cannibals, and not a body could be found next morning. (He tells me that two men will easily eat one man in a night.) He sent for water in the night to wash his hands and to drink, the water there being in a well. When it was brought, he could not make out why it stuck to his hands, and was so oily and bad to drink. Next 
day he and several Arabs went up to see what was the matter with the water, and there they saw a most horrible sight. The top of the water was all covered with a thick layer of yellow fat, which was running over the side, and he found out that his natives had taken all the human meat to the well to wash it before eating. At the next place he camped by a stream, and made the natives camp below him. I told him that people at home generally believed that these were only "travellers' tales," as they are called in our country, or, in other words, lies. He then said something to an Arab called Ali, seated next him, who turned round to me and said, "Give me a bit of cloth, and see." I sent my boy for six handkerchiefs, thinking it was all a joke, and that they were not in earnest, but presently a man appeared, leading a young girl of about ten years old by the hand, and I then witnessed the most horribly sickening sight I am ever likely to see in my life. He plunged a knife quickly into her breast twice, and she fell on her face, turning over on her side. Three men then ran forward, and began to cut up the body of the girl; finally her head was cut off, and not a particle remained, each man taking his piece away down to the river to wash it. The most extraordinary thing was that the girl never uttered a sound, nor struggled, until she fell. Until the last moment, I could not believe that they were in earnest. I have heard many stories of this kind s nce I have been in this country, but never could believe them, and I never would have been such a beast as to witness this, but I could not bring myself to believe that it was anything save a ruse to get money out of me, until the last moment.

The girl was a slave captured from a village close to this town, and the cannibals were Wacusu slaves, and natives of this place, called Mculusi. When I went home I tried to make some small sketches of the scene while still fresh in my memory, not that it is ever likely to fade from it. No one here seemed to be in the least astonished at it.

In the afternoon I had a long talk with Tippu-Tib. 
1888. May 11. I explained to him that Mr. Stanley had left orders to communicate with the Committee when pcssible, and that, as no steamer had come to the Falls, Major Barttelot had considered it necessary before leaving on such a journey to telegraph the facts to the Committee, also to try to obtain a steamer for the conveyance of Mr. Troup away from the Falls, in case of our going home by another route. I considered it necessary to explain these matters to Tippu-Tib, as he seemed to think there was some other end in view, and had said last night that did we not send the loads, he would send the men after Mr. Stanley without them. This makes me all the more certain of what I have thought ever since reaching Kassongo, that if we had any row with him, this is what he would do. He told me to-day that Barttelot had had a row with Selim Mahommed, and that Nzige had written to Selim Mahommed, telling him on no account to have any row with the Major. TippuTib could not tell me what it was about. I told him that he must remember that the Major was quicktempered, and had been fearfully tried by the long delay at the camp; that he must not think much about it, as I knew Selim Mahommed was the man the Major wanted to go with us; that he, the Major, was only quick-tempered, not bad-tempered; that we all had had rows with one another in camp; and that we should be sure to find it all settled when we returned. He told me that he would wait three days at the Falls, then start all the men overland from Yalisula for our camp, and go himself with his chief Arabs up the Aruwimi in canoes. He asked me whether I would wait at the Falls and accompany the men, or go on straight to our camp. I told him I thought it better to go straight on to camp. I want to see Major Barttelot before he sees Tippu-Tib.

May 12th.-Left Riba-Riba just before sunrise, and camped on the river-bank about an hour before sunset. Had a long conversation with Tippu-Tib this evening. He began by asking me how we had obtained India, 
the Cape, and most of our Colonies. I told him most of them by conquest, and that the last of them was Burmah, where our troops were fighting when we left England. He said, "You see all this river from Nyangwé to the Falls, it is all quiet now, but when we first came the natives were very warlike, and we had to fight every village in turn. The Belgians have made me chief of Stanley Falls Station down to Bangala, and I want to see all that part of the river like this. What I propose doing is to fight each lot of natives on both sides of the river all the way from Basoko to Bangala, and leave men in charge of each large place; but the Belgians have never communicated with me since I came up to Stanley Falls last year." I told him I was as much astonished as he was that they had not done so ; we had often talked about it in camp, and Mr. Ward might say something about it on his way to Banana; their only excuse could be that they had no steamer. He then said, "We were at the Falls long before the Belgians. I had been wandering about and fighting in Central Africa for fourteen years, when I met a Belgian officer near Tanganyika, who asked me whether I agreed to the Falls belonging to Belgium. I asked him whether he had consulted the Sultan of Zanzibar. He said, 'No.' So I replied, 'Unless the Sultan gives the Falls to you, I will not." 'Tippu-Tib then saw the Sultan, who at that time would not have given them up. He returned to the Falls, where Mr. Deane then was, and settled numerous matters about the Lumami River and other places, and again left for Zanzibar, telling his brother Nzige not to quarrel with Mr. Deane, but that they ought both rather to try and help one another. Just after his arrival at Zanzibar, the news was brought to him of the fighting at the Falls, and he went straight to the Sultan, but, as he expressed it, "he found his power all gone," for the Sultan declined to have anything to do with it. Tippu-'Tib told him he would go to England about it, and he replied, "All right." Tippu-'lib then went to Mr. Holmwood, who told him there was no occasion to go to England, that he could 
1888. settle the matter from Zanzibar, and the present state May 12.

Congo River. of affairs is the result of that settlement. $\mathrm{He}$ said, laughing, "If I find all the power gone from the Belgians as it is from the Sultan, then I will take it all myself." He has written to the King of the Belgians, asking him to send two officers and about thirty men to the Falls, not to assist him in any fighting, but as visible authority on behalf of the State, during his own stay there, and in case of his absence at any time; but ever since the despatch of this letter (about a year ago) not a word have they sent him to the Falls.

He told me that if no steamer arrived before we left Yambuya, he would go himself to Bangala and ask for an explanation. I told him I thought he was perfectly right, as they had no business to keep him in suspense all this time, and that, when Mr. Stanley left, I did not think he ever expected they would have behaved as they had done. He said that the Germans had been treating with him for that country, but he had told them that as the Belgians were friends of England, and he wished to remain friends with both, he would settle matters with the Belgians. I told him that if I could help him by wiiting a letter to Mr. Liebrichts, fully explaining what his views were on the matter, I would willingly do so, and he said that if a steamer did not come before we left he would beg me to do this. $\mathrm{He}$ then asked me what it cost the King of the Belgians a year. I said I believed about $£ 40,000$. He asked if he got any return for this. I said, No; that the only people who made any money out of the country were the trading-houses, Dutch, English, and Portuguese. Tippu-Tib said, "If he will only give me half of it, I will guarantee him a handsome return from a tax on all ivory from Nyangwé to Bangala." The way the Belgians have treated Tippu-Tib seems very strange. He is extremely anxious to have a definite settlement made about the matter, and they have kept him for a whole year without any communication whatever. Tippu-Tib naturally cannot understand this way of doing things, and looks upon it as a decided slight upon himself. 


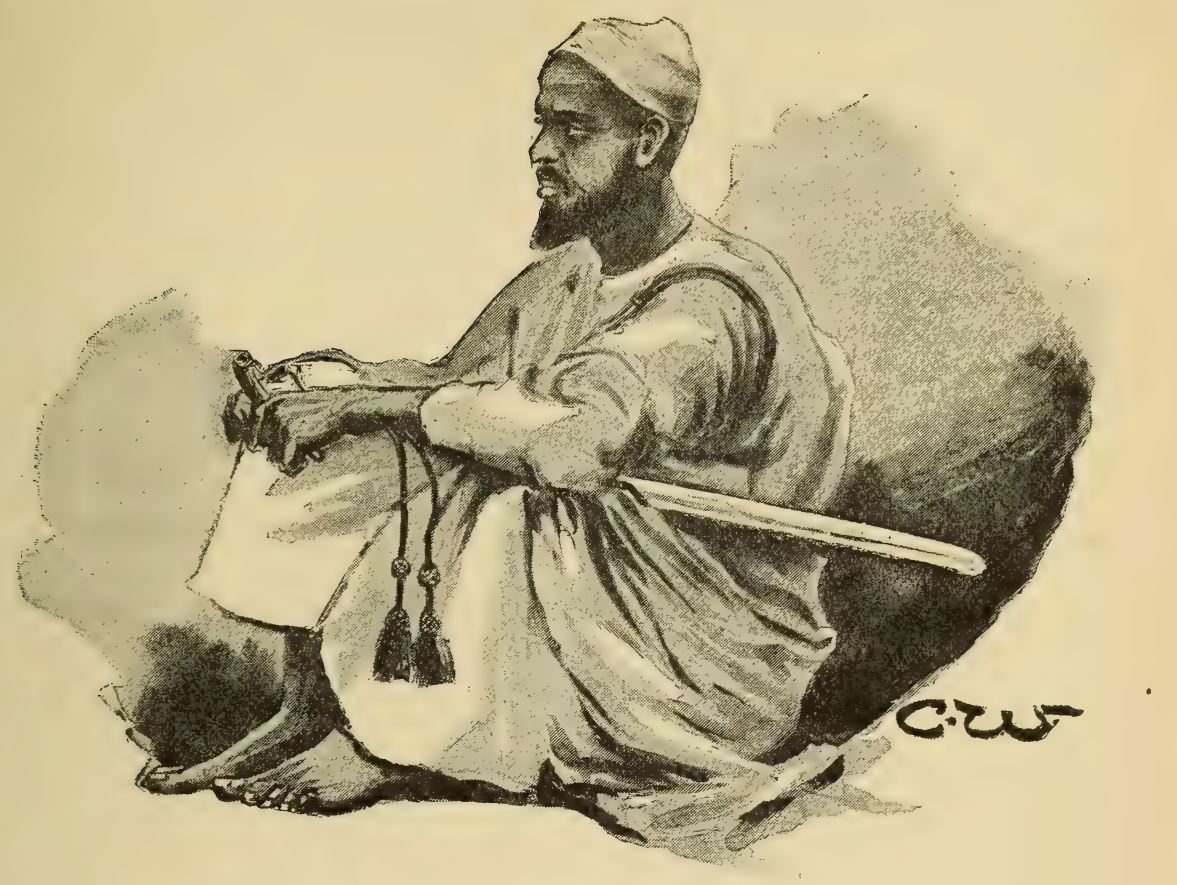

Muni SomaI.

May 13th, Sunday.-Started before sunrise, but did not do a very good day's work. We camped on an island just below the entrance of the Linde River. Tippu-Tib told me last night that the second chief of Riba-Riba, a tall dark Arab called Muni Somai, was coming with us, and would command the men, whether Selim Mahommed went or not. He seems pleasant, and Tippu-Tib says he is a good man for the work. When I told Assad Farran of this to-day, he quietly informed me that he had known it before, as the other Riba-Riba chief had told him that Muni Somai was paying Tippu-Tib $£ 300$ in order to go with us! Had I not spoken to Assad about it, he would never have mentioned this to me, and yet Major Barttelot's definite orders to him were to find out all he could from the Arabs that had to do with the Expedition, and to tell it to me at once. I

1888. May 13. Congo River. 
1888.

May 13.

Oongo

River.

asked him this very morning whether he had heard anything new, and he said "No." $\mathrm{He}$ is the dirtiest, laziest, and most useless specimen I have had to deal with, and is simply an encumbrance to me instead of a help.

May 14th.-Got away again before daybreak, and did the best day's work we have yet done, camping on the mainland about an hour before sunset. We ought to reach Kibongé early to-morrow.

May 15th.-Started after sunrise, as it rained heavily for about an hour. Reached Kibongé at 11 o'clock. Three of Tippu-Tib's men took some fish from the natives this morning, who in their turn took the men's guns. I was shown into the reception house, where Kibongé, the chief, Tippu-Tib, and all the head men were assembled. Among them was a tall dark Arab with a long black beard, exactly like one of the Indian Sikh Cavalry, who was giving 'Tippu-Tib all the information about the men left by Stanley at Eturi, and about the country itself. This man is a Soudanese, and deserted from Sir Samuel Baker in Uganda. It seems that he is the first man who has taught them how to make soap in this country. On my questioning him, Tippu-Tib declared he had received no other news of Stanley than what I already knew. Kibongé himself conducted me to the same house which I had before stayed in! This time, however, I had it to myself, as my host Kapruta was away fighting the natives at Yankéwé, beyond Wamanga Rapids. Kibongé, the chief, is exactly like a Chinese mandarin. In the afternoon I went to see two chimpanzees, just brought by the natives to an Arab. They are both females, and fine large specimens. Their owner keeps them in strong baskets slung from the roof of the verandah, and it is most amusing to see them rocking themselves backwards and forwards, evidently enjoying the motion. In the evening I made a sketch of one of Kapruta's Lights of the Harem, called Assimene, whom he has left behind in charge of the house. One great drawback to art in 


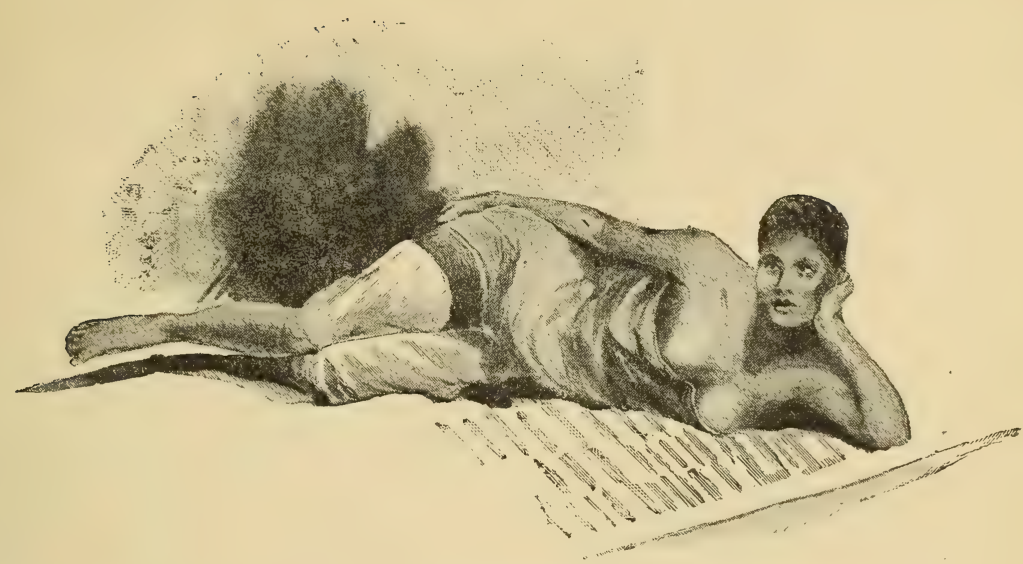

Assimene.

this country is the fact that all the natives and a great many of the Arabs believe that they will certainly die if you make a picture of them, and so one loses many sketches. Another whole day will have to be spent here for the men to collect food, which principally consists of sweet potatoes. The race of the whole fleet of canoes into Kibongé this morning was a fine sight.

May 16th.-Bad news to-day. Three guns were taken from the last lot of Tippu-Tib's canoes, that went down the river, by the same natives who took those yesterday, so men have been sent to recover them, and we shall have to wait here over to-morrow. Salem Masudi told me this morning that he had dreamed last night that he was with me on the march from our camp, just after we had left it, and that a messenger arrived to say that Stairs was at Tanganyika, and that we were to return and go down that way. Salem said that his dreams always came true, and that he was willing to bet one hundred dollars that we should never go to the Lake, and that most likely a canoe would come after us with the news, before we reached the Falls. Whether this is a quiet way of breaking some news to me, or an invention of his brain, remains to be

1888. May 15. Kibongé. 
1888. proved. I asked Tippu-Tib in Kibongé's presence this May 16. afternoon whether any of Mr. Stanley's men had reached Kibong'. this place. He turned round and asked Kibongé, who assured him that none had come here, and that all the men that Stanley had left were still at Eturi. He added they were all sick, and could not move when left. Tippu-Tib then said to me, "If one or two men had reached this place, I should have known it, for I am just as anxious to see them as you are." Took a sketch of one of the chimpanzees to-day, but it would not remain still for one instant.

May 17th.-After breakfast I went to see Tippu-Tib, and found with him Muni Somai, the chief from RibaRiba, who has a fine, good-natured, intelligent face, and I like the little I have seen of him. I told him I hoped we should soon know one another, and be good friends, as we should have to spend a long time together. Thank goodness! the guns have been returned, and we shall get away to-morrow. Kibongé came to my house and we had a long talk. He told me that he was here before Mr. Stanley went down the Congo, and that he had sent with him men to help him; that Stanley had given him and his men nothing, and that the only thing he got was a present of a $20 \mathrm{lb}$. keg of gun. powder from Ngalyéma, the native chief at Stanley Pool. He said that if Mr. Stanley had behaved well to him then, he would have sent all his men after him now. He told me that he had been with Livingstone, with the chief Sekrutu, and the Makalolos. It took him five years' hard fighting to conquer the country in which he now is. He said he would have found me in food, and taken me through the whole of Equatorial Africa, for the money which I paid Mr. Stanley. The camp at Eturi, on the Aruwimi River, is only one month's journey from the Lake. He was as much astonished as all the other Arabs at my coming on this Expedition, but came to the conclusion that "white men are curious people." He asked me if Stanley would make me no return in the way of money or land, and was greatly astonished when 
I told him that I should not make a farthing out of the whole Expedition! There is a fence of about $10 \mathrm{ft}$. in height all round the yard at the back of the house, and I succeeded to-day, after much persuasion, in getting a woman, who had come in to sell manioc, to stand for a sketch. I had hardly begun to draw, when she made a race at the fence, went over it like a bird, and alighted like a sack of coals on the other side. I saw no more of her. 'Tippu-'Tib sent for me this morning to look at a large bunch of plantains. Two men were carrying it, and it measured $6 \mathrm{ft} .9$ in. in length, and had nine points of fruit upon it.

May 18th.-Got away early, before the market opened, and reached the rapids above those at Wamanga. The river was so low that everything had to be taken out of the canoes and carried overland. Two of the canoes were

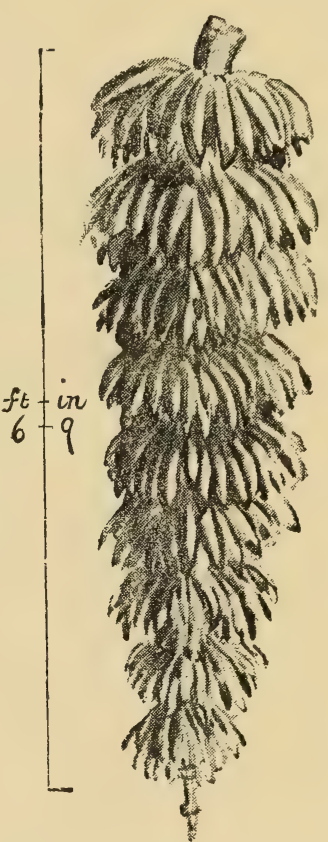

Bunce of Plantains. very nearly lost.

May 19th.-Tippu-Tib's canoe did not get over until late, and we had to wait at the head of the Wamanga Rapids until he arrived. There are about forty canoes belonging to Kibongé coming up the rapids, which causes a delay. Tippu-Tib camped at the head of the rapids, and I followed suit. He told us that Major Barttelot would meet us at the Falls; he also told me all about himself and Mr. Stanley, at the time when the latter crossed Africa. Tippu-'ib was at Kassongo, when Mr. Stanley arrived there and told him he wanted to go up north into the Munza country, promising him a lot of money if he would help him. He started with

1888.

May 17.

Kibongé 

1888. Stanley, taking a number of men, and they went for about fifteen days, through thick forest, water, and mud. Rapids. Tippu-Tib had told Stanley that it would take them sixty days, but the road was so bad that Stanley asked Tippu to take him back to the Congo that he might go down the river. They went back accordingly, and struck the river at the rapids, a day below Nyangwé. Here they tried to obtain canoes from the natives, but as they could not get them they put the boat together, crossed, fought the natives, and got canoes. Stanley and his men then proceeded down the river in the boat and canoes, whilst 'Tippu-Tib went along the bank. They journeyed on thus to Kasuku, when Tippu-Tib decided to return. Mr. Stanley agreed to his doing so, but when he wished to start all his men deserted, and said they were going back with Tippu-Tib. He went to 'Tippu, who promised to make it all right. Next morning, however, Stanley went again to Tippu, and told him that if he allowed his men to desert, and go back with him, he would write to the Sultan of Zanzibar, and have all his country taken away from him. Tippu-Tib then told Mr. Stanley's men that he would shoot any of them who followed him (Tippu), and at last got them into the canoes, and saw them start. Mr. Stanley said to him, "If I cannot get through, I will return, so wait here for some time; but if I get through, I don't know what present will be good enough to send you, for it will make a great name for me, and much money. I will send you my watch, which is a very valuable one, my gun, my tent, and anything you may fancy of mine," and then bade him good-bye. From that day to this he never sent him a thing, and Tippu-Tib told him so on board the Madura. Mr. Stanley replied, "Did you not get the beautiful cloth and gun I sent you?" 'Tippu said, "No. You sent the gun, a Winchester, to the Sultan, and the cloth to Terria Topin." There was a short amusing scene, I hear, to-day, when some of the natives, who were getting the canoes over the rapids, tried to run away. There was a grand hunt over the rocks and through the water. 
May 20th, Sunday.-Struck tents soon after daybreak. It is a fine sight to see the canoes shoot the last piece of the rapids, which they do right down the centre fall. Sometimes half of the canoe is clean out of the water. Four were smashed and lost, but no one was drowned. It is a curious sight to see one of these great, long canoes shoot up in the air, and then come crash down on a rock, when the longer half may be seen standing straight on end, and whirling round and round, only to disappear suddenly for good and all. I got a sketch of Tippu-Tib to-day, and one of Muni Somai.

May 21st.-Two more canoes were smashed this morning, but Tippu did not wait to buy more; we went straight on till sunset, when we camped at Yankéwé. There is not a native to be seen, and only the charred ruins remain of their villages. Kibongé's men have done their ruthless work thoroughly. 'The natives sent a present of ivory to Nzige, begging him to intercede for them, which he did.

May 22nd.-Started before sunrise and reached Stanley Falls at sunset. Found Major Barttelot and Mons. Van Kerckhoven, the chief of Bangala, here, the latter having come up in the S.S. A. I. A., on hearing of Tippu-Tib's annoyance at the non-arrival of any steamer. It is a real pleasure to talk to a white man again. It appears that Selim Mahommed has been trying to turn the natives against us, and there has been serious trouble between his men and ours. At one time, from his misbehaviour, the camp was considered to be in danger.

May 23rd.-Major Barttelot had a long interview to-day with Tippu-Tib, who said he could only give us 400 men altogether, and pretended that he did not understand at Kassongo that the 400 men asked for then were to be extra, besides the 600 already promised; yet at my interview with him on April 12th, at Kas-

1888. May 20. Wamanga Rapids. 
1888. Stanler the 600 men he would settle with Stanley, and that he

Falls. would leave the payment for the 400 extra men until our return. Every man of the 400 now given came with us from Kassongo this time, and he told me himself, on my arrival there, that he had already sent away 700 men. Judging from the number I met coming to the Falls on my road to Kassongo, in addition to the 250 already sent to the Aruwimi, he must have sent about 700, and I have not the slightest doubt that he would have given them all to us, had it not been for the arrival of Mons. Van Kerckhoven. This has caused him to hold back the men, either for fear of trouble with the Belgians, or in consequence of Van Kerckhoven having informed him that he would give him a protectorate over all the Aruwimi and up to the Wellé, or Mobangé, where Selim Mahommed's people have already been, and advised him to put as many men into that country as possible. It is a very serious blow to us. Muni Somai agreed to come as commander of the 400 men supplied by Tippu-Tib, on the payment of $£ 1,000$, and a right to any ivory he might get on the road. Tippu-Tib swore that he did not care whether he was paid one farthing for his men. He stipulated, however, that they were not to go into Uganda, and were to return to his territory, either to Stanley Falls, Kassongo, or Ujiji. Barttelot has explained to TippuTib his differences with Selim Mahommed. Tippu himself, and several other Arabs, said he was a bad man, and no friend to the white men. It is agreed that we start the day after to-morrow.

May 24th.-Tippu-Tib came over early and settled everything finally with us, and then had an interview with Van Kerckhoven. Tippu-Tib requested us not to go until the day after to-morrow. Wrote out agreements between Muni Somai and ourselves ready for signing, and bought fowls for the road.

May 25th.-Went over to the other side before 
breakfast, and got the agreements signed. In the afternoon crossed again, to say good-bye to old Nasoro Masudi.

May 26th.-A terrific storm of wind and rain came on last night, and fairly flooded me out of my bed. We did not get away until after lunch, having said good-bye to Tippu-Tib, and all the chief Arabs. We stopped at Tatiacusu for the night. We are eighty men short of the 400, but Tippu-Tib says we shall get those at our camp. He himself follows in three days with Van Kerckhoven in the A.1.A. Muni Somai follows to-morrow. Van Kerckhoven has been very kind indeed to us, giving us everything he could spare, and doing all he could to help us.

May 27th, Sunday.-Started at daylight, and reached Yangumbi, below Yalisula, about 3 o'clock. Men met us in canoes from every village, without our having to land, and took us on to the next. The head muniapara did not arrive until late, and as Muni Somai did not turn up, we had some difficulty in arranging about carriers.

May 28th.-Muni Somai arrived, and settled the question of carriers by giving us forty. Did not get away until 11.30, and camped at the third water. The road is a very good one, so far the best I have seen in this country.

May 29th.-Got away at 7 o'clock, and camped at a village called Yerina. The road was bad, owing to a quantity of cane-brake.

May 30th.-Barttelot went on ahead to the camp, while I followed with the carriers. Passed a number of the Aruwimi natives (under two Arabs), who were being taken from near our camp to fight some natives on the Congo. When Abdullah Karongo guided me to Stanley Falls the first time, he had natives with him from close to Stanley Falls, whom he had employed to 
1888. fight the Aruwimi natives. The muniapara with our Return to carriers got drunk on malafu, or palm-wine, to-day, and Yambuya fell off a log into a deep spot in one of the rivers, greatly to every one's amusement.

May 31st.-Reached camp before 11 o'clock. I was quite glad to get back to the old place again, for it has been a kind of home to me for a long time. Found Troup very ill in bed, and to-day he sent in an application to Major Barttelot to be sent home, which was granted. Busy repacking rice all the afternoon. Selim Mahommed came into camp and gave me a most

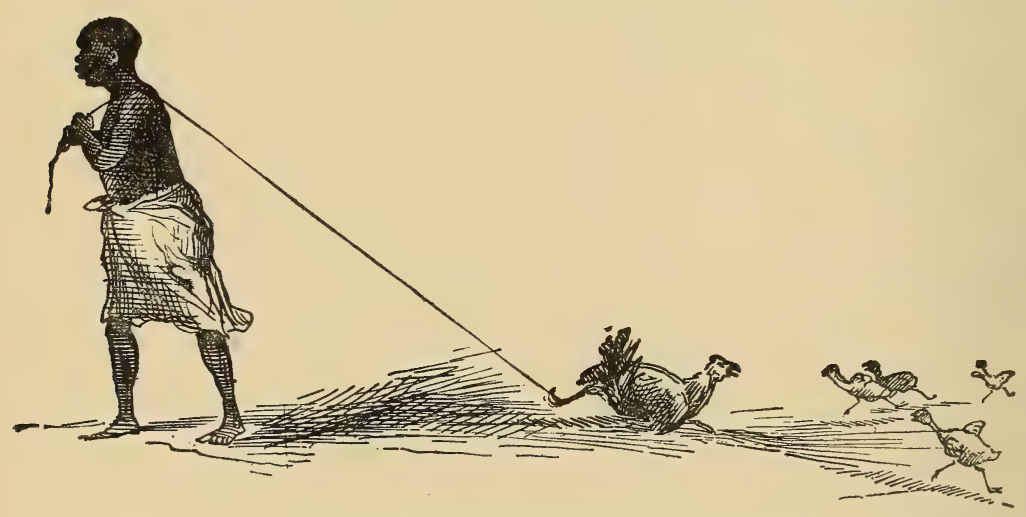

A N飞w Way of Catching Chickens.

affectionate greeting. Over eighty men have died in this camp altogether, and there are a good many little better than dead. I can see that I have a heavy task before me in the reduction of the loads. Barttelot has too much writing to do to be able to help, Troup is ill in bed, and Bonny has a very bad hand, which quite incapacitates him from doing any work whatever, so that I must do the whole lot myself.

June 1st.-Busy reducing loads all day. Muni Somai arrived, and said that Selim Mahommed will do nothing for him. He can get no fish, and says he came away in such a hurry that he has no rice, or anything to eat, and no clothes for his women! 
June 2 nd.-A hard day again at the stores.

June 3rd, Sunday.-All day again at the stores. Heavy rain.

June 4th.-All day at the ammunition boxes. The Stanley and the A. I. A. arrived, bringing TippuTib, Mons. Van Géle, Mons. Baert, who is to be Tippu-Tib's secretary, and Mons. Van Kerckhoven, and the new Belgian officer for Stanley Falls Station. The Stanley brought a great number of letters, principally for Troup and Bonny. My share of them, alas! consisted only of a receipt from Rowland Ward for things sent home with Mr. Walker. No news of Mr. Stanley. Ward cannot possibly return before July. 'Thank goodness, Mr. Werner, the engineer of the $A$. I. A., has offered his services in assisting me with the ammunition, and is bringing three carpenters from the steamers.

June 5th.-Busy again all day and part of the night at the stores. Barttelot had an interview with Tippu-Tib, and succeeded in getting thirty more men.

June 6th.-Still at loads all day, and busy at night writing out list, \&c., for the Major. Mons. Van Géle has agreed to keep the steamers here until Saturday, we having given him six goats as food. Barttelot again interviewed Tippu-Tib, and obtained fifteen slaves for his 500 express rifle.

June 7 th.-Busy day at the loads. Tippu-Tib and Muni Somai signed agreements, on receiving part payment of their money. I hear that the relations between Tippu-Tib and Van Kerckhoven are decidedly strained at present. We discovered three parts of a bottle of whiskey in an old box of William's, the last remains of that which I brought from England. Needless to remark, it was seized upon, and consumed at intervals during the next three days. I have not had a moment of time to pack my collection or to write home. 
1888. June 8th.-The loads that Tippu-Tib's people are to June 8. carry were handed over to him to-day. A good many of them were a pound or two over the exact weight, and he refused point-blank to carry them, although yesterday he himself handled many of those now objected to, and said they were perfectly right. Whilst repacking them, I had called Barttelot's attention to the fact that some of them were over weight, asking him if he thought it would matter, to which he replied, "Certainly not." We therefore cannot start to-morrow, but must re-open a number of the cases, and reduce them, in many cases by only two small packets of cartridges. The chief objection raised was that the specially packed Remington ammunition had not been reduced. Troup was carried on board the Stanley this evening.*

June 9th.-Got all the loads finished to-day. The Stanley and $A$. I. A. left for Stanley Falls.

June 10th, Sunday.-Gave out loads, guns, \&c. Nearly all the caps turn out to be bad. When packing them on board the S.S. Madura, I tried some of them, and told Mr. Stanley that they were bad, but he would not listen to me; the consequence is, we have had to buy 40,000 from Tippu-Tib. I had just time to pack my collections roughly, but God knows how they will all get home! I am sending them by Tippu-Tib to Stanley Falls, there to await the arrival of Mr. Greshoff, whom I have asked to forward them home. Had scarcely an hour left to write my letter for home.

* From a letter to Mr. Andrew Jameson, dated June 8th :- "Major Barttelot and I have had to sign our names to an agreement to pay the man going in charge of the 400 men, of Tippu-Tib's, the sum of $£ 1,000$ on the completion of our journey after Mr. Stanley and Emin Pasha. We are almost certain the Committee will give this sum; but, so that there may be no mistake about it, Major Barttelot has asked his father to place $£ 500$ to his credit at Zanzibar, in about six months' time; so I want you to send me a letter of credit for that amount in about six or seven months." 
LETTER TO MRS. JAMESON.

1888.

June 8.

Yambuya Camp, June 8th, 1888.

.... Ward is away down the Congo sending telegrams to England. Troup has just gone off in the Stanley, I fear in a dying state, leaving only Barttelot, Bonny, and myself to do all the work. Bonny has a frightfully bad hand, which prevents his doing anything at all, and the Major's time is entirely taken up with official correspondence, so I have had a bad time of it. I have had to convert nearly 500 loads of $60 \mathrm{lbs}$. each into loads of $40 \mathrm{lbs}$. each, and write out all the lists, \&c., for the Major. We start the day after to-morrow, and I have had not one atom of time to pack my collections, and the steamers are gone. I don't know what I shall do. I will try and get 'Tippu-Tib, who is here, to take them to Stanley Falls for me, where they may catch one of the Belgian steamers. We have only got 400 men from 'Tippu-Tib after all his promises to me at Kassongo, so we have to leave many of our loads, but are going to do our best to reach the Lake, and find out something about Stanley and Emin Pasha. . . . I do hope we shall be able to get home in about nine months from now. . . . It was so sad to see the steamer arrive the other day, and not a letter for me* I am to do all the advance work of the march; Mr. Bonny will be in the centre, and the Major in the rear. . . . . The next news you will hear from me will be a telegram from Zanzibar, telling you I am just leaving for England. Not one word of news have I had since your letter from Italy of April, a year ago; it is this entire lack of news that makes it so hard to one. And now I must bid you a long good-bye, and may God bless and guard you and our little ones until my return. . . .

* By some inexplicable mischance, Jameson's letters were detained at Banana, and even upon Mr. Walker's application for them, with a written order from Jameson, they were not given up to him.-ED. 


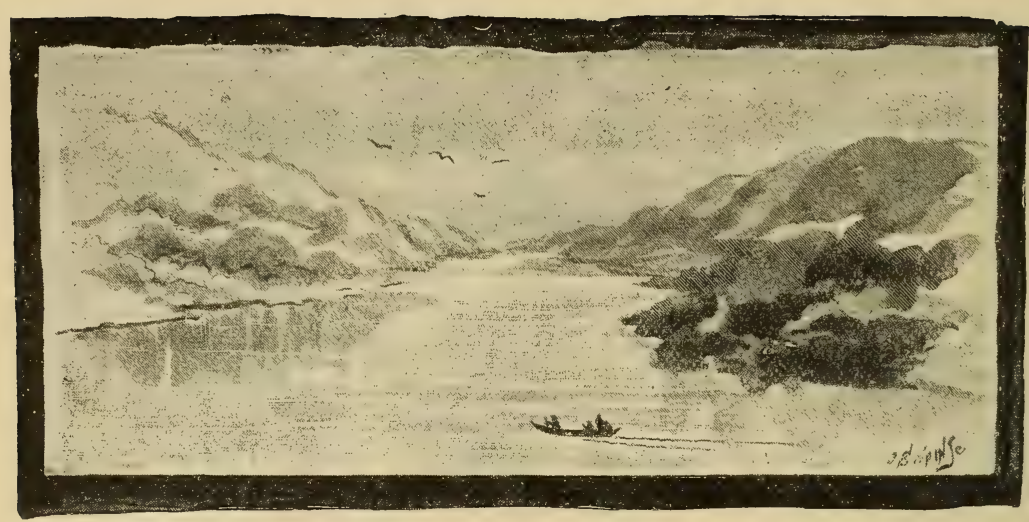

River Scene.

\section{CHAPTER IX.}

\section{June 11th to August 8th.}

Final start from Yambuya Camp.-Manyémas loot the camp.-Abdullah's village.-Muni Somai has trouble with Manyémas.-Fourteen men desert.-Jameson returns to Yambuya in search of missing loads.-Selim Nahommed guarantees to recover loads and rifles.-More desertions.Small-pox.-Muni Somai goes in search of deserters, and is fired at.Theft of beads.-Trouble with the Muniaparas.-A long day of disaster. -Major Barttelot returns to Stanley Falls, leaving Jameson in command.-Fresh trouble with Manyémas.--Jameson arrives at Ujéle.Takes over command from Bonny.-Muni Somai utterly useless as a commander.-Mquangandy.-Letters from Barttelot ordering whole force to proceed to Unaria.-War amongst head men.-A night fusillade. -Bonny loses his way.-Muni Haméla hands over to Jameson 40,000 Enfield caps.-News of Major Barttelot's death.-Arrival at Unaria.Interview with three head Manyémas. -Jameson offers reward for Sanga's arrest.-Jameson proceeds to Stanley Falls.-Finds the Manyémas camped in forest.-Meets Muni Somai.-Nasoro Masudi warns Jameson that Manyémas have threatened to shoot him.-Arrival at Stanley Falls.-Interview with Tippu.-Muni Somai tried and convicted of desertion.-Letter to Andrew Jameson.-Letter to Mrs. Jameson.-Rachid declines to accompany Jameson.-Tippu volunteers to do so for $£ 20,000$. - Trial and death of Sanga. - Jameson determines to go to Bangala in order to obtain reply from Committee.-Mr. Stanley's letter to Jameson.

\section{DIARY (continued).}

1888. June 11th, Suédi's Village.-Thank God, we have left June 11. Yambuya Camp at last, and I hope for good. Got all the 


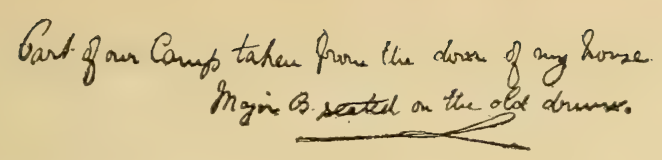

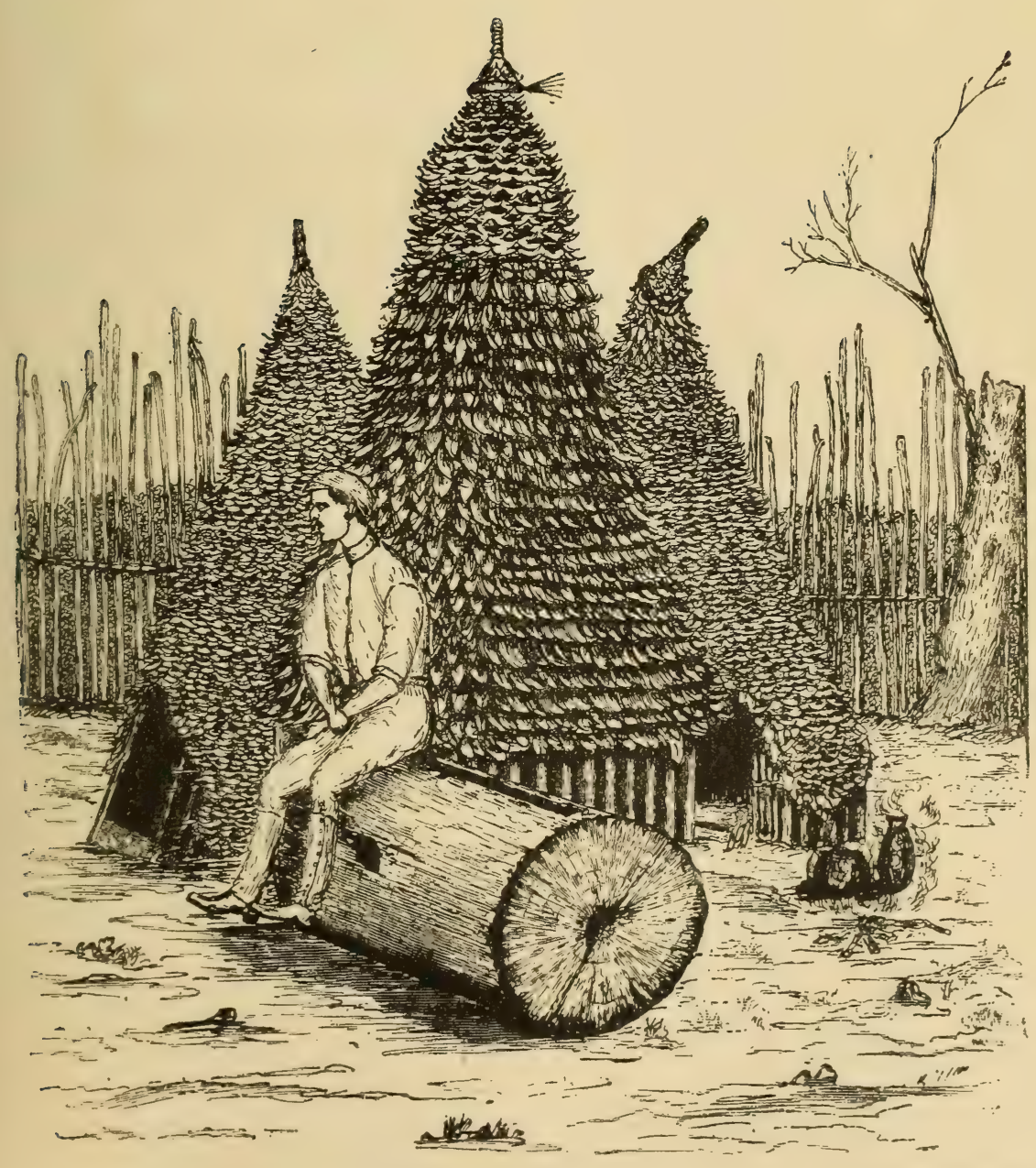

Fac-simile of a Pen-And-Ink Sketci by J. S. Jameson. [Page 308.] 

men and loads started at 7.30. Before we had actually quitted the camp, and were standing outside, Tippu-Tib's people made a rush in, and looted everything remaining in it. I had left five cases in my house, containing all my natural history collections and curios firmly screwed down, and in charge of Mons. Baert, Tippu-Tib's new Belgian secretary, who was kind enough to say he would look after them for me, until Mr. Greshoff's arrival at the Falls, to which place Tippu-Tib had promised to take them himself. The following letter from Mons. Baert, sent after me, will show what happened to them :-

\section{DEAR SIR,}

I have a bad news to announce you. Whilst I was going to ask Tippu to take your loads, the Manyémas came in the camp, and robbed all what they could. Just in returning I saw one man with one of your boxes, and I took it with me. But when I arrived at your house, I find one of your boxes broken and all that was in it stolen. I immediately made a furious talk to Tippu, and his man slave been send over the camp. Lucky have found of your boxes, and I will do all what I can to have the rest, but I have not a great hope. I am very sorry of that, but I assure you it is not my fault. It is a good lesson for my future conduct with those beggars. A last time, good chance, and my compliments to Major and Mr. Bonny.

\section{Yours sincerely, \\ A. BAERT.}

You may imagine my feelings on receiving this note. Our men followed the example of the Manyémas, and before starting fired off about twenty rounds before we could stop them. They marched well, and seemed willing. Frightful bother with Muni Somai's loads in camp. Men continually firing off guns. The road lay for the most part up the bed of streams, which made the going bad.

June 12th.-Reached Abdullah's village at the rapids 
1888. June 12. Abdullah's Village.

about 4 o'clock. The road is the worst I have seen in this country, lying through old plantations, overgrown with manioc, and full of large fallen timber, with one bad river to cross. Muni Somai's men did not start until after us, and only reached a village not quite halfway, where they camped. Bonny's donkey could not get over the fallen timber, and was left on the road. A little more than half-way here we crossed Stanley's road, running parallel to the river about a mile above it. The men came along very well. No loads lost. I fear there will be trouble before long between our men and the Manyémas. Our men are afraid of them, but taunt them for not carrying heavier loads, and for being cannibals, as, for a fact, the majority of them are. Canoes pass the rapids here up the northern bank. There are hippos below the rapids on the southern bank. This is one of the advanced posts of the Arabs on the Aruwimi, and was formed by an Arab of Tippu-Tib's called Abdullah Corona, after our arrival at Yambuya this time last year, when it was a native village. It is now in the charge of an Arab called Sala Sala; it possesses four or five large Arab houses, and many smaller ones, and promises to be a large post. Abdullah has formed another camp at Unaria, about nine days from here, higher up the river, which is 'Tippu-Tib's most advanced post. The only other Arab camp is at Eturi, said to be within a month of Lake Albert Nyanza, formed by Arabs from Kibongé on the Congo, the head of it being Lugalowa, an Arab and a freed slave.

June 13th.-Halted all day. Muni Somai's men began to pass through about 11 o'clock, but he himself, with the rear-guard, did not come in until two hours later. Had a busy day, mending helmet, boots, revolver, holster, \&c., and making a bed. One man ran away yesterday with two guns.

June 14th.-Started at 6.30 from Abdullah's camp, and reached the last native village between it and one of Nasoro bin Saef's, which is five days further on. I arrived about 10 o'clock, the rear at 11 o'clock. The 
road lay for the first hour amongst low bush and manioc plantations, then through a large village into a swamp, and on to another long native village of huts shaped exactly like bee-hives (not the candleextinguisher type met with lower down the river); then passing very large plantations of manioc and plantains, led through another village into this one. Muni Somai says his men cannot start till the day after tomorrow, as they have to collect four days' food. The Major decided upon going on slowly to Nasoro bin Saef's village to-morrow (as his men had plenty of time to get food), and to leave me to follow with Muni Somai and look after his loads. A few of the worst men made a complaint about starting, but none of the good ones, which makes the Major all the more anxious to start to-morrow. Muni Somai seems very anxious to get on well with us, and to make the whole thing a success, but he evidently has a good deal of trouble with the Manyémas.

June 15th.-The Major, Bonny, and myself all breakfasted together before daylight. Tents were struck, the men took their loads, and all went quietly off, only my own carriers and bags remaining with me. Just after they had left, Muni Somai brought me one of our rifles, and said that one of his men had caught one of ours deserting in the night, and had tied him up, but in the morning the man had gone, having left his rifle. He told me that after the Major had gone, Dahomey, the head man in charge of our goats, had passed, going back on our old road, and when stopped had stated that the Major had ordered him to go after the other man to try and catch him. I told Muni Somai to send men after him at once, and started off to the far village next Sala Sala's myself, offering a reward there to any man who would catch him. I had just returned, when the Major came back into camp, telling me that fourteen men with their loads and rifles had bolted between this and his camp, about four hours from here. He said they might have lost their road, but he thought not, and returned to his 

June 15. camp to see. About 4 o'clock I received a note from

Sala

Sala's

Village.

Two rifles given up by Selim Mahommed to me.

him, by the man who brought me some meat, saying eleven loads were missing, amongst them three boxes of provisions, one double load of medicines, and two bales of our most valuable cloth, as well as that for present expenditure. He asked me to start for Sala Sala's at once, which I did. The meat had gone bad, so I had nothing to eat but a little rice, and a few biscuits to take with me. Got into Sala's village before dark. $\mathrm{He}$ told me he knew nothing about the loads, but had sent in two of our rifles (which the man Mabruki had run away with on our second march) to Selim Mahommed, so I determined to start for Yambuya at daybreak and get the rifles if I could not get the loads. About 10 o'clock P.M. Salem sent me in a little rice, and a chicken the size of a sparrow.

June 16th.-Started about an hour after daylight; reached Yambuya before 10 o'clock, although the swamps and paths were very bad from the rising of the rivers. Saw Bonny's donkey quietly grazing in the village where we slept the first night. Selim Mahommed sent out men at once to stop all the roads to the Falls, and told me that though he meant to start for Singatini next morning, he would wait and do all he could to recover the loads. He had a big chief with him from the country due north of the Aruwimi at Yambuya, called Golema. The country of which he is chief is Oockwa, on the Wellé River, the people being named Wackwa. $\mathrm{He}$ is a fine-looking native, dressed like an Arab, and he wishes to see and treat with Tippu-Tib, fearing that he means to invade his country; he has brought him a present of sixty-seven very fine tusks of ivory. It was into his country that Selim Mahommed went north of our camp. It is a complicated business. Mons. Van Géle, in the $A$. I. A., has been up the Mobangé or Wellé, and endeavoured to treat with his people, and Selim Mahommed's men attacked him from the south, overland, and he is now going to treat with Tippu-Tib, little dreaming that 
Tippu and Van Géle are both officers of the same Free State. I wonder how much of the ivory the Free State will get! After a frugal meal of some rice, flavoured with fish, I tramped back to Sala Sala's, getting in there at 5 o'clock, too late to start for our camp. Salem again gave me a sparrow, and having had no breakfast I went to bed desperately hungry, but more sorry for my dog, who had fared worse. No news of men or loads.

June 17th, Sunday.-Started at daylight, and reached Muni Somai's camp at 8 o'clock. No news of loads. About an hour later the Major arrived, when we interviewed Muni Somai. Selim Mahommed had told me, and had written the same to Muni Somai, that if we would wait five or six days, he would guarantee to get us back the loads and rifles. This decided the Major to leave me here with Muni Somai until Friday, as the loads are about the most important we possess, and to start himself to-morrow morning for Nasoro bin Saef's village, five days from here, where he will await us. He wrote all the facts of the case to Tippu-Tib, and asked his aid. This village consists of a long double row of small penthouse-shaped huts; it is called Wobari, being inhabited by the Wonga Wobari. Not two miles nearer Sala Sala's is a big village similarly shaped, of huts like beehives, and built of large dried leaves. This is Bungari; the people are called Wonga Bungari. The tribes seem to be very much mixed. In some villages the three distinguishing huts, viz., the candle-extinguisher type, as at Yambuya, beehive-shaped, as at Bungari, and pent-house-shaped, as at Wobari, are all found represented. I have made sketches of both the latter villages, showing the different huts. Just after our interview a perfect torrent of rain came down, and although $I$ had a trench round my tent, it quickly filled with sand and water.

June 18th.-Spent most of my day in cleaning rifles, revolvers, \&c., and in copying my diary to Kassongo and back, in ink. I was greatly astonished, at 5 P.M., by the arrival of Muni Hamésé, one of the Zanzibari munia- 
1888. June 18.

Wobari Village.

paras, with a note from the Major. More desertions have taken place. Munichandi, one of the men whom we rnost trusted, has bolted with his rifle, and the fly of the Major's tent. A man called Rasasi has gone also with two rifles. Munichandi left this place with another man late last evening, for the Major's camp. I asked him before he started where he had been, and he said only to the next village. I thought something was wrong, so I sent a note to the Major telling him I imagined Munichandi had been either to Sala Sala's village or with the deserters. It appears that Munichandi told him he had been to Sala Sala's village for food. I thought of keeping him here last night, but the Major would have been short of two carriers this morning, and I felt that should he suspect him, after questioning him, the man would be safer under a guard of Soudanese on the march than here. This man, Munichandi, came to me during our first march from Yambuya, and begged to have his load lightened, as he wanted to be ahead with me, and help to stack the loads and pitch the tents. I knew he was a useful man, and gave him a very light load. This is the result. It is awful to think that the very men one trusts most, and is kindest to, may bolt at any moment, perhaps with all one's diaries, drawings, \&c. I left Yambuya full of bright hopes, but I must say they have received rather a damper at the start. Muni Somai received a letter from Selim Mahommed to-day, saying he had sent natives after the Zanzibaris in every direction, and had stopped the roads, and hoped to catch them in two or three days at most.

Two rifles rescued by Muni Somai.
June 19th.-This morning Muni Somai brought a rifle and a sack with corn-flour in it. He says that last night one of the deserters, called Hamadi bin Masuri, had tried to pass through the village next to Sala Sala's. When stopped, he flung down his rifle and the sack and bolted, getting clean away. I think they must be mistaken in their man, as Hamadi was carrying a sack of cloth, not corn. Just as I was going to have my dinner, some of Muni Somai's men brought in a deserter with 
his rifle; they had caught him in the bush. He is an old man who was employed as a goat-driver, not being strong enough to carry a full load. I tied him up with the three natives, under the Soudanese, and gave the man who caught him twenty matakas. Muni Somai says he has ordered all his men to come into this village, but that they are not like Zanzibaris, who obey at once; they are hard people to deal with. He told me he wanted to start the day after to-morrow, as his men were getting sick, and that he was going to Sala Sala's village tomorrow. I told him I was just as anxious to get ahead as he was, but that the recovery of our loads was most important to us. I was going to Sala Sala's myself to try to shoot some buffaloes near there, but as Muni Somai is going I will remain in camp. He is very anxious to start, as four of his men in another village have got small-pox; this is evidently his reason for not getting them together.

June 20th--Muni Somai left for Sala Sala's village after breakfast. Sadi, one of his head men, brought me three sacks of beads and one of cowries, which were damaged and required sewing. I pointed out to him that a quantity of beads had been taken out of one of the sacks, but he only said he knew nothing about it. A heavy storm of rain, thunder, and wind came up about 1 o'clock, and it rained steadily on until sunset. One of Muni Somai's men came in about an hour after dark, to say he was not coming back to-night, but would sleep in Sala Sala's village. He had recovered two rifles, a box of tea, and some matakas, also a sick man, but no loads. It is a nuisance, his stopping away, as I want to go there myself to-morrow, and mend any boxes or sacks that were broken in the two villages where his men are, as they evidently don't mean coming in until we start.

June 21st.-Awoke with a bad cold, which I hope ivill go off before we start, as on the road one is wet all day long. Muni Somai did not arrive until after 5 o'clock, which prevented my going to the other villages. 
1888.

June 21

Wobari Village.

He seemed very worried and tired. He told me that last night natives had come in to Sala Sala's village, reporting that some of the deserters were camped in a village some distance from the river to the south. Muni Somai and Sala Sala then started for the village with some of their men, taking the natives as guides. Upon their approach one of the Zanzibaris jumped up out of the path and ran into the village shouting, "The white man is coming." Muni Somai and his men ran in, when one of the deserters fired a shot at him; they all bolted, not one being caught or shot. They left six rifles, a bottle of salt, a lot of cloth, cartridge-belts, \&c. Altogether Muni Somai handed over to me: 8 rifles, 10 pieces of cloth, 2 tins milk, 1 tin cocoa (broken), 1 bottle salt, 1 lot broken candles, 1 box tea open (box had been used for cooking), 86 matakas, 1 cartridgepouch, 1 packet cartridges, 2 cartridge-belts, 1 bar soap. No loads were recovered. From what we found it is evident that they have broken open and are using the provision boxes and cloth, but so far no signs of the medicine-chest. The natives tell Muni Somai that some of them belonging to another village have caught and eaten three of the deserters. He promised me to get all his men in to-morrow, and to start on Saturday. Six or seven of them now have the small-pox. I saw one man with it here in the camp to-day. Sala Sala told Muni Somai that he feared Tippu-Tib too much either to hide the men or take the loads. I wish I had another officer with me, so that I could leave him here and go and have a hunt for them myself. From the evidence of a small skin pouch found in the deserters' camp, my men say that Mabruki, the deserter from Stanley, was one of them.

June 22nd.-Another capture was made to-day, and by one of my own men. He was out in the direction of the Major's first camp, where, I believe, there is plenty of manioc, and he saw a man trying to run away; shouting out that he would fire, he went up to him and found it was Rasasi, with two rifles. He was one of the men who bolted the day Major Barttelot left this 
ramp. I have put him in chains. I complained to Muni Somai to-day about one of the sacks of beads being short in weight. He called up Sadi, the muniapara, and made him produce the sack. It was distinctly short, but Sadi said he did not know where they could have been taken, nor who carried the sack. Muni Somai promises faithfully to have every man and load at the Major's first camp from here by to-morrow. Some of his men have been fighting with some of Tippu's people in another village, and one of the latter came in to-day to complain, with a scratch upon his stomach where he said he had been shot. No sign of loads. I handed over 16 rifles (13 good and 3 bad) to Muni Somai today, to convey as far as Nasoro bin Saef's village. He asked me if I handed them over to him for the use of his men, and I said No, only to be taken to the next village, where, I had no doubt, Major Barttelot would give them to his men as he had promised. I also gave him 110 matakas, the reward for each rifle recovered being ten matakas. (Eleven of them were taken by his men.) I also gave Suédi, my man, twenty matakas for the two rifles captured with Rasasi. D. V. and the Manyémas, we will make a fresh start to-morrow. What a chapter might be written on the starts and delays ever since we have been in Yambuya Camp! Muni Somai told me to-day that the Manyémas were not men, but simply "meat like beasts," for, said he, "How can they be men and yet love to eat men as they do? If there were two goats and one man offered them to choose from for food, they would take the man; all they think of now is what a lot of natives they will eat further on." He added, "The first lot of natives that they fight, they will eat as many as they can, and when their stomachs are full will then catch others to carry their loads." He told me late last night that the man he had sent after the Major as guide bolted, leaving his load in the Major's camp. This morning he had the man in chains.

June 23rd.-Just as I expected, wars and rumours of wars about the stacking of the loads. I went on ahead on purpose to see them properly stacked, and

1888.

June 22

Wobari Village. 
1888. June 23.

Native

succeeded in getting four of the muniaparas to leave theirs in the camp and stack them. Ngombé's men quietly went on, refusing to stop, and camped, I believe, a long way ahead. Muni Somai's people took all his loads over to his tent across the river. It has been simply impossible to take a correct tally of them. When Muni Somai came up he made a great row about it, but all to no purpose, for although he promised me that the loads that had gone ahead should be returned, they never appeared. The men travelled remarkably well; we could very easily have gone double the distance.

June 24th, Sunday.-Had rather a serious row with the muniaparas to-day, but one which I think has cleared the atmosphere generally, more especially as regards the loads being all in one place at night. Rain came down heavily before daylight, and we did not get away until about 7 o'clock. Muni Somai had promised me that all the loads should be stopped at the Major's next camp, and asked me especially to be ahead to see that it was all right. I was rather astonished to find that Ngombé's camp (the muniapara who went ahead last night) was over two miles ahead of ours, and it took me all my time to get through his men before we reached the camp; but I got in about a quarter of an hour before them. They flatly refused to stop, and then there was war until the arrival of Muni Somai, more than an hour afterwards. I made Ngombé stay there until he arrived, although his loads had gone ahead, and I trust now there is a thorough understanding between all of us. I must say for Ngombé that he had capital shelters made for his loads last night, and his argument is a good one, viz., that whilst the men are strong, the road good, and all in the shade, with very little food, our marches ought to be longer. Just now the men are quite fit to do longer marches, and none of us know how far we have to go without food, for we have no guide. I went out to try and shoot a monkey for my poor dog, who is starving, but could not get one. I was greatly astonished, on going down 
the small river at the back of the camp, to come upon another road leading to another camp due E. of this one, and evidently one of the Major's. The road was freshly blazed, but, as far as I could see, by only one party. I then went ahead on the road we are now taking, and found it also freshly blazed, but blazed by many people at different dates. There is a very old blazing on it, nearly overgrown, of four regular cuts, equidistant, which I cannot believe to have been done by Arabs, but think it must be Stanley's. At present we are a long way to the south of our right course, and must some day make a lot of way north, to get into it again.

I found a very beautiful flowering tree to-day; the flower I could have believed to be that of an orchid, but I shot down a branch and satisfied myself that it was not; took it into camp and drew it. I am in great trouble about the bales of Zanzibar cloth. The matting on the outside is all tearing, and no sewing will hold it together. The road lies through a beautiful open forest, with every few miles a clear stream, and very little swamp. This is my second day on nothing but a cup of boiled rice and roast plantains. I am afraid my plantains will give out to-morrow. A row with these Arabs is exactly like taking a pot of boiling water off and on a fire.

June 25th.*-To-day is one long story of disaster. We started off at daylight [from camp marked ++ ] along the road well blazed, on which Ngombé had camped. He promised yesterday not to let his men start before I came up, but on my arrival I found they had all gone on at daybreak, and were well ahead, on what I at once saw was the wrong road altogether. The road to his camp $[$ marked +++$]$ lay too much to the south, and, beyond his camp, turned due south. I went on ahead at a run, but what was my astonishment, after going over a mile, to come upon another camp [marked

- Explanatory remarks in brackets inserted by Editor.-ED. 
1888. ++++$]$, which one of his head men had quietly made on his own account! Here, thank Heaven, I On the found all the men stuck. There a perfect babel of voices, but I elicited that yesterday some of the men belonging to this muniapara had gone ahead on this road, and had met five of Tippu-Tib's people and two

N.
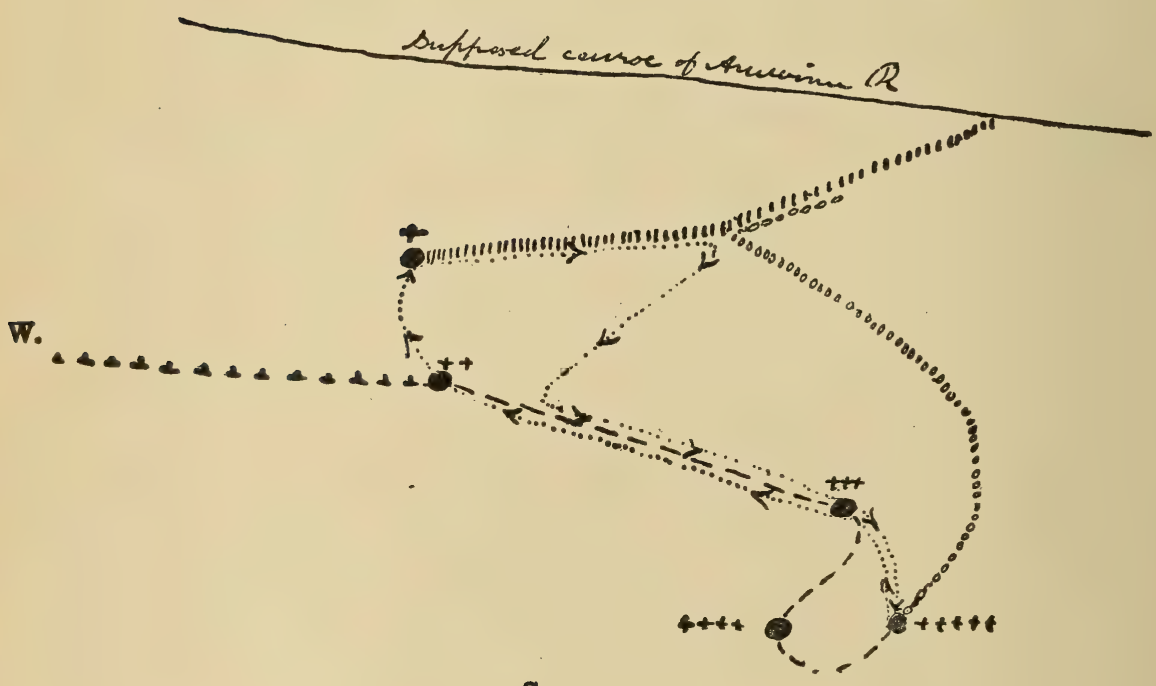

8.

+ Oamp of Major Barttelot to the N. of our camp of last night. ++ Our camp last night.

+++ Ngombés do.

++++ His muniapara's do.

+++++ Our present camp.

$\perp \perp \perp \perp \perp \perp$ Our road yesterday.

- - - - D - Do-day.

IIIIIIIIIIIIIIIIIIIII Major Barttelot's road.

$\rightarrow \rightarrow-\ldots \rightarrow$ Road taken by me to-day to look for right one.

00000000000000000 Road by which we finally left no man's camp.

Distance +++ to ++++ a little over a mile.

natives. The latter they tried to catch to serve as guides, but the Tamba-Tambas interfered, and stated that they were Tippu's people, and were coming from the village where two white men and a number of Wangwana had arrived, and that, being afraid of them, they were 
returning to Tippu. Upon our men's inquiry as to which road led to the village they had left, they pointed back to that by which they had just come. I now saw that if it turned out to be a good road, it would be shorter to take it than to go all the way back to the Major's other camp [marked + , which I knew to be on the right road. I took one of the men who had spoken to the Tamba-Tambas and went ahead; the road lay N.E., which was right, but I presently came to nothing but a mere track, which it was quite impossible for the carriers to follow. I then stopped every one, and waited until Muni Somai came up. We decided to camp, and look out for the road. After making camp $[$ marked +++++$]$ I settled to go due north and strike either the Major's road or our own further back. After going through the most awful bush for about an hour, straight as a line, without a path, I struck across our own road, followed it to our camp $[$ marked ++$]$ of last night, went to the next camp [marked +$]$, followed the Major's road out of it for a long way, saw that it was undoubtedly the right one, and then struck back across to our own road by a path that was blazed, and which we could easily have seen had Ngombé's people not gone ahead yesterday.

On my return to camp I told Muni Somai what I had done, and he agreed to go back and camp on the Major's road to-morrow. I discovered afterwards that thirty of his men had gone out to look for the road, and they have not yet returned. Now comes the worst part of the story. As I was just starting this morning, Muni Somai brought me one of the sacks of cloth, and showed me that it had been opened and some taken out, though not much. I had it carefully tied up, as the sewing things were all packed away, and told him specially to look after it, and give it to me at our next camp. He could give me no explanation about it at all, but that the cloth had been taken during the night. The Soudanese were flatly accused of the theft by the Manyémas, although for no reason. I did not pretend to suspect them at all, but when well started stopped them and 
1888. June 25.

On the march.

searched all their bundles, loads, and persons, also the loads of the deserters and natives in their charge, but found no trace of the cloth. When Sadi brought me the sack at this camp, I saw that more had been taken out of it. Upon my return to camp, a few minutes before this, I found that not more than half of the loads were stacked together, although I had seen wood cut, and started them at it before I left to hunt for the road. I now sent for Muni Somai and asked him why there were no people looking after the loads, and why they were not all there. I could get no satisfactory reply out of him about anything, and so I told him that since he would not get in the loads together that I might check them, and declined to put guards over them, maintaining, at the same time, that he was looking after them every day himself, I would take no further responsibility about them until we saw Major Barttelot, when he would have to answer for every load to him. I also informed him that his people need no longer accuse mine of stealing from the loads, for since I gave Sadi the sack of cloth this morning more had been stolen out of it. He then called Sadi, and there was great war, but no satisfaction. I am more sick of the whole business to-night than $I$ have been since we started.

June 26th.-It began to rain heavily before daylight, and did not stop until about 11 o'clock. Muni Somai came to me this morning, and asked me whether I had noticed how Sadi had come when called to speak to him yesterday about the cloth. I told him I did not understand the question. He said, "Did you not see that he had a revolver in his hand and a big knife with him?" I told him I had noticed it. "These are the men," said he, "that I have to deal with; they are only meat, like beasts, not men. There are three of us here from Zanzibar, myself and those two men" (here he called up two of the other head men); "you must rely on us." He added that he and these two always camped together, and that were he to hit Sadi, or 
Ngombé, or any of the other head men, there would be war at once, and this he wished to avoid-not that he was afraid of them, for his guns and men were better than theirs, but what would Tippu-Tib say if a lot of men were shot and our loads left on the road? He assured me that the loads were all right and well looked after. At 2 o'clock the thirty men returned, having found the Major's road and followed it to a deserted village. They have discovered a path on which the loads can be taken, so we will go that way, as it is a shorter one to return. I had a great day among the cloth bales and sacks, tying and sewing with camba as best I could.

June 27th.-Reached Nasoro bin Saef's village quite unexpectedly after a long march of eight hours, covering about twelve miles. Had my advice been followed, and our old road been returned to, the men would have done it in much less time; but Muni Somai warned me that there would be a mutiny if he tried to make the men go back. We struck Major Barttelot's road within twenty yards of where I had marked it the day before yesterday, and spent four hours wading through swamp and cane-brake. They were rather astonished to find my marks on the road ahead, as they none of them believed I had found the right one. Two men actually died to-day beside their loads. It is a nasty thing suddenly to bump up against a man covered with smallpox, as I did several times to-day. The men who died had not got that disease. It is astonishing to see a man covered from head to foot with the sores of small-pox carrying a load. On arrival at this village, I was surprised to hear from one of the Zanzibaris, and some Scradanese who had come over from the Major's camp about three hours from here, that he had left for Stanley Falls four days ago, and had missed us on the road. Two more men and two of his boys have run away, one of them with his revolver. I am sorry to have missed him on the road, as I don't suppose he can possibly get back before another ten days at earliest. I will go over

1888. June 26 On the march. 

1888.
June 27. to the other camp to-morrow, which lies E. of this, and

see Bonny, and I have advised Muni Somai to camp here with his men, as I hear the men from the other camp have to come here for food. I will remain with Muni Somai until the Major's return, as there is always a chance of trouble in this camp.

June 28th.-Walked over to Ujéle, to the Major's camp. Three hours' fast walking, distance about ten miles. The road is on the whole good, save where it lies through old manioc plantations. Passed two very large native villages and several smaller ones. Found Bonny rather seedy. Barttelot left for Singatini on the 24th inst., with 14 Zanzibaris and 3 Soudanese, leaving Bonny in charge of camp until my arrival, when I was to take command, and proceed with our whole force to Abdullah Karongo's camp at Unaria*. Bonny says that five Manyéma people from the village Mampuya came in yesterday, and he succeeded in buying from them a man as carrier and guide. This village is a day and a half from Bonny's present camp, but the men say it can be done in a day. There are eighteen or twenty loads now without carriers, and all the rifles and ammunition have been taken away from the Zanzibaris, in consequence of which the Major has left orders for me to obtain men from Muni Somai to carry these loads, and act as escort to the Zanzibaris, their rifles being carried as loads. One case of small-pox at Bonny's camp. Upon my return to this camp, I told Muni Somai that I wished him to proceed to Bonny's camp to-morrow, and that the Major had left me in command, with orders to proceed to Abdullah's camp. Having called together and consulted his head men, he told me that though they were all most anxious to get on to Abdullah's camp, they begged to be allowed to wait one day longer,

* According to Mr. Bonny's statement, he was left in command over Jameson, under orders dated April 22nd. The orders referred to by Jameson above are those of June 23rd (vide Log of the Rear Column, June 24th, 1888 ; 'Darkest Africa,' vol. i. p. 506'), curiously not mentioned by Mr. Bonny in his official report to Mr. Stanley; vide 'Darkest Africa,' vol. i. p. 491 .-ED. 
as so many of the men were weak, and one day's rest and good food would make all the difference to them. (Handed over to Bonny:-2 tins milk, 1 tin cocoa (condensed), 1 bottle salt, 2 tins tea, 1 bar soap, 1 sack 10 pieces of cloth, 95 cartridges in 2 belts. All recovered from deserters' loads.) Knowing the weak state of the men, as illustrated by the two who died on the road yesterday, I granted the extra day. He cannot possibly give me the twenty men in order to move all the loads from Bonny's camp at once, so I propose to move on all the Zanzibaris and a number of his men always two days ahead, enough men returning each time to carry on the extra loads. In this way an extra chance is secured to our men of getting the pick of the food on the road, wherever it is scarce. Abdullah's camp is said to be six days' march from Ujéle, with only one break of two days without food on the road.

Muni Somai reports one load of ammunition lost yesterday. The Major has proceeded to Stanley Falls for the purpose of obtaining more men from Tippu-Tib*, as well as to try to recover some of the lost loads and rifles; he expected to be absent twenty-six days. The majority of the huts in these villages are of the extinguisher type, but the beehive-shape appears too, as do the penthouse and round huts found below Yambuya. Some of them are beautifully constructed, with hard floors of baked clay, and are kept exceptionally clean. I had a narrow escape of being bitten by a snake to-day. I was walking along fast, bare-legged, and I stepped right over one which was crossing the path.

June 29th.-Began the day by a regular inspection of every load carried by the people supplied by TippuTib. Took the names of all the muniaparas, and made a list of the loads carried by each. In consequence of the discovery that of the thirteen sacks carried by the muniapara Sadi, containing beads, cowries, and rice, several were short of weight, I handed them over to Muni Somai, taking from him in their place thirteen loads

* See Appendix VIII. 
1888. of ammunition, principally Winchester. Wrote out a June 29. full report of inspection for the Major. Completed mareh. map of road to this village: then came trouble. I asked Muni Somai if he was ready to start for the other camp to-morrow morning. He told me that all the head men had been to speak with him, and told him that their men were still weak. I replied that at the next camp all the weak men could have a rest. He declared himself and Kapranga ready and willing to go, but that the others now said they had put manioc into the water, and wanted another day for it to soak. I said I would take no excuse about food, as they had already been here two days, and were going to a camp where they would find plenty of food, and that I could not leave Bonny's camp another day without a sufficient armed force, as all the rifles had been taken away from the Zanzibaris. He announced his intention of calling together all his head men, after prayers, to consult with them. The result was a message to say they were still unwilling to go. I then went up to see him, and gave him my positive orders that he and all his head men should proceed to-morrow morning to Bonny's camp with all the loads. I told him I should go, whatever happened, and that whoever did not do so would be positively disobeying orders, and that a direct report of the same would be made to Tippu-Tib. I believe he and Kapranga will be the only men who will obey, and in this case I will try and get a letter conveyed to the Major. I told Muni Somai that were I to allow them to remain longer here I should be disobeying Barttelot's direct orders to me, and that if this sort of thing took place at every pleasant village they came to, the Expedition might as well be at an end. This row was bound to take place sooner or later; I am only sorry it has occurred during Barttelot's absence.

June 30th.-Struck my tent at daylight. Muni Somai told me his head men still refuse to come on, and will not start until the day after to-morrow, when their manioc will be dried. I said my orders remained the 
same. He said he and Kapranga would follow me. On my arrival at Ujéle, took over command from Bonny. Found everything quiet; no more desertions. One 1888.

Zanzibari had died yesterday. Muni Somai, Kapranga, and Sadi arrived some time afterwards with their men and loads, about 130 in all. I told Muni Somai, almost immediately after his arrival, that Mr. Bonny would start for Mampuya to-morrow morning, leaving the twenty loads, for which men would return here, where I should remain with him (Muni Somai), and that I required an escort of his men, as I had before told him, to go with Bonny to Mampuya, and return from thence with the men for the loads. He then informed me that every man they had brought had returned to Nasoro bin Saef's village for food, but that he would tell me later on if he could get them. In the evening he said the men would not return until to-morrow, at what time he did not know. I asked him when he would ever be able to obey my orders, to which he replied that the Wacusu and Manyémas were very hard to deal with, and would not leave the village until it pleased them. I informed him that the sooner Tippu-Tib knew that his men would not obey him the better, and that as he will not send the men with Bonny, I would accompany him myself, and return with the men for the loads left behind, leaving him (Muni Somai) in charge of the said loads. I cannot myself leave for Stanley Falls, nor can I send any of our men, but I shall try to get a letter conveyed to Barttelot from Mampuya, and in any case I will try to get the whole force on as far as Abdullah Karongo's. I can now see that Muni Somai is utterly useless as a commander, although himself willing.

July 1st, Sunday-Got away about 7 o'clock, and marched until 11 o'clock. Road lay nearly due N. all the way, and a very bad one, through old plantations full of fallen timber. Passed over three rivers. Latter part of road lay through a long string of villages, all lying close together, and due N. and S. The country must have been very thickly inhabited, although now 
1888. July 1. On the march.

many of the villages are deserted, and in several cases burnt by the Tamba-Tambas. The majority of the huts are still of the extinguisher type. Men marched well and willingly. No deserters. In the evening three of Barttelot's slaves escaped from the Soudanese soldiers in charge of them. Search party sent out under Omaha had not returned at dark.

July 2nd.-Started at 7 o'clock, and marched until 12 A.M., reaching a village called Mquangandy, belonging to the Waburu tribe. This part of the country is inhabited by three tribes-the Waburu, Wamanga, and Wabunga. The road for the first mile lay through six villages, which, with the four passed yesterday, make ten all close together, lying due N. and S. After these the road became very bad, running through swampy forest and old plantations. The most important of the villages is called Mpunga, and further on, about a mile from this, we passed through a very pretty group of villages called Lixari. Each village is situated on the summit of a small hill, and consists of about six or seven huts, all dotted about in the clearings close together. Met Tamba-Tambas belonging to TippuTib, who say that the Aruwimi is three hours' distant to the N.W. Unaria, Abdullah Karongo's camp, is distant only one day's march without loads, but three with them. Stanley's blazing on his road beyond Unaria is still quite visible. They have promised to convey a letter to Stanley Falls, the Congo being only four days distant. They strike it at Atiacusu. The search party failed to find the three women who escaped yesterday. We marched a little over eight miles to-day. I saw a conical hut, raised five feet off the ground, with a ladder attached to it, at Mpunga, also telegraph from road to village to tell of any one's approach at night.

July 3rd.-Sat up last night, writing to Tippu-Tib and the Major. One of Tippu's people has promised to call for my letters this morning, and take them to Singatini as quickly as possible. Started at 7A.M. for Ujéle, with seven Zanzibaris, thirteen slaves, and guard of one sergeant and 
five Soudanese, to bring up the extra loads. Reached our first camp from Ujéle about 10 A.M., and got in there about 1 P.M. Muni Somai greeted me with the fact that letters had come for him and for myself, stating that the whole force was to return to Singatini. This rather took my breath away, and it was with anxious hands that I opened the two letters which Muni Hamésé had brought to me from Major Barttelot. The first one I opened contained orders to proceed with the whole force with all possible despatch to Unaria, where Barttelot would join us about the 14th of July. I hastened to open the other one, but it only contained the same orders, and upon asking Muni Somai whence he had received the other orders, he told me he had had a letter from Sala Sala by the same messenger, stating that Major Barttelot had arrived at his village, and had written to me to say that the whole force was to return to Singatini. I then told Muni Somai that the orders remained the same, and he promised that all his men should leave for my camp on the following day. He says there are many cases of small-pox, and other sickness (about sixty in all), and that seven of his men have run away. Sala Sala told him that a large new steamer had arrived at Yambuya Camp after the departure of Selim Mahommed and everyone else, and had planted a flag there. Major Barttelot's boy Sadi, with his revolver, came to his camp at Wobari, and gave himself up, the others having run away from him. 'The Major's letters were dated June 25th.

July 4th.- Told Muni Somai that my last orders to him were to get the whole force together, and push on to my camp with all possible despatch. It began to rain before leaving, and came down in torrents when we had gone a short distance. I pushed on, however, and we reached Mpunga at 12 A.M., when it cleared up. The natives carried the double loads remarkably well.

July 5th.-Paid for my wetting yesterday with a fearful dose of rheumatism in my back; had not a wink of sleep, but started and walked it off. Reached

1888.

July 3.

Ujéle. 
1888.

July 5.

Mquangandy.

Mquangandy about 12 A.M. ; the swamps are in a fearful state after the rain. Bonny reports all quiet during my absence. Another Zanzibari dead. Bonny had not been able to buy any carriers, as they only brought in two small boys, for whom they wanted a gun, and two girls, for a gun each.

July 6th.-Started Bonny off to the next village, with all the loads he could possibly carry, with orders to send back enough men under Soudanese escort to bring up the extra loads with myself to-morrow. No signs of Muni Somai !

July 7 th.-Started soon after daylight and reached Lipula, where Bonny is encamped, about 11 A.M. It is not more than five miles, but the road is very bad. Found one of the Zanzibaris had fallen behind yesterday, and opened our chop box, smashing it with a heavy stick. He was caught red-handed by Faragi, who was sent back for him. One tin of milk and one of corned beef were missing, three other tins being opened. We gave him 100 lashes and put him in chains. Dr. Parke's box fell yesterday, and was smashed beyond all repair. Made a list of the contents, and discarded a lot of 12-bore bullets, cartridge cases, \&c., as we are very short of carriers, packing what remained in Nelson's and Stairs' bags. Shortly after my arrival, I heard that Muni Somai had come up to the camp. I left this morning, so I sent back Muni Hamésé and two Soudanese soldiers to tell him to come on here to-morrow. Am sending on Bonny and all his men to Unaria to-morrow, which is four easy marches from here, with food to be had all the way. I shall wait here till he sends back men for the extra loads. There is a great deal of small-pox amongst Muni Somai's men, and I wish to avoid the chance of its breaking out amongst ours as far as possible.

July 8th, Sunday.-Bonny left for Unaria. Muni Somai and his men arrived about two hours later. There 
was a grand row here shortly after their arrival. Muni Somai was sitting drinking coffee with me in the shade at the back of my tent, and several of the head men were standing round. Muni Somai was telling me that a good many of the people had lost the road to-day, and I asked him how that was when it was so well blazed. One of the head men called Kimputa exclaimed, " $\mathrm{Oh}$, if people will walk with their noses on the ground, and not look at the trees, they must get lost." Ngombé, another head man, most of whose men were those that were lost, took this as a personal insult, and said something rather nasty, for Kimputa retorted, "You sit still for months at Kassongo, eating manioc and getting fat, whilst I am on the road! No wonder you know nothing about it!" Then words rose very high, their followers rushed up with guns, and a grand scene ensued. Men with guns, trying to cock them, were rolled over by men without guns, while others with logs of wood and huge poles sailed in too. There were broken heads and scars innumerable, and at one time it looked serious, and I had thoughts of finding something myself, not a stick; but I sat still, and it gradually developed into a strife of words, and more allies interfered to separate the aggrieved parties. Muni Somai reports a good many deaths from small-pox.

July 9th.-A day of disaster. Last night, just as I had turned in, nearly every man in camp began to fire off his gun, as if at a given signal. Several of the shots were fired at the very side of my tent. I jumped out of bed, got my Winchester, sent for Muni Somai, and told him, before all the men, that I would shoot the very first man who fired another shot near my tent. He said, "Beat them with a stick;" but I said, "No, you can do that. I will shoot. Let a man fire, and you will see." There was perfect peace for the rest of the night. I told Muni Somai that, had I men enough to carry them, I would take all the rifles, and that I should strongly advise the Major to take them from his

1888. July 8 . Lipula, 
1888.

July 9.

men, and give them to the men he got from Tippu-

Lipula. Tib. Not a shot has been fired in this camp to-night. About 12.30 A.M. some of Bonny's men came into camp to get plantains, and told me that he had lost the road, and was camped not far from here. I waited until 3 o'clock, but got no message or note from him, so I sent a man with a letter telling him to remain where he was until he heard again from me, and in the meantime I would try to procure a guide. I started off and walked to Mampuya, but found that all the natives and Tippu-Tib's people had run away, and I don't wonder at it, after the fusillade of last night. Returned to camp, and as there was still no note from Bonny, I started off to his camp. Half-way there, met my messenger returning with a note from him. Went on to him. He says that yesterciay the guides, two of Tippu-Tib's people, took him all wrong, and then ran away. He then went too much to the north, and sighted the Aruwimi. Went out with him along the road he had blazed this morning, and found a path which he had missed, going to the eastward and well blazed. Returned to his camp, had a cup of tea, and told him not to start until I arrived in the morning. Came back here, and got in at dark, thoroughly beat. Told Muni Somai that I would go with Bonny in the morning, taking only one carrier with me, and leaving my boys, two Zanzibaris, and two Soudanese here, and that he must remain until my return. All loads left behind will be placed in his tent. Bonny reports one of the goats lost, which is very serious, for we cannot get meat of any kind.

Muni Somai told me to-night that he owns a village north of Riba-Riba, on the other side of the Congo. It takes two months, going north, to get to it. The country is open, as at Kassongo, but there are large mountains there. Four rivers, he says, arise from one of them: two called Lindé, one Lela, and I could not catch the name of the fourth. He says no white man has been in that country. 
July 10th.-Joined Bonny. Went on a road which I afterwards found to be the one he had followed the day before. General direction S.E. Muni Hamela and a lot of men turned up from Unaria. He told me he had brought the caps from Tippu-Tib to Unaria, and as we were so long in arriving he had come to meet us. He handed over to me the three deserters from $\mathrm{Mr}$. Stanley, who have been so long at Unaria, and they all swear that they did not desert, but were left sick on the road, and that Mr. Stanley's books will show this to be the case. I made them guide us on to the right road. They took us straight along the road Bonny had taken the day before yesterday, and he camped to-day in the very village, close to the Aruwimi, where he camped the day before yesterday, and from which point he had turned straight back. I placed the three men belonging to Stanley in the charge of the Soudanese, and left Abdullah Karongo's brother-in-law with Bonny, so he has enough guides now. He told me of a much shorter way back to camp which he had blazed, and sent Faragi to show it to me. It turned out to be twice as long as the way we had come.

When I returned here, Muni Hamela (who I find is really the head man at Unaria, and not Abdullah Karongo) handed over to me 40,000 Enfield caps, from Tippu-Tib, for which we owe him $£ 48$. I gave him a receipt for the caps, and another for the three men. Although I told Muni Somai that there could now be no difficulty about the road, and that he must therefore send on all his people to Unaria, he now tells me that he cannot tell till to-morrow when he will be able to start them. He is simply utterly useless. Muni Hamela gave me a letter from Mr. Greshoff, of the Dutch house, who had arrived at Singatini, saying he had not received the boxes I had sent him.

July 11th.-It rained heavily, a miserable day. Muni Somai busy writing to Tippu-Tib. I warned him, upon his stating that his men could not start

1888. July 10 On the march. 
1888.

July 11 .

On the march.

until the day after to-morrow, that he must not think he would have to wait long at Unaria, for he had wasted all the time on the road, and Major Barttelot would certainly expect us to be ready to start when he arrived.

July 12th.-Told Muni Somai he must be ready to start for Unaria to-morrow. He made another excuse, saying they did not like to leave the white man behind. I said that was my business, not his. He asked me to give out some caps to the men, as they wished to catch natives at Unaria. I told him I could not possibly do so unless the Major ordered it.

July 13th.-Muni Somai, with all his people and loads, started for Unaria. He has left a good many sick, who are going on slowly. Some in this village who have small-pox will, I am afraid, die, they are such bad cases. I am in hopes that Barttelot will turn up with enough men to carry the extra loads, before the return of the men from Unaria. The stench round this camp is something frightful, and I have not enough men to remove the loads to another village.

July 14th.-Sent two men to Mampuya to bring in Tippu-Tib's people. They arrived in about an hour and a half. They have heard nothing of Major Barttelot. Rained heavily.

July 15th, Sunday.-Another wretched day of waiting at this camp. No signs of either Barttelot or the men from Unaria. The smell after the rain, with a hot sun, is something horrible.

July 16th.-'Tippu-Tib's men from Mampuya came into camp to-day, bringing with them a quantity of plantains, a pleasant addition to plain boiled rice and mouldy biscuit. They had with them some natives of the Babura tribe, one of whom I sketched. His face is very typical of the natives in these parts. I gave a 
lot of plantains to the sick. The natives are quite friendly to the white man, but had any of Muni Somai's people been here they would not have come near the camp. The huts of the Babura tribe are cylinder-shaped, with a domed roof; this village consists entirely of their huts.

July 17th.-One of the messengers who took my letter to Tippu-Tib came here, and told me that TippuTib had given Major Barttelot four chains to put on any of the head men who refused to obey him. He says the Major has gone by a short route to Unaria and ought to be there by to-day, that he had no fresh men with him, but had recovered several deserters. The men from Unaria have not yet arrived, and are now two days overdue.

July 18th.-Thank God, the men arrived this afternoon. Told them to get as much food as they could. Received a letter from Bonny. He states that he arrived at Unaria on the 15th, having taken five days from his camp on the river (beyond this) to get there. He says that there are three days without food in the forest, and reports two desertions.

July 19th.-Started at 7 o'clock, and marched to Bonny's first camp, near the banks of the Aruwimi River, where I stopped to let the men gather manioc. One of my men brought in two beautiful longicorn beetles, which I drew and coloured. Muni Somai's men have burnt nearly every village, which is a great shame, as the natives have done nothing to them.

July 20th.-Our road lay right along the bank beside the river, and through a long line of deserted villages, all burnt a long time ago. The natives have all crossed to the other side of the river and built there. Opposite the camp is a long series of rapids. Our road now is the one taken by Mr. Stanley a year ago, and the blazing on the trees is still quite distinct.

1888.

July 16

On the march. 
1888.

July 21 .

On the march.

July 21st.-Poor Major Barttelot was shot dead by one of the Manyémas early on the morning of the 19th instant. Such is the news I have received from Bonny to-day. It was a case of deliberate murder, as far as I can judge from the scant knowledge his messengers have of any details. Bonny's note is shorter than a telegram ought to have been, merely stating the fact that he was shot, and that all the Manyémas, Muni Somai, and Abdullah Karongo have left, also that he has written to Tippu-Tib. As far as I can learn from the messenger, early on the morning of the 19th, before daylight, some of the Manyémas were making a great noise, beating on their drums. Major Barttelot sent his boy Sudi to tell them to be quiet, as he could not sleep. They still kept on beating the drums, and fired a couple of shots. He then went down to stop this himself, and all that the men know is that he was shot stone dead, through the breast, the bullet passing out and grazing another man's face. It is a fearfully sad piece of news to me, for ever since we were left alone together at Yambuya Camp, more than a year ago, there has been the closest friendship between us, never so much as a single quarrel. In all difficulties we went to one another for advice, and many a happy picture did we draw of times at home together after all this unlucky Expedition was over. He was a straightforward, honest English gentleman; his only fault, being a little too quicktempered. He loved plain, straightforward dealing far ton much ever to get on well with the Arabs. He hated their crafty, roundabout way ot doing everything, and showed it to them, and, of course, was disliked in turn. He was far too good a man to lose his life in a miserable way like this, and God knows what I shall do without him.

I am going right through to Unaria to-morrow, leaving the loads to come on in charge of Muni Hamésé (?), our head muniapara, and Sergeant Paquit, with eight of the Soudanese. Our whole march to-day was done in pouring rain, and it is raining still, 8 P.M. 
July 22nd, Sunday.-Got away an hour after daybreak, and reached Unaria an hour before sunset, over twenty miles of the very worst road I have ever seen in any country. Four of the natives ran away during a heavy storm last night. On my arrival I found all quiet, only Bonny and the Zanzibaris with the Soudanese occupying the village, and two or three of the head muniaparas of the Manyémas, with their men, camped outside the village. Bonny had done all that a man could do under very trying circumstances. He had recovered about three hundred of the loads carried by the Manyémas, and had succeeded in quieting those of them who remained. It appears that just at daybreak, on the morning of the 19th, one of the Manyémas camped in the village close to this house began to beat his drum and sing, which is their constant practice, although an unpleasant one. Barttelot had been annoyed by the same noise early in the night, between 9 and 10 o'clock, and had sent his boy Sudi to them, when they had ceased. He sent his boy again in the morning, when loud murmurs were heard, and two guns were fired off in the air. He then jumped out of bed, taking his revolver, and went out of the house, although Bonny tried to persuade him not to do so. Immediately afterwards a shot was fired, and shouts were heard that the Major was killed. A fearful scene of panic then followed. Bonny went out and could not find a Zanzibari; called for Muni Somai, who did not appear; ordered the Soudanese to follow him, but they stood to arms, and refused to follow. Then Bonny went towards the spot where the shot had been fired, Chana, the Somali, and Omaha, the Soudanese officer, following him. He proceeded until he came to the body of Major Barttelot, which was lying face upwards, with one hand under the body holding his revolver, which had not been discharged. He must have been shot dead on the spot, the bullet passing in under the centre of the breast-bone, and out through his back behind the heart, having travelled slightly upwards; not a muscle of the face had moved. Bonny thinks that he was shot from a narrow passage between

1888. July 22 Unaria. 
1888. two houses, but all the men report that he was shot July 22 . from a door, and went a few steps before falling. The Unaria. body was then conveyed back to the house. The shouts and cries through the village were frightful, so much so that Bonny thought a general massacre was taking place, but it was really a stampede. He did all he could $t_{\text {1) }}$ quiet them, but they all left the village. The Major was buried in a quiet spot in the forest, close to the village, the same day, and Bonny spent the rest of it in recovering loads.

July 23rd.-Made an inventory of all the effects of poor Major Barttelot, and packed all those things we considered necessary to send home, a full account of the disposal of everything being sent to Sir Walter Barttelot. Had an interview with three of the head Manyémas who came into camp, and impressed upon them the necessity for my seeing them all before leaving for Stanley Falls to see Tippu-Tib. They said the others were afraid to come in. I then offered to go out alone, without arms, and meet them anywhere they chose to name. Finally Sadi, one of the head men, said he would go out and see them and bring me their answer, and in case they would not see me, would bring information respecting loads and number of men. I then offered a reward for the arrest of Sanga, the man who shot Major Barttelot. Any steps taken by us against them now towards the finding of this man would end in the loss of all the loads, and a general massacre of us all, for were the Zanzibaris given their guns, they would either desert with them, or have them taken by the Manyémas, and we have only a mere handful of Soudanese to do guard, and upon whom we can depend to use their guns in case of a fight. All loads and men whom I left arrived all right.

July 24th.-A very busy day. Began by examining and making a list of all the loads recovered from the Manyémas. After this, we instituted a search amongst the Soudanese, in consequence of one of the bales of clıth in their charge having been tampered with, and 
found a quantity of cloth, although none of it was taken from these bales. Had just completed this, when Sadi arrived with a number of the head Manyémas. I told them that I was going to Stanley Falls to see TippuTib, and try to come to some arrangement with him, so that all matters might be settled and the Expedition proceed. I then got a list from each man, concerning the loads he had returned, how many were lost, \&c. They told me that Muni Somai, six head men, and Sanga, the man who shot Barttelot, were all at Stanley Falls. I find there are 193 Manyéma carriers still camped in the vicinity. We have recovered $298 \frac{1}{2}$ loads, and $47 \frac{1}{2}$ are missing. I then arranged all the papers connected with the Expedition found amongst the Major's effects. There are missing a packet of letters to the officers who went with Mr. Stanley, and a large sealed letter for Mr. Stanley, which I handed to Barttelot at Yambuya Camp, and for which I have a receipt. These are believed to have been lost in a bag of his which one of his men ran away with, on his return here from Stanley Falls. Had all the defects in the sacking of the loads repaired. There is a sadness hanging over everything, which no amount of work will shake off.

July 25th.-Did not get away until 9 o'clock, but marched until 5 o'clock, when we camped in the forest. The men had to stop for half an hour to collect manioc, as we shall have two days in the forest without food. The road is a very bad one. Had to wade six streams in the first hour, most of them up to my arm-pits. One box and my rifle and cartridges were dropped in one of the streams, so we made a bad start. I found Ngombé and nearly all the head Manyémas camped in the forest, about two hours from Unaria, close to the edge of the manioc plantations. I stopped and spoke to them, especially to those who did not come in yesterday. I can now only find 183 men camped near Únaria. The camp had a strong zariba round it, with places cut in it for the use of guns. The men were very civil, giving me all the information they could; they all say that 
1888. July 2? On the march to Stanley

Falls.

Sanga is at Stanley Falls. They told me they would do whatever I asked them to. I am glad to get on the march again, for one has not so much time to think. I have not slept more than six hours altogether in the last three nights.

July 26th.-Started at 6.30 A.M., camped at 4.30 P.M. The road lay through forest and swamp, with canebrakes and creepers in abundance, of the very worst description. It appears that a day beyond this, on the road to Stanley Falls, Muni Somai met Nasoro Masudi and Ali bin Saidi, on their way to Unaria with 200 guns, to shoot natives, as they express it. Nasoro Masudi asked him what business he had there, when he knew his place was at Unaria, and told him to return at once. I found him camped at this place with Kapranga, on his way back to Unaria. He began a long explanation to me of his reasons for going back to Stanley Falls, saying that the morning the Major was shot the Manyémas wanted to shoot him. I told him that he and Kapranga had deliberately run away; that had he gone straight to Mr. Bonny he would have been perfectly safe; and that there were forty-seven loads lost, for which he would have to answer to Tippu-Tib. He told me that he had twice sent out men to shoot Sanga, but that he had gone to Tippu-Tib at Singatini. I told him to send all his men with Kapranga to Unaria, to camp near Mr. Bonny (but not into the village), and to come himself straight to Tippu-Tib with me. He gave me two letters addressed to Major Barttelot, one from Tippu-Tib, the other from Mons. Baert. Tippu-Tib's letter was to advise him to be very careful with the Manyémas, as some of them had died on the road; and always to stop some time where there was food, as there were many places on the road with no food to be got for three or four days. Mons. Baert's letter was merely sending his compliments to all of us, and telling us that Tippu-Tib assured him everything would be all right. These letters were brought to Nasoro Masudi only a day beyond this, and it appears Mr. Bonny's letter was taken on by the same messenger 
yesterday, so that it is only two days ahead of me. Nasoro Masudi and Co. evidently meant to follow up on our road beyond Unaria, just as Abdullah Karongo followed Mr. Stanley.

July 27 th.-Started at 6 o'clock and camped at a ' large village called Unyoy, tribe Babura, at 5 o'clock, doing a good ten hours' march. The road was one mass of creepers, cane-brake, and swamp. Here I found Nasoro Masudi and Ali bin Saidi. The former, with his usual hospitality, sent me a delicious curried fowl, and offered me rice for the road, and chickens ; but I declined them with thanks, telling him that he was going where there was neither, and I was going where there was plenty. His cooking is just as good in the bush as at Stanley Falls. He wrote a letter for me to TippuTib, telling him I am coming to Stanley Falls as fast as possible, where all my business can be better settled than if he were to meet me on the road. This letter goes by special messenger, and ought to reach Singatini at least a whole day before me. Nasoro Masudi and Co. are going on beyond Unaria on Mr. Stanley's road, for nine or ten days, when they intend to make a strong boma, and fight the natives there, settling up the villages as they have done here, and leaving a few men in each. The natives periodically rise and eat these men, but fresh ones take their place. Their force here is a very strong one of 200 guns; they left Stanley Falls on this big slave and ivory hunt, after the Belgians had taken up their residence there. Nasoro Masudi tells me that Tippu-Tib's people at Mampuya had told him that many of the Manyémas said they would shoot me, but they did not expect me to get into Unaria as quickly as I did.

July 28th.-Started at 6.30, and camped in the forest at 5.30, having done a good twenty miles on the road. Nasoro Masudi and Ali bin Saidi came to me this morning before starting, and told me to be very careful on the road, and sent nine men with guns, and a head man with orders to keep close to me the whole time. 
1888. July 28.

On the march to Stanley Falls.

They say that many of the men who tried to bolt to Stanley Falls are on the road, and have no good intentions towards me. The worst of these brutes is that they will not fight openly, but will shake hands with you one moment and shoot you the next.

July 29th, Sunday.-Got away shortly after 6 A.M., and reached Tanjika, tribe Wamanga, at 5 o'clock. The road good, and the men went very fast, doing in one day two marches of Major Barttelot's, distance about twenty miles. On the road we met two of Muni Mahara's head men from Nyangwé, with about 200 guns, to whom TippuTib has given leave to hunt for ivory up the Aruwimi. This means that they will fight the natives, settle a lot of villages, and then he will claim them. The huts here are long, low sheds, quite different from any on the Aruwimi.

July 30th.-Started at 6 A.M., and marched to a village called Yarulea, where we stopped for three hours to let the men buy and cook food. This is a large village, with many Arabs in it. The head man Marijana sent me lunch, and whilst waiting for the men I made a sketch of the native chief Tina-Tina, tribe Wamanga. Started again at 12 o'clock and marched until after 5 P.M., and having done a good sixteen miles, camped in the forest. The Arabs hate the way that the natives show their liking for a white man, and try and prevent one's paying them for anything or giving them a present.

July 31st.-Started before 6 A.M., and reached the first village at 12 o'clock, where I found Salem Masudi, with a letter from Tippu-Tib, asking me to leave all loads at Unaria, and to come to Stanley Falls as soon as possible. Salem Masudi's orders were to catch Sanga, the man who shot Barttelot, and then to find me. He has found and sent Sanga to Stanley Falls. Marched to this village, Yatatuka, about four hours further. Salem had orders to open the bundles of every man he met on the road, and we found cloth and beads on one of my men, who was with me, and not in Unaria, when the things were stolen. He confessed that Faragi, the head muniapara of our Zanzibaris, had 
given them to him to buy rice at the Falls. Whom is one to trust? I hear Tippu-Tib is in a terrible state about the whole matter, and Muni Somai received such a letter from him that it made him quite sick, and he asked my leave to go ahead, as he felt bad! Salem found some stolen cloth also on Abdullah Karongo's men.

1888.

July 31 .

On the march to Stanley

Falls.

August 1st.-Started before 6 A.M. and reached Yarracombi, on the Congo, opposite to Yatuka, at a little after 9 A.M. I allowed the men to buy food, and get away in canoes as fast as possible. Could obtain no news of Héri, or Daodi, the men who ran away from the Major. Reached Upper Atiacusu at dark, where the natives refused to go in canoes in the night, but Salem Masudi threatened to burn their village, as Tippu-Tib had sent for me, so we got away at last and spent a most miserable night amongst the rocks, getting in here (Stanley Falls) shortly after daybreak.

August 2nd.-Found that the new Belgian paddlesteamer En Avant arrived here yesterday, with the new chief of this Station. Went straight to Tippu-Tib on arrival, and told him I wished to have a house on this side close to him, as I had much business to do with him and not much time to do it in. He gave me the house of Nasoro bin Saef, who is not here. Wrote a note over to Mons. Baert, as I heard Ward was at Bangala, asking him if he had sent up any letters or telegrams, at the same time thanking him (Baert) and his brother officers for their kind invitation to go and stay with him on the other side. Received a reply from Baert, saying Ward was not very pleased with his position, but telling me nothing about telegrams or letters, adding that he would come over and see me in a few hours.

Later.-Mons. Baert arrived in about an hour. He tells me that Ward had come up in the En Avant to Bangala, having seen Van Kerckhoven on the road. There he received his orders to remain in charge of the loads, and it seems that he reserved the letters and the reply to the telegram also on shore! 'The captain of the steamer says there were boxes for me from England, with 15 letters, and letters for the other officers, a reply 
1888. Angust 2. Stanley Falls.

to telegram, from the Committee, \&c. \&c. Now I am left here in a most serious position, not knowing what reply the Committee have sent, and I can only judge that it is not a recall from the fact that Ward did not send it on, and that, according to the last news from Europe, nothing is known of Mr. Stanley. Tippu-Tib sent me a capital breakfast, and after Baert's departure came over to have a private interview with me. I told him all that I had done at Unaria, and that I had come to him to help me to make such arrangements as would permit of the Expedition proceeding as soon as possible, and to demand justice on the murderer of Major Barttelot. He said, "I am almost afraid to send you with these men; I think Major Barttelot's murder must have been a thing thought of by many." I told him there might have been a bad feeling against the Major, and there might be against me, but it was evidently not a premeditated act, and that his murder and the loss of so many loads were due undoubtedly to the utter incapacity of Muni Somai to command the men; that if he could give me a man who was a sufficient representative of his power, to command them, that I might feel some safety for the loads, and some hope of success in the undertaking, it was my duty, in the absence of all news in Europe from Mr. Stanley, and with no news from the Committee, to proceed at once. As regarded my own life, I said that he could not be held answerable for its safety, for there were a hundred ways in which I might die on such an Expedition, and that if I undertook it with my eyes open, I alone was answerable for anything that might happen to me, or to the loads, and for the loss of Mr. Bonny's life, should such a thing occur. I told him that Muni Somai's contract with me was utterly broken, and asked him if he could send Rachid, Nzige's son, with me. He made an excuse about his not being able to march well, which I knew to be untrue, and found out that the real reason was that Nzige does not wish him to go. I told Tippu-Tib that if he sent Rachid with me I would give him the same amount that Muni Somai was to have received, and further, 
that if he stuck to me right through I would guarantee him $£ 500$ besides out of my own pocket. He asked me for time until to-morrow to think it all over, and inquired whether he would be held answerable for the loss of the loads and Major Barttelot's death. I told him the truth, that according to his contract he was not, but that Muni Somai was, according to his contract, certainly answerable for all; that this was my opinion, but that the real people to judge the matter would be the Committee, when they knew all the facts of the case. I then asked him for justice on Sanga, the man who shot Major Barttelot. He replied, "I have him here in prison; it is your case; I will deliver him over to you." I told him that as the new Belgian chief of the Station had arrived, and the act had been committed in their territory, I should communicate the facts to him without delay, and that although I could, after what he had said, take Sanga out and have him shot, many voices would be raised against such a proceeding. He said, "You are right." Finally he said he would think over everything and see me again to-morrow morning. I then got a canoe and crossed over to the Belgian Station, was introduced to Mons. Haneuse, the new Resident, and told him about the case of the man Sanga, and that he admitted his guilt. He said, "There is only one thing to be done. TippuTib, Mons. Baert, and I will hold a council of war, call out a file of men, and have him shot." It is my duty to answer the call of justice, and to see this man shot before I leave. Yet, again, it may turn out against the interests of the Expedition to have him executed until after my departure, in that it may cause a doubly bad feeling amongst the Manyémas against the white men. It is, however, only just that he should be shot before there is any possibility of his escape, and there is a chance of its having a good effect on the Manyémas instead of a bad one. Mons. Haneuse offered to send the steamer back at once for the loads and letters, if I would write to Ward telling him to deliver them all up, and make arrangements with Tippu-Tib that he might receive them. 
1888. On my return to this side I again saw Tippu-Tib, who August 2. appears to be very anxious about the news of the Falls. Sultan of Zanzibar's death, and wanted to know if the news had gone to Europe by telegram or letter. Told him it would be probably by telegram, but that I would find out. He said, "I have been expecting canoes from Kassongo since the middle of the month; they will be here in the next two days; if there is any news from Uganda or Unyoro I will know it" (concerning Stanley). He was deeply interested in the news that General Boulanger was likely to become head of the French Government, as he hoped it might lead to a war with Germany. I can only hope that he will send Rachid with me, for he has more personal authority over the Manyémas than any one except himself.

August 3rd.-Tippu-Tib crossed over to the Belgian Station this morning, and told them that there are only three men in the country who could now go in command of the Manyémas: Sefo, his son, Rachid, Nzige's son, and himself. He said that he himself could go in two days' time, if it was necessary (this he told me yesterday). They told him they could not consent to his going, as all his duties lay here as chief of the Station, but that he ought to use all his influence with Rachid to make him go. Sefo is chief at Kassongo, and it would take him too long to get here. Tippu-Tib says he has sent for Rachid to the Lumami River to-day, and that he will be here in two or three days' time; that he is a perfectly free agent, having his own money and men, and that I should have to treat with him personally. After breakfast I told Tippu-Tib that I wished to have Muni Somai's case tried before him and all the other Arabs, so that no one could say I had torn up his contract unfairly. They all accordingly assembled, and he was sent for. I read out to them the whole of the contract, and stated that at Nasoro bin Saef's village he had confessed to me that he could not make the Manyémas obey him, and that he had refused to send a guard of his men with Mr. Bonny to Unaria. I then 
stated all the facts concerning Major Barttelot's death, when Muni Somai had openly deserted, and I turned round and asked him if he had anything to say against 1888. these statements. He began to mutter something, when Tippu-Tib said, "Stop, you have not one word to say in defence; I know all this to be true." He then asked me what I wished to do. I answered that, in the first place, I should destroy all the contracts, and then make him deliver up all ammunition, rifles, tent, revolver, \&c. which he had received from us, and try to recover from him the sums of money advanced in part payment to himself and his men. Tippu-Tib then asked me to state the sums, and wrote them down on paper, saying, "I will settle all this matter for you." I mentioned the fact to Mons. Baert to-day that Tippu-Tib was rather puzzled at the arrival of a Belgian chief of the Station, when he had himself been appointed chief. Baert explained that Mons. Haneuse was not to be chief here, but only Resident, and promised to explain the position to Tippu-Tib. I see from Barttelot's instructions to Ward, which I read to-day for the first time, that he is not wrong in the matter of keeping things at Bangala, for his instructions were that if on arrival there he heard that we had left Yambuya, he was to keep all stores brought up by him there, and only forward the reply of the Committee in case of its being a recall.

\section{LETTER TO ANDREW JAMESON, EsQ.}

Stanley Falls, August 3rd, 1888.

\section{Mr DEAR ANDY,}

... A few days after our departure from Yambuya Camp, the desertions of the Zanzibaris with their loads and rifles began, and at last they became so bad, fourteen having bolted in one lot, that, on June 24th, Major Barttelot left for Stanley Falls, leaving me in command, to see what Tippu-Tib could do towards the recovery of men and loads. My personal duties then lay almost 
1888.

August 3. Stanley Falls. entirely with the Manyémas (400) supplied by TippuTib. I had serious trouble with them on many cccasions. When within four or five days of Unaria, a long way up the Aruwimi River, I sent on Mr. Bonny with the Soudanese and Zanzibaris to that place. At this time we had a number of loads, and no men to carry them, for we had had to take all the rifles and ammunition from the Zanzibaris, and carry them as loads, under an escort, to prevent their deserting. I had therefore to remain where I was, with those loads, until the return of men from Unaria to carry them. At this time the Manyémas were with me, and I had serious trouble in getting them to start for Unaria, and a pretty narrow squeak for my life, when I think of poor Major Barttelot's death afterwards. One night, after Mr. Bonny left, I had gone to bed, and out of pure devilment they fired off about 100 guns in a minute round my tent, I suppose to frighten me. Some of the guns were fired off right beside the tent, lighting it up with the flash. I jumped out of bed, and ran out, catching one man in the act of firing off his gun at the back of the tent. I ran at him, when he flung his gun to another man, and I caught him by the arm, and shouted out to the head Arab in charge (Muni Somai) to come to me. He had run into his tent in a funk. The man was a big fellow, and it was all I could do to hold him. I sent a Soudanese for Muni Somai, when another Manyéma came up, and put his gun on full cock right up close to my breast, when Muni Somai arrived, and then there was a devil of a row. I told them all that I would shoot the very next man that fired off his gun beside my tent, and not another gun was fired whilst they remained in that camp. I did not think much of it at the time, but since then I have. I got the Manyémas at last to go on to Unaria, and a few days afterwards the men returned for the loads, and I started. On the 21st July at midday, when nearing our camping-place, I met two messengers from Bonny, with a note simply stating the fact that poor Major Barttelot had been shot dead by one of the Manyémas, early on the morning of the 19th, 
and that the head man and all of them had bolted. There had been a perfect downpour of rain all morning, so I camped, as the men were too tired to go on, and my starting for Unaria that evening was useless. Next morning at daybreak I started with three men, leaving the loads to come on after me in charge of a Soudanese escort, and reached Unaria at sunset, having done three marches in one day. Here I found all quiet, and Mr. Bonny told me the following story:-Major Barttelot arrived at Unaria on the evening of the 17 th. On the 18th he gave one of the Manyémas (the men supplied by Tippu-Tib) a thrashing for firing off his gun in the village. On the night of the 18th some of them were beating their drums, and singing, when the Major sent his boy to them, and the noise ceased. About 4 o'clock next morning, just before daybreak, they began again (it is their constant practice every morning at this hour). He again sent his boy to them, when loud murmurs were heard, and two shots were fired off in the air. The Major then jumped out of bed, put his clothes on, and his revolver in his pocket, and left the house, although Bonny tried to persuade him not to do so. Immediately afterwards a shot was fired, and loud shouts were heard of, "'The Major is killed." A fearful panic then took place, the Manyémas bolting in every direction. Bonny went out, but could not find a Zanzibari; called for Muni Somai, but he did not come; told the Soudanese to follow him; they stood to arms, but would not follow. He then went towards where the shot was fired, followed by Chana, a Somali, and Omaha, a Soudanese officer, until he came to the Major's body, which was lying outside a house, quite close by. He had been shot stone dead on the spot, for not a muscle of his face had moved. He was lying on his back, with one hand under him, holding his revolver, which had not been discharged. From what I have heard since, it appears he went to this house, where a woman was beating a drum, and singing, and said, "Who is that making this noise? Stop it!" The man inside, on seeing who it was, turned round to a boy of his, and

1888.

August 3 .

Stanley

Falls. 
1888. August 3. Stanley Falls. said, "Oh! here is the white man come to beat my wife; shoot him"-upon which the boy picked up a gun, and shot him stone dead through the chest. He was buried that afternoon in a quiet spot in the forest, and Bonny spent the rest of the day in recovering loads. Muni Somai had bolted in his shirt, leaving his praying things on the ground, and was not seen again. I remained two days in Unaria, arranging everything and interviewing the head Manyémas, whom I succeeded in getting to come in and see me. Any act of reprisal on Mr. Bonny's part at the time, or on my part after my arrival, would have been fatal to the whole Expedition, for had we given the Zanzibaris their guns, they would only have run away with them, and that would have left us with less than twenty Soudanese to fight 400 Manyémas. I told all the head men that I was going straight to Tippu-Tib to try and arrange for a fresh start, and that I wanted them to camp in the vicinity, where there was plenty of food; on no account to come into the village, for that might only lead to fresh trouble, but to wait quietly until I returned from Tippu-Tib, which I would do as quickly as possible. They all agreed to this, and told me that Sanga, the man who had caused Major Barttelot to be shot, had gone to Stanley Falls. I started on the 25th, and reached Yarracombi, on the Congo, on Aug. 1st, having taken seven days and two hours to do 130 miles with loads. Our road lay through swamp and cane-brake for the most part, and was in a frightful state after the late heavy rains. Got a canoe, and reached Stanley Falls morning at daybreak, having spent all night dodging amongst the rocks in the river. On my road I met Muni Somai returning to Unaria, he having been turned back by one of Tippu-Tib's head Arabs. I told him to send all his men back, but to come himself with me to Tippu-Tib. I also met Nasoro Masudi and Ali bin Saidi, two big Arabs, who were very kind to me, and insisted on giving me a guard of nine men, and a head man to stick to me day and night, for they said that there were a good many of the men on the road who had tried to bolt to Stanley Falls, and 
that they had no good intentions towards me. They also told me that some of them meant to have a shot at me before I got into Unaria, but they never thought I could get there so quickly. God bless them! Went straight to Tippu-Tib on my arrival here, and had a perfectly private interview with him. Told him that I had come to seek his aid, in order to proceed at once, and to demand justice on Sanga. He told me that he was afraid to let the Expedition proceed-my life had been threatened, Major Barttelot had been shot, and the Manyémas were even worse than he thought. I told him that, as regarded my own life, there were a hundred ways on such an expedition in which I might lose it; my duty was to go on at all hazards, and if he could get me a big Arab, sufficiently representative of his authority to insure to some extent the safety of the loads, and the ultimate success of the Expedition, I would go on at once. I then told him I wanted Rachid, his brother Nzige's son. He asked me to give him until the next day to think it all over, and said that he had Sanga here in chains, and would deliver him over to me for justice, as it was my case. I told him that as the deed was done in what the Belgians call their territory, and the new Resident had arrived here the day before, I should see him about it. It appears that Ward, who was sent down the Congo with telegrams in March, returned on board the steamer that brought the Belgian Resident here, but his orders were only to send on the answer from the Committee if it was a recall, and if he heard that we had left Yambuya Camp, he was to keep all the stores, \&c., which he had brought up, at Bangala. This is an awful blow to me, as the captain of the steamer told me he had about fifteen letters for me, also cases from England, as well as letters for all the other officers.

Poor Major Barttelot little thought what was going to happen when he sent those orders to Ward; we expected by this time to be far on our way to Albert Nyanza. . . . . Tippu-Tib told me that he had sent to the Lumami River for Rachid. 


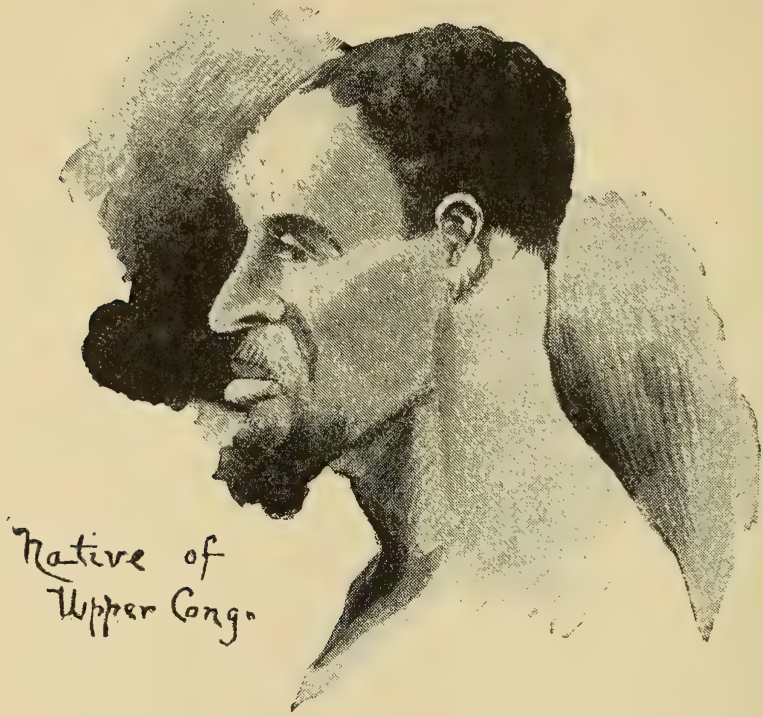

1888. August 5.

(Aug. 5th.) Sefo has the command at Kassongo, and it would take him too long to get here. You see I did not make a bad choice in my man, and he (Rachid) is the man that I always tried to get the poor Major to ask for, but he had taken some dislike to him, and would not do so. I know he dislikes Europeans, but he is a young manambitious, and fond of money, and I think I can touch him on all those points. He is feared like the very devil by all the Manyémas, and will be about the biggest man in the whole of this country. He is a perfectly free agent, having his own money and men, and I shall have to deal with him personally. Sanga, the man who shot the Major, is to be tried to-morrow morning at the Belgian Station, before the Resident and 'Tippu-Tib, and will be shot afterwards. As this will happen before I leave for Unaria, they will hear of it there when I arrive, and I suppose it will make a few more ambitious to have a pot at me, but it is my pure bounden duty to see this man shot before I leave, so I can't help that. . . . . . .... It is a long, long road that has no turning, and I hope to God ours will take a turn in the right 
direction before long. The only game to play with the Arabs is a perfectly open one, keeping your own hands clean, and watching like the very devil to see what cards they have up their sleeves. Whatever happens to me, old man, I've tried to do my duty in this blessed Expedition, and many a time, when I have thought of Ethel and home, I would have liked to chuck the whole thing up, when there were plenty of officers to take my place. ...

\section{LETTER TO MRS. JAMESON.}

Stanley Falls, August 3rd, 1888.

... Little did I think, when I spoke to you of my feelings of duty, that I should ever be placed in such a position as I now am, in which all that I feel for you and our little ones cries out against what I must do as an officer of this Expedition. With one word, or even a show of weakness on my part, I could stop the whole Expedition, which seems fated to meet with nothing but reverses, and return to you, but God knows such a thought never entered my heart, although I could easily defend such an action on my part. The first thing that flashed across my brain on finding myself so placed was your father's favourite text, "Know, O man, that to know and love justice, and to do the thing that is right, that shall bring a man peace at the last," and you will see what a help every word in that verse has been to me now. Poor Major Barttelot was shot dead by one of the Manyémas early on the morning of the 19th July. . . . . . I am writing this in the early morning before my interview with Tippu-Tib, as I have to seize every moment I can, for I have much to write to the Committee. Poor Barttelot was one of the closest friends I ever had, and the absence of all news from you makes me, as you can imagine, rather low, to say the least of it. TippuTib is almost afraid to send on the Expedition for fear of what would be said of him, should anything happen to it, and I have to appear before him as full of life and 
1888. hope as I possibly can to keep him up to the mark. . . Behind my back there are the most foul reports being Falls. spread by Assad Farran, the dismissed Soudanese interpreter, but, thank God, I can clear my character from them. I will fully explain all this afterwards.

(August 5th, Sunday). . . . I will try my utmost to induce Rachid to go with us. . . The reports that Assad Farran, the dismissed interpreter, wrote down on paper for some of the Belgian officers are one tissue of falsehoods. They are about my shooting natives on the way to Kassongo, and buying a girl to be eaten by cannibals at Riba-Riba on my way back. I am almost sure that in my letter to you from Kassongo I mentioned the fact of having shot at some natives for the protection of the caravan of canoes I was going with. I have sent a true account of both affairs to Mr. Mackinnon, and I am having the necessary witnesses examined here before one of the Belgian officers, and papers signed to send home. It is a blessing that I am enabled to do so. It is an awful thing to think that a low scoundrel like Assad Farran should be allowed to traduce one behind one's back, when one has not a chance of defending oneself! I am so anxious about everything that I lie awake for hours at night thinking, but when once on the march again, all that will pass. I only do pray that I may get the Expedition started again, but the Arabs are very hard customers to deal with. Whatever happens, you, at any rate, will know that I have done my best.

\section{DIARY (continued).}

August 4th.-Copying letters all day. Tippu-Tib is sending men at once to a number of villages to try and recover loads and deserters. $\mathrm{He}$ seems much more hopeful to-day. Wrote to Mr. Mackinnon explaining Assad Farran's statements about me. 'Took over all letters and poor Barttelot's things to the Belgian Station in the evening. Wrote to Ward at Bangala, telling him to hand over all letters for us to the captain of the first steamer that passed up to the Falls, and on no account 
to leave Bangala until hearing from the Committee, as I might wish to employ him at any moment either with the loads or telegrams.

August 5th, Sunday.-Mons. Haneuse, Botson, and Baert came over to see Tippu-Tib and sent for me, when it was agreed that Tippu-Tib should cross to the Belgian Station to-morrow morning, bringing with him Sanga, the man who shot Barttelot, when he will be tried and executed. I know that his being shot before I leave will create many enemies for me among the Manyémas in our camp, as they will then hear of it, but it is my duty to see it done myself. Wrote my private letters. Muni Somai came to see me, and in the most abject manner begged to be allowed to keep the tent and revolver, or buy them. I told him they were Mr. Stanley's, and I could not think of such a thing. He then insisted on presenting me with two slaves of his who are at Unaria-a man to carry a load, and a woman to cook and keep things tidy. I told him I did not want either, and that they would be much more useful to him. He said he might never see me again, and that he would hand them over to $\mathrm{Mr}$. Bonny at Unaria. I believe he would tell the man to shoot me if he got the chance, and the woman to poison me, for when he came in here, the evening after his trial, while shaking hands with me before leaving, he simply clenched his teeth and shivered from head to foot, and I could see it was all he could do to contain himself. He went to Tippu-Tib this morning, and asked him who was going to pay him the money for his men and himself, for the time they had been with us. Tippu-Tib merely said, "You had better go and ask Mr. Jameson that." $\mathrm{He}$ is going to join one of the ivory-hunting parties from Unaria to-morrow, I believe Nasoro Masudi's. I wish them joy of him.

August 6th.-Rachid arrived from the Lumami River this morning. After breakfast he came and had an interview. I told him he was the man I wanted to

1888.

August 4.

Stanley

Falls.

Handed over by Muni Somai seven good rifles, 137 rounds for same; one revolver, 18 rounds for sare one side of tent. 
1888. help me, and that if he came now, after all that had August 6. taken place, and got us through either to Stanley or

Emin Pasha, he would be making a very great name for himself; few men have ever had the same chance. He urged that he had a country of his own, many people, and a regular quantity of ivory coming in every month, and that there was no one left to look after his business. I told him that I knew well that he was a very big man, but that he would win a greater name than any one in this country, should he be the means of our getting through to Emin Pasha. I offered him $£ 1,000$ (the same as to Muni Somai), and a further sum of $£ 500$, as well as hiring 100 of his men, not to carry loads, but as a fighting force. He asked for a short time to think it over, and returned in an hour to say that he was sorry that he could not come this time. Next month he expected to receive 500 tusks of ivory, his father was going to Zanzibar, there was no one to look after his affairs, the road was a long one, Mr. Stanley had gone away for only some months, and had now been away for more than a year, and no one knew anything of him. I explained to him that Stanley's men did not understand fighting natives as well as the Manyémas did; that many men had run away on the road, and many had died; that from Eturi, where he was last heard of, to the Lake was only a month's journey; that nothing having been heard of him beyond the Lake, it would appear that he was somewhere on that month's journey, most probably in a strong camp, expecting us every day. He still maintained that he could not come, and went away. I sent for Tippu-Tib, and gave him the reasons Rachid had given me, and asked him whether he thought that I might yet induce him to go by guaranteeing him any sum in case of any loss he might incur in ivory. He told me No, that the real reason of his refusal was that he was afraid to come, for he feared death. He said he had now sent for Selim Mahommed, thinking he might come, as he is a man who is anxious to make money. I reminded him that Selim Mahommed had had very serious trouble at Yambuya with Major 
Barttelot and Mr.Bonny, and that should anything wrong occur on the road, the Committee would justly blame me for having taken him, knowing what I did; but that if he, Tippu-Tib, would send him, not as a free agent, but as a personal representative of his own, carrying out his (Tippu-Tib's) orders, I might consider the matter. I told Tippu that I must go on in any case, whatever happened; that I had come to him for his aid and advice; and that if he had given me all he could of both, I must try and think of a means of going on still. $\mathrm{He}$ jumped up out of his chair and said, "Give me $£ 20,000$ and I and my people will go with you, find Mr. Stanley, and relieve Emin Bey," and went out of the house. This, to say the least of it, put me into a rather trying position. Selim Mahommed is, I know, afraid to go, and after what took place at Yambuya, I could not take him even were he willing to do so. There is not another man in the whole country able to go, Sefo having gone to Zanzibar. As a matter of fact the whole Expedition at the present moment has broken down, and yet there are all the loads and everything a long way on our road, ready at Unaria. Tippu-Tib will do it for no less, for I afterwards tried to get him to agree to so much a month, in case it took us only a very short time, when $£ 20,000$ would be too large a sum to pay anyone. I also tried to make it conditional on success, but he said those were his terms. The Belgians have refused to allow him to go ; they say his duties lie here, yet they will let him go to Kassongo for ten months or a year without a murmur. Tippu-'ib's proposition came from himself, for after what he and the Belgians told me the other day, I never thought of asking him. If I sign for this $£ 20,000$, surely the Committee and the country would not see me ruined by making me pay it all, and refuse to acknowledge the contract. I will write to my brothers at home, and tell them to see the Committee on the subject, and if they will not pay more than part of it, try to raise a subscription for the rest. 'TippuTib sent to me several times to know what my intentions were, and at last I sent back to say that I would agree 
1888. A ugust 6. Stanley Falls.

to his terms, being driven to desperation and having thought of every other way out of it with a hope in it of our going on. It must not be forgotten that since my arrival here the Manyémas in our camp have openly avowed their intention (if I went on with them myself) of going on with the loads until they could take a good village with a boma, where they would fling them down, and go off ivory-hunting, leaving Mr. Bonny and myself to do what we could. Tippu-Tib sent in the afternoon to beg me to cross to the other side with him, and settle the question about his going, with the Belgians. We crossed, and Tippu-Tib opened his case by telling them he had tried to get Rachid to go with me, but that he could not do so, and that there was no one else in the country to go but himself. I had told him that I would go on myself with his people, " but," said he, "if they have already acted as they have in my territory, what would they do further on?" He now wished to know if Mons. Haneuse thought he was right or wrong in going. Haneuse told him that if he was going he had no power to stop him; that Tippu-Tib himself knew what his contract with the King of the Belgians was; that he (Mons. Haneuse) thought he ought not to go, but that he had no power to stop him. Tippu-Tib then said :- " At Zanzibar I signed a contract with Mr. Stanley for the supply of 600 men; and Mr. Holmwood said, 'If you cannot get 600, get as many as you can.' I asked Mr. Stanley if he wanted me to go, but Mr. Stanley said No. When I got to Stanley Falls, I could not get men, so I went to Kassongo for them, where Mr. Jameson followed me; the result of this was that we got 400 men. Whilst at Kassongo I heard from Assad Farran that Major Barttelot wanted Selim Mahommed to go in command of my men, but on asking Major Barttelot at Stanley Falls if he wanted him, he said, 'No, I do not even want him near me.' I then introduced him to Muni Somai, with the result that Muni Somai signed an agreement to belong to Major Barttelot and Mr. Jameson, and to command my men. I then handed my men over to 
Muni Somai, giving him full powers over them, to cut off their hands or do anything to them if necessary, but he could not command them. Major Barttelot has been killed. Mr. Jameson then came to me. I brought him Rachid. Rachid would not go. Mr. Jameson said, 'I will go myself, for I must go on.' I then told Mr. Jameson that I would go myself. You and I, Mons. Haneuse, are both officers of the State; will you tell me if I am right in going?" Mons. Haneuse told him he could not say he was right in going, but that if he was bent on going, he could not stop him. It was then agreed to settle the matter to-morrow morning, and Sanga's trial also. After Tippu-Tib had gone, I said to Mons. Haneuse and the other Belgian officers present, that I was sure the King of the Belgians would not blame Tippu-Tib for what he was going to do, but rather commend him. They all agreed to this. I told them that although it was a private Expedition, both the English people and the English Government had a great interest in it, and that the King of the Belgians would never blame Tippu-Tib for helping us as he was going to do. To this they also agreed. I said the same to Tippu-Tib afterwards, and it greatly re-assured him. Mons. Haneuse, in acting as he did, was only doing his duty towards the State, for Tippu-Tib knows perfectly well that his contract with the State forbids his leaving their territory. He assured me that personally he was prepared to do all he could to help the Expedition, and I must say that he and all the other officers have done so already.

August 7 th.-Crossed to the other side after breakfast, and Sanga was tried before Mons. Haneuse, three other Belgian officers, and Tippu-Tib. Sanga was first asked what he had to say. He told a rambling story about Major Barttelot coming to his house where his women were drumming and singing, and that Kapranga came too; that Major Barttelot kicked him; and that when Kapranga, the Major, and he were outside, some one fired a shot from behind him, and shot the Major 
1888. dead, the ball going in at his back, but that he had not August 7. done it. Here Tippu-Tib stated that Sanga had told him, Falls. on arrival here, that he was in bed at the time the Major was shot. Mons. Haneuse asked him what made him run away and come here. He said that many people had accused him of having done it, and so he ran away. I then made the statement which Mr. Bonny had given me on my arrival at Unaria, and further stated that all the muniaparas of the Manyéma had assured me that Sanga had shot Major Barttelot. Sanga was asked if he had anything further to say. He repeated that he had not done it, and had run away because people said he had, and that on the road to Yarracombi he had met Muni Somai, who, when he saw him, ran away as fast as he could. Voting papers were then given to Tippu-Tib, Mons. Haneuse, and the three other Belgian officers, to mark with a cross, if they considered him guilty, and to leave blank if innocent. All five papers were found crossed, so Mons. Haneuse told Sanga that he had been found guilty and would be shot. He laughingly replied "Well, do it quick." He was chained to a large log, and when carried outside said again with a laugh, "It is all right; the white man is dead, I am going to die too." He was carried down to the rocks on the shore, where a firing-party of six Houssas, at six paces, fired at him, and did not kill him; fired a second time and did not kill him; then one of the Belgian officers ran up with a revolver, and fired two shots into his head. Only four bullets had hit him, two in the right breast, one in the knee, and one in the throat, besides the two from the revolver. After the first discharge, when he was hit by some of the bullets, the look he gave us was the most horrible I think I ever saw on a man's face.

We then had lunch, and afterwards tried to arrange a contract with Tippu-Tib. He began by a long statement, saying that he would accept no less sum than $£ 20,000$, and that he would not agree to that sum being; lessened, even were we to accomplish everything in three months or less; that if beyond Eturi he met a man with a stronger force, and was attacked by him, if he saw that 
he would lose many men he should return, but would still expect the $£ 20,000$; in fact, the only agreement he would sign would be to go in command of his own men for the sum of $£ 20,000$. He then said to me, "It is to Unyoro you want to get the loads. I will take you there for $£ 20,000$; 1st, guaranteeing to reach there in six months from date of starting; 2nd, guaranteeing payment of any loss of loads ; 3rd, guaranteeing, after delivery of loads at Kibero, to assist in finding Stanley. Road by Kassongo, Tanganyika, and Unyoro. In case of finding the kings of Unyoro and Uganda at war with one another, I cannot guarantee reaching Kibero." I asked him to think over everything. After dark he came to my house, and we had a perfectly private interview. I told him that Mr. Stanley's very last orders on leaving Yambuya were to follow on his road. Major Barttelot had written to Mr. Mackinnon to say we had gone on that road, and his intention before he was killed had been to continue on that road. The reply to our telegram could not have been to go by any other route, or we should have received it. Emin Pasha's last statement was to the effect that, were he not soon relieved, he would put himself at the head of his men and try and get out to the Congo. Finally, I said that in the face of all this I could not adopt a new route unless ordered to do so from home. Tippu-Tib said, "You are right." I then said to him, "You cannot get me a head man to put over the Manyémas; you yourself say you will turn back (should you go with me), if any serious loss is threatened to your men; the only thing left for me to do now is to get a canoe at once and go to Bangala. If I find the reply from the Committee to be 'go on at all hazards,' I will return at once and start with your men myself. If I find that it does not tell me to go on at all hazards, I will send Mr. Ward with a telegram to Banana stating my present position, your proposals, and asking for orders." In this case, I told him, I should return with the steamer, which ought to arrive in about a fortnight. Tipl,u-Tib then agreed to make his men at Unaria carry all their loads to 


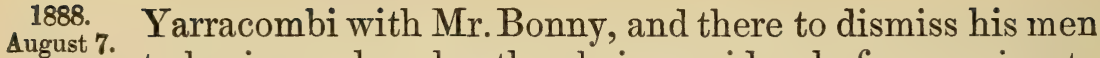
to business close by, they being paid only for carrying to Falls. Unaria, and from Unaria to Yarracombi, so that in case they were required again they could be called together in two days' time. He also agreed to find me canoes and men to go to Bangala. One of my men told me that it took Mr. Ward six days and six nights to reach Bangala from Yalisula, and that after passing the mouth of the Aruwimi we could buy food at all villages.

August 8th.-Tippu-Tib the first thing this morning told me he did not think he would have the canoes ready till to-morrow, so I told him if he did not it was no use my going. He gave me his word they would be ready. Reminded him about four times in the day. Crossed over to the Belgian Station before breakfast to ask Mons. Haneuse to give me a letter to the captain of the Stanley, authorising him, if I met the steamer within one day of Bangala, to return there with me, and bring me up again. Baert told me that, according to the State laws, no Zanzibaris could be taken to Bangala, for fear of their telling the Arabs the road. As if this would affect them in the least should the Arabs wish to go there! Mons. Haneuse was not in, so I returned and wrote two formal letters of application, asking him to let the Zanzibaris go, and to write to the captain of the Stanley for me; took these over, and Mons. Haneuse said he would give me both the letters I required. Tippu-Tib keeps getting in pieces of Expedition cloth from all over the country, He has at last discovered the refuge of the runaway Zanzibaris, viz. Said bin Habib's village behind Yatuka. He has sent men down there with the promise that they shall recover a number before I return.

[Vide Mr. Stanley's charge of desertion against Jameson, in 'Darkest Africa,' vol. ii. page 15 :-“Mr. Jameson's letter from Stanley Falls arrived. Though 
the letter stated he purposed to descend to Bangala, the messenger reported that he was likely to proceed to Banana Point, but whether Banana Point or Bangala mattered rery little. When he descended from Stanley Falls, he deliberately severed himself from the Expedition, and no inducement would tempt me to remain in the neighbourhood of Banalya... I wrote a letter, however, to Mr. Jameson, wherein I suggested that if he could muster sixty men, and immediately follow our blazed path, which was too broad to be mistaken, he might easily overtake our large column, marcling in single file through the forest, along a road. bristling with obstacles, of sloughs, marshes, creeks, and rivers ...."

The letter itself is as follows :-

\section{To J. S. JAMESON.}

One March above Banalya.

Dear Sir, August 30th, 1888.

I know that Bonny has written to you about my arrival, so I may be brief. Arriving at Banalya 17th inst. I have been busy ever since reorganising the Expedition, which I found to be in a terrible state. To-day the second march from Banalya has begun, and we shall continue on. Bonny showed me your letter of the 12th inst., wherein you stated it to be your purpose to go to Bangala.

I cannot make out why the Major, you, Troup, and Ward have been so demented-demented is the word. You understand English; an English letter of instructions was given you. You said it was intelligible-yet for some reason or another you have not followed one paragraph. You paid $£ 1,000$ to go on this Expedition; you have voluntarily thrown your money away by leaving the Expedition. Ward is not a whit better; he has acted all through, as I hear, more like an idiot than a sane being. You have left me naked. I have no clothes, no medicine; I will say nothing of my soap 
and candles, photograph apparatus and chemicals, two silver watches, a cap, and a score of other trifles. You believed I was dead, yet you brought along my boots, and two hats, and a flannel jacket. You believed the Expedition had gone to Ujiji, yet you took Stairs' and the other officers' goods along. Is not this rather inconsistent?

I shall proceed along the $\mathrm{S}$. bank of the river for nearly two months, and then cross the river to the $\mathrm{N}$. bank, thence straight to the Nyanza. If you can bring my kit with you, you are welcome to go on with us if you can catch us up. Forty guns will take you along safely to the point when we cross the river. Emin Pasha is quite well. All our officers are well. We have lost none. We have lost 50 per cent. of men. I came from the Nyanza in eighty-two days, and from our fort in sixty-one days.

Our track will be quite clear, as a highway, two marches from Banalya, or, as you call it, Unaria, it will be white all the way to the crossing. If you can find where we landed on the N. bank, -it will be one march above Nepoko confluence with the Aruwimi,-you will be able to follow us with 40 guns. With less it would be dangerous.

'The plains are 25 marches from the crossing place. Splendid game country, game of all kinds. I have left all the officers at Fort Bodo, except Jephson, who is with Emin Pasha.

Though,- - as reported to me,- - you and all of you seem to have acted like madmen,-your version may modify my opinion. Therefore I write this brief note to you in the midst of bustle and hurry.

Yours truly,

(Signed) Henry M. Stanley.

Jameson never received this letter; it arrived after his death and was sent home. Comment upon Mr. Stanley's charge against Jameson, his description of his own letter, and the letter itself, would be superfluous.-ED.] 


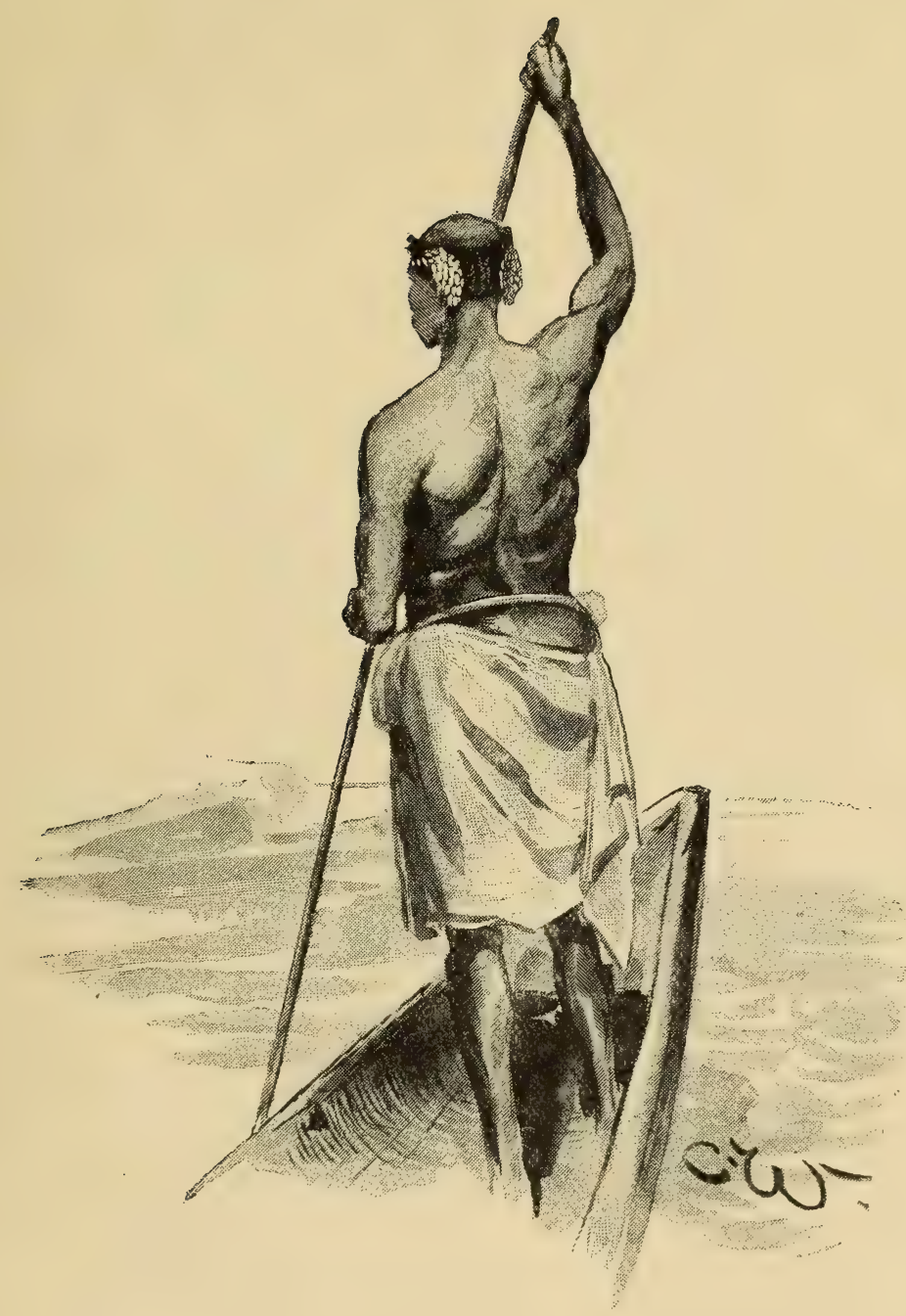

A Canoe Journey.

\section{CHAPTER X.}

August 9тh to August 18тh.

Last Journey.-Mr. Ward's diary.-Death.

August 9th.-Left Stanley Falls for Bangala. Did not get away until nearly mid-day, one canoe not arriving 1888. until very late. Started with six Zanzibaris, two boys, 
1888.
uugust 9. Farani, fourteen Waganias, and two of Tippu's men in Last charge. Tippu-Tib promised me that everything would Journey. be right at Unaria. Muni Hamela and Salem Masudi leave for there to-morrow. I am sending Bonny two sacks of rice and twenty fowls. I had to write letters from Tippu-Tib to Mr. Greshoff, urging him to come up without delay, as there was a great quantity of ivory.

August 10th, Friday.-Reached the Lumami River at daybreak. I was frightfully seedy, having caught cold inside after a big dose of medicine. Another delay here. One of the canoes I bought from Tippu leaked so much that I had to exchange it for one from Rachid. A great quantity of ivory arrived for him, and he could attend to nothing. Had the two canoes lashed together at last and four days' food on board, and started early in the afternoon.

August 11th, Saturday.-After a long night's work found ourselves past the Aruwimi in the morning. The natives told us to-day, a long way below the mouth of the Aruwimi, that the Tamba-Tambas had killed a tremendous number of them on the south bank. This is where Rachid's enormous lot of ivory came from that I saw arrive yesterday. I had the greatest difficulty all day in quieting the natives, who thought we were more Tamba-Tambas, and had to sit in the sun all day to let them see me, and speak with them. They are perfectly mad.

Auqust 12th, Sunday.-Got through the worst of the natives during the night. One very curious scene. Shot out of an open reach-fine clear night-into a dark narrow channel, not more than forty yards wide. All at once it became lit up with dozens of fires on both sides, throwing a bright light back into the forest and across the water. We glided on without a sound from us but the zip-zip of the paddles, drums beating, horns blowing, shouts and cries on every side, the white loin-cloths of our men showing plainly who 
they were. Down this lane of fires and noise we went for nearly half a mile, when suddenly it opened out into a grand open reach of the river on our right, the fires, drums, \&c., going on for more than a mile away down on our left. I don't think I ever heard such a noise before. We shot out away to our right, and soon left all the tumult behind. What they thought of us I should like to know. This morning we passed a village, which one of my men tells me it took them three days to reach from Bangala in the steamer $A$. I. A. Here the natives came out in crowds, without spears or anything, and were wishing to sell us everything they had. Passed three large villages before sunset, but there was a strong head wind the whole day, which knocked us back frightfully.

THIs vivid sketch of the weird night scene on the river was the last pencilled entry ever made in his diary by Jameson. The chill which he had contracted on the 10th August rapidly developed into hæmaturic fever, and, although he made no complaint and wrote bravely as ever, he was then fighting his last battle with death. Unable to take nourishment of the coarse description which his Zanzibaris could offer him, he touched nothing for all the days of the weary voyage, save one or two bananas and a cup of soup made from goat's flesh. During the 11th and 12th, though able to write short pencil notes in his pocket-book, he was gradually sinking. For the next three days he lay dying in the canoe, with not a soul to help him, and could only murmur, "Quick! paddle quick," to his men, who night and day paddled on down the mighty river, striving to reach Bangala in time to save their master's life. They reached it on the 16th, and Mr. Ward, who the day before had received the sad news of Major Barttelot's murder, was summoned hurriedly to the canoes, and lifted out the almost lifeless body of his dying comrade. 


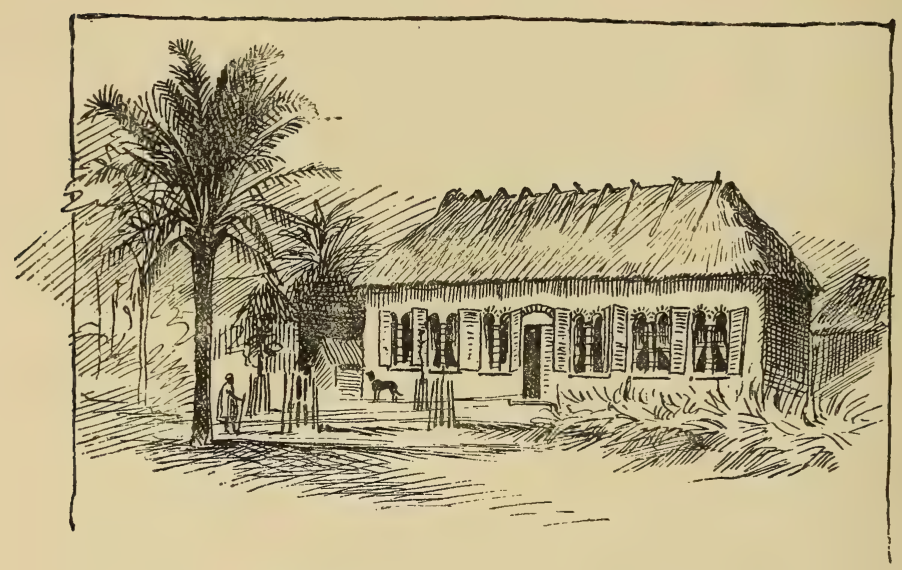

The House in which Mr. Jameson died at Bangala.

The following notes of the next two days are taken, by kind permission, from Mr. Ward's diary:-

1888. August 16. August 16th.-We carried him up into Van Kerckhoven's room; he did not recognize me. I took his hand, his eyes were half closed, and his skin a ghastly yellow colour. . . . When laid on the bed, he regained consciousness, and said, "Oh, Ward, is that you ?" and again became insensible. With the aid of my Zanzibari servant Msa, I bathed him carefully in warm water ... after which he brightened up, and took some Madeira and chicken soup. He said that he had had an awful journey down from Stanley Falls, exposed to tornadoes of wind and rain, lying helpless in the canoe. Being too feeble to converse, he only made occasional remarks about his illness. He once said, "You know, Ward, if I could only get a square show at this sickness, I should be all right." He slept fairly well during the night, but had several attacks of spasms. I remained beside him all night. 


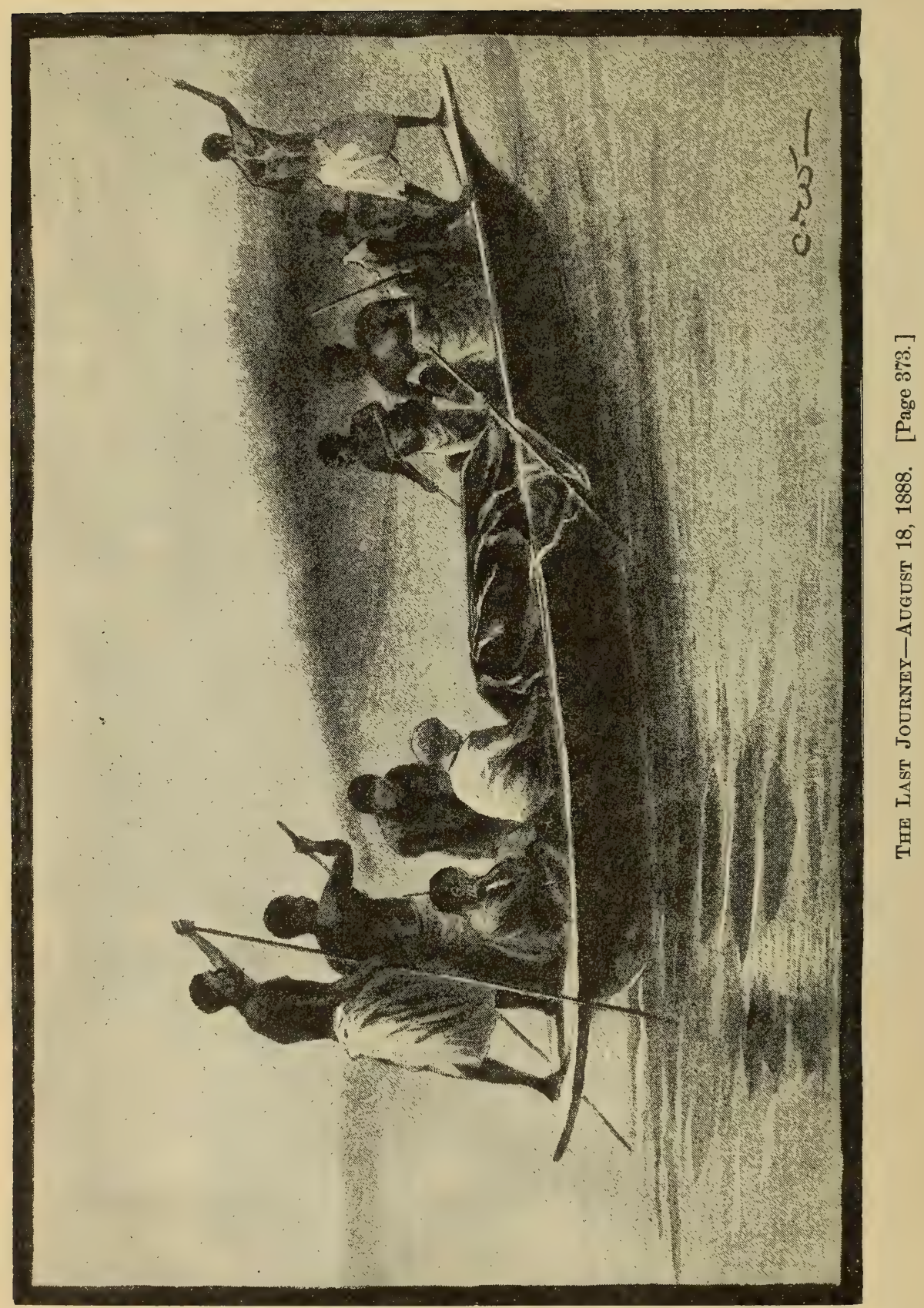


August 17th.-His pulse was feeble, and he could not retain his senses for more than a minute or two, and could only take a spoonful of soup at long intervals. Every quarter of an hour or so, he came to, and, with a faint smile of recognition, stretched out his hand and clasped mine, as if by so doing he steadied his nerves, and looking at me once, he said, "You're so well and clean-looking that it does me good to look at you." His reply to almost every question was a feeble "Splendid!" and to inquiries about his condition, " $\mathrm{Oh}$ ! in-fi-nitely better," but so feeble, and such an effort to utter it, that he relapsed after every answer into unconsciousness.

1 P.M. I asked him just now if he was in any pain. "No, old chap, no pain, only tired--Oh! so tired. I think it's time to turn in; it's so dark-so tired," and again became unconscious. - 3 P.M. I have given him nourishment upon every occasion, but he does not rally, and only gets feebler.-6 P.M. Daruru and I put hot bricks round him, as his extremities have grown cold. He grows weaker and weaker. The drums just now sounded to knock off work in the Station, he opened his eyes and stared at me, clutching my hands, and said, with a husky voice, "Ward! Ward! they're coming; listen!" (and as the drums rumbled in the distance), "Yes! they're coming-now let's stand together." He was thinking of the drums calling the savages to fight him, while he drifted down the river past the villages.

7.20. His pulse grows weaker and weaker.-7.30. As I supported him to administer brandy, he drew a long breath, and his pulse stopped.

August 18th.-I walked about until daylight quite beside myself with sadness. . . . My "Union Jack" covered the coffin, which was borne to the canoe by four Houssa soldiers, and we all proceeded across the river in the early morning, without a sound but the splashing of the paddles. Upon arriving at the opposite 
1888. shore, we bore the coffin to the grave, and I read a Bugust 18. chapter from the Bible. His resting-place is at the foot of a giant cotton tree, on the island opposite Bangala, one thousand miles from the sea.

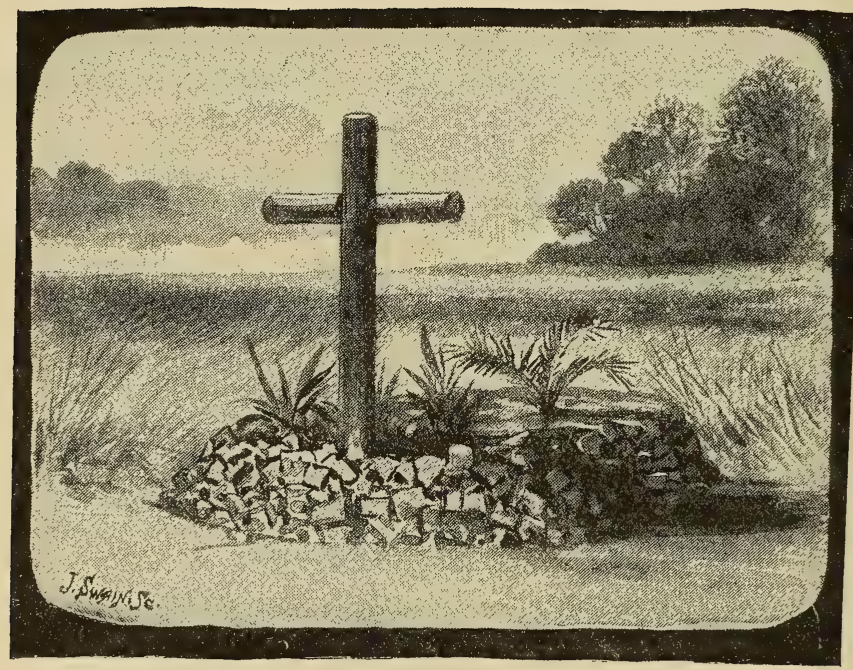

Photograph of Grave. 


\title{
“MY JUSTIFTOA'TION;"*
}

OR

\section{“THE LIGHT OF EQUATORIAL AFRICA,"}

\author{
SLIGHTLY ALTERED FROM
}

"THE LIGHT OF ASIA."

(With Apologies to Sir EdwIN ARNold.)

\section{Unto this}

Came I, and unto this all nights and days

Have led me ; for I cannot lead that life

Which may be mine-a life of empty pleasure Which clogs the little spirit still within me.

My days shall not roll on with even wheels

From month to month, and year to year, till death

Ends the whole record of my name: I choose

Another life, to which that spirit leads me,

Making the dust my bed, the loneliest wastes

My dwelling, and the meanest men my mates;

Clad in no woven garbs that mashers wear,

Fed with no savoury meats from cooks of France,

Mazed with no wine, sheltered by no more pomp

Than the thin canvas or the jungle bush.

How hath it steaded men to live and think

Of dining, drinking, sport, and lovely women,

To dress themselves for empty show, to rear

The stately house, to feed their so-called friends

And list to empty words of flattery

Ascending day by day like wasted smoke?

Hath any of my town friends 'scaped thereby

The slow dull sinking into withered age?-

Lighted by no bright thoughts of times gone by,

But sick to death of every thing they see,

Filled with cravings for some pleasures new

Which have their end in the old mockeries!

* Written by Jameson in a letter dated Yambuya Camp, June 8th, 1888.-ED. 
Truly, it may be some of them are good-

And evil some, but all in action weak :

Both pitiful and pitiless, and all

Without a past to dwell upon when they

Can no more lead that life which is their being.

Man is not put upon this earth to live,

And spend, what others toil to make, on pleasures :

There must be work, there must be work for all.

What good gift have my brothers, but it came

From search and strife, and loving sacrifice?

If one, then, being rich and fortunate,

Young, dowered with health and ease, from birth designed

To live, if he would live, just as he chose-

If one not tired with life's long day, but glad

I' the freshness of its morning, one not cloyed

With love's delicious feasts, but hungry still-

If one not worn and wrinkled, sadly sage,

But joyous in the glory and the grace

Of living here below, with loving wife,

A little child, and many many friends-

If such a one, having so much to leave,

Left all, going forth to do some work

He felt was noble, and he fitted for,

Surely, at last, far off, sometime, somewhere,

His recompense would come, and he would meet

His death with no regrets for deeds not done!

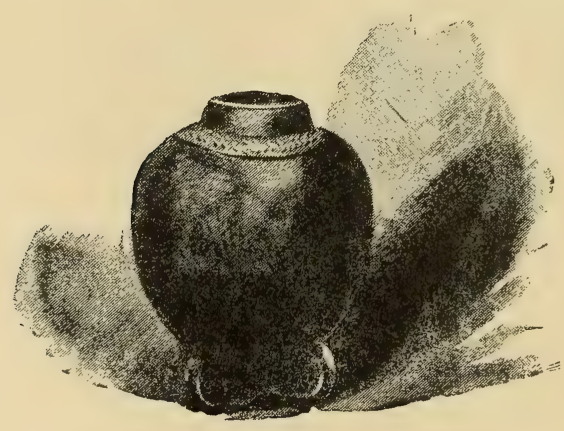




\section{APPENDIX I.}

\section{Contract between}

I, JAMES S. JAMESON, agree to accompany the Emin Pasha Relief Expedition, and place myself under the command of Mr. H. M. Stanley, the leader of the Expedition, and to accept any post or position in that Expedition which he may assign to me.

I further agree to serve him loyally and devotedly, to obey all his orders, and to use my utmost endeavours to bring the Expedition to a successful issue.

I also agree to pay the sum of One Thousand Pounds to the credit of the Emin Pasha Relief Expedition at Messrs. Ransome, Bouverie, and Sims, No. 1 Pall Mall, and to pay expenses of my passage from and to England, and to forfeit the above mentioned surn of $£ 1,000$ if I leave the Expedition through sickuess or my own free will.

For the above I am to receive a due share of the European provisions provided for the Expedition, and also a share of native provisions purchased in the country; also 1 Winchester Rifle and 1 Revolver, with ammunition for the same.

I also undertake not to publish anything connected with the Expedition, or to send any account to the newspapers, for six months after the issue of the official publication of the Expedition by the leader or his representative.

\section{(Signed) JAMES S. JAMESON.}

$$
\text { Approved, }
$$

HENRY M. STANLEY,

Jan. 20th, 1887.

Witnesses $\left\{\begin{array}{l}\text { F. de Winton, Col. } \\ \text { William Hofmann. }\end{array}\right.$ 


\section{APPENDIX II.}

Copy of Letter of Instructions from Mr. STANLeY, Commanding Expedition, to Major BaRtTELot.

Major Barttelot's Appointment as Commander of Stockaded

Camp at Yambuya Village, Aruwimi Rapids.

To Major Barttelot, \&c. \&c. \&c.

June 24th, 1887.

SrR,

As the senior of those officers accompanying me on the Emin Pasha Relief Expedition, the Command of this important Post naturally devolves upon you. It is also for the interest of this Expedition that you accept this Command, from the fact that your Soudanese Company being only soldiers, and more capable of garrison duty than the Zanzibaris, will be better utilized here than on the road.

The steamer Stanley left Yambuya on the 22nd of this month for Stanley Pool. If she meets with no mischance, she ought to be at Leopoldville on the 2nd July. In two days more she will be loaded with about 500 loads of our goods which were left in charge of Mr. J. R. Troup. This gentleman will embark, and on the 4th July I assume that the Stanley will commence the ascent of the river and arrive at Bolobo on the 9th July. Fuel being ready, the 125 men in charge of Messrs. Ward and Bonny, now at Bolobo, will embark, and the steamer will continue her journey. She will be at Bangala on the 19th July, and arrive on the 31st July. Of course the lowness of the river in that month may delay her a few days, but having great confidence in her Captain, you may certainly expect her before the 10th August.

It is the non-arrival of these goods which compels me to appoint you as Commandant of this Post. But as I shall shortly expect the arrival of a strong re-inforcement of men, greatly exceeding the Advance Force, which must at all hazards push on to the rescue of Emin Pasha, I hope you will not be detained longer than a few days after the departure of the Stanley on her final return to Stanley Pool in August.

Meantime, pending the arrival of our men and goods, it 
behoves you to be very alert and wary in the Command of this Stockaded Camp. Though the Camp is farourably situated and naturally strong, a brave enemy would find it no difficult task to capture if the Commandant is lax in discipline, vigour, and energy. Therefore I feel sure that I have made a wise choice in selecting you to guard our interests here during our absence.

The interests now entrusted to you are of vital importance to this Expedition. The men you will eventually have under you consist of more than an entire 3rd of the Expedition. The goods that will be brought up are the currency needed for transit through the regions beyond the Lakes; there will be a vast store of ammunition and provisions, which are of equal importance to us. The loss then of these men and goods would be certain ruin to us, and the Advance Force would need to solicit relief in its turn. Therefore, weighing this matter well, I hope you will spare no pains to maintain order and discipline in your Camp and make your defences complete, and keep them in such a condition that however brave an enemy may be he can make no impression on them. For this latter purpose I would recommend you to make a ditch of $6 \mathrm{ft}$. wide $3 \mathrm{ft}$. deep, leading from the natural ditch where the spring is round the Stockade. A platform like that on the Southern side of the Camp, constructed near the Eastern as well as the Western Gate, would be of advantage to the strength of the Camp. For remember it is not the natives alone who may wish to assail you, but the Arabs and their followers may through some cause or other quarrel with you and assail your Camp. Our course from here will be true East or by Magnetic Compass East by S. as near as possible. Certain marches that we may take may not exactly lead in the direction aimed at, nevertheless it is the South-west corner of Lake Albert, near or at Kavalli, that is our destination. When we arrive there we will form a strong Camp in the neighbourhood, launch our boat and steer for Kibero, in Unyoro, to hear from Signor Casati, if there, of the condition of Emin Pasha. If the latter is alive and in the neighbourhood of the Lake, we shall communicate with him, and our after conduct must be guided by what we learn of the intentions of Emin Pasha. We may

$$
2 \text { c } 2
$$


assume that we shall not be longer than a fortnight with him before deciding on our return towards this Camp along the same route traversed by us when going East.

We will endeavour, by blazing trees and cutting saplings along our road, to leave sufficient traces of the route taken by us. We shall always take by preference tracks leading eastwards. At all crossways, where paths intersect, we shall hoe up and make a hole a few inches deep across all paths not used by us, besides blazing trees when possible.

It may happen, should Tippu-Tib have sent the full number of adults promised by him to me, viz., 600 men (able to carry loads), and the Stanley has arrived safely with the 125 men left by me at Bolobo, that you will feel yourself sufficiently competent to march the column, with all the goods brought by the Stanley and those left by me at Yambuya, along the road pursued by me. In that event, which would be very desirable, you will follow closely our route, and before many days we should most assuredly meet. No doubt you will find our bomas intact and standing, and you should endeavour to make your marches so that you could utilize these as you marched. Better guides than these bomas of our route could not be made. If you do not meet them in the course of two days' march, you may rest assured that you are not on our route.

It may happen, also, that although Tippu-Tib has sent some men, he has not sent enough men to carry the goods with your own force. In that case, of course you will use your discretion as to what goods you can dispense with to enable you to march. For this purpose you should study your list attentively.

1st. Ammunition especially fixed is most important.

2nd. Beads, brass wire, and cowries rank next.

3rd. Private baggage.

4th. Powder and caps.

5th. European provisions.

6th. Brass rods as used on the Congo.

7th. Provisions (rice, beans, peas, mettammeh, biscuits).

Therefore you must consider after those, sacking, tools, such as shovels (never discard an axe or a bill-hook), how many sacks of provisions you can distribute among your men 
to enable you to march,- whether half of the brass rods in your boxes could not go also, and there stop. If you still cannot march, then it would be better to make marches of 6 miles twice over, if you prefer marching to staying for our arrival, than throw too many things away.

With the Stanley's final departure from Yambuya, you should not fail to send a report to Mr. William Mackinnon, of Gray, Dawes, and Co., 13 Austin Friars, London, of what has happened at your Camp in my absence, of when I started away Eastward; whether you have heard of or from me at all; when you do expect to hear, and what you propose doing. You should also send him a true copy of this order, that the Relief Committee may judge for themselves whether you have acted or purpose to act judiciously.

Your present garrison shall consist of eighty rifles, and from forty to fifty supernumeraries. The Stanley is to bring you, within a few weeks, fifty more rifles and seventy-five supernumeraries under Messrs. Troup, Ward, and Bonny.

I associate Mr. J. S. Jameson with you at present. Messrs. Troup, Ward, and Bonny will submit to your authority. In the ordinary duties of the defence and conduct of the Camp or of the march, there is only one chief-which is yourself; but should any vital step be proposed to be taken, I beg you will take the voice of Mr. Jameson also; and when Messrs. Troup and Ward are here pray admit them to your confidence and let them speak freely their opinions.

I think I have written very clearly upon everything that strikes me as necessary. Your treatment of the natives, I suggest, should depend entirely upon their conduct to you. If they do not molest you, suffer them to return to the neighbouring villages in peace; and if you can in any manner, by moderation, small gifts occasionally of brass rods, \&c., hasten an amicable intercourse, I should recommend your doing so. Lose no opportunity of gaining all kinds of information respecting the natives, the position of the various villages in your neighbourhood, \&c., \&c.

I have the honour to be,

Your obedient servant, (Signed) HENRY M. STANLEY, Commr. Expedition. 


\section{APPENDIX III.}

\section{Extract from a Letter to ANDREw JAMEson, Esq}

Entrenched Camp,

Yambuya, Aruwimi Rapids, Aug. 7th, 1887.

Having quoted Mr. Stanley's letter of instructions to Major Barttelot, Jameson goes on to say :-

"Well, suppose the Stanley arrived here on the 10th of August, and Tippu-Tib's men were here (which they are not yet), and we started, say on the 17 th, and did ten miles a day (Mr. Stanley only proposed doing twelve on his forced march when he left us). We have, roughly speaking, 400 miles to do, and it would take us forty days, or until the 1st October, giving us four days for delays. Say we started for Zanzibar in a fortnight, or the 14th October, and it takes us six months to reach Zanzibar, that would be the 14th April; then supposing all these things happened quite smoothly, I should get home by June in next year, or, if we missed the mail at Zanzibar, July. Again, if Tippu-Tib's people do not turn up (which I shall know before this letter leaves, as if they do not come before then, there is little chance of their coming at all), -in that case we should have to wait here until late in November or the beginning of December, when Mr. Stanley would return with his men from Lake Albert to help us carry all the goods up there. (He will start to return here in any case, as he cannot know whether Tippu's people have come or not; if they have, we shall meet him on the road, and he will turn, and we will all go on together.) Say we could leave here by the middle of December, and reach the Lake in the first week of February, leaving the Lake finally in the third week of that month, we should reach Zanzibar in the third week of August, and get home in October. In neither of those cases, with or without Tippu-Tib's men, have I allowed any time for his exploration of Lake Muta Nzige. He himself, I believe, thinks we may be home any time between June and September next year. However, there is one thing certain, that I cannot be 
home before June in next year in any case. As regards myself, the whole trip has been a vast sell. I have not had a single chance the whole time of collecting, drawing, or doing anything but the duties of a slave-driver. I have never been on any trip which was so much like a funeral: no fun, all dampness, and this is greatly owing to Stanley himself, for no matter how hard you work, or how well you do a thing, you get no thanks, no encouragement, no cheery words, nothing but blame and hard words, from him. I know, to give the devil his due, that his anxiety and worry of mind, besides the immense amount of things he has to think about, are immense, but he ought not to be so single-minded and visit it upon us poor devils. One cannot help admiring the man for his tremendous strength of will, and power of overcoming all difficulties, also for his great pluck, but he is a man one could never make a friend of. My time here has been the happiest I have had since leaving Banana, for the Major and I pull well together, and I am gradually getting over the feeling I had of bitter disappointment at being left here. The natives have only killed one man (one of the Soudanese), whom they stabbed with a spear in the stomach. We have had eight deaths from sickness, however, and a good many more are little better than dead. It is not easy, with not a single thing to cheer one, to pick up when you are low, after a dose of fever, but, thank Heaven, I do not have one often. I had one bad dose whilst shooting hippos, for I had to spend the whole day in a broiling sun, partly on the water and partly on sand-banks, all the time without a bit of shade, and sleep in a swamp at night. This fever kept coming back to me for some time, but at present $I$ am in splendid health, and when marching $I$ am always well. I think Barttelot and I were the only two who were not sick for a single day on the whole march from Matadi to Stanley Pool. There is a comic side to everything however, and I have often laughed heartily since at what annoyed me most at the time. . .." 


\section{APPENDIX IV.}

Entrenched Camp,

Yambuya, Aruwimi River,

Aug. 15th, 1837.

Dear Mr. Bates,

I am sorry to tell you that all my dreams of col. lecting have proved only dreams after all, for my duties have been such that they entirely stopped all my chances of collecting. I have, however, picked up a few butterflies*, which I hope will interest Lepidopterists, and which I will ask you to be kind enough to keep for me until my return, when we will have a long chat about them, and when I will bring you the notes in my Diary about them. Please be careful to keep the numbers aud letters on each paper attached to the butterflies, as they correspond to the numbers in my Diary. L. C. stands for Lower Congo, U. C. for Upper Congo, and A. for Aruwimi R. In my Diary of course I have the localities much more clearly specified. I am awfully disappointed with the beetles, having heard so much about the wonderful quantity and quality in the regions of the Congo. I unfortunately found on putting spirits into the zinc bottles which I bought in London that they leaked and were of no use. Luckily I had a large silver flask with me which holds a quart; this I filled with spirits which a Dutch gentleman at Kinshassa was kind enough to give me, and have been popping a beetle into it every now and again ever since. When I get home, I will hand over to you all its treasures. I have really had no chance whatever of collecting, as I will show you by my Diary when I get back. I certainly did expect a little sport, but that also has proved a myth. Mr. Stanley would not allow me a single extra carrier to take my collecting things, and the consequence was I had to give away all my pipes, tobacco, and lots of clothes, and take the smallest possible quantity of anything in order to carry the few things I did. It was rather hard lines on me, as the other officers of course had to carry nothing of the kind. Some of the butterflies are very beautiful, but I was rather disappointed with the scarcity of new

* This collection was entrusted to Messrs. F. D. Godman and O. Salvin for determination. 
species here differing from those on the Congo. You must tell me a lot about both the beetles and butterflies when we meet, which will certainly not be before June or July at the earliest. The few specimens of birds I got, I have sent to Mr. Bowdler Sharpe, of the Natural History Museum, South Kensington. You may imagine that if it was difficult to collect butterflies and beetles, how much more so it was to collect birds. How often, when toiling along and driving the Zanzibaris with their loads, like slaves, I have seen gorgeous specimens of all sorts of insect and bird life, and not been able to stir one foot out of the way to gather them. Please tell Mr. Sclater when you see him that I have not seen a single antelope of any kind, and no game except hippopotami. As far as I can see, there will be no better chance between this and Zanzibar. It will be one long time of driving niggers and their loads, and the only thing one does collect at that game is a bad temper. By the time you get this I suppose you will have seen all Mr. Stanley's report of our progress so far, but I hope to have many pleasant talks with you about it all. I am sending the butterflies home with Mr. Walker, the engineer of the Expedition, who is going straight home, as, thank goodness, we have now done with the steamers. I must now say good-bye, as the steamer leaves to-morrow, and I have a large number of letters still unwritten. Trusting to find you none the worse for the horrible winter I hear you have had,

I remain, sincerely yours,

(Signed) JAMES S. JAMESON.

\section{APPENDIX V.}

Letter of Instructions from Major BARTtELOT.

Camp, Yambuya Village, Aruwimi Falls,

To Mr. Jameson,

Aug. 19th, 1887.

Sir,

Owing to information received, I have determined to 
send you with a party of these Arabs of Tippu-Tib's, who have their camp above us, to the Stanley Falls, Congo, where Tippu-Tib now is.

The object for which I am sending you is this: that having ascertained that through an error the men did not come here, you will inform Tippu-Tib that we are still here, and that if Tippu-Tib is still willing, and will allow the men to come without delay, the agreement of Zanzibar will still hold good.

You, and you alone, will hold speech with Tippu-Tib; Mr. Ward, who accompanies you, being solely as a witness.

You will take Bartholomew as an interpreter, and will use him and no other, more especially Salem. Should Tippu-Tib allow the men to go, you and Mr. Ward will wait at the Falls till such time as the men start, when you will start with them. After one day's march out, you will send Mr. Ward on ahead with orders to proceed to this Camp with all dispatch; you yourself accompanying the men to this Camp.

By Mr. Ward you will send me a letter of what you have done.

It may be that you come across the Arabs intended for us on your way to the Falls, in which event you will ask them whether they are willing to come back at once, but do not try to coerce them. Should they be willing to come back at once, there will be no necessity for your going to the Falls; and you and Mr. Ward will accompany them back, and, as in the former case, after one day's march, you will send Mr. Ward on, with all dispatch, with a letter. Should they not be willing to come, or say they will come shortly, you will go on to the Falls and acquaint Tippu-Tib of their whereabouts, as it may aid him to collect them. Remember $600 \mathrm{men}$, able to carry loads, is the number. In either the former or the second case, you will inform Tippu-Tib, or the men, that the powder and the caps are here; the Arabs who are with you having had ocular demonstration of it.

Should your mission be unsuccessful, you will, after resting yourselves and Arabs, come back here without delay.

Remember that expedition is all to us, and use all your 
endeavours, should you obtain the men, to proceed with all speed to this Camp. Do not force then, but persuade.

I have the honour to be, Sir,

Your most obedient servant,

EDMUND M. BARTTELOT, Major,

Commanding Camp, Yambuya Village, Aruwimi Falls.

\section{APPENDIX VI.}

Camp, Yambuya Village,

Aruwimi Falls,

Aug. 19th, 1887.

\section{To Sheik Hamed bin MAHommed, my Friend,}

I, Major Barttelot, sending greeting, knowing that you are willing to aid Mr. Stanley in his expedition, and that it was through error that the 600 men you had already sent did not come here to me, but turned back, thinking we had gone away, I venture to solicit your aid by asking you to send me the 600 men back again.

The powder and caps are here, and we are all ready to start.

I have sent Mr. Jameson in my place, as I could not come myself; indeed, I am far from well, having had but little to eat, and suffering from fever.

It was through your Arabs that we heard of the mistake, and it is they who have undertaken to escort Mr. Jameson and Mr. Ward to you, for which they shall be amply repaid.

Trusting you are in good health, also Sheik Selim Mahommed, to whom I send greeting, and that you will do me the honour to accept the small present I am sending you by Mr. Jameson,

I am your faithful friend, (Signed) EDMUND M. BARTTELOT, Major. 


\section{APPENDIX VII.}

\section{Agreements between Muni Somal and \\ $\{$ Major BaRtTelot, \\ $\{$ Mr. JAMESON.}

I.

Stanley Falls,

May 24th, 1888.

I, the undersigned, Muni Somai, hereby agree for the sum of $£ 1,000$ (one thousand pounds sterling), 600 dollars or £120 (one hundred and twenty pounds sterling) to be paid to me in goods of that value before our departure from Yambuya Camp, to faithfully serve Major Barttelot in my capacity of the commander of the 400 men supplied to the Emin Pasha Relief Expedition by Sheik Hamed bin Mahommed, and to accompany him with these men as far as Wadelai, or whatever place short of that it may be necessary for Major Barttelot to go to in his quest of Emin Pasha and Mr. Stanley, and to return from thence with the aforesaid men with him (Major Barttelot), or whatever white officer he may appoint, by the nearest route to the territory of Sheik Hamed bin Mahommed after he, Major Barttelot, considers his relief of Emin Pasha or Mr. Stanley, or both, to have been accomplished; and I also agree, in case of Major Barttelot being rendered incapable of continuing his command, to fulfil all the above conditions, under whatever white officer he, Major Barttelot, may appoint.

\section{Witnessed,} signed $\left\{\begin{array}{l}\text { HAMED BIN MAHOMMED. } \\ \text { MUNI SOMAI. }\end{array}\right.$

$\{$ Edmund Barttelot.

$\{$ JaMES S. JAMESON.

\section{II.}

Stanley Falls.

May 24th, 1888.

WE, the undersigned, Major Barttelot, Commander Rear-guard of the Emin Pasha Relief Expedition, and Mr. James S. Jameson, officer of the same, hereby agree to pay to Muni Somai the sum of $£ 1,000$ (600 dollars of which sum to be paid 
to him in goods of that value before our departure from Yam. buya Camp) under the following conditions :-

That he, Muni Somai, faithfully serves and obeys Major Barttelot, in his (Muni Somai's) capacity of leader of the 400 men supplied by Sheik Hamed bin Mahommed to the Emin Pasha Relief Expedition, and to accompany him with these men to Wadelai, or whatever place short of that he, Major Barttelot, may have to go to in his quest of Emin Pasha or Mr. Stanley, and that he, Muni Somai, returns with these men under Major Barttelot, or whatever white officer he may appoint, by the shortest route to the Territory of Sheik Hamed bin Mahommed, at whatever time he, Major Barttelot, may consider his relief of Emin Pasha or Mr. Stanley, or of both, to have been accomplished, and that he, Muni Somai, also agrees, in case of Major Barttelot being rendered incapable of continuing his Command, to fulfil all the above conditions, under whatever white officer he, Major Barttelot, may appoint.

The said Muni Somai having fulfilled all the above conditions, we, the undersigned, Major Barttelot and Mr. J. S. Jameson, agree to pay him the remaining sum, £880, as soon as possible after our return to Zanzibar or Banana Point.

\section{Signed $\left\{\begin{array}{l}\text { EDMUND M. BARTTELOT. } \\ \text { J. S. JAMESON. }\end{array}\right.$}

Witnesses:

$\left\{\begin{array}{l}\text { Tippu-Tiв. } \\ \text { Muni Somai. }\end{array}\right.$

\section{APPENDIX VIII.}

Dear Jameson,

June 25, 1888,

Village Wobari.

You will not be surprised to hear I am off to Tippu-Tib. Four more men, three loads and rifles, and my boy Sadi with my revolver and knife, have deserted. The latter I caught here; he says he was with the others, but they ran away from him. One of them is that man Jalu, who was with Munichandi. We cannot go on losing rifles like this; we shall soon be destitute. The loarls that went last were a box of provisions (not ours), the last of the assorted cloth, and the pot of 
gee (?). That more men intend to desert I know, so I have deprived them of their rifles. I want you to get Muni Somai to let you have sixty men, good men, to go back with you to where Bonny is, which cannot be far from Nasoro bin Saef's, to help bring up the loads and rifles and to act as guards to the Zanzibaris, then go on together to Abdulla's and wait me. I am going to the Falls to ask Tippu either for sixty Manyémas or for slaves; if the former I will arm them with the Zanzibaris' rifles, so please make Muni Somai understand that he is not to keep the rifles you get from Bonny. You had better get a guide to go with you to take you from where Bonny is to Nasoro's. I am sending Muni Hamesi to show you B.'s camp. I passed two of your camps to-day, leaving Bonny yesterday. In the first the fires were alight. You appear to have gone the same road I did; if so, it ends in a block, where you will find one of our camps. By going up that stream to the N.W. I hit off a road crossing it to the N.E., and that is the road I have pursued. There are many villages, plenty of food, and good road to the N. and N.E., and well blazed. I am sure it is the right one.

Sala, so everyone says, knows where our men are. I have sent a Soudanese on to search his village to-night. Make it clear to Muni Somai the sixty men he sends will have to help carry loads, as we shall at least be ten men short, if not more. Do not give more than two rounds apiece to the men who get the rifles. Make the remainder up into loads, -400 rounds $=$ 1 load,- - and give it to Zanzibaris and put them under Soudanese escort. If you had been with us, I should have sent you, but it is imperative some one should go, and Bonny, owing to his slowness \&c., is not available. It is useless for me to tell you about speed, for you always do your utmost, but we must have men to help carry the loads. In case you should have gone on to Abdulla's, I am leaving another letter for you at Nasoro's.

Hoping you are well,

Yours very sincerely,

EDMUND M. BARTTELOT.

Impress on Muni Somai the necessity of his aid. I go straight to Abdulla's from the Falls, and shall be there about July 14th. 
Agrement hetween, Sheith Hamed hin thohamed his Ohuma, on the

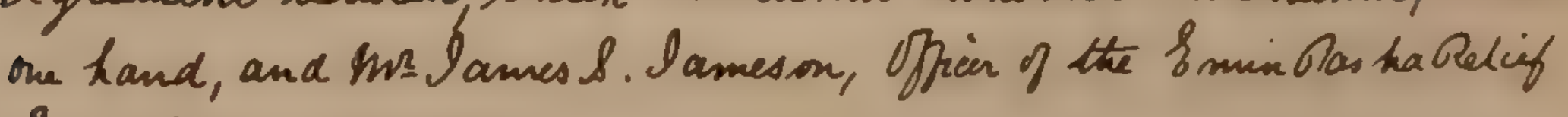
Ixpestitus, on the other.

Pagel

$\sum_{\text {having refused to acupt any less suonir }}$ I the un dersigned, Sheit Hamed bin hok anned bin D huma kerechy

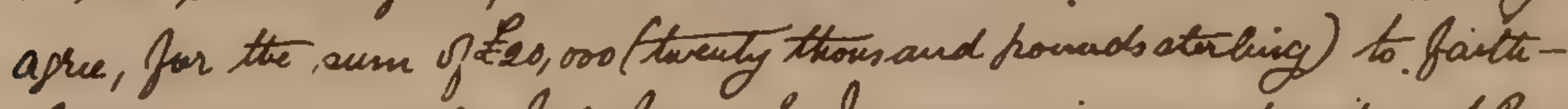

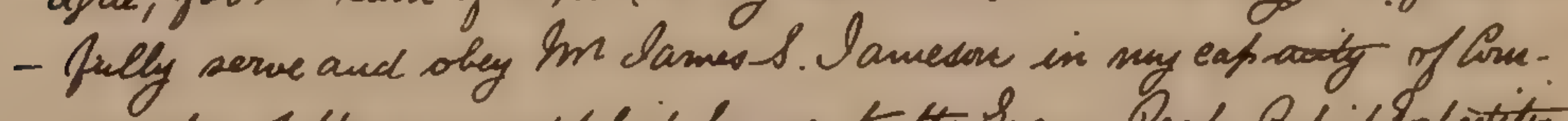

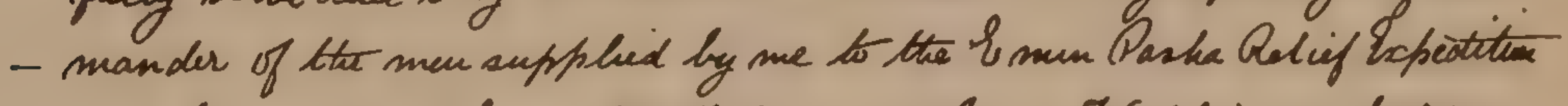
and to accompany him with these men as far as Wadelai or whatever

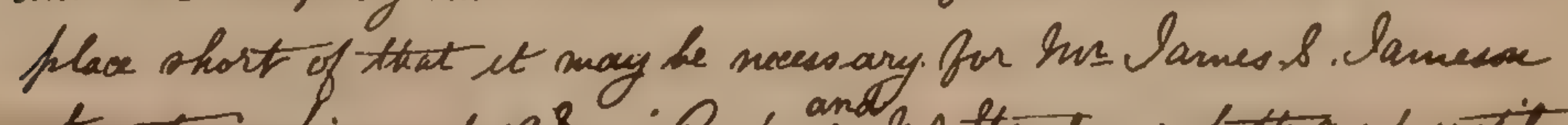

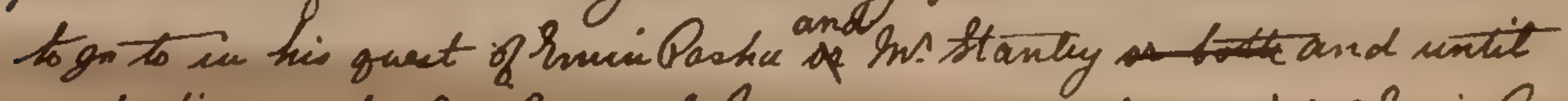

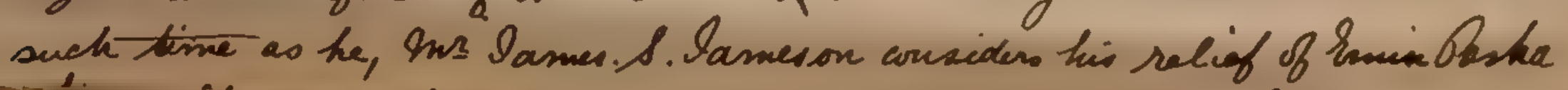

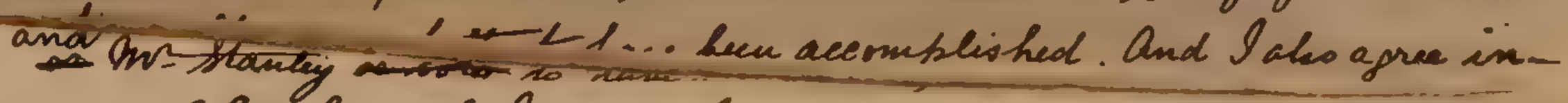
case of Ins Y ames S. lanceson being rendered incaps able of contenising

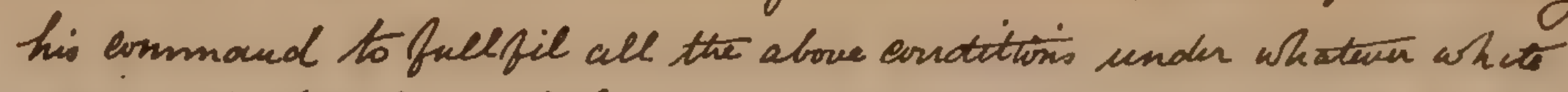
offien he, Ins lames b. Sameun moy appoint, and in cose of hrs Iames' 8. lameson and Ins. W. Bonny botte haing rendered meap-able of con-

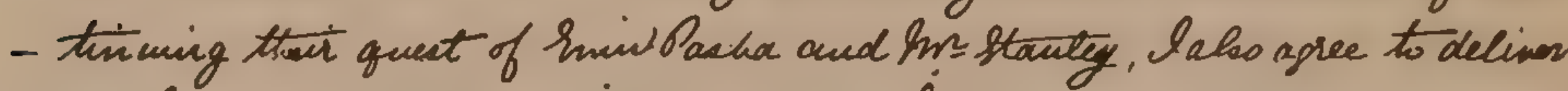
all bads cavried hy the Zangibaris of the Imin Pasha Relif hrpeditus and also all boreb carried by the man supphed by me to the aforesaid be- heditiox, to Mmin Pasha at Wadelace or to Signor Casate Ribero in

- Unyoro and to enderover to the hest of my ability to find his stanty and to hand oner either to Imin Dasha or Irs stancly all riftes and annu- unition lent by InI lames. S Sameson to me or to the men

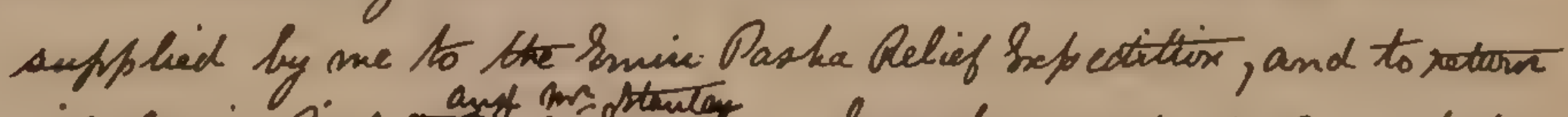

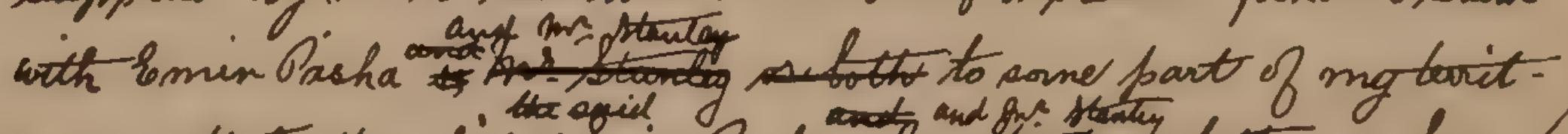

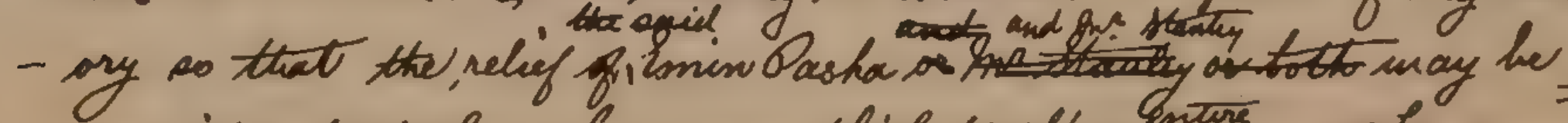

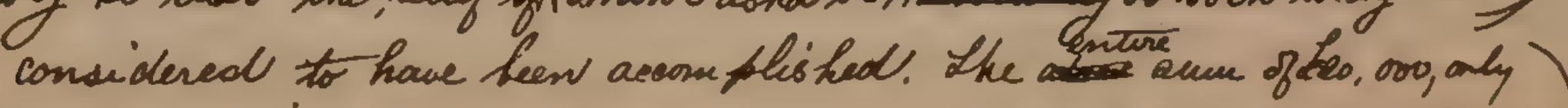

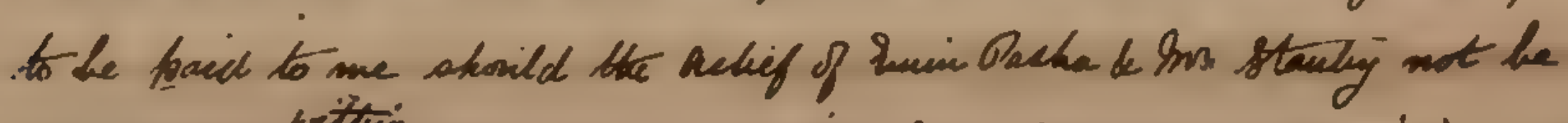

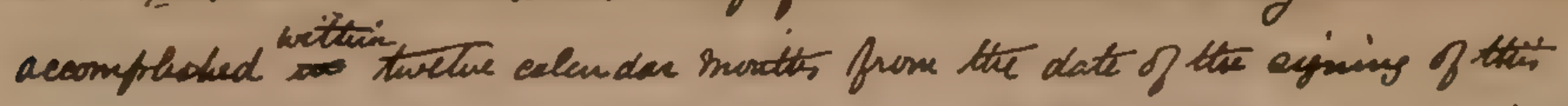

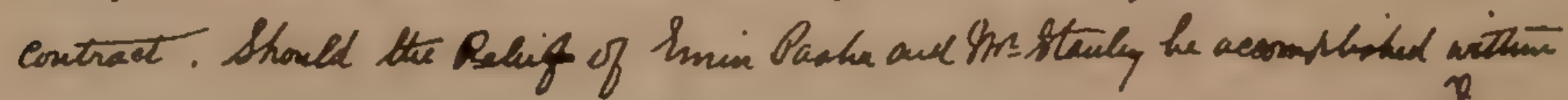

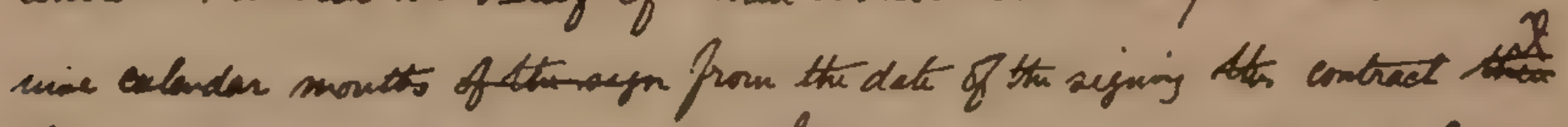

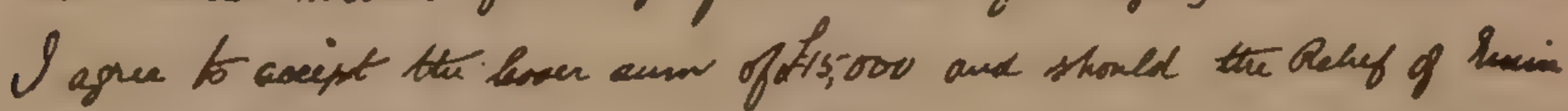

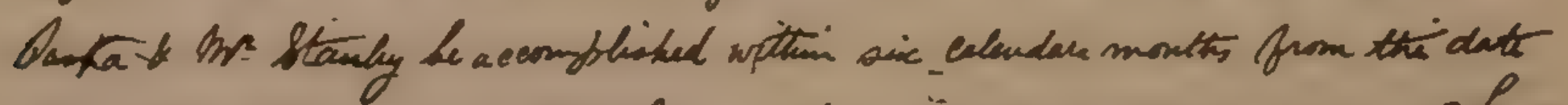

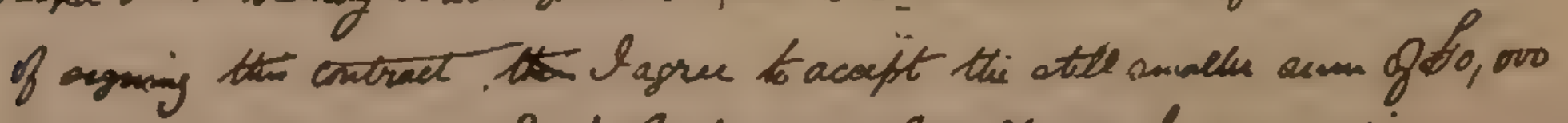

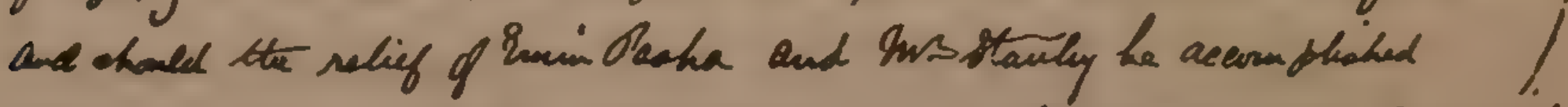

sopetert

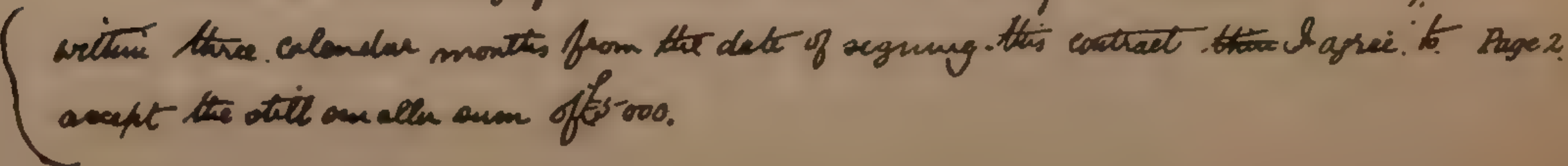





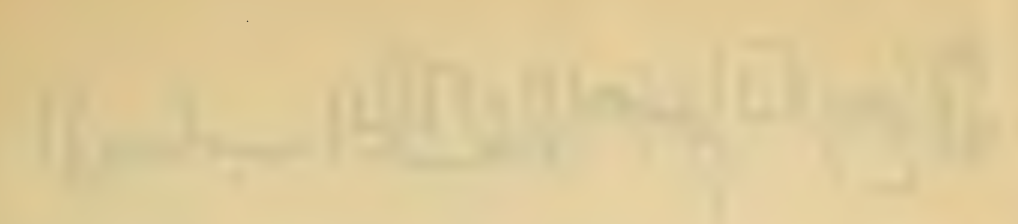

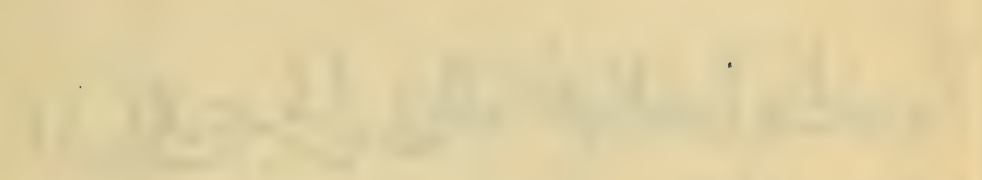

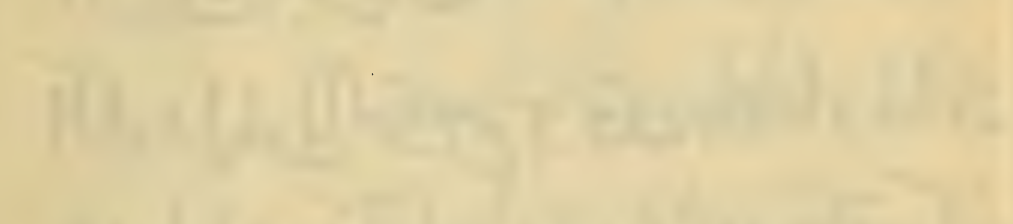

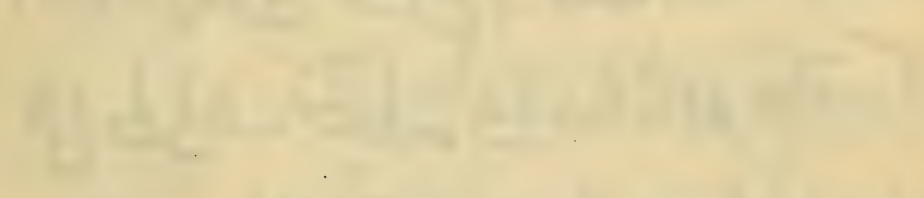

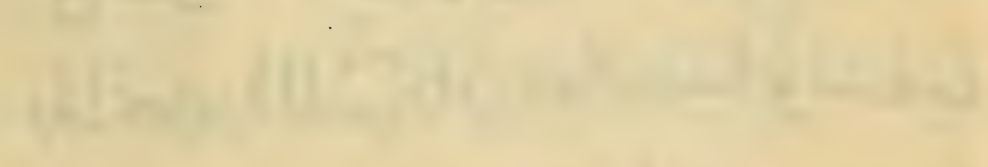

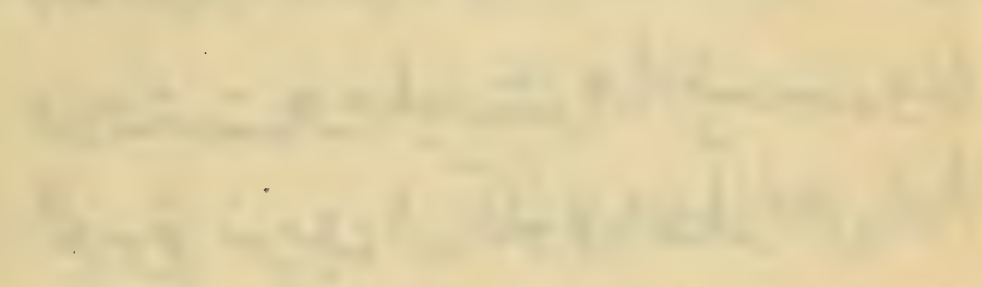

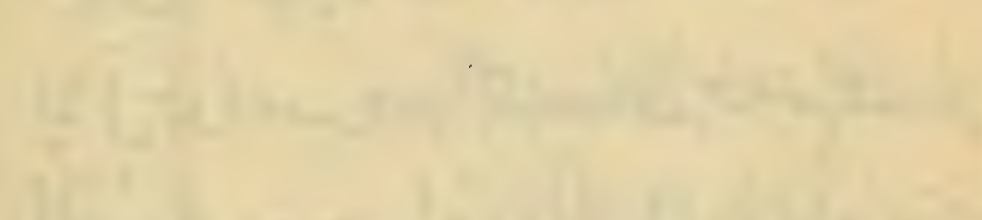

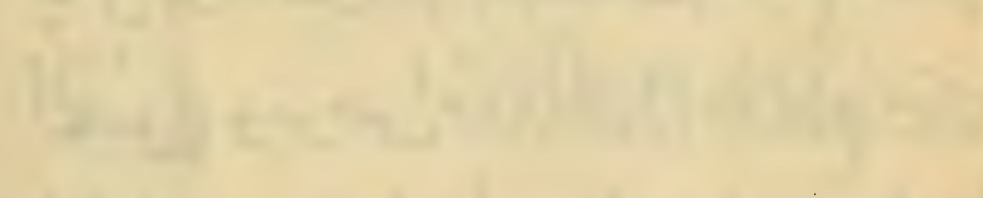

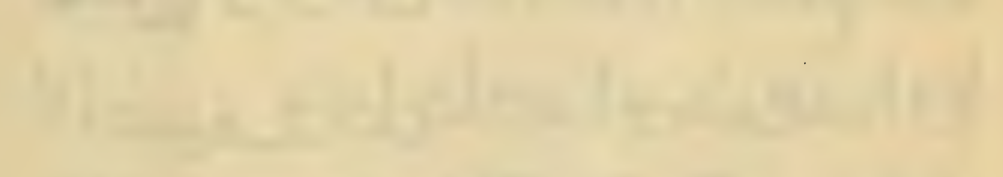

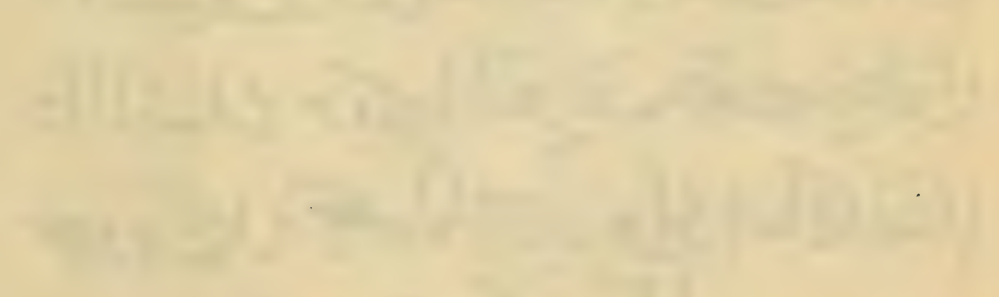

$y=3 x$ 


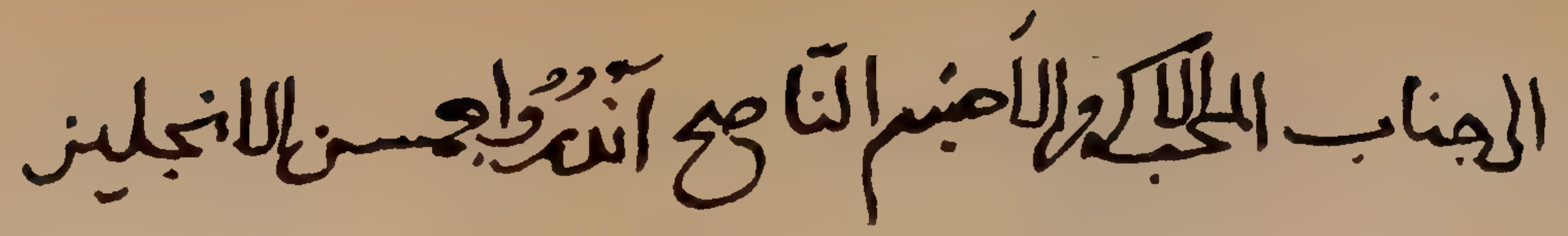

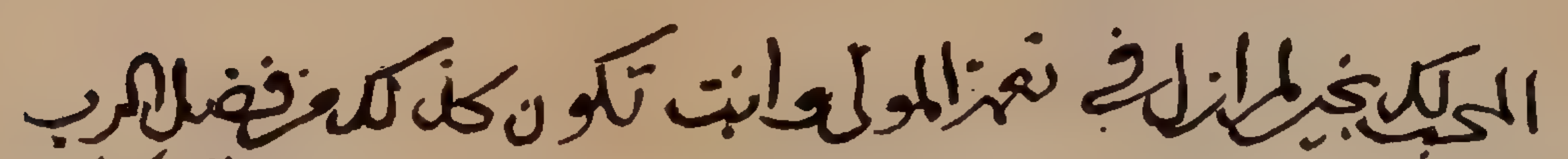

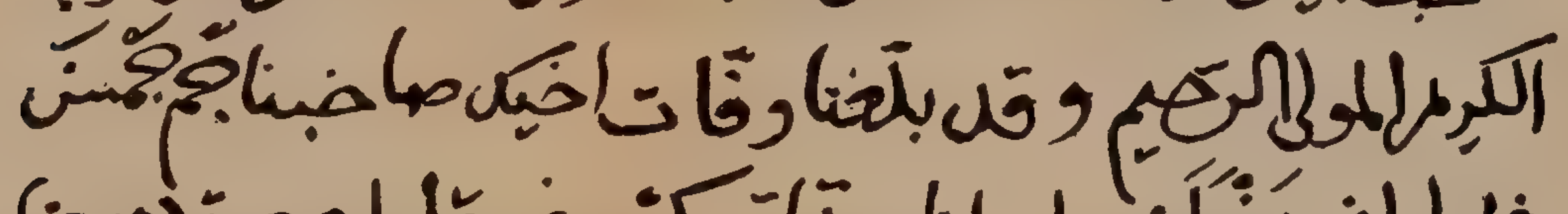

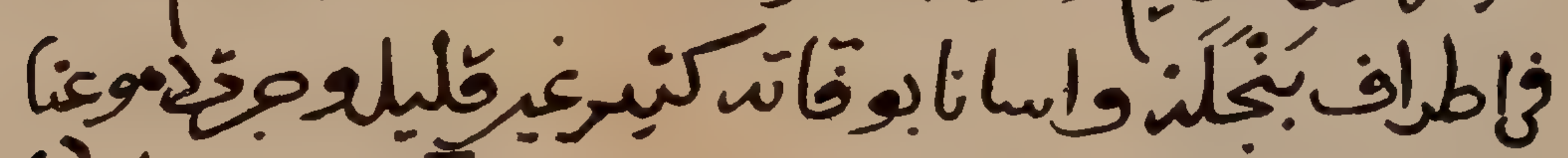

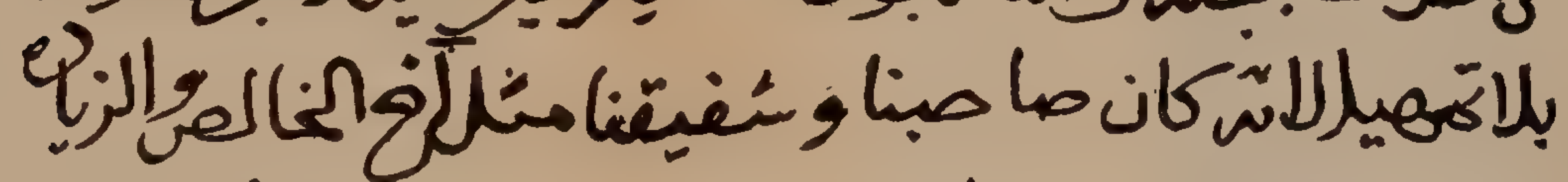

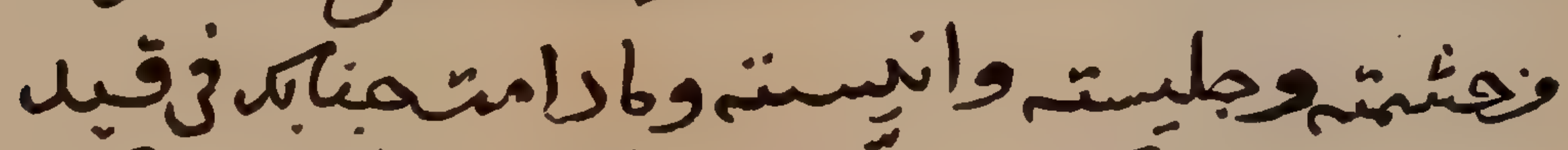

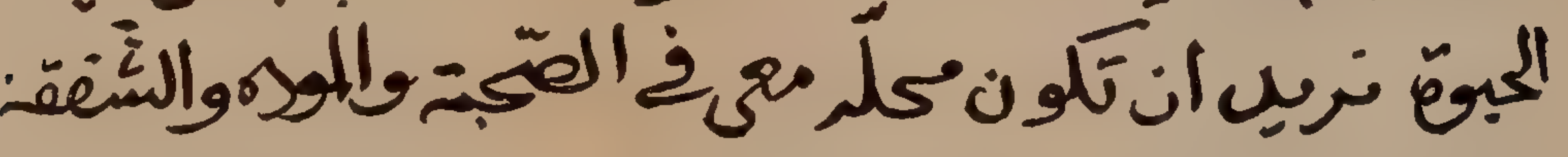

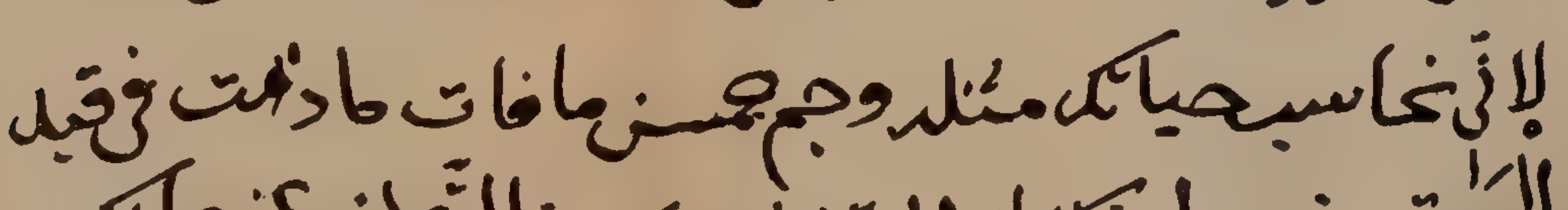

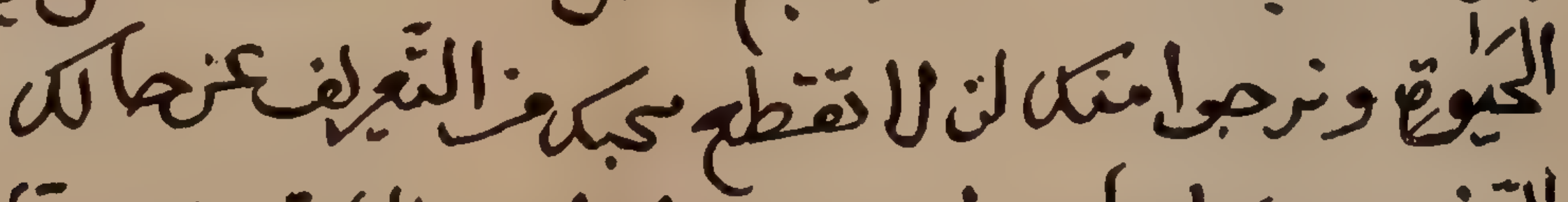

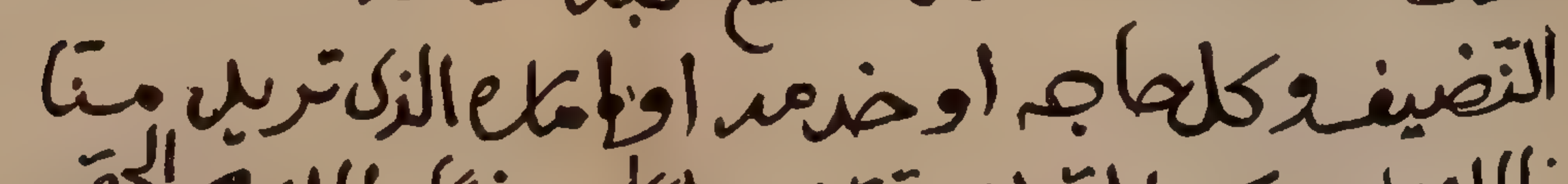

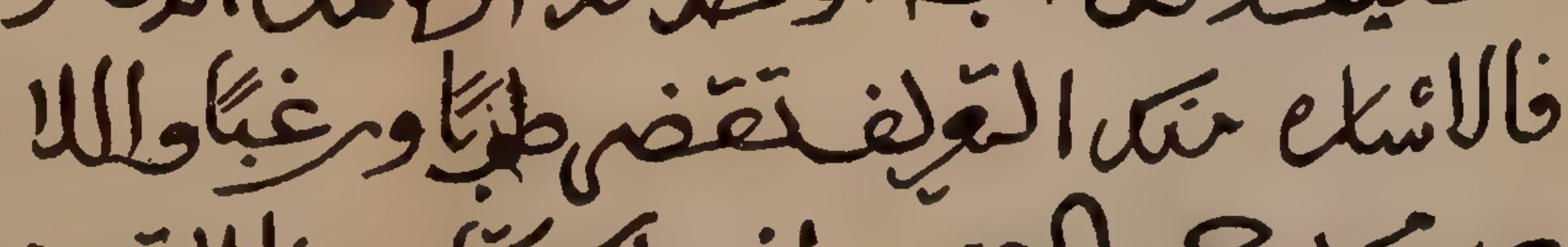

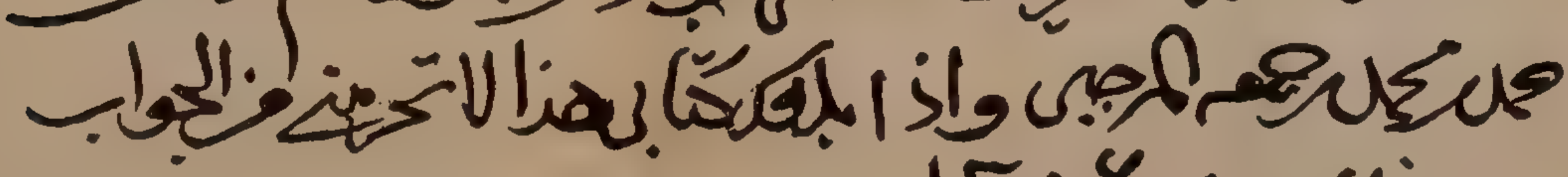

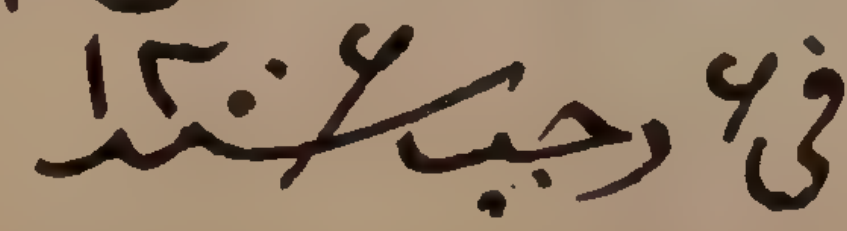




\section{APPENDIX $\mathbf{X}$.}

Final Agreement drafted by Mr. J. S. Jameson.

I, the undersigned Sheik Hamed bin Mahommed bin Dhuma, agree, for the sum of $\$ 20,000$ (twenty thousand pounds sterling) to faithfully serve and obey Mr. James S. Jameson in my capacity of Commander of the four hundred men supplied by me to the Emin Pasha Relief Expedition, and to accompany him with those men as far as Wadelai or to whatever place short of that it may be necessary for Mr. James S. Jameson to go to in his quest of Emin Pasha and Mr. Stanley, and until such time as he, Mr. James S. Jameson considers his relief of Emin Pasha or Mr. Stanley, or both, to have been accomplished. And I also agree, in case of $\mathrm{Mr}$. James S. Jameson being rendered incapable of continuing his command, to fulfil all the above conditions under whatever white officer he, Mr. James S. Jameson, may appoint.

(Signed)

\section{APPENDIX XI.}

\section{Tippu-Tib's Letter.}

\section{To the excellent, beloved, honoured Friend the}

Englishman, ANDREW J JMESON,

He who loves you in all that is beneficial for man is, as I trust you also are, in the favour of God. May the same be with thee, through the goodness of the Lord, the Liberal, the Master of all things, the Merciful. We have heard of the sad decease of thy brother, our friend Jameson, in the environs of Bangala. I, the survivor of his so recent death, could scarcely refrain from tears of weakness, for he was my companion and loving friend, pure, courteous, wise, and sat with me and gave me rest in difficulties; and I wish that his place with me in friendship, and love and tender affection could be filled by you. Jameson, however, has not perished so long is you remain in life.

Do not, therefore, deprive him who loves you of the news of your honourable state, of every want of yours, of any service or order; only let me know, and it shall be executed with obedience and good will.

TIPPU-TIB.

6 of Redjeb, 1888. 


\section{NATURAL-HISTORY APPENDIX.}

\section{THE ORNITHOLOGICAL WORK}

or

J. S. J A M E S O N.

BY

R. BOWDLER SHARPE, F.L.S. ETC.,

ZOOLOGICAL DEPARTMENT, BRITISI MUSEUM.

IT must have been in the year 1877 that I first made the acquaintance of my friend the late J.S. Jameson. I remember his coming in to my room at the British Museum and introducing himself to me; and a bright, good-looking young fellow he was. The conversation that ensued was somewhat as follows, as far as I can recollect :-

"I am going to India, to travel and collect specimens of Natural History, and I want to know something about the birds, and if I can do anything for you."

"What part of India are you gning to?"

"Well, I thought of going to Kashmir, where there is some big game in the shape of Deer and wild Sheep to be got, I fancy."

"That seems a useless sort of thing to do. Why, having the time and the means, do you not go somewhere where you could make some really useful discoveries for science? Kashmir is well known, comparatively speaking." 
"That is what I should like to do, but I don't know how to set about it."

"Will you take my advice?"

"Yes."

"Whereabouts in India are you bound for?"

"Calcutta."

"Good! Now when you get to Calcutta, instead of turning north, go south to Singapore, get across to Labuan, where my friend Ussher is Governor. You will find native hunters who will skin your birds for you, and he will tell you how to get up the Lawas River or explore Kina Balu*, both comparatively unknown localities."

I gave Jameson a letter of introduction to Governor Ussher, aud, with many expressions of thanks, he departed.

I heard occasionally about him in Borneo, but in the correspondence with my friend Ussher, which I have preserved, I do not now find any mention of Jameson, and I rather fancy that the Governor was away from Labuan when he arrived there, and that he was the guest of Mr. Treacher. Anyhow, thanks to the hospitality of one of these gentlemen, Jameson was able to ascend the Lawas River in North-western Borneo, and he made a large collection of birds, which have been mounted for him by Mr. Rowland Ward.

It is a great pity that no record of this collection was ever published, for Jameson met with some interesting species, and he was the first to discover the Black Pern, a kind of Honey-Buzzard, in Borneo, a fact of singular importance at the time. The genus Macharhamphus contains two species of Black Pern-one Oriental (M. alcinus) and one African (M. anderssoni). The latter was discovered by the late $\mathrm{Mr}$. C. J. Andersson in Damara-Land, and was named in his honour hy Mr. J. H. Gurney. It has since been found in Somali-Land and in Madagascar. Previously to Mr. Andersson's discovery, the genus Macharhamphus was known only from the

* Within the last few years another young friend of mine, Mr. John Whitehead, acting under my advice, ascended Kina Balu after great difficulties, and obtained about fifty new species of birds, some of them of the most beautiful plumage and form. 
Malayan Peninsula, though it has since been found in Tenasserim and in New Guinea! Within the last few years it has been met with in several parts of Borneo, but the first discoverer of the species in that island was Jameson.

The expedition to Mashona-Land, which was his next exploit, was a very important one, and added a great deal to our knowledge of the birds of South-eastern Africa. On this occasion Jameson took with him Mr. Thomas Ayres, of Potchefstroom, one of the best field-naturalists of the day, and the collection was described by Captain Shelley in the 'Ibis' for 1882. During this expedition 219 species of birds were observed, and the notes on habits written by Mr. Ayres were of the highest interest.

Several species of birds were found for the first time in South Africa, and our knowledge of the geographical distribution of many forms was much extended. For instance, Salvadori's Creeper (Hylypsornis salvadorii) was discovered on the Gangani River; it was previously only known from Benguela. Sir John Kirk's Sun-bird (Cinnyris kirki) was found on the Umvuli River, never having been known from the south of the Zambesi before. Andersson's Penduline Tit (Anthoscopus caroli), supposed to be peculiar to Ovampo-Land, was met with on the Gangani River. Jameson's Flycatcher (Hyliota australis) was a new species discovered on the Umvuli River; and on the 23rd of October they found our Common Martin (Chelidon urbica) on the Quae-Quae River; its occurrence in winter so far south was previously unsuspected.

Jardine's Cuckoo-Shrike (Graucalus pectoralis), hitherto believed to be peculiar to West Africa, was found on the Umvuli; and the series of Weaver-birds (Ploceidce) was most important, two being new to science-Ayres's Weaver (Sharpia ayresi, Shelley) and Jameson's Weaver (Hyphantornis jamesoni, Sharpe).

Mr. Ayres gives the following account of the finding of the first of these species :-

"This is by no means a common bird. We found it breeding at the Tatin. It makes a rough retort-shaped nest, which it hangs, mouth downwards, from the outer twigs of rather tall 
trees. Sometimes a new nest is hung on the tube of the last year's structure.

"Mr. Jameson found a nest to the north of the Umvuli in October, with two blue eggs in it; and at the Tatin we pulled down one of the double nests, and Mr. Jameson, on trying to put his hand up the tube, very nearly got bitten by a snake which was lying in the nest, and had swallowed the old bird as well as her blue eggs. It is evident, therefore, that nests of this shape do not always keep out snakes."

A new Weaver-Finch, named by Captain Shelley Lagonosticta jamesoni, was discovered on the Umvuli, and again seen on the Tatin River. It has been figured by me in the 'Catalogue of Birds' (vol. xiii. pl. xi. fig. 1).

It only remains to add that Jameson's Mashona collection (which contained also a large series of Butterflies and Beetles, some of which have been named after him) resulted in a very marked improvement in our knowledge of South-African birds; and as, with his usual liberality, he presented the most interesting of his specimens to Captain Shelley, they will pass, with the rest of the Shelley Collection, to the British Museum and become national property.

It pleases me greatly to know that in his country's Museum will thus be found the evidences of Jameson's zeal for Science, while his memory will be treasured by the writer and other students of African Zoology, who are able to appreciate the good work he did on his Mashona Expedition.

\section{NOTES ON THE BIRDS OF THE CONGO REGION.}

So at last came the time of the Stanley Expedition, and Jameson came to me and told me he was intending to join it. He was full of delight at the prospect, especially at the thought of meeting Emin Pasha, while I was equally pleased to think of the gain to Science which would result from the work of these two naturalists, if they could study together in Equatorial Africa. 
I gave him a letter for Emin Pasha*, and he promised to come and see me again before he sailed, though he was naturally much occupied with his preparations for departure. This was unfortunately my last interview with Jameson. The next day he sent me his photograph, as I had begged him to do, and shortly after I got a letter from him.

\section{"Mr dear Sharpe,}

$$
\begin{gathered}
\text { “S.S. 'Assam,' Brindisi, } \\
\text { Monday. }
\end{gathered}
$$

"I was very sorry not to have time to call upon you again before leaving. I found out, however, almost at the last moment, that there was no possibility of my going through with the mails on Friday evening, as they had been full up for some time before, and they would not give me a seat or anything. Thanks so much for your kind letter bidding me goodbye and for the letters of introduction also, and I hope to have many a long chat with you about our trip on our return, and will attend to your instructions.

\section{"Yours sincerely, "JAMES S. JAMESON."}

I only heard from my poor friend once more. In a letter from Yambuya (which at the moment of writing I cannot find, to my great regret) he announced the despatch of a collection of birds, and expressing his disappointment at the locality as a collecting-ground, and his regret that he had not got more specimens together. The collection, however, though small, proved of considerable value; and it was described by Captain Shelley, to whom I handed it over, as he had already"worked out the results of the Mashona collection. I cannot do better than quote from Captain Shelley's preface to show that, singularly poor as Mr. Stanley's Expedition has been in scientific results, the efforts of Jameson and some of the officers of the Rear Guard were not altogether unproductive. The collections of Butterflies made by Mr. Bonny at Banalya and by $\mathrm{Mr}$. Herbert Ward at Bangala have been described by Mr. H.

* What became of this letter I do not know. Emin apparently never got it; at least he does not mention it in his recent letters tó me. 
Grose-Smith and by my daughter, Miss Emily Mary Sharpe, and both were found to contain several novelties.

Captain Shelley, who also knew Jameson well, thus writes concerning his Yambuya collection in the 'Ibis' for 1890, p. $156 *$ :-

"In 1882 I had the pleasure of describing Mr. Jameson's ornithological collections from Matabele-Land. It is with the greatest regret that I now have to give a final list of the birds obtained by this ardent young naturalist during his residence at Yambuya, on the Upper Congo, where he was stationed with the rear guard of the Stanley Expedition for the relief of Emin Pasha. His untimely death has been a loss to science, which naturalists will regret equally with the loss of those scientific pioneers of ornithology in Eastern Africa, Drs. G. A. Fischer and R. Böhm, both cut off in their prime, when there was every reason to expect that their work had only just commenced. Mr. Stanley is more celebrated as an explorer than as a naturalist, and the unfortunate death of Mr. Jameson, who would have contributed much to the scientific interest of the expedition, is therefore the more to be deplored:

"Small though the present collection be, it will be found to be of great interest to students of Ethiopian ornithology, and it is in some respects extremely important as regards the geographical distribution of species, as it serves to show how small is our knowledge of the range of African birds, and how little we are acquainted with the physical configuration of the interior of Africa, which might give us some explanation of the distribution of species. The majority of the birds collected on the Aruwhimi are identical with species from the Lower Congo, and as these are mostly the same as the forms of Gaboon, the affinities of the avifauna of these two districts receive ample confirmation. Thus, when a species inhabiting the Gold Coast or the Niger Region is represented by an allied species in Gaboon or in the Congo district, the Aruwhimi bird will be found to belong to the Congo species and not to that of the Gold Coast. But this is not invariably so; for the Pholidornis

* "On a Collection of Birds made by the late Mr. J. S. Jameson on the Aruwhimi River, Upper Congo." By Capt. G. E. Shelley, F.Z.S. 
discovered by Mr. Jameson is allied to the species of the Gold Coast, as are also Pytelia schlegeli and Diaphorophyia blissetti*, which are purely Guinean species. Many birds recorded by Mr. Bowdler Sharpe as found in the Niam-Niam country, from Mr. Bohndorff's collection in 1884 ( $c f$. Journ. Linn. Soc., Zool. xvii. p. 419), are now shown to have an intermediate habitat, and a zoological connection is thus established with the Monbuttu country explored by Emin Pasha. Mr. Jameson's collection, therefore, limited though it be by reason of the distractions and responsibility of his position at Yambuya, is of great importance for our knowledge of the geographical distribution of African birds, and had he lived there is no doubt that he would have added greatly to the renown of the Stanley Expedition, to which he contributed a considerable sum of money, and for which he ultimately sacrificed his life."

The following extracts from Mr. Jameson's diaries have been supplied to me by Mrs. Jameson; and as nearly all the birds were carefully labelled by her husband, I have been able to identify the species referred to in nearly every case. I have quoted Captain Shelley's paper on the Collection in the 'Ibis' for 1890, and have made one or two additional identifications.

\section{BIRDS COLLECTED ON LOWER CONGO, BETWEEN MATADI AND STANLEY POOL.}

\section{Wydah Finch.}

Head, breast, tail, and wings black. Shoulders and back bright yellow. Common on the whole of Lower Congo. [Penthetriopsis macrura (Gm.); Shelley, t. c. p. 166.]

2. Swallow.

Wings, tail, and back blue-black. Rump reddish brown.

* I have re-examined the Diaphorophyia, and, having come to the conclusion that it is distinct from $D$. blissetti, I have called it $D$.jamesoni.R. B. S. 
Top of head ditto. Breast white, with pointed spots of black. Vent white. Common on whole of Lower Congo. [Hirundo puella, T.; Shelley, t. c. p. 163.]

\section{WEAVER-BIRD.}

Cheeks, throat, wings, belly, and tail black. Head, neck, breast, and rump bright orange-scarlet. Back, shoulders, and vent pale reddish brown. Common on Lower Congo. [Pyromelana flammiceps (Sw.); Shelley, t. c. p. 166.]

\section{WARBLER.}

Head, wings, and back dark olive-green. Throat, breast, belly, and vent pale olive-green. Tail light olive-brown. Common on whole of Lower Congo. [Andropadus curvirostris, Cass.; Sharpe, Cat. B. Brit. Mus. vi. p. 111 (1881).]

5. BeE-eAter.

Throat, breast, and belly pale red. Vent grey. Head, back, and wings olive-greenish grey. Tail grey with a reddish tinge. White streak on each side of throat. Uncommon on Lower Congo. [Merops malimbicus, Shaw; Shelley, t. c. p. 166.]

6. Small paradise-tailed Finch.

Top of head, wings, back, and tail black. Neck, throat, breast, and vent white. Wing-coverts white, mottled with black. Beak light red. Congo Da Lamba. Common up here, but not observed nearer coast. [Vidua principalis (L.); Sharpe, Cat. B. Brit. Mus. xiii. p. 203.]

7. Couy.

Forehead black. Top of head crested and light grey. Back light brownish grey. Rump, tail, and upperside of wings olivebrown. Tail very long. Throat black; breast light brown, barred with black. Belly and vent dirty yellow. Inside of wings light brownish red. Feet bright red. Could not observe whether common or uncommon. [Colius nigricollis, V. ; Shelley, t. c. p. 168.] 


\section{BIRDS COLLEC'TED BETWEEN STANLEY POOL AND ARUWIMI RIVER.}

\section{SUn-BIRD.}

Head, throat, back, wing-coverts, and rump bright metallic green; breast, belly, and vent lemon-yellow. Tail metallic green and dark blue. Wings brown tinged with olive-green. Bolobo ; common on Upper Congo. [Anthothreptes hypodilus (Jard.) ; Shelley, t. c. p. 162.]

\section{Flucatcher.}

Head, back, wings, and tail of a sepia-colour. Throat grey. Breast and belly greyish brown. Vent grey, with brown bars. Scarce here at Bolobo, but common on Aruwimi. [Artomyias fuliginosa, Verr.; Shelley, t. c. p. 158.]

\section{0 and 11. Cock and Hen Woodpecker.}

Throat barred black and white. Breast and belly olivegreenish brown, barred with white. Vent greenish brown. Cheeks white barred with black. Back and wings olive-green. Tail black. Inside of wings dark brown, barred with white. Rump greenish yellow tipped with gold. Head of hen dark brown. Bright golden crest on cock bird. [Mesopicus xantholophus, Hargitt; Shelley, t. c. p. 168.]

\section{BIRDS COLLECTED AT ENTRENCHED CAMP, ARUWIMI RIVER.}

July 12 th.

12. KinghUNTER.

Throat white with tinge of grey. Breast and belly grey. Vent white. Head and neck dark grey. Wing-coverts and tip of wing-feathers black. Centre of wing bright blue. Rump and tail bright blue. Back darker blue tinged with grey. Feet black. Upper mandible of beak deep red; lower one black. Common. Female. [Halcyon cyanoleuca (V.); Shellev, t. c. p. 167.]

13. Ditto. 


\section{Black Weaver-bird.}

Jet-black all over. Feet bright brown. Eyes bright lemon; black pupil. Common. Cock. [Melanopteryx nigerrimus (V.); Sharpe, t. c. p. 476. Ploceus nigerrimus, Shelley, t. c. p. 164.]

\section{Ditto.}

\section{July 18th.}

\section{SHRIKE?}

Head crested. Head, wings, back, neck, throat, and tail black with dark green lustre. Belly and vent white; breast and sides white barred with black. Underside of wings black, with broad bar of white across centre. Feet pale lemon. Eyes bright lemon, black pupil. Cock. Scarce, the pair shot being the only ones seen. [Bias musicus (V.); Shelley, t. c. p. 159.]

\section{Shrike? Hen bird of no. 16.}

Top of head crested and dark brown. Cheeks and neck lighter brown. Throat white. Breast, belly, and vent white, with a light reddish-brown tint. Back, wings, rump, and tail bright light red-brown. Eyes bright lemon. Feet pale lemon.

\section{W ARBLER.}

Forehead, cheeks, and upper part of throat grey. Line of bright yellow over each eye. Lower part of throat, vent, and underside of wings bright yellow. Breast and sides grey with a green tint. Belly grey; neck, back, and wing-coverts olivegreen. Wings brown; two short rows of feathers in wing pointed with yellow; three of principal feathers next body pointed with yellow, rest of feathers in wing edged with yellow. Tail olive-green, feathers tipped with yellow. Eyes sepia. Feet lavender. Scarce. Cock. Only pair seen. [Nicator vireo, Cab.; Shelley, t. c. p. 161.]

\section{WARBLER.}

Head dark olive-brown. Throat grey tinged with brown. Breast and belly light olive-brown. Sides darker. Vent light brown. Neck light olive-brown. Back, wings, and tail olivebrown. Rump reddish brown. Eyes pale sepia. Feet lavender. [Turdinus fulvescens, Sharpe; Shelley, t. c. p. 161.] 
July 19 th.

20. Small Warbler.

Head, back, and tail olive-green. Wings slightly brighter green. Throat pale yellow. Breast pale olive-green tinged with yellow. Belly bright pale yellow. Vent pale yellow. Feet very light brown. Eyes dark brown. Common. Cock. [Camaroptera brevicaudata (Cretzschm.); Shelley, t. c. p. 160.]

21. Hen bird of no. 20.

Top of head, neck, and back greenish grey. Rump, sides, and breast grey. Belly and vent white. Wings olive-green. Tail olive-brown. Feathers of legs yellow. Feet very light brown. Eyes dark brown.

\section{Small Warbler.}

Forehead pale olive-green. Top of head bright reddish brown. Cheeks pale olive-green. Throat bright yellow. Top of breast black, lower part white and grey tinged with yellow; belly greyish white tinged with yellow. Vent yellow. Back grey tinged with olive-green. Wings and tail olive-brown. Feet ochre. Eyes dark grey. Scarce. Hen. [Eremomela badiceps (Fras.), juv.; Shelley, t. c. p. 160.]

\section{July 16 th.}

\section{REDSTART?}

Top of head, neck, and cheeks black. Line of white running from beak over eye to back of neck. Throat, breast, sides, and vent yellow-ochre. Belly white. Back very dark greyish olive. Rump olive-brown. Shoulders sky-blue. Wings black, feathers edged with pale blue. Tail bright light reddish brown, with the two central feathers black. Feet dark brown. Eyes very light brown. Hen. [Cossypha bartteloti, Shelley, t. c. p. 159, pl. v. fig. 2.]

\section{July 19 th.}

24. Small Finch.

Cheeks, throat, and breast white. Belly white tinged with grey. Vent light grey. Sides light grey tinged with crimsonlake. Head black. Upper part of back, neck, and wingcoverts dark grey, closely barred with black. Lower part of 
back and rump crimson-lake. Wings and tail black. Feet and eyes black. Cock. Scarce. Beak crimson-lake and black. [Estrelda nonnula, Hartl. ; Shelley, t. c. p. 165.]

\section{July 11 th.}

25. SUN-BIRD.

Head, throat, neck, upper part of breast, back, shoulders, and rump bright metallic green. Lower half of breast bright red and yellow. Belly and vent dark olive-green. Wings and tail black. Eyes dark brown. Cock. Common. [Cinnyris chloropygius (Jard.); Shelley, t. c. p. 162.]

26. Ditto.

\section{July 13 th.}

\section{Small Kinghunter.}

Throat white; cheeks lilac; line of very bright reddish brown over eye. Top of head black barred with blue. Back and wing-coverts very deep blue. Rump brighter blue. Tail black. Neck, breast, belly, vent to underside of wings bright light reddish brown. Wings black, feathers edged with dark blue. Feet and beak vermilion. Eyes brown. Common. Cock. [Ispidina picta (Bodd.) ; Shelley, t. c. p. 167.]

28. Kinghunter.

Same as no. 27 in description, but a hen.

29. Ditto. Hen.

\section{July 15 th.}

30. Small Finch.

Head, neck, breast, back, wing-coverts, and tail black. Belly and vent white. Centre of wings, rump, and sides black, barred with white. Tips of wings black. Feet black. Eyes black. Common. Cock. [Spermestes poensis (Fras.); Shelley, t. c. p. 166.]

31. Ditto.

July 26th.

32. SANDPIPER.

Head, neck, back, wing-coverts, rump, tail, and feathers of 
wing next body a shiny ashen brown, with dark streak down centre. Wing-coverts, feathers of wing next body, and tail barred with darker brown. Shoulder white, and streak of white across outer part of wing. Throat white. Upper part of breast grey, streaked with brown; rest of breast, belly, and vent white. Legs pale yellowish grey. Eyes very dark brown; large dark pupil. Hen; only one seen. Distinct ruffs on each side of neck. [Tringoides hypoleucus in full breeding-plumage, rather worn, as if on its way south after breeding. C $C f$. Shelley, t. c. p. 170.]

\section{July $27 t h$.}

33. Swallow.

Length from tip of tail to beak $8 \frac{1}{2}$ inches. Head, neck, wings, back, and tail deep blue-black. Throat, breast, belly, vent, and rump light reddish buff. White bar across underside of tail. Eyes very deep brown. Cock. [Hirundo gordoni, Jard.; Shelley, t. c. p. 163.]

July 29th.

34. Weaver-bird. Hen of no. 14.

Head, back, and wing-coverts dark olive-green, marked down the centre with dark brown. Rump lighter olive-green. Tail brown tinged with green. Wings very dark brown; feathers edged with ochre. Throat greenish gold, breast darker ditto. Belly and vent bright yellow. Eyes hazel. Feet pale pinky brown. [Melanopteryx nigerrimus (V.); Ploceus nigerrimus, Shelley, t. c. p. 164.]

35. WEAVER-BIRD.

Throat, line round eyes, line at back of the neck and shoulders black. Cheeks, top of head, sides of neck, and breast rich deep gold. Belly and vent very bright yellow. Back very dark brown. Wings, rump, and tail olive-brown. Eyes dark brownish grey. Feet pinkish brown. Cock. [This is Melanhyphantes nigricollis (V.), Sharpe, Cat. B. xiii. p. 415. Ploceus nigricollis, Shelley, t. c. p. 165.]

36. WOONPECKER.

Top of head black, closely spotted with white. Back of head bright red and crested. Throat, cheeks, and neck dirty 
white, every feather with a black spot in centre. Breast, belly, and vent dirty yellowish white, closely barred with black. Back, wing-coverts, shoulders, and rump dark olive-green. Wings and tail olive-brown. Eyes dark brown. Feet greenish yellow. Hen. [Campothera permista, Reichen.; Shelley, t.c. p. 168.]

July 31 st.

37. Nightjar.

Top of head dark reddish brown barred with black. Neck: upper part, a bar of closely mottled dark brown and dirty white; lower part, a bar of light reddish brown barred with black. Throat pale reddish yellow barred with black, and a bar of white running across the centre. Upper part of breast reddish yellow barred with black. Lower half of breast dirty white barred with black. Belly and vent dirty yellowish white, closely barred with black. Back dark brown, mottled with reddish brown. Wing-coverts and shoulders dark brown, mottled with light reddish brown and reddish yellow. Rest of wings light reddish brown, barred with black. Tail, broad bars of black and mottled light red, black, and white. Eyes very dark brown, large black pupils. Hen. Only one seen. [Cosmetornis vexillarius (Gould); Shelley, t. c. p. 167.]

July $30 t h$.

38. Plover.

Forehead and cheeks light reddish brown. Top and back of head dark greyish brown. Throat white, going off into grey at sides and bottom. Upper half of breast and back dark grey. Lower half of breast reddish brown in centre, with grey on each side. Belly and vent white. Underside of wings, upper half from shoulders white, lower black. Back and wing-coverts olive greenish grey, tipped with bright red. Wings black, with a white bar running right across from under shoulder to body. Rump and upper half of tail white. Lower half of tail black. Eyes dark sepia, very large black pupil. Hen. Believe to be hen bird of Spur-winged Plover shot on Stanley Pool. [Lobivanellus superciliosus, Reichen.; Shelley, t. c. p. 169.]

39. LaRge Weaver-bird.

Top of head, cheeks, throat, and a line running down into 
breast black. Back of head dark reddish brown. Neck rich golden yellow. Back between shoulders, a line of bright yellow bordered by a line of black on each side. Rest of back bright yellow and black, mottled. Rump yellow. Tail olive-green tinged with yellow. Wing-coverts bright yellow. A line of black across shoulders; rest of wings brown, feathers tipped and edged with yellow. Breast and belly rich dark golden yellow. Vent bright pale yellow. Eyes deep orange-red. Cock. Scarce here. [Ploceus bohndorffi, Reichen.; Shelley, t. c. p. 164. Hyphantornis bohndorff, Sharpe, Cat. B. xiii. p. 455. This species was not in the British Museum, to which it has now been presented by Mrs. Jameson.]

40. SwiFt.

Head, back, neck, breast, and wings glossy greenish black. A small white spot immediately below beak on throat; rest of throat black. Belly and vent white. Rump white with black quills. Tail: upper half white with black quills; lower half glossy greenish black, with the black quills extending into sharp spikes. Eyes very dark brown. Feet grey. Hen. [Chatura sabinei, Gray; Shelley, t. c. p. 168.]

August 2nd.

41. WOODPECKER.

Top of head dark brown, with golden crest. Cheeks white, with black bar in centre. Throat white, slightly barred with black. Breast and belly dirty brownish green spotted with white. Vent dark olive-green. Back of neck black; sides of ditto white and black. Back and wing-coverts dark olive-green. Rump dark gold. Outer feathers of wing dark brown, slightly barred with white spots; rest of wing dark olive-green. Tail black. Cock. Eyes dark brown. [Mesopicus xantholophus, Hargitt; Shelley, t. c. p. 168 . Captain Shel'ey observes:"This species was originally described from Gaboon, was also found on the Lower Congo by Lucan and Petit, and afterwards by Bohndorff in the Niam-Niam country.'”]

Basoko.

42. WOODPECKER.

Hen bird of no. 41. Description exactly the same, except want of crest on head, and it has two dark brown feathers in tail. 
43 to 45 . Small Finches.

Same as no. 24. Cocks.

46. Hen of no. 24.

Same as no. 24. Only dark grey where light in cock bird. [Estrelda nonnula, Hartl.; Shelley, t. c. p. 165.]

August 10th.

47 and 48 . Rollers.

Head, neck, back, wing-coverts, feathers of wing next body, and shoulders reddish brown. Throat, breast, and belly reddish brown tinged with magenta. Vent and underside of tail and wings pale sky-blue. Leg-coverts slightly deeper blue. Rest of wing very dark blue. Upperside of tail very dark brownish grey tinged with blue. Other feathers light blue tipped with black. Beak light brown. Eyes dark brown. Both hens. Scarce. [Eurystomus afer (Lath.); Shelley, t. c. p. 167.]

\section{August 11th.}

49. W ARBLER.

Head, throat, and cheeks glossy blue-black. Neck, breast, belly, and vent dark bluish grey. Back, rump, wing-coverts, and feathers of wings next body bright red-brown. Outer feathers of wing and tail very dark bluish grey. Eyes deep claret. Beak, legs, feet, and rim round eye lavender. Hen. Scarce. [Terpsiphone cristata (Gm.); Shelley, t. c. p. 158.]

50 and 51. BeE-EAters.

Head, cheeks, neck, and upper part of back black tinged with dark green. Line over eyes and forehead bright greenish blue. Throat bright crimson-lake. Breast black, spotted with bright blue. Belly and vent dull Kingfisher-blue. Back and wing-coverts black tinged with dark green. Wings black and light brownish red; feathers edged with blue. Rump bright Kingfisher-blue. Tail black tinged with dark blue. Cock birds, and scarce. Eyes deep claret-red. [Mellitophagus gularis (Shaw); Shelley, t. c. p. 167.]

52 and 53. Bee-eaters. Hens of nos. 50 and 51.

Throat paler crimson. Vent and belly duller blue. No blue line over eyes and forehead. Eyes dark brown. 


\section{SHRIKE.}

Top of head and neck black. Throat, line from beak over eyes, breast, belly, and vent white. Back, wings, and tail very dark grey. Rump very bright grey. Eyes dark grey. Legs and feet dark lavender. Scarce. [Dryoscopus tricolor, Cab. \& Reichen.; Shelley, t. c. p. 162.]

\section{ShriKe.}

Jet-black all over. Very long fluffy feathers on back and rump. Eyes dark brown. Cock. Scarce. [Dryoscopus leucorhynchus, Hartl.; Shelley, t. c. p. 161.]

56. Small Kinghunter.

Same as no. 27. [Ispidina picta (Bodd.); Shelley, t. c. p. 167.]

\section{Small Shrike?}

Throat, side of neck, vent, belly, and rump pure white: Breast, back, head, neck, wings, and tail black. Eyes very dark red, next pupil fading into brown. Faded purple wattles round eyes. Feet faded purple. Cock. Scarce. [Diaphorophyia castanea (Fras.) ; Shelley, t. c. p. 158.]

58. WARBLER.

Top of head and neck brown. Throat, breast, belly, and vent yellowish white. Sides grey. Back, wings, and tail brownish grey. Leg-coverts reddish yellow. Scarce. Cock. [Cisticola ruficapilla (Fras.) ; Shelley, t. c. p. 160.]

59. WOODPECKER. Cock bird of no. 36.

Description same, only whole top of head red. [Campothera permista, Reichen.; Shelley, t. c. p. 168.]

\section{November 7 th.}

60.

Head, neck, and breast deep indigo. Sides, belly, and vent very dark grey. Back and wing-coverts light reddish brown. Tail black, with two central feathers very long and pure white, about two and a half times length of tail. Feet and beak dark lavender. Eyes dark brown. Cock. Wings black, with a bar of white running from shoulder across centre. This bird I 
believe to be the cock of no. 49, already sent home, and I think a Paradise Flycatcher. [Terpsiphone cristata (Gm.); Shelley, t. c. p. 158.]

\section{December 9 th.}

61. Plover.

Forehead light reddish brown. Top of head and crest black. Cheeks, neck, and lower half of throat grey. Throat white. Sides of breast and upper part grey; rest a rich warm brown. Belly, vent, underside of tail, rump, and upper half of tailfeathers white. Extremity of tail black. Wing-coverts an ashen green; broad white bar across centre of wing. Outer feathers of wing black; underside of wing white, with long feathers black. Back a rich olive greenish ash. Eye a rich yellow-ochre, with large black pupil. Feet a pinkish slatecolour. Bright lemon-coloured wattles round the eyes and over forehead. Believe to be cock bird of no. 38. [Lobivanellus superciliosus, Reichen.; Shelley, t. c. p. 169.]

\section{October 28th.}

62. Spine-tailed Swift.

Head and cheeks black tinged with dark green. Throat dirty white streaked with dark grey. Upper half of breast grey, with centre of each feather darker grey. Rest of breast, belly, and vent white, with a black streak down centre of each feather. Rump white, with ditto. Tail black, with sharp black spine at end of each feather. Back and wings black tinged with dark green. Eyes dark sepia. Believe to be hen of no. 40. [Chatura cassini, Scl.; Shelley, t. c. p. 168.]

\section{October 23rd.}

63. Chaunting Falcon.

Forehead and cheeks very pale bluish grey. Top of head, neck, and upper half of breast slightly darker ditto. Throat white, with streak of grey down centre. Lower half of breast, belly, and leg-coverts white, closely barred with dark grey. Wing-coverts and back bluish grey; rest of wing very dark grey, almost black, with white tips to feathers. Rump very dark grey over white. Tail black, with white tip and white 
bar across, one inch from tip. Beak : upper half bright reddish orange. Legs ditto. Eyes very dark brown, with orange lids. [Asturinula monogrammica, Shelley, t. c. p. 157.]

\section{December 16th.}

64. Large Bee-eater.

Forehead and line over eyes pale sky-blue. Top of head and neck bright green tinged with pale blue. Line of jet-black running from beak under eyes, forming broad patch over ear. Under this line, and of same length, line of white with under edge of sky-blue. Throat next beak light gold fading into patch of pale sienna, bordered on each side by light green; rest of throat, breast, belly, vent, back to rump bright green tinged with skyblue, particularly on vent and rump. Wing-coverts a rich olive-green tinged with gold; four central feathers and outer feathers edged with sky-blue, all feathers tipped with black. Tail bright olive-green, with two central feathers long and pointed. Underside of wing pale golden-brown. Eyes crimsonlake. Beak black. Feet dark grey. Cock. [Merops persicus, Pall. Merops superciliosus, Shelley, t. c. p. 167 (nec L.).]

65. Ditto, with exception of central feathers of tail not fully developed. Cock.

66. Hen of last bird.

Top of head, neck, back, and wing-coverts faded green, tinged with very pale blue. Upper half of throat pale gold; cheeks and throat very pale reddish yellow. Breast and belly pale green, tinged with very pale blue. Rump very light greenish blue, almost white. Inside of wings pale reddish yellow. Rump bright green, tinged with pale blue; tail pale bluish green. Wings: upper half faded green; central feathers faded blue, tipped with brown; outer feathers faded greenish blue, tipped with brown; four central feathers of very dark olive-green, tipped with black. Many feathers still in quill. Believed to be young bird.

\section{December 8 th.}

67. Small Bee-eater.

Forehead, line over eyes, and upper half of throat white; 
cheeks black. Top of head very dark brown; lower half of throat black, edged above and below with bright sky-blue. Neck pale reddish yellow, tinged with green. Breast pale green, tinged with very pale blue. Belly and vent white; tinged with very pale light blue. Rump bright sky-blue. Back and wing-coverts bright green. Wing-feathers next body blue, tipped with black; outer feathers bright golden green, edged with blue. Tail bright blue, with two central feathers long and pointed. Cock. Eyes crimson-lake; feet grey. [Merops albicollis, V.; Shelley, t. c. p. 167.]

68. Bee-eater. Hen bird of no. 67.

Same description; but colour of feathers distinctly paler, and without two long pointed feathers in tail. [Merops albicollis, V.; Shelley, t. c. p. 167.]

\section{November 9 th.}

\section{Thrush.}

Top of head and neck yellowish green. Cheeks bright yellow. Throat very light grey. Breast grey, with light streak down centre. Belly white. Sides, long fluffy feathers of an olivegreen, tipped with lemon. Vent and leg-coverts bright lemonyellow. Underside of wings bright lemon, except outer feathers, which are grey. Back and wing-coverts dark olive-green. Rump light olive-green. Tail golden olive. On wings two distinct bars of bright lemon spots, and two longest feathers next body tipped with bright lemon. Rest of feathers of wing brown, edged with golden olive. Eyes dark sepia. Hen. Feet grey. [Nicator chloris (Val.); Shelley, t. c. p. 161.]

\section{October 7th.}

70. RAIL.

Head, throat, neck, breast, and top of back bright reddish brown. Tail dark reddish brown. Back, wing, rump, and belly black, covered with round white spots. Vent and legcoverts olive-brown, spotted with black. Legs and feet dark pinkish brown. Cock. Eyes light brown. [Corethrura pulchra, J. E. Gray; Hartl. Orn. W.-Afr. p. 241 (1857).] 
October 18 th.

71. Dotterel.

Forehead white, tinged with pale buff. Top of head dark grey, edged with creamy brown. Throat white. Ring of white round neck; below this a ring of black, edged with grey, and forming ruffs on side of breast. Breast, belly, vent, underside of tail, and wings white. Back and wing-coverts ash, edged with creamy brown. Long feathers of wing next body olive-ash. Central feathers of ditto light grey, with white line through centre of wing. Outer feathers of wing black, and quill of outer one of all pure white. Cock. Eyes dark brown. [AEgialitis minor (Meyer and Wolf); Shelley, t. c. p. 169.]

\section{December 21st.}

72. Kinghunter.

Same as no. 12. Cock. Eyes dark brown. [Halcyon cyanoleuca (V.); Shelley, t. c. p. 167.]

\section{Golden Cuckoo.}

Top of head dark purplish bronze. Neck and back bright purplish bronze, tinged with green. Throat, neck, and breast pale buff, streaked with brown. Streak of white down centre of belly and vent; rest of belly, vent, and sides bright bronzy green, barred with white. Wing-coverts and rump bright bronzy green. Central feathers of wing and feathers next body bright bronzy green; the central feathers barred with reddish brown on outside edge. Outer feathers of wing dark bronzy green, barred on inside edge with reddish brown. Two central feathers of tail dark bronzy green, edged, tipped, and barred next body with reddish brown. Rest of tail-feathers reddish brown, barred with bronzy green, and tipped with white. Underside of wings bright bronzy green, barred with white. Underside of other feathers of wing dark grey, barred with white and light reddish brown. Eyes hazel. Hen. [Chrysococcyx klaasi, V.; Shelley, t. c. p. 168.]

December 18th.

74. Large Sun-bird.

Throat and upper half of breast metallic prussian-blue, with 
shades of purple. Cheeks bronzy purple. Top of head bright metallic, very dark green. Line from back of eyes, neck, back, rump, and wing-coverts bright metallic bronzy green. Wings black, with a shade of very dark brown. Lower half of breast and belly very dark crimson-claret. Vent black, with a spot of crimson-claret on each feather, and each feather edged with bright metallic golden-green. Tail black. Eyes dark sepia. Cock. Legs and feet black. [Cinnyris superbus, V.; Shelley, t. c. p. 162.]

\section{Same as no. 74. Cock.}

\section{Large Sun-bird. Hen of nos. 74 and $\mathbf{7 5}$.}

Throat pale lemon-yellow, slightly tinged with green. Breast pale olive-green tinged with lemon. Belly lemon. Sides light olive-green tinged with lemon. Vent bright reddish orange. A line of bright lemon over eye; from beak to eye and over ears a line of dark olive-green. Cheeks lemon. Top of head dark olive-green tinged with brown. Neck, back, and wingcoverts green tinged with grey. Rump bright green. Tail dark brown, edged with olive-green. Wings dark brown, edged with olive-green, and central feathers edged with orange. Eyes dark brown. Legs and feet black.

\section{December 22nd.}

77 and 78. Small Swallows.

Upper half of throat and sides of throat, top of head, neck, breast, belly, vent, back, rump, and wing-coverts bright metallic prussian-blue. Centre of throat white; sides white. Upperside of tail bright prussian-blue; underside black, with inside edge of each feather nearly down to end white. Outer feathers of wing black tinged with deep blue. Hen. Eyes very dark sepia. Feet black. [Hirundo nigrita, Gray; Shelley, t. c. p. 163.]

\section{SANDPIPER.}

Sides of forehead, throat, lower half of breast, belly, vent, undersides of wings, and tail and tail-coverts white. Centre of forehead, top of head, neck, breast, and cheeks grey, with a streak of darker grey down centre. Back dark grey, feathers edged with white. Rump ditto. Two lines of white across 
centre of wings. Centre of wings light ashen grey. Long outer feathers of wing very dark grey, with white quills. Tail light grey, edged with white. Eyes sepia. Hen. Beak long and slightly curved. [Tringa subarquata (L.); Shelley, t. c p. 170.]

80. Sun-Bird. Same as no. 25. Cock. [Cinnyris chloropygius.]

November $9 t h$.

81. Small Shrike?

Top of head dark bluish grey. Throat light reddish brown. Breast, back, and wing-coverts reddish brown. Belly and vent white. Rump and sides light grey. Tail black. Wattles round eye rose-madder or faded purple. Feet and legs pinkish grey. Eyes dark lake. Feathers of rump, vent, sides, and legcoverts very long and fluffy. Hen. [Diaphorophyia castanea (Fras.) ; Shelley, t. c. p. 158.]

November $\mathbf{7 t h}$.

82. Small Shrike.

Head, neck, throat, upper half of breast, back, rump, tail, wing-coverts, and wings very dark metallic green. Lower half of breast, belly, vent, and leg-coverts white. Cheeks bright reddish brown. Wattles round eye rose-madder. Feet and legs pinkish grey. Eyes dark lake. Cock. [Diaphorophyia blissetti (nec Sharpe); Shelley, t. c. p. 159.] This appears to me to be a distinct species from $D$. blissetti. The patch of feathers on the ear-coverts is not only much smaller and does not extend to the hinder cheeks as in D. blissetti, but it is of a different colour, being more maroon than ferruginous. Total length $3 \cdot 8$ inches, wing $2 \cdot 15$, tail $0 \cdot 85$, tarsus $0 \cdot 65$. I therefore propose to call the Yambuya bird Diaphorophyia jamesoni, sp. n.

November 9 th.

83. Species unknown.

Head, neck, back, rump, and wing-coverts very dark brown, feathers tipped with bright yellowish green. Wings and tail dark brown, edged with ditto. Throat, breast, belly, and vent 
dirty white, feathers barred with bright greenish yellow and black. Eyes pale lemon. Young bird. [Barbatula scolopacea (T.) ; Shelley, t. c. p. 169.]

\section{October 28th.}

84. Yellow Wagtail.

Top of head dark grey tinged with olive-green. Line of lemon passing over eye to ear-coverts. Cheeks olive-green. Throat bright lemon-yellow. Breast a dull yellow tinged with grey. Belly and vent bright lemon-yellow. Neck and back grey, tinged with olive-green. Rump olive-green. Tail black, with the two outer feathers on each side white. Wings dark greyish brown, feathers edged with dirty white. Cock. [Motacilla campestris, Pall.; Shelley, t. c. p. 164.]

\section{November 1 st.}

85. Flycatcher.

Top of head grey, with darker streak down centre of each feather. Throat and breast dirty white, with grey streak down centre of each feather. Belly and vent white. Neck, back, and wing-coverts light brownish grey. Wings and tail greyish brown, feathers edged with dirty white. Two central feathers of tail short and very dark grey. Cock. [Muscicapa grisola, L. ; Shelley, t. c. p. 158.]

\section{December 27th.}

\section{Finch.}

Head, cheeks, throat, breast, sides, and rump bright crimson. Neck, back, belly, and vent black. Wings very dark brown, almost black. Tail dark red. Beak dark prussian-blue, with shade of mother-of-pearl in upper mandible. Eyes deep claret. Legs and feet deep yellow-ochre. Cock. [Pyrenestes coccineus, Cass. ; Shelley, t. c. p. 166.]

\section{Golden Cuckoo.}

Young bird. Eyes light grey. Eyelids green. Feet seagreen. Cock. [Chrysococcyx smaragdineus, Sw., juv.; Shelley, t. c. p. 169.]

88. Warbler. Same as no. 58. Cock. 
89. Swifr.

Total expanse of wings 16 in. Length of each wing $7 \frac{1}{2}$ in. Length from tip of beak to tip of tail $7 \frac{3}{4}$ in. Top of head dark brownish grey, with an olive-green tinge upon it, slightly lighter on the forehead. Cheeks very dark brownish grey. Throat dirty white. Breast, belly, back, rump, and wingcoverts very dark brownish grey, with an olive-green gloss on it. Vent a light ashen grey. Tail dark ashen grey, and very much forked. Wings, the two long outer feathers black; rest of wing a dark sepia-like grey, with a rich sheen of olive-green. Eyes very dark brown. Legs feathered down to beginning of toes. Feet grey. Cock. [Cypselus apus, L.; Shelley, t. c. p. 168.]

90. Small Finch?

Forehead and half of top of head bright crimson. Cheeks, throat, breast, belly, and vent bright reddish brown or raw sienna. Back of head, neck, back, rump, and wing-coverts dark green, with a tinge of olive-green all over it. Tail dark grey. Feet pinkish ochre. Wings, long feathers dark brown, short ones greyish green. Eyes deep claret. Cock. [Pholidornis jamesoni, Shelley, t. c. p. 163, pl. v. fig. 1. Similar to Pholidornis rubrifrons of the Gold Coast, but distinguished by having the whole of the face chestnut and not spotted with ashy grey.]

91. Finch. Same as no. 86 . Cock.

\section{BIRDS COLLECTED AT YAMBUYA CAMP.}

\section{Warbler. Cock.}

Throat white. Line from beak to eye and cheeks very dark grey, almost black. Top of head very dark grey, feathers edged with lighter grey. Neck, back, and wing-coverts Frenchgrey. Breast and sides light French-grey. Belly and centre of lower half of breast white. Vent dirty greyish white. Tail light brownish grey. Wings of a uniform brownish grey. Eyes dark brown. [Burnesia leucopogon (Cab.); Shelley, t. c. p. 160.] 
Finches. 93. Cock. 94. Hen.

Forehead, cheeks, throat, breast, belly, vent, and tail black. Top of head next forehead very light grey, almost white; rest dark French-grey. Neck, back, and tail-coverts dark Frenchgrey. Rump very light grey, almost white. Wings black, with white spots on shoulder, and bar of white-tipped feathers across wing below shoulder, and three main feathers of wing next body tipped with white. Cock. Eyes orange.

Hen. Eyes orange. Exactly the same as cock-bird, but light grey, not so nearly white.

[Nigrita canicapilla, Strickl. ; Shelley, t. c. p. 165.]

\section{Small Sun-bird.}

Head, cheeks, neck, back, rump, and wing-coverts metallic bronze-green. Throat bluish grey. Lower part of throat and upper part of breast bright metallic green, succeeded by a thin line of orange. On each side of breast a tuft of bright lemon. Belly and sides pale olive-green. Vent pale lemon-yellow. Tail very dark brown, almost black, with feathers edged with metallic bronze. Wings very dark brown; feathers edged with golden olive. Cock. Eyes pinkish red. Legs and feet black. [Anthothreptes tephrolema, Jard.; Shelley, t. c. p. 163.]

\section{Small Sun-bird.}

Throat dirty greyish white. Breast, sides, and vent a dirty greyish white, tinged with yellow and streaked with brown. Centre of breast and belly same, with more yellow in it. A line of dirty white from beak over eye. Top of head, cheeks, neck, back, rump, and wing-coverts and tail a warm brown. Wings same brown, edged with whiter brown. Hen. Eyes dark sepia. Legs and feet black. [Cinnyris angolensis (Less.); Shelley, t. c. p. 162.]

\section{W ARbler. Cock.}

Top of head, neck, back, rump, wing-coverts, and tail a rich dark olive-green. A line of yellow from beak over eye. Cheeks dark olive greenish-brown. Throat, breast, belly, and vent a light grey tinged with green. Wings dark brown; feathers edged with olive-green. Eyes dark brown. Legs and feet pale grey. Cock. [Hylia prasina, Cass.; Sharpe, t. c. p. 160.] 
98. SUn-BIRd.

Same as no. 74. Cock. Not quite mature plumage.

99. W ARBLER. Cock.

Top of head, neck, back, and wing-coverts pale sepia. Line of white barred with black over eye. Throat, breast, sides, vent, rump, and leg-coverts white, closely barred with black. Wings dark brown; feathers edged with lighter brown. Whitetipped feathers on shoulder, and two bars of white-tipped feathers across upper half of wing. Three main feathers next body tipped with white. Tail, upperside only showing two long brown feathers, tipped with white; underside showing five feathers on each side of tail in a straight line, one longer than the other, tipped with white. Cock. Eyes dark brown. Feet dark grey. [Burnesia bairdi (Cass.); Shelley, t. c. p. 160.]

100. WARBLER.

Same as no. 99. Hen.

101. Paradise Flycatcher. Cock.

Immature bird, without long white feathers of tail. Same as no. 60 .

102. Paradise Flycatcher. Hen.

Same as no. 49. [Terpsiphone cristata, Shelley, t. c. p. 158.] 103. Weaver-Bird. Cock.

Same as no. 35. [Melanhyphantes nigricollis (V.). Ploceus nigricollis (V.); Shelley, t. c. p. 165.]

104. Weaver-Bird. Hen.

Hen of above. Cheeks dark gold. Forehead, line over eyes, throat, breast, belly, and vent bright lemon-yellow. Top of head black. Neck and back dark olive-brown. Rump olivebrown tinged with yellow. Tail olive-brown. Wing-shoulders very dark brown, rest of wing dark brown; feathers edged with olive greenish-yellow. [M. nigricollis, ut suprà.]

105. Species unknown.

Top of head, sides of neck, and line across top of breast rich dark clarot. Throat and upper half of breast claret, shot with whitie. Neck, back, and rump deep shiny indigo- 
blue. Breast and belly bright lemon-yellow. Sides, legcoverts, and vent black; feathers tipped with lemon. Tail black. Shoulder of wings white. Rest of wing deep blueblack, with feathers edged with brown. Beak and large wattles round eye bright golden yellow. Eyes dark red. Legs and feet dark slate. Hen? [Trachyphonus purpuratus, Verr.; Shelley, t. c. p. 169.]

\section{Large Warbler. Hen?}

Top of head and neck light greyish brown. Back and wingcoverts light yellowish brown. Rump still lighter yellowish brown. Cheeks pale ochre. Throat white. Breast, belly, and vent ochre, nearly buff at the sides, and white in centre. Wings light brown, enged with yellowish brown. Tail light brown. Legs and feet lavender. Eyes light grey. Hen? [Acrocephalus turdoides (Bechst.); Shelley, t. c. p. 159.]

\section{SHRIKE.}

Same as no. 55. Hen.

\section{Cardinal Finch.}

Same as no. 86. Cock.

\section{Finch. Cock.}

Top of head, neck, back, wings, tail, sides, centre of breast, belly, and vent black. Throat, breast, and sides of lower half of breast bright crimson. Rump dark crimson. Beak prussianblue and red. Cheeks dark crimson. Eyes red. Cock. [Spermospiza guttata (V.); Shelley, t. c. p. 166.]

[110. Macrosphenus flavicans, Cass.; Shelley, t. c. p. 160. This species was not in the British Museum, and was one of the most interesting in the Collection.]

\section{Small Sun-bird. Cock.}

Head, throat, neck, back, wing-coverts, and rump bright metallic green. Line on upper part of breast below green of bright metallic purple. Lower half of breast, sides, and vent olive-greenish yellow. Centre of lower half of breast and belly lemon. Tuft of bright lemon on each side of breast. Wings brown; feathers edged with olive-green. Tail deep prussianblue, edged with metallic green. Cock. Eyes dark brown. 
Legs and feet black. [Anthothreptes hypodilus, Jard.; Shelley, t. c. p. 162.]

112. Thrush.

Believed to be young of no. 69 .

113. WARBLER.

Same as no. 58. Cock.

114. Sun-BIRd. Cock.

Forehead black. Top of head next forehead bright metallic bluish green; behind this a patch of bright metallic purple. Cheeks and line over eye black. Centre of throat and upper portion of breast metallic golden green. On each side of throat, below cheeks, line of bluish metallic-green. Green on breast ends in a strip of prussian-blue; feathers edged with crimson. Lower half of breast, belly, and vent dark sepia. Back of head, neck, back, wing-coverts, rump, and tail dark brown tinged with gold. Wings very dark sepia. Eyes dark brown. Cock. Legs and feet black. [Cinnyris angolensis, Less. ; Shelley, t. c. p. 162.]

\section{5 and 116. WARBLERS.}

Top of head claret-grey tinged with brown. Neck and upper half of back reddish brown. Lower half of back and rump bright reddish brown. Line above and below eye white. Line from beak to eye black. Cheek light reddish brown. Line of white under cheeks. Throat white, with line of black on each side. Breast white, streaked with very dark greyish brown. Belly and vent white. Sides lighter reddish brown. Tail, upperside, upper half bright reddish brown, extremity black; four outer feathers on each side tipped with white. Wings very dark brown, almost black, with feathers edged with very light brown. Two bars of white-tipped feathers across shoulder of wing. Hens. Eye dark brown. [Erythropygia ruficauda, Sharpe; Shelley, t. c. p. 159.]

\section{Small Finch. Cock.}

Forehead, cheeks, throat, breast, belly, and vent rose-madder. Top of head, neck, back, and wing-coverts dark olive brownish grey. Wings very dark greyish brown. Tail black. Cock. 
Eyes dark reddish brown. [Nigrita bicolor, Hartl.; Shelley, t. c. p. 165.]

\section{Dove.}

[Chalcopelia afra (L.); Shelley, t. c. p. 169.]

119. Small Finch.

Same as no. 30. Hen. [Spermestes poensis (Fras.).]

120. Sparrow.

Hen. [Passer diffusus, Smith; Shelley, t. c. p. 164.]

121. Small Finch. Hen.

Top of head, neck, back, wing-coverts, and tail dark olivegreen. Rump light olive-green. Cheeks and upper part of throat light pinkish brown. Throat, breast, belly, and vent greyish olive-green. A few black feathers with white spots on breast. Wings dark olive-green. Hen. Eyes hazel. Beak crimson. [Pytelia schlegeli, Sharpe; Shelley, t. c. p. 165.]

122. Crow-Like Bird. Cock.

Eyes crimson. [Onychognathus hartlaubi, Gray; Shelley, t. c. p. 164.]

\section{3 and 124. Sun-BIRds. Cocks.}

Top of head, upper half of throat, and lower half of back bright metallic bluish green. Cheeks, neck, back, and rump metallic prussian-blue. Lower half of throat, breast, belly, and vent dirty white. A tuft of bright crimson-orange on each side of breast. Wings black; feathers edged with bright metallic green. Tail deep prussian-blue. Eyes very dark brown. Legs and feet black. [Anthothreptes aurantia, Verr.; Shelley, t. c. p. 163.]

\section{Sun-Bird. Hen.}

Forehead pale yellowish olive-green. Top of head, neck, back, and rump light ashen brown. Wings ashen brown; feathers edged with pale olive-green. Throat and upper half of breast a dirty whitish yellow. Breast, belly, and vent a pale olive-yellow. Tail-coverts metallic green. Tail dark blue, edged with metallic green. Eyes dark brown. Feet and legs black. [Anthothreptes aurantia, Verr.; Shelley, t. c. p. 163.] 
126. Sun-BIRd. Hen.

Top of head, back, neck, rump, and wing-coverts very dark olive-green. Throat dirty yellowish white. Breast, belly, and vent pale greyish olive-green. A tuft of bright lemon on each side of breast. Wings dark greyish brown; feathers edged with olive-green. Tail black; feathers edged with olive-green. Hen. Eyes dark brown. Feet and legs black. [Cinnyris obscurus (Jard.); Shelley, t. c. p. 162.]

It will be seen from the foregoing pages that Mr. Jameson was a careful and observant naturalist; and there is no doubt that had his opportunities for collecting been greater, and had he been less overshadowed by the weight of responsibility at the Yambuya Camp, we should have received from him a still greater increase of our knowledge of the ornithology of the Upper Congo. As it is, the collection has added many important details to the geographical distribution of the West-African Avifauna. Not the least interesting of the new facts brought forward in this collection is the indication of the route followed by some of our European species on their way to their winter home in South Africa, such as the Common Flycatcher, the Great Sedge-Warbler, the Curlew Sandpiper, \&c.

I must not forget to add that Mrs. Jameson has, with the utmost liberality, presented to the British Museum every specimen from her late husband's collection which was considered to be of value to that Institution. 


\section{LIST OF COLEOP'TERA}

COLLECTED BY MR. JAMESON $D N$

THE ARUWIMI.

BY

H. W. BATES, F.R.S., F.L.S., ETC.

[The Curculionida have been named and described by Mr. H. W. SnMPson, who has paid especial attention to this family.]

Fam. CARABID $Æ$.

Terruus Jamesoni, Bates, n. sp.

T. Raffrayi (Chaud.) affinis, sed differt, inter alia, corpore toto glabro. Niger, thorace sat angusto, hexagono, supra grosse confluenter et subrugose punctato, lateribus postice leviter sinuatis, angulis posticis obtusis; elytris graciliter ovatis, utrinque acute sexcostatis, costis prope apicem 2-6 et 3-5 conjunctis, interstitiis multo grossius quam in cæteris speciebus transverso-foveolatis et granulis medianis inter se valde distantibus. Subtus lævissimus; tibiæ anticæ extus rectæ; antennæ sicut in $T$. violaceo graciles ; frons inter oculos et in sulcis longitudinalibus rugoso-punctata, medio et antice lævi, sutura epistomali distincta.

Long. 35 millim.

This species belongs to the group defined by Kolbe as having (besides the raised suture) only six carinæ on each elytron, and differs from the other species of the group in the absence of pilosity and the very coarse sculpture and widely-spaced line of granules in the interstices. The thorax is nearly as long as it is broad, the median dilatation is strongly angular, and the sides behind the angle ollique (very slightly sinuated) to the hind angles, which are therefore obtuse as in T. Raffrayi, and not rectangular as in $T$. juvenilis, from which also the species differs in the perfectly smooth episterna. 
Fam. DYNASTID坐.

Archon crintaurus, Fabr.

Fam. CETONIIDA:

Smaragdesthes mutica, Harold.

Fam. EROTYLID 压.

Linodesmus cacus, Fabr.

Fam. LAMIID $\not$.

Sternotomis Regalis, Fabr.

Volumnia westermanni, Thomson.

Fam. CURCULIONID必.

Xenostes (Lithinide), nov. gen.

Rostrum longer than the head, slightly convex, very robust, somewhat narrowed at base, and much thickened at apex; scrobes deep, abruptly curved and confluent beneath. Antennæ rather short, very robust, pubescent; scape a little swollen at apex and inserted in the middle of the rostrum; joints of funiculus cylindrical and rather indistinctly separated, the first two a little longer than the others; club very large, obtuse. Eyes long and narrow. Prothorax convex, a little broader than long, with the sides slightly produced before the middle; straightly truncate at base. Elytra oval, convex. Legs moderately long, robust; the anterior and intermediate coxæ contiguous; femora a little clavate; tibia obtusely ungulate at apex. Tarsi moderately long, spongy beneath. Abdomen elongate, its second segment a little longer than the two following, and separated from the first by a straight suture.

Xenostes Jamesoni, n. sp.

Sub-elongate, covered above with yellowish-brown and white scales. Rostrum rugose above, with sparse ferruginous setæ at apex, and a deep lateral furrow in front of the eyes; separated from the head by a fine transverse groove. Prothorax with small shining black tubercles and a short longitudinal ridge in the middle; its constricted anterior portion nearly smooth, and defined posteriorly by a series of deep irregular transverse grooves. Elytra narrow at base, gradually dilated at the sides 
to about the middle, convex above, nearly vertically declivous at apex, irregularly covered with squamose protuberances crowned with small shining black tubercles (similar to those on the prothorax), and presenting a large elevation on either side of the suture at the commencement of the declivity, which is clothed with ashy scales, and has two sutural series of small black shining tubercles; apex truncate. Abdomen and legs densely clothed with fulvous scales. Long. (rostr. excl.) 18 mm., lat. $9 \frac{1}{2} \mathrm{~mm}$.

Lixus coarctatus, Klug.

Rhyncophorus phenicis, Fabr.

Oxyopisthen PYgidiale, n. sp.

Elongate, depressed, black, shining, with a silvery spot on the epimera, and longitudinal bands on the sides of the metasternum, the first abdominal segment, and pygidium.

Rostrum smooth, shining, with two narrow slightly punctured grooves above, originating just beyond the eyes, and deepening towards the apex. Antennæ shining; scape cylindrical; joints of funiculus of equal length. Head very finely punctured. Prothorax conical, much flattened above, rather dull, closely and deeply punctured, and with a fine longitudinal line in the middle. Scutellum oblong-ovate. Elytra a little broader than prothorax at base, slightly attenuated towards the apex, somewhat depressed, shining, and with rather coarsely punctured strix; interstices smooth and flattish; the second interstice is interrupted near the disc by two obscure depressions. Pygidium conical, finely punctured, carinate, the carina somewhat produced at apex. Underside and legs of a brilliant black; metasternum and abdomen finely punctured; the first segment of the abdomen rather more coarsely so in the middle; femora beneath clothed with fulvous setæ. Long. (rostr. excl.) 12 mm., lat. $3 \frac{1}{2} \mathrm{~mm}$.

o. Pygidium more acutely produced at apex; posterior tibia toothed near the base, and somewhat longer than in the male.

This species is allied to $O$. linea-alba, Thom., but is easily distinguished by the absence of any white markings on the prothorax and elytra. 


\section{LEPIDOPTERA RHOPALOCERA.}

BY

F. D. GODMAN, F.R.S., AND OSBERT SALVIN, F.R.S.

THE collection of Butterflies made by the late Mr. James S. Jameson during the expedition undertaken for the relief of Emin Pasha has been submitted to us by Mrs. Jameson for determination.

The collection contains about 218 specimens belonging to 132 species. So far as we can now determine, it was formed either in the valley of the Lower Congo between Matadi and Stanley Pool, or at the camp at Yambuya on the Aruwimi river.

The very adverse conditions under which the specimens were collected and the subsequent treatment they must have undergone after Mr. Jameson's death account for the smallness of the collection, as from some of the notes in the foregoing diary it is evident that many more specimens must have been preserved than ever reached Mrs. Jameson's hands.

Mr. Jameson made notes of his captures, and numbered each specimen on the paper containing it; but the numbers have in many cases been lost, so that we are unable to collate the specimens with the notes except in comparatively few instances.

The general relationship of the Butterflies of the Congo Valley, as shown in this collection, is evidently with the Tropical portion of the West Coast of Africa, many of the species being the same as those found at Calabar, the Cameroons, and other neighbouring places; and some of these, such as Papilio hesperus and P. zalmoxis, are characteristic of the region.

Further researches will, no doubt, prove this great valley of the Congo to be one of the richest of the whole of Africa in the variety of its natural productions. 
At present the subject has been scarcely touched by the collector, and it is greatly to be regretted that so ardent a naturalist as Mr. Jameson should have had so few opportunities for following his studies, and that so small a portion of his collections should have reached this country.

\section{RHOPALOCERA.}

Fam. NYMPHALID Æ.

Subfam. D A N A I N $\mathbb{E}$.

1. Amauris vashti.

Danais vashti, Butl. Cist. Ent. i. p. i.

Amauris vashti, Butl. Lep. Ex. p. 54, t. 21. f. 1; H. G. Smith, P. Z. S. 1890 , p. 467.

Hab. Nkalama R., Aprll 18th. No. 63. "Very scarce; deep forest on river-bank."

One specimen, agreeing with the type from Old Calabar, and with other examples in our collection from the Cameroon Mountains.

2. Amauris niavius.

Papilio niavius, Linn. Mus. Ulr. p. 253 ; Clerck, Icon. t. 32. f. 2 .

Hab. Yambuya Camp, Aruwimi River.

One example agreeing with others from various places on the West Coast.

3. Amauris egialea.

Papilio egialea, Cram. Pap. Ex. t. 192. f. D.

Amauris egialea, H. G. Smith, P. Z. S. 1890, p. 467.

$H a b$. Near Mswata. No. 22. "Rather scarce. Distributed generally along the river."

One specimen.

4. Amauris damocles.

Papilio damocles, Pal. Beauv. Ins. Afr. et Am. p. 239, t. 6. ff. $3, a, b$.

Amauris damocles, H. G. Smith. P. Z. S. 1890, p. 467.

$H a b$. Inkissi R., April 16th. No. 31. "Scarce, usually met with in deep shady forest."

A singie specimen, with more white at the base of the secon- 
daries than shown in Palisot de Beauvois's figure, but agreeing with many West-Coast specimens.

5. Danais petiverana.

Danais limniace, var. petiveruna, Doubl. \& Hew. Gen. Diurn. Lep. p. 93, t. 12. f. 1.

Tirumala petiverana, H. G. Smith, P. Z. S. 1890, p. 467.

Hab. Yambuya Camp and Congo Valley.

Two examples, without numbers.

6. Danats chrysippus.

Papilio chrysippus, Linn. Mus. Ulr. p. 263 ; Cram. Pap. Ex. t. 118. ff. B, C.

Hab. Mpalaballa, 27th March. No. 21. "Common along the whole march."

A single male specimen, without a trace of white on the secondaries.

Subfam. S A T Y R I N $\mathbb{A}$.

7. Melanitis Leda.

Melanitis leda (Linn.) ; H. G. Smith, P. Z. S. 1890, p. 472.

Hab. Inkissi River. No. 3. "Decidedly scarce, only a few seen in the deep shade of the forest."

8. Idiomorphus nanodes.

Idiomorphus nanodes, H. G. Smith, P.Z. S. 1890, p. 472.

Hab. Yambuya Camp.

Also in Mr. Bonny's Collection.

9. Mrcalesis auricruda.

Mycalesis auricruda, Butl. Cat. Sat. Brit. Mus. p. 131, t. 3. f. 6 .

Hab. Vombo. No number.

A single specimen, agreeing with Mr. Butler's type in the British Museum.

10. Mycalesis safitza.

Mycalesis safitza, Hew. Gen. Diurn. Lep. p. 394, t. 66. f. 3 ; Ex. Butt. Mycalesis, t. i. f. 4.

$H a b$. Vombo, A pril 6th. No. 45. "Commonest of this genus in shaded spots." 


\section{Mrcalesis, sp.?}

Hab. Kimbamwanga, 10th April. No. 52. "Common."

A single specimen, in very worn condition.

\section{Yрthima itonia?}

Ypthima itonia, Hew. Trans. Ent. Soc. ser. 2, ii. p. 287, t. 18. f. 13.

Hab. Near Mswata. No. 54. "Very scarce in open paths." A single specimen, agreeing fairly with a Zanzibar example which we attribute to $Y$. itonia, the type of which came from the "White Nile."

\section{3. Үртніма, sp.?}

Hab. Vombo, April 6th. No. 49. "Common."

A single specimen, in bad condition, agreeing with one in our collection from the Cameroons.

\section{Subfam. A C R 开 I N $\mathbb{E}$.}

\section{Acrea vestalis.}

Acraa vestalis, Feld. Reise d. Nov. Lep. p. 369, t. 46. ff. 8,9 .

Hab. Mwembi, 6th April. No. 13. "Common."

A single female specimen.

\section{Acrea pseudeuryta.}

Acrea pseudeuryta, Staud. in litt.

Wings dark brown, primaries crossed by a wide tawny band, the inner edge of which passes the end of the cell to a little beyond the middle of the inner margin and is sharply defined and very undulating, the outer edge at first passes towards the middle of the outer margin, and then curves round towards the anal angle, where it is deeply dentate; the whole of the distal area of the secondaries is tawny, sharply defined along the inner border, which includes a row of dark spots, outwardly the tarvny colour gradually blends into the outer border, and is clearly marked by the dark nervules and a dark line on each interspace, that below the first submedian branch being double. Beneath the primaries are paler than above; the secondaries are paler brown at the base and marked with a number of nearly round, clearly defined black spots, a light band crosses 
the wing beyond the cell, and, as well as the outer portion of the wing, is divided by dark nervules and a dark line on each interspace; the abdomen tawny, with dark brown transverse marks, especially towards the proximal end; the thorax, prothorax, and head dark brown spotted with white.

Hab. Yambuya Camp. No. 78, a. "On river-banks."

A distinct species, allied to $A$. euryta (Linn.), but differing in the darker brown colour of the wings, the wider tawny band of the primaries, the greater extent of the tawny discal area of the secondaries, and their darker and more sharply defined base; the outer border, especially towards the apical angle, is much darker, and the dark nervures and the intermediate lines much more clearly defined.

Dr. Staudinger, to whom we submitted the single male specimen before us, rightly, we think, considers it separable from $A$. euryta, and suggested the name we employ.

16. Acrea elongata.

Planema elongata, Butl. Cist. Ent. i. p. 212.

Acraa eurita, Hew. Ex. Lep. Acraa, t. 5. ff. 28, 30.

$H a b$. Congo Valley. No number or special locality.

A female specimen, agreeing with others in our collection from the Cameroons. The inner margin of the primaries is dark brown and not tawny as in Hewitson's figure of the female referred by Mr. Butler to this species.

17. ACREA PSEUdegina.

Papilio egina, Stoll, Suppl. Cram. t. 25. ff. 3, $3 c$ (nec Cram.). Acrcea pseudegina, Westw. in Doubl. \& Hew. Gen. Diurn. Lep. p. 531.

Hab. Banza Manteka, 1st April ; Kimbamwango, 10th April. Nos. 6, 12. "Common in great variety. River-banks and all open spaces."

Two females, with the subapical spot on the primaries rather large.

18. ACrea rogersi.

Acrae rogersi, Hew. Ent. Monthly Mag. x. p. 57.

Hab. Congo Valley.

A single small specimen. 
19. ACrAa ORINA.

Acrea orina, Hew. Ent. Monthly Mag. xi. p. 130 ; Ex. Butt. Acrea, t. 7. ff. 43, 48.

$H a b$. Congo valley.

A single example, which agrees with Hewitson's types from Fernando Po.

\section{Acrea cepheus.}

Papilio cepheus, Linn. Mus. Ulr. p. 252 ; Clerck, Icon. t. 43. f. 4 .
Acraa cepheus, H. G. Smith, P. Z. S. 1890, p. 466.

$H a b$. Bolobo, Congo Valley. No special locality, and no number.

A male and two females.

21. Acrea dejana, sp. $n$.

Acraa circeis, H. G. Smith, P. Z. S. 1890, p. 466 (nec Drury).

Allied to $A$. circeis of Drury, but differs in the greater width of the yellow discal patch of the secondaries, its outer margin being curved and subparallel to the outer margin of the wing instead of nearly straight and transverse; the primaries have white scales within the semihyaline subapical spots, there is also a patch of scales within the cell, and a large one between the first and second submedian branches, but hardly any below the first branch. A. circeis has only two spots on the primaries, and these are yellowish; the smaller is between the first and second median branches, and the larger is below the first branch near the anal angle; the insect, too, appears to be of larger size.

Hab. Congo Valley, no special locality.

We have several specimens closely allied to that now described, but presenting slight differences which prove to be specific; these, again, represent two forms, one from Angola and one from Fernando Po. They all differ from the true A. circeis in having more spots on the primaries and a larger yellow discal patch on the secondaries. We thus have evidence of at least four forms of this section of Acrcea, but at present we content ourselves with describing the one represented in the present collection. 
22. ACREA LYCOA.

Acrea lycoa, Godt. Enc. Méth. ix. p. 239.

$H a b$. Congo Valley. No number and no special locality. A damaged specimen, agreeing with others in our collection thus named.

23. Acrea cydonia.

Acrea cydonia, Ward, Ent. Monthly Mag. x. p. 59; H. G. Smith, P. Z. S. 1890, p. 466.

$H a b$. Inkissi River, 16th April. No. 30. "Generally common in shady glades."

Three specimens, agreeing with others thus named in our collection.

24. Acrea eponina.

Papilio eponina, Cram. Pap. Ex. t. 268. ff. A, B.

Acrea eponina, H. G. Smith, P. Z. S. 1890, p. 466.

$H a b$. Vombo, April 6th.

Two specimens, one agreeing closely with Cramer's figure; in the other the common fuscous band is united to the costal band of the primaries at its distal end.

25. Acrea serena.

Acraa serena (Fabr.), H. G. Smith, P. Z. S. 1890, p. 466.

Papilio eponina, o , Cram. Pap. Ex. t. 268. ff. C, D.

$H a b$. Congo Valley. No precise locality and no number.

\section{Subfam. Ny м P н A L I N ж.}

26. Lachnoptera iole.

Papilio vole, Fabr. Sp. Ins. ii. p. 78.

Lachnoptera iole, Doubl. \& Hew. Gen. Diurn. Lep. p. 161, t. 22.f. 2 .

Hab. Inkissi River, April 16th.

One male specimen.

27. Atella phalantha.

Papilio phalantha, Drury, Ill. Ex. Ent. i. p. 41, t. 21. ff. 1 , 2 . Atella columbina, H. G. Smith, P.Z. S. 1890, p. 467.

Hab. Inkissi River, April 10th.

A pair of this common species. 
28. Hypanartia delius.

Papilio delius, Drury, Ill. Ex. Ent. iii. p. 17, t. 14. ff. 5, 6.

Yambuya Camp.

Two specimens.

29. JUNONIA WESTERMANNI.

Junonia westermanni, Westw. Ent. Monthly Mag. vi. p. 278.

Hab. Yambuya Camp.

'I'wo examples.

30. Junonia clelia.

Junonia clelia (Cram.), H. G. Smith, P. Z. S. 1890, p. $46 \%$.

No special locality and no number.

31. Precis terea.

Papilio terea, Drury, Ill. Ex. Ent. ii. p. 32, t. 18. ff. 3, 4.

Hab. Banza Manteka, April 1st. No..77.

Three examples.

32. Precis pelasgis.

Vanessa pelasgis, Godt. Enc. Méth. ix. Suppl. p. 820.

Precis pelasgis, Trim. S. Afr. Butt. i. p. 236.

Hab. Inkissi River, April 16th. No. 8.

"Scarce, in bright open glades."

33. Precis sophia.

Papilio sophia, Fabr. Ent. Syst. iii. p. 218; Don. Inء. Ind. t. 36 . f. 3 .

$H a b$. Congo Valley.

One example. No special locality and no number.

34. Salamis ethyra.

Salamis ethyra, Feisth. Ann. Soc. Ent. Fr. 1850, p. 250.

Hab. Inkissi River, April 16th.

35. Salamis cacta.

Salamis cacta (Fabr.); H. G. Smith, P. Z. S. 1890, p. 467. Hab. Aruwimi River. No. 79, $a$.

"Not observed on the Congo.". 
36. Salamis a Nacardit.

Papilio anacardii, Linn. Syst. Nat. i. p. 755.

Salamis anacardii, H. G. Smith, P. Z. S. 1890, p. 467.

Hab. Yambuya Camp.

37. Eurytela ophione.

Papilio ophione, Cram. Pap. Ex. t. 114. ff. E, F.

Hab. Mswata, April 16th.

38. Eurytela ethosea.

Papilio ethosea, Drury, Ill. Ex. Ent. iii. p. 51, t. 37. ff. 3, 4.

$H a b$. Congo Valley.

A single specimen, with hardly any indication of the usual discal spot on the primaries.

39. Eurytela hiarbas.

Papilio hiarbas, Drury, Ill. Ex. Ent. iii. p. 17, t. 14. ff. 1, 2.

Eurytela hiarbas, H. G. Smith, P. Z. S. 1890, p. 473.

$H a b$. Congo Valley.

40. Ergolis enotrea.

Papilio enotrea, Cram. Pap. Ex. t. 236. ff. A, B.

Ergolis enotria, H. G. Smith, P. Z. S. 1890, p. 473.

$H a b$. Congo Valley.

41. Hypanis ilithyia.

Papilio ilithyia, Drury, Ill. Ex. Ent. ii. p. 29, t. 17. ff. $1,2$.

Hypanis ilithyia, H. G. Smith, P. Z. S. 1890, p. 473.

Hab. Nkalama River, April 18th. No. 44.

"Common on river-banks and open glades."

42. Crenis concordia.

Harma concordia, Hopff. Monatsb. k. Ak. Wiss. Berl. 1855,

p. 641 ; Peters, Reise n. Mossamb. p. 391, t. 22. ff. 3, 4.

$H a b$. Congo Valley.

A single male specimen.

43. Crenis pechuelit.

Crenis pechuelii, Dewitz, Nov. Act. Ac. C. L.-C. Nat. Cur. xli. (2) no. 2, p. 195, t. 26. f. 1.

Hab. Mswata, April 16th. No. 26.

"Common on high open ground away from rivers." 


\section{Crenis vadimonis.}

Crenis vadimonis, Druce, Ent. Monthly Mag. xiv. p. 226.

Crenis ribbei, Dewitz, Nov. Act. Ac. C. L.-C. Nat. Cur. xli. (2) no. 2, p. 196, t. 26. f. 3 (1879).

Hab. Kimbamwanga, Congo Valley.

45. Crenis amulia.

Papilio amulia, Cram. Pap. Ex. t. 180. ff. C, D.

Hab. Mpwka River, April 11th. No. 73.

46. Crenis benguela.

Crenis benyuele, Chapman, Ent. Monthly Mag. viii. p. 175.

$H a b$. Congo Valley.

47. Hypolimas salmacis.

Papilio salmacis, Drury, Ill. Ex. Ent. ii. p. 14, t. 8. ff. 1, 2. Hypolimnas salmacis, H. G. Smith, P. Z. S. 1890, p. 469.

Hab. Upper Congo, Yambuya Camp.

48. Hypolimnas anthedon.

Diadema anthedon, Doubl. Ann. Nat. Hist. xvi. p. 181 ; Doubl. \& Hew. Gen. Diurn. Lep. t. 37. f. 2.

Hab. Yambuya Camp.

This also varies slightly from the figure, the transverse band of the primaries being narrower and the dark outer border of the secondaries wider than in Hewitson's figure.

49. Hypolimnas stanleyi.

Hypolimnas stanleyi, H. G. Smith, P. Z. S. 1890, p. 467.

Hab. Yambuya Camp.

One male specimen.

50. Hypolimnas dubius.

Papilio dubius, Pal. Beauv. Ins. Afr. et Am. p. 238, t. 6. f. 2, $a, b$.

Hypolimnas dubius, H. G. Smith, P. Z. S. 1890, p. 469.

Hab. Vombo, April 6th. No. 53.

A single specimen, agreeing with a dark form of this species; common on the West Coast.

51. Pseudacrea lucretia.

Papilio lucretia, Cram. Pap. Ex. t. 45. ff. C, D.

Hab. Yambuya Camp. 
52. Pseudacrea hostilia.

Papilio hostilia, Drury, Ill. Ex. Ent. iii. p. 38, t. 28. ff. 5, 6. Hab. Nkalama River, April 18th.

53. Pseudacrea semire.

Papilio semire, Cram. Pap. Ex. t. 194. ff. B, C.

Hab. Congo Valley. No special locality.

54. Catuna crithea.

Papilio crithea, Drury, Ill. Ex. Ent. ii. p. 29, t. 16. ff. 5 , 6. Iara crithea, H. G. Smith, P. Z. S. 1890, p. 469.

Hab. Congo Valley.

55. Catuna duodecimpunctata.

Iara duodecimpunctata, Snell, Tijdschr. Ent. xv. p. 15, t. 1. ff. 1, 2 (1872).

Aterica clorana, Druce, Trans. Ent. Soc. 1874, p. 157.

Hab. Congo Valley.

56. Neptis Jamesoni, sp. $\mathrm{n}$.

Male. Above brownish black; nearly the whole of the cell (the lower and apical portions of which are bluish), seven more or less elongated spots beyond the cell from the costa to the inner margin (that next the costa small and narrow, less than half the second and third, the fourth very small and roundish, the fifth oval, the sixth roundish, and the seventh next the inner margin large and bifid), white; four submarginal lines whitish, the innermost and that next the costa faint: secondaries with a wide transverse white band deeply indented on its lower margin ; four submarginal bands, the innermost dusky, the rest whitish, the third from the margin widest. Underside as above but paler, and all the white marks and the submarginal lines clearer; the spot over the cell of the primaries is divided towards its distal end by two transverse black lines; the base of the costa of both wings and two subparallel curved bands towards the base of the secondaries white.

$H a b$. Congo Valley. No special locality.

A conspicuous species, not very nearly allied to any that we are acquainted with, but perhaps closer to $N$. nebrodes, Hew., than to any other known Neptis. 
57. Neptis nemetes.

Neptis nemetes, Hew. Ex. Butt. Neptis, ff. ], 2; II. G. Smith, P. Z. S. 1890 , p. 467.

Hab. Congo Valley.

58. Neptis agatha.

Papilio agatha, Cram. Pap. Ex. t. 327. ff. A, B.

Neptis agatha, H. G. Smith, P. Z. S. 1890, p. 467.

Hab. Vombo.

59. Neptis, sp.

A single specimen, in poor condition; allied to N. nicomedes, Hew.

Hab. Congo Valley.

60. Euryphene mandinga.

Euryphene mandinga, Feld. Wien. ent. Mon. iv. p. 108; H. G. Smith, P. Z. S. 1890, p. 469.

$H a b$. Congo Valley; no special locality.

61. Euryphene mardania.

Papilio mardania, Fabr. Ent. Syst. iii. p. 249.

$H a b$. Congo Valley.

62. Euryphene sophus.

Papilio sophus, Fabr. Ent. Syst. iii. p. 46.

Euryphene sophus, Doubl. \& Hew. Gen. Diurn. Lep. t. 43.

f. 4 .

Hab. Yambuya Camp, March 7th.

A single female example.

63. Euryphene, sp.

$H a b$. Congo Valley. A male and female, without special locality.

We have been unable to find a name for this butterfly, which is allied to $\boldsymbol{E}$. doralice, Hew. We hesitate, however, to name it, seeing that the genus is in considerable confusion.

64. Euryphene, sp.?

$H a b$. Congo Valley. No special locality.

A female, similar to E. aramis, Hew., but with the buff spots of the upper surface of the wings replaced by crimson; that of the primaries extends nearer to the base of the wings. 
65. Romalatosoma medon?

Papilio medon, Linn.

$H a b$. Congo Valley. Four males and a female.

Doubtfully referable to this species. The males differ considerably from one another, two of them being of the form described by Mr. Butler as $R$. viridinota.

66. Romaleosoma, sp.?

$H a b$. Congo Valley. A male and female, without exact locality.

Allied to $\boldsymbol{R}$. xypete, Hew., but with the underside of the wings much less distinctly marked.

67. Romaleosoma, sp. ?

$H a b$. Congo Valley. A single male specimen, without special locality.

Dr. Staudinger, to whom we sent this specimen, considers it to be between $R$. inanum, Butl., and $R$. rana, Staud.; but that, without a series of specimens, it was not desirable to describe it.

68. Romaläosoma Ruspina.

Romalcosoma ruspina, Hew. Ex. Butt. Romalcosoma, t. 2. ff. 6, 7; H. G. Smith, P. Z. S. 1890, p. 470.

Hab. Congo Valley. No special locality.

69. Aterica AFER.

Papilio afer, Drury, Ill. Ex. Ent. iii. p. 49, t. 36. ff 1, 2.

Hab. Yambuya Camp.

70. Aterica cupavia.

Papilio cupavia, Cram. Pap. Ex. t. 193. ff. E, F.

Aterica cupavia, H. G. Smith, P. Z. S. 1890, p. 469.

Hab. Above Mswata, May 7th, and Aruwimi River.

71. Aterica, sp.?

Hab. Nkalama River, April 18th.

A female specimen of a species allied to $A$. veronica.

72. Сумотнӧ̈ тнеоDosia.

Cymothoë theodosia, Staud.

Cymothoë theodota, H. G. Smith, P. Z. S. 1890, p. 471.

o. Similar to C. theodota, but the dark outer border of both primaries and secondaries less clearly defined, the submarginal 
lunules being thus more conspicuous; the secondaries have the outer border more sinuated. The female is very similar to that sex of $C$. theodota, but the interior of the secondaries is creamy white, and there is no discal tawny patch.

Hab. Aruwimi River.

73. Сумотнов̈ тнеовеNE.

Harma theobene, Doubl. \& Hew. Gen. Diurn. Lep. t.40. f. 3.

Cymothoë theobena, H. G. Smith, P. Z. S. 1890, p. 471.

Hab. Congo Valley.

74. Сұмотнов̈ јоDUtта.

Harma jodutta, Westw. Gen. Diurn. Lep. p. 289.

$H a b$. Congo Valley. Three males and three females, without special locality.

75. Сумотнов̈ CANIS.

Papilio canis, Drury, Ill. Ex. Ent. ii. p. 33, t. 19. ff. 1, 2.

Hab. Vombo.

Two males and four females; the latter all differ from one another; one of them is very similar to the male, another resembles the insect figured by Hewitson as Harma adelina, the other two are intermediate between these two extremes. Whether all really belong to one species must remain an open question, as the materials are not sufficient to settle the point satisfactorily.

76. Сумотнӧ̈ SANGaris.

Nymphalis sanguris, Godt. Enc. Méth. ix. p. 384 ; Lucas, Lep. Ex. p. 129, t. 69. f. 2.

Hab. Aruwimi River.

Three males, all with a common dark transverse band on the under surface of the wings, a character which appears to separate this species from the nearly allied $C$. coccinata.

77. Сумотнов̈ hesiodus?

Harma hesiodus, Hew. Ex. Butt. Hurma, t. 4. ff. 15-18.

$H a b$. Aruwimi river.

A single female, either of this or a closely allied species.

78. Charaxes castor.

Papilio castor, Cram. Pap. Ex. t. 37. ff. C, D.

Charaxes castor, H. G. Smith, P. Z. S. 1890, p. 472.

Hab. Aruwimi River. 
79. Charaxes brutus.

Papilio brutus, Cram. Pap. Ex. t. 24l. ff. E, F.

Charaxes brutus, H. G. Smith, P. Z. S. 1890, p. 472.

$H a b$. Aruwimi River.

80. Charaxes lucretius.

Papilio lucretius, Cram. Pap. Ex. t. 82. ff. E, F.

Hab. Aruwimi River.

81. Charaxes etesipe.

Nymphalis etesipe, Godt. Enc. Méth. ix. p. 355.

Charaxes etesipe, H. G. Smith, P. Z. S. 1890, p. 472.

Hab. Upper Congo, Aruwimi River.

82. Charaxes tiridates.

Papilio tiridates, Cram. Pap. Ex. t. 161. ff. A, B.

Charaxes tiridates, H. G. Smith, P. Z. S. 1890, p. 472.

Hab. Aruwimi River.

83. Charaxes numenes.

Nymphalis numenes, Hew. Ex. Butt., Nymphalis, t.'2. ff. 9-11.

$H a b$. Aruwimi River.

84. Charaxes smaragdalis.

Charaxes smaragdalis, Butl. P. Z.S. 1865, p. 630, t. 36. f. 5;

Lep. Ex. p. 5, t. 2. f. 1.

Hab. Yambuya Camp.

Two males, agreeing with the type.

85. Charaxes fiphyra.

Nymphalis ephyra, Godt. Enc. Méth. ix. p. 355.

$H a b$. Aruwimi River.

86. Charaxes carteri.

Charaxes carteri, Butl. Ent. Monthly Mag. xviii. p. 108.

Hab. Nkalama River, April 18th.

87. Charaxes candiope.

Nymphalis candiope, Godt. Enc. Méth. ix. p. 353.

Charaxes candiope, H. G. Smith, P.Z. S. 1890, p. 472.

Hab. Aruwimi River.

88. Charaxes eupale.

Papilio eupale, Drury, Ill. Ex. Ent. iii. p. 7, t. 6. f, 3.

Charaxes eupale, H. G. Smith, P.Z. S. 1890, p. 472.

$H a b$. Aruwimi River. 
89. Charaxes? zingha.

Papilio zingha, Cram. Pap. Ex. t. 315. ff. B, C.

Hab. Yambuya Camp.

90. Philggnoma varanes.

Papilio varanes, Cram. Pap. Ex. t. 160. ff. D, E.

Philognoma varanes, H. G. Smith, P. Z. S. 1890, p. 472.

Hab. Congo Valley.

\section{Fam. ERYCINID $Æ$.}

91. Abisara herwigit.

Abisara herwigii, Dewitz, Deutsch. ent. Zeitschr. 1886,

p. 429 , t. 2. ff. $1,1 a, 1 b, 1 c$.

$H a b$. Congo Valley.

A male with no special locality.

Fam. LYCANID无.

92. LyC

Papilio juba, Fabr. Mant. Ins. p. 82.

Lampides juba, Butl. Cat. Fabr. Lep. p. 163, t. 2. f. 9.

$H a b$. Congo Valley.

A male without exact locality.

93. LyCANA IsIs.

Papilio isis, Drury, Ill. Ex. Ent. ii. p. 6, t. 3. ff. 4, 5. Hab. Congo Valley.

A male without special locality.

94. Lycena pulchra.

Lycena pulchra, Murr. Trans. Ent. Soc. 1874, p. 524, t. 10.

ff. 7,8 .

Hab. Vombo.

A pair in poor condition.

95. Lyc $2 N A, s p$ ?

One example near $L$. gamra of Lederer.

Hab. Inkissi River, April 16th.

96. LyCenesthes LARYDAS.

Papilio larydas, Cram. Pap. Ex. t. 282. f. H. Hab. Congo Valley.

A male without exact locality. 
97. Lyc enesthes sylvanus.

Papilio sylvanus, Drury, Ill. Ex. Ent. ii. p. 5, t. 3. ff. 2, 3. $H a b$. Congo Valley.

A male without exact locality.

98. Lychnesthes, sp.?

Hab. Congo Valley.

A male specimen.

99. Iolaus iutus.

Iolaus iulus, Hew. Ill. Diurn. Lep., Suppl. p. 9, t. 4. ff. $41-43$.

Hab. Congo Valley.

A damaged male, probably of this species, without exact locality.

100. Myrina nomenia.

Myrina nomenia, Hew. Trans. Ent. Soc. 1874, p. 353 ; Ill. Diurn. Lep. Suppl. p. 25, t. 3 b. ff. 105, 106.

$H a b$. Inkissi River, April 16th.

101. Hypolycena antifaunus.

Iolaus antifaunus, Doubl. \& Hew. Gen. Diurn. Lep.t. 75. f. 1. $H a b$. Congo Valley.

A single male specimen, without exact locality.

102. Pithecops elorea.

Papilio elorea, Fabr. Ent. Syst. iii. p. 194; Don. Nat. Rep. ii. t. 53.

Hab. Kiliamanga? (probably Kimbamanga).

A single example agreeing with Donovan's figure.

103. Pentila tachyroides.

Pentila tachyroides, Dewitz, Nov. Act. Ac. C. L.-C. G. Nat. Cur. xli. pt. 2, no. 2, p. 201, t. 62. f. 5.

Hab. Bolobo.

104. Liptena ilma.

Liptena ilma, Hew. Ex. Butt., Pent. \& Lipt. t. 2. f. 13. Hab. Near Mswata. 
Fam. PAPILIONID A.

Subfam. P I E R I N 瓜.

105. Terias brigitita.

Papilio brigitta, Cram. Pap. Ex. t. 331. ff. B, C.

$H a b$. Banza Manteka, April 1st.

One example, probably a female of this species.

106. Terias senegalensis.

Terias senegalensis, Boisd. Sp. Gén. i. p. 672.

$H a b$. Congo Valley, Mpalaballa, and elsewhere.

Several specimens, probably of this species.

107. Pieris dentigera?

Pieris dentigera, Butl.

Hab. Congo Valley.

108. Pieris phaola.

Pieris phaola, Doubl. Ann. Mag. Nat. Hist. xx. p. 6u.

$H a b$. Congo Valley.

109. Belenots sylvia.

Papilio sylvia, Fabr. Syst. Ent. p. 470.

Belenois sylvia, H. G. Smith, P. Z. S. 1890, p. 464.

Hab. Inkissi River, April 16th.

110. Eronia pharis.

Pieris pharis, Boisd. Sp. Gén. i. p. 443.

Hab. Congo Valley.

One male example.

111. Eronia ARgia.

Papilio argia, Fabr. Syst. Ent. p. 4770.

Eronia argia, H. G. Smith, P.Z. S. 1890, p. 465.

$H a b$. Congo Valley.

112. Pieris calypso.

Papilio calypso, Drury, Ill. Ex. Ent. ii. p. 30, t. 17. ff. 3, 4. $H a b$. Congo Valley.

113. Catopsilia pyrene.

Colias pyrene, Swains. Zool. Ill. i, t. 51.

Catopsilia pyrene, H. G. Smith, P. Z. S. 1890, p. 465.

Hab. Congo Valley. 
Subfam. P A P I I I O N I N $\mathbb{K}$.

114. Papilio policenes.

Papilio policenes, Cram. Pap. Ex. t. 37.ff. A, B ; H. G. Smith, P. Z. S. 1890 , p. 464.

Hab. Inkissi River, April 16th.

115. Papilio antheus.

Papilio antheus, Cram. Pap. Ex. t. 234. ff. B, C; H. G. Smith, P. Z.S. 1890, p. 464.

$H a b$. Inkissi River, April 16th.

116. Papilio corinneus.

Papilio corinneus, Berth. Mem. Bologna, p. 9, t. 1. f. 1.

Hab. Inkissi River, April 16th.

117. Papilio leonidas.

Papilio leonidas, Fabr. Ent. Syst. iii. p. 35 ; H. G. Smith, P. Z. S. 1890, p. 464.

$H a b$. Congo Valley. No exact locality.

118. Papilio Ridleyanus.

Papilio ridleyanus, White, Ann. Mag. Nat. Hist. xii. p. 262;

Doubl. \& Hew. Gen. Diurn. Lep. t. 3. f. 3.

Hab. Inkissi River, April 16th.

119. Papilio tynderaus.

Papilio tynderæus, Fabr. Ent. Syst. iii. p. 35 ; H. G. Smith

P. Z. S. 1890 , p. 464 .

Hab. Yambuya Camp.

120. Papilio demoleus.

Papilio demoleus, Linn. Syst. Nat. i. p. 753; Cram. Pap. Ex.

t. 231. ff. A, B ; H. G. Smith, P. Z. S. 1890, p. 464.

Hab. Mpalaballa, March 27th; Yambuya Camp.

121. Papilio menestheus.

Papilio menestheus, Drury, Ill. Ex. Ent. ii. p. 15, t. 9. ff. 1, 2 ;

H. G. Smith, P. Z. S. 1890, p. 464.

$H a b$. Congo Valley. No special locality.

122. Papilio bromius.

Papilio bromius, Doubl. Ann. Mag. Nat. Hist. xvi. p. 176; H. G. Smith, P. Z. S. 1890, p. 464.

Hab. Inkissi River, April 16th. 
123. Papilio erinds.

Papilio erinus, Gray, Cat. Lep. Ins. Brit. Mus. i. p. 26.

$H a b$. Inkissi River, April 16th.

124. Papilio hesperus.

Papilio hesperus, Westw. Arc. Ent. i. p. 189, t. 48.

Hab. Congo Valley. No precise locality.

125. Papilio merope.

Papilio merope?, Cram. Pap. Ex. t. 151. ff. A, B; H. G. Smith, P.Z. S. 1890, p. 464.

$H a b$. Kuilu River, April 5th.

One male specimen, agreeing with Sierra Leone examples in our collection.

126. Papilio zalmoxis.

Papilio zalmoxis, Hew. Ex. Butt. Papilio, t. 6. f. 18; H. G. Smith, P. Z. S. 1890, p. 464.

Hab. Congo Valley. No precise locality.

\section{Fam. HESPERID $Æ$.}

127. IsMene Forestan.

Papilio forestan, Cram. Pap. Ex. t. 391. ff. E, F.

Hab. Banza Manteka.

128. Tagiades Flesus.

Tagiades flesus, Fabr. Spec. Ins. ii. p. 135.

Papilio ophion, Drury, Ill. Ex. Ent. iii. p. 21, t. 17. ff. 1, 2.

$H a b$. Congo Valley.

129. Proteides ophiusa.

Hesperia ophiusa, Hew. Trans Ent. Soc. ser. 3, ii. p. 497.

$H a b$. Congo Valley.

130, 131, 132.

There are representatives of three other species of Hesperidæ which, in the present state of the nomenclature of the family, we cannot determine with certainty. 


\title{
LEPIDOPTERA HETEROCERA.
}

\author{
BY
}

HERBERT DRUCE, F.L.S.

Fam. SPHINGID必.

Subfam. MA C R GLOS I N

Hemaris hylas.

Hemaris, Dalm.

Sphinx hylas, Linn. Mant. i. p. 539.

Hemaris hylas, Butl. Trans. Zool. Soc. ix. p. 522 ; Druce, Moloney's Forestry of Western Africa, appendix v. p. 492.

One specimen, captured 27th March. It is identical with those in my collection from the Gambia, Calabar, and Cameroons.

\section{Macroglossa, Ochs.}

MACROGLOSSA TROCHILOIDES.

Macroglossa trochiloides, Butl. P. Z. S. 1875, p. 5 ; Trans. Zool. Soc. ix. p. 525.

The type in the National Collection is from Sierra Leone; the two specimens captured in April by the late Mr. Jameson are slightly smaller than any I have seen, but they do not differ in any other point from those I have from the Cameroons and Delagoa Bay.

Subfam. С н ж R о C A M P I N

Philampelus, Harris.

Philampelus megrara.

Sphinx megara, Linn. Mus. Lud. Ulr. p. 358; Clerck's Icones, t. 47. f. 2.

Philampelus megara, Walk. Cat. viii. p. 179 ; Butl. Trans. Zool. Soc. ix. p. 577.

One specimen, that in no way differs from those in my collection from West Africa, Delagoa Bay, and Madagascar. 
This species is very widely distributed in Africa, but examples from the West Coast and the one captured by Mr. Jameson are larger than those I have from Natal and Delagoa Bay.

\section{Fam. AGARISTID $\approx$. \\ Eusemia, Dalm.}

\section{Eusemia palitida.}

Eusemia pallida, Walk. Cat. i. p. 52.

One specimen that differs slightly from all those in my own collection in having an additional spot on the apical band of the primaries, but in one or two of the female specimens from Cape Palmas the faintest trace of the spot is shown.

\section{Fam. ZYG $\mathbb{E N I D}$ ÆE.}

\section{Subfam. T н т в E T I $\mathbb{N}$.}

\section{SALiUnCA, Walk.}

\section{Salidnca thoracica.}

Tipulodes? thoracica, Walk. Cat. vii. p. 1626.

Saliunca thoracica, Walk. Cat. xxxi. p. 108; Butl. Journ. Linn. Soc., Zool. xii. p. 358.

One example of this beautiful little insect, much brighter in colour than those from Sierra Leone in the National Collection or than any from Elobey in my own collection.

Subfam. E U с н R о м і і N $\mathbb{\text { I. }}$.

Euchromia, Hübn.

\section{Euchromia fulvida.}

Euchromia fulvida, Butl. Trans. Ent. Soc. 1888, p. 112, t. iv. f. 5 .

Four specimens, captured in March and April. This species varies slightly in colour, judging from the twenty specimens in my collection from various localities in West Africa.

Euchromia LEONIS.

Euchromia leonis, Butl. Journ. Linn. Soc., Zool. xii. p. 363 ; Trans. Ent. Soc. 1888, p. 113.

Two specimens, captured the 18th April, are identical with those from Logos, Elobey, and the Oogowai River in my col. lection; they do not vary in the least. 


\section{Fam. ARCTIID E.}

Areas lutescens.

Areas, Walk.

Spilosoma lutescens, Walk. Cat. iii. p. 672.

Halesidota mundata, Walk. Cat. xxxi. p. 309.

Areas lutescens, Butl. Cist. Ent. ii. p. 22.

Also in the National Collection. This species is now placed in the genus Phissama, Moore.

\section{Fam. LITHOSIID Æ.}

Argina, Hübn.

\section{Argina cingulifera.}

Deiopeia cingulifera, Walk. Cat. ii. p. 569.

Argina cingulifera, Druce, Moloney's Forestry of Western Africa, appendix v. p. 495.

One specimen, captured 12th April, in all respects identical with those from the Gambia, Abyssinia, and Lake Nyassa in my collection.

\section{Fam. NYCTEMERID $\not$.}

Aletis helcita.

\section{Aletis, Hübn.}

Papilio helcita, Linn. Amœn. Acad. vi. p. 405 ; Clerck, Icon. t. 39. f. 4 .

Aletis helcita, Walk. Cat. ii. p. 353.

One specimen of this common insect was captured by Mr. Jameson; it in no respect differs from those before me from the East and West Coasts of Africa.

\section{Fam. SATURNIID无.}

Bunæa, Hübn.

BUNAA JAMESONI, sp. $\mathrm{n}$.

Primaries olive-brown, with a hyaline spot at the end of the cell, a brown line crossing the wing from the costal to the inner margin near the base on the outer side of the line; the wing is thickly irrorated with purplish white, extending along the costal margin as far as the end of the cell. A narrow purplish-white line, edged on both sides with black, crosses the 
wing from the apex to the inner margin above the anal angle; on the outer side of the line is a wide purplish-white band, which gradually widens from the apex to the inner margin; the outer margin olive-brown; the costal margin near the apex is irrorated with purplish-white scales. Secondaries olivebrown, rather darker than the primaries; the costal margin from the base to near the apex, but not quite reaching it, broadly banded with bright rose-pink. A broad line, broadly edged with purplish white, crosses the wing near the base from the inner margin to the edge of the pink costal margin; about the middle of the wing is a large ocellus, with the central spot hyaline, round which is a wide ring of bright olive-brown, broadly bordered with black, which is again bordered with a wide ring of pale dove-colour. A purplish-white line, edged on the outer side with black, crosses the wing below the ocellus from the costal margin just above the apex to the inner margin, considerably above the anal angle, below the line the wing is broadly irrorated with purplish-white scales; the underside of both wings dark brown, thickly irrorated with purplish white and crossed by a dark brown line; the inner margin of the primaries from the base to almost the anal angle broadly bordered with bright rose-pink ; the head, thorax, and abdomen olive-brown, banded with dark brown; the collar, tips of the tegulæ, and the sides and base of the abdomen pinkish white; the underside of the head and the legs dark brown; the antennæ black. Expanse $6 \frac{1}{2}$ inches.

A single specimen of this fine and very distinct insect was captured; I have named it after its discoverer, the late Mr. Jameson. The broad pink costal margin of the secondaries at once distinguishes it from all the species known to me.

\section{Fam. OPHIDERID Æ.}

Ophideres, Boisd.

Ophideres divitiosa.

Ophideres divitiosa, Walk. Proc. Nat. Hist. Soc. Glasgow, i. pp. 326, 356, t. vii. f. 11 ; Druce, Moloney's Forestry of Western Africa, appendix v. p. 500.

One specimen, identical with those from Old Calabar and the 
Cameroons. This species varies considerably in the colour of the primaries; some of the specimens in the large series before me have a wide green line extending from the apex to the inner margin. The specimen captured by the late Mr. Jameson has no green, which appears to be the normal form from the Cameroons.

\section{Fam. OMMATOPHORID $\approx$.}

Patula, Guén.

\section{Patula walkeri.}

Patula walkeri, Butl. Ann. \& Mag. Nat. Hist. ser. 4, xvi. p. 406; Druce, Moloney's Forestry of Western Africa, appendix v. p. 500 .

A specimen in fine condition of this common insect, captured by the late Mr. Jameson at the Yambuya Camp, Aruwimi River, is identical with those from all parts of Tropical Africa and Madagascar in my collection.

\section{Fam. HYPOPYRID E. \\ Hypopyra, Guén.}

Hypopyra CAPENSIS.

Hypopyra capensis, Herr.-Schäff. Samml. aussereur. Schmett. p. 79, ff. 121, 122; Druce, Moloney's Forestry of Western Africa, appendix v. p. 501.

One example, identical with those from the Gambia and South Africa in my collection.

\section{Fam. OPHIUSID正. АснжА, Hübn.}

\section{ACH Æa illustrata.}

Achcea illustrata, Walk. Cat. xiv. p. 1392 ; Druce, Moloney's Forestry of Western Africa, appendix v. p. 501.

The specimen captured on the 18th August differs slightly from those from the Gambia and Fantee in my collection: it is slightly paler in colour, and the markings on the primaries are not so distinct, but I have no doubt it belongs to the same species, as most of the Achra vary considerably: 
Fam. EUSCHEMID无.

Pitthea, Walk.

Pitthea continda.

Pitthea continua, Walk. Cat. ii. p. 463.

One specimen, that in no respect differs from examples from Lagos, Addah, Cameroons, and the Congo in my collection. This species has a wide range in Western Africa; it has not, so far as I know, yet been recorded from East Africa, its place being taken on the East Coast by Pitthea trifasciata, Dewitz, Nova Acta Acad. Nat. Fur. xlvii. p. 82, t. iii. f. 3.

\section{Pitthea agenoria, sp. $n$.}

Primaries and secondaries deep black, both the wings crossed by a semihyaline white band, that on the secondaries not reaching the outer margin; the underside the same as above; the head, antennæ, thorax, abdomen, and legs deep black; the collar and the underside of the abdomen bright orange-red. Expanse 1 $\frac{3}{4}$ inch.

Two specimens of this very distinct species are in the collection: it is allied to Pitthea trifasciata, Dewitz, from which it is at once distinguished by the entire absence of the apical hyaline band on the primaries, and by the anal segments being black instead of yellow as in that species.

\section{Fam. SPILOMELID压.}

\section{Zebronia, Hübn.}

\section{Zebronia phenicealis.}

Phalana-Pyralis Phenice, Cram. Pap. Exot.iv. p. 185, t. 382. f. $\mathrm{G}$.

Zebronia fœederalis, Hübn. Verz. bek. Schmett. p. 361.

Spilomela phenicealis, Guén. Sp. gén. des Lép. viii. p. 281. Spilomela podalirialis, Guén. Sp. gén. des Lép. viii. p. 281. Zebronia phenicealis, Walk. Cat. xvii. p. 476; Druce, Moloney's Forestry of Western Africa, appendix v. p. 505.

One specimen, identical with those before me from the Gambia and the Cameroons. 


\section{Fam. BOTYDID丑.} Вотуs, Latr.

Botys MaRgINALIS.

Phalana-Geometra marginata, Cram. Pap. Exot. iv. p. 243, t. 400. f. I.

Botis marginata, Swains. Zool. Illustr. ii. t. 77.

Botys marginalis, Guén. Sp. gén. des Lép. viii. p. 343; Walk. Cat. xviii. p. 633 ; Druce, Moloney's Forestry of Western Africa, appendix v. p. 506.

Two specimens, identical with those from the Gambia, Cameroons, and Lake Nyassa in my collection.

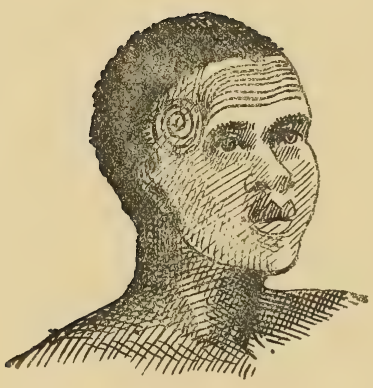

TATrootre. 


\title{
MAP OF UPPER CONGO
}

\author{
BETWEEN STANLEY FALLS AND KASSONGO.
}

A. Atratela.-Native village, or group of villagis (all groups oí villages being called by one name). Friendly natives in Tippu-Tib's territory.

B. FIRst RAPIDs above Stanley Falls.-Unless these rapids are very bad, loads need not be removed from the canoes, although all extra men are put out. Natives are always ready to piiuo the canoes over the rapids for one eshoka, or native axe, for each canoe. The road round the rapids is only bad in heary rains, but it requires clearing from heavy creepers. Road one hour fast walking.

C. Y Y the Arab chief of the town of that name being himseif subservient to Said bin Abéde, at Nyangwé. Yankéwé has just been burned by men from Kibongé, as the Arabs had traded guns and powder to the natives, and they had begun attacking unprotected canoes.

D. Opposite Yankéwé are limestone cliffs, with caves and stalactites in them.

E. Wamanga Rapids.-The worst on the whole river between Stanley Falls and Kassongo. When the water is low here, the Congo rushes through a passage between the rocks, not more than 50 or 60 yards wide at the narrowest parts. All goods, extra men, and awnings have to be removed, and go by road, either when coming down or going up the rapids. The road round is a good one. There are always pienty of natives from the village of Wamanga at the foot of the rapids, ready to take the canoes up or down them. In several places the canoes have to be hauled over the bare rocks. Fish abound here, and can be bought from the natives. Road one hour fast walking.

F. These rapids are very bad only in low water, but all goods and extra men ought to go by land. The road is good, and only half an hour easy walking. 
G. Kibongé.-A large Arab town under an Arab chief called by that name, who founded it, but who is subservient to Said bin Abéde, at Nyangwé. Here there are Arabs from Bagamoya, Zanzibar, Madagascar, Muscat, and other places, many of them owing allegiance to no one, notably Lugalowa, a freed slave, who now has a station on the Aruwimi River, within one month of Lake Albert Nyanza. Kibongé is chief over all the north bank, and most of the south bank of the river, from Yankéwé to the Kasendo Rapids, in fact as far as Nyangwé, as he is subservient to Said bin Abéde.

E snd I. The Robs and LInde rivers.-These fine large rivers are in the territory of Kibongé, and are said to be densely inhabited by a very fierce and treacherous lot of natives, whom the Arabs have never succeeded in taming. Over and over again they have asked for Arab residents, but have nearly always ended by eating them.

I. KAsøKס.-An Arab village, standing on both sides of the river of that name, inhabited by Arabs subservient to Kibongé. This is a small settlement, but I believe the Arab influence extends for a long distance up the river, which (although very small at the mouth) they assure me flows from a source far up in the interior, to the south-west of the Congo.

K. RIBA-RIBA. - A large Arab settlement, not so large as Kibongé, but an important one, belonging to an Arab chief called "Mahommed bin Hamis," who owns a large territory here on the western bank of the Congo, and is quite independent. The natives in this district are the Mculusi, but most of the slaves are Wacusu.

I. The Kasendo Rapids. - These rapids are not bad, and unless the canoes are very heavily laden there is no necessity to remove either men or loads. The natives here have a very bad reputation for plundering canoes, but they have just received a severe lesson from Kibongé, in whose territory they are, and who burned all their villages and took all their guns.

M. LoANGa. - The first Wagania village we stopped at. From here to Kassongo the river-banks are principally inhabited by this tribe, who are a harmless and apparently industrious race, and furnish paddlers for the canoes of almost all the principa! Arabs. 
N. These rapids are bad in low water, and both loads and extra people have to go by road, which is a good one, if cleared of creepers.

0. Nrangwe is a large Arab town, really consisting of three villages. which are the head-centres of three Arab chiefs, Said bir. Abéde, Said bin Habib, and Muni Mahara, the latter being subservient, I believe, to Mahara of Bagamoya. The other two chiefs are both powerful and independent.

P. KABANGA, a large native village where there is a market, and at which point Tippu-Tib's territory commences.

Q. The landing-place for Kassongo, which is an easy three hours' walk from here to the N.E., with a good road all the way.

R. Kassongo.-Tippu-Tib's chief town, and the largest of all the Arab towns on the Congo. I have heard Nyangwé mentioned as being the largest, but this is not a fact, nor can I believe it to be a place of so much importance, although it is on ine river-bank.

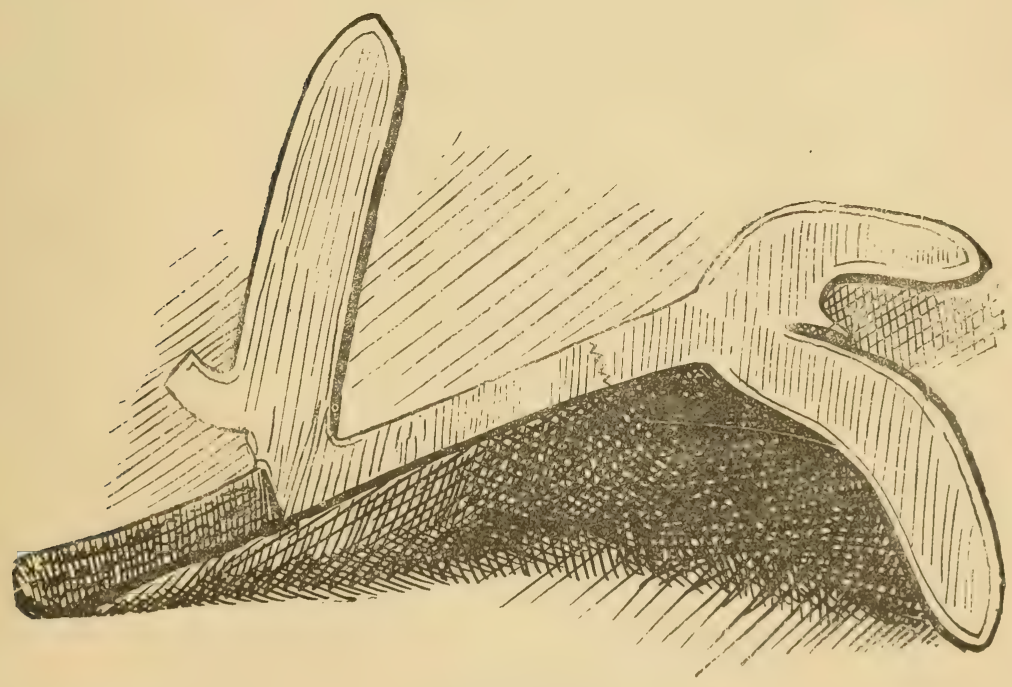

WAR KNIR⿴. 



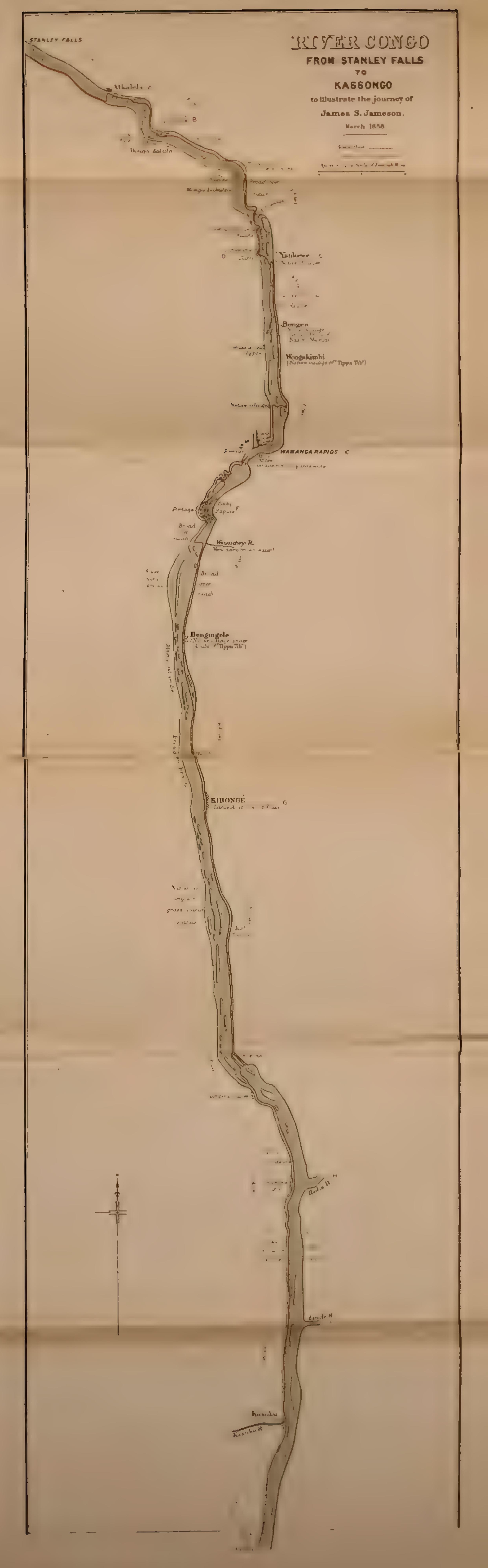





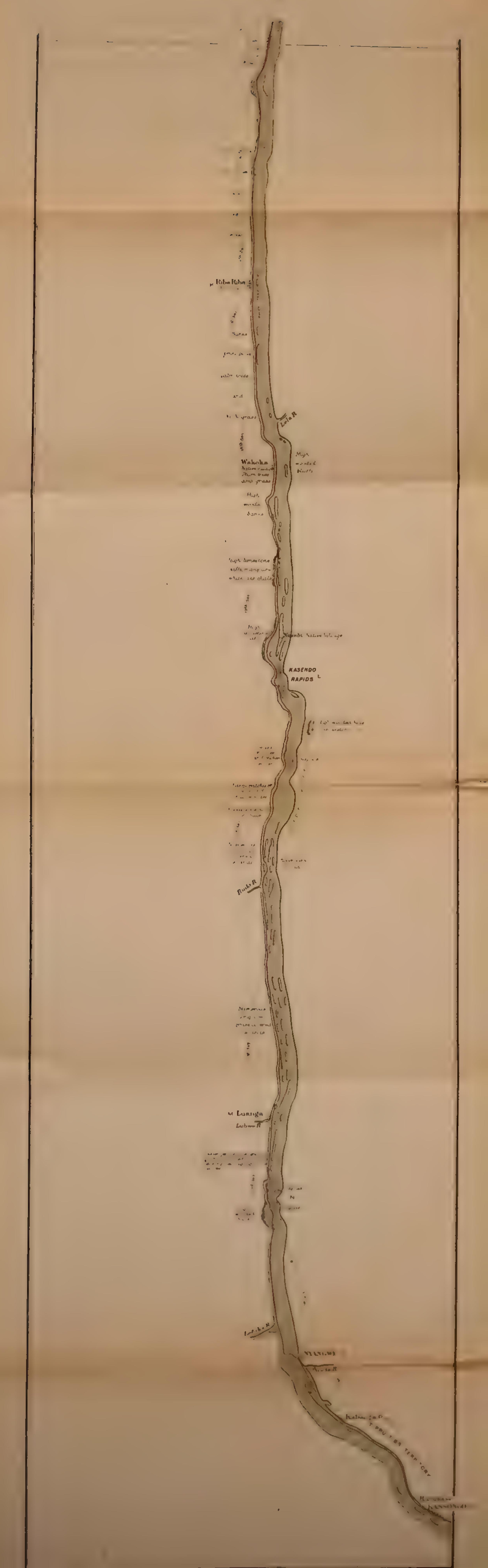










LIBRARY OF CONGRESS

|| |||||||||||||||||||||||||||||||||

0029988269

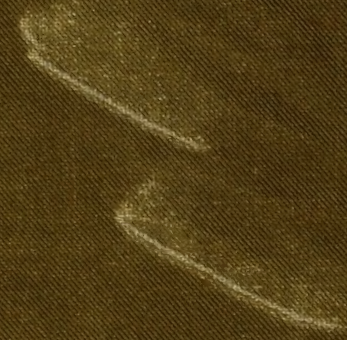

